\title{
Molecular studies of New Zealand Fucales: Phylogeography, phylogeny and taxonomy in Carpophyllum and Cystophora (Phaeophyceae)
}

by

Joseph Buchanan

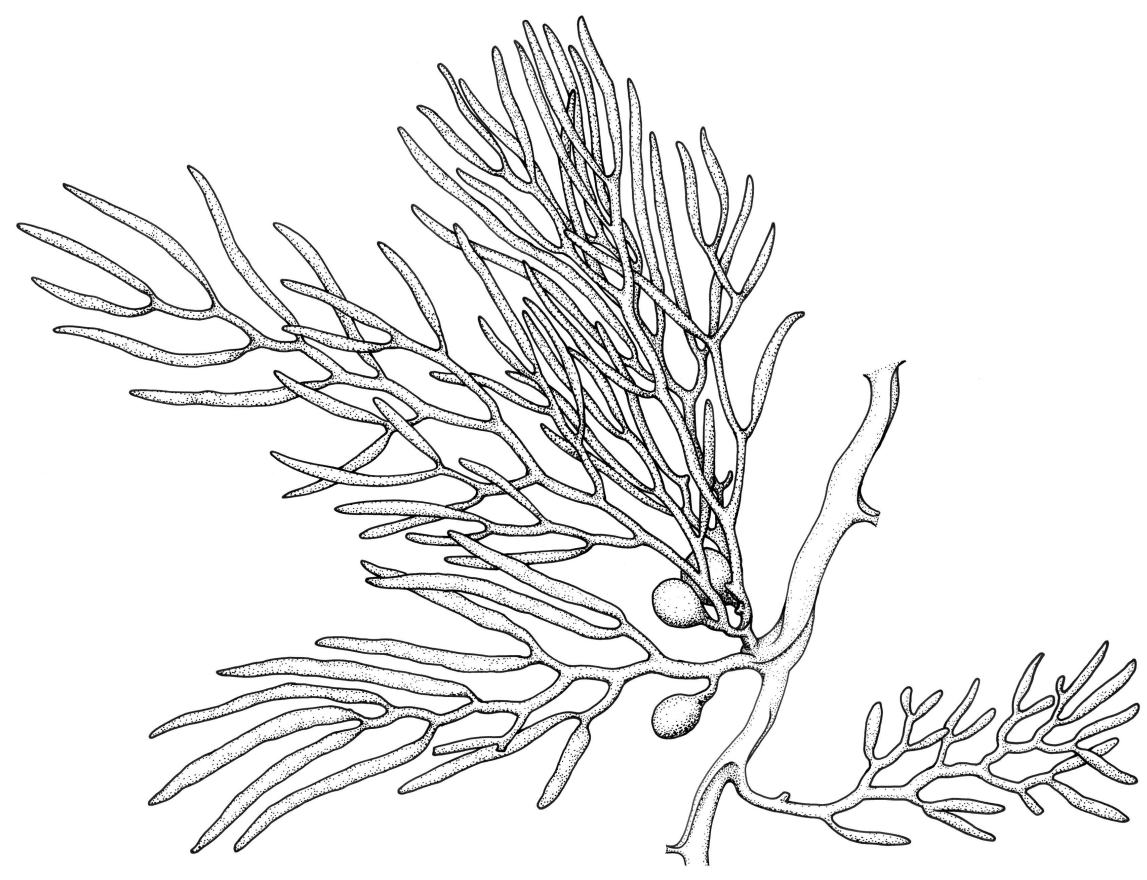

A thesis submitted to the Victoria University of Wellington in fulfilment of the requirements for the degree of Doctor of Philosophy in Marine Biology
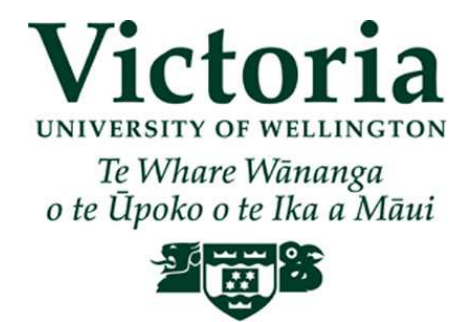

School of Biological Sciences

Victoria University of Wellington

Te Whare Wānanga o te Ūpoko o te Ika a Māui 
Previous page: Main axis and laterals of Cystophora scalaris J. Agardh. 
On the rocky shore of the island in the offing, the lovely seaweed -I will miss it when it goes under the flowing tide.

- Yamabe no Akahito

composed in the fifth of the tenth month, 724 . 


\begin{abstract}
Genetic variation in Carpophyllum Greville and Cystophora J. Agardh (Fucales, Phaeophyceae) was investigated at a variety of scales. An extensive survey of mitochondrial spacer variation in Carpophyllum maschalocarpum from 32 populations around New Zealand shows strong population differentiation at relatively small scales (50-100 kilometres), but also pathways of long distance dispersal that connect populations over much greater distances. In addition, historical climate change appears to have restricted $C$. maschalocarpum to the northern North Island during the last glacial maximum, with subsequent southward range expansion revealed by low genetic diversity in southern populations. These results are consistent with limited dispersal at the gamete and zygote stage, expected in fucalean algae, but with occasional long distance dispersal by detached floating thalli. The genetic signature suggests these two modes of dispersal are decoupled.
\end{abstract}

Internal Transcribed Spacers sequences show little differentiation between C. maschalocarpum and C. angustifolium, and hybridisation was found in several populations where these species are broadly sympatric. In the Bay of Plenty the two species had different ITS ribotypes, but most C. angustifolium specimens had a mitochondrial spacer haplotype that clustered with $C$. maschalocarpum haplotypes. This indicates mitochondrial introgression from C. maschalocarpum into $C$. angustifolium. In Northland species were difficult to separate by morphology or molecular markers, and some populations appear to be comprised entirely of hybrids.

Genetic distances between different species of Cystophora are very variable, and in some cases intra-species distances are similar to interspecies distances. This is problematic for DNA barcoding methods that rely on thresholds between inter-species and intra-species genetic distances. In some (but not all) cases, the absence of molecular differentiation can be attributed to oversplitting of Cystophora species by 
morphological methods, and I synonymise $C$. congesta with $C$. retroflexa, and $C$. distenta with $C$. scalaris. These studies exemplify the difficulties of delimiting species in brown algae: Morphology is often misleading or uninformative; genetic differentiation of species is very variable and often low; and species' histories show complex patterns of isolation and secondary contact. I argue for an explicitly historical concept of species, with species' history included in species descriptions. 


\section{Acknowledgements}

Many people contributed to the completion of this thesis in a variety of ways. My supervisor, Joe Zuccarello, provided tireless support, advice and enthusiasm, both for the preparation of the thesis and in all matters phycological. I could not have found a better person to oversee this project. Pete Ritchie undertook the role of secondary supervisor and was always available when advice was needed.

Maria McMillan provided tireless support for me, my work and my family during this time. Abbie and Lily provided welcome distraction.

Wendy Nelson, Tracy Farr, Kate Neill, Peter Martin, Erasmo Macaya, Fiona Hodge, Kyatt Dixon and Maria helped with collecting specimens. Chris Hepburn, Rochelle Dewdney, Francisco "Pancho" Neira and an anonymous Australian surfer were helpful in directing me to some excellent collecting sites.

Transport and accommodation during fieldwork were provided by Claire Haglund, Simon Hart and Andrea McMillan, Woodford Rouse and family, Maraehako Backpackers, Stuart and Nancy McMillan, Marty Smith and Phil (Napier) and Department of Conservation Chatham Islands staff.

Martin Thiel provided advice on Chapter 2. Alan Millar from the Sydney Royal Botanic Gardens Herbarium and Jenn Dalen from Te Papa Tongarewa (WELT) assisted with access to herbaria. Members of the Wellington phycological group and the VUW Plant Club provided feedback and advice at different stages of the project.

Financial assistance was provided by the Victoria University of Wellington ViceChancellor's Strategic Research Scholarship and by the Education New Zealand Post Graduate Study Abroad Scheme. The Department of Conservation assisted with fieldwork costs.

Many Victoria University staff assisted in many different ways, in particular I would like to thank Cam, Jo, Chris, Mary and Patricia for logistical support.

Essential to completion of this project was the assistance with childcare. In particular, I would like to thank the entire VUW crèche staff, Jane Buchanan, Lenka Rocheford and Pip, and Pip Adam. 


\section{Contents}

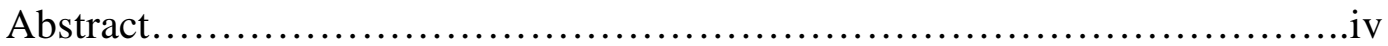

Acknowledgements...................................................... vii

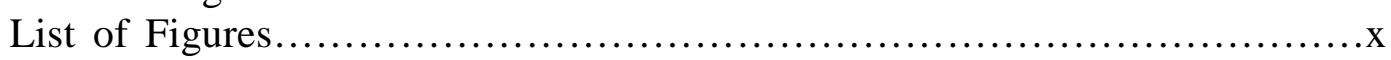

Chapter 1: Introduction and taxonomic background......................

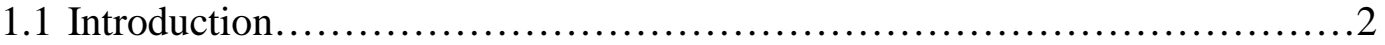

1.2 Carpophyllum Greville................................................ 3

1.3 Cystophora J. Agardh.................................................6

1.4 Research questions.................................................. 8

1.4.1 Hybridisation.......................................................... 8

1.4.2 Genetic variation and population structure ............................. 8

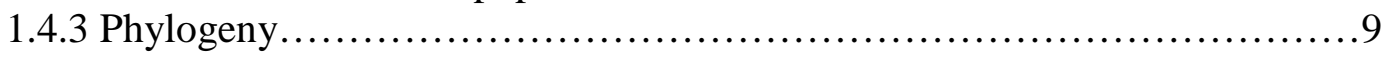

1.4.4 Taxonomic questions.................................................. 10

1.5 Structure of this thesis...................................................... 10

1.6 References............................................................ 11

Chapter 2: Decoupling of short and long distance dispersal pathways in the endemic New Zealand seaweed Carpophyllum maschalocarpum

(Phaeophyceae, Fucales)............................................. 15

2.1 Abstract............................................................. 16

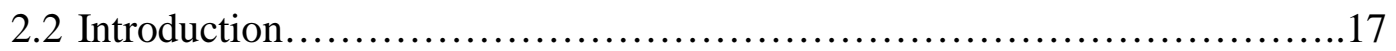

2.3 Materials and methods.................................................. 21

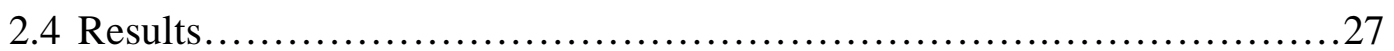

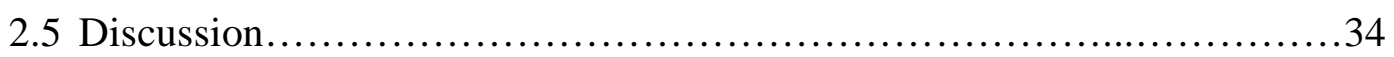

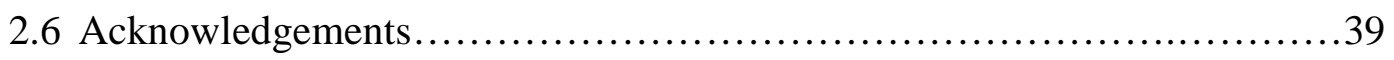

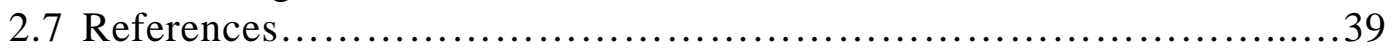

Chapter 3: Patterns of hybridisation in Carpophyllum (Phaeophyceae,

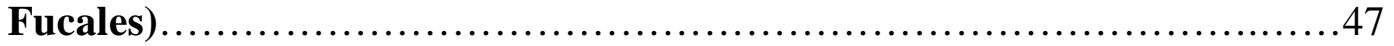

3.1 Abstract................................................................ 48

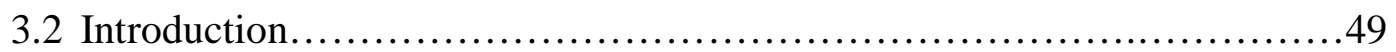

3.3 Materials and methods................................................ 51

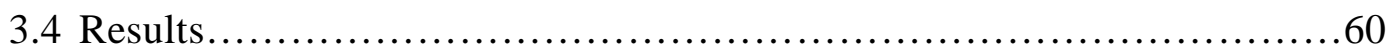

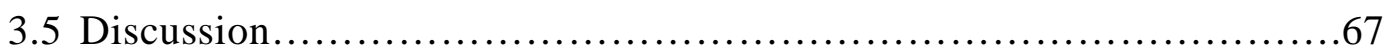

3.6 Acknowledgements............................................. 73

3.7 References........................................................... 73

Chapter 4: Barcoding brown algae: Does cox1 identify species of Cystophora

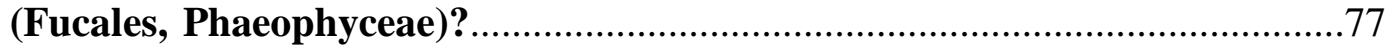

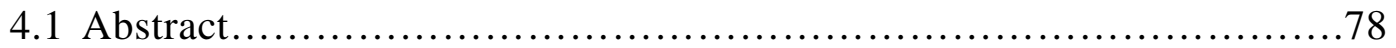

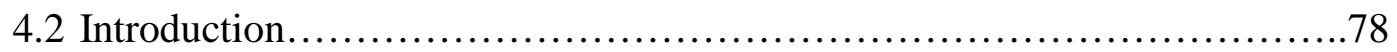

4.3 Materials and methods............................................... 81

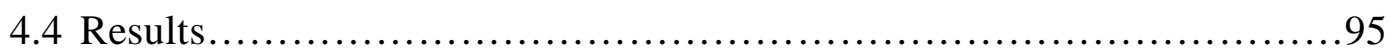

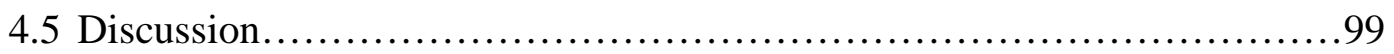

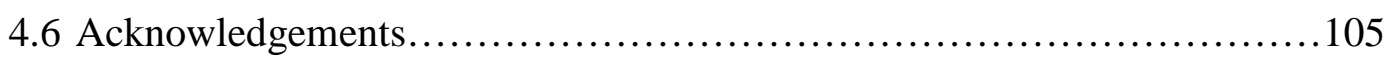

4.7 References............................................................ 
Chapter 5: Taxonomic oversplitting in the New Zealand members of the brown algal genus Cystophora (Phaeophyceae, Sargassaceae):

Synonymisation of two species.............................................. 111

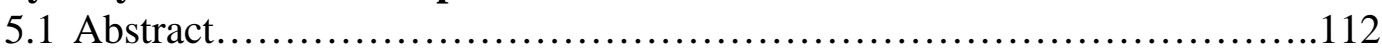

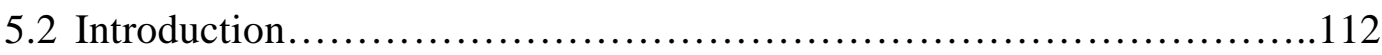

5.3 Materials and methods.................................................. 118

5.4 Results............................................................ 118

5.5 Discussion........................................................ 121

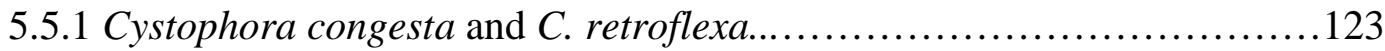

5.5.2 Amended species description: Cystophora retroflexa....................126

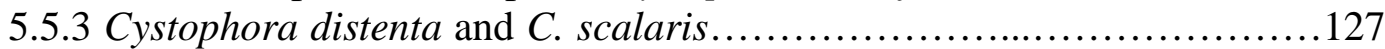

5.5.4 Amended species description: Cystophora scalaris......................128

5.6 Conclusion........................................................... 131

5.7 Acknowledgements................................................. 131

5.8 References.......................................................... 131

Chapter 6: Species delimitation in brown algae.........................133

6.1 Abstract................................................................ 134

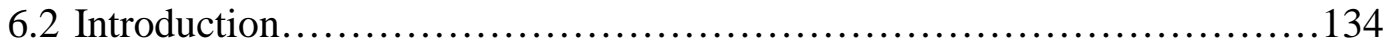

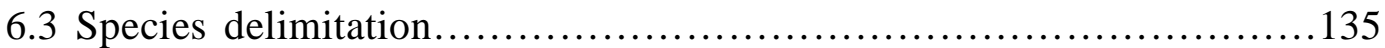

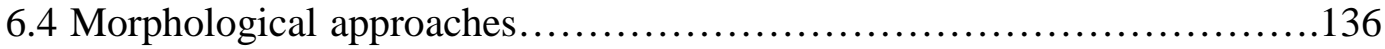

6.5 Culture experiments................................................. 137

6.6 Crossing experiments and reproductive isolation.........................137

6.7 Hybridisation as natural crossing experiments............................139

6.8 Molecular data.......................................................... 142

6.9 Species delimitation in Carpophyllum.....................................147

6.10 Species delimitation in Cystophora ................................. 148

6.11 Dispersal and history............................................... 148

6.12 Genetic distance - molecular data without history....................... 150

6.13 Model-based methods............................................. 155

6.14 Synthesising species concepts.................................... 156

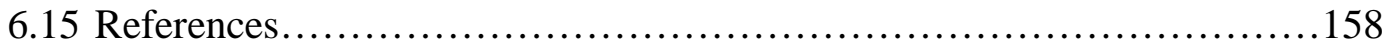

Chapter 7: Appendices................................................ 173

7.1 Appendix 1. Alignment of mitochondrial spacer sequences from

Carpophyllum maschalocarpum......................................175

7.2 Appendix 2. Alignment of ITS2 sequences from Carpophyllum............178

7.3 Appendix 3. Alignment of cloned ITS sequences from Carpophyllum......183

7.4 Appendix 4. Alignment of cox1 sequences from Cystophora................187

7.5 Appendix 5. Alignment of ITS sequences from Cystophora.................199

7.6 Appendix 6. Alignment of mitochondrial spacer sequences from Cystophora retroflexa and related species......................................... 212

7.7 Appendix 7: Additional work.....................................214

7.8 Appendix 8: Poster: Phylogeography of Carpophyllum maschalocarpum...215

7.9 Appendix 9: Hodge et al. (2010) Hybridisation in Carpophyllum............ 216 


\section{List of Figures}

\section{Chapter 2}

Fig. 2.1. Map of New Zealand showing major currents and bioregions .20

Fig. 2.2a. Distribution of mitochondrial haplotypes of Carpophyllum maschalocarpum.

Fig. 2.2b. Statistical parsimony network inferred from haplotypes of $C$. maschalocarpum.

Fig. 2.3. SAMOVA groupings of populations of C. maschalocarpum.........31

Fig. 2.4. Mismatch distributions of C. maschalocarpum haplotypes.

\section{Chapter 3}

Fig. 3.1. ITS2 statistical parsimony network for C. maschalocarpum and $C$. angustifolium..............................................62

Fig. 3.2. Geographical patterns of ITS2 ribotypes in Carpophyllum. .68

\section{Chapter 4}

Fig. 4.1. Map showing sampling locations of Cystophora spp ................82

Fig. 4.2. Distance tree inferred from cox 1 sequences from Cystophora spp......96

Fig. 4.3. Maximum likelihood tree inferred from $\operatorname{cox} 1$ and ITS sequences from Cystophora spp.........................................97

\section{Chapter 5}

Fig. 5.1. Graphs showing morphological variation in receptacles of Cystophora scalaris...................................................119

Fig. 5.2. Statistical parsimony network inferred from mitochondrial spacer sequences of Cystophora retroflexa and $C$. subfarcinata............120

Fig. 5.3. Morphological variation in Cystophora retorta...................122

Fig. 5.4. Morphological variation in Cystophora retroflexa.................124

Fig. 5.5. Morphological variation in receptacles of Cystophora scalaris.....125

Fig. 5.6. Organisation of ramuli and receptacles of Cystophora retroflexa and C. scalaris. 

Chapter 1

Introduction and background 


\subsection{Introduction}

THE BROWN ALGAE, or Phaeophyceae, are a monophyletic class within the Stramenopiles (Baldauf 2008). They are distantly related to the other eukaryote lineages that have evolved complex multicellular thalli (Metazoans, Fungi, Archaeplastida) and have unique characteristics (Charrier et al. 2007). In this project I investigate evolutionary processes in two genera of brown algae, Carpophyllum Greville and Cystophora J. Agardh. By comparing evolutionary processes in different lineages of life we can progress towards a general understanding of the variation and commonalities in evolutionary processes.

In a review of the state of knowledge of New Zealand marine macroalgae, Nelson (1994) wrote: "Speciation and endemism, and our lack of understanding about rates and processes involved, remain as outstanding issues." Fucoid algae are ideal organisms to investigate evolutionary processes as: (1) They are diverse, Australasia is the probable origin and centre of diversity of the Fucales (Clayton 1984); (2) New Zealand has endemic species and genera and others that are shared with Australia (Parsons 1985); and (3) Fucalean algae have a relatively simple life history, with a single life stage (Chapman 1995). This last character simplifies interpretation of genetic variation, as ecological and evolutionary processes are not acting differently on the dominant macrothallus phase and on the cryptic and phenotypically distinct microthallus phase.

Carpophyllum is endemic to New Zealand, Cystophora is found in New Zealand and southern Australia. Species of both genera are among the most common shallow marine macroalgae of New Zealand (Shears \& Babcock 2007). Stands of Carpophyllum dominate the shallow sub-tidal around a large part of rocky New Zealand coastline. Cystophora species are common in the shallow subtidal, rock pools and lower intertidal. Species of both genera provide structure and shelter for other marine organisms and are a significant contributor to primary productivity (Schiel 1990).

Some difficulties arise in species identifications in both genera (Adams 1994). Some forms appear morphologically intermediate between species (Lindauer et al. 1961) and ecological studies often identify specimens to generic 
level only. This lack of taxonomic information can lead to problems in identifying introduced species, recording distributional changes in species resulting from climate change and in investigating ecological and phylogenetic relationships of these algae.

This project aims to use molecular techniques to investigate genetic variation in these algae at different scales, to provide insights into processes effecting speciation. Specifically, I investigate phylogeny, taxonomy, dispersal and hybridisation. Here I review the taxonomic background and ecology of these genera and outline some questions that will be addressed.

\subsection{Carpophyllum Greville 1830}

Carpophyllum has four species ${ }^{1}$, all endemic to New Zealand (Adams 1994). A fifth species of Carpophyllum is under consideration based on two specimens collected in Antarctica (M. Clayton \& W. Nelson pers. comm.). Carpophyllum flexuosum (Esper) Greville is the most widespread species, extending throughout the North and South Islands, Stewart Island, and the Chatham Islands.

Carpophyllum maschalocarpum Turner (Greville) is the most abundant species (Shears \& Babcock 2007) and is found around the North Island, Chatham Islands and South Island as far south as Fiordland and Banks Peninsula. Carpophyllum plumosum (A. Richard) J. Agardh and C. angustifolium J. Agardh have more restricted distributions. Carpophyllum plumosum is found only on the eastern coasts of the North Island, from Northland to the Wairarapa Coast, and on the Chatham Islands. Carpophyllum angustifolium is found only on the east coast of the North Island, from Northland to just north of East Cape. Adams \& Nelson (1985) also recorded C. angustifolium and C. plumosum from the Three Kings Islands, ${ }^{2}$ off the northern tip of New Zealand's North Island. Carpophyllum is generally absent from the sub-Antarctic islands, although $C$. flexuosum has been recorded from the Auckland Islands (Papenfuss 1964), but Adams (1994) suggests

\footnotetext{
${ }^{1}$ Algaebase (Guiry \& Guiry 2011) includes Carpophyllum macrophyllum as a current species. This was created by Montagne (1845) from material from the Auckland Islands. According to Lindauer et al. (1961) C. macrophyllum is a synonym for C. flexuosum.

${ }^{2}$ I examined specimens of $C$. angustifolium collected from the Three Kings Islands held in WELT and consider them to be $C$. angustifolium $\times C$. maschalocarpum hybrids.
} 
reports from the sub-Antarctic islands are from drift material. Reports of Carpophyllum species from the Kermadec Islands appear to be based only on drift material (Adams \& Nelson 1984).

Carpophyllum is placed in the Sargassaceae and is related to some species of Sargassum (Draisma et al. 2010). The phylogenetic relationships within Sargassum have yet to be completely elucidated (Mattio et al. 2008, Draisma et al. 2010), and Carpophyllum's relationship to the various sub-groupings of Sargassum is not entirely clear. BLAST searches and preliminary trees using my sequence data suggest Carpophyllum is monophyletic and most closely related to some species of the Sargassum subg. Phyllotricha, with S. verruculosum the closest relative found (albeit with limited species sampling). Draisma et al. (2010), in the only published phylogeny that included Carpophyllum, placed Carpophyllum maschalocarpum as sister species to $S$. decurrens (in the clade Sargassum-2 in their system) in a phylogeny inferred from $23 \mathrm{~S}$ rDNA and $p s a \mathrm{~A}$ chloroplast DNA (they did not include $S$. verruculosum in their dataset). My ITS data suggest a close relationship between $S$. verruculosum and $S$. decurrens. Draisma et al. (2010) also show a close relationship between Carpophyllum and Nizamuddinia zanardinii from Oman (suggested by Nelson 1994).

Carpophyllum was established by Greville (1830, xxxii), with two species, C. maschalocarpum and C. flexuosum. His description is brief: "Frons plana vel compresso-plana. Folia ramiformia, distichia. Receptacula minuta, tuberculata, cylindracea, in racimes marginalibus." The description emphasises the flattened thallus (found in all species except $C$. angustifolium) and distichous laterals. Marginal receptacles are only found in C. flexuosum, in other species receptacles are axillary. Lindauer et al. (1961, p. 306) listed six characters that, in combination, separate Carpophyllum from Cystophora and Sargassum: "1. the flattened stem; 2. elongate flattened holdfast with short haptera at intervals on edges; 3. rounded or elongate vesicles; 4. leafy appendages; 5 . reproductive organs on special branchlets; 6 . absence of special basal leaves (these are present in C. flexuosum)." I consider that only the flattened holdfast reliably separates Carpophyllum from Sargassum. Carpophyllum appears to have affinities with the distichous members of Sargassum subg. Phyllotricha (based on unpublished 
molecular data $\left.{ }^{3}\right)$. The holdfast of all Carpophyllum species is flattened, creeping over the substrate, with haptera on the edges. In all species except $C$. angustifolium, the holdfast gives rise to a flattened main axis, with no intermediate terete stipe. In C. angustifolium the holdfast is flattened and gives rise to a terete stipe. Holdfasts in Sargassum subg. Phyllotricha species are conical or discoid and give rise to an initially terete stipe. In some species this stipe then becomes flattened and distichous (Womersley 1954, Rainbo Dixon, personal communication, January 16, 2011).

Carpophyllum species were collected by early visitors to New Zealand (Laing 1926) and returned to Europe for description. Carpophyllum flexuosum was described by Esper (1802) as Fucus flexuosus. Carpophyllum maschalocarpum was described by Turner (1811) as Fucus maschalocarpus. Carpophyllum plumosum was described by A. Richard (1832) as Sargassum plumosum, from material collected on Dumont D'Urville's second voyage to New Zealand. Carpophyllum angustifolium was described by J. Agardh (1877), from material supplied by Sven Berggren. Synonyms and other taxonomic details are recorded in Lindauer et al. (1961).

Some descriptive work on Carpophyllum, mainly related to the reproductive anatomy was undertaken by Delf (1939), Dawson (1940), and Naylor (1954). I can find no systematic treatment of Carpophyllum since the compilation of early work in Lindauer et al. (1961), although Dromgoole's (1973) largely ecophysiological study included some taxonomic notes. Other studies have investigated the chemistry of Carpophyllum maschalocarpum (Glombitza \& Li 1991a, 1991b, Li \& Glombitza 1991) and C. angustifolium (Glombitza \& Schmidt 1999).

A major survey of macroalgal abundance (Shears \& Babcock 2007) found Carpophyllum maschalocarpum was the second most abundant macroalgal species around New Zealand (after Ecklonia radiata). Other Carpophyllum species are locally abundant. Ecological studies have investigated relationships between Carpophyllum species and invertebrates, especially effects of urchin grazing, in northern New Zealand (Choat \& Schiel 1982, Andrew 1988), the

\footnotetext{
${ }^{3}$ These and other data suggests Phyllotricha should be elevated to a distinct genus (Rainbo Dixon, Pers. Comm. 3 May 2011). A paper addressing this is in preparation.
} 
Chatham Islands (Schiel et al. 1995) and Fiordland (Villouta et al. 2001). Taylor (1998a and b) investigated epifauna on Carpophyllum. A study by Cole et al. (2001) investigated recruitment of $C$. flexuosum around Northland. Various studies have recorded Carpophyllum distribution and abundances in local areas (refs. in Hurd et al. 2004).

Carpohyllum species are all dioecious, Fertile thalli have axillary clusters of receptacles. Carpophyllum flexuosum also has marginal receptacles on some lateral lamina (Lindauer et al. 1961).

\subsection{Cystophora J. Agardh 1848}

Womersley (1964) monographed Cystophora, describing 23 species, separated mainly by characters of the vegetative morphology and the arrangement of conceptacles on the receptacle. Adams (1994) lists six species of Cystophora from New Zealand: Cystophora torulosa (R. Brown) J. Agardh and C. retroflexa (Labillardière) J. Agardh are widespread. Cystophora distenta J. Agardh, C. platylobium (Mertens) J. Agardh, C. scalaris J. Agardh, and C. congesta Womersley \& Nizamuddin ex Womersley are found from Cook Strait southwards. Two species ( $C$. scalaris and $C$. distenta) are reported from the Auckland Islands (Adams 1994). Other species extend south as far as Stewart Island and east to the Chatham Islands (Nelson 1994).

Lindauer et al. (1961) also list C. dumosa (Greville) J. Agardh, a species that Womersley (1964) rejected as a nomen confusum under the then current ICBN rules. Womersley (1964) found most of the material used to establish Cystophora dumosa consisted of fragments of $C$. monilifera. The earliest valid description of $C$. dumosa is by Sonder (1846). According to Womersley, Sonder's material is a mix of fragments of C. monilifera and probably C. brownii. Doubtful reports of Australian species from New Zealand include Cystophora (= Caulocystis) cephalornithos, C. monilifera, $C$. paniculata and C. retorta. These are either misidentifications or Australian specimens with localities mislabelled (Lindauer et al. 1961, Womersley 1964, 1987).

Womersley (1964) created a new species, Cystophora congesta Womersley \& Nizamuddin that includes specimens recorded as C. dumosa, 
including those from New Zealand. Cystophora congesta is reported from the New Zealand mainland from Wellington southwards and from Stewart Island and the Chatham Islands. According to Womersley (1964) it is closely related to $C$. retroflexa and "occasional intergrades occur." Hybridisation has been reported in other species of Cystophora. Lindauer et al. (1961) states: "Within the New Zealand species [of Cystophora] a degree of hybridization occurs in certain areas where some of the species overlap. Cystophora platylobium seems quite distinct, but $C$. torulosa, $C$. scalaris, $C$. retroflexa and $C$. dumosa [=distenta] seem to intergrade. A full analysis of the degree of this variation needs to be made."

Several studies have recorded ecological interactions involving Cystophora. Cystophora species are settled preferentially by some reef fish (McDermott \& Shima 2005) and shelter higher numbers of invertebrates than other, less ramified, large brown algae (Taylor \& Cole 1994). Other workers have investigated the chemistry of Cystophora (Glombitza et al. 1997). Amico (1995) included several Cystophora species in a chemotaxonomic study of the Cystoseiraceae.

Several phylogenetic studies have included specimens of Cystophora. Rousseau \& De Reviers' (1999) phylogeny of the order Fucales, based on rDNA LSU and SSU, included three species of Cystophora and other Australian fucalean species. Cho et al. (2006) included a single (unidentified) specimen of Cystophora from Brighton Beach, New Zealand, in a phylogeny of the Fucales inferred from the psaA gene. A multi-locus phylogeny of the "crown" group of brown algae (Silberfield et al. 2010) included the Australian species Cystophora retorta and C. grevillei. Draisma et al. (2010) included two species of Cystophora in a multi-gene phylogeny. These studies have not elucidated relationships within Cystophora, but have identified Landsburgia as the sister genus to Cystophora, and placed Cystophora among other Cystoseiraceae, as well as showing the Cystoseiraceae are polyphyletic.

Most Cystophora species have bisexual conceptacles, although sometimes individual conceptacles have mainly oogonia or antheridia. Womersley (1964) notes that $C$. monilifera and $C$. racemosa can have unisexual conceptacles, but either single receptacles bear both types of conceptacle, or adjoining receptacles 
bear different types. Only $C$. siliquosa is fully dioecious, with separate male and female plants.

\subsection{Research questions}

\subsubsection{Hybridisation}

Hybrids have been reported in Carpophyllum (Hodge et al. 2010) and Cystophora (Womersley 1964). Hybridisation has been extensively investigated in the northern hemisphere fucalean genus Fucus. Morphological variation in Fucus has been ascribed to both environmental (Chapman 1995) and genetic factors (Anderson \& Scott 1998), and natural and artificial hybrids have been studied extensively (McLachlan et al. 1971, Coyer et al. 2002, Coyer et al. 2010).

Two questions immediately arise: (1) Are intermediate forms hybrids?; and (2) are hybrid zones widespread or geographically limited? A number of additional questions are likely to arise: If hybrids are widespread how are the species maintained? If they are limited do they represent zones of secondary contact following speciation due to climate change, geological processes or long distance dispersal (e.g., from Australia)? Further, if hybrids have persisted, is there evidence of hybridisation leading to speciation (reticulate evolution)?

\subsubsection{Genetic variation and population structure}

Large, negatively buoyant and non-motile eggs are assumed to limit dispersal ability at the gamete and zygote stage in fucalean algae, such as Carpophyllum and Cystophora, but drifting detached thalli might facilitate longer dispersal distances (Coleman \& Brawley 2005, Coleman \& Kelaher 2009, Fraser et al. 2009). Dispersal might also be extended by the retention of sporelings on the receptacles followed by release and rapid attachment (Schiel \& Foster 2006).

Dispersal ability should be closely related to genetic variation within and between populations. Broad-scale studies of population genetic structure in macroalgae often find high population structure, and this is related to (1) limited dispersal ability (Dayton 1973, Coleman \& Brawley 2005); and (2) historical 
processes, especially historical climate change (Hoarau et al. 2007, Maggs et al. 2008, Coyer et al. 2010). These processes have mostly been studied in the northern hemisphere, especially Europe, and there is little understanding of the effect of these processes in New Zealand, although some phylogeographic work has been done on fish (Hickey et al. 2009) and invertebrates (Goldstien et al. 2006, 2009).

All Carpophyllum species are endemic to New Zealand, which simplifies sampling across the range of the species, and allows population level studies to capture the history of the species. I will use mitochondrial markers to attempt to discern historical patterns of range expansion and contemporary patterns of gene flow by dispersal. Trans-Tasman distributions of some species of Cystophora are presumed to arise from long-distance dispersal (Parsons 1985), but the degree of isolation of New Zealand and Australian populations has not been studied. This raises the question of whether there have been multiple dispersal events between New Zealand and Australia or whether dispersal events are rare and ancient, with subsequent genetic differentiation.

\subsubsection{Phylogeny}

The relationships between species of Cystophora and Carpophyllum are not clear. In Carpophyllum characters such as the terete main axis of C. angustifolium or the large basal lamina of $C$. flexuosum might link Carpophyllum to a shared common ancestor with Sargassum. Alternatively these might be derived characters relating to the sheltered habitat of $C$. flexuosum and the exposed habitat of $C$. angustifolium.

Womersley (1964) produced a tentative phylogeny of Cystophora based on the arrangement of branching of the main axis and laterals, and Amico (1995) used a chemotaxonomical approach to group C. torulosa, $C$. congesta, $C$. scalaris and $C$. monilifera together, separate from a second group containing $C$. expansa and C. platylobium together, with $C$. monilifera (which Amico (1995) considered "more developed") distinct from both of these. It is not clear whether characters such as branching from the edge (rather than the face) of main axes are shared or 
derived characters. In both genera a molecular phylogeny might shed light on the development of these characters.

\subsubsection{Taxonomic questions}

Characters used to separate New Zealand species of Cystophora vary between authors. Lindauer et al. (1961) recognise $C$. dumosa as a species with characters intermediate between $C$. scalaris, $C$. retroflexa and C. torulosa. Womersley (1964) created a new species, $C$. congesta, which included some specimens assigned to $C$. dumosa, but Womersley's characters are hardly intermediate between the above three species. Adams (1994) also recognised C. congesta, but her illustration (Adams 1994, p. 141) does not agree with Womersley's description, and her choice of characters provided in a key for New Zealand species appears closer to Lindauer et al.'s (1961) than Womersley's (1964). I have found this key difficult to use, with ambiguous outcomes for several specimens. Molecular markers might be useful for testing species limits in Cystophora and assessing the value of different morphological characters.

\subsection{Structure of this thesis}

In Chapter 2 I investigate the phylogeography of Carpophyllum maschalocarpum using extensive sampling of a mitochondrial spacer marker from 32 populations. In Chapter 3 I look at patterns of hybridisation between Carpophyllum maschalocarpum and C. angustifolium from several populations from the northeastern North Island. In Chapter 4 I infer a phylogeny for Cystophora and compare this to species delimited using a DNA barcoding methodology. Chapter 5 examines the taxonomy of New Zealand species of Cystophora in some detail, resulting in the synonymisation of two pairs of species. Finally in Chapter 6 I present a summary of my findings, together with some additional data, in the context of approaches taken by other workers to species delimitation in brown algae. 
Because this thesis was written as a series of independent papers, there is some unavoidable repetition of introductory material and general information in each chapter.

\subsection{References}

ADAmS, N. M. (1994). Seaweeds of New Zealand: An illustrated guide. Christchurch, New Zealand: Canterbury University Press.

AdAMs, N. M. \& Nelson, W. A. (1984). Marine algae of the Kermadec Islands. A list of species. National Museum of New Zealand Miscellaneous Series, 10, 1-29.

AdAms, N. M. \& Nelson, W. A. (1985). The marine algae of the Three Kings Islands. A list of species. National Museum of New Zealand Miscellaneous Series, 13, 1-29.

AGARDH, J. G. (1848). Species genera et ordines algarum, seu descriptiones succinctae specierum, generum et ordinum, quibus algarum regnum constituitur. Volumen Primum. Algas fucoideas complectens. Lundae [Lund], Sweden: C.W.K. Gleerup.

AgARDH, J. G. (1877). De Algis Novae Zelandiae marinis. Lunds Universitets Års-Skrift, Afdelningen for Mathematik och Naturvetenskap, 14, 1-32.

AMICO, V. (1995). Marine brown algae of family of Cystoseiraceae: Chemistry and chemotaxonomy. Phytochemistry, 39, 1257-1279.

ANDERSON, C. I. H. \& SCOTT, G. W. (1998). The occurrence of distinct morphotypes within a population of Fucus spiralis. Journal of the Marine Biological Association of the U.K., 78, 1003-1006.

ANDREW, N. L. (1988). Ecological aspects of the common sea-urchin, Evechinus chloroticus, in northern New Zealand - A review. New Zealand Journal of Marine and Freshwater Research, $22,415-426$.

BALDAUF, S. L. (2008) An overview of the phylogeny and diversity of eukaryotes. Journal of Systematics and Evolution, 46, 263-273.

ChAPMAN, A. R. O. (1995). Functional ecology of fucoid algae: Twenty-Three years of progress, Phycologica, 34, 1-32.

Charrier, B., Coelho, S. M., Le Bail, A., Tonon, T., Michel, G., Potin, P., Kloareg, B., BoYen, C., Peters A. F. \& COCK, J. M. (2007). Development and physiology of the brown alga Ectocarpus siliculosus: two centuries of research, New Phytologist, 177, 319-322.

Cho, G. Y., Rousseau, F., Reviers, B. DE \& Boo, S. M. (2006). Phylogenetic relationships within the Fucales (Phaeophyceae) assessed by the photosystem I coding $p s a$ A sequences. Phycologia, $45,512-519$.

CHOAT, J. H. \& SCHIEL, D. R. (1982). Patterns of distribution and abundance of of large brown algae and invertebrate herbivores in subtidal regional of northern New Zealand. Journal of Experimental Marine Biology and Ecology, 60, 129-162.

Clayton, M. N. (1984). Evolution of the Phaeophyta with particular reference to the Fucales. Progress in Phycological Research, 3, 11-46.

Cole, R. G., BABCoCK, R. C., TRAVERS, V. \& CReESE, R. G. (2001). Distributional expansion of Carpophyllum flexuosum onto wave exposed reefs in northeastern New Zealand. New Zealand Journal of Marine and Freshwater Research, 35, 17-32. 
Coleman, M. A. \& BRAwley, S. H. (2005). Are life history characteristics good predictors of genetic diversity and structure? A case study of the intertidal alga Fucus spiralis (Heterokontophyta; Phaeophyceae). Journal of Phycology, 41, 753-762.

COlEman, M. A. \& Kelaher, B. P. (2009). Connectivity among fragmented populations of a habitat-forming alga, Phyllospora comosa (Phaeophyceae, Fucales) on an urbanised coast. Marine Ecology Progress Series, 381, 63-70.

Coyer, J. A., Hoarau, G., Costa, J. F., Hogerdjik, B., Billard, E., Valero, M., Pearson, G. A. \& OLSEN, J. L. (2010). Evolution and species diversification within the intertidal brown macroalgae Fucus spiralis/F. vesiculosus species complex in the North Atlantic. Molecular Phylogenetics and Evolution, doi:10.1016/j.ympev.2010.11.015.

Coyer, J. A., Peters, A. F., Hoarau, G., Stam, W. T. \& Olsen, J. L. (2002). Inheritance patterns of ITS1, chloroplasts and mitochondria in artificial hybrids of the seaweeds Fucus serratus and F. evanescens (Phaeophyceae). European Journal of Phycology 37: 173-178.

DAwson, A. E. E. (1940). Studies in the Fucales of New Zealand - II. Observations on the female frond of Carpophyllum flexuosum (Esp.) Grev. =Carpophyllum phyllanthus (Turn.) Hook. \& Harv. New Phytologist, 39, 285-302.

DAYTON, P. K. (1973). Dispersion, dispersal, and persistence of the annual intertidal alga Postelsia palmaeformis Ruprecht. Ecology, 54, 433-438.

DELF, E. M. (1939). Studies in the fucales of New Zealand I. The genus Carpophyllum Grev. Journal of Botany, London, 77, 129-138.

Draisma, S. G. A., BALlesteros, E., Rousseau, F. \& ThiBAut, T. (2010). DNA sequence data demonstrate the polyphyly of the genus Cystoseira and other Sargassaceae genera (Phaeophyceae). Journal of Phycology, 46, 1329-1345.

Dromgoole, F. I. (1973). A contribution to the biology of the genus Carpophyllum Grev. Unpublished PhD. thesis, University of Auckland, Auckland, New Zealand.

ESPER, E. J. C. (1802). Icones fucorum cum characteribus systematicis, synonimis (sic) auctorum et descriptionibus novarum specierum. Abbildungen der Tange mit beygefügten systematischen Kennzeichen, Anführungen der Schriftsteller, und Beschribungen der neuen Gattungen. Vol. Zweyter Theil. Nürnberg: Raspe.

FrASER, C. L., NikUla, R., SPENCER, H. G. \& WATERS, J. M. (2009). Kelp genes reveal effects of subantarctic sea ice during the Last Glacial Maximum. Proceedings of the National Academy of Sciences of the U.S.A., 106, 3249-3253.

GlombitzA, K. W., Keusgen, M. \& HAuperich, S. (1997). Fucophlorethols from the brown alga Sargassum spinuligerum and Cystophora torulosa. Phytochemistry, 46, 1417-1422.

GlombitZA, K. W. \& LI, S. (1991a). Fucophlorethols from the brown alga Carpophyllum maschalocarpum. Phytochemistry, 30, 3423-3427.

GlombitZA, K. W. \& LI, S. (1991b). Hydroxyphlorethols from the brown alga Carpophyllum maschalocarpum. Phytochemistry, 30, 2741-2745.

GLOMBITZA, K. W. \& SCHMIDT, A. (1999). Trihydroxyphlorethols from the brown alga Carpophyllum angustifolium. Phytochemistry, 51, 1095-1100.

Goldstien, S. J., Gemmell, N. J. \& SCHIEL, D. R. (2009). Colonisation and connectivity by intertidal limpets among New Zealand, Chatham and Sub-Antarctic Islands. I. Genetic connections. Marine Ecology Progress Series, 388, 111-119.

Goldstien, S. J., Gemmell, N. J., \& SchiEl, D. R. (2006). Comparative phylogeography of coastal limpets across a marine disjunction in New Zealand. Molecular Ecology, 15, 32593268 .

GREVILLE, R. K. (1830). Algae britannicae, or descriptions of the marine and other inarticulated plants of the British islands, belonging to the order Algae; with plates illustrative of the genera. Edinburgh \& London, United Kingdom: McLachlan \& Stewart; Baldwin \& Cradock. 
GUIRY, M. D. \& GUIRY, G. M. (2011). AlgaeBase. Retrieved, January 21, 2011, from http://www.algaebase.org.

Hickey, A. J. R., LAVERY, S. D., HANnAN, D. A., BAKer, C. S. \& Clements, K. D. (2009). New Zealand triplefin fishes (family Tripterygiidae): contrasting population structure and mtDNA diversity within a marine species flock. Molecular Ecology, 18, 680-696.

Hodge, F., Buchanan, J. \& ZucCAREllo, G. C. (2010). Hybridization between the endemic brown algae Carpophyllum maschalocarpum and C. angustifolium (Fucales): Genetic and morphological evidence. Phycological Research, 58, 239-247.

Hoarau, G., Coyer, J. A., Veldsink, J. H., Stam, W. T. \& Olsen, J. L. (2007). Glacial refugia and recolonization pathways in the brown seaweed Fucus serratus. Molecular Ecology, 16, 3606-3616.

Hurd, C. L., Nelson, W. A., FAlshaw, R. \& Neil, K. F. (2004). History, current status and future of marine macroalgal research in New Zealand: Taxonomy, ecology, physiology and human uses. Phycological Research, 52, 80-106.

LAING, R. M. (1926). A reference list of New Zealand marine algae. Transactions of the New Zealand Institute, 57, 126-185.

LI, S. \& GlOMBITZA, K. W. (1991). Carmalols and phlorethofuhalols from the brown alga Carpophyllum maschalocarpum. Phytochemistry, 30, 3417-3421.

Lindauer, V. W., Chapman, V. J. \& Aiken, M. (1961). The Marine Algae of New Zealand II: Phaeophyceae. Nova Hedwigia, 3, 129-350.

Maggs, C. A., Castilho, R., Foltz, D., Henzler, C., Jolly, M. T., Kelly, J., Olsen, J., Perez, K. E., STAM, W., VÄINÖLÄ, R., VIARD, F., \& WARES, J. (2008). Evaluating signatures of glacial refugia for North Atlantic benthic marine taxa. Ecology, 89, S108-S122.

Mattio, L., PAyri, C. E. \& Stiger-Pouvreau, V. (2008). Taxonomic revision of Sargassum (Fucales, Phaeophyceae) from French Polynesia based on morphological and molecular analyses. Journal of Phycology, 44, 1541-1555.

MCDERMOTT, C. J. \& SHIMA, J. S. (2006). Ontogenetic shifts in microhabitat preference of the temperate reef fish Forsterygion lapillum: implications for population limitation. Marine Ecology Progress Series, 320, 259-266.

MCLachlan, J., ChEn, L. C-M. \& Edelstein, T. (1971). The culture of four species of Fucus under laboratory conditions. Canadian Journal of Botany, 49, 1463-1469.

Montagne, C. (1845). Plantes cellulaires. In: Voyage au Pôle Sud et dans l'Océanie sur les corvettes l'Astrolabe et la Zelée, pendant les années 1837-1838-1839-1840, sous le commandement de M.J. Dumont-d'Urville. Botanique. 1, i-xiv, 1-349.

NAYLOR, M (1954). The female conceptacle and young sporeling of the four New Zealand species of Carpophyllum. Transactions and Proceedings of the Royal Society of New Zealand, 82, 1-6.

NELSON, W. A. (1994). Distribution of macroalgae in New Zealand - an archipelago in space and time. Botanica Marina, 37, 221-223.

PAPENFUSS, G. F. (1964). Catalogue and bibliography of Antarctic and Sub-Antarctic benthic marine algae. In Lee, M. O. (Ed.), Bibliography of the Antarctic Seas, 1, 1-76. Washington DC, American Geophysical Union.

PARSONS, M. J. (1985). New Zealand seaweed flora and its relationships. New Zealand Journal of Marine and Freshwater Research, 19, 131-138.

RICHARD, A. (1832). Essai d'une flore de la Nouvelle-Zélande. In Lesson, A. \& Richard, A. (Eds.) Voyage de découvertes de l'Astrolabe exécuté.pendant les années 1826-1827-1828-1829, sous le commandement de M.J. Dumont d'Urville. Paris: J. Tastu, Éditeur.

Rousseau, F. \& DE REVIERS, B. (1999). Circumscription of the order Ectocarpales (Phaeophyceae): bibliographical synthesis and molecular evidence. Cryptogamie Algologie, 20, 5-18. 
SCHIEL, D. R. (1990). Macroalgal assemblages in New Zealand: structure, interactions and demography. Hydrobiologia, 192, 59-76.

SCHIEL, D. R. \& FOSTER, M. S. (2006). The population biology of large brown seaweeds: Ecological consequences of multiphase life histories in dynamic coastal environments. Annual Review of Ecology, Evolution and Systematics, 37, 343-372.

SCHIEL, D. R., ANDREW, N. L. \& Foster, M. S. (1995). The structure of subtidal algae and invertebrate assemblages at the Chatham Islands, New Zealand. Marine Biology, 123, 355-367.

SHEARS, N. T. \& BABCOCK, R. C. (2007). Quantitative description of New Zealand's shallow subtidal reef communities (Science for Conservation No. 280). Wellington, New Zealand: New Zealand Department of Conservation.

Silberfeld, T., Leigh, J. W., Verbruggen, H., Cruaud, C., De ReViers, B. \& Rousseau, F. (2010). A multi-locus time-calibrated phylogeny of the brown algae (Heterokonta, Ochrophyta, Phaeophyceae): Investigating the evolutionary nature of the "brown algal crown radiation." Molecular Phylogenetics and Evolution, 56, 659-674.

Sonder, O. G. (1846). Algae. In Lehmann, C. (Ed.) Plantae Preissianae sive enumeratio plantarum quas in Australasia occidentali et meridionali-occidentali annis 1838-1841 collegit Ludovicus Preiss. Vol. 2. Hamburgi [Hamburg], Germany: Sumptibus Meissneri.

TAYLOR, R. B. (1998a). Seasonal variation in assemblages of mobile epifauna inhabiting three sub-tidal brown seaweeds in northeastern New Zealand. Hydrobiologia, 361, 25-35.

TAYLOR, R. B. (1998b). Short-term dynamics of a seaweed epifaunal assemblage. Journal of Experimental Marine Biology and Ecology, 227, 67-82.

TAYLOR, R. B. \& COLE, R. G. (1994). Mobile epifauna on subtidal brown seaweeds in northeastern New Zealand. Marine Ecology Progress Series, 115, 271-282.

TURNER, D. (1809-1811). Fuci sive plantarum fucorum generi a botanicis ascriptarum icones descriptiones et historia. Fuci, or coloured figures and descriptions of the plants referred by botanists to the genus Fucus. Vol. 3. Londini [London]: typis J. M'Creery, impensis J. et A. Arch.

Villouta, E., Chadderton, W. L., Pugsley, C. W. \& Hay, C. H. (2001). Effects of the sea urchin (Evechinus chloroticus) grazing in Dusky Sound, Fiordland, New Zealand. New Zealand Journal of Marine and Freshwater Research, 35, 1007-1024.

Womersely, H. B. S. (1964). The morphology and taxonomy of Cystophora and related genera (Phaeophyta). Australian Journal of Botany, 12, 53-110.

Womersley, H. B. S. (1987). The marine benthic flora of southern Australia. Part II. Adelaide, Australia: South Australian Government Printing Division.

Womersley, H. B. S. (1954). Australian species of Sargassum, subgenus Phyllotrichia. Australian Journal of Botany, 2, 337-354. 
Chapter 2

Decoupling of short and long distance dispersal pathways in the endemic New Zealand seaweed Carpophyllum maschalocarpum (Phaeophyceae, Fucales). 


\subsection{Abstract}

The processes that produce and maintain genetic structure in organisms operate at different time scales and on different life history stages. In marine macroalgae, gene flow occurs through gamete/zygote dispersal and rafting by adult thalli. Population genetic patterns arise from this contemporary gene flow interacting with historical processes. Spatial patterns of mitochondrial DNA variation were analysed to investigate contemporary and historical dispersal patterns in the New Zealand endemic fucalean brown alga Carpophyllum maschalocarpum (Turner) Greville. Populations bounded by habitat discontinuities were often strongly differentiated from adjoining populations over scales of tens of kilometres and intrapopulation diversity was generally low, except for one region of north-east New Zealand (the Bay of Plenty). There was evidence of strong connectivity between the northern and eastern regions of New Zealand's North Island and between the North and South Islands of New Zealand and the Chatham Islands (separated by $650 \mathrm{~km}$ of open ocean). Moderate haplotypic diversity was found in Chatham Islands populations while other southern populations showed low diversity consistent with Last Glacial Maximum retreat and subsequent recolonisation. I suggest that ocean current patterns and prevailing westerly winds facilitate long distance dispersal by floating adult thalli, decoupling genetic differentiation of Chatham Island populations from dispersal potential at the gamete/zygote stage. This study highlights the importance of encompassing the entire range of a species when inferring dispersal patterns from genetic differentiation, as realised dispersal distances can be contingent on local or regional oceanographic and historical processes.

Abbreviations:

AMOVA, Analysis of Molecular Variation; LGM, Last Glacial Maximum; CTAB, Cetyltrimethylammonium Bromide; SSCP, Single Stranded Conformational 
Polymorphism; SAMOVA, Spatial Analysis of Molecular Variance; SST, Sea Surface Temperature; TBE, Tris-Borate-EDTA.

\subsection{Introduction}

MuLTIPLE dispersal mechanisms are found in many organisms. In many plant species most seed dispersal is limited to local populations, but alternative dispersal mechanisms connect distant populations (Higgins et al. 2003). Short dispersal distances are also found in many sessile or demersal marine species, but occasional long distance dispersal events connect populations across wide habitat disjunctions (Pakker et al. 1996, Reed et al. 1988, Fraser et al. 2009). Dispersal distance in marine organisms is often correlated with the duration of a pelagic larval stage (Bohonak 1999), but many marine organisms have the potential to disperse as adults, either because of inherent buoyancy or by rafting on floating substrata (e.g., drift wood, algae or pumice) (Thiel \& Gutow 2005a).

Long distance dispersal mechanisms differ from short distance mechanisms in two ways: Firstly, long distance dispersal mechanisms are often mediated by large scale processes (climate patterns, ocean currents, seasonal migrations of animal vectors), rather than local conditions (turbulence, wave regimes, inshore currents). Secondly, long distance dispersal events are rare, stochastic and will seldom be observed directly, but will become evident in a species' range or population genetic structure over long time scales. Consequently, factors that mediate long distance dispersal are decoupled from factors that mediate most observed dispersal (Kinlan et al. 2005, Thiel \& Haye 2006).

Dispersal by floating thalli might be an important dispersal mechanism for macroalgae (Deysher \& Norton 1982, van den Hoek 1987, Thiel \& Gutow 2005b, Fraser et al. 2009). Floating macroalgal thalli are abundant and can release viable propagules for a considerable time (Kingsford 1992, Smith 2002, Macaya et al. 2005, Hernandez-Carmona et al. 2006, McKenzie \& Bellgrove 2008), allowing dispersal between populations separated by habitat disjunctions such as soft sediment coasts or large stretches of open water (Dethier et al. 2003). Genetic evidence for long distance dispersal in macroalgae across open ocean is accumulating but still rare (Tatarenkov et al. 2007, Fraser et al. 2009). 
Fucalean algae (Phaeophyceae) have a monophasic life history with dispersal from maternal thalli by non-motile, negatively buoyant eggs or zygotes (Kendrick \& Walker 1991, 1995, Norton 1992, Reed et al. 1992, Chapman 1995). Populations are predicted to show strong genetic differentiation because of limited dispersal potential at this stage. Population genetic studies of northern hemisphere Fucaceae have shown population differentiation (Coyer et al. 2003, Coleman \& Brawley 2005a, Hoarau et al. 2007, Tatarenkov et al. 2007), but often at larger scales than predicted from direct measurements of propagule dispersal. Long distance dispersal by detached, floating thalli is often invoked to explain population connectivity at large scales (van den Hoek 1987, Coleman \& Brawley 2005b, Thiel \& Gutow 2005b), especially where local population differentiation is high (Muhlin et al. 2008, Coleman \& Kelaher 2009),

More generally, the use of molecular markers has uncovered higher than expected genetic population structure in marine organisms. Currents, upwelling, habitat disjunctions, and larval behaviour limit dispersal even for organisms with long pelagic duration (Sotka et al. 2004). Historical events are also evident in genetic structure. Marko (2004), for example, found different biogeographical histories in two species of the intertidal gastropod Nucella in the northeastern Pacific, despite similar dispersal modes. Retreat from high latitudes following glacial cooling, followed by recolonisation from either northern or southern refugia is a common pattern (Hoarau et al. 2007, Maggs et al. 2008) although marine species appear to show more variable responses to global cooling than terrestrial species (Wares \& Cunningham 2001, Marko et al. 2010).

Carpophyllum maschalocarpum (Turner) Greville is a common fucalean alga that is endemic to New Zealand. All Carpophyllum species are dioecious. Female thalli produce large (c. $200 \mu \mathrm{m}$ diameter) non-motile eggs that are extruded to the surface of receptacles but retained by a mucilaginous stalk during fertilisation (Naylor 1954, Clayton 1992). Following fertilisation, zygotes remain attached to the maternal thallus for up to 28 days before release (Delf 1939, Dromgoole 1973). As eggs and zygotes are negatively buoyant, the species is expected to have low dispersal ability at these life stages, but long distance dispersal is possible as adult thalli usually possess pneumatocysts and are 
frequently found floating on the sea surface (Kingsford 1992). Floating female thalli bearing zygotes or germlings could establish new populations in the absence of fertile males.

Carpophyllum maschalocarpum forms extensive stands in the shallow subtidal of New Zealand's rocky coasts, where it is the second most abundant algal species by biomass and an important structuring organism (Shears \& Babcock 2007). The species is present around both main islands of New Zealand and the Chatham Islands, but is absent from the south-east of the South Island and the sub-Antarctic islands (Morton \& Miller 1968, Shears \& Babcock 2007, Nelson et al. 1991, Schiel et al. 1995).

Carpophyllum maschalocarpum's extensive range, potential multiple dispersal modes, ecological importance and ubiquity in rocky habitats make it an ideal organism for investigating phylogeographic processes. The species' range is interrupted by significant habitat breaks (Fig. 2.1), including extensive soft sediment coast around both main islands of New Zealand and stretches of deep water between the main islands (Cook Strait), and between the mainland and the Chatham Islands, $650 \mathrm{~km}$ east of the mainland (Morton \& Miller 1968, Nelson 1994, Shears et al. 2008). The factors mediating the two mechanisms of dispersal should be a major determinant of genetic structure in Carpophyllum maschalocarpum. If dispersal by floating thalli is rare, high population differentiation is expected, especially between populations separated by discontinuities in habitat. If floating dispersal is common, connectivity is expected to be mediated by current and wind patterns.

The aim of this study is to determine if the population genetic variation of C. maschalocarpum is congruent with dispersal modes. Specifically I compare connectivity between adjacent (10s of kilometres) and distant (100s of kilometres) populations, test for congruence between phylogeographic structure and biogeographic provinces proposed by Shears et al. (2008) (Fig. 2.1), and test for genetic isolation by distance and population expansion. 


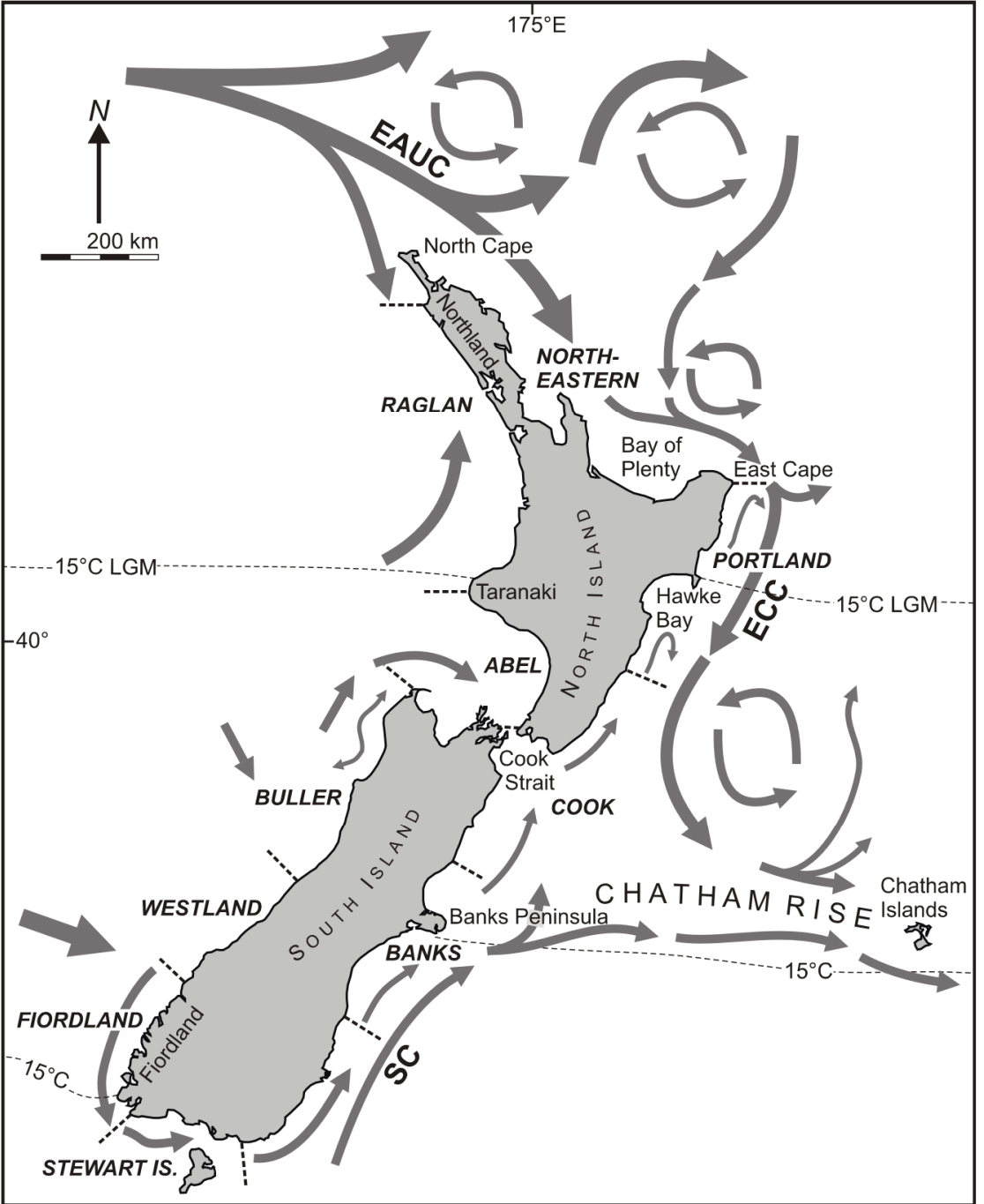

Fig. 2.1 New Zealand map showing major currents (Heath 1985) and locations referred to in the text. Boundaries of bioregions proposed by Shears et al. 2008 are indicated by dashed lines and named in italics. EAUC: East Auckland Current; ECC: East Cape Current; SC:

Southland Current. Dashed lines show present day $15^{\circ} \mathrm{C} \mathrm{SST} \mathrm{isotherm}$ and estimated $15^{\circ} \mathrm{C}$ isotherm for the Last Glacial Maximum (Barrows \& Juggins 2005). 


\subsection{Materials and Methods}

\section{Sampling and DNA extraction}

Specimens identified in the field as Carpophyllum maschalocarpum were collected from 32 sites around New Zealand (Table 1.1), representing the entire range of $C$. maschalocarpum with the exception of Fiordland, where the species is relatively rare (Shears \& Babcock 2007). Thalli were collected haphazardly, at least $1 \mathrm{~m}$ apart. Tips of thalli for DNA extraction were rapidly dried and stored in silica gel. In addition, one or more typical thalli from each species/site were prepared as voucher specimens. Five Carpophyllum angustifolium J. Agardh specimens and a number of putative $C$. angustifolium $\times C$. maschalocarpum hybrid thalli were also included as outgroup specimens and to assist in genetic identification of hybrid specimens. DNA was extracted from approximately 2-5 mg of dry tissue using a modified CTAB buffer procedure (Zuccarello \& Lokhorst 2005), with the addition of $1 \%$ polyvinylpolypyrrolidone to the extraction buffer.

PCR conditions and primers

The 23S-tRNA Lys mitochondrial spacer (225 bp) was amplified from a total of 651 samples, using primers (forward: fuc2625F 5'-

GCTGTGAGGTTTTTAGCTGACC-3' and reverse: fuc3141R 5'TCCACCACTCTAACCAACTGAG-3') designed from alignments of the Fucus, Laminaria and Desmarestia mitochondrial genomes (Oudot-Le Seq et al. 2002, 2006).

PCR amplifications used a touchdown routine with an initial denaturation step of $94^{\circ} \mathrm{C}$ for $4 \mathrm{~min}$, followed by 5 cycles of $1 \mathrm{~min}$ at $94^{\circ} \mathrm{C}, 1 \mathrm{~min}$ at $55^{\circ} \mathrm{C}$ $\left(-1^{\circ} \mathrm{C} /\right.$ cycle $)$ and $1 \mathrm{~min}$ at $72^{\circ} \mathrm{C}$, followed by 30 cycles of $1 \mathrm{~min}$ at $94^{\circ} \mathrm{C}, 1 \mathrm{~min}$ at $50^{\circ} \mathrm{C}$ and $1 \mathrm{~min}$ at $72^{\circ} \mathrm{C}$, with a final extension of $72^{\circ} \mathrm{C}$ for $10 \mathrm{~min}$. The PCR mix contained $1 \mu \mathrm{L}$ genomic DNA, 0.5 U Taq DNA polymerase (New England Biolabs, MA. USA) 1X ThermoPol reaction buffer (NEB), 7.5 pmoles of each primer, 200 nmoles dNTP, 5\% DMSO and 0.01\% BSA. Amplified products were checked for length and yield on $1 \%$ agarose gels stained with ethidium bromide. 
Populations were screened for variable haplotypes by SSCP (Zuccarello et al. 1999, Sunnucks et al. 2000). 3-4 $\mu \mathrm{L}$ PCR product was mixed with $9 \mu \mathrm{L} 98 \%$ formamide, $10 \mathrm{mM} \mathrm{NaOH}, 0.025 \%$ bromophenol blue, $0.025 \%$ xylene cyanol. Samples were denatured at $95-100^{\circ} \mathrm{C}$ for $5 \mathrm{~min}$, then snap cooled on ice before loading. Gels (225 mm long and $0.75 \mathrm{~mm}$ thick, D-Code System, BioRad, Hercules, CA. USA) contained 9\% 37.5:1 acrylamide/bis-acrylamide (Sigma Aldrich, St Louis, MO. USA) in 0.5X TBE buffer with the addition of $10 \%$ glycerol. Electrophoresis was carried out for $18-20 \mathrm{hrs}$ at $7 \mathrm{~W}$ in $0.5 \mathrm{X}$ TBE buffer at $4^{\circ} \mathrm{C}$. After electrophoresis, gels were silver stained following protocols in Bassam et al. (1991) and banding patterns scored by eye. One or more of each haplotype indicated by SSCP was sequenced from each population, as well as any samples giving ambiguous SSCP profiles. Amplification for sequencing used the same PCR conditions and reverse primer as above, but used a novel forward primer (fuc2512F: 5' -CCGGGTAGCTACATCGAGAA-3') that anneals approximately $100 \mathrm{bp}$ further toward the 5 ' end of the fragment, to ensure accurate reads of the $5^{\prime}$ end of the spacer.

Generally SSCP banding and sequencing results were concordant. In very few cases haplotypes were not easily distinguished by SSCP and all samples were sequenced. PCR products were cleaned with ExoSAP-IT (USB, Cleveland, OH, USA) enzymes and sequenced commercially (Macrogen Inc., Seoul, South Korea). Sequences from 210 samples were included in the alignment.

\section{Data analysis}

Sequences were aligned using the ClustalW algorithm in MEGA 3.1 (Kumar et al. 2004) and checked by eye. Alignment was straightforward, requiring insertion of a single gap to accommodate outgroups. Haplotype networks were generated in TCS 1.21 (Clement et al. 2000). Arlequin 3.11 (Excoffier et al. 2005) was used to generate summary population genetic statistics and perform neutrality tests (Tajima's D, Fu \& Li's F* and D*, and Fu's $\mathrm{F}_{\mathrm{s}}$ ). Neutrality indices were tested against 2000 coalescence simulations assuming demographic stability and neutrality.

Pairwise $\Phi_{\text {st }}$ values were calculated in Arlequin 3.11 for Bay of Plenty populations (in which shared haplotypes were reasonably frequent) and tested for 
significance by 1023 permutations. Mantel tests, also implemented in Arlequin 3.11, were used to determine isolation by distance, first for all populations then for mainland populations (excluding Chatham Island populations). A matrix of shortest over-water geographic distances between populations was calculated and tested for correlation with pairwise $\Phi_{\text {st }}$, with significance tested against 2000 permutations. A second test was made using only the north-south component of these distances.

AMOVAs, implemented in Arlequin 3.11, were used to compare population partitions found in C. maschalocarpum with proposed marine biogeographic regions (Shears et al. 2008). These were compared to genetic structure indicated by SAMOVA (Spatial Analysis of Molecular Variance, Dupanloup et al. 2002) implemented in SAMOVA 1.0. This uses a simulated annealing process to group adjoining populations into K-groups so as to maximise genetic distance between groups (maximum $\mathrm{F}_{\mathrm{ct}}$ ), while minimising distance within groups (minimum $\mathrm{F}_{\mathrm{sc}}$ ). $\mathrm{K}$ was iterated in successive runs until a maximum $\mathrm{F}_{\mathrm{ct}}$ was calculated, and significance of fixation indexes tested by 1000 permutations.

Mismatch distribution analysis (Rogers \& Harpending 1992), implemented in Arlequin 3.11, was used to test for signatures of spatial expansion in frequency distributions of pairwise sequence differences. Analyses were applied to the total data and separately to populations partitioned into two groups as indicated by SAMOVA and tested against 5000 coalescent simulations assuming spatial expansion. Results were interpreted in the context of simulations using stepping stone and infinite island models. Here unimodal frequency distributions of pairwise mutational distances are regarded as evidence for past population expansions, but this signature is weakened or removed where populations are subdivided with low migration rates (Ray et al. 2003, Excoffier 2004). 
Table 2.1: Geographic locations, numbers of specimens sampled, mtDNA spacer haplotype designations and population diversity indices for Carpophyllum maschalocarpum. Hyphens in gene diversity and nucleotide diversity columns indicate populations where substantial introgression by $C$. angustifolium was detected and values were not calculated.

\begin{tabular}{|c|c|c|c|c|c|c|c|c|}
\hline $\begin{array}{l}\text { Map ID } \\
\text { (Fig 2.2) }\end{array}$ & Site & $\mathbf{N}$ & Latitude & Longitude & $\begin{array}{l}\text { Herbarium } \\
\text { number of } \\
\text { exemplars }\end{array}$ & Haplotypes present (n) & $\begin{array}{l}\text { Gene diversity } \boldsymbol{h} \pm \\
\text { S.D. }\end{array}$ & $\begin{array}{l}\text { Nucleotide diversity } \\
\pi \square \pm \text { S.D. }\end{array}$ \\
\hline 1 & $\begin{array}{l}\text { Hooper Point, } \\
\text { Northland }\end{array}$ & 47 & $34^{\circ} 24^{\prime} 56^{\prime \prime} \mathrm{S}$ & $172^{\circ} 51^{\prime} 13^{\prime \prime} \mathrm{E}$ & - & $\begin{array}{l}21(10), 34(34), 65(1), \\
66(1), 67(1)\end{array}$ & - & - \\
\hline 2 & $\begin{array}{l}\text { North Cape, } \\
\text { Northland }\end{array}$ & 10 & $34^{\circ} 24^{\prime} 57^{\prime \prime} \mathrm{S}$ & $173^{\circ} 03^{\prime} 09^{\prime \prime} \mathrm{E}$ & WELT A031664 & $30(8), 31(1), 32(1)$ & - & - \\
\hline 3 & $\begin{array}{l}\text { Matai Bay, } \\
\text { Northland }\end{array}$ & 18 & $34^{\circ} 49^{\prime} 37^{\prime \prime} \mathrm{S}$ & $173^{\circ} 24^{\prime} 54^{\prime \prime} \mathrm{E}$ & - & $68(18)$ & 0 & 0 \\
\hline 4 & Ahipara, Northland & 25 & $35^{\circ} 10^{\prime} 10^{\prime \prime} \mathrm{S}$ & $173^{\circ} 06^{\prime} 30^{\prime \prime} \mathrm{E}$ & - & $40(1), 52(24)$ & $0.0800 \pm 0.0722$ & $0.0004 \pm 0.0008$ \\
\hline 5 & $\begin{array}{l}\text { Wekarua, } \\
\text { Northland }\end{array}$ & 19 & $34^{\circ} 56^{\prime} 42^{\prime \prime} \mathrm{S}$ & $173^{\circ} 39^{\prime} 12^{\prime \prime} \mathrm{E}$ & WELT A031665 & $\begin{array}{l}30(7), 33(1), 47(7), 50 \\
(4)\end{array}$ & - & \\
\hline 6 & $\begin{array}{l}\text { Cape Wiwiki, } \\
\text { Northland }\end{array}$ & 21 & $35^{\circ} 09^{\prime} 22^{\prime \prime} \mathrm{S}$ & $174^{\circ} 07^{\prime} 20^{\prime \prime} \mathrm{E}$ & - & $21(21)$ & 0 & 0 \\
\hline 7 & $\begin{array}{l}\text { Bland Bay, Bay of } \\
\text { Islands }\end{array}$ & 20 & $35^{\circ} 20^{\prime} 31^{\prime \prime} \mathrm{S}$ & $174^{\circ} 21^{\prime} 58^{\prime \prime} \mathrm{E}$ & WELT ASG290 & $13(20)$ & 0 & 0 \\
\hline 8 & $\begin{array}{l}\text { Poor Knights } \\
\text { Islands }\end{array}$ & 10 & $35^{\circ} 27^{\prime} 40^{\prime \prime} \mathrm{S}$ & $174^{\circ} 44^{\prime} 20^{\prime \prime} \mathrm{E}$ & $\begin{array}{l}\text { WELT A031311, } \\
\text { A031317, A031319 }\end{array}$ & $21(10)$ & 0 & 0 \\
\hline 9 & $\begin{array}{l}\text { Waterfall Reef, } \\
\text { Leigh, Northland }\end{array}$ & 11 & $36^{\circ} 16^{\prime} 08^{\prime \prime} \mathrm{S}$ & $174^{\circ} 47^{\prime} 53^{\prime \prime} \mathrm{E}$ & $\begin{array}{l}\text { WELT A031318, } \\
\text { A031320 }\end{array}$ & $01(2), 13(8), 36(1)$ & $0.4727 \pm 0.1617$ & $0.0067 \pm 0.0049$ \\
\hline 10 & $\begin{array}{l}\text { Matheson Bay, } \\
\text { Northland }\end{array}$ & 34 & $3618^{\prime} 05^{\prime \prime} \mathrm{S}$ & $174^{\circ} 47^{\prime} 58^{\prime \prime} \mathrm{E}$ & - & $\begin{array}{l}01(2), 13(27), 55(1), 56 \\
(1), 57(2), 66(1)\end{array}$ & $0.3708 \pm 0.1042$ & $0.0063 \pm 0.0044$ \\
\hline 11 & $\begin{array}{l}\text { Sailors Grave, Bay } \\
\text { of Plenty }\end{array}$ & 20 & $36^{\circ} 57^{\prime} 37^{\prime \prime} \mathrm{S}$ & $175^{\circ} 50^{\prime} 43^{\prime \prime} \mathrm{E}$ & $\begin{array}{l}\text { WELT A031312- } \\
\text { A031316, A031331 }\end{array}$ & $\begin{array}{l}20(1), 21(1), 25(2), 27 \\
(1), 28(13), 29(1), 70(1)\end{array}$ & $0.5842 \pm 0.1270$ & $0.0084 \pm 0.0056$ \\
\hline
\end{tabular}


Table 2.1 (Continued)

\begin{tabular}{|c|c|c|c|c|c|c|c|c|}
\hline $\begin{array}{l}\text { Map ID } \\
\text { (Fig 2.2) }\end{array}$ & Site & $\mathbf{N}$ & Latitude & Longitude & $\begin{array}{l}\text { Herbarium } \\
\text { number of } \\
\text { exemplars }\end{array}$ & Haplotypes present (n) & $\begin{array}{l}\text { Gene diversity } h \pm \\
\text { S.D. }\end{array}$ & $\begin{array}{l}\text { Nucleotide diversity } \\
\pi \square \pm \text { S.D. }\end{array}$ \\
\hline 12 & $\begin{array}{l}\text { Otanga, Bay of } \\
\text { Plenty }\end{array}$ & 25 & $37^{\circ} 32^{\prime} 59^{\prime \prime} \mathrm{S}$ & $178^{\circ} 09^{\prime} 41^{\prime \prime} \mathrm{E}$ & - & $\begin{array}{l}14(3), 16(3), 21(2), 22 \\
(1), 26(3), 28(9), 39(3), \\
43(1)\end{array}$ & $0.8367 \pm 0.0539$ & $0.0152 \pm 0.0090$ \\
\hline 13 & $\begin{array}{l}\text { Maraehako Bay, } \\
\text { Bay of Plenty }\end{array}$ & 25 & $37^{\circ} 40^{\prime} 20^{\prime \prime} \mathrm{S}$ & $177^{\circ} 47^{\prime} 48^{\prime \prime} \mathrm{E}$ & - & $\begin{array}{l}14(15), 15(3), 16(2), 17 \\
(1), 18(1), 19(2), 23(2), \\
38(2), 71(1), 72(1)\end{array}$ & $0.7425 \pm 0.0813$ & $0.0065 \pm 0.0045$ \\
\hline 14 & $\begin{array}{l}\text { Maketu, Bay of } \\
\text { Plenty }\end{array}$ & 24 & $37^{\circ} 44^{\prime} 41^{\prime \prime} \mathrm{S}$ & $176^{\circ} 28^{\prime} 13^{\prime \prime} \mathrm{E}$ & WELT A031333 & $58(21), 59(1), 60(2)$ & $0.2355 \pm 0.1093$ & $0.0017 \pm 0.0019$ \\
\hline 15 & $\begin{array}{l}\text { Opape, Bay of } \\
\text { Plenty }\end{array}$ & 21 & $37^{\circ} 58^{\prime} 20^{\prime \prime} \mathrm{S}$ & $177^{\circ} 25^{\prime} 15^{\prime \prime} \mathrm{E}$ & - & 01 (1), 14 (19), 69 (1), & $0.1857 \pm 0.1102$ & $0.0021 \pm 0.0021$ \\
\hline 16 & Horoera, East Cape & 24 & $37^{\circ} 38^{\prime} 17^{\prime \prime} \mathrm{S}$ & $178^{\circ} 28^{\prime} 29^{\prime \prime} \mathrm{E}$ & WELT A031310 & $\begin{array}{l}21(19), 52(1), 61(1), 62 \\
(1), 64(2)\end{array}$ & $0.3768 \pm 0.1224$ & $0.0050 \pm 0.0038$ \\
\hline 17 & $\begin{array}{l}\text { Whale Bay, } \\
\text { Waikato }\end{array}$ & 20 & $37^{\circ} 49^{\prime} 22^{\prime \prime} \mathrm{S}$ & $174^{\circ} 48^{\prime} 02^{\prime \prime} \mathrm{E}$ & - & $\begin{array}{l}01 \text { (17), } 06 \text { (1), } 35 \text { (1), } 37 \\
\text { (1) }\end{array}$ & $0.2842 \pm 0.1284$ & $0.0013 \pm 0.0016$ \\
\hline 18 & $\begin{array}{l}\text { Kiritehere, } \\
\text { Waikato }\end{array}$ & 20 & $38^{\circ} 19^{\prime} 31^{\prime \prime} \mathrm{S}$ & $174^{\circ} 42^{\prime} 07^{\prime \prime} \mathrm{E}$ & WELT A024176 & $\begin{array}{l}01 \text { (17), } 02 \text { (1), } 04 \text { (1), } 05 \\
\text { (1) }\end{array}$ & $0.2842 \pm 0.1284$ & $0.0022 \pm 0.0022$ \\
\hline 19 & $\begin{array}{l}\text { Kaiti Beach, } \\
\text { Gisborne }\end{array}$ & 23 & $38^{\circ} 40^{\prime} 56^{\prime \prime} \mathrm{S}$ & $178^{\circ} 01^{\prime} 46^{\prime \prime} \mathrm{E}$ & WELT A031332 & $21(21), 63(1), 67$ (1) & $0.1700 \pm 0.1025$ & $0.0054 \pm 0.0040$ \\
\hline 20 & $\begin{array}{l}\text { Waipatiki, Hawke } \\
\text { Bay }\end{array}$ & 23 & $39^{\circ} 18^{\prime} 19^{\prime \prime} \mathrm{S}$ & $176^{\circ} 58^{\prime} 29^{\prime \prime} \mathrm{E}$ & $\begin{array}{l}\text { WELT A031324, } \\
\text { A031325 }\end{array}$ & $08(21), 11(2)$ & $0.1660 \pm 0.0976$ & $0.0015 \pm 0.0017$ \\
\hline 21 & $\begin{array}{l}\text { Ahuriri St, Port } \\
\text { Napier }\end{array}$ & 15 & $39^{\circ} 28^{\prime} 42^{\prime \prime} \mathrm{S}$ & $176^{\circ} 54^{\prime} 13^{\prime \prime} \mathrm{E}$ & WELT A031323 & $08(15)$ & 0 & 0 \\
\hline 22 & $\begin{array}{l}\text { Pihama, South } \\
\text { Taranaki }\end{array}$ & 21 & $39^{\circ} 31^{\prime} 17^{\prime \prime} \mathrm{S}$ & $173^{\circ} 54^{\prime} 55^{\prime \prime} \mathrm{E}$ & $\begin{array}{l}\text { WELT A031321, } \\
\text { A031322, A031330 }\end{array}$ & $01(18), 07$ (3) & $0.2571 \pm 0.1104$ & $0.0011 \pm 0.0015$ \\
\hline 23 & $\begin{array}{l}\text { Pukerua Bay, } \\
\text { Wellington }\end{array}$ & 20 & $41^{\circ} 01^{\prime} 29^{\prime \prime} \mathrm{S}$ & $174^{\circ} 54^{\prime} 06^{\prime \prime} \mathrm{E}$ & WELT A031309 & $01(20)$ & 0 & 0 \\
\hline
\end{tabular}




\begin{tabular}{|c|c|c|c|c|c|c|c|c|}
\hline $\begin{array}{l}\text { Map ID } \\
\text { (Fig 2.2) }\end{array}$ & Site & $\mathbf{N}$ & Latitude & Longitude & $\begin{array}{l}\text { Herbarium } \\
\text { number of } \\
\text { exemplars }\end{array}$ & Haplotypes present (n) & $\begin{array}{l}\text { Gene diversity } \boldsymbol{h} \pm \\
\text { S.D. }\end{array}$ & $\begin{array}{l}\text { Nucleotide diversity } \\
\pi \square \pm \text { S.D. }\end{array}$ \\
\hline 24 & $\begin{array}{l}\text { Riversdale, } \\
\text { Wairarapa }\end{array}$ & 15 & $41^{\circ} 06^{\prime} 25^{\prime \prime} \mathrm{S}$ & $176^{\circ} 04^{\prime} 11^{\prime \prime} \mathrm{E}$ & WELT A031308 & $01(12), 12(3)$ & $0.3429 \pm 0.1278$ & $0.0046 \pm 0.0036$ \\
\hline 25 & $\begin{array}{l}\text { Wharanui, } \\
\text { Kaikoura }\end{array}$ & 23 & $41^{\circ} 55^{\prime} 20^{\prime \prime} \mathrm{S}$ & $174^{\circ} 06^{\prime} 00^{\prime \prime} \mathrm{E}$ & * & $01(23)$ & 0 & 0 \\
\hline 26 & $\begin{array}{l}\text { Waipapa Point, } \\
\text { Kaikoura }\end{array}$ & 17 & $42^{\circ} 12^{\prime} 41^{\prime \prime} \mathrm{S}$ & $173^{\circ} 52^{\prime} 29^{\prime \prime} \mathrm{E}$ & $*$ & $01(17)$ & 0 & 0 \\
\hline 27 & $\begin{array}{l}\text { Ripapa Island, } \\
\text { Banks Peninsula }\end{array}$ & 24 & $43^{\circ} 37^{\prime} 07^{\prime \prime} \mathrm{S}$ & $172^{\circ} 45^{\prime} 13^{\prime \prime} \mathrm{E}$ & $*$ & $01(24)$ & 0 & 0 \\
\hline 28 & $\begin{array}{l}\text { Cape Three Points, } \\
\text { Banks Peninsula }\end{array}$ & 16 & $43^{\circ} 49^{\prime} 50^{\prime \prime} \mathrm{S}$ & $172^{\circ} 54^{\prime} 30^{\prime \prime} \mathrm{E}$ & $*$ & $01(16)$ & 0 & 0 \\
\hline 29 & $\begin{array}{l}\text { Wharekauri, } \\
\text { Chatham Islands }\end{array}$ & 10 & $43^{\circ} 42^{\prime} 18^{\prime \prime} \mathrm{S}$ & $176^{\circ} 34^{\prime} 55^{\prime \prime} \mathrm{W}$ & WELT ASG257 & $24(10)$ & 0 & 0 \\
\hline 30 & $\begin{array}{l}\text { Point Dorset, } \\
\text { Chatham Islands }\end{array}$ & 24 & $43^{\circ} 49^{\prime} 34^{\prime \prime} \mathrm{S}$ & $176^{\circ} 42^{\prime} 21^{\prime \prime} \mathrm{W}$ & WELT A031328 & $01(16), 03(6), 24(2)$ & $0.5072 \pm 0.0929$ & $0.0060 \pm 0.0043$ \\
\hline 31 & $\begin{array}{l}\text { Waitangi, Chatham } \\
\text { Islands }\end{array}$ & 22 & $43^{\circ} 56^{\prime} 42^{\prime \prime} \mathrm{S}$ & $176^{\circ} 33^{\prime} 42^{\prime \prime} \mathrm{W}$ & WELT A031329 & $\begin{array}{l}01(6), 08(1), 09(3), 10 \\
(5), 24(4), 39(3)\end{array}$ & $0.8398 \pm 0.0368$ & $0.0206 \pm 0.0117$ \\
\hline 32 & $\begin{array}{l}\text { Manukau Reef, } \\
\text { Chatham Islands }\end{array}$ & 5 & $37^{\circ} 44^{\prime} 41^{\prime \prime} \mathrm{S}$ & $176^{\circ} 28^{\prime} 13^{\prime \prime} \mathrm{W}$ & WELT A024213 & $08(5)$ & 0 & 0 \\
\hline
\end{tabular}

\footnotetext{
"Vouchers for these sites were lost as a result of a chemical spillage accident.
} 


\subsection{Results}

Haplotypic diversity and population structure

SSCP and subsequent sequencing identified 67 haplotypes (Genbank numbers HM070070 to HM070166; Appendix 1). While SSCP might underestimate haplotypic diversity, sequencing of a large proportion of samples should reduce the likelihood of significant underestimation of diversity. A statistical parsimony network (Fig. 2.2b) grouped haplotypes into three clusters, each separated by five or more steps. The largest cluster (labelled (1) in Fig. 2.2b) joined 52 haplotypes. These are considered to arise from the C. maschalocarpum mitochondrial lineage. A second cluster (labelled (2) in Fig. 2.2b) joined four closely related haplotypes from North Cape (pop. 2 in Fig. 2.2a) and Wekarua (pop. 5). This cluster was five steps removed from the nearest $C$. maschalocarpum haplotype and six steps removed from the nearest haplotype of the sister species $C$. angustifolium. It is unclear whether these haplotypes arise from the $C$. angustifolium or C. maschalocarpum maternal lineage. A third cluster (labelled (3) in Fig. 2.2b), joined eleven haplotypes from C. angustifolium and putative hybrid specimens, and was six steps removed from the nearest $C$. maschalocarpum haplotype. Haplotypes from Carpophyllum angustifolium and any specimens considered to have hybrid origin (including all of pops. 1, 2 and 5), are not included in population genetic analyses. Three haplotypes $(15,23$ and 36) were found only in specimens identified morphologically as either $C$. angustifolium or hybrids, but which differed from haplotypes found in specimens morphologically identified as C. maschalocarpum by only one mutational step. These are considered to have arisen in the C. maschalocarpum mitochondrial lineage and are included in subsequent analyses.

Geographically restricted haplotypes were common (Fig. 2.2a). Forty-one $C$. maschalocarpum haplotypes were private (sampled from a single population only). At two sites, Matai Bay (pop. 3 in Fig 2.2a) and Maketu (pop. 14) all haplotypes sampled were private. At Ahipara (pop. 4) both haplotypes sampled were private aside from a single specimen of haplotype 52 also sampled at Horoera (pop. 16). Haplotypes from Bay of Plenty and Hawke Bay populations were not shared with neighbouring regions, apart from one Hawke Bay haplotype that was also sampled in the Chatham Islands. Four haplotypes were endemic to the Chatham Islands. Population differentiation was moderate to strong between populations with shared haplotypes (Table 2.2). 
A small number of haplotypes were widely distributed (Fig. 2.2a). Haplotype 01 was sampled in Northland (pops. 9 and 10), Bay of Plenty (pop. 15), Riversdale (pop. 24), the west coast of the North Island (all populations except 4), the Chatham Islands (pops. 31 and 30) and in all South Island populations. Haplotype 01 was the only haplotype sampled from the South Island. Three haplotypes were shared between Northland and East Coast populations. Haplotype 21 was sampled frequently in both regions. Also shared were haplotype 52 (pop. 4 and a single sample from pop. 16) and haplotype 67 (pops. 1 and 19). Haplotype 67 appears to be derived from the $C$. angustifolium lineage and is 14 mutational steps removed from the closest $C$. maschalocarpum haplotype. Three Chatham Island haplotypes were shared with mainland New Zealand: haplotype 39 was sampled in Otanga (pop. 12) and Waitangi (pop. 31) only; haplotype 08 was shared with two Hawke Bay sites (pops. 20 and 21); and the common southern haplotype 01 was sampled at two Chatham Islands sites (pops. 30 and 31).

Haplotype and nucleotide diversity (Table 2.1) was highest in three Bay of Plenty populations: Sailors Grave, Otanga and Maraehako Bay (pops. 11, 12 and 13 respectively), and in two Chatham Island populations: Waitangi and Point Dorset (pops. 31 and 30). Diversity was lowest in the South Island (a single haplotype sampled in four populations).

\section{Biogeographic regions}

SAMOVA analyses reached maximum $F_{\mathrm{ct}}$ at $\mathrm{K}=14\left(F_{\mathrm{ct}}=0.811425\right)$. At $\mathrm{K}=14$ populations were partitioned into five groups and nine singletons (Fig. 2.3). The largest group of ten populations, dominated by the common haplotype 01, included all South Island sites, Riversdale (pop. 24), Point Dorset (pop. 30) and all west coast North Island

Fig. 2.2. (opposite) (a) Distribution of mitochondrial haplotypes of Carpophyllum maschalocarpum. Area of pie charts is proportional to sample size. Locations are described in Table 2.1. (b) Statistical parsimony network inferred by TCS software (95\% confidence limits). Area of circles is proportional to number of haplotypes sampled. Small black circles represent extinct or unsampled haplotypes. Dashed line indicates an alternative but unlikely connection. 

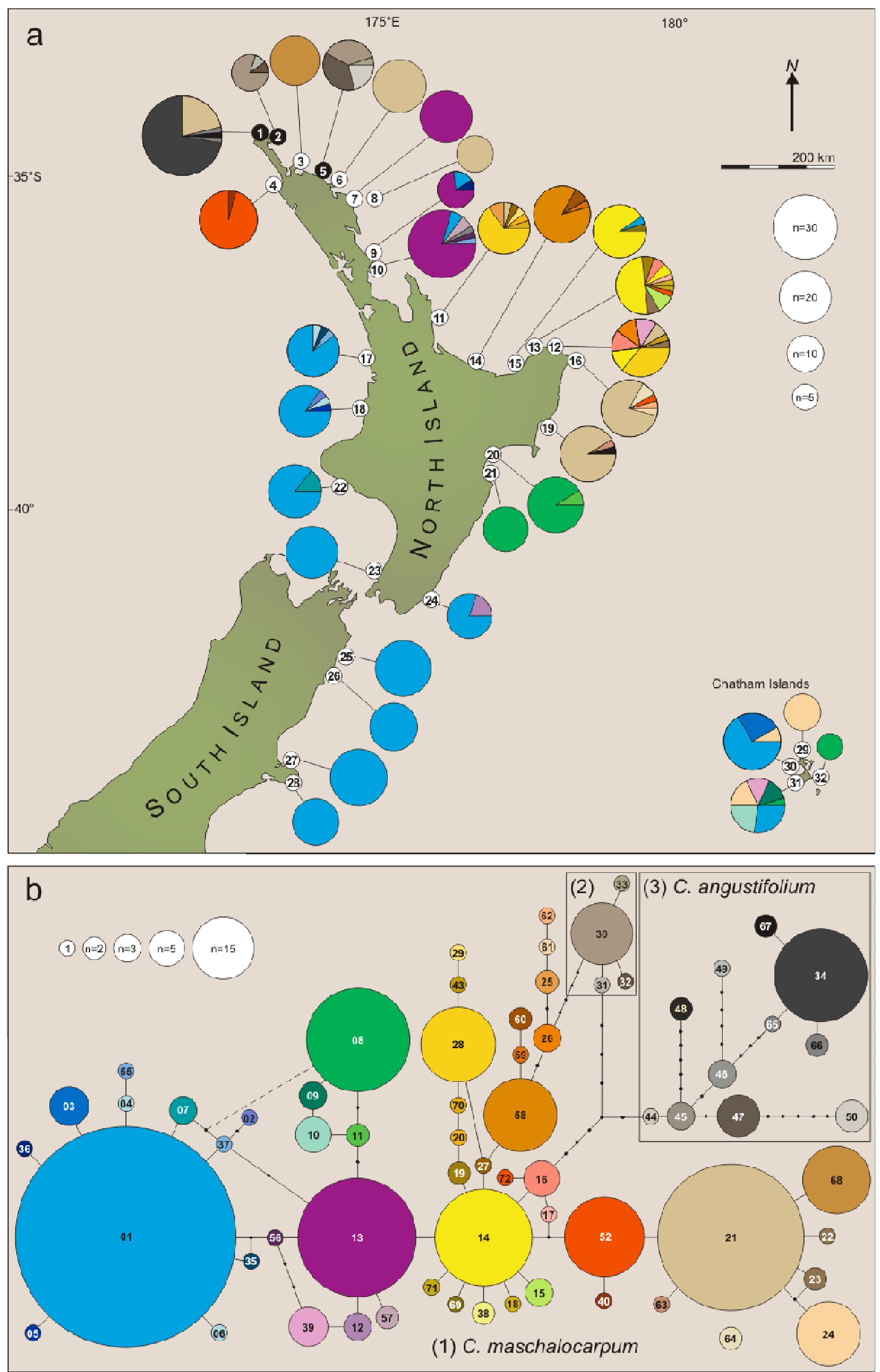
Table 2.2. Pairwise $\Phi_{\mathrm{st}}$ estimates from mtDNA spacer data (below diagonal) and minimum round coast distances ( $\mathrm{km}$, above diagonal) for Bay of Plenty populations of Carpophyllum maschalocarpum. Significance shown as: $* *=p \leq 0.01$ and $*=p \leq 0.05$ after sequential Bonferroni correction for multiple tests. N. S. = No significant difference. Population numbers refer to Table 2.1/Fig. 2.2.

\begin{tabular}{|c|c|c|c|c|c|}
\hline & Sailors Grave & Maketu & Opape & Maraehako Bay & Otanga \\
\hline $\begin{array}{l}\text { Sailors Grave } \\
\text { (pop. 11) }\end{array}$ & - & 103 & 179 & 190 & 215 \\
\hline $\begin{array}{l}\text { Maketu (pop. } \\
\text { 14) }\end{array}$ & $0.54931 * *$ & - & 87 & 117 & 151 \\
\hline Opape (pop. 15) & $0.46280 * *$ & $0.84906 * *$ & - & 48 & 86 \\
\hline $\begin{array}{l}\text { Maraehako Bay } \\
\text { (pop. 13) }\end{array}$ & $0.42232 * *$ & $0.68024 * *$ & N. S. & - & 38 \\
\hline $\begin{array}{l}\text { Otanga (pop. } \\
12 \text { ) }\end{array}$ & $0.12573 *$ & $0.26357 * *$ & $0.11334 *$ & $0.12548 * *$ & - \\
\hline
\end{tabular}

sites except Ahipara (pop. 4). This group was unchanged for all iterations of $K>2$. Chatham Island populations did not group together despite their proximity. Only Waitangi and Manukau Reef (pops. 31 and 32) were retained in the same group above $\mathrm{K}=3$ and these two populations separated into singletons at $\mathrm{K}=13$ and above. Wharekauri (pop. 29) grouped with Northland populations and two populations south of East Cape, then formed a singleton at $K=8$. Point Dorset (pop. 30) remained grouped with South Island and southern North Island populations.

AMOVA based on biogeographic regions and provinces proposed by Shears et al. (2008) explained considerably less between-group variance than the maximum obtained by SAMOVA (Table 2.3). The low haplotype diversity in South Island and southern North Island samples precluded showing the North/South disjunction found in other studies. A biogeographic break at East Cape was not shown in C. maschalocarpum, rather the data showed connectivity between two populations south of East Cape (pops. 16 and 19) and Northland. 


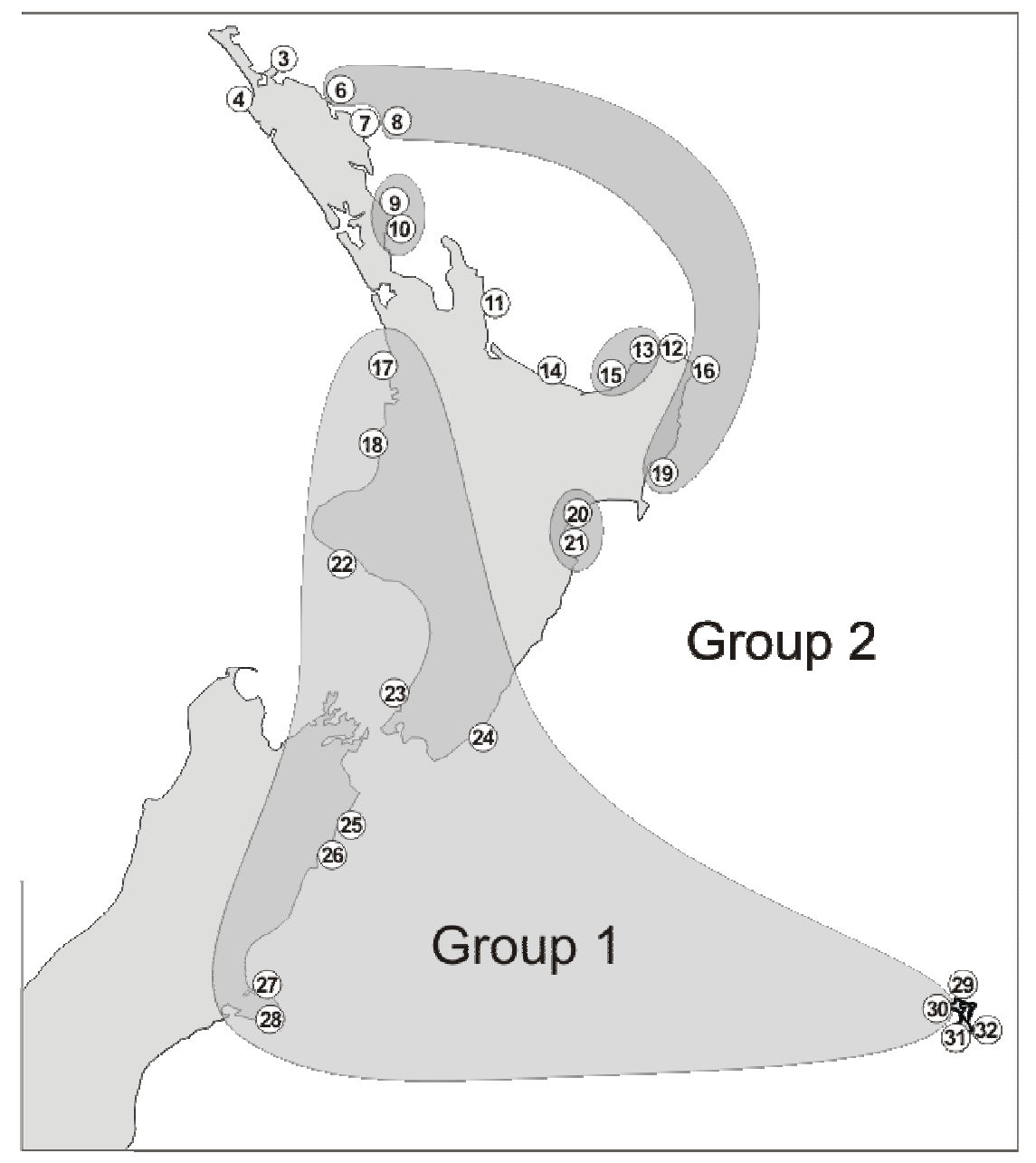

Fig. 2.3. Grouping of populations of Carpophyllum maschalocarpum inferred by SAMOVA to maximise $F_{c t}$. Shaded areas show groups inferred with $K=14$.

Division into two groups shown was used for mismatch distribution analyses (Fig. 2.4).

\section{Departures from neutrality}

Neutrality tests compare estimates of $\theta$ using different parameters. Data from demographically stable populations using neutral markers should estimate similar values of $\theta$. Discrepancies in estimates of $\theta$ indicate departure from neutrality, with different tests sensitive to different underlying factors (Fu 1997).

Tajima's D value (Tajima 1989) was negative $(\mathrm{D}=-0.7109)$, which suggests population expansion, but not significant $(\mathrm{P}=0.268) . \mathrm{Fu}$ and Li's $\mathrm{D}^{*}$ test $(\mathrm{Fu} \& \mathrm{Li} 1993)$ was significant $\left(\mathrm{D}^{*}=-2.3973, \mathrm{P}=0.016\right)$. Fu and $\mathrm{Li}^{\prime} \mathrm{s} \mathrm{F}^{*}$ test $(\mathrm{Fu} \& \mathrm{Li} 1993)$ was also significant $\left(\mathrm{F}^{*}=-2.1275, \mathrm{P}=0.024\right) . \mathrm{Fu}^{\prime} \mathrm{s} \mathrm{F}_{\mathrm{s}}$ value, which is sensitive to population 
Table 2.3: Hierarchical partitioning of molecular variance estimated by AMOVA from Carpophyllum maschalocarpum mtDNA spacer data. (a) Variation explained by grouping in biogeographic regions proposed by Shears et al. (2008); and (b) groupings at maximum $\mathrm{F}_{\mathrm{ct}}$ inferred by SAMOVA.

\section{a. Groupings by Biogeographic Regions}

\begin{tabular}{lrrrr}
\hline Source of variation & d.f. & Sum of squares & Variance & \multicolumn{2}{c}{$\begin{array}{c}\text { Percentage of } \\
\text { variation }\end{array}$} \\
\hline Among groups & 6 & 603.55 & $\mathrm{~V}_{\mathrm{a}}=1.026$ & 33.05 \\
Among populations & 22 & 626.90 & $\mathrm{~V}_{\mathrm{b}}=1.402$ & 45.14 \\
Within populations & 552 & 373.84 & $\mathrm{~V}_{\mathrm{c}}=0.677$ & 21.81
\end{tabular}

Fixation indices: $\mathrm{F}_{\mathrm{sc}}=0.674, \mathrm{~F}_{\mathrm{st}}=0.782, \mathrm{~F}_{\mathrm{ct}}=0.331$

b. Groupings by SAMOVA (Fig. 2.3)

\begin{tabular}{lrrrr}
\hline Source of variation & $d . f$. & Sum of squares & Variance & \multicolumn{2}{c}{$\begin{array}{c}\text { Percentage of } \\
\text { variation }\end{array}$} \\
\hline Among groups & 13 & 804.64 & $\mathrm{~V}_{\mathrm{a}}=1.652$ & 81.14 \\
Among populations & 15 & 6.94 & $\mathrm{~V}_{\mathrm{b}}=0.004$ & 0.21 \\
Within populations & 550 & 208.93 & $\mathrm{~V}_{\mathrm{c}}=0.380$ & 18.65 \\
\hline Fixation indices: $\mathrm{F}_{\mathrm{sc}}=0.011, \mathrm{~F}_{\mathrm{st}}=0.814, \mathrm{~F}_{\mathrm{ct}}=0.811$ & \\
\hline
\end{tabular}

expansion ( $\mathrm{Fu} 1997)$, was strongly negative, and highly significant $\left(\mathrm{F}_{\mathrm{s}}=-25.2996, \mathrm{P}=\right.$ 0.0002). $\mathrm{F}_{\mathrm{s}}$ tests were also carried out on data split into two groups as indicated by SAMOVA. Group 1 (North Island west coast/South Island/Riversdale/Port Dorset) and Group 2 (all other samples) both gave negative and significant $F_{\mathrm{s}}$ values $\left(\mathrm{F}_{\mathrm{s}}=-11.7910\right.$, $\mathrm{P}<0.0001$ and $\mathrm{F}_{\mathrm{s}}=-23.1464, \mathrm{P}=0.0002$ respectively).

Isolation by distance

Correlation between geographic distance and genetic distance was low but significant $\left(\mathrm{r}^{2}=0.10388, \mathrm{P}<0.0001\right)$. Recalculating distances to exclude east-west distances gave 
similar results $\left(\mathrm{r}^{2}=0.10820, \mathrm{P}<0.0001\right)$. Stronger correlation $\left(\mathrm{r}^{2}=0.20768, \mathrm{P}<\right.$ 0.0001 ) was obtained by excluding Chatham Islands samples from the analysis.

\section{Mismatch analysis}

Mismatch analyses showed an approximation to the expected distribution under a model of sudden expansion (Fig. 2.4). Separation of data into two groups as indicated by SAMOVA resulted in two distinct distributions: an L-shaped distribution in Group 1 (North Island west coast/South Island/Riversdale/Port Dorset) and a unimodal distribution in Group 2 (all other populations). No group showed significant departure from the expected distribution under a model of sudden expansion (Group 1: $\mathrm{P}=0.355$; Group 2: $\mathrm{P}=0.881$; combined populations: $\mathrm{P}=0.624$ ). $\mathrm{M}$ (the parameter for gene flow where $\mathrm{M}=2 \mathrm{Nm}$ and $\mathrm{N}$ is the deme size and $\mathrm{m}$ is the migration rate) is low in Group 1 $(\mathrm{M}=0.035)$ and high in Group $2(\mathrm{M}=12.156)$.

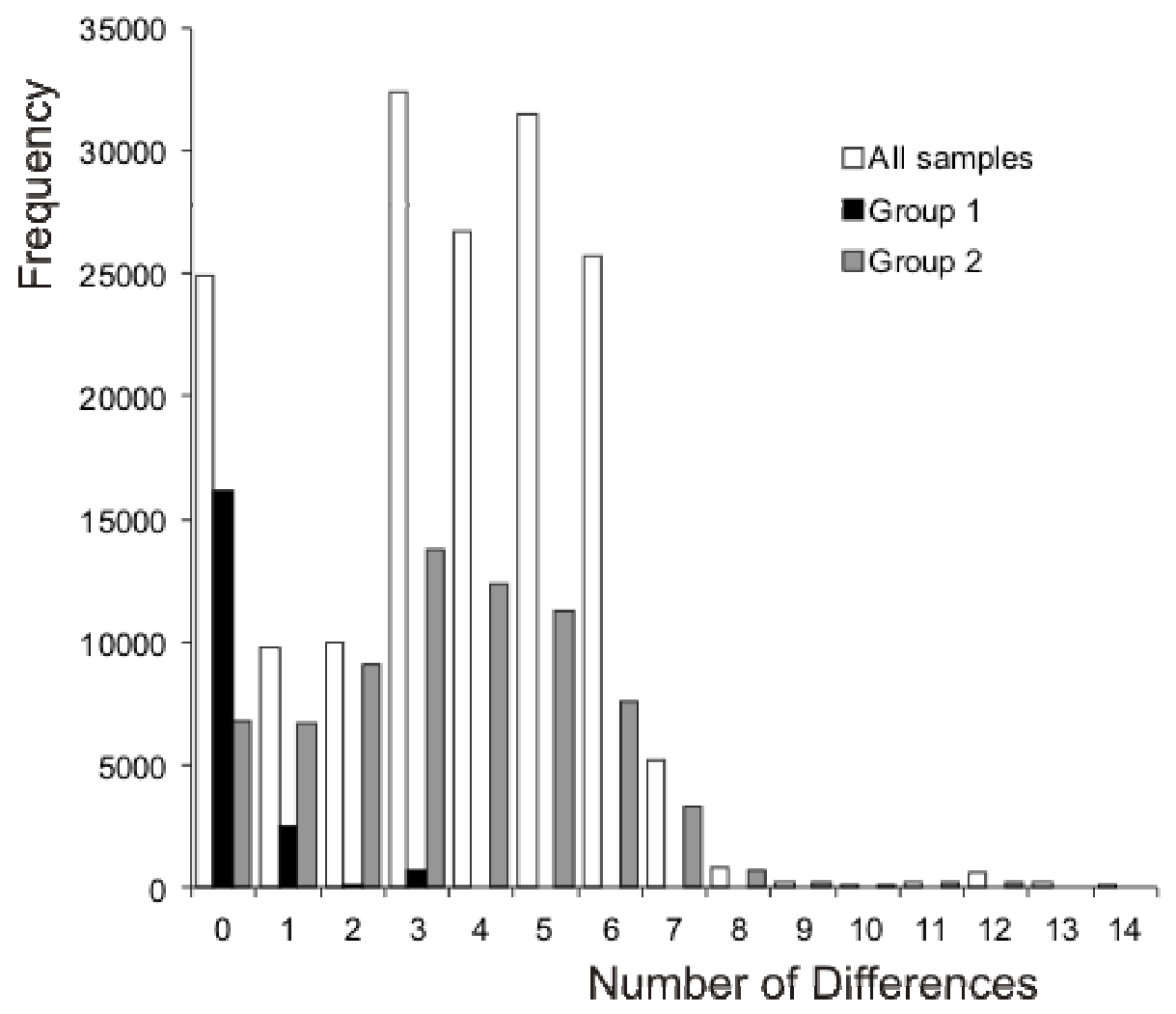

Fig. 2.4 Mismatch distributions: Group 1 (South Island/North Island West Coast, Riversdale and Point Dorset populations): black bars; Group 2 (all other populations): Grey bars; Combined populations: open bars. 


\subsection{Discussion}

Patterns of gene flow that arise from multiple dispersal modes are complex as dispersal patterns might overlap, especially when each mode is facilitated by different physical processes and influenced by separate historical events. In these data three main patterns are evident: (1) Often high genetic differentiation between populations, including adjacent populations; (2) Connectivity between some distant populations, with only slight overall isolation by distance; and (3) Generally low southern diversity, with the notable exception of the Chatham Islands. These patterns are consistent with fucalean morphological and life history characteristics that limit dispersal at the gamete/zygote stage, but facilitate occasional long distance dispersal (Thiel \& Haye 2006). Historical climatic changes also appear to have influenced the distribution of C. maschalocarpum.

\section{Genetic differentiation}

Genetic differentiation between many populations of Carpophyllum maschalocarpum was in the order of that expected for fucalean algae (Coleman \& Brawley 2005b, Hoarau et al. 2007, Tatarenkov et al. 2007, Coleman \& Kelaher 2009). Strong genetic differentiation was found between some adjacent populations that were separated by habitat discontinuities, even where distances were relatively short (for example, Cape Wiwiki (pop. 6) and Bland Bay (pop. 7), 39 kilometres apart but separated by the estuarine Bay of Islands). These discontinuities would be expected to provide a barrier to gametic or zygotic dispersal, but not to dispersal of floating thalli. Despite the abundance of floating thalli (Kingsford 1992), it appears that this mode of dispersal seldom contributes to gene flow.

Explanations for limited gene flow by floating thalli include dioecy, small target areas for immigrant floating algae (e.g., Maketu a short, $1 \mathrm{~km}$, rocky peninsula flanked by long stretches of soft sediment coast) and density blocking (Deysher \& Norton 1982, Hewitt 1996, Austerlitz et al. 2000), where relatively rare immigrants seldom contribute alleles to established stands of algae. High regional haplotype endemism might reflect isolation of water masses, for example limited current transport into embayments such as Hawke Bay and Bay of Plenty (Ridgway 1960, 1962, Stanton et al. 1997). Direct studies of transport of floating algae have not been undertaken in New Zealand. A high prevalence of westerly winds might mean surface floating species are usually exported and lost from nearshore habitat. 


\section{Long distance dispersal}

Shared haplotypes in Northland and North Island east coast populations, and North Island and Chatham Island populations, show some haplotypes have dispersed over long distances. Haplotype 21 is common in Northland and East Coast populations, and it is improbable that this haplotype arose independently in two areas. Further, haplotype 67, which clusters with $C$. angustifolium, was only sampled at Hooper Point (pop. 1) and Kaiti Beach (pop. 19). Kaiti is well outside of the range of $C$. angustifolium, which does not extend south of East Cape (Morton \& Miller 1968 and my observations). It appears this haplotype entered the $C$. maschalocarpum gene pool by hybridisation and dispersed to southern populations (Hodge et al. 2010). This connection, and the connection between the mainland and the Chatham Islands, is congruent with contemporary currents and surface winds. Northland and the East Coast are connected by the East Auckland/East Cape Current. This current does not extend to the inner area of the Bay of Plenty (Heath 1985, Stanton et al. 1997) and my data suggest Bay of Plenty populations occupy an isolated eddy. Despite their spatial separation, the outer populations (Sailors Grave-pop. 11 and Otanga-pop. 12) are more connected to each other than to inner populations. Haplotype 28 occurs in high frequencies in these populations, but was absent from the other Bay of Plenty populations.

Four lineages are present in Chatham Island populations, with haplotypes in each lineage the same or closely related to haplotypes found in North and South Island populations, suggesting at least four dispersal events between mainland New Zealand and the Chatham Islands. High connectivity between the mainland and the Chatham Islands is surprising as many Chatham Island marine algae are endemic (Nelson et al. 1991, Schiel et al. 1995), several common mainland species are absent (e.g., the nonbuoyant laminarian species Ecklonia radiata and Lessonia variegata) (Nelson et al. 1991, Nelson 1994), and studies in other organisms have shown genetic isolation in Chatham Island populations (Goldstien et al. 2009). My data suggest a very different pattern for algae capable of dispersal by floating, with prevailing westerly winds and currents facilitating eastward dispersal from the mainland to the Chatham Islands (Chiswell \& Booth 2008). Removing the East-West component of geographic distance between populations did not affect correlation with genetic connectivity. These data 
suggest wind and currents facilitate long distance transport to the Chatham Islands, while North to South movement proceeds mostly by stepping stone dispersal.

The North/South disjunction found in other New Zealand studies (Apte \& Gardner 2002, Sponer \& Roy 2002, Waters \& Roy 2004, Ayres \& Waters 2005, Goldstien et al. 2006) was evident in the sudden reduction in haplotype diversity in southern populations, but this occurs further north than the break found in previous studies. A barrier to dispersal by upwelling or current transport of propagules offshore around the north of the South Island has been suggested, but evidence for this is equivocal (Ross et al. 2009). I suggest historical climate change explains the pattern in these data better than a dispersal barrier and discuss this below. Bioregions proposed by Shears et al. (2008) are partly reflected in the distribution of C. maschalocarpum haplotypes (Table 2.3). In particular, disjunctions just south of Ahipara and south of Hawke Bay (pops. 4 and 20/21, Fig. 2.3) in these data are congruent with boundaries of bioregions in Shears et al. (2008). Conversely, the connection between Northland and the East coast, and the relative isolation of the Bay of Plenty and Hawke Bay populations of $C$. maschalocarpum is not evident in data obtained by Shears et al. (2008). It is not clear whether this arises from sampling differences, the stochastic nature of floating dispersal or factors unique to C. maschalocarpum.

This pattern of population differentiation and connectivity is consistent with a species that is generally restricted in dispersal, but with intermittent long distance dispersal by floating (Thiel \& Haye 2006). Leapfrog dispersal, where more distant populations show greater connectivity than adjacent populations, is a predicted outcome of intermittent floating dispersal (Thiel \& Haye 2006) and has been found in a variety of organisms (Snyder \& Gooch 1973, Bockelmann et al. 2003, Colson \& Hughes 2004). In C. maschalocarpum, leapfrog dispersal appears to be overlaid on patterns of low dispersal or stepping stone dispersal.

\section{Low southern diversity and post-LGM recolonisation}

The abundant centre model (Eckert et al. 2008) predicts greatest genetic diversity in the centre of a species' range, with a decline toward peripheral populations. My data are broadly consistent with this model. Diversity is highest in the Bay of Plenty in NorthEast New Zealand and generally declines with distance from this region. But there are two departures from this pattern: (1) Haplotypically diverse populations in the far north 
(pops. 1, $2 \& 5$ ); and (2) high haplotypic diversity in the Chatham Islands. I invoke both contemporary factors and historical factors to explain these departures.

Far north diversity appears to have hybrid origin, with gene flow between $C$. angustifolium and C. maschalocarpum. Far north populations have been identified as either species by different workers (e.g., C. maschalocarpum by Shears \& Babcock 2007, C. angustifolium by Hay \& Grant 2003). Hybrids have been reported between Carpophyllum species based on intermediate morphology (Lindauer et al. 1961, Dromgoole 1973, Shears \& Babcock 2007) and molecular data (Hodge et al. 2010), and hybridisation in fucalean species has been widely reported (Scott \& Hardy 1994, Kim et al. 1997, Coyer et al. 2002, Engel et al. 2005).

The pattern of high northern diversity and low southern diversity suggests relatively recent southward expansion with warming of the ocean waters following the Last Glacial Maximum (LGM). Water temperature is a major determinant of species range in many macroalgae (Lüning 1990, Adey \& Steneck 2001). Low diversity at high latitudes is often reported in species that have recolonised high latitudes during postglacial warming (Coyer et al. 2003, Marko 2004, Hoarau et al. 2007, Maggs et al. 2008, Fraser et al. 2009). The present day distribution of Carpophyllum maschalocarpum extends south to Fiordland $\left(46^{\circ} \mathrm{S}\right)$ on the South Island's west coast (Nelson et al. 2002), where warm currents push in from the Tasman Sea, but only as far south as Banks Peninsula $\left(43^{\circ} 45^{\prime} S\right)$ on the east coast, where cold currents push up from the south (Adams 1994). This southern limit is correlated with the $15^{\circ} \mathrm{C}$ Sea Surface Temperature (SST) isobar for the warmest month of the year (Fig. 2.1). While there are few direct data on thermal tolerances in C. maschalocarpum, the correlation between southern limit and SST on both coasts suggests this is a low temperature limit. Records of specimens of $C$. maschalocarpum from driftlines on Stewart Island and Sub-Antarctic Islands (Dromgoole 1973) show thalli are transported further south, but populations have not established.

Climate reconstructions of the LGM (Barrows \& Juggins 2005) place the $15^{\circ} \mathrm{C}$ warmest month SST isobar north of Taranaki on the New Zealand's west coast and north of Hawke Bay on the east coast (Fig. 2.1). These temperatures would have restricted $C$. maschalocarpum to the northern half of the North Island during the LGM. Recolonisation southwards down the North Island west coast, through the reopened 
Cook Strait (Lewis et al. 1994) and down the east coast of the South Island would explain the low diversity and the different patterns of population expansion indicated by mismatch distributions.

Genetic diversity in northern hemisphere algae has been shown to retain the signature of past climate events - in particular the last glaciation, which removed algae from higher latitudes (reviewed by Maggs et al. 2008). Similar patterns have been shown for marine species in the southern hemisphere (Hickey et al. 2009) including algae (Fraser et al. 2009). The distribution of haplotype diversity in my data is strikingly similar to patterns of the same marker in Fucus serratus from Europe (Hoarau et al. 2007), and is similar to distributions interpreted as showing post-glacial range expansion for a number of species (Hewitt 1999, Provan et al. 2005, Maggs et al. 2008).

I offer two explanations for the presence of four endemic haplotypes in the Chatham Islands. Either this is further evidence for the ease of dispersal to the Chatham Islands, with these haplotypes either extinct or not sampled on the main islands of New Zealand, and with dispersal pathways facilitating co-dispersal of closely related haplotypes (e.g., haplotypes 08, 09 and 10); or Chatham Island populations of $C$. maschalocarpum have persisted for a considerable time, allowing the accumulation of unique mutations. At present summer water temperatures around the Chatham Islands are elevated as seasonal north/south movement of the sub-tropical convergence is constrained by an area of shallow bathymetry, the Chatham Rise (Stanton 1997). Paleoclimate studies indicate warm summer water temperatures around the Chatham Islands might have persisted during the LGM (Nelson et al. 2000, Fenner et al. 1992). Hoarau et al. (2007) estimated a mutation rate of $2 \%$ to $3.4 \% / \mathrm{Myr}$ for this mitochondrial spacer in Fucus. While I would be cautious in applying this rate directly to $C$. maschalocarpum, a much faster mutation rate would be required if four endemic haplotypes arose following post-LGM recolonisation.

The pattern of local population differentiation, but with specific pathways for gene flow between distant populations, overlaid on a historical pattern of retreat and recolonisation is consistent with the intermittent and stochastic dynamics of long distance dispersal by floating (Thiel \& Haye 2006), and might be a general pattern for buoyant algae (Fraser et al. 2009) and organisms rafting on these algae. An important finding is that connectivity between distant populations can be high, even where local 
connectivity is often low. This highlights the importance of sampling across species' ranges when investigating dispersal, as large scale processes driving long distance dispersal might not be apparent in studies at local scales.

\subsection{Acknowledgements}

I thank Wendy Nelson, Kate Neill, Tracy Farr, Nick Shears, Peter Martin, Erasmo

Macaya, Fiona Hodge and Chatham Islands Department of Conservation staff for help

with collections, and Peter Ritchie for help with early drafts of the manuscript. Dr

Martin Thiel provided many useful comments. I also thank the New Zealand

Department of Conservation for funding assistance.

\subsection{References}

AdAMs, N. M. (1994). Seaweeds of New Zealand: An illustrated guide. Christchurch, New Zealand: Canterbury University Press.

ADEY, W. H. \& STENECK, R. S. (2001). Thermogeography over time creates biogeographic regions: A tempreature/space/time-integrated model and an abundance weighted test for benthic marine algae. Journal of Phycology, 37, 677-698.

APTE, S. \& GARDNER, J. P. A. (2002). Population genetic variation in the New Zealand greenshell mussel, Perna canaliculus: SSCP and RFLP analyses of mitochondrial DNA. Molecular Ecology, 11, 16171628.

Austerlitz, F., MARIETTE, S., MACHON, N., GOUYON P-H. (2000). Effects of colonization processes on genetic diversity: Differences between annual plants and tree species. Genetics, 154, 1309-1321.

Ayres K. L. \& WATERS, J. M. (2005). Marine biogeographic disjunction in central New Zealand. Marine Biology, 147, 1045-1052.

BARROWs, T. T. \& JUGGINS, S. (2005). Sea-surface temperatures around the Australian margin and Indian Ocean during the Last Glacial Maximum, Quaternary Science Review, 24, 1017-1047.

Bassam, B. J., CAETANO-AnOlles, G. \& GResshofF, P. M. (1991). Fast and sensitive silver staining of DNA in polyacrylamide gels. Analytical Biochemistry, 196, 80-83.

Bockelmann, A. C., Reusch, T. B. H., Bijlsma, R. \& BAKKer, J. P. (2003). Habitat differentiation vs. isolation by distance: The genetic population structure of Elymus athericus in European salt marshes. Molecular Ecology, 12, 505-515.

BoHONAK, A. J. (1999). Dispersal, gene flow and population structure. Quarterly Review of Biology, 74, 21-45.

Chapman, A. R. O. (1995). Functional ecology of fucoid algae: Twenty-three years of progress. Phycologia, 34, 1-32.

Chiswell, S. H. \& Booth, J. D. (2008). Sources and sinks of larval settlement in Jasus edwardsii around New Zealand: Where do larvae come from and where do they go? Marine Ecology Progress Series, 354, 201-217.

Clayton, M. N. (1992). Propagules of marine macroalgae: Structure and development. European Journal of Phycology, 27, 219-232.

Clement, M., Posada, D., Crandall, K. A. (2000). TCS: a computer program to estimate gene genealogies. Molecular Ecology, 9, 1657-1659. 
Coleman, M. A. \& BRAWLEY, S. H. (2005a). Spatial and temporal variability in dispersal and population genetic structure of a rockpool alga. Marine Ecology Progress Series, 300, 63-77.

COLEMAN. M. A. \& BRAwLEY, S. H. (2005b). Are life history characteristics good predictors of genetic diversity and structure? A case study of the intertidal alga Fucus spiralis (Heterokontophyta; Phaeophyceae). Journal of Phycology, 41, 753-762.

COLEMAN, M. A. \& KelaheR, B. P. (2009). Connectivity among fragmented populations of a habitatforming alga, Phyllospora comosa (Phaeophyceae, Fucales) on an urbanised coast. Marine Ecology Progress Series, 381, 63-70.

COLSON, I. \& HUGHES, R. N. (2004). Rapid recovery of genetic diversity of dogwhelk (Nucella lapillus L.) populations after local extinction and recolonization contradicts predictions from life-history characteristics. Molecular Ecology, 13, 2223-2233.

Coyer, J. A., Peters, A. F., Hoarau, G., Stam, W. T. \& Olsen, J. L. (2002). Hybridization of the marine seaweeds Fucus serratus and Fucus evanescens (Heterokontophyta: Phaeophyceae) in a 100-year old zone of secondary contact. Proceedings of the Royal Society of London B Series, 269, 1829-1834.

Coyer, J. A., Peters, A. F., StAM, W. T. \& Olsen, J. L. (2003). Post ice-age recolonization and differentiation of Fucus serratus L. (Phaeophyceae; Fucaceae) populations in Northern Europe. Molecular Ecology, 12, 1817-1829.

DELF, E. M. (1939). Studies in the Fucales of New Zealand I. The genus Carpophyllum Grev. Journal of Botany, London, 77, 129-138.

DethiER, M. N., MCDONALD, K. \& StRATHMANN, R. R. (2003). Colonization and connectivity of habitat patches for coastal marine species distant from source populations. Conservation Biology, 17, 1024 1035.

DEYSHER, L. \& NORTON, T. A. (1982). Dispersal and colonisation of Sargassum muticum (Yendo) Fensholt. Journal of Experimental Marine Biology and Ecology, 56, 179-195.

Dromgoole, F. I. (1973). A contribution to the biology of the genus Carpophyllum Grev. Unpublished $\mathrm{PhD}$. thesis. University of Auckland, Auckland, New Zealand.

DUPANLOUP, I., SCHNEIDER, S. \& EXCOFFIER, L. (2002). A simulated annealing approach to define the genetic structure of populations. Molecular Ecology, 11, 2571-2581.

ECKERT, C. G., SAMIS, K. E. \& LOUGHEED, S. C. (2008). Genetic variation across species' geographical ranges: the central-marginal hypothesis and beyond. Molecular Ecology, 17, 1170-1188.

ENGEL, C. R., DAGUIN, C. \& SERRÃO, E. (2005). Genetic entitries and mating systems in hermaphroditic Fucus spiralis and its close dioecious relative F. vesiculosus (Fucaceae, Phaeophyceae). Molecular Ecology, 14, 2033-2046.

EXCOFFIER, L. (2004). Patterns of DNA sequence diversity and genetic structure after a range expansion: Lessons from the infinite island model. Molecular Ecology, 13, 853-864.

EXCOFFIER, L., LAVAL, G. \& SCHNEIDER, S. (2005). ARLEQUiN, version 3.0: An integrated software package for population genetics data analysis. Evolutionary Bioinformatics Online, 1, 47-50.

FENNER, J., CARTER, L. \& STEWART, R. (1992). Late Quaternary paleoclimate and paleoceanographic change over northern Chatham Rise, New Zealand. Marine Geology, 108, 383-404.

Fraser, C. L., NikUla, R., Spencer, H. G. \& WATERS, J. M. (2009). Kelp genes reveal effects of subantarctic sea ice during the Last Glacial Maximum. Proceedings of the National Academy of Sciences of the U.S.A., 106, 3249-3253.

Fu, X. Y. (1997). Statistical tests of neutrality of mutations against population growth, hitchhiking and background selection, Genetics, 147, 915-925.

Fu, X. Y. \& LI, W. H. (1993). Statistical tests of neutrality of mutations. Genetics, 133, 693-709.

GoldSTIEN, S. J., GEMMELL, N. J. \& SCHIEL, D. R. (2006). Comparative phylogeography of coastal limpets across a marine disjunction in New Zealand. Molecular Ecology, 15, 3259-3268. 
Goldstien, S. J., GeMmell, N. J. \& SCHIEL, D. R. (2009). Colonisation and connectivity by intertidal limpets among New Zealand, Chatham and Sub-Antarctic Islands. I. Genetic connections. Marine Ecology Progress Series, 388, 111-119.

HAY, B. \& GRANT, C. (2003). Marine Resources in Tai Tokerau. Auckland, New Zealand: James Henare Maori Research Centre, University of Auckland.

HEATH, R. A. (1985). A review of the physical oceanography of the seas around New Zealand. New Zealand Journal of Marine and Freshwater Research, 19, 79-124.

Hernández-CARmona, G., Hughes, B. \& Graham, M. H. (2006). Reproductive longetivity of drifting kelp Macrocystis pyrifera (Phaeophyceae) in Monterey Bay, USA. Journal of Phycology, 42, 11991207.

HEwITT, G. M. (1996). Some genetic consequences of ice ages, and their role in divergence and speciation. Biological Journal of the Linnean Society, 58, 247-276.

HewITT, G. M. (1999). Post-glacial re-colonisation of European biota. Biological Journal of the Linnean Society, 68, 87-112.

Hickey, A. J. R., Lavery, S. D., Hannan, D. A., BAKer, C. S. \& Clements, K. D. (2009). New Zealand triplefin fishes (family Tripterygiidae): contrasting population structure and mtDNA diversity within a marine species flock. Molecular Ecology, 18, 680-696.

Higgins, S. I., NATHAN, R. \& CAin, M. L. (2003). Are long distance dispersal events in plants usually caused by non-standard means of dispersal? Ecology, 84, 1945-1956.

Hotrau, G., Coyer, J. A., Veldsink, J. H., StAM, W. T. \& Olsen, J. L. (2007). Glacial refugia and recolonization pathways in the brown seaweed Fucus serratus. Molecular Ecology, 16, 3606-3616.

Hodge, F., Buchanan, J. \& ZucCarello, G. C. (2010). Hybridization between the endemic brown algae Carpophyllum maschalocarpum and C. angustifolium (Fucales): Genetic and morphological evidence. Phycological Research, 58, 239-247.

KENDRICK, G. A. \& WALKER, D. I. (1991). Dispersal distances for propagules of Sargassum spinuligerum (Sargassaceae, Phaeophyta) measured directly by vital staining and venturi suction sampling. Marine Ecology Progress Series, 79, 133-138.

KENDRICK, G. A. \& WALKER, D. I. (1995). Dispersal of propagules of Sargassum spp. (Sargassaceae: Phaeophyta): Observations of local patterns and consequences for recruitment and population structure. Journal of Experimental Marine Biology and Ecology, 192, 273-288.

KIM, K. Y., O'LEARY, S. J. \& GARBARY, D. J. (1997). Artificial hybridization between Ascophyllum nodosum and Fucus vesiculosus (Phaeophyceae) from Nova Scotia, Canada. Canadian Journal of Botany, 75, 1133-1136.

KINGSFORD, M. J. (1992). Drift algae and small fish in coastal waters of northeastern New Zealand. Marine Ecology Progress Series, 80, 41-55.

Kinlan, B. P., GAines, S. D. \& LeSTER, S. E. (2005). Propagule dispersal and the scales of marine community processes. Diversity and Distributions, 11, 139-148.

KUMAR, S., TAMURA, K. \& NEI, M. (2004). MEGA3: Integrated Software for Molecular Evolutionary Genetics Analysis and Sequence Alignment. Briefings in Bioinformatics, 5, 150-163.

LEWIS, K. B., CARTER, L. \& DAVEY, F. J. (1994). The opening of Cook Strait: Interglacial tidal scour and aligning basins at a subduction to transform plate edge. Marine Geology, 116, 293-312.

Lindauer, V. W., Chapman, V. J. \& Aiken, M. (1961). The Marine Algae of New Zealand II: Phaeophyceae Nova Hedwigia, 3, 129-350.

LÜNING, K. (1990). Seaweeds: Their environment, biogeography, and ecophysiology. New York, Wiley.

Macaya, E., Boltaña, S., Buschmann, A., Hinojosa, I., Macchiavello, J., VAldivia, N. et al. (2005). Presence of sporophylls in floating kelp rafts of Macrocystis spp. (Phaeophyceae) along the Chilean Pacific Coast. Journal of Phycology, 41, 913-922. 
Maggs, C. A., Castilho, R., Foltz, D., Henzler, C., Jolly, M. T., Kelly, J. et AL. (2008). Evaluating signatures of glacial refugia for North Atlantic benthic marine taxa. Ecology, 89, S108-S122.

MARKo, P. B. (2004). 'What's larvae got to do with it?' Disparate patterns of post-glacial population structure in two benthic marine gastropods with identical dispersal potential. Molecular Ecology, 13, 597-611.

Marko, P. B., Hoffman, J. M., Emme, S. A., McGovern, T. M., Keever, C. C. \& Cox, L. N. (2010). The 'Expansion-Contraction' model of Pleistocene biogeography: rocky shores suffer a sea change? Molecular Ecology, 19, 146-169.

McKenzie, P. F. \& Bellgrove, A. (2008). Dispersal of Hormosira banksii (Phaeophyceae) via detached fragments: Reproductive viability and longetivity. Journal of Phycology, 44, 1108-1115.

Morton, J. E. \& Miller M. C. (1968). The New Zealand Sea Shore. London-Auckland: Collins.

Muhlin, J. F., Engel, C. R., Stessel, R., Weatherbee, R. A. \& BraWley, S. H. (2008). The influence of coastal topography, circulation patterns and rafting in structuring populations of an intertidal alga. Molecular Ecology, 17, 1198-1210.

NAYLOR, M. (1954). The female conceptacle and young sporeling of the four New Zealand species of Carpophyllum. Transactions and Proceedings of the Royal Society of New Zealand, 82, 1-6.

Nelson, C. S., Hendy, I. L., NeIl, H. L., Hendy, C. H. \& WeAVER, P. P. E. (2000). Last glacial jetting of cold waters through the Subtropical Convergence zone in the Southwest Pacific off eastern New Zealand, and some geological implications. Palaeogeography Palaeoclimatology Palaeoecology, 156, 103-121.

NeLson, W. A. (1994). Distribution of macroalgae in New Zealand - an archipelago in space and time. Botanica Marina, 37, 221-233.

Nelson, W. A., AdAms, N. M. \& HAY, C. H. (1991). Marine Algae of the Chatham Islands. (National Museum of New Zealand Miscellaneous Series No. 23). Wellington, New Zealand: National Museum of New Zealand.

Nelson, W. A., Villouta, E., Neill, K. F., Williams, G. C., Adams, N. M. \& SlivsgaArd, R. (2002). Marine macroalgae of Fiordland, New Zealand. Tuhinga, 13, 117-152.

NorTon, T. A. (1992). Dispersal by macroalgae. British Phycological Journal, 27, 293-301.

Oudot-Le SeCQ, M-P., KLOAREG, B., LOISEAUX-DE GöER, S. (2002). The mitochondrial genome of the brown alga Laminaria digitata: a comparative analysis. European Journal of Phycology, 37, 163-172.

Oudot-Le SecQ, M-P., LoiseAuX-De GoËr, S., StAM, W. T. \& Olsen, J. L. (2006). Complete mitochondrial genomes of the three brown algae (Heterokonta: Phaeophyceae) Dictyota dichotoma, Fucus vesiculosus and Desmarestia viridis. Current Genetics, 49, 47-58.

Pakker, H., Breeman, A. M., Prud'homme van Reine, W. F., VAn Oppen, M. J. H. \& Van den Hoek, C. (1996). Temperature responses of tropical to warm-temperate Atlantic seaweeds. I. Absence of ecotypic differentiation in amphi-Atlantic tropical Canary Islands species. European Journal of Phycology, 31, 123-132.

Provan, J., Wattier, R. A. \& MAggs, C. A. (2005). Phylogeographic analysis of the red seaweed Palmaria palmata reveals a Pleistocene marine glacial refugium in the English Channel. Molecular Ecology, 14, 793-803.

RAY, N., CURRAT, M. \& EXCOFFIER, L. (2003). Intra-deme molecular diversity in spatially expanding populations. Molecular Biology and Evolution, 20, 76-86.

ReED, D. C., Amsler, C. D. \& Ebeling, A. W. (1992). Dispersal in kelps - Factors affecting spore swimming and competence. Ecology, 73, 1577-1585.

REED, D. C. LAUR, D. R. \& EBELING, A. W. (1998). Variation in algal dispersal and recruitment: The importance of episodic events. Ecological Monographs, 58, 321-335.

RIDGWAY, N. M. (1960). Surface water movements in Hawke Bay, New Zealand. New Zealand Journal of Geology and Geophysics, 3, 253-261. 
RIDGWAY, N. M. (1962). Nearshore surface currents in southern Hawke Bay, New Zealand. New Zealand Journal of Geology and Geophysics, 5, 545-566.

Rogers, A. R. \& HARPENDING, H. (1992). Population growth makes waves in the distribution of pairwise genetic differences. Molecular Biology and Evolution,9, 552-569.

Ross, P. M., HogG, I. D., Pilditch, C. A. \& LundQuist, C. J. (2009). Phylogeography of New Zealand's coastal benthos. New Zealand Journal of Marine and Freshwater Research, 43, 1009-1027.

SCHIEL, D. R., ANDREW, N. L. \& FOSTER, M. S. (1995). The structure of subtidal algae and invertebrate assemblages at the Chatham Islands, New Zealand. Marine Biology, 123, 355-367.

SCOTT, G. W. \& HARDY, F. G. (1994). Observations of the occurrence of hybrids between two sympatric species of fucoid algae. Cryptogamie, Algologie, 15, 297-305.

SHEARS, N. T. \& BABCOCK, R. C. (2007). Quantitative description of New Zealand's shallow sub-tidal reef communities. (Science for Conservation 280). Wellington, New Zealand: New Zealand Department of Conservation.

Shears, N. T., Smith, F., BABCock, R. C., Duffy, C. A. \& Villouta, E. (2008). Evaluation of biogeographic classification schemes for conservation planning: application to New Zealand's coastal marine environment. Conservation Biology, 22, 467-481.

SMith, S. D. A. (2002). Kelp rafts in the Southern Ocean. Global Ecology \& Biogeography, 11, 67-69.

SNYDER, T. P. \& GoOCH, J. L. (1973). Genetic differentiation in Littorina saxatilis (Gastropoda). Marine Biology, 22, 177-182.

SotKa, E. E., WARES, J. P., BArth, J. A., GroseberG, R. K. \& PAlumbi, S. R. (2004). Strong genetic clines and geographical variation in gene flow in the rocky intertidal barnacle Balanus glandula. Molecular Ecology, 13, 2143-2156.

SPONER, R. \& RoY, M. S. (2002). Phylogeographic analysis of the brooding brittle star Amphipholis squamata (Echinodermata. along the coast of New Zealand reveals high cryptic genetic variation and cryptic dispersal potential. Evolution, 56, 1954-1967.

StANTON, B. R. (1997). Sea level and sea surface temperature variability at the Chatham Islands, New Zealand. New Zealand Journal of Marine and Freshwater Research, 31, 525-536.

Stanton, B. R., Sutton, P. J. H. \& Chiswell, S. M. (1997). The East Auckland Current, 1994-95. New Zealand Journal of Marine and Freshwater Research, 31, 537-549.

Sunnucks, P., Wilson, A. C. C., Beheregaray, L. B., Zenger, K., French, J. \& TAYlor, A. C. (2000). SSCP is not so difficult: the application and utility of single-stranded conformation polymorphism in evolutionary biology and molecular biology. Molecular Ecology, 9, 1699-1710.

TAJIMA, F. (1989). Statistical method for testing the neutral mutation hypothesis by DNA polymorphism. Genetics, 123, 585-595.

TATARENKOV, A., JÖNSSON, R. B., KAUTSKY, L. \& JOHANNESSON, K. (2007). Genetic structure in populations of Fucus vesiculosus (Phaeophyceae) over spatial scales from $10 \mathrm{~m}$ to $800 \mathrm{~km}$. Journal of Phycology, 43, 675-685.

THIEL, M. \& GuTOW, L. (2005a). The ecology of rafting in the marine environment. II. The rafting organisms and community. Oceanography and Marine Biology, 43, 279-418.

THIEL, M. \& GuTOW, L. (2005b). The ecology of rafting in the marine environment. I. The floating substrata. Oceanography and Marine Biology, 42, 181-263.

THIEL, M. \& HAYE, P. A. (2006). The ecology of rafting in the marine environment. III. Biogeographical and evolutionary consequences. Oceanography and Marine Biology, 44, 323-429.

VAN DEN HOEK, C. (1987). The possible significance for long range dispersal for the biogeography of seaweeds. Helgolä̈der wissenschaftliche Meeresuntersuchungen, 41, 261-72.

WARES, J. P. \& CunNingham, C. W. (2001). Phylogeography and historical ecology of the North Atlantic intertidal. Evolution, 55, 2455-2469 
WATERS, J. M. \& ROY, M. S. (2004). Phylogeography of a high dispersal New Zealand sea-star: does upwelling block gene flow? Molecular Ecology, 13, 2797-2806.

ZuCCARELLO, G. C. \& LOKHORST, G. M. (2005). Molecular phylogeny of the genus Tribonema (Xanthophyceae) using rbcL gene sequence data: monophyly of morphologically simple algal species. Phycologia, 44, 384-392.

ZuCCARELlo, G. C., WeSt, J. A., KAMiYA, M. \& King, R. J. (1999). A rapid method to score plastid haplotypes in red seaweeds and its use in determining parental inheritance of plastids in the red alga Bostrychia (Ceramiales). Hydrobiologia, 401, 207-214. 

Chapter 3

Patterns of hybridisation in Carpophyllum (Phaeophyceae, Fucales) 


\section{1 Abstract}

Hybrid zones can vary in time and space, even where the same species are involved. Carpophyllum maschalocarpum (Phaeophyceae, Fucales) and $C$. angustifolium hybridise in sites in north-eastern New Zealand where the two species are broadly sympatric, with $C$. angustifolium limited to more waveexposed habitats. Patterns of hybridisation were investigated by sampling across this zone of sympatry, from the northern tip of New Zealand to near the south-eastern limit of $C$. angustifolium. Specimens were assigned to species using morphological criteria. Hybrids have an intermediate morphology, specifically, a stipe width intermediate between the two parental species. Ribotypes and haplotypes were determined for ITS2 and a mtDNA spacer. In the southern range of $C$. angustifolium, most hybrids have heterozygous ITS2 and ribotypes associated with both parent species, and are interpreted as F1 hybrids, with a low frequency of backcrossing. Mitochondrial haplotypes were species specific in southern populations, but one haplotype found only in C. angustifolium and hybrids clustered with haplotypes found only in C. maschalocarpum, suggesting previous mitochondrial introgression in $C$. angustifolium. In the northern range of $C$. angustifolium, shared ITS ribotypes suggest backcrosses are more common, and all specimens in some populations resemble hybrids with parent plants apparently absent. Unlike Fucus, where asymmetrical hybridisation results from different mating systems between sister species, Carpophyllum is dioecious and either species can act as the maternal parent in the production of hybrids. High frequencies of $C$. angustifolium-associated mtDNA haplotypes in hybrids probably arise from imbalances in population sizes of parent species.

Abbreviations:

CTAB, Cetyltrimethylammonium Bromide; ITS, Internal Transcribed Spacer; SSCP, Single Stranded Conformational Polymorphism; TBE, Tris-Borate-EDTA. 


\subsection{Introduction}

Natural interspecific hybridisation events are natural experiments that can provide insight into evolutionary processes that lead to divergence and speciation (Hewitt 1988). Hybridisation can enable gene flow between lineages (Arnold 2006, Mallet 2005), reversing species divergence, and can produce novel phenotypes and initiate new species (Riesberg 1997, 2006). Gametic contact between potentially hybridising species is usually restricted in space creating hybrid zones, where genetically distinct populations overlap (Barton \& Hewitt 1985, 1989, Arnold 1993, Gardner 1997). Hybrid zones can arise from secondary contact following natural range expansion (Hewitt 2001, Neiva et al. 2010) or anthropogenic introductions (Coyer et al. 2002a, 2006b, Rhymer \& Simberloff 1996). Early studies assumed hybrid zones were an ephemeral stage in species divergence, occurring when development of reproductive barriers was incomplete (Howard et al. 2003). Subsequent theoretical work suggested hybrid zones might be stable, either maintained by a balance of selection against hybrids and dispersal into the zone (Bigelow 1965, Barton \& Hewitt 1985), or by greater fitness of hybrids in some habitats (Moore 1977). Recently, a more complex picture has emerged, with variable hybrid genotypes (Arnold \& Hodges 1995) interacting with patchy and dynamic environmental conditions to create a mosaic hybrid zone, with multiple potential evolutionary outcomes (Butlin et al. 2008, Jiggins \& Mallet 2000, Schwenk et al. 2008). Consequently, all hybrid zones are not all alike, even where the same species are involved (Riginos \& Cunningham 2005). In the marine environment, hybridisation is probably common (Gardner 1997) but has been extensively studied in only a few systems (Rawson \& Hilbish 1998, Rawson et al.1999, Coyer et al. 2004, Lewis 1996, Coyer et al. 2007). Fucalean brown algae are a useful system for studying hybridisation as they have a simple life history, with no alternation of generations and predominantly sexual reproduction (Chapman 1995). Various scenarios lead to hybridisation in Fucus: anthropogenic secondary contact (Coyer et al. 2002a, 2006b, 2007); marginal habitat (Wallace et al. 2004, Coyer et al. 2006a); and natural sympatry (Billard et al. 2005, Engel et al. 2005, Neiva et al. 2010). Species integrity in Fucus appears to be maintained by selection against hybrids (Coyer et al. 2007) and contrasting mating systems (Billard et al. 2005, Engel et al. 2005), but some populations show extensive 
introgression (Neiva et al. 2010), and possible incipient hybrid speciation (Coyer et al. 2010 in press).

In New Zealand, species of the endemic genus Carpophyllum Greville typically dominate the shallow rocky sub-tidal (Adams 1994, Shears \& Babcock 2007). Hybridisation, inferred from observations of morphologically intermediate specimens where two species are in contact, has been reported between Carpophyllum maschalocarpum Turner (Greville) and the three other species in the genus (Lindauer et al. 1961, Dromgoole 1973). Carpophyllum maschalocarpum is a common species, growing in dense stands around the Chatham Islands and most of mainland New Zealand (Adams 1994). A sister species, Carpophyllum angustifolium J. Agardh, has a more restricted range, extending from the northern tip of New Zealand's North Island to just short of East Cape (Adams 1994). These species are broadly sympatric, but $C$. angustifolium is absent from sheltered areas and replaces $C$. maschalocarpum in sites exposed to strong wave action (Shears \& Babcock 2007). Morphologically, they can be distinguished by their main axes, broad and flattened in $C$. maschalocarpum and narrow and terete in C. angustifolium (Adams 1994).

Hodge et al. (2010, Appendix 8) combined ribosomal DNA and morphological data to show that hybridisation occurred between Carpophyllum maschalocarpum and C. angustifolium J. Agardh from two populations in the eastern Bay of Plenty, New Zealand. Specimens were morphologically assigned to species, primarily by stipe width (stipe $<2 \mathrm{~mm}=C$. angustifolium, stipe $2-5 \mathrm{~mm}$ $=$ hybrid, stipe $>5 \mathrm{~mm}=C$. maschalocarpum). Parent species had homozygous ITS2, with one of two species-specific ribotypes. In contrast, ITS2 electropherograms from morphologically intermediate specimens showed a pattern of double peaks consistent with the presence of both ribotypes in each individual. A small number of individuals had morphological characters consistent with $C$. angustifolium, but had hybrid (heterozygous) ITS2 sequences. Hodge et al. (2010) suggested these were backcrosses, possibly indicating asymmetrical introgression.

Hybrids have also been reported from Auckland localities (Dromgoole 1973) and Shears \& Babcock (2007) reported what they considered to be a slender form of C. maschalocarpum from sites in the far north of New Zealand. These specimens somewhat resembled $C$. angustifolium and were found in wave 
exposed locations, but where the authors considered $C$. angustifolium was absent. As hybrids collected from the Bay of Plenty (Hodge et al. 2010) could be described as resembling "slender" C. maschalocarpum, I consider it likely that specimens observed by Shears \& Babcock (2007) are also hybrids. Hay \& Grant (2003) reported only C. angustifolium from the northern tip of the North Island, whereas Shears \& Babcock (2004) reported only C. maschalocarpum. This situation is unsatisfactory and the taxonomic status of these populations needs to be clarified.

Here I investigate evidence for hybridisation across the range of $C$. angustifolium, by comparing populations from Northland and the Bay of Plenty, New Zealand. In addition to ribotyping by ITS2, a mitochondrial intergenic spacer (Hoarau et al. 2007) was used to determine the maternal species of putative hybrid specimens. The utility of this spacer was shown in an extensive survey of $C$. maschalocarpum and C. angustifolium (Chapter 2) where haplotypes formed three clusters, two associated with $C$. angustifolium and one associated with $C$. maschalocarpum. The aim of this study is to determine if other hybridising populations of Carpophyllum follow the same patterns as those investigated by Hodge et al. (2010), and how species boundaries are maintained in Carpophyllum.

\subsection{Materials and Methods}

Sampling

Carpophyllum maschalocarpum specimens were collected from around New Zealand, and C. angustifolium and putative C. maschalocarpum $\times C$. angustifolium hybrids from northern New Zealand (Table 3.1 and Fig. 3.2). More intensive sampling of parent species and putative hybrids, identified by morphological characters, was done at four sites: the Poor Knights Islands $(\mathrm{N}=36)$ and Leigh $(\mathrm{N}=29)$ in Northland, and Maraehako Bay $(\mathrm{N}=75)$ and Otanga $(\mathrm{N}=66)$ in the eastern Bay of Plenty. In addition, morphologically intermediate thalli were collected at Wekarua $(\mathrm{N}=7)$ and Hooper Point $(\mathrm{N}=14)$, both Northland sites where parental forms were not found.

Thalli were collected haphazardly, at least 1 metre apart. Tips of thalli for DNA extraction were dried with silica gel. In addition, one or more typical thalli from each species/site were prepared as voucher specimens. A priori species assignments were made using morphological characters developed by Hodge $e t$ al. 
(2010), primarily a wide ( $>5 \mathrm{~mm}$ ) flattened primary axis in C. maschalocarpum and a narrow terete axis in $C$. angustifolium. Putative hybrids had a flattened primary axis intermediate in width $(2-5 \mathrm{~mm})$.

\section{Molecular methods}

DNA was extracted from approximately $2-5 \mathrm{mg}$ of dry tissue in a modified CTAB buffer following procedures described in Zuccarello \& Lokhorst (2005), with the addition of $1 \%$ polyvinylpolypyrrolidone to the extraction buffer. The ITS2 rDNA region and a variable mitochondrial spacer region were amplified and screened for variation by SSCP and sequencing. Amplification and sequencing of ITS2 (448-450 bp) used KP5 (forward) and KG4 (reverse) primers (Lane et al. 2006). Two further primers, ITS86F (5'-ACAGCTTCGGGTTCGATCT-3') and ITS424R (5'-ACCGGTCTCTCTCCGGTATT-3'), were developed from preliminary Carpophyllum ITS2 sequences to amplify a 337-339 bp fragment for SSCP analyses. This shorter fragment produced clearer SSCP profiles while retaining all known variable positions.

A 222 bp mitochondrial DNA fragment, containing 78 bp of the $3^{\prime}$ end of the 23S rRNA gene and 144 bp of spacer was amplified from Frasers Landing (Poor Knights Islands) and Maraehako Bay specimens with primers from Chapter 2. In addition, mtDNA sequences from Hooper Point and Wekarua specimens (Chapter 2) are included in the dataset. 
Table 3.1. Exemplars of specimens sampled with ITS2 ribotypes and locality information.

\begin{tabular}{|c|c|c|c|c|c|c|}
\hline $\begin{array}{l}\text { ITS2 } \\
\text { ribotype }\end{array}$ & $\begin{array}{l}\text { Specimen } \\
\text { field } \\
\text { number }\end{array}$ & $\begin{array}{l}\text { Herbarium } \\
\text { number }^{5}\end{array}$ & Species & Site & $\begin{array}{l}\text { Latitude/ } \\
\text { Longitude }\end{array}$ & $\begin{array}{l}\text { GenBank } \\
\text { Accession } \\
\text { number }\end{array}$ \\
\hline B & A220 & $\begin{array}{l}\text { WELT } \\
\text { ASG290\#1 }\end{array}$ & Carpophyllum maschalocarpum & $\begin{array}{l}\text { Bland Bay, Bay of } \\
\text { Islands, Northland }\end{array}$ & $\begin{array}{l}35.342^{\circ} \mathrm{S} \\
174.366^{\circ} \mathrm{E}\end{array}$ & JF313148 \\
\hline $\mathrm{G} \times \mathrm{N}$ & A397 & $\begin{array}{l}\text { WELT } \\
\text { A031674a }\end{array}$ & Carpophyllum angustifolium & $\begin{array}{l}\text { Cavalli Passage, } \\
\text { Northland }\end{array}$ & $\begin{array}{l}35.051^{\circ} \mathrm{S} \\
173.943^{\circ} \mathrm{E}\end{array}$ & JF313160 \\
\hline G & A398 & $\begin{array}{l}\text { WELT } \\
\text { A031674b }\end{array}$ & Carpophyllum angustifolium & $\begin{array}{l}\text { Cavalli Passage, } \\
\text { Northland }\end{array}$ & $\begin{array}{l}35.051^{\circ} \mathrm{S} \\
173.943^{\circ} \mathrm{E}\end{array}$ & JF313161 \\
\hline I & A404 & $\begin{array}{l}\text { WELT } \\
\text { A031673 }\end{array}$ & $\begin{array}{l}\text { Carpophyllum maschalocarpum } \times \\
\text { C. angustifolium hybrid }\end{array}$ & $\begin{array}{l}\text { Cavalli Passage, } \\
\text { Northland }\end{array}$ & $\begin{array}{l}35.051^{\circ} \mathrm{S} \\
173.943^{\circ} \mathrm{E}\end{array}$ & JF313162 \\
\hline B & A561 & PKI008 & Carpophyllum maschalocarpum & $\begin{array}{l}\text { Frasers Landing, Poor } \\
\text { Knights Islands }\end{array}$ & $\begin{array}{l}35.483^{\circ} \mathrm{S} \\
174.745^{\circ} \mathrm{E}\end{array}$ & JF313165 \\
\hline G & A563 & $\begin{array}{l}\text { WELT } \\
\text { A031326 }\end{array}$ & Carpophyllum angustifolium & $\begin{array}{l}\text { Frasers Landing, Poor } \\
\text { Knights Islands }\end{array}$ & $\begin{array}{l}35.483^{\circ} \mathrm{S} \\
174.745^{\circ} \mathrm{E}\end{array}$ & JF313166 \\
\hline
\end{tabular}

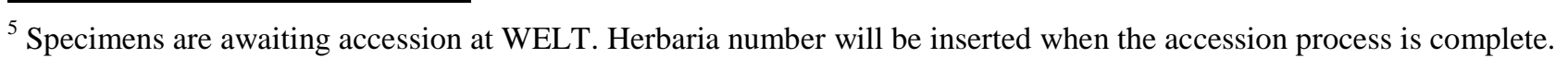


Table 3.1 (Continued)

\begin{tabular}{|c|c|c|c|c|c|c|}
\hline $\begin{array}{l}\text { ITS2 } \\
\text { ribotype }\end{array}$ & $\begin{array}{l}\text { Specimen } \\
\text { field } \\
\text { number }\end{array}$ & $\begin{array}{l}\text { Herbarium } \\
\text { number }\end{array}$ & Species & Site & $\begin{array}{l}\text { Latitude/ } \\
\text { Longitude }\end{array}$ & $\begin{array}{l}\text { GenBank } \\
\text { Accession } \\
\text { number }\end{array}$ \\
\hline $\mathrm{D}$ & A885 & - & $\begin{array}{l}\text { Carpophyllum maschalocarpum } \times \\
\text { C. angustifolium hybrid }\end{array}$ & $\begin{array}{l}\text { Hooper Point, } \\
\text { Northland }\end{array}$ & $\begin{array}{l}34.416^{\circ} \mathrm{S} \\
172.854^{\circ} \mathrm{E}\end{array}$ & JF313175 \\
\hline B & A905 & - & $\begin{array}{l}\text { Carpophyllum maschalocarpum } \times \\
\text { C. angustifolium hybrid }\end{array}$ & $\begin{array}{l}\text { Hooper Point, } \\
\text { Northland }\end{array}$ & $\begin{array}{l}34.416^{\circ} \mathrm{S} \\
172.854^{\circ} \mathrm{E}\end{array}$ & JF313176 \\
\hline B & A725 & - & Carpophyllum maschalocarpum & Otanga, Bay of Plenty & $\begin{array}{l}37.550^{\circ} \mathrm{S} \\
178.161^{\circ} \mathrm{E}\end{array}$ & JF313168 \\
\hline A & A1000 & - & Carpophyllum maschalocarpum & Otanga, Bay of Plenty & $\begin{array}{l}37.550^{\circ} \mathrm{S} \\
178.161^{\circ} \mathrm{E}\end{array}$ & JF313178 \\
\hline B & A758 & BOP339 & $\begin{array}{l}\text { Carpophyllum maschalocarpum } \times \\
\text { C. angustifolium hybrid }\end{array}$ & $\begin{array}{l}\text { Maraehako Bay, Bay } \\
\text { of Plenty }\end{array}$ & $\begin{array}{l}37.672^{\circ} \mathrm{S} \\
177.797^{\circ} \mathrm{E}\end{array}$ & JF313169 \\
\hline B & A766 & - & Carpophyllum maschalocarpum & $\begin{array}{l}\text { Maraehako Bay, Bay } \\
\text { of Plenty }\end{array}$ & $\begin{array}{l}37.672^{\circ} \mathrm{S} \\
177.797^{\circ} \mathrm{E}\end{array}$ & JF313170 \\
\hline B & A808 & BOP350 & $\begin{array}{l}\text { Carpophyllum maschalocarpum } \times \\
\text { C. angustifolium hybrid }\end{array}$ & $\begin{array}{l}\text { Maraehako Bay, Bay } \\
\text { of Plenty }\end{array}$ & $\begin{array}{l}37.672^{\circ} \mathrm{S} \\
177.797^{\circ} \mathrm{E}\end{array}$ & JF313171 \\
\hline
\end{tabular}


Table 3.1 (Continued)

\begin{tabular}{|c|c|c|c|c|c|c|}
\hline $\begin{array}{l}\text { ITS2 } \\
\text { ribotype }\end{array}$ & $\begin{array}{l}\text { Specimen } \\
\text { field } \\
\text { number }\end{array}$ & $\begin{array}{l}\text { Herbarium } \\
\text { number }\end{array}$ & Species & Site & $\begin{array}{l}\text { Latitude/ } \\
\text { Longitude }\end{array}$ & $\begin{array}{l}\text { GenBank } \\
\text { Accession } \\
\text { number }\end{array}$ \\
\hline B & A809 & BOP351 & $\begin{array}{l}\text { Carpophyllum maschalocarpum } \times \\
\text { C. angustifolium hybrid }\end{array}$ & $\begin{array}{l}\text { Maraehako Bay, Bay } \\
\text { of Plenty }\end{array}$ & $\begin{array}{l}37.672^{\circ} \mathrm{S} \\
177.797^{\circ} \mathrm{E}\end{array}$ & JF313172 \\
\hline B & A639 & - & Carpophyllum maschalocarpum & $\begin{array}{l}\text { Matts Crack, Poor } \\
\text { Knights Islands }\end{array}$ & $\begin{array}{l}35.476^{\circ} \mathrm{S} \\
174.741^{\circ} \mathrm{E}\end{array}$ & JF313167 \\
\hline G & A378 & $\begin{array}{l}\text { WELT } \\
\text { A031669 }\end{array}$ & Carpophyllum angustifolium & Flat Island, Northland & $\begin{array}{l}34.984^{\circ} \mathrm{S} \\
173.865^{\circ} \mathrm{E}\end{array}$ & JF313155 \\
\hline G & A379 & $\begin{array}{l}\text { WELT } \\
\text { A031669 }\end{array}$ & Carpophyllum angustifolium & Flat Island, Northland & $\begin{array}{l}34.984^{\circ} \mathrm{S} \\
173.865^{\circ} \mathrm{E}\end{array}$ & JF313156 \\
\hline $\mathrm{D}$ & A423 & $\begin{array}{l}\text { WELT } \\
\text { A031670 }\end{array}$ & $\begin{array}{l}\text { Carpophyllum maschalocarpum } \times \\
\text { C. angustifolium hybrid }\end{array}$ & $\begin{array}{l}\text { North Cape, } \\
\text { Northland }\end{array}$ & $\begin{array}{l}34.416^{\circ} \mathrm{S} \\
173.053^{\circ} \mathrm{E}\end{array}$ & JF313164 \\
\hline $\mathrm{C}$ & A935 & $\begin{array}{l}\text { WELT } \\
\text { A031313 }\end{array}$ & Carpophyllum angustifolium & $\begin{array}{l}\text { Sailor's Grave, } \\
\text { Coromandel }\end{array}$ & $\begin{array}{l}36.960^{\circ} \mathrm{S} \\
175.845^{\circ} \mathrm{E}\end{array}$ & JF313177 \\
\hline I & A387 & $\begin{array}{l}\text { WELT } \\
\text { A031671 }\end{array}$ & $\begin{array}{l}\text { Carpophyllum maschalocarpum } \\
\times \text { C. angustifolium hybrid }\end{array}$ & $\begin{array}{l}\text { Stephenson Island, } \\
\text { Northland }\end{array}$ & $\begin{array}{l}34.965^{\circ} \mathrm{S} \\
173.777^{\circ} \mathrm{E}\end{array}$ & F313157 \\
\hline
\end{tabular}


Table 3.1 (Continued)

\begin{tabular}{|c|c|c|c|c|c|c|}
\hline $\begin{array}{l}\text { ITS2 } \\
\text { ribotype }\end{array}$ & $\begin{array}{l}\text { Specimen } \\
\text { field } \\
\text { number }\end{array}$ & $\begin{array}{l}\text { Herbarium } \\
\text { number }\end{array}$ & Species & Site & $\begin{array}{l}\text { Latitude/ } \\
\text { Longitude }\end{array}$ & $\begin{array}{l}\text { GenBank } \\
\text { Accession } \\
\text { number }\end{array}$ \\
\hline $\mathrm{D}$ & A388 & $\begin{array}{l}\text { WELT } \\
\text { A031672 }\end{array}$ & $\begin{array}{l}\text { Carpophyllum maschalocarpum } \\
\times \text { C. angustifolium hybrid }\end{array}$ & $\begin{array}{l}\text { Stephenson Island, } \\
\text { Northland }\end{array}$ & $\begin{array}{l}34.965^{\circ} \mathrm{S} \\
173.777^{\circ} \mathrm{E}\end{array}$ & JF313158 \\
\hline G & A390 & $\begin{array}{l}\text { WELT } \\
\text { A031672 }\end{array}$ & $\begin{array}{l}\text { Carpophyllum maschalocarpum } \\
\times \text { C. angustifolium hybrid }\end{array}$ & $\begin{array}{l}\text { Stephenson Island, } \\
\text { Northland }\end{array}$ & $\begin{array}{l}34.965^{\circ} \mathrm{S} \\
173.777^{\circ} \mathrm{E}\end{array}$ & JF313159 \\
\hline G & A408 & $\begin{array}{l}\text { WELT } \\
\text { A031666 }\end{array}$ & Carpophyllum angustifolium & $\begin{array}{l}\text { Stephenson Island, } \\
\text { Northland }\end{array}$ & $\begin{array}{l}34.965^{\circ} \mathrm{S} \\
173.777^{\circ} \mathrm{E}\end{array}$ & JF313163 \\
\hline B & A341 & - & Carpophyllum maschalocarpum & $\begin{array}{l}\text { Waterfall Reef, Leigh, } \\
\text { Northland }\end{array}$ & $\begin{array}{l}36.269^{\circ} \mathrm{S} \\
174.798^{\circ} \mathrm{E}\end{array}$ & JF313149 \\
\hline B & A342 & - & Carpophyllum maschalocarpum & $\begin{array}{l}\text { Waterfall Reef, Leigh, } \\
\text { Northland }\end{array}$ & $\begin{array}{l}36.269^{\circ} \mathrm{S} \\
174.798^{\circ} \mathrm{E}\end{array}$ & $\mathrm{JF} 313150$ \\
\hline $\mathrm{F}$ & A345 & - & Carpophyllum angustifolium & $\begin{array}{l}\text { Waterfall Reef, Leigh, } \\
\text { Northland }\end{array}$ & $\begin{array}{l}36.269^{\circ} \mathrm{S} \\
174.798^{\circ} \mathrm{E}\end{array}$ & JF313151 \\
\hline $\mathrm{F}$ & A869 & $\begin{array}{l}\text { WELT } \\
\text { A031320 }\end{array}$ & Carpophyllum maschalocarpum & $\begin{array}{l}\text { Waterfall Reef, Leigh, } \\
\text { Northland }\end{array}$ & $\begin{array}{l}36.269^{\circ} \mathrm{S} \\
174.798^{\circ} \mathrm{E}\end{array}$ & JF313173 \\
\hline
\end{tabular}


Table 3.1 (Continued)

\begin{tabular}{|c|c|c|c|c|c|c|}
\hline $\begin{array}{l}\text { ITS2 } \\
\text { ribotype }\end{array}$ & $\begin{array}{l}\text { Specimen } \\
\text { field } \\
\text { number }\end{array}$ & $\begin{array}{l}\text { Herbarium } \\
\text { number }\end{array}$ & Species & Site & $\begin{array}{l}\text { Latitude/ } \\
\text { Longitude }\end{array}$ & $\begin{array}{l}\text { GenBank } \\
\text { Accession } \\
\text { number }\end{array}$ \\
\hline B & A870 & - & Carpophyllum angustifolium & $\begin{array}{l}\text { Waterfall Reef, Leigh, } \\
\text { Northland }\end{array}$ & $\begin{array}{l}36.269^{\circ} \mathrm{S} \\
174.798^{\circ} \mathrm{E}\end{array}$ & JF313174 \\
\hline $\mathrm{H}$ & A350 & $\begin{array}{l}\text { WELT } \\
\text { A031668 }\end{array}$ & $\begin{array}{l}\text { Carpophyllum maschalocarpum } \\
\times \text { C. angustifolium hybrid }\end{array}$ & Wekarua, Northland & $\begin{array}{l}34.945^{\circ} \mathrm{S} \\
173.653^{\circ} \mathrm{E}\end{array}$ & JF313152 \\
\hline $\mathrm{D}$ & A353 & $\begin{array}{l}\text { WELT } \\
\text { A031667 }\end{array}$ & $\begin{array}{l}\text { Carpophyllum maschalocarpum } \\
\times \text { C. angustifolium hybrid }\end{array}$ & Wekarua, Northland & $\begin{array}{l}34.945^{\circ} \mathrm{S} \\
173.653^{\circ} \mathrm{E}\end{array}$ & JF313153 \\
\hline $\mathrm{E}$ & A358 & $\begin{array}{l}\text { WELT } \\
\text { A031667 }\end{array}$ & $\begin{array}{l}\text { Carpophyllum maschalocarpum } \\
\times \text { C. angustifolium hybrid }\end{array}$ & Wekarua, Northland & $\begin{array}{l}34.945^{\circ} \mathrm{S} \\
173.653^{\circ} \mathrm{E}\end{array}$ & JF313154 \\
\hline $\mathrm{B} \times \mathrm{G}$ & A562 & $\begin{array}{l}\text { WELT } \\
\text { A031326 }\end{array}$ & Carpophyllum angustifolium & $\begin{array}{l}\text { Frasers Landing, Poor } \\
\text { Knights Islands }\end{array}$ & $\begin{array}{l}35.483^{\circ} \mathrm{S} \\
174.745^{\circ} \mathrm{E}\end{array}$ & - \\
\hline $\mathrm{H} \times \mathrm{L}$ & A349 & $\begin{array}{l}\text { WELT } \\
\text { A031320 }\end{array}$ & $\begin{array}{l}\text { Carpophyllum maschalocarpum } \\
\times \text { C. angustifolium hybrid }\end{array}$ & $\begin{array}{l}\text { Waterfall Reef, Leigh, } \\
\text { Northland }\end{array}$ & $\begin{array}{l}36.269^{\circ} \mathrm{S} \\
174.798^{\circ} \mathrm{E}\end{array}$ & - \\
\hline $\mathrm{B} \times \mathrm{G}$ & A810 & BOP352 & $\begin{array}{l}\text { Carpophyllum maschalocarpum } \\
\times \text { C. angustifolium hybrid }\end{array}$ & $\begin{array}{l}\text { Maraehako Bay, Bay } \\
\text { of Plenty }\end{array}$ & $\begin{array}{l}37.672^{\circ} \mathrm{S} \\
177.797^{\circ} \mathrm{E}\end{array}$ & - \\
\hline
\end{tabular}


ITable 3.1 (Continued)

\begin{tabular}{|c|c|c|c|c|c|c|}
\hline $\begin{array}{l}\text { ITS2 } \\
\text { ribotype }\end{array}$ & $\begin{array}{l}\text { Specimen } \\
\text { field } \\
\text { number }\end{array}$ & $\begin{array}{l}\text { Herbarium } \\
\text { number }\end{array}$ & Species & Site & $\begin{array}{l}\text { Latitude/ } \\
\text { Longitude }\end{array}$ & $\begin{array}{l}\text { GenBank } \\
\text { Accession } \\
\text { number }\end{array}$ \\
\hline $\mathrm{B} \times \mathrm{G}$ & A814 & BOP356 & $\begin{array}{l}\text { Carpophyllum maschalocarpum } \\
\times \text { C. angustifolium hybrid }\end{array}$ & $\begin{array}{l}\text { Maraehako Bay, Bay } \\
\text { of Plenty }\end{array}$ & $\begin{array}{l}37.672^{\circ} \mathrm{S} \\
177.797^{\circ} \mathrm{E}\end{array}$ & - \\
\hline
\end{tabular}


The PCR mix contained $1 \mu$ l genomic DNA, 0.5 U Taq DNA polymerase (New England Biolabs), 1X Thermopol reaction buffer (NEB), 7.5 pmoles each primer, 200 nM dNTP, 5\% DMSO and 0.01\% BSA. All PCR amplifications used a touchdown protocol with an initial denaturation step of $94^{\circ} \mathrm{C}$ for $4 \mathrm{~min}$, followed by 5 cycles of 1 $\min$ at $94^{\circ} \mathrm{C}, 1 \mathrm{~min}$ at $55^{\circ} \mathrm{C}\left(-1^{\circ} \mathrm{C} /\right.$ cycle $)$ and $1 \mathrm{~min}$ at $72^{\circ} \mathrm{C}$, followed by 30 cycles of 1 min at $94^{\circ} \mathrm{C}, 1 \mathrm{~min}$ at $50^{\circ} \mathrm{C}$ and $1 \mathrm{~min}$ at $72^{\circ} \mathrm{C}$, with a final extension of $72^{\circ} \mathrm{C}$ for $10 \mathrm{~min}$. Amplified products were checked for length and yield on $1 \%$ agarose gels stained with ethidium bromide.

\section{SSCP screening}

$3 \mu 1$ PCR product was mixed with $9 \mu \mathrm{L} 98 \%$ formamide, $10 \mathrm{mM} \mathrm{NaOH}, 0.025 \%$ bromophenol blue, $0.025 \%$ xylene cyanol, denatured at $100^{\circ} \mathrm{C}$ for $5 \mathrm{~min}$, then snap cooled on ice before loading. Gels were $225 \mathrm{~mm}$ long and $0.75 \mathrm{~mm}$ thick (BioRad DCode System) and contained 10\% Mutation Detection Acrylamide (Sigma A5934, Sigma Aldrich, St Louis, USA) for ITS2 or 9\% 37.5:1 acrylamide/bis-acrylamide (Sigma Aldrich) for the mitochondrial spacer, in 0.5X TBE buffer with the addition of $10 \%$ glycerol. Electrophoresis was carried out for $16-18 \mathrm{hrs}$ at $8 \mathrm{~W}$ in $0.5 \mathrm{X}$ TBE buffer at $4^{\circ} \mathrm{C}$. After electrophoresis, gels were silver stained following protocols in Bassam et al. (1991) and banding patterns scored by eye.

Sequences were obtained from random samples of each ITS2 ribotype or mitochondrial haplotype indicated by SSCP analyses, as well as any samples that showed ambiguous SSCP patterns. In addition, sequences were obtained from other populations where low sampling did not warrant use of SSCP (Table 3.1). PCR products were cleaned with ExoSAP-IT (USB, Cleveland, Ohio) enzymes and sequenced commercially (Macrogen Inc., Korea).

\section{ITS2 Cloning}

Four hybrid specimens were selected for cloning, two from Leigh and one each from Maraehako Bay and Otanga, to determine if both parental ribotypes could be obtained. The complete ITS1-5.8S-ITS2 cistron was amplified using KP1 and KG4 primers. Purified PCR product was cloned using the pGEM-T Easy vector kit (Promega Corporation, Madison, Wisconsin USA) following the manufacturer's protocols. 
Transformed colonies were sub-cultured and plasmid preparations carried out by alkali lysis (Sambrook et al. 1989). Inserts were sequenced commercially using the pUC M13 forward and reverse primers.

\section{Data analysis}

Homozygous sequences were aligned using ClustalW in MEGA 3.1 (Kumar et al. 2004) and checked by eye (Appendix 2). A statistical parsimony map was inferred from ITS2 data using TCS 1.21 (Clement et al. 2000) from 83 sequences from parental specimens, and six cloned sequences from hybrid specimens.

Heterozygous ITS2 sequences were assumed to result from inheritance of only two ribotypes. Electropherograms were examined and assigned the most likely parental ribotypes required to produce the observed heterozygosity (Table 3.1, Fig. 3.2). Three heterozygous sequences could not be explained as progeny of sampled homozygous ribotypes. Parental ribotypes of these could be inferred from heterozygous sequences as these all differed from frequently sampled ribotypes by a single heterozygous position. These inferred parental ribotypes were included in the statistical parsimony analysis. Mitochondrial spacer haplotypes were all identical to haplotypes obtained in a previous study (Chapter 2). Haplotypes were assigned to species according to clusters inferred by statistical parsimony in that study.

\subsection{Results}

\section{Morphology}

Specimens from Bay of Plenty sites (Maraehako Bay and Otanga), Leigh and the two Poor Knights Islands sites were able to be assigned to three morphological classes $(C$. maschalocarpum, C. angustifolium or putative hybrids) based on stipe width (Hodge et al. 2010). All three classes were sampled at these sites All specimens sampled fromWekarua and Hooper Point showed intermediate $(2-5 \mathrm{~mm})$ stipe width and no specimens from these sites were assigned to parental species (Table 3.1, Fig. 3.1)..

\section{SSCP data}

SSCP successfully distinguished mitochondrial spacer haplotypes in all populations. Variation in the longer ITS2 fragment was less well resolved by SSCP, but ribotypes 
could be distinguished among populations of low ribotype diversity (Bay of Plenty, Poor Knights Islands). Assigning ribotypes from SSCP profiles was difficult in Northland populations where ribotype diversity was higher and differences were often single base changes only. I therefore rely on sequence data for most Northland populations.

ITS2

Nine ITS2 ribotypes were sampled by direct sequencing from homozygous specimens, three of these were common (Fig. 3.1). Ribotype $\mathrm{G}$ was associated with $C$. angustifolium, and was widespread, from Otanga to Stephenson Island. Ribotypes D and B were widespread and mainly associated with C. maschalocarpum. Ribotype D is predominantly northern, from Leigh to Hooper Point; ribotype B was found throughout New Zealand. Two ribotypes, A and E, were found in single specimens only. Other uncommon ribotypes appeared to be fairly local: Ribotype $\mathrm{C}$ was found only in $C$. angustifolium from Sailor's Grave; ribotype I from parental species and hybrids from North Cape to Cavalli Passage in Northland; ribotype $\mathrm{H}$ from $C$. angustifolium from Wekarua and one hybrid from the Poor Knights Islands; and ribotype F from $C$. angustifolium from Leigh and the Alderman Islands.

Four ribotypes (L, M, N and O, enclosed by dashed lines in Fig. 3.1) were not sampled in homozygous specimens but were obtained by inferring parental ribotypes from heterozygous specimens. Ribotypes $\mathrm{M}, \mathrm{N}$ and $\mathrm{O}$ were each inferred from single specimens that differed from common ribotypes by one heterozygous position. Ribotype L was inferred from sequences from six heterozygous specimens from Leigh (Fig. 3.2) and two heterozygous specimens sequenced from North Cape (Table 3.1). Ribotype L was also found in cloned sequences from a hybrid specimen from Leigh (Table 3.2).

Statistical parsimony analysis did not cluster ribotypes with morphological species assignments (Fig. 3.1). Ribotypes $\mathrm{G}$ and $\mathrm{H}$ were predominantly found in $C$. angustifolium or hybrids and were separated by two substitutions, but ribotypes F, I and 


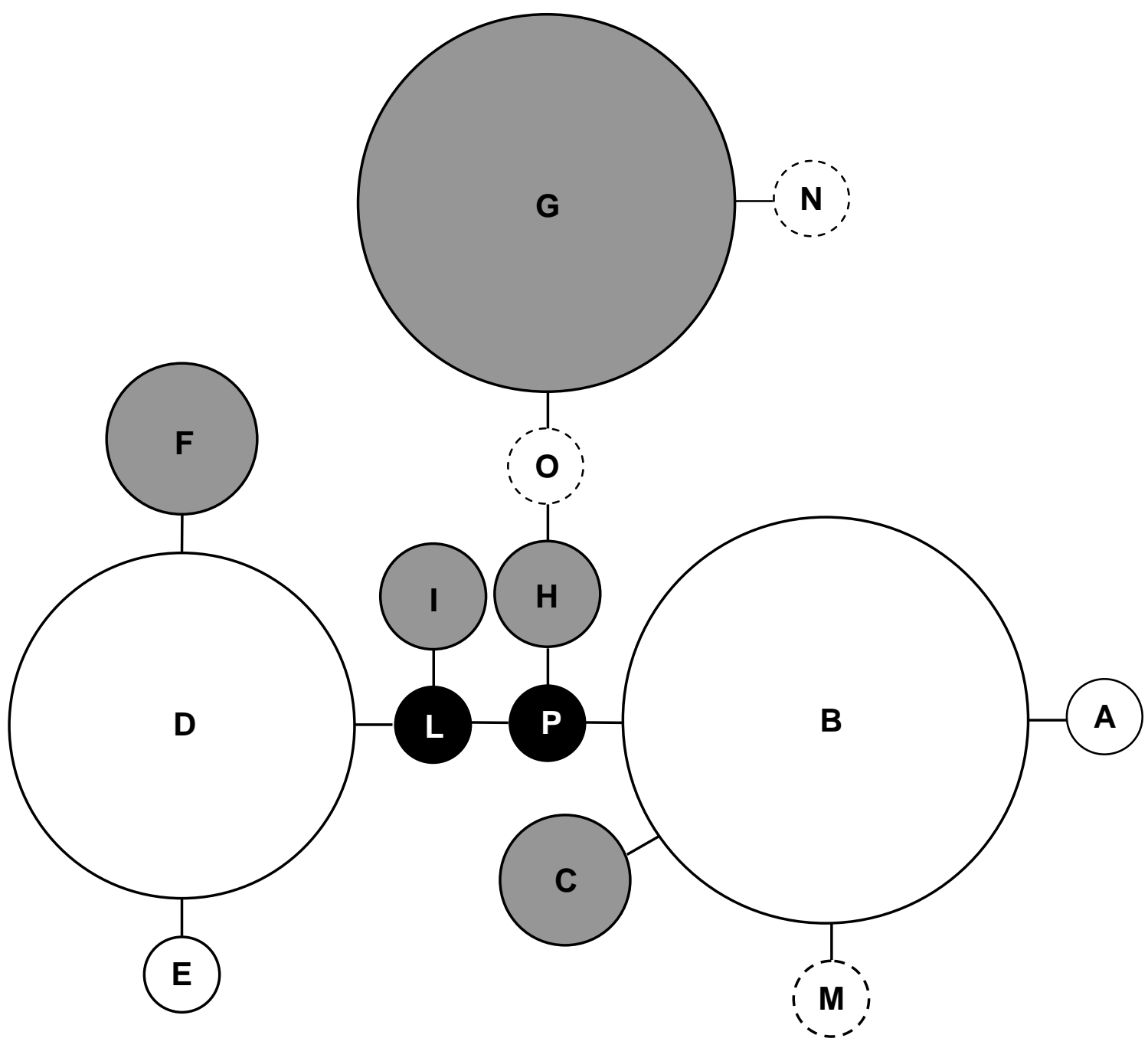

Fig. 3.1. Statistical parsimony map inferred from 83 homozygous ITS2 sequences and six cloned sequences from Carpophyllum maschalocarpum, C. angustifolium and putative hybrids. Shaded circles are predominantly $C$. angustifolium; clear circles are predominantly C. maschalocarpum. Black circles represent ribotypes sampled only by cloning. Dashed circles indicate ribotypes not found in homozygotes but are parental ribotypes required to produce heterozygotic sequences sampled in some specimens. Area of circles is proportional to number of samples with that haplotype. Connections are made at $95 \%$ probability. 
$\mathrm{C}$ were also predominantly found in $C$. angustifolium but were connected by single changes to ribotypes sampled extensively in $C$. maschalocarpum. The most common $C$. maschalocarpum ribotypes (B and D) were separated by three changes, and by ribotypes only sampled from cloned specimens.

\section{Hybrids}

With three exceptions, all specimens from Bay of Plenty and Poor Knights Islands sites that had intermediate morphologies also had heterozygous ITS2 (Fig. 3.2). In heterozygous specimens, double peaks were visible at particular sites in electropherograms. Both sequences could be read from these electropherograms. One ribotype was identical to ribotypes from $C$. maschalocarpum specimens from the same population, and the other ribotype was identical to ribotypes from $C$. angustifolium specimens from the same population. At Leigh, six hybrid specimens were heterozygous but one ribotype (ribotype L in Fig. 3.1) was not sampled in any non-hybrid specimens. Ribotype L differed from a common Northland C. maschalocarpum-associated ribotype by one substitution (Fig. 3.1). Three specimens with hybrid morphology from Maraehako Bay were homozygous for ribotype B, the ribotype found in all C. maschalocarpum specimens from this site. Specimens from Wekarua and Hooper Point were all assigned to hybrids based on morphology but nearly all specimens were homozygous for ITS2, except for two heterozygous specimens from Wekarua. All specimens sampled at these two sites had ribotypes associated with $C$. maschalocarpum, apart from two Wekarua specimens that had the $C$. angustifolium-associated Ribotype H (Fig. 3.1).

At Frasers Landing (Poor Knights Islands) and Leigh, two specimens morphologically assigned to $C$. maschalocarpum and seven specimens assigned to $C$. angustifolium also had heterozygous ITS2. These specimens all possessed the common C. maschalocarpum-associated ribotype B (Fig. 3.1) and C. angustifolium-associated ribotypes $\mathrm{F}$ or $\mathrm{G}$.

\section{ITS cloning}

Eight to eleven clones containing PCR products were sequenced for each specimen selected for cloning (Table 3.2; Appendix 3). Single base changes that appear in one cloned sequence only, and were not detected in any directly sequenced sample, are 
regarded as copy errors from PCR, and are excluded from further analysis. Multiple copies of expected parental ribotypes were obtained from all cloned specimens. In addition, two ribotypes ( $\mathrm{L}$ and $\mathrm{P}$, shown as black circles in Fig. 3.1) obtained from one specimen from Leigh (A347 in Table 3.2) were not sampled by direct sequencing of homozygous specimens. Both these ribotypes were predicted as unsampled ribotypes by statistical parsimony analysis using homozygous sequences, and ribotype L was inferred as one ITS2 variant in heterozygous specimens from Leigh and North Cape. 
Table 3.2: Frequency of ribotypes from cloned ITS 2 sequences from heterozygous specimens of Carpophyllum. Ribotype designation is shown in Fig.3.1.

Ribotype

Specimen/site

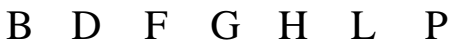

A980 Otanga

$2-\quad-9-\quad-\quad-$

A810 Maraehako Bay 3 - $\quad-5$ - $\quad-\quad$

A868 Leigh

$\begin{array}{lllllll}4 & 1 & 3 & - & - & - & -\end{array}$

A347 Leigh

$\begin{array}{llllll}- & - & - & 5 & 3\end{array}$ 
Table 3.3. Mitochondrial haplotype frequency from Carpophyllum maschalocarpum, $C$. angustifolium and hybrids from northern New Zealand. Haplotypes associated with $C$. angustifolium are shaded. Other haplotypes were associated with C. maschalocarpum. Haplotype numbers are from Chapter 2, Fig. 2.2.

\begin{tabular}{|c|c|c|c|}
\hline Site & MorphoSpecies & Haplotype & $\mathrm{N}$ \\
\hline \multirow[t]{15}{*}{ Maraehako Bay } & \multirow[t]{2}{*}{ C. angustifolium } & 48 & 3 \\
\hline & & 23 & 17 \\
\hline & \multirow[t]{8}{*}{ C. maschalocarpum } & 14 & 15 \\
\hline & & 16 & 2 \\
\hline & & 17 & 1 \\
\hline & & 18 & 1 \\
\hline & & 19 & 2 \\
\hline & & 38 & 2 \\
\hline & & 71 & 1 \\
\hline & & 72 & 1 \\
\hline & \multirow[t]{5}{*}{ Hybrids } & 14 & 3 \\
\hline & & 15 & 3 \\
\hline & & 16 & 3 \\
\hline & & 23 & 14 \\
\hline & & 48 & 3 \\
\hline \multirow[t]{3}{*}{ Frasers Landing } & C. angustifolium & 45 & 7 \\
\hline & C. maschalocarpum & 21 & 6 \\
\hline & Hybrids & 21 & 6 \\
\hline \multirow[t]{5}{*}{ Hooper Point } & \multirow[t]{5}{*}{ Hybrids } & 21 & 10 \\
\hline & & 34 & 34 \\
\hline & & 65 & 1 \\
\hline & & 66 & 1 \\
\hline & & 67 & 1 \\
\hline \multirow[t]{5}{*}{ Wekarua } & \multirow[t]{5}{*}{ Hybrids } & 30 & 7 \\
\hline & & 33 & 1 \\
\hline & & 47 & 7 \\
\hline & & 50 & 4 \\
\hline & & 67 & 1 \\
\hline
\end{tabular}




\section{Mitochondrial DNA}

Mitochondrial DNA haplotypes associated with both $C$. angustifolium and $C$. maschalocarpum (Chapter 2) were found in morphologically intermediate specimens from the Bay of Plenty and Hooper Point (Table 3.3). At Frasers Landing (Poor Knights Islands) all hybrids had C. maschalocarpum-associated mtDNA haplotypes. At all other sites the ratios of $C$. angustifolium-associated haplotypes: $C$. maschalocarpum-associated haplotypes were $>0.5$. Departure from a 0.5 ratio was significant at Hooper Point (Binomial Test, $\mathrm{P}=0.01)$ and Wekarua $(\mathrm{P}<<0.01)$.

Morphologically intermediate specimens from the most northern sites (Wekarua and Hooper Point) had predominantly $C$. maschalocarpum-associated ITS2 ribotypes but $C$. angustifolium-associated mtDNA haplotypes. At Wekarua, five out of seven specimens sequenced had C. maschalocarpum-associated ITS2 ribotypes, but all specimens had C. angustifolium-associated mtDNA haplotypes. At Hooper Point, all 14 specimens sequenced showed C. maschalocarpum-associated ITS2 ribotypes, but ten of these had C. angustifolium-associated mtDNA haplotypes.

\subsection{Discussion}

These data suggest hybridisation with $C$. maschalocarpum is occurring across the range of $C$. angustifolium, but patterns of hybridisation differ between localities. Three patterns are evident: (1) Carpophyllum populations from the Bay of Plenty and the Poor Knights Islands show strong congruence between intermediate morphology and ITS heterozygosity. I interpret this as interspecies crossing resulting in morphologically distinct hybrids with few backcrosses. (2) At Leigh, specimens with intermediate morphology and heterozygous ITS2 were also present, but four (out of ten) specimens assigned morphologically to $C$. angustifolium had heterozygous ITS2, with one ribotype inferred from electropherograms associated with $C$. maschalocarpum. These data suggest backcrosses between hybrids and $C$. angustifolium, resulting in $C$. maschalocarpum-associated ITS2 ribotypes being found in specimens resembling $C$. angustifolium. (3) At Hooper Point and Wekarua, all specimens were morphologically similar to hybrids found in other populations, and parental species were not seen, and are assumed to be rare or absent. Specimens were predominantly homozygous at ITS2, with $C$. maschalocarpum-associated ribotypes, but the majority of samples had $C$. 


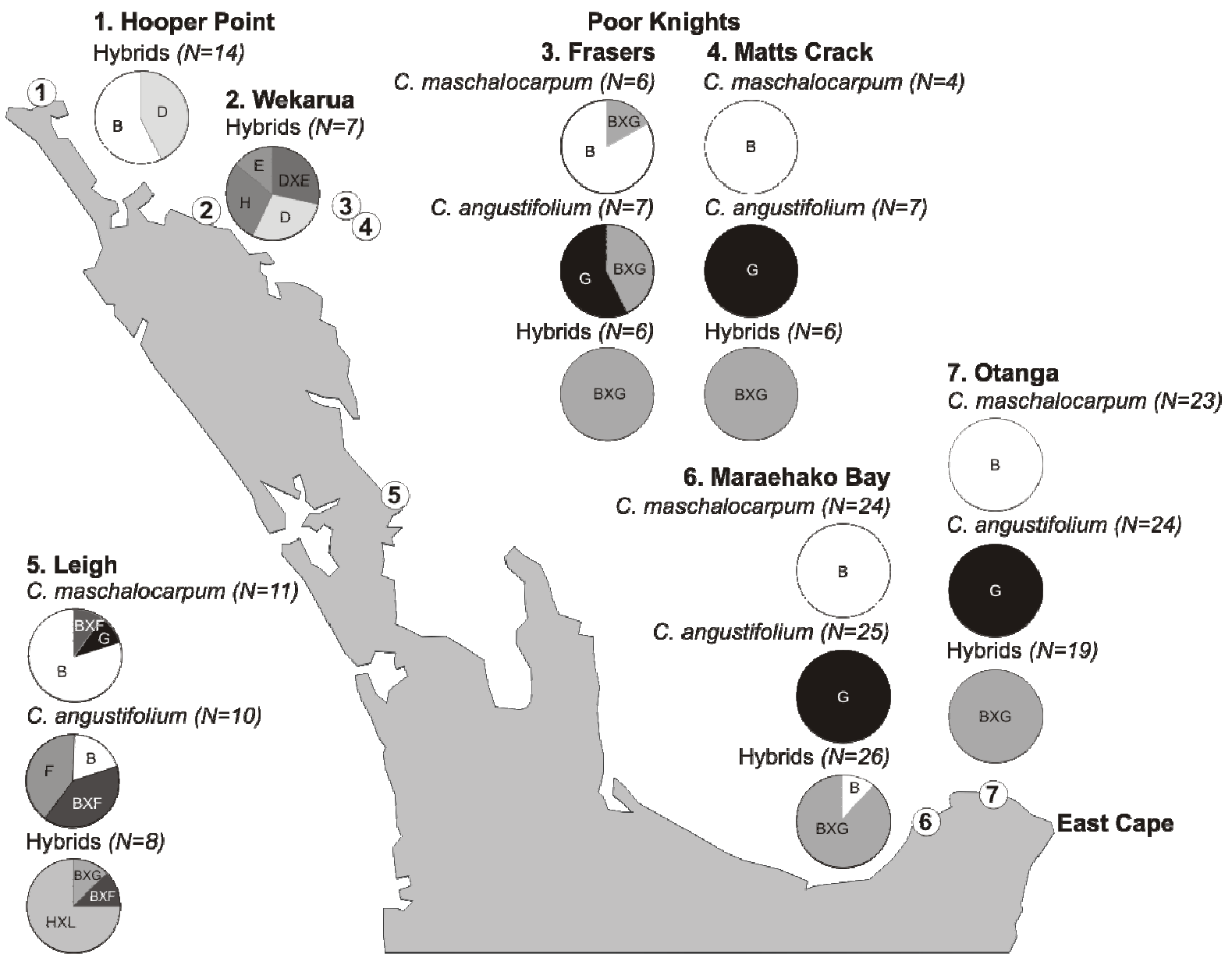

Fig. 3.2. Geographical patterns of ITS2 ribotypes in Carpophyllum maschalocarpum, C. angustifolium and hybrids from northern New Zealand populations. Pie charts show proportion of ribotypes sampled at each site. 
angustifolium mtDNA haplotypes. These data suggest a population with hybrid origins, but where ITS homogenisation has taken place.

In the Bay of Plenty, hybrids are found predominantly in areas of moderate wave exposure, where $C$. maschalocarpum begins to be replaced by the more wave exposure-tolerant $C$. angustifolium (Hodge 2009). These hybrid zones are consistent with Barton \& Hewitt's (1985) tension model, where hybrids are selected against relative to parents, but hybrid zones are maintained by migration into the zone. Hybrid populations at Hooper Point and Wekarua appear to persist without obvious sources of immigrants, but also without competition from parent populations. Either local environmental conditions favour hybrid morphologies (Moore 1977) or hybrid populations have established through founder effects (Neiva et al. 2010). Further research is needed to clarify this.

These ITS2 data from the Bay of Plenty are broadly in agreement with Hodge et al. (2010) who sampled Carpophyllum from Maraehako Bay and the adjoining Uncles Bay. I extended ITS2 data by including a third, more distant site (Otanga, near Lottin Point). Two ITS2 ribotypes dominated Bay of Plenty sites, although an additional ITS2 ribotype (A) was sampled in one Otanga specimen. With the exception of three specimens from Maraehako Bay, morphology is a reliable predictor of ITS2 ribotype in these populations: in homozygous specimens one ribotype was associated with $C$. angustifolium, the other with $C$. maschalocarpum. Specimens with intermediate morphology from these sites were heterozygous, with both parental ribotypes, and could be interpreted as F1 hybrids.

Hodge et al. (2010) found six specimens that were assigned to C. angustifolium on the basis of morphology, but had heterozygous ITS2, and suggested these were backcrosses between F1 hybrids and $C$. angustifolium. No specimens with $C$. maschalocarpum morphology were found with C. angustifolium-associated ribotypes, suggesting backcrossing might be asymmetrical. No thalli with heterozygous ribotypes and parental morphology were found in the Bay of Plenty in this study. Instead, three specimens had both an intermediate hybrid morphology and homozygous ITS2, with the C. maschalocarpum-associated ribotype B. I interpret these as F2 or later progeny of hybrid parents, where ITS2 DNA has homogenised to a single ribotype. ITS homogenisation, where a single, randomly selected ITS variant is fixed within the 
individual (Elder \& Turner 1995), is expected to remove the signature of hybridisation. However, the rate of homogenisation in brown algae is not known. Curiously, these three specimens had a unique mitochondrial spacer haplotype (haplotype 15 in Chapter 2 ), which was not sampled in any other population in this study (or in Chapter 2).

Possible explanations are that this is a quirk of stochastic sampling and this haplotype is more widespread, or these might represent an incipient hybrid lineage, such as is found in the low-shore variety of Fucus spiralis (Coyer et al. 2010).

Biparental inheritance of ribosomal DNA provides a useful tool for the detection of hybridisation (Coleman 2002, Carine et al. 2007), but its value is limited (Álvarez \& Wendel 2003) because of homogenisation. ITS heterozygosity is expected in F1 hybrids, but the signature of backcrosses will disappear if F1 hybrids homogenise to the same ribotype as the parental species involved in the backcross. Hence backcrosses will be underestimated by this method, especially where ribotype diversity is low, such as the Bay of Plenty. In addition, direct sequencing might not reveal the intra-individual diversity of ITS where homogenisation is incomplete and some ribotypes are retained in low copy number. One solution is to use cloning to estimate intra-individual ITS diversity. In my data, Ribotype L was predicted by statistical parsimony analysis as an intermediate haplotype, and inferred from heterozygous specimens, but was only confirmed in one cloned specimen, from Leigh. This specimen also provided a single cloned sequence of ribotype $\mathrm{P}$, also predicted by statistical parsimony analysis. PCR artifacts can be a problem during cloning, but it is unlikely that copy errors would produce five copies of predicted ribotypes. This suggests backcrossing might be more frequent in Bay of Plenty populations, but other markers, such as microsatellites need to be developed to accurately estimate rates.

Patterns of hybridisation in Bay of Plenty populations are relatively straightforward. A more complicated pattern was found in Northland sites. At Frasers Landing and Leigh, three and four specimens (out of seven and ten samples, respectively) specimens had $C$. angustifolium morphology but heterozygous ITS2, with one ribotype that is usually associated with $C$. maschalocarpum. Two specimens from Leigh had C. angustifolium morphology and were homozygous, but had $C$. maschalocarpum-associated ribotypes (Fig. 3.1). Conversely, only a single specimen from each site had Carpophyllum maschalocarpum morphology and heterozygous ITS2, 
and only one $C$. maschalocarpum specimen (from Leigh) was homozygous with a $C$. angustifolium-associated ribotype. I interpret this mis-match between morphology and ITS sequence(s) as backcrosses. Backcrosses mostly had C. angustifolium morphology, a result also found by Hodge et al. (2010), suggesting hybrids are more likely to backcross with $C$. angustifolium.

Maternal mitochondrial inheritance seems to be ubiquitous in oogamous algae, such as the Fucales, although rare heteroplasmy does occur (Coyer et al. 2002b, Coyer et al. 2004, Hoarau et al. 2009). There was no evidence of heteroplasmy in my samples, and I consider mitochondrial data to reflect maternal lineages. My mitochondrial data show that either Carpophyllum species can act as the maternal parent in hybridisation events, but in all populations except the Poor Knights Islands, hybrids had a higher frequency of $C$. angustifolium mtDNA (Table 3.3). The simplest explanation for this is a greater frequency of motile C. maschalocarpum male gametes (sperm) available for contact with immotile C. angustifolium female gametes (eggs). Carpophyllum angustifolium is usually restricted to the most wave exposed areas, often on the exposed parts of headlands, whereas C. maschalocarpum occupies a wide zone, from moderately exposed to moderately sheltered areas and is more abundant at most sites (Shears \& Babcock 2007). This should result in a greater likelihood of C. maschalocarpum sperm being carried into stands of $C$. angustifolium than vice versa, and a greater potential for hybrids with $C$. angustifolium mtDNA. In contrast, hybrids from Frasers Landing had exclusively $C$. maschalocarpum mtDNA. This pattern might arise stochastically from low sampling at this site, but in an extensive survey of macroalgal abundance in New Zealand, the Poor Knights Islands were the only locality where C. angustifolium occurred more frequently than C. maschalocarpum (Shears \& Babcock 2007). This might reverse the usual imbalance in gamete availability.

Haplotype 23 was common in C. angustifolium and hybrids from Maraehako Bay (Table 3.3). This haplotype was not sampled in C. maschalocarpum in this study or a previous study (Chapter 2), so I consider it indicative of a C. angustifolium maternal parent. However, statistical parsimony analysis in Chapter 2 places haplotype 23 in a cluster with C. maschalocarpum haplotypes, and just one change from a common haplotype found in C. maschlocarpum from Northland and the east coast of New Zealand's North Island. This suggests this haplotype or its ancestor has introgressed into 
C. angustifolium populations in the past, and is now either extinct or rare in $C$. maschalocarpum. Founder effects might account for its high frequency at Maraehako Bay. A similar pattern is found in Europe, where a mitochondrial haplotype associated with $F$. vesiculosus is found in $F$. ceranoides throughout the latter species' northern range. This extensive introgression is believed to result from repeated founder effects (Neiva et al. 2010)

The high frequency of $C$. angustifolium-associated mtDNA haplotypes but mostly $C$. maschalocarpum-type ITS ribotypes in morphologically intermediate specimens from the most northern populations of Wekarua and Hooper Point suggest that these populations have hybrid origin, rather than being a wave-exposed ecotype of C. maschalocarpum as suggested by Shears \& Babcock (2007). As no parent specimens were found at these sites, they appear to be self-sustaining populations of hybrid origin that have undergone ITS homogenisation, but retain hybrid morphology.

Mitochondrial spacer haplotypes are usually diagnostic for Carpophyllum species (Chapter 2). In contrast, only some ITS2 ribotypes had strong species associations, and most had exceptions (Table 3.1, Fig. 3.1). Most mitochondrial haplotypes also formed species-specific clusters (Chapter 2), whereas ITS2 ribotypes did not. It is not clear from these data whether ITS paraphyly is a consequence of gene transfer by hybridisation, or if this results from incomplete lineage sorting, with ancestral polymorphisms retained in both species. These results agree with the prediction that lineage sorting will proceed at a faster rate in mitochondrial DNA compared to nuclear DNA, due to a smaller effective population size in the former (Avise 2000). However, this prediction is probabilistic and cannot be applied to individual lineages with certainty (Hudson \& Turelli 2003).

Carpophyllum populations in the Bay of Plenty are strongly segregated by habitat (Hodge 2009), with C. maschalocarpum occupying relatively sheltered embayments, but being replaced by $C$. angustifolium on the exposed headlands. Hybrids are predominantly found in a zone between the most exposed and sheltered areas. Species integrity in the Bay of Plenty might be maintained by segregation by habitat and limited gamete dispersal, with episodic selection against hybrids, possibly by physical removal of hybrids during storm events and overgrowth by $C$. maschalocarpum during calm periods. Habitat segregation is a factor in maintaining 
species integrity in hybridising Fucus (Coyer et al. 2007, 2010). Northland sites appeared to have less sheltered habitat than Bay of Plenty sites. This might limit habitat segregation and increase the frequency of hybridisation events and backcrosses. Unlike Fucus, all Carpophyllum species are dioecious, which is expected to increase the frequency of hybridisation.

Three main findings arise from my data: (1) Hybridisation between $C$. angustifolium and C. maschalocarpum is widespread; (2) Patterns of hybridisation differ across the range of $C$. angustifolium; and (3) Initial hybridisation events appear symmetrical, but limited data suggests backcrosses are more likely between hybrids and C. angustifolium. Further ecological research and additional genetic markers are needed to determine if hybrids are under selection and if this varies between sites. While mitochondrial introgression from $C$. angustifolium into C. maschalocarpum appears rare (Chapter 2), the high frequency of haplotype 23 in C. angustifolium from Maraehako Bay suggests introgression in $C$. angustifolium might be more common. Further mitochondrial DNA data for $C$. angustifolium populations is needed to elucidate this pattern.

\subsection{Acknowledgements}

I thank Nick Shears, Wendy Nelson, Franz Smith, Kate Neill, Tracy Farr, Fiona Hodge and Peter Martin for assistance with collections.

\subsection{References}

ADAms, N. M. (1994). Seaweeds of New Zealand: An illustrated guide. Christchurch, New Zealand: Canterbury University Press.

ÁlVAREZ, I. \& WENDEL, J. F. (2003). Ribosomal ITS sequences and plant phylogenetic inference. Molecular Phylogenetics and Evolution, 29, 417-434.

ARnOlD, J. (1993). Cytonuclear disequilibria in hybrid zones. Annual Review of Ecology and Systematics, 24, 521-554.

ARNOLD, M. L. (2006). Evolution through Genetic Exchange. Oxford, United Kingdom: Oxford University Press.

ARNOLD, M. L. \& Hodges, S. A. (1995). Are natural hybrids fit or unfit relative to their parents? Trends in Ecology and Evolution, 10, 67-71.

Avise, J. C. (2000). Phylogeography: The History and Formation of Species. Cambridge MA: Harvard University Press.

BARTON, N. H. \& HEWITT, G. M. (1985). Analysis of hybrid zones. Annual Reviews of Ecology and Systematics, 16, 113-148.

Barton, N. H. \& HewitT, G. M. (1989). Adaption, speciation and hybrid zones. Nature, 341, 497-503. 
Bassam, B.J., CAETANO-AnOlles, G. \& GResshofF, P. M. (1991). Fast and sensitive silver staining of DNA in polyacrylamide gels. Analytical Biochemistry, 196, 80-83.

BIGELOW, R. S. (1965). Hybrid zones and reproductive isolation. Evolution, 19, 449-458.

Billard, E., Daguin, C., Pearson, G. Serrão, E., Engel, C. \& Valero, M. (2005). Genetic isolation between three closely related taxa: Fucus vesiculosus, F. spiralis and F. ceranoides (Phaeophyceae). Journal of Phycology, 41, 900-905.

Billard, E., Serrão, E., Pearson, G. A., Engel, C. R., Destombe, C. \& Valero, M. (2005). Analysis of sexual phenotyoe and prezygotic fertility in natural populations of $F$, spiralis, $F$. vesiculosus (Fucaceae, Phaeophyta) and their putative hybrids. European Journal of Phycology, 40, 397-407.

BUTLIN, R. K., GALINDO, J. \& GRAHAME, J. W. (2008). Sympatric, parapatric or allopatric: the most important way to classify speciation? Philosophical Transactions of the Royal Society of London B Series, 363, 2997-3007.

CArine, M. A., RobBA, L., LitTle, R., Russell, S. \& SAntos Guerra, A. (2007). Molecular and morphological evidence for hybridization between endemic Canary Island Convolvulus. Botanical Journal of the Linnaean Society, 154, 187-204.

Chapman, A. R. O. (1995). Functional ecology of fucoid algae: Twenty-three years of progress. Phycologia, 34, 1-32.

Clement, M., PosAdA, D. \& CRANDALl, K. A. (2000). TCS: a computer program to estimate gene genealogies. Molecular Ecology, 9, 1657-1659.

COLEMAN, A. W. (2002). Comparison of Eudorina/Pleodorina ITS sequences of isolates from nature with those from experimental hybrids. American Journal of Botany, 89, 1523-1530.

Coyer, J. A., Hoarau, G., Costa, J. F., Hogerdjik, B., Billard, E., Valero, M., Pearson, G. A. \& OLSEN, J. L. (2010). Evolution and species diversification within the intertidal brown macroalgae Fucus spiralis/F. vesiculosus species complex in the North Atlantic. Molecular Phylogenetics and Evolution, doi:10.1016/j.ympev.2010.11.015.

Coyer, J. A., Hoarau, G., Pearson, G. A., Serrao, E. A., Stam, W. T. \& Olsen, J. L. (2006a). Convergent adaptation to a marginal habitat by homoploid hybrids and polyploid ecads in the seaweed genus Fucus. Biology Letters, 2, 405-408.

Coyer, J. A., HoArau, G., Skage, M., StAm, W. T. \& Olsen, J. L. (2006b). Origin of Fucus serratus (Heterokontophyta; Fucaceae) populations in Iceland and the Faroes: a microsatellite based assessment. European Journal of Phycology, 41, 235-246.

Coyer, J. A., HoArau, G., Stam, W. T. \& Olsen, J. L. (2004). Geographically specific heteroplasmy of mitochondrial DNA in the seaweed, Fucus serratus (Heterokontophyta: Phaeophyceae, Fucales). Molecular Biology, 13, 1323-1326.

Coyer, J. A., HoArau, G., StAM, W. T. \& Olsen, J. L. (2007). Hybridization and introgression in a mixed population of the intertidal seaweeds Fucus evanescens and F. serratus. Journal of Evolutionary Biology, 20, 2322-2333

Coyer, J. A., Peters, A. F., HoArau, G., StAM, W. T. \& Olsen, J. L. (2002a). Hybridization of the marine seaweeds Fucus serratus and Fucus evanescens (Heterokontophyta: Phaeophyceae) in a 100year-old zone of secondary contact. Proceedings of the Royal Society of London B Series, 269, 18291834.

Coyer, J. A., Peters, A. F., HoArau, G., Stam, W. T. \& Olsen, J. L. (2002b). Inheritance patterns of ITS1, chloroplasts and mitochondria in artificial hybrids of the seaweeds Fucus serratus and $F$. evanescens (Phaeophyceae). European Journal of Phycology, 37, 173-178.

Dromgoole, F. I. (1973). A contribution to the biology of the genus Carpophyllum Grev. Unpublished $\mathrm{PhD}$. thesis. Auckland, New Zealand: University of Auckland.

ELDER, J. F \& TURNER, B. J. (1995). Concerted evolution of repetitive DNA sequences in eukaryotes. The Quarterly Review of Biology, 70, 297-320. 
Engel, C. R., DAGuin, C. \& SERRÃO, E. (2005). Genetic entities and mating systems in hermaphroditic Fucus spiralis and its close dioecious relative F. vesiculosus (Fucaceae, Phaeophyceae). Molecular Ecology, 14, 2033-2046.

GARDNER, J. P. A. (1997). Hybridization in the Sea. Advances in Marine Biology, 31, 1-78.

HAY, B. \& GRANT, C. (2003). Marine Resources in Tai Tokerau: Prepared for the James Henare Mäori Research Centre's Capacity Building for Sustainable Mäori Development research programme. Auckland, New Zealand: James Henare Mäori Research Centre.

HEWITT, G. M. (1988). Hybrid zones - natural laboratories for evolutionary studies. Trends in Ecology and Evolution, 3, 158-167.

HewiTT, G. M. (2001). Speciation, hybrid zones and phylogeography - or seeing genes in space and time. Molecular Ecology, 10, 537-549.

HoArau, G., Coyer, J. A. \& Olsen, J. L. (2009). Paternal leakage of mitochondrial DNA in a Fucus (Phaeophyceae) hybrid zone. Journal of Phycology, 45, 621-624.

Hoarau, G., Coyer, J. A., Veldsink, J. H., Stam, W. T. \& Olsen, J. L. (2007). Glacial refugia and recolonization pathways in the brown seaweed Fucus serratus. Molecular Ecology, 16, 3606-3616.

Hodge, F. J. (2009). Hybridisation in the brown algae Carpophyllum: Investigating morphology, distribution and wave exposure. Unpublished masters thesis. Wellington, New Zealand: Victoria University of Wellington.

Hodge, F., Buchanan, J. \& ZuCCAREllo, G. C. (2010). Hybridization between the endemic brown algae Carpophyllum maschalocarpum and C. angustifolium (Fucales): Genetic and morphological evidence. Phycological Research, 58, 239-247.

Howard, D. J., Britch, S. C., Braswell, W. E. \& Marshall, J. L. (2003). Evolution in hybrid zones. In Singh, R. K. \& Uyenoyama, M. K. (Eds.), The Evolution of Population Biology (pp. 297-314). Cambridge, United Kingdom: Cambridge University Press.

HudSON, R. R. \& TURELLI, M. (2003). Stochasticity overrules the "three-times rule": Genetic drift, genetic draft, and coalescence times for nuclear loci versus mitochondrial DNA. Evolution, 57, 182.

JigGins, C. D. \& MALLET, J. (2000). Bimodal hybrid zones and speciation. Trends in Ecology and Evolution, 15, 250-255.

KUMAR, S., TAMURA, K. \& NEI, M. (2004). MEGA3: Integrated Software for Molecular Evolutionary Genetics Analysis and Sequence Alignment. Briefings in Bioinformatics, 5, 150-163.

LANE, C. E., MAYes, C. M., Druehl, L. \& SAunders, G. W. (2006). A multi-gene molecular investigation of the kelp (Laminariales, Phaeophyceae) resolves competing phylogenetic hypotheses and supports substantial taxonomic re-organization. Journal of Phycology, 42, 493-512.

LEWIS, R. J. (1996). Hybridization of brown algae: Compatibility and speciation. In Chaudhary, B. R. \& Agrawal, S. B., Cytology, Genetics and Molecular Biology of Algae (pp. 275-289). Amsterdam: SPB Academic Publishing.

Lindauer, V. W., ChAPMAn, V. J. \& AiKen, M. (1961). The Marine Algae of New Zealand II: Phaeophyceae. Nova Hedwigia, 3, 129-350.

MALLET, J. (2005). Hybridization as an invasion of the genome. Trends in Ecology and Evolution, 20, $229-237$.

MOORE, W. S. (1977). An evaluation of narrow hybrid zones in vertebrates. The Quarterly Review of Biology, 52, 263-277.

Neiva, J., Pearson, G. A., VAlero, M. \& Serrão, E. A. (2010). Surfing the wave on a borrowed board: range expansion and spread of introgressed organellar genomes in the seaweed Fucus ceranoides L. Molecular Ecology, 19, 4812-4822.

RAWSON, P. D. \& HILBISH, T. J. (1998). Asymmetric introgression of mitochondrial DNA among European populations of Blue Mussels (Mytilus spp.). Evolution, 52, 100-108. 
Rawson, P. D., Agrawal, V. \& Hilbish, T. J. (1999). Hybridization between the blue mussels Mytilus galloprovincialis and M. trossulus along the Pacific coast of North America: evidence for limited introgression. Marine Biology, 134, 201-211.

RHYMER, J. M. \& SIMBERLOFF, D. (1996). Extinction by hybridization and introgression. Annual Review of Ecology and Systematics, 27, 83-109.

RIESEBERG, L. H. (1997). Hybrid origins of plant species. Annual Review of Ecology and Systematics, 28, 359-389.

RIESEBERG, L. H. (2006). Hybrid speciation in wild sunflowers. Annals of the Missouri Botanical Garden, 93, 34-48.

RiginOs, C. \& CUNNINGHAM, C. W. (2005). Local adaptation and species segregation in two mussel (Mytilus edulis $\times$ Mytilus trossulus) hybrid zone. Molecular Ecology, 14, 381-400.

SAMBROOK, J., FritSCH, E.F. \& MANIATIS, T. (1989). Molecular cloning: a laboratory manual (2nd ed.). Cold Spring Harbor NY: Cold Spring Harbor Press.

SCHWENK, K., BREDE, N. \& STREIT, B. (2008). Introduction: Extent, processes and evolutionary impact of interspecific hybridization in animals. Philosophical Transactions of the Royal Society B Series, 363, $2805-2811$.

SHEARS, N. T. \& BABCOCK, R. C. (2004). Community composition and structure of shallow subtidal reefs in northeastern New Zealand (Science for Conservation 245). Wellington, New Zealand: New Zealand Department of Conservation.

SHEARS, N. T. \& BABCOCK, R. C. (2007). Quantitative description of New Zealand's shallow sub-tidal reef communities (Science for Conservation 280). Wellington, New Zealand: New Zealand Department of Conservation.

ZuCCARELlO, G. C. \& LOKHORST, G. M. (2005). Molecular phylogeny of the genus Tribonema (Xanthophyceae) using $r b c \mathrm{~L}$ gene sequence data: monophyly of morphologically simple algal species. Phycologia, 44, 384-392. 
Chapter 4

Barcoding brown algae: Does cox1 identify species of Cystophora (Fucales, Phaeophyceae)? 


\subsection{Abstract}

Many brown macroalgal species can be confused because of limited morphological differentiation and plasticity. DNA barcoding has been proposed as an alternative to morphological species identification. In barcoding, short (c. 600 bp) mitochondrial DNA sequences are analysed by distance methods and discontinuities between intraspecific and interspecific mtDNA variation are used as indicators of species boundaries. The utility of cox 1 DNA barcoding was evaluated by comparing 108 sequences from 13 species of Cystophora, an Australasian genus of brown algae. A 615 base pair fragment of the $\operatorname{cox} 1$ gene was adequate to assign most specimens to species and resolved some morphologically difficult specimens, but molecular distance between some species was low - often only slightly greater than intraspecific distances. Morphologically ambiguous specimens of $C$. subfarcinata, $C$. retorta and $C$. siliquosa could be identified by cox 1 sequences. Neither $\operatorname{cox} 1$ nor ITS data supported the maintenance of $C$. congesta or $C$. distenta as independent species. I suggest cox 1 alone might be too conserved for reliable barcoding in the brown algae.

\subsection{Introduction}

DNA BARCODING uses phenetic differences between short mtDNA sequences from a single region for species identification (Hebert et al. 2003, 2004; Ratnasingham \& Hebert 2007). Proponents of DNA barcoding have suggested that the technique can fill gaps in taxonomic knowledge, document biodiversity loss, facilitate ecological studies and allow objective delimitation of species (Hebert et al. 2003). The approach attracted controversy (Will \& Rubinoff 2004; Rubinoff et al. 2006), in part because both proponents and detractors have failed to distinguish barcoding from DNA taxonomy, species discovery, and molecular phylogenetics. In practice, establishing databases of species tagged sequences has required use of additional markers and morphological and ecological data to assign species names to specimens, effectively engaging in integrative taxonomy (Dayrat 2005), and early suggestions that the approach might supplant traditional taxonomy have abated (Schindel \& Miller 2005; Rubinoff 2006). Large 
DNA barcoding programmes have been established, particularly in animal groups (Frézal \& Leblois 2008; Janzen et al. 2009; Golding et al. 2009; Ward et al. 2009).

Most barcoding studies have delimited species using a discontinuity between intraspecific and interspecific genetic distances (either uncorrected p-distance or Kimura 2-parameter). Hebert et al. (2004) proposed a species level threshold of 10times mean intraspecific variation. Using mean distances inflates discontinuities and the smallest distance should be used (Meier et al. 2008). Ten-times thresholds cannot be rigidly applied, as genetic distance between congeners is variable, depending on the time since speciation, generation time, the strength of different speciation processes, population size and connectivity, and mutation and repair rate variation between lineages (Ferguson 2002; Will \& Rubinoff 2004; Kumar 2005; Hickerson et al. 2006). One solution is to test species divergence using coalescence models (Papadopoulou et al. 2008; Baker et al. 2009). Character-based species delimitation has been proposed as an alternative to distance methods (DeSalle et al. 2005), but its application, so far, is limited (Rach et al. 2008).

Spatial heterogeneity of intraspecific variation (Avise 2000; Hoarau et al. 2007; Maggs et al. 2008) is problematic for barcoding as even geographically widespread sampling might not encompass the most variable populations (Zuccarello et al. 2006), and the limited sampling of conspecifics in many barcoding studies might seriously underestimate intraspecific variation and overestimate the number of fixed differences between species. This will produce misleading estimates of genetic distance between species. Alternatively, where genetic structure is high, extensive sampling might result in demes being identified as species (Trewick 2008).

As a technical method of assigning specimens to species, either character-based or distance-based barcoding procedures might assist species identification if a preliminary study shows sufficient interspecific distance or fixed characters to separate closely related (i.e. sister) species, based on adequate sampling over the geographical range of the species; and if interspecific distances or fixed characters are corroborated in a preliminary study with morphological or other characters (i.e. integrated taxonomy, Dayrat 2005).

Most barcoding studies aim to evaluate the efficacy of a marker to delineate species within a group, and to establish a reference database of species tagged 
sequences to identify samples from subsequent studies. Specimens are assigned to species according to existing taxonomic criteria; the congruence of disjunctions in genetic variation with a priori species assignments is assessed; and, if necessary, taxonomic revisions are made on the basis of corroborated information. I suggest four criteria for a conservative evaluation of a locus for species identification: (1) does the marker resolve discrete clusters within a genus? (2) Are these clusters concordant with species boundaries indicated by other taxonomic information (e.g., morphology, anatomy, ecology, chemistry, physiology, mating studies)? (3) Is sampling sufficient to represent intraspecific variation across the range of each species? (4) Does sampling include closely related species?

The $5^{\prime}$ end of the cytochrome oxidase $1 \mathrm{mtDNA}$ gene ( $\left.\operatorname{cox} 1\right)$ is the preferred locus for barcoding in vertebrates and arthropods (Hebert et al. 2004; Linares et al. 2008; Ward et al. 2008; Golding et al. 2009). This region is too conserved at the species level in plants and green algae, and various combinations of regions have been proposed as potential barcodes for terrestrial plants (Chase et al. 2007; Kress \& Erickson 2007; Lahaye et al. 2008; Ford et al. 2009; Seberg \& Petersen 2009) or green algae (Presting 2006; Engelmann et al. 2009). Barcoding has been attempted in red algae (Saunders 2005, 2008, 2009; Robba et al. 2006; Yang et al. 2008), dinoflagellates (Litaker et al. 2007), diatoms (Evans et al. 2007; Moniz \& Kaczmarska 2009, 2010), and brown algae (Lane et al. 2007; Kucera \& Saunders 2008; McDevit \& Saunders 2009). The cox1 region has been proposed as a suitable locus for barcoding red and brown algae (Saunders 2005; Robba et al. 2006).

To evaluate $\operatorname{cox} 1$ as a locus for species identification in brown algae, I compare a barcoding approach to phylogenetic and morphological species delimitation in the genus Cystophora J. Agardh (Sargassaceae, Fucales), with an emphasis on New Zealand representatives. Cystophora is an ideal genus for testing the barcoding approach as a thorough morphological taxonomy is available (Womersley 1964, 1987), the genus is relatively speciose (23 species listed in Womersley 1964), and includes species with highly disjunct morphologies and others that are morphologically similar.

Barcoding of brown algae by cox 1 has had limited success. Lane et al. (2007) attempted a cox 1 barcoding study of Alaria species from the north-east Pacific. Intergeneric variation was relatively low and there was no clear threshold between inter- 
clade and intra-clade variation. In addition, clusters of cox 1 mitotypes were not congruent with a priori morphological species assignments, nor with clades inferred from nrDNA internal transcribed spacer (ITS) sequences. ITS variation was relatively high, but did not resolve species level groups. Lane et al. (2007) suggest that widespread introgressive hybridisation precludes molecular delimitation of Alaria species in the study region. Kucera \& Saunders (2008) used cox 1 sequences to delineate samples of Fucus into three clusters, but it is not clear whether these results support wider use of $\operatorname{cox} 1$ in brown algae, as sampling did not extend across the species' ranges, some morphological assignments were not congruent with sequence data and one cluster included two species. McDevit \& Saunders (2009) reported cox1 barcodes for 29 species of brown algae, but did not assess intraspecific or intrageneric diversity. Most genera were represented by a single species and sampling of congeners or conspecifics was geographically restricted. This study shows adequate cox 1 variation to separate genera, but does not address the separation of sister species.

These studies leave the efficacy of cox 1 barcoding of brown algae uncertain. This study aims to further evaluate $\operatorname{cox} 1$ species identification in brown algae by comparing cox 1 species delimitation of Cystophora species against morphological criteria and combined cox 1 and ITS phylogenetic analysis.

\subsection{Materials and Methods}

Cystophora species and close relatives were collected from 51 sites in New Zealand and southern Australia (Table 4.1, Fig. 4.1). Thalli were pressed as voucher specimens. Clean apices were detached and rapidly dried and stored in silica gel for subsequent DNA extraction. Morphological identifications used characters specified by Womersley (1964, 1987). Key diagnostic characters are listed in Table 4.2.

DNA was extracted from approximately $2-5 \mathrm{mg}$ of dry tissue using a modified CTAB buffer procedure (Zuccarello \& Lokhorst 2005), with the addition of $1 \%$ polyvinylpolypyrrolidone to the extraction buffer.

\section{PCR and primers}

A $615 \mathrm{bp}$ fragment from the $5^{\prime}$ end of the cox 1 mitochondrial gene was amplified using primer pairs GAZF2 and GAZR2 (Lane et al. 2007) or GAZF2 and a new primer, 
fcox808R (5'-TAAACTTCGGGGTGTCCAAA-3'). The latter primer was designed from alignments of the Fucus, Laminaria and Desmarestia mitochondrial genomes (Oudot-Le Seq et al. 2002, 2006). Amplification of the ITS1-5.8S-ITS2 cistron used either AFP2(F) (Peters \& Burkhardt 1998) or P1 (Tai et al. 2001) forward primers and KG4 reverse primer (Lane et al. 2006).

Cox 1 amplification used a PCR routine with an initial denaturation step of $94^{\circ} \mathrm{C}$ for $4 \mathrm{~min}$, then 35 cycles of 1 min at $94^{\circ} \mathrm{C}, 30$ seconds at $50^{\circ} \mathrm{C}$ and $1 \mathrm{~min}$ at $72^{\circ} \mathrm{C}$, with a final extension of $72^{\circ} \mathrm{C}$ for $7 \mathrm{~min}$. ITS amplifications used a touchdown PCR routine with an initial denaturation step of $94^{\circ} \mathrm{C}$ for $4 \mathrm{~min}$, then 5 cycles of $1 \mathrm{~min}$ at $94^{\circ} \mathrm{C}$, seconds at $55^{\circ} \mathrm{C}\left(-1^{\circ} \mathrm{C} /\right.$ cycle $)$ and $1 \mathrm{~min}$ at $72^{\circ} \mathrm{C}$, followed by 30 cycles of $1 \mathrm{~min}$ at $94^{\circ} \mathrm{C}$,

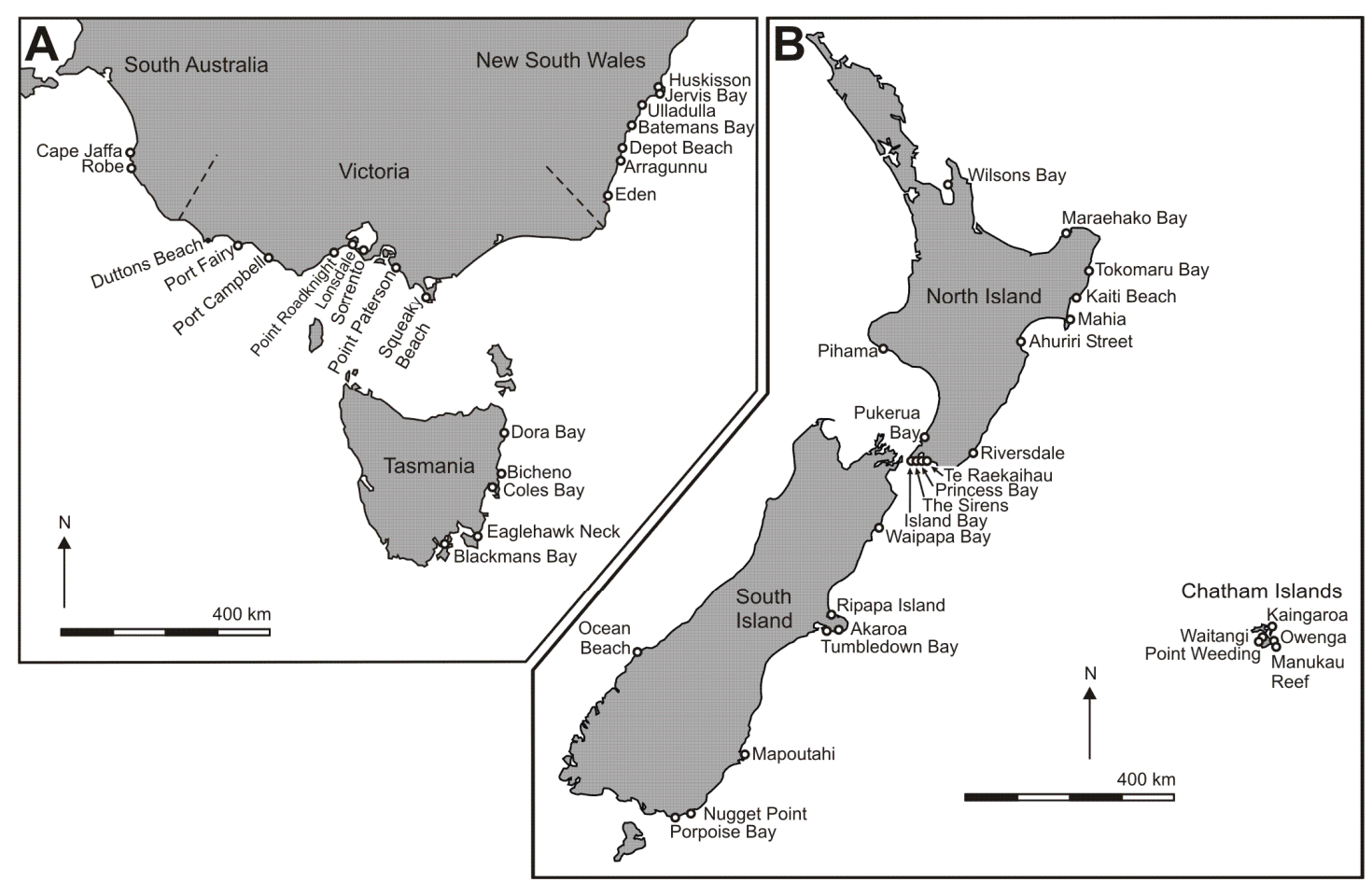

Fig. 4.1. Map showing sampling locations (for details see Table 4.1). A. Southern Australia. B. New Zealand.

45 seconds at $50^{\circ} \mathrm{C}$ and $1 \mathrm{~min}$ at $72^{\circ} \mathrm{C}$, with a final extension of $72^{\circ} \mathrm{C}$ for $10 \mathrm{~min}$. The PCR mix for both regions contained $1 \mu 1$ genomic DNA, $0.5 \mathrm{U}$ Taq DNA polymerase (New England Biolabs) 1× ThermoPol reaction buffer (NEB), 7.5 pmoles each primer, 
$200 \mathrm{nM}$ dNTP and $0.01 \%$ BSA. Amplified products were checked for length and yield on $1 \%$ agarose gels stained with ethidium bromide.

PCR products were cleaned with ExoSAP-IT (USB, Cleveland, Ohio) enzymes and sequenced commercially (Macrogen Inc., Seoul, Korea). Sequencing cox 1 fragments used the same primers as amplification. ITS sequencing used the additional internal primers KP5 and KIR1 (Lane et al. 2006).

\section{Data analysis}

Cox1 fragments were aligned using the ClustalW algorithm in MEGA3 (Tamura et al. 2007). Alignment was straightforward with no gaps (Appendix 4). A neighbour-joining tree was inferred in PAUP*4.10 (Swofford 2002), with the parameters estimated from MODELTEST 3.7 (Posada \& Crandall 1998) (HKY85 + $\Gamma+\mathrm{I}$, transition/transversion ratio $=3.6467$, kappa $=7.489067$, nucleotide frequencies: $\mathrm{A}=0.1948, \mathrm{C}=0.1909, \mathrm{G}=$ $0.2191, \mathrm{~T}=0.3952$, invariable sites $=0.6392, \Gamma=0.9596$ ). Confidence limits of branches were tested with 1000 bootstrap replications.

ITS sequences were aligned using the ClustalW algorithm in MEGA3, and the alignment edited manually (Appendix 5). A partition homogeneity test for incongruity between cox 1 and ITS datasets was executed in PAUP* (1000 replicates). Maximumparsimony trees were inferred from the combined ITS and cox 1 sequences (2074 bp) in PAUP* with the parameters estimated from MODELTEST $(\mathrm{HKY}+\mathrm{I}+\Gamma$, transition/transversion ratio $=2.5289$, nucleotide frequencies: $\mathrm{A}=0.1801, \mathrm{C}=0.2663$, $\mathrm{G}=0.3050, \mathrm{~T}=0.2486$, invariable sites $=0.5809, \Gamma=0.7626) .1000$ maximum likelihood trees were inferred using GARLI 1.0 (Zwickl 2006) using the same parameters, and a consensus tree was calculated in PAUP*. A Bayesian tree for the combined data was inferred using MrBayes 3.1.2 (Huelsenbeck \& Ronquist 2001) with ITS and $\operatorname{cox} 1$ regions partitioned, and each $\operatorname{cox} 1$ codon position partitioned. 
Table 4.1. Voucher numbers of specimens used in analyses, collection locations, latitude and longitude and GenBank accession numbers of sequences.

\begin{tabular}{lllll}
\hline $\begin{array}{l}\text { Herbarium } \\
\text { voucher }\end{array}$ & Species & Location & Latitude, & \multicolumn{2}{l}{ GenBank Accession } \\
number & & Longitude & $\begin{array}{ll}\text { numbers } \\
\text { nox } 1\end{array}$ & ITS
\end{tabular}

\begin{tabular}{|c|c|c|c|c|c|}
\hline $\begin{array}{l}\text { WELT } \\
\text { A031507 }\end{array}$ & C. congesta & Lonsdale VIC & $\begin{array}{l}38^{\circ} 17^{\prime} 5.30^{\prime \prime} \mathrm{S}, \\
144^{\circ} 36^{\prime} 54.74^{\prime \prime} \mathrm{E}\end{array}$ & GU289263 & GU289363 \\
\hline $\begin{array}{l}\text { WELT } \\
\text { A031510 }\end{array}$ & C. congesta & Lonsdale VIC & $\begin{array}{l}38^{\circ} 17^{\prime} 5.30^{\prime \prime} \mathrm{S}, \\
144^{\circ} 36^{\prime} 54.74^{\prime \prime} \mathrm{E}\end{array}$ & GU289264 & GU289364 \\
\hline $\begin{array}{l}\text { WELT } \\
\text { A031509 }\end{array}$ & C. congesta & $\begin{array}{l}\text { Port Campbell } \\
\text { VIC }\end{array}$ & $\begin{array}{l}38^{\circ} 37^{\prime} 14.84^{\prime \prime} \mathrm{S}, \\
142^{\circ} 59^{\prime} 32.69^{\prime \prime} \mathrm{E}\end{array}$ & GU289281 & - \\
\hline $\begin{array}{l}\text { WELT } \\
\text { A031512 }\end{array}$ & C. congesta & Robe SA & $\begin{array}{l}37^{\circ} 9^{\prime} 23.33^{\prime \prime} \mathrm{S}, \\
139^{\circ} 44^{\prime} 56.32^{\prime \prime} \mathrm{E}\end{array}$ & GU289330 & - \\
\hline $\begin{array}{l}\text { WELT } \\
\text { A031511 }\end{array}$ & C. congesta & Robe SA & $\begin{array}{l}37^{\circ} 9^{\prime} 23.33^{\prime \prime} \mathrm{S}, \\
139^{\circ} 44^{\prime} 56.32^{\prime \prime} \mathrm{E}\end{array}$ & GU289285 & GU289374 \\
\hline $\begin{array}{l}\text { WELT } \\
\text { A031508 }\end{array}$ & C. congesta & Robe SA & $\begin{array}{l}37^{\circ} 9^{\prime} 23.33^{\prime \prime} \mathrm{S}, \\
139^{\circ} 44^{\prime} 56.32^{\prime \prime} \mathrm{E}\end{array}$ & GU289286 & GU289375 \\
\hline $\begin{array}{l}\text { WELT } \\
\text { A030927 }\end{array}$ & C. congesta & $\begin{array}{l}\text { The Sirens, } \\
\text { Wellington NZ }\end{array}$ & $\begin{array}{l}41^{\circ} 20^{\prime} 56.91^{\prime \prime} \mathrm{S}, \\
174^{\circ} 45^{\prime} 51.05^{\prime \prime} \mathrm{E}\end{array}$ & GU289316 & GU289388 \\
\hline $\begin{array}{l}\text { WELT } \\
\text { A031340 }\end{array}$ & C. distenta & $\begin{array}{l}\text { Manukau Reef, } \\
\text { Chatham Islands }\end{array}$ & $\begin{array}{l}44^{\circ} 2^{\prime} 4.90^{\prime \prime} \mathrm{S}, \\
176^{\circ} 19^{\prime} 44.31^{\prime \prime} \mathrm{W}\end{array}$ & GU289317 & GU289389 \\
\hline $\begin{array}{l}\text { WELT } \\
\text { A030933 }\end{array}$ & C. distenta & $\begin{array}{l}\text { Mapoutahi, Otago } \\
\text { Peninsula NZ }\end{array}$ & $\begin{array}{l}45^{\circ} 44^{\prime} 5.57^{\prime \prime} \mathrm{S}, \\
170^{\circ} 37^{\prime} 4.53^{\prime \prime} \mathrm{E}\end{array}$ & GU289338 & - \\
\hline $\begin{array}{l}\text { WELT } \\
\text { A031343 }\end{array}$ & C. distenta & $\begin{array}{l}\text { Owenga, Chatham } \\
\text { Islands }\end{array}$ & $\begin{array}{l}44^{\circ} 2^{\prime} 0.30^{\prime \prime} \mathrm{S}, \\
176^{\circ} 19^{\prime} 58.80^{\prime \prime} \mathrm{W}\end{array}$ & GU289318 & GU289390 \\
\hline $\begin{array}{l}\text { WELT } \\
\text { A031497 }\end{array}$ & C. monilifera & Eden NSW & $\begin{array}{l}37^{\circ} 4^{\prime} 16.80^{\prime \prime} \mathrm{S}, \\
149^{\circ} 54^{\prime} 21.85^{\prime \prime} \mathrm{E}\end{array}$ & GU289255 & GU289356 \\
\hline $\begin{array}{l}\text { WELT } \\
\text { A031500 }\end{array}$ & C. monilifera & Huskisson, NSW & $\begin{array}{l}35^{\circ} 2^{\prime} 34.31^{\prime \prime} \mathrm{S}, \\
150^{\circ} 40^{\prime} 38.77^{\prime \prime} \mathrm{E}\end{array}$ & GU289248 & GU289352 \\
\hline $\begin{array}{l}\text { WELT } \\
\text { A031501 }\end{array}$ & C. monilifera & Lonsdale VIC & $\begin{array}{l}38^{\circ} 17^{\prime} 5.30^{\prime \prime} \mathrm{S}, \\
144^{\circ} 36^{\prime} 54.74^{\prime \prime} \mathrm{E}\end{array}$ & GU289266 & - \\
\hline $\begin{array}{l}\text { WELT } \\
\text { A031498 }\end{array}$ & C. monilifera & Ulladulla, NSW & $\begin{array}{l}35^{\circ} 21^{\prime} 37.65^{\prime \prime} \mathrm{S}, \\
150^{\circ} 29^{\prime} 5.55^{\prime \prime} \mathrm{E}\end{array}$ & GU289251 & - \\
\hline
\end{tabular}


Table 4.1. (continued)

\begin{tabular}{|c|c|c|c|c|c|}
\hline $\begin{array}{l}\text { Herbarium } \\
\text { voucher } \\
\text { number }\end{array}$ & Species & Location & $\begin{array}{l}\text { Latitude, } \\
\text { Longitude }\end{array}$ & $\begin{array}{l}\text { GenBank A } \\
\text { numbers } \\
\operatorname{cox} 1\end{array}$ & $\begin{array}{l}\text { cession } \\
\text { ITS }\end{array}$ \\
\hline WELT & C. monilifera & Ulladulla, NSW & $35^{\circ} 21^{\prime} 37.65^{\prime \prime} \mathrm{S}$ & GU289306 & GU289387 \\
\hline A031499 & & & $150^{\circ} 29^{\prime} 5.55^{\prime \prime} \mathrm{E}$ & & \\
\hline WELT & $C$. & Blackmans Beach, & $43^{\circ} 0^{\prime} 27.26^{\prime \prime} \mathrm{S}$ & GU289291 & GU289379 \\
\hline A031496 & moniliformis & Tasmania & $147^{\circ} 19^{\prime} 44.06^{\prime \prime} \mathrm{E}$ & & \\
\hline WELT & $C$. & Jervis Bay, NSW & $35^{\circ} 8^{\prime} 11.52^{\prime \prime} \mathrm{S}$ & GU289249 & GU289353 \\
\hline A031495 & moniliformis & & $150^{\circ} 44^{\prime} 28.69^{\prime \prime} \mathrm{E}$ & & \\
\hline WELT & C. & Cape Paterson & $38^{\circ} 40^{\prime} 29.26^{\prime \prime} \mathrm{S}$ & GU289257 & GU289358 \\
\hline A031493 & platylobium & VIC & $145^{\circ} 37^{\prime} 2.65^{\prime \prime} \mathrm{E}$ & & \\
\hline WELT & C. & Duttons Beach, & $38^{\circ} 19^{\prime} 42.74^{\prime \prime} \mathrm{S}$ & GU289279 & - \\
\hline A031494 & platylobium & Portland VIC & $141^{\circ} 36^{\prime} 22.27^{\prime \prime} \mathrm{E}$ & & \\
\hline WELT & $C$ & Porpoise Bay, & $46^{\circ} 39^{\prime} 39.37^{\prime \prime} \mathrm{S}$, & GU289237 & GU289348 \\
\hline A030929 & platylobium & Otago NZ & $169^{\circ} 6^{\prime} 29.32^{\prime \prime} \mathrm{E}$ & & \\
\hline WELT & C. & Cape Paterson & $38^{\circ} 40^{\prime} 29.26^{\prime \prime} \mathrm{S}$, & GU289261 & GU289361 \\
\hline A031492 & polycystidea & VIC & $145^{\circ} 37^{\prime} 2.65^{\prime \prime} \mathrm{E}$ & & \\
\hline WELT & $C$ & Cape Paterson & $38^{\circ} 40^{\prime} 29.26^{\prime \prime} \mathrm{S}$ & GU289262 & GU289362 \\
\hline A031489 & polycystidea & VIC & $145^{\circ} 37^{\prime} 2.65^{\prime \prime} \mathrm{E}$ & & \\
\hline WELT & $C$ & Coles Bay, & $42^{\circ} 77^{\prime} 35.52^{\prime \prime} \mathrm{S}$ & GU289298 & GU289383 \\
\hline A031491 & polycystidea & Tasmania & $148^{\circ} 17^{\prime} 32.09^{\prime \prime} \mathrm{E}$ & & \\
\hline WELT & $C$ & Port Fairy VIC & $38^{\circ} 23^{\prime} 42.65^{\prime \prime} \mathrm{S}$ & GU289284 & GU289373 \\
\hline A031490 & polycystidea & & $142^{\circ} 14^{\prime} 35.99^{\prime \prime} \mathrm{E}$ & & \\
\hline WELT & C. retorta & Cape Jaffa SA & $36^{\circ} 56^{\prime} 30.94^{\prime \prime} \mathrm{S}$ & GU289309 & - \\
\hline ASZ243A & & & $139^{\circ} 40^{\prime} 30.93^{\prime \prime} \mathrm{E}$ & & \\
\hline $\begin{array}{l}\text { WELT } \\
\text { ASZ243B }\end{array}$ & C. retorta & Cape Jaffa SA & $\begin{array}{l}36^{\circ} 56^{\prime} 30.94^{\prime \prime} \mathrm{S}, \\
139^{\circ} 40^{\prime} 30.93^{\prime \prime} \mathrm{E}\end{array}$ & GU289310 & - \\
\hline $\begin{array}{l}\text { WELT } \\
\text { A031546 }\end{array}$ & C. retorta & $\begin{array}{l}\text { Cape Paterson } \\
\text { VIC }\end{array}$ & $\begin{array}{l}38^{\circ} 40^{\prime} 29.26^{\prime \prime} \mathrm{S}, \\
145^{\circ} 37^{\prime} 2.65^{\prime \prime} \mathrm{E}\end{array}$ & GU289258 & - \\
\hline $\begin{array}{l}\text { WELT } \\
\text { A031545 }\end{array}$ & C. retorta & $\begin{array}{l}\text { Cape Paterson } \\
\text { VIC }\end{array}$ & $\begin{array}{l}38^{\circ} 40^{\prime} 29.26^{\prime \prime} \mathrm{S}, \\
145^{\circ} 37^{\prime} 2.65^{\prime \prime} \mathrm{E}\end{array}$ & GU289259 & GU289359 \\
\hline
\end{tabular}


Table 4.1. (continued)

\begin{tabular}{|c|c|c|c|c|c|}
\hline $\begin{array}{l}\text { Herbarium } \\
\text { voucher } \\
\text { number }\end{array}$ & Species & Location & $\begin{array}{l}\text { Latitude, } \\
\text { Longitude }\end{array}$ & $\begin{array}{l}\text { GenBank A } \\
\text { numbers }\end{array}$ & cession \\
\hline WELT & C. retorta & Coles Bay, & $42^{\circ} 7^{\prime} 35.52^{\prime \prime} \mathrm{S}$ & GU289297 & - \\
\hline A031547 & & Tasmania & $148^{\circ} 17^{\prime} 32.09^{\prime \prime} \mathrm{E}$ & & \\
\hline WELT & C. retorta & Point Roadknight & $38^{\circ} 25^{\prime} 40.72^{\prime \prime} \mathrm{S}$ & GU289273 & - \\
\hline A031550 & & VIC & $144^{\circ} 11^{\prime} 7.78^{\prime \prime} \mathrm{E}$ & & \\
\hline WELT & C. retorta & Point Roadknight & $38^{\circ} 25^{\prime} 40.72^{\prime \prime} \mathrm{S}$ & GU289275 & GU289369 \\
\hline A031548 & & VIC & $144^{\circ} 11^{\prime} 7.78^{\prime \prime} \mathrm{E}$ & & \\
\hline WELT & C. retorta & Squeaky Beach, & $39^{\circ} 1^{\prime} 45.89^{\prime \prime} \mathrm{S}$ & GU289278 & - \\
\hline A031549 & & Wilsons & $146^{\circ} 18^{\prime} 24.24^{\prime \prime} \mathrm{E}$ & & \\
\hline & & Promontory VIC & & & \\
\hline WELT & C. retroflexa & Akaroa, Banks & $43^{\circ} 49^{\prime} 49.58^{\prime \prime} \mathrm{S}$ & GU289246 & - \\
\hline A030919 & & Peninsula, NZ & $172^{\circ} 54^{\prime} 30.03^{\prime \prime} \mathrm{E}$ & & \\
\hline WELT & C. retroflexa & Blackmans Beach, & $43^{\circ} 0^{\prime} 27.26^{\prime \prime} \mathrm{S}$ & GU289288 & GU289377 \\
\hline A031488 & & Tasmania & $147^{\circ} 19^{\prime} 44.06^{\prime \prime} \mathrm{E}$ & & \\
\hline WELT & C. retroflexa & Coles Bay, & $42^{\circ} 7^{\prime} 35.52^{\prime \prime} \mathrm{S}$ & GU289296 & - \\
\hline A031534 & & Tasmania & $148^{\circ} 17^{\prime} 32.09^{\prime \prime} \mathrm{E}$ & & \\
\hline WELT & C. retroflexa & Coles Bay, & $42^{\circ} 7^{\prime} 35.52^{\prime \prime} \mathrm{S}$ & GU289324 & - \\
\hline A031537 & & Tasmania & $148^{\circ} 17^{\prime} 32.09^{\prime \prime} \mathrm{E}$ & & \\
\hline WELT & C. retroflexa & Depot Beach & $35^{\circ} 37^{\prime} 37.91^{\prime \prime} \mathrm{S}$, & GU289252 & - \\
\hline A031531 & & NSW & $150^{\circ} 19^{\prime} 37.27^{\prime \prime} \mathrm{E}$ & & \\
\hline WELT & C. retroflexa & Island Bay, & $41^{\circ} 20^{\prime} 51.22^{\prime \prime} \mathrm{S}$ & GU289329 & - \\
\hline A030917 & & Wellington, NZ & $174^{\circ} 46^{\prime} 9.77^{\prime \prime} \mathrm{E}$ & & \\
\hline WELT & C. retroflexa & Kaiti Beach, & $38^{\circ} 40^{\prime} 55.97^{\prime \prime} \mathrm{S}$ & GU289333 & - \\
\hline A030934 & & Gisborne NZ & $178^{\circ} 1^{\prime} 45.79^{\prime \prime} \mathrm{E}$ & & \\
\hline WELT & C. retroflexa & Mahia, East Coast & $39^{\circ} 5^{\prime} 14.33^{\prime \prime} \mathrm{S}$ & GU289331 & - \\
\hline \multirow[t]{2}{*}{ A030918 } & & Road, Eastland & $177^{\circ} 55^{\prime} 46.40^{\prime \prime} \mathrm{E}$ & & \\
\hline & & $\mathrm{NZ}$ & & & \\
\hline WELT & C. retroflexa & Point Lonsdale & $38^{\circ} 17^{\prime} 20.52^{\prime \prime} \mathrm{S}$ & GU289269 & - \\
\hline A031533 & & VIC & $144^{\circ} 36^{\prime} 4.42^{\prime \prime} \mathrm{E}$ & & \\
\hline
\end{tabular}


Table 4.1. (continued)

\begin{tabular}{|c|c|c|c|c|c|}
\hline $\begin{array}{l}\text { Herbarium } \\
\text { voucher } \\
\text { number }\end{array}$ & Species & Location & $\begin{array}{l}\text { Latitude, } \\
\text { Longitude }\end{array}$ & \multicolumn{2}{|c|}{$\begin{array}{l}\text { GenBank Accession } \\
\text { numbers }\end{array}$} \\
\hline WELT & C. retroflexa & Porpoise Bay, & $46^{\circ} 39^{\prime} 39.37^{\prime \prime} \mathrm{S}$, & GU289340 & - \\
\hline A030928 & & Otago NZ & $169^{\circ} 6^{\prime} 29.32^{\prime \prime} \mathrm{E}$ & & \\
\hline WELT & C. retroflexa & Port Fairy VIC & $38^{\circ} 23^{\prime} 42.65^{\prime \prime} \mathrm{S}$ & GU289342 & - \\
\hline A031536 & & & $142^{\circ} 14^{\prime} 35.99^{\prime \prime} \mathrm{E}$ & & \\
\hline WELT & C. retroflexa & Princess Bay, & $41^{\circ} 20^{\prime} 43.05^{\prime \prime} \mathrm{S}$ & GU289325 & - \\
\hline A030914 & & Wellington NZ & $174^{\circ} 47^{\prime} 14.08^{\prime \prime} \mathrm{E}$ & & \\
\hline WELT & C. retroflexa & Princess Bay, & $41^{\circ} 20^{\prime} 43.05^{\prime \prime} \mathrm{S}$ & GU289326 & - \\
\hline A030913 & & Wellington NZ & $174^{\circ} 47^{\prime} 14.08^{\prime \prime} \mathrm{E}$ & & \\
\hline WELT & C. retroflexa & Princess Bay, & $41^{\circ} 20^{\prime} 43.05^{\prime \prime} \mathrm{S}$ & GU289232 & GU289345 \\
\hline A030926 & & Wellington NZ & $174^{\circ} 47^{\prime} 14.08^{\prime \prime} \mathrm{E}$ & & \\
\hline A085 & C. retroflexa & Princess Bay, & $41^{\circ} 20^{\prime} 43.05^{\prime \prime} \mathrm{S}$ & GU289233 & GU289346 \\
\hline & & Wellington NZ & $174^{\circ} 47^{\prime} 14.08^{\prime \prime} \mathrm{E}$ & & \\
\hline WELT & C. retroflexa & Sorrento, VIC & $38^{\circ} 20^{\prime} 5.35^{\prime \prime} \mathrm{S}$ & GU289268 & - \\
\hline A031535 & & & $144^{\circ} 44^{\prime} 33.96^{\prime \prime} \mathrm{E}$ & & \\
\hline WELT & C. retroflexa & Sorrento, VIC & $38^{\circ} 20^{\prime} 5.35^{\prime \prime} \mathrm{S}$ & GU289267 & GU289366 \\
\hline A031530 & & & $144^{\circ} 44^{\prime} 33.96^{\prime \prime} \mathrm{E}$ & & \\
\hline WELT & C. retroflexa & Te Raekaihau, & $41^{\circ} 20^{\prime} 50.92^{\prime \prime} \mathrm{S}$, & GU289238 & GU289349 \\
\hline A030900 & & Wellington NZ & $174^{\circ} 47^{\prime} 29.01^{\prime \prime} \mathrm{E}$ & & \\
\hline WELT & C. retroflexa & Tokomaru Bay, & $38^{\circ} 6^{\prime} 35.83^{\prime \prime} \mathrm{S}$, & GU289328 & - \\
\hline A030932 & & Eastland, NZ & $178^{\circ} 21^{\prime} 18.27^{\prime \prime} \mathrm{E}$ & & \\
\hline WELT & C. sp. cf. & Ahuriri Street, & $39^{\circ} 28^{\prime} 42.28^{\prime \prime} \mathrm{S}$ & GU289312 & - \\
\hline A030930 & scalaris & Napier NZ & $176^{\circ} 54^{\prime} 12.89^{\prime \prime} \mathrm{E}$ & & \\
\hline WELT & C. scalaris & Akaroa, Banks & $43^{\circ} 49^{\prime} 49.58^{\prime \prime} \mathrm{S}$ & GU289245 & - \\
\hline A030919 & & Peninsula NZ & $172^{\circ} 54^{\prime} 30.03^{\prime \prime} \mathrm{E}$ & & \\
\hline WELT & C. scalaris & Kaingaroa, & $43^{\circ} 43^{\prime} 51.20^{\prime \prime} \mathrm{S}$ & GU289303 & GU289385 \\
\hline A031346 & & Chatham Islands & $176^{\circ} 16^{\prime} 2.26^{\prime \prime} \mathrm{W}$ & & \\
\hline WELT & C. scalaris & Manukau Reef, & $44^{\circ} 2^{\prime} 4.90^{\prime \prime} \mathrm{S}$ & GU289241 & GU289350 \\
\hline ASG207 & & Chatham Islands & $176^{\circ} 19^{\prime} 44.31^{\prime \prime} \mathrm{W}$ & & \\
\hline
\end{tabular}


Table 4.1. (continued)

\begin{tabular}{|c|c|c|c|c|c|}
\hline $\begin{array}{l}\text { Herbarium } \\
\text { voucher }\end{array}$ & Species & Location & $\begin{array}{l}\text { Latitude, } \\
\text { Longitude }\end{array}$ & $\begin{array}{l}\text { GenBank A } \\
\text { numbers }\end{array}$ & cession \\
\hline WELT & C. scalaris & Ocean Beach, & $43^{\circ} 57^{\prime} 54.44^{\prime \prime} \mathrm{S}$ & GU289243 & GU289351 \\
\hline A030922 & & Jackson Bay NZ & $168^{\circ} 36^{\prime} 21.70^{\prime \prime} \mathrm{E}$ & & \\
\hline WELT & C. scalaris & Point Weeding, & $43^{\circ} 56^{\prime} 32.08^{\prime \prime} \mathrm{S}$ & GU289302 & - \\
\hline A031345 & & Chatham Islands & $176^{\circ} 34^{\prime} 14.74^{\prime \prime} \mathrm{W}$ & & \\
\hline WELT & C. scalaris & Point Weeding, & $43^{\circ} 56^{\prime} 32.08^{\prime \prime} \mathrm{S}$, & GU289335 & - \\
\hline A030909 & & Chatham Islands & $176^{\circ} 34^{\prime} 14.74^{\prime \prime} \mathrm{W}$ & & \\
\hline WELT & C. scalaris & Point Weeding, & $43^{\circ} 56^{\prime} 32.08^{\prime \prime} \mathrm{S}$, & GU289336 & - \\
\hline A030908 & & Chatham Islands & $176^{\circ} 34^{\prime} 14.74^{\prime \prime} \mathrm{W}$ & & \\
\hline WELT & C. scalaris & Point Weeding, & $43^{\circ} 56^{\prime} 32.08^{\prime \prime} \mathrm{S}$, & GU289337 & - \\
\hline A030910 & & Chatham Islands & $176^{\circ} 34^{\prime} 14.74^{\prime \prime} \mathrm{W}$ & & \\
\hline WELT & C. scalaris & Point Weeding, & $43^{\circ} 56^{\prime} 32.08^{\prime \prime} \mathrm{S}$, & GU289319 & GU289391 \\
\hline A031345 & & Chatham Islands & $176^{\circ} 34^{\prime} 14.74^{\prime \prime} \mathrm{W}$ & & \\
\hline WELT & C. scalaris & Pukerua Bay NZ & $41^{\circ} 1^{\prime} 28.36^{\prime \prime} \mathrm{S}$, & GU289235 & - \\
\hline A030925 & & & $174^{\circ} 54^{\prime} 5.54^{\prime \prime} \mathrm{E}$ & & \\
\hline A596* & C. scalaris & Ripapa Island, & $43^{\circ} 37^{\prime} 7.12^{\prime \prime} \mathrm{S}$ & GU289244 & - \\
\hline & & Banks Peninsula & $172^{\circ} 45^{\prime} 13.27^{\prime \prime} \mathrm{E}$ & & \\
\hline & & $\mathrm{NZ}$ & & & \\
\hline WELT & C. scalaris & Riversdale, & $41^{\circ} 6^{\prime} 24.49^{\prime \prime} \mathrm{S}$, & GU289339 & - \\
\hline A030921 & & Wairarapa NZ & $176^{\circ} 4^{\prime} 10.73^{\prime \prime} \mathrm{E}$ & & \\
\hline $\mathrm{B} 176^{*}$ & C. scalaris & Auckland Islands, & $50^{\circ} 41^{\prime} 5.44^{\prime \prime} \mathrm{S}$ & GU289301 & - \\
\hline & & NZ & $166^{\circ} 17^{\prime} 55.93^{\prime \prime} \mathrm{E}$ & & \\
\hline WELT & C. scalaris & Te Raekaihau, & $41^{\circ} 20^{\prime} 50.92^{\prime \prime} \mathrm{S}$, & GU289313 & - \\
\hline A031342 & & Wellington NZ & $174^{\circ} 47^{\prime} 29.01^{\prime \prime} \mathrm{E}$ & & \\
\hline WELT & C. scalaris & Te Raekaihau, & $41^{\circ} 20^{\prime} 50.92^{\prime \prime} \mathrm{S}$ & GU289314 & - \\
\hline A031341 & & Wellington NZ & $174^{\circ} 47^{\prime} 29.01^{\prime \prime} \mathrm{E}$ & & \\
\hline WELT & C. scalaris & Te Raekaihau, & $41^{\circ} 20^{\prime} 50.92^{\prime \prime} \mathrm{S}$, & GU289315 & - \\
\hline A031344 & & Wellington NZ & 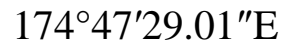 & & \\
\hline
\end{tabular}

\footnotetext{
*Vouchers for these sites were lost as a result of a chemical spillage accident.
} 
Table 4.1. (continued)

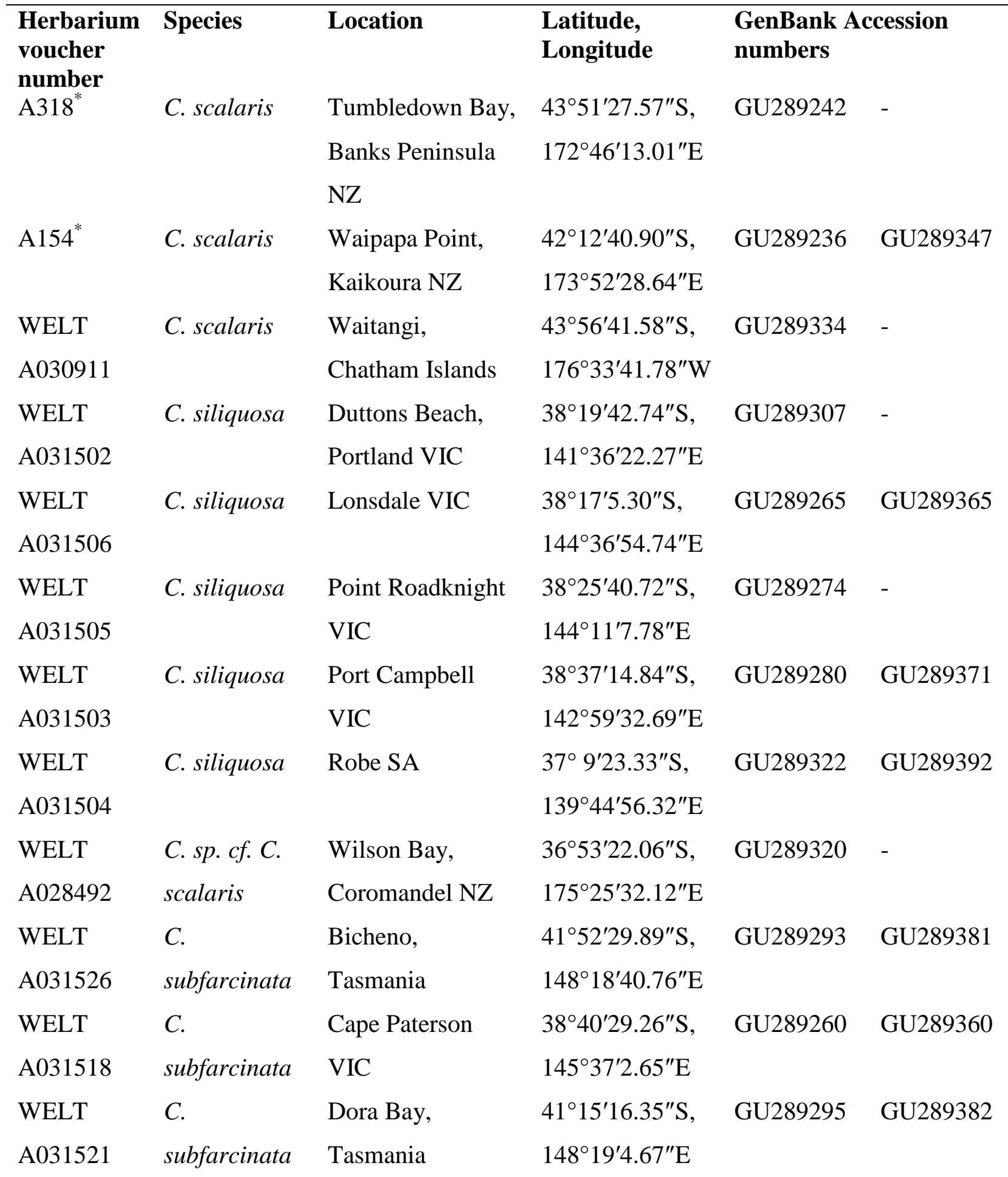

Table 4.1. (continued)

\begin{tabular}{|c|c|c|c|}
\hline $\begin{array}{l}\text { Herbarium Species } \\
\text { voucher }\end{array}$ & Location & $\begin{array}{l}\text { Latitude, } \\
\text { Longitude }\end{array}$ & $\begin{array}{l}\text { GenBank Accession } \\
\text { numbers }\end{array}$ \\
\hline
\end{tabular}




\begin{tabular}{|c|c|c|c|c|c|}
\hline WELT & $C$ & Duttons Beach, & $38^{\circ} 19^{\prime} 42.74^{\prime \prime} \mathrm{S}$ & GU289276 & - \\
\hline A031522 & subfarcinata & Portland VIC & $141^{\circ} 36^{\prime} 22.27^{\prime \prime} \mathrm{E}$ & & \\
\hline WELT & $C$ & Duttons Beach, & $38^{\circ} 19^{\prime} 42.74^{\prime \prime} \mathrm{S}$ & GU289341 & - \\
\hline A031520 & subfarcinata & Portland VIC & $141^{\circ} 36^{\prime} 22.27^{\prime \prime} \mathrm{E}$ & & \\
\hline WELT & $C$ & Lonsdale VIC & $38^{\circ} 17^{\prime} 5.30^{\prime \prime} \mathrm{S}$ & GU289323 & - \\
\hline A031528 & subfarcinata & & $144^{\circ} 36^{\prime} 54.74^{\prime \prime} \mathrm{E}$ & & \\
\hline WELT & C. retroflexa & Mimosa Rocks, & $36^{\circ} 35^{\prime} 2.07^{\prime \prime} \mathrm{S}$ & GU289254 & GU289355 \\
\hline A031532 & & Arragunnu NSW & $150^{\circ} 3^{\prime} 15.18^{\prime \prime} \mathrm{E}$ & & \\
\hline WELT & $C$ & Observation Head, & $35^{\circ} 43^{\prime} 45.50^{\prime \prime} \mathrm{S}$ & GU289253 & GU289354 \\
\hline \multirow[t]{2}{*}{ A031523 } & subfarcinata & Batemans Bay & $150^{\circ} 12^{\prime} 30.26^{\prime \prime} \mathrm{E}$ & & \\
\hline & & NSW & & & \\
\hline WELT & $C$ & Point Roadknight & $38^{\circ} 25^{\prime} 40.72^{\prime \prime} \mathrm{S}$ & GU289272 & - \\
\hline A031519 & subfarcinata & VIC & $144^{\circ} 11^{\prime} 7.78^{\prime \prime} \mathrm{E}$ & & \\
\hline WELT & $C$ & Point Roadknight & $38^{\circ} 25^{\prime} 40.72^{\prime \prime} \mathrm{S}$ & GU289271 & GU289368 \\
\hline A031523 & subfarcinata & VIC & $144^{\circ} 11^{\prime} 7.78^{\prime \prime} \mathrm{E}$ & & \\
\hline WELT & $C$ & Port Campbell & $38^{\circ} 37^{\prime} 14.84^{\prime \prime} \mathrm{S}$, & GU289343 & - \\
\hline A031525 & subfarcinata & VIC & $142^{\circ} 59^{\prime} 32.69^{\prime \prime} \mathrm{E}$ & & \\
\hline WELT & C. & Port Campbell & $38^{\circ} 37^{\prime} 14.84^{\prime \prime} \mathrm{S}$, & GU289287 & GU289376 \\
\hline A031514 & subfarcinata & VIC & $142^{\circ} 59^{\prime} 32.69^{\prime \prime} \mathrm{E}$ & & \\
\hline WELT & $C$ & Port Fairy VIC & $38^{\circ} 23^{\prime} 42.65^{\prime \prime} \mathrm{S}$ & GU289344 & - \\
\hline A031517 & subfarcinata & & $142^{\circ} 14^{\prime} 35.99^{\prime \prime} \mathrm{E}$ & & \\
\hline WELT & $C$ & Port Fairy VIC & $38^{\circ} 23^{\prime} 42.65^{\prime \prime} \mathrm{S}$ & GU289282 & GU289372 \\
\hline A031516 & subfarcinata & & $142^{\circ} 14^{\prime} 35.99^{\prime \prime} \mathrm{E}$ & & \\
\hline WELT & $C$ & Port Fairy VIC & $38^{\circ} 23^{\prime} 42.65^{\prime \prime} \mathrm{S}$ & GU289289 & GU289378 \\
\hline A031524 & subfarcinata & & $142^{\circ} 14^{\prime} 35.99^{\prime \prime} \mathrm{E}$ & & \\
\hline WELT & $C$ & Squeaky Beach, & $39^{\circ} 1^{\prime} 45.89^{\prime \prime} \mathrm{S}$ & GU289321 & - \\
\hline A031527 & subfarcinata & Wilsons & $146^{\circ} 18^{\prime} 24.24^{\prime \prime} \mathrm{E}$ & & \\
\hline & & Promontory VIC & & & \\
\hline WELT & $C$ & Squeaky Beach, & $39^{\circ} 1^{\prime} 45.89^{\prime \prime} \mathrm{S}$ & GU289277 & GU289370 \\
\hline A031515 & subfarcinata & Wilsons & $146^{\circ} 18^{\prime} 24.24^{\prime \prime} \mathrm{E}$ & & \\
\hline & & Promontory VIC & & & \\
\hline
\end{tabular}


Table 4.1. (continued)

\begin{tabular}{|c|c|c|c|c|c|}
\hline $\begin{array}{l}\text { Herbarium } \\
\text { voucher } \\
\text { number }\end{array}$ & Species & Location & $\begin{array}{l}\text { Latitude, } \\
\text { Longitude }\end{array}$ & \multicolumn{2}{|c|}{$\begin{array}{l}\text { GenBank Accession } \\
\text { numbers }\end{array}$} \\
\hline WELT & $C$ & Ulladulla, NSW & $35^{\circ} 21^{\prime} 37.65^{\prime \prime} \mathrm{S}$ & GU289250 & - \\
\hline A031529 & subfarcinata & & $150^{\circ} 29^{\prime} 5.55^{\prime \prime} \mathrm{E}$ & & \\
\hline WELT & C. torulosa & Cape Paterson & $38^{\circ} 40^{\prime} 29.26^{\prime \prime} \mathrm{S}$, & GU289308 & - \\
\hline A031544 & & VIC & $145^{\circ} 37^{\prime} 2.65^{\prime \prime} \mathrm{E}$ & & \\
\hline WELT & C. torulosa & Coles Bay, & $42^{\circ} 7{ }^{\prime} 35.52^{\prime \prime} \mathrm{S}$ & GU289294 & - \\
\hline A031543 & & Tasmania & $148^{\circ} 17^{\prime} 32.09^{\prime \prime} \mathrm{E}$ & & \\
\hline WELT & C. torulosa & & & GU289305 & - \\
\hline A031540 & & Tasmania & $148^{\circ} 19^{\prime} 4.67^{\prime \prime} \mathrm{E}$ & & \\
\hline $\begin{array}{l}\text { WELT } \\
\text { A031538 }\end{array}$ & C. torulosa & $\begin{array}{l}\text { Eaglehawk Neck, } \\
\text { Tasmania }\end{array}$ & $\begin{array}{l}43^{\circ} 0^{\prime} 32.91^{\prime \prime} \mathrm{S}, \\
147^{\circ} 55^{\prime} 59.87^{\prime \prime} \mathrm{E}\end{array}$ & GU289292 & GU289380 \\
\hline $\begin{array}{l}\text { WELT } \\
\text { A030912 }\end{array}$ & C. torulosa & $\begin{array}{l}\text { Maraehako Bay, } \\
\text { Bay of Plenty NZ }\end{array}$ & $\begin{array}{l}37^{\circ} 40^{\prime} 19.74^{\prime \prime} \mathrm{S}, \\
177^{\circ} 47^{\prime} 47.80^{\prime \prime} \mathrm{E}\end{array}$ & GU289300 & - \\
\hline $\begin{array}{l}\text { WELT } \\
\text { A030915 }\end{array}$ & C. torulosa & $\begin{array}{l}\text { Nugget Point, } \\
\text { Otago NZ }\end{array}$ & $\begin{array}{l}46^{\circ} 26^{\prime} 26.91^{\prime \prime} \mathrm{S} \\
169^{\circ} 48^{\prime} 1.78^{\prime \prime} \mathrm{E}\end{array}$ & GU289240 & - \\
\hline $\begin{array}{l}\text { WELT } \\
\text { A030920 }\end{array}$ & C. torulosa & $\begin{array}{l}\text { Pihama, Taranaki, } \\
\text { NZ }\end{array}$ & $\begin{array}{l}39^{\circ} 31^{\prime} 16.48^{\prime \prime} \mathrm{S}, \\
173^{\circ} 54^{\prime} 54.98^{\prime \prime} \mathrm{E}\end{array}$ & GU289304 & GU289386 \\
\hline $\begin{array}{l}\text { WELT } \\
\text { A031539 }\end{array}$ & C. torulosa & $\begin{array}{l}\text { Point Roadknight } \\
\text { VIC }\end{array}$ & $\begin{array}{l}38^{\circ} 25^{\prime} 40.72^{\prime \prime} \mathrm{S}, \\
144^{\circ} 11^{\prime} 7.78^{\prime \prime} \mathrm{E}\end{array}$ & GU289270 & GU289367 \\
\hline $\begin{array}{l}\text { WELT } \\
\text { A031541 }\end{array}$ & C. torulosa & Port Fairy VIC & $\begin{array}{l}38^{\circ} 23^{\prime} 42.65^{\prime \prime} \mathrm{S}, \\
142^{\circ} 14^{\prime} 35.99^{\prime \prime} \mathrm{E}\end{array}$ & GU289283 & - \\
\hline $\begin{array}{l}\text { WELT } \\
\text { A030916 }\end{array}$ & C. torulosa & $\begin{array}{l}\text { Princess Bay, } \\
\text { Wellington NZ }\end{array}$ & $\begin{array}{l}41^{\circ} 20^{\prime} 43.05^{\prime \prime} \mathrm{S}, \\
174^{\circ} 47^{\prime} 14.08^{\prime \prime} \mathrm{E}\end{array}$ & GU289327 & - \\
\hline $\begin{array}{l}\text { WELT } \\
\text { A030924 }\end{array}$ & C. torulosa & Pukerua Bay NZ & $\begin{array}{l}41^{\circ} 1^{\prime} 28.36^{\prime \prime} \mathrm{S}, \\
174^{\circ} 54^{\prime} 5.54^{\prime \prime} \mathrm{E}\end{array}$ & GU289234 & - \\
\hline $\begin{array}{l}\text { WELT } \\
\text { A031542 }\end{array}$ & C. torulosa & $\begin{array}{l}\text { Squeaky Beach, } \\
\text { Wilsons }\end{array}$ & $\begin{array}{l}39^{\circ} 1^{\prime} 45.89^{\prime \prime} \mathrm{S}, \\
146^{\circ} 18^{\prime} 24.24^{\prime \prime} \mathrm{E}\end{array}$ & GU289256 & GU289357 \\
\hline & & Promontory VIC & & & \\
\hline
\end{tabular}


Table 4.1. (continued)

\begin{tabular}{llllll}
\hline $\begin{array}{l}\text { Herbarium } \\
\text { voucher } \\
\text { number }\end{array}$ & Species & Location & $\begin{array}{l}\text { Latitude, } \\
\text { Longitude }\end{array}$ & $\begin{array}{l}\text { GenBank Accession } \\
\text { numbers }\end{array}$ & \\
$\begin{array}{l}\text { WELT } \\
\text { A031347 }\end{array}$ & C. torulosa & Te Raekaihau, & $41^{\circ} 20^{\prime} 50.92^{\prime \prime} \mathrm{S}$, & GU289239 & - \\
WELT & Landsburgia & Pihama, Taranaki, & $39^{\circ} 31^{\prime} 16.48^{\prime \prime} \mathrm{S}$, & GU289299 & GU289384 \\
A030931 & quercifolium & $\mathrm{NZ}$ & $173^{\circ} 54^{\prime} 54.98^{\prime \prime} \mathrm{E}$ & & \\
\hline
\end{tabular}

Table 4.2. Key morphological characters used in species assignments.

\begin{tabular}{|c|c|c|c|c|c|}
\hline Species & Primary axis & $\begin{array}{l}\text { Primary } \\
\text { branching }\end{array}$ & $\begin{array}{l}\text { Branching } \\
\text { of laterals }\end{array}$ & Receptacles & Vesicles \\
\hline C. congesta & $\begin{array}{l}\text { Fairly straight, } \\
\text { compressed, } \\
4-6(-10) \mathrm{mm} \\
\text { broad } \times 2-4 \\
\text { mm thick }\end{array}$ & $\begin{array}{l}\text { Alternately } \\
\text { distichously } \\
\text { branched from } \\
\text { face of the main } \\
\text { axes, Secondary } \\
\text { axes usually 20- } \\
50 \mathrm{~mm} \text { long } \\
\text { forming crowded } \\
\text { tufts }\end{array}$ & $\begin{array}{l}\text { Irregularly } \\
\text { branched on } \\
\text { all sides }\end{array}$ & $\begin{array}{l}\text { Slightly } \\
\text { compressed, 10-30 } \\
\text { mm long } \times 1-1.5 \\
(-2) \text { mm wide, } \\
\text { usually with sterile } \\
\text { apical awn }\end{array}$ & $\begin{array}{l}\text { Subspherical, 3- } \\
7(-10) \mathrm{mm} \\
\text { diameter, } \\
\text { occasionally } \\
\text { absent }\end{array}$ \\
\hline C. distenta & $\begin{array}{l}\text { Strongly zig- } \\
\text { zag, flattened, } \\
2-5 \mathrm{~mm} \text { broad } \\
\times 1.5-2 \mathrm{~mm} \\
\text { thick }\end{array}$ & $\begin{array}{l}\text { Alternately } \\
\text { distichously } \\
\text { branched from } \\
\text { face of the main } \\
\text { axes }\end{array}$ & $\begin{array}{l}\text { Alternately } \\
\text { distichously } \\
\text { branched } \\
\text { with rounded } \\
\text { axils }\end{array}$ & $\begin{array}{l}\text { Compressed, } \\
\text { torulose with rows } \\
\text { of prominent } \\
\text { conceptacles, } 10- \\
40(-50) \mathrm{mm} \text { long } \times \\
1.5-3 \mathrm{~mm} \text { broad }\end{array}$ & $\begin{array}{l}\text { Spherical to } \\
\text { subspherical, 4- } \\
10 \mathrm{~mm} \text { diameter }\end{array}$ \\
\hline C. expansa & $\begin{array}{l}\text { Fairly straight, } \\
\text { flattened, } 2- \\
5(-10) \mathrm{mm} \\
\text { broad } \times 1-2(- \\
\text { 4) } \mathrm{mm} \text { thick }\end{array}$ & $\begin{array}{l}\text { Alternately } \\
\text { distichously } \\
\text { branched from } \\
\text { the face of the } \\
\text { main axes }\end{array}$ & $\begin{array}{l}\text { Tristichously } \\
\text { branched } \\
\text { from a three- } \\
\text { sided rhachis }\end{array}$ & $\begin{array}{l}\text { Terete to slightly } \\
\text { compressed, } \\
\text { slender, } 0.5-1(- \\
1.5) \mathrm{mm} \text { long } \times \\
0.5-1(-1.5) \mathrm{mm} \\
\text { diameter }\end{array}$ & $\begin{array}{l}\text { Small, elongate- } \\
\text { ellipsoid, } 3-5(-7) \\
\text { long } \times 1-2 \mathrm{~mm} \\
\text { broad }\end{array}$ \\
\hline $\begin{array}{l}C . \\
\text { monilifera }\end{array}$ & $\begin{array}{l}\text { Flattened, } 3- \\
8(-15) \mathrm{mm} \\
\text { broad } \times 1-2 \\
\text { mm thick, with } \\
\text { narrow edges }\end{array}$ & $\begin{array}{l}\text { Alternately } \\
\text { distichously } \\
\text { branched from } \\
\text { the face of the } \\
\text { main axes }\end{array}$ & $\begin{array}{l}\text { Tristichously } \\
\text { branched } \\
\text { from a } \\
\text { subterete } \\
\text { rhachis }\end{array}$ & $\begin{array}{l}\text { Terete, slender, }(5- \\
10-20(-30) \text { long } \times \\
0.5-1 \mathrm{~mm} \\
\text { diameter, } \\
\text { constricted } \\
\text { between } \\
\text { conceptacles }\end{array}$ & $\begin{array}{l}\text { Subspherical to } \\
\text { ovoid, } 3-6(-8) \\
\text { mm diameter }\end{array}$ \\
\hline $\begin{array}{l}\text { C. } \\
\text { moniliformis }\end{array}$ & $\begin{array}{l}\text { Straight, } \\
\text { strongly } \\
\text { compressed, } \\
5-20 \mathrm{~mm} \\
\text { broad } \times 2-3(- \\
\text { 7) } \mathrm{mm} \text { thick }\end{array}$ & $\begin{array}{l}\text { Alternately } \\
\text { distichously } \\
\text { branched from } \\
\text { the edge of the } \\
\text { main axes }\end{array}$ & $\begin{array}{l}\text { Alternately } \\
\text { distichously } \\
\text { branched, } \\
\text { fasciculate }\end{array}$ & $\begin{array}{l}\text { Moniliform to } \\
\text { torulose, } 5-15(- \\
40) \text { long } \times 0.5-1 \\
\text { mm diameter }\end{array}$ & Absent \\
\hline
\end{tabular}


Table 4.2 (Continued)

\begin{tabular}{|c|c|c|c|c|c|}
\hline Species & Primary axis & $\begin{array}{l}\text { Primary } \\
\text { branching }\end{array}$ & $\begin{array}{l}\text { Branching } \\
\text { of laterals }\end{array}$ & Receptacles & Vesicles \\
\hline $\begin{array}{l}\text { C. } \\
\text { platylobium }\end{array}$ & $\begin{array}{l}\text { Strongly } \\
\text { compressed, } \\
\text { flexuous, }(3- \\
) 5-10(-15) \\
\text { mm broad } \times \\
2-4(-5) \mathrm{mm} \\
\text { thick }\end{array}$ & $\begin{array}{l}\text { Alternately } \\
\text { distichously } \\
\text { branched from } \\
\text { the edge of the } \\
\text { main axes }\end{array}$ & $\begin{array}{l}\text { Alternately } \\
\text { distichously } \\
\text { branched, } \\
\text { complanate, } \\
\text { once pinnate }\end{array}$ & $\begin{array}{l}\text { Strongly flattened, } \\
\text { lanceolate to } \\
\text { elliptic-lanceolate, } \\
\text { basally stalked, } \\
10-30 \mathrm{~mm} \text { long } \times \\
3-8 \\
(-10) \mathrm{mm} \text { broad }\end{array}$ & $\begin{array}{l}\text { Spherical to } \\
\text { ovoid, } 5-15 \mathrm{~mm} \\
\text { diameter }\end{array}$ \\
\hline $\begin{array}{l}\text { C. } \\
\text { polycystidea }\end{array}$ & $\begin{array}{l}\text { Compressed, } \\
\text { quadrangular, } \\
2-7 \mathrm{~mm} \text { broad } \\
\times 2-5 \mathrm{~mm} \\
\text { thick }\end{array}$ & $\begin{array}{l}\text { Alternately } \\
\text { distichously } \\
\text { branched from } \\
\text { the face of the } \\
\text { main axes }\end{array}$ & $\begin{array}{l}\text { Radially and } \\
\text { spirally } \\
\text { branched on } \\
\text { all sides }\end{array}$ & $\begin{array}{l}\text { Distantly } \\
\text { moniliform, 5-20 } \\
\text { mm long and 0.4- } \\
0.7(-1) \mathrm{mm} \\
\text { diameter at } \\
\text { conceptacles }\end{array}$ & $\begin{array}{l}\text { Numerous, small, } \\
\text { elongate, tapering } \\
\text { at both ends, in } \\
\text { clusters, }(2-) 3- \\
5(-7) \mathrm{mm} \text { long } \times \\
(1-) 2-3(-4) \mathrm{mm} \\
\text { diameter }\end{array}$ \\
\hline C. retorta & $\begin{array}{l}\text { Relatively } \\
\text { straight, } \\
\text { strongly } \\
\text { compressed, } \\
2-5(-7) \mathrm{mm} \\
\text { broad } \times 1-2 \\
\text { mm thick }\end{array}$ & $\begin{array}{l}\text { Alternately } \\
\text { distichously } \\
\text { branched from } \\
\text { the face of the } \\
\text { main axes }\end{array}$ & $\begin{array}{l}\text { Alternately } \\
\text { distichously } \\
\text { branched, } \\
\text { becoming } \\
\text { subdichotom } \\
\text { ous with } \\
\text { broadly } \\
\text { rounded axils }\end{array}$ & $\begin{array}{l}\text { Terete to slightly } \\
\text { compressed, }(10- \\
\text { 20-50(-80) long } \times \\
1-2 \text { mm diameter, } \\
\text { conceptacles } \\
\text { bisexual, often } \\
\text { separated by } \\
\text { considerable sterile } \\
\text { tissue }\end{array}$ & Usually absent \\
\hline C. retroflexa & $\begin{array}{l}\text { Straight to zig- } \\
\text { zag, } \\
\text { compressed, } \\
3-10 \mathrm{~mm} \\
\text { broad } \times 2-5 \\
\text { mm thick, } \\
\text { narrow edged }\end{array}$ & $\begin{array}{l}\text { Alternately } \\
\text { distichously } \\
\text { branched from } \\
\text { the face of the } \\
\text { main axes }\end{array}$ & $\begin{array}{l}\text { Terete, } \\
\text { irregularly } \\
\text { branched on } \\
\text { all sides }\end{array}$ & $\begin{array}{l}\text { Compressed, } \\
\text { smooth to slightly } \\
\text { torulose, } 20- \\
50(-60) \mathrm{mm} \text { long } \\
\times 1-2(-2.5) \mathrm{mm} \\
\text { broad, apex } \\
\text { attenuate with } \\
\text { sterile awn, ostiole } \\
\text { in axils of } \\
\text { conceptacle } \\
\text { swelling. }\end{array}$ & $\begin{array}{l}\text { Ovoid to } \\
\text { subspherical, } 4- \\
10 \mathrm{~mm} \text { long } \times 3-6 \\
\mathrm{~mm} \text { broad }\end{array}$ \\
\hline C. scalaris & $\begin{array}{l}\text { Zig-zag, } \\
\text { compressed, } \\
2.5-15(-20) \\
\text { mm broad } \times \\
2-3 \text { mm thick }\end{array}$ & $\begin{array}{l}\text { Alternately } \\
\text { distichously } \\
\text { branched from } \\
\text { face of main axes }\end{array}$ & $\begin{array}{l}\text { Alternately } \\
\text { distichously } \\
\text { branched, } \\
\text { complanate }\end{array}$ & $\begin{array}{l}\text { Ovoid to } \\
\text { compressed, } \\
\text { smooth to torulose, } \\
1.5-2.5 \text { mm wide } \times \\
1 \mathrm{~mm} \text { thick }\end{array}$ & $\begin{array}{l}\text { Spherical to ovoid } \\
2-7(-10) \mathrm{mm} \\
\text { diameter }\end{array}$ \\
\hline C. siliquosa & $\begin{array}{l}\text { Straight, } \\
\text { quadrangular } \\
\text { to square in } \\
\text { section, 2-5 } \\
\text { mm broad and } \\
\text { thick }\end{array}$ & $\begin{array}{l}\text { Alternately } \\
\text { distichously } \\
\text { branched from } \\
\text { the face of the } \\
\text { main axes }\end{array}$ & $\begin{array}{l}\text { Alternately } \\
\text { distichously } \\
\text { branched, } \\
\text { becoming } \\
\text { subdichotom } \\
\text { ous with } \\
\text { rounded axils }\end{array}$ & $\begin{array}{l}\text { Slightly to } \\
\text { markedly } \\
\text { compressed, } 30-80 \\
\text { mm long } \times 1-2 \mathrm{~mm} \\
\text { broad, } \\
\text { conceptacles } \\
\text { unisexual and thalli } \\
\text { dioecious }\end{array}$ & Absent \\
\hline
\end{tabular}


Table 4.2 (Continued)

\begin{tabular}{|c|c|c|c|c|c|}
\hline Species & Primary axis & $\begin{array}{l}\text { Primary } \\
\text { branching }\end{array}$ & $\begin{array}{l}\text { Branching } \\
\text { of laterals }\end{array}$ & Receptacles & Vesicles \\
\hline C. cuspidata & $\begin{array}{l}\text { Fairly straight, } \\
\text { compressed, } \\
3-6 \mathrm{~mm} \text { broad } \\
\times 1-2 \text { thick }\end{array}$ & $\begin{array}{l}\text { Alternately } \\
\text { distichously } \\
\text { branched from } \\
\text { the face of the } \\
\text { main axes }\end{array}$ & $\begin{array}{l}\text { Usually } \\
\text { irregularly } \\
\text { alternately } \\
\text { (sometime } \\
\text { sub- } \\
\text { distichously) } \\
\text { and closely } \\
\text { branched. }\end{array}$ & $\begin{array}{l}\text { Simple or } \\
\text { branched, (10-)20- } \\
60(-80) \text { mm long } \\
\text { with prominent } \\
\text { swollen } \\
\text { conceptacles } \\
\text { closely arranged in } \\
2-3 \text { rows in the } \\
\text { basal half or more } \\
\text { of receptacles, and } \\
\text { here } 1.5-4 \mathrm{~mm} \\
\text { broad }\end{array}$ & Absent \\
\hline $\begin{array}{l}\text { C. } \\
\text { subfarcinata }\end{array}$ & $\begin{array}{l}\text { Slightly } \\
\text { flexuous, } \\
\text { compressed, } \\
2-7 \text { mm broad } \\
\times 1-2(-3) \\
\text { thick }\end{array}$ & $\begin{array}{l}\text { Densely and } \\
\text { distichously } \\
\text { branched from } \\
\text { the face of the } \\
\text { main axes }\end{array}$ & $\begin{array}{l}\text { Irregularly } \\
\text { alternately } \\
\text { branched on } \\
\text { all sides }\end{array}$ & $\begin{array}{l}\text { Often branched, } \\
(5-) 10-30(-50) \\
\text { mm long } \times 1-2 \\
\text { mm thick at } \\
\text { conceptacles, with } \\
\text { prominent } \\
\text { scattered } \\
\text { conceptacles } \\
\text { separated by sterile } \\
\text { tissue with a sterile } \\
\text { awn, ostiole apical } \\
\text { on conceptacle } \\
\text { swelling. }\end{array}$ & $\begin{array}{l}\text { Present or absent, } \\
\text { elongate ovoid to } \\
\text { sub spherical, 2- } \\
04(-6) \mathrm{mm} \text { long } \times \\
2-3(-4) \mathrm{mm} \\
\text { diameter }\end{array}$ \\
\hline C. torulosa & $\begin{array}{l}\text { Compressed, } \\
3-10 \mathrm{~mm} \\
\text { broad } \times 2-5 \\
\text { mm thick, } \\
\text { straight to } \\
\text { slightly } \\
\text { flexuous }\end{array}$ & $\begin{array}{l}\text { Alternately } \\
\text { densely branched } \\
\text { from the face of } \\
\text { the main axes }\end{array}$ & $\begin{array}{l}\text { Densely, } \\
\text { irregularly } \\
\text { alternately } \\
\text { subdistichous } \\
\text { ly branched }\end{array}$ & $\begin{array}{l}\text { Terete to slightly } \\
\text { three sided, } \\
\text { swollen with a } \\
\text { blunt rounded } \\
\text { apex, } 10-50(-70) \\
\text { mm long } \times(1-) 2- \\
3(-4) \text { mm diameter }\end{array}$ & $\begin{array}{l}\text { Subspherical to } \\
\text { ovoid, } 3-8(-10) \\
\text { long } \times 3-6(-9) \\
\text { mm diameter }\end{array}$ \\
\hline
\end{tabular}




\subsection{Results}

\section{Amplification and species sampling}

The cox 1 region was amplified from 108 specimens of 13 species of Cystophora and five specimens of putative outgroup genera (Caulocystis, Carpoglossum and Landsburgia) (Table 4.1). I was unable to amplify the cox 1 region of Cystophora expansa (Areschoug) Womersley with any primer combination and suspect a primer mismatch. The GAZF2-fcox808R primer combination successfully amplified most Cystophora species, whereas the GAZF2-GAZR2 combination was successful when amplifying Caulocystis, Carpoglossum, Landsburgia and other outgroup species.

The ITS1-5.8S-ITS2 cistron was amplified from 47 specimens of Cystophora and from Landsburgia quercifolia (Hooker f. et Harvey) Harvey. Preliminary trees positioned Landsburgia as the genus most closely related to Cystophora and L. quercifolia was designated as an outgroup in subsequent analyses.

\section{Molecular distance}

A distance tree inferred from cox 1 sequences showed clusters that were generally consistent with morphological species assignments. Sequences from four specimens of Cystophora were incongruent with morphological assignments (indicated by arrows in Fig. 4.2). DNA from these specimens was subsequently re-extracted and sequenced, with the same results. In two of these specimens (WELT A031539 and WELT A031523) morphological identification was unambiguous and this identification is retained. Two specimens (WELT A028492 and WELT A030930) were initially assigned to C. scalaris J. Agardh but grouped with C. torulosa (R. Brown) J. Agardh and C. retroflexa (Labillardière) J. Agardh respectively. These specimens were re-examined and as identity is ambiguous I designated them as Cystophora sp. cf. scalaris.

Uncorrected interspecific pairwise differences between $\operatorname{cox} 1$ sequences in Cystophora varied from 0 to 49 (0-8\%). Intraspecific distances varied from 0 to 4 (0$0.65 \%$ ). Kimura 2-parameter distances ranged from 0 to $8.6 \%$ between species and 0 to $0.7 \%$ within species (Table 4.2, Fig. 4.2). In general, species with wide geographic ranges (e.g., C. retorta (Mertens) J. Agardh, C. retroflexa) showed greater intraspecific variation than geographically restricted species (e.g., C. monilifera J. Agardh). 


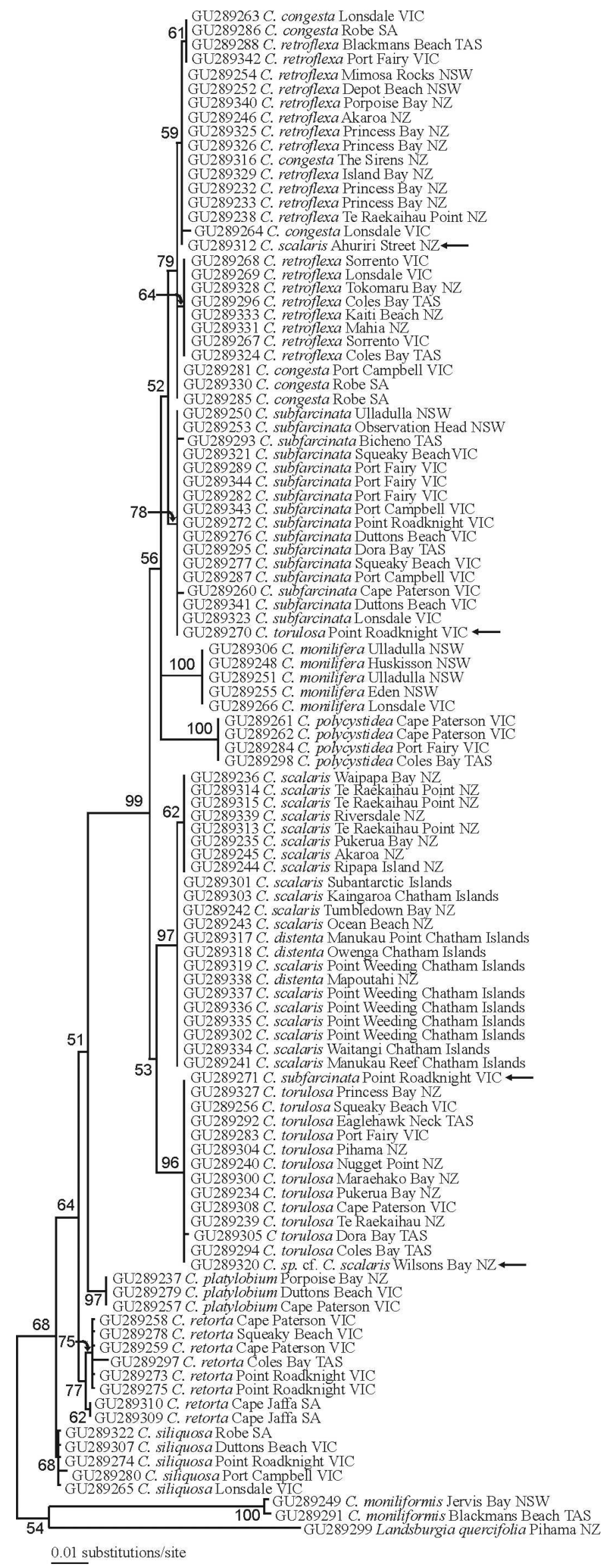






$\overline{10 \text { changes }}$

Fig. 4.3. ML topology of Cystophora species inferred using combined ITS1-5.8S-ITS2 and $\operatorname{cox} 1$ sequences, support is shown at nodes as maximum parsimony/maximum likelihood/Bayesian posterior probabilities. Specimen labels show GenBank accession numbers for ITS sequences only.

Fig. 4.2. (Previous page). Distance tree inferred in PAUP* by neighbour-joining from 108 cox 1 sequences of Cystophora and one outgroup. Confidence is shown at nodes based on 1000 bootstrap replicates. Arrows indicate specimens where morphology and sequence position were incongruent. 
Table 4.3. Number of changes in cox 1 sequences between species (above diagonal) and K2P distances (below diagonal)

\begin{tabular}{|c|c|c|c|c|c|c|c|c|c|c|c|}
\hline & C. congesta & C. monilifera & C. moniliformis & C. platylobium & C. polycystidea & C. retorta & C. retroflexa & C. scalaris & C. siliquosa & C. subfarcinata & C. tor \\
\hline C. congesta & $0-2$ & $9-11$ & $47-48$ & $16-18$ & $11-13$ & $16-20$ & $0-3$ & $8-11$ & $18-21$ & $3-6$ & $10-13$ \\
\hline C. monilifera & $0.015-0.018$ & $0(0.00)$ & 49 & 18 & 14 & $19-22$ & $10-11$ & $13-14$ & $20-21$ & $8-9$ & $13-14$ \\
\hline C. moniliformis & $0.082-0.084$ & 0.086 & $2(0.003)$ & $41-43$ & 51 & $40-43$ & $47-48$ & 46 & $37-40$ & $47-49$ & $48-49$ \\
\hline C. platylobium & $0.027-0.030$ & 0.030 & $0.071-0.075$ & $0(0.00)$ & 19 & $6-9$ & $17-18$ & $16-17$ & $8-9$ & $15-16$ & $15-16$ \\
\hline C. polycystidea & $0.018-0.022$ & 0.023 & 0.090 & 0.032 & $0(0.00)$ & $20-23$ & $12-13$ & $15-16$ & $23-24$ & $10-11$ & $13-14$ \\
\hline C. retorta & $0.029-0.034$ & $0.032-0.037$ & $0.069-0.075$ & $0.010-0.015$ & $0.035-0.039$ & $\begin{array}{l}0-4(0.00- \\
0.07)\end{array}$ & $17-20$ & $16-19$ & $7-10$ & $16-20$ & $16-20$ \\
\hline C. retroflexa & $0.00-0.005$ & $0.017-0.018$ & $0.082-0.084$ & $0.027-0.030$ & $0.020-0.22$ & $\begin{array}{l}0.028- \\
0.032\end{array}$ & $\begin{array}{l}0-3(0.00- \\
0.005)\end{array}$ & $8-10$ & $19-21$ & $4-6$ & $11-13$ \\
\hline $\begin{array}{l}\text { C. } \\
\text { scalaris/distenta }\end{array}$ & $0.013-0.018$ & $0.022-0.023$ & 0.080 & $0.028-0.027$ & $0.025-0.027$ & $\begin{array}{l}0.027- \\
0.032\end{array}$ & $0.013-0.017$ & $\begin{array}{l}0-1(0.00- \\
0.002)\end{array}$ & $18-20$ & $9-11$ & $8-10$ \\
\hline C. siliquosa & $0.030-0.035$ & $0.034-0.035$ & $0.064-0.069$ & $0.013-0.015$ & $0.039-0.041$ & $\begin{array}{l}0.012- \\
0.015\end{array}$ & $0.032-0.034$ & $0.030-0.034$ & $\begin{array}{l}0-1(0.00- \\
0.002)\end{array}$ & $19-21$ & $19-21$ \\
\hline C. subfarcinata & $0.002-0.010$ & $0.013-0.015$ & $0.082-0.086$ & $0.025-0.027$ & $0.017-0.018$ & $\begin{array}{l}0.027- \\
0.034\end{array}$ & $0.007-0.010$ & $0.015-0.018$ & $0.032-0.035$ & $\begin{array}{l}0-2(0.00- \\
0.003)\end{array}$ & $9-11$ \\
\hline C. torulosa & $0.017-0.022$ & $0.022-0.023$ & $0.084-0.086$ & $0.025-0.027$ & $0.032-0.035$ & $\begin{array}{l}0.029- \\
0.034\end{array}$ & $0.018-0.022$ & $0.015-0.017$ & $0.034-0.035$ & $0.015-0.018$ & $\begin{array}{l}0-1(0 \\
0.002)\end{array}$ \\
\hline
\end{tabular}


Distances between closely related species were often low, in the same order as intraspecific distances. In some cases these species were easily distinguished by morphology (e.g., C. retorta and C. platylobium (Mertens) J. Agardh), in other cases they were not (C. siliquosa J. Agardh and C. retorta, C. retroflexa and C. subfarcinata (Mertens) J. Agardh).

\section{Phylogeny}

A partition homogeneity test showed significant congruence between ITS and cox 1 data sets $(\mathrm{P}=0.999)$. Analyses of combined data produced trees with good support for most branches, but did not separate $C$. congesta/retroflexa and $C$. scalaris/distenta, and did not show support for the position of C. platylobium (Fig. 4.3).

Cystophora moniliformis (Esper) Womersley \& Nizamuddin is sister to all other Cystophora species. The early branching position of $C$. moniliformis is consistent with the rather anomalous form of this species (a straight, dorsiventrally flattened main axis, with fine laterals developing from the sides of the main axes). The remaining species formed two groups, with $C$. platylobium sister to a group containing $C$. retorta and $C$. siliquosa, but with only weak support, and this group is sister to a larger group containing all other species. Species level clades were well supported within this latter group, but the higher level branching was only weakly supported (61-68\%).

\subsection{Discussion}

Few studies have attempted cox 1 DNA barcoding of brown algae. These studies have either not discriminated species (Lane et al. 2007), not sampled across species ranges, risking underestimating intraspecific divergence (Kucera \& Saunders 2008), or have sampled a limited number of congeners (McDevit \& Saunders 2009). While using DNA sequences to identify algae is an established technique (e.g., Sasaki et al. 2003; Lane \& Saunders 2005; Fox \& Swanson 2007), a prerequisite for extending this caseby-case molecular identification into a DNA barcoding system is to firmly establish the utility of one or more markers for delimiting a wide range of species. I discuss the utility of cox 1 barcoding in Cystophora according to the criteria outlined in the introduction: 
1. Does the marker resolve discrete clusters within a genus? Yes, a 615 bp fragment from the cox 1 was sufficient to resolve clusters, albeit with little bootstrap support, and in some cases, with low molecular distances between clusters.

\section{Are clusters concordant with recognised species boundaries? Most specimens} collected in this study could be assigned to species using cox 1 sequences alone. In two cases, closely related species could not be separated by cox 1 or combined cox $1-$ ITS (C. distenta-C. scalaris, $C$. retroflexa-C. congesta). In several cases, interspecific variation between morphologically distinct species was only slightly greater than intraspecific variation. This is unsatisfactory if distance methods alone are used to define species boundaries.

\section{Is sampling sufficient to represent intraspecific variation across the range of} each species? Sampling of species that occur in New Zealand was reasonably intensive and widespread, which strengthens confidence in cox1 as an estimator of species identity, estimates of intraspecific variation in Australian species is likely to be low because of limited sampling of Australian populations. Further sampling of these species might unearth novel haplotypes that are difficult to assign to species. 4. Is sampling of congeners sufficient to show resolution of closely related species? Some western Australian Cystophora species and some deepwater species were not sampled. I was unable to amplify $C$. expansa with any primer combination. Cystophora expansa is morphologically similar to $C$. monilifera, and I am unable to evaluate cox 1 for discriminating these species. However species sampled included several pairs of sister species, an important consideration for evaluating a barcoding marker.

\section{Distance methods}

McDevit \& Saunders (2009) suggested that the ten-fold threshold between intraspecific and interspecific variation proposed by Hebert et al. (2004) for separating species with cox 1 could be applied to brown algae. In Cystophora, $C$. moniliformis was highly divergent from most other species, with pairwise distances between all other species exceeding the ten-fold threshold. Species in which low intraspecific variation was detected were also separated from most other congeners by this threshold. However, species with moderate intraspecific variation (C. retorta, $C$ retroflexa and $C$. subfarcinata) often showed distances to closely related congeners of around twice intraspecific distances. A lower threshold must be applied if this method 
is used to separate species in Cystophora. The appeal of distance thresholds is that species can be efficiently demarcated from large datasets using sequence data alone and automated using algorithms. It is generally recognised that a single threshold value cannot be applied to all groups of organisms (Vogler \& Monaghan 2006), but establishing an operational threshold requires extensive sampling to accurately estimate intraspecific marker variation. Mitochondrial DNA variation in brown algae is often highly spatially structured (Hoarau et al. 2007; Fraser et al. 2009; Uwai et al. 2009; Chapter 2) so sampling has to be intensive within populations and, ideally, across the range of the species. Only Lane et al. (2007) have applied barcoding methods to an intensively sampled collection of brown algae and they failed to delineate species. Kucera \& Saunders (2008) used multiple samples of Fucus species, but only sampled in Canada where their most clearly delineated species, F. serratus, is a recent introduction (Lyons \& Scheibling 2009). While I sampled across the range of several Cystophora species, it is likely that intraspecific variation is underestimated.

Species level differences in intraspecific variation in Cystophora did not correlate with sampling effort. Cox 1 variation was high in $C$. subfarcinata $(\mathrm{n}=16)$ and $C$. retroflexa $(\mathrm{n}=20)$ which were extensively sampled, but was also high in $C$. retorta, where sampling was limited $(\mathrm{n}=8)$. Conversely low intraspecific variation was found in C. scalaris $(\mathrm{n}=19)$ and $C$. torulosa $(\mathrm{n}=12)$, but collections span mainland Australia, Tasmania and New Zealand. Intraspecific cox 1 variation in brown algae appears to vary widely. Kucera \& Saunders (2008) found low (0-0.3\%) cox1 intraspecific variation in Fucus, albeit based on limited geographical sampling, whereas a worldwide study of Durvillea antarctica (Fraser et al. 2009) found relatively high cox 1 diversity (uncorrected distances of up to 5.4\%). Similar problems have been found when using cox 1 to demarcate well sampled red algal species (Sherwood et al. 2008; Yang et al. 2008).

Geographically widespread sampling and the inclusion of sister species are expected to reduce variation thresholds between species, especially if the marker used is not evolving and sorting sufficiently quickly to demarcate species formed in recent radiations (Shaffer \& Thomson 2007). McDevit \& Saunders' (2009) survey of interspecies cox 1 variation of brown algae did not include sister species or extensive intraspecies sampling (apart from Fucus sequences from Kucera \& Saunders (2008)), and their support for a ten-times threshold in brown algae is likely to be an artefact of 
low sampling of conspecifics and congenerics rather than an indicator of the efficacy of cox 1 barcoding.

Character based DNA barcoding is an alternative to distance methods (DeSalle et al. 2005; Rach et al. 2008). This has the advantage of defining species by synapomorphies, rather than phenetic clustering, and is concordant with phylogenetic species concepts, but would also require wider geographical sampling of closely related species to ensure characters nominated are conserved in species.

\section{Taxonomic oversplitting}

Four Cystophora species were not delimited in any molecular analyses. No evidence was found for a distinct obligate epiphyte species equivalent to C. cymodoceae; no specimens could be unequivocally assigned to $C$. cuspidata, and specimens assigned to $C$. congesta and $C$. distenta grouped with other species in molecular analyses. Failure to separate species by molecular markers can be attributed to three processes: (1) insufficient time for stochastic lineage sorting processes (coalescence) to sort the marker to reciprocal monophyly; (2) ongoing gene flow by hybridisation; or (3) taxonomic over-splitting of species. In these cases taxonomic oversplitting (Dayrat 2005) is a probable cause.

Cystophora retroflexa (Labillardière) J. Agardh and C. congesta Womersley \& Nizamuddin ex Womersley are morphologically similar and these two species were not separated in any molecular analysis (Figs. 4.2, 4.3). Rather, haplotypes and ribotypes from $C$. congesta and $C$. retroflexa were intermixed. Womersley (1964, 1987) separated these species by vegetative characters, but accepted that intergrades occurred. Cystophora retroflexa has longer $(20-60 \mathrm{~mm})$ receptacles and a more openly branched habit. Cystophora congesta has shorter $(15-30 \mathrm{~mm})$ receptacles and tufted laterals and ramuli, and usually ridges on the primary axes. Seven specimens were assigned to $C$. congesta, including three from the type locality (Robe, SA) but some species assigned to $C$. retroflexa (e.g., WELT A031533) tended toward a $C$. congesta-like morphology.

Cystophora scalaris and C. distenta did not separate in any molecular analysis. Cystophora distenta was established by J. Agardh based on material from the Chatham Islands (Agardh 1870). The species has been reported from Wellington, New Zealand southwards and the Chatham Islands (Lindauer et al. 1961). It is similar to $C$. scalaris but with longer, broader and more torulose receptacles, but dimensions 
given by Womersley (1964) overlap (Table 4.2). Three specimens collected from the Chatham Islands and the South Island of New Zealand were considered sufficiently morphologically distinct to assign to $C$. distenta, other specimens showed intermediate morphologies and were assigned to C. scalaris.

I consider that morphological characters used to separate $C$. distenta/C. scalaris and C. retroflexa/C. congesta are continuous and in the absence of molecular divergence oversplitting is probable. These results should be regarded as provisional as other closely related species of brown algae cannot be separated using mitochondrial sequences, due to ongoing gene flow or incomplete lineage sorting, but can be resolved with microsatellite data (Bergström et al. 2005; Billard et al. 2005; Pereyra et al. 2009).

The southern Australian species Cystophora subfarcinata and C. cuspidata are separated according to the arrangement and development of conceptacles (Womersley 1987). Cystophora cuspidata has receptacles that are broader $(1.5-4 \mathrm{~mm})$ with the lower conceptacles less scattered and arranged in two or three rows. Cystophora subfarcinata has narrower $((5-) 10-30(-50) \mathrm{mm}$ long $\times 1-2 \mathrm{~mm})$ receptacles with usually scattered conceptacles. These characters intergrade and some specimens (e.g., WELT A031517) could have been assigned to either species. Specimens resembling C. cuspidata did not cluster separately from $C$. subfarcinata in the molecular analyses. I agree with Womersley (1987) that $C$. cuspidata is probably only a form of $C$.

subfarcinata, but I was unable to collect samples from the type locality of $C$. cuspidata (Encounter Bay, SA), and specimens sampled did not have conceptacles as prominent as those illustrated by Womersley 1987 (Fig. 149 H, p. 403). Therefore I do not reduce $C$. cuspidata to synonymy with $C$. subfarcinata but recommend further work on these species.

\section{Revisions in species assignments}

Some specimens were morphologically intermediate between $C$. retroflexa and $C$. subfarcinata, or between C. retorta and C. siliquosa, and preliminary morphological assignments were incongruent with cox 1 sequence clusters. These specimens were reexamined and species assignments were revised using characters discussed below.

Cystophora retroflexa and $C$. subfarcinata can resemble one another when young, infertile or stunted, but fertile specimens could be distinguished using the shape of the conceptacle. In $C$. subfarcinata the conceptacle is spherical or 
subspherical; in Cystophora retroflexa the conceptacles are elongate. Some specimens that were initially assigned to $C$. retroflexa clustered with $C$. subfarcinata in molecular analyses. Careful examination of conceptacles in these specimens allowed us to reassign them to $C$. subfarcinata, despite other characters being consistent with C. retroflexa.

Cystophora siliquosa and C. retorta share complanately branched laterals, rounded axils and relatively straight main axes. Presence of vesicles is a diagnostic character for $C$. retorta, but this is of limited value as vesicles are absent on some specimens (Womersley 1964, 1987). I could not distinguish species by the shape of the main axis, as suggested by Womersley (1964) (see Table 4.2), and found microscopic examination of conceptacles to determine monoecy/dioecy was required to confidently assign specimens to species.

In both these species pairs, low morphological divergence and plasticity made species assignments difficult. In these cases $\operatorname{cox} 1$ sequences provided a useful indication that more careful morphological examination was required.

\section{Other markers}

These results, together with similar low variation in previous studies (Lane et al. 2007; Kucera \& Saunders 2008) suggests while $\operatorname{cox} 1$ has some utility for species identification in brown algae, it is too conserved to serve as a basis for a single marker barcoding system. Mitochondrial markers with sufficient resolution to discriminate closely related brown algae are rare, and low genetic divergence between recognised species of brown algae appears common (Van Oppen et al. 1993; Coyer et al. 2001, 2006; Stiger et al. 2000). A small proportion of errors (either failing to separate sister species, or recognising demes as species) might be acceptable in some applications of barcoding, where the trade-off is reduced time and cost (e.g., Moniz \& Kaczmarska 2009), but if barcoding is to contribute usefully to brown algal taxonomy other candidate markers should be evaluated.

Screening the mitochondrial genome of Saccharina species (Yotsukura et al. 2009) found mitochondrial regions that are more variable than cox 1 and these could be evaluated for species discrimination. In addition, the ITS1-5.8S-ITS2 cistron, or for ease of amplification, ITS 2 alone, might be a useful addition to cox 1 for species identification (see Coleman \& Mai 1997 in Chlorophyta, Guillemin et al. 2008 and Hu et al. 2009 in Rhodophyta, Litaker et al. 2007 in dinoflagellates, Moniz \& 
Kaczmarska 2009, 2010 in diatoms). The use of ITS sequences for barcoding has been criticised because length differences between species create alignment problems (McDevit \& Saunders 2009). However if barcoding is limited to species assignment (Ratnasingham \& Hebert 2007) this is not problematic, as inability to produce an alignment can be regarded as strong evidence for separating species (Müller et al. 2009) and alignment methods that better handle indels (Steinke et al. 2005) or alignment-free methods of sequence comparison (Chu et al. 2006, 2009; Kuksa \& Pavlovic 2009) can be used.

In conclusion, molecular data did not support the separate species status of $C$. distenta and $C$. congesta, and further work is required to confirm the separate status of C. cuspidata and C. cymodoceae. Other species were well supported by both morphological and molecular data. These results suggest that cox 1 barcoding might have utility in brown algae where delimiting closely related or sister species is not an issue (for example many studies identifying invasive algae, or studies where generic identity of cryptic life stages is sufficient). Species identification by cox 1 might also be useful in selected groups of brown algae or in restricted geographical areas, but reliance on this marker will require preliminary sampling across the area of interest with adequate sampling and corroboration by other data.

\subsection{Acknowledgements}

I thank the New Zealand Department of Conservation and Education NZ Study Abroad Scheme for funding assistance; Wendy Nelson, Tracy Farr, Kate Neill and the Department of Conservation Chatham Islands staff for assistance with collections and Alan Millar (National Herbarium of New South Wales) and Jenn Dalen (Museum of New Zealand Te Papa Tongarewa herbarium) for assistance with herbaria access.

\subsection{References}

AgARDH, J. G. (1870). Om Chatham-öarnes Alger. Öfversigt af Kongl. Vetenskaps-Adademiens Förhandlingar, Stockholm, 5, 435-456.

Avise, J. C. (2000). Phylogeography: The History and Formation of Species. Cambridge MA: Harvard University Press.

BAKer, A. J., TAVERES, E. S. \& Elbourne, R. F. (2009). Countering criticisms of single mitochondrial DNA gene barcoding in birds. Molecular Ecology Resources, 9, (Suppl. 1) 257-268.

Bergström, L., TAtarenkov, A., Johannesson, K. Jönsson, R. B. \& KAUTSKy, L. (2005). Genetic and morphological identification of Fucus radicans sp. nov. (Fucales, Phaeophyceae) in the brackish Baltic Sea. Journal of Phycology, 41, 1025-1038. 
Billard, E., Daguin, C., Pearson, G. Serrão, E., Engel, C. \& Valero, M. (2005). Genetic isolation between three closely related taxa: Fucus vesiculosus, F. spiralis and F. ceranoides (Phaeophyceae). Journal of Phycology, 41, 900-905.

Chase, M. W., Cowan, R. S., Hollingsworth, P. M., van DEn Berg, C., Madriñan, S., ET AL. (2007). A proposal for a standardised protocol to barcode all land plants. Taxon, 56, 295-299.

CHU, K. H., LI, C. P.\& QI, J. (2006). Ribosomal RNA as molecular barcodes: a simple correlation analysis without sequence alignment, Bioinformatics, 22, 1690-1701

CHU, K. H., XU, M \& LI, C. P. (2009). Rapid DNA barcoding analysis of large datasets using the composition vector method. BMC Bioinformatics, 10, (Suppl. 14), S8.

COLEMAN, A. W. \& MAI, J. C. (1997). Ribosomal DNA ITS-1 and ITS-2 sequence comparisons as a tool of predicting genetic relatedness. Journal of Molecular Evolution, 45, 168-177.

Coyer, J. A., SMith, G. J. \& Andersen, R. A. (2001). Evolution of Macrocystis spp. (Phaeophyceae) as determined by ITS1 and ITS2 sequences. Journal of Phycology, 37, 574-585.

Coyer, J. A., Hoarau, G., Oudot-Le SecQ, M-P., Stam, W. T. \& Olsen, J. L. (2006). A mtDNAbased phylogeny of the brown algal genus Fucus (Heterokontophyta; Phaeophyta). Molecular Phylogenetics and Evolution, 39, 209-222.

DAYRAT, B. (2005). Towards integrative taxonomy. Biological Journal of the Linnean Society, 85, $407-415$.

DeSalle, R., Egan, M. G. \& Siddall, M. (2005). The unholy trinity: taxonomy, species delimitation and DNA barcoding. Philosophical Transactions of the Royal Society of London B Biological Sciences, 360, 1905-1916.

Engelmann, J. C., Rahmann, S., Wolf, M., Schultz, J., Fritzilas, E., ET AL. (2009). Modelling cross-hybridization on phylogenetic DNA microarrays increases the detection power of closely related species. Molecular Ecology Resources, 9, 83-93.

Evans, K. M., Wortley, A. H. \& MAnN, D. G. (2007). An assessment of potential diatom "barcode" genes (cox $1, r b c \mathrm{~L}, 18 \mathrm{~S}$ and ITS rDNA) and their effectiveness in determining relationships in Sellaphora (Bacillariophyta). Protist, 158, 349-364.

FERGUSON, J. W. H. (2002). On the use of genetic divergence for identifying species. Biological Journal of the Linnean Society, 75, 509-516.

Ford, C. S., Ayres, K. L., ToOmey, N., Haider, N., van Alphen StAhl, J., Kelly, L. J., ET AL. (2009). Selection of candidate coding DNA barcoding regions for use on land plants. Botanical Journal of the Linnean Society, 159, 1-11.

Fox, C. H. \& SWANSON, A. K. (2007). Nested PCR detection of microscopic life-stages of laminarian macroalgae and comparison with adult forms along intertidal height gradients. Marine Ecology Progress Series, 332, 1-10.

Fraser, C. L., NikUla, R., SpEnCER, H. G. \& WATERS, J. (2009). Kelp genes reveal effects of subantarctic sea ice during the Last Glacial Maximum. Proceedings of the National Academy of Sciences of the U.S.A., 106, 3249-3253.

FRÉZAL, L. \& LEBLOIS, R. (2008). Four years of DNA barcoding: Current advances and prospects. Infection, Genetics and Evolution, 8, 727-736.

Golding, G. B., HANNER, R. \& Hebert, P. D. N. (2009). Preface. Molecular Ecology Resources, 9 , (Suppl. 1) iv-vi.

Guillemin, M.-L., Ait AKki, S., Givernaud, T., Mouradi, A., VAlero, M., Destombe, C. (2008). Molecular characterisation and development of rapid molecular methods identify species of Gracilariaceae from the Atlantic coast of Morocco. Aquatic Botany, 89, 324-330.

HeBert, P. D. N., CYWInSKA, A., BALL, S. L. \& DE WAARD, J. R. (2003). Biological identifications through DNA barcodes. Proceedings of the Royal Society of London B Series, 270, 313-321.

Hebert, P. D. N., Stoeckle, M. Y., ZEMLAK, T. S. \& FranCiS, C. M. (2004). Identification of birds through DNA barcodes. PLoS Biology, 2, e312. doi: 10.1371/journal.pbio.0020312. 
Hickerson, M. J., MeYer, C. P. \& MoritZ, C. (2006). DNA barcoding will often fail to discover new animal species over broad parameter space. Systematic Biology 55: 729-739.

Hotrau, G., Coyer, J. A., Veldsink, J. H., Stam, W. T. \& Olsen, J. L. (2007). Glacial refugia and recolonization pathways in the brown seaweed Fucus serratus. Molecular Ecology, 16, 3606-3616.

HU, Z. M., GUIRY, M. D. \& DUAN, D. L. (2009). Using the ribosomal internal transcribed spacer (ITS) as a complement marker for species identification of red macroalgae. Hydrobiologia, 635, 279-287.

HuELSENBECK, J. P. \& RONQUIST, F. (2001). MRBAYES: Bayesian inference of phylogenetic trees. Bioinformatics, 17, 754-755.

Janzen, D. H., Hallwachs, W., Blandin, P., Burns, J. M., Cadiou, J-M., Chacon, I., Et al. (2009). Integration of DNA barcoding into an ongoing inventory of complex tropical biodiversity. Molecular Ecology Resources, 9, (Suppl. 1), 1-26.

KRESS, W. J. \& ERICKSON, D. L. (2007). A two-locus global DNA barcode for land plants: The coding $r b c \mathrm{~L}$ gene complements the non-coding $t r n \mathrm{H} / p s b \mathrm{~A}$ spacer region. PLoS ONE, 2, e508. doi 10.1371/journal.pone.0000508.

KuCERA, H. \& SAUnders, G. W. (2008). Assigning morphological variants of Fucus (Fucales, Phaeophyceae) in Canadian waters to recognized species using DNA barcoding. Botany, 86, 10651079.

KuKSA, P. \& PAVLOVIC, V. (2009). Efficient alignment-free DNA barcode analytics. BMC Bioinformatics, 10, (Suppl. 14), S9.

KuMAR, S. (2005). Molecular clocks - four decades of evolution. Nature Reviews Genetics, 6, 654-662.

LAHAYe, R., VAn Der BAnK, M., Bogarin, D., WARner, J., PuPulin, F., Gigot, G., et Al. (2008). DNA barcoding the floras of biodiversity hotspots. Proceedings of the National Academy of Sciences of the USA, 105, 2923-2928.

LANE, C. E. \& SAUNDERS, G. W. (2005). Molecular investigation reveals epi/endophytic extrageneric kelp (Laminariales, Phaeophyceae) gametophytes colonizing Lessoniopsis littoralis thalli. Botanica Marina, 48, 426-436.

LAne, C. E., Mayes, C. M., Druehl, L. \& Saunders, G. W. (2006). A multi-gene molecular investigation of the kelp (Laminariales, Phaeophyceae) resolves competing phylogenetic hypotheses and supports substantial taxonomic re-organization. Journal of Phycology, 42, 493-512.

LANE, C. E., LindSTROM, S. C. \& SAUNDERS, G. W. (2007). A molecular assessment of northeast Pacific Alaria species (Laminariales, Phaeophyceae) with reference to the utility of DNA barcoding. Molecular Phylogenetics and Evolution, 44, 634-648.

Linares, M. C., Soto-CAlderón, I. D., LeEs, D. C. \& AnThony, N. M. (2008). High mitochondrial diversity in geographically widespread butterflies of Madagascar: A test of the DNA barcoding approach. Molecular Phylogenetics and Evolution, 50, 485-495.

Lindauer, V. W., Chapman, V. J. \& Aiken, M. (1961). The Marine Algae of New Zealand II: Phaeophyceae. Nova Hedwigia, 3, 129-350.

LitaKer, R. W., Zandersea, M. W., Kibler, S. R., Reece, K. S., Stokes, N. A., Lutzoni, F. M., ET AL. (2007). Recognizing dinoflagellate species using ITS rDNA sequences. Journal of Phycology, 43, 344-355.

LYONS, D. A. \& SCHEIBLING, R. E. (2009). Range expansion by invasive marine algae: rates and patterns of spread at a regional scale. Diversity and Distributions, 15, 1-14.

Maggs, C. A., Castilho, R., Foltz, D., Henzler, C., Jolly, M. T., Kelly, J., et al. (2008). Evaluating signatures of glacial refugia for North Atlantic benthic marine taxa. Ecology, 89, S108S122.

MCDEVIT, D. C. \& SAUNDERS, G. W. (2009). On the utility of DNA barcoding for species differentiation among brown macroalgae (Phaeophyceae) including a novel extraction protocol. Phycological Research, 57, 131-141. 
MeIER, R., ZHANG, G. Y. \& ALI, F. (2008). The use of mean instead of smallest interspecific distances exaggerates the size of the "Barcoding Gap" and leads to misidentification. Systematic Biology, 57, 809-813.

Moniz, B. J. M. \& KACZMARSKA, I. (2009). Barcoding diatoms: Is there a good marker? Molecular Ecology Resources, 9, (Suppl. 1), 65-74.

MONIZ, B. J. M. \& KACZMARSKA, I. (2010). Barcoding of diatoms: Nuclear encoded ITS revisited. Protist, 161, 7-34.

MÜller, T. PhiliPPI, N., DANDEKAR, T., Schultz, J. \& WOLF, M. (2009). Distinguishing species. RNA $13,1469-1472$.

Oudot-Le SecQ, M-P., KloAREG, B. \& LOISEAUX-DE GÖER, S. (2002). The mitochondrial genome of the brown alga Laminaria digitata: a comparative analysis. European Journal of Phycology, 37, $163-172$.

Oudot-Le SeCQ, M-P, LOISEAUX-DE GoËr, S., StAM, W. T. \& Olsen, J. L. (2006). Complete mitochondrial genomes of the three brown algae (Heterokonta: Phaeophyceae) Dictyota dichotoma, Fucus vesiculosus and Desmarestia viridis. Current Genetics, 49, 47-58.

Papadopoulou, A., Bergsten, J., Fujisawa, T., Monaghan, M. T., Barraclough, T. G. \& Vogler, A. P. (2008). Speciation and DNA barcodes: testing the effects of dispersal on the formation of discrete sequence clusters. Philosophical Transactions of the Royal Society of London B Biological Sciences, 363, 2987-2996.

Pereyra, R. T., Bergström, L., KAUtSky, L. \& JohAnnesson, K. (2009). Rapid speciation in a newly opened postglacial marine environment, the Baltic Sea. BMC Evolutionary Biology, 9, 70. doi: $10.1186 / 1471-2148-9-70$

PETERS, A. F. \& BURKHARDT, E. (1998). Systematic position of the kelp endophyte Laminarionema elsbetiae (Ectocarpales sensu lato, Phaeophyceae) inferred from nuclear ribosomal DNA sequences. Phycologia, 37, 114-120.

PosadA, D. \& CRANDAll, K. A. (1998). Modeltest: Testing the model of DNA substitution. Bioinformatics, 14, 817-818.

PRESTING, G. G. (2006). Identification of conserved regions in the plastid genome: implications for DNA barcoding and biological function. Canadian Journal of Botany, 83, 1434-1443.

RACH, J., DeSAlle, R., SARKAR, I. N., Schierwater, B. \& HADRYs, H. (2008). Character-based DNA barcoding allows discrimination of genera, species and populations in Odonata. Philosophical Transactions of the Royal Society of London B Biological Sciences, 275, 237-247.

Ratnasingham, S. \& Hebert, P. D. N. (2007). BOLD: The Barcode of Life Data System (www.barcodinglife.org). Molecular Ecology Notes, 7, 355-364.

RobBA, L., Russell, S. J., BARKer, G. L.\& Brodie, J. (2006). Assessing the use of the mitochondrial cox1 marker for use in DNA barcoding of red algae (Rhodophyta). American Journal of Botany, 93, 1101-1108.

RUBINOFF, D. (2006). DNA barcoding evolves into the familiar. Conservation Biology, 20, 1548-1549.

RubinOFF, D., CAMERON, S. \& WiLl, K. (2006). A genomic perspective on the shortcomings of mitochondrial DNA for "barcoding" identification. Journal of Heredity, 97, 581-594.

SASAKI, H., LINDSTROM, S. C., WAALAND, J. R. \& KAWAI, H. (2003). Occurrence of the gametophyte of Agarum clathratum (Laminariales, Phaeophyceae) as an endophyte in Orculifilum denticulatum (Gigartinales, Rhodophyceae). Phycological Research, 51, 192-202.

SAUNDERS, G. W. (2005). Applying DNA barcoding to red macroalgae: a preliminary appraisal holds promise for future applications. Philsophical Transactions of the Royal Society B Series, 360, 1879-1888.

SAUNDERS, G. W. (2008). A DNA barcode examination of the red algal family Dumontiaceae in Canadian waters reveals substantial cryptic species diversity. 1. The folose Dilsea-Neodilsea complex and Weeksia. Botany, 86, 773-789. 
SAUNDERS, G. W. (2009). Routine DNA barcoding of Canadian Gracilariales (Rhodophyta) reveals the invasive species Gracilaria vermiculophylla in British Columbia. Molecular Ecology Resources, 9, (Suppl. 1), 140-150.

SChINDEL, D. E. \& MiLleR, S. E. (2005). DNA barcoding a useful tool for taxonomists. Nature, $435,17$.

Seberg, O. \& Petersen, G. (2009). How many loci does it take to DNA barcode a Crocus? PLoS ONE, 4, e4598. doi: 10.1371/journal.pone.0004598.

SHAFFER, H. B. \& THOMPSON, R. C. (2007). Delimiting species in recent radiations. Systematic Biology, 56, 896-906.

Sherwood, A. R., Vis, M. L., Entwisle, T. J., Necchi, O. JR. \& Presting, G. G. (2008). Contrasting intra versus interspecies DNA sequence variation for representatives of the Batrachospermales (Rhodophyta): Insights from a DNA barcoding approach. Phycological Research, 56, 269-279.

Steinke, D., Vences, M., SAlzburger, W. \& Meyer, A. (2005). TaxI: a software tool for DNA barcoding using distance methods. Philosophical Transactions of the Royal Society of London B Biological Sciences, 360, 1975-1980.

Stiger, V., Horiguchi, T., Yoshida, T., Coleman, A. W. \& Masuda, M. (2000). Phylogenetic relationships of Sargassum (Sargassaceae, Phaeophyceae) with reference to a taxonomic revision of section Phyllocystae based on ITS-2 nrDNA sequences. Phycological Research, 48, 251-260.

SwofFord, D. L. (2002). PAUP*: Phylogenetic Analysis Using Parsimony (*and Other Methods). Version 4. Sunderland MA: Sinauer Associates.

TAI, V., Lindstrom, S. C. \& SAUnders, G. W. 2001. Phylogeny of the Dumontiaceae (Gigartinales, Rhodophyta) and associated families based on SSU rDNA and internal transcribed spacer sequence data. Journal of Phycology, 37, 184-196.

TREWICK, S. A. (2008). DNA Barcoding is not enough: mismatch of taxonomy and genealogy in New Zealand grasshoppers (Orthoptera: Acrididae). Cladistics, 24, 240-254.

Uwai, S., Kogame, K., Yoshida, G., Kawai, H. \& AJISAKA, T. (2009). Geographical genetic structure and phylogeography of the Sargassum horneri/filicinum complex in Japan, based on the mitochondrial cox3 haplotype. Marine Biology, 156, 901-911.

VAn Oppen, M. J. H., Olsen, J.L., StAm, W. T., VAn DEN Hoek, C. \& WIENCKe, C. (1993). ArcticAntarctic disjunctions in the benthic seaweeds Acrosiphonia arcta (Chlorophyta) and Desmarestia viridis/willii (Phaeophyta) are of recent origin. Marine Biology, 115, 381-386.

Vogler, A. P. \& Monaghan, M. T. (2006). Recent advances in DNA taxonomy. Journal of Zoological Systematics and Evolutionary Research, 45, 1-10.

WARD, R. D., Holmes, B. H. \& O'HARA, T. D. (2008). DNA barcoding discriminates echinoderm species. Molecular Ecology Resources, 8, 1202 - 1211.

WARD, R. D., HANNER, R. \& HEBERT, P. D. N. (2009). The campaign to DNA barcode all fishes, FISHBOL. Journal of Fish Biology, 74, 329-356.

WILL, K. W. \& RUBINOFF, D. (2004). Myth of the molecule: DNA barcodes for species cannot replace morphology for identification and classification. Cladistics, 20, 47-55.

WOMERSELY, H. B. S. (1964). The morphology and taxonomy of Cystophora and related genera (Phaeophyta). Australian Journal of Botany, 12, 53-110.

Womersley, H. B. S. (1987). The marine benthic flora of southern Australia. Part II. Adelaide, Australia: South Australian Government Printing Division.

YAnG, E. C., Kim, M. S., Geraldino, P. J. L., SAHOO, D., Shin, J-H. \& BoO, S. M. (2008). Mitochondrial cox 1 and plastid $r b c \mathrm{~L}$ genes of Gracilaria vermiculophylla (Gracialariaceae, Rhodophyta). Journal of Applied Phycology, 20, 161-168.

Yotsukura, N., Shimizu, T., Katayama, T. \& Druehl, L. D. (2009). Mitochondrial DNA sequence variation of four Saccharina species (Laminariales, Phaeophyceae) growing in Japan. Journal of Applied Phycology. doi: 10.1007/s10811-009-9452-7. 
ZUCCARELLO, G. C. \& LOKHORST, G. M. (2005). Molecular phylogeny of the genus Tribonema (Xanthophyceae) using $r b c \mathrm{~L}$ gene sequence data: monophyly of morphologically simple algal species. Phycologia, 44, 384-392.

ZUCCARELlO, G. C., BUCHANAN, J. \& WEST, J. A. (2006). Increased sampling for inferring phylogeographic patterns in Bostrychia radicans/B. moritziana (Rhodomelaceae, Rhodophyta) in the Eastern USA. Journal of Phycology, 42, 1349-1352.

ZWICKL, D. J. (2006). Genetic algorithm approaches for the phylogenetic analysis of large biological sequence datasets under the maximum likelihood criterion. Unpublished Ph.D. dissertation. Austin TX: The University of Texas at Austin. 


\section{Chapter 5}

Taxonomic oversplitting in the New Zealand members of the brown algal genus Cystophora (Phaeophyceae, Sargassaceae): Synonymisation of two species 


\subsection{Abstract}

Six species of Cystophora are currently recognized in New Zealand waters. Molecular evidence supports four of these (C. platylobium (Mertens) J. Agardh, C. retroflexa (Labillardière) J. Agardh, C. scalaris J. Agardh and C. torulosa (R. Brown) J. Agardh), but data have failed to separate two currently accepted species from sister species: Cystophora congesta Womersley \& Nizamuddin is a form of $C$. retroflexa, with short laterals and fascicled ramuli, and represents part of a range of morphological variation; Cystophora distenta $\mathrm{J}$. Agardh is a form of $C$. scalaris, with wide, compressed receptacles, but receptacle dimensions do not separate species. I synonymise $C$. congesta with $C$. retroflexa and $C$. distenta with $C$. scalaris on the basis of available molecular and morphological data, and provide amended descriptions of these species and a key to New Zealand species of Cystophora.

\subsection{Introduction}

ALGAE OF THE GENUS CYSTOPHORA are a significant component of the New Zealand marine flora (Shears \& Babcock 2007). Cystophora thalli are common in the shallow sub-tidal, rock pools and lower intertidal. They provide structure and shelter for other marine organisms (Taylor \& Cole 1994, McDermott \& Shima 2006), and are a significant contributor to primary productivity (Schiel 1990).

Six species of Cystophora are currently recognised in New Zealand (Womersley 1964, 1987, Adams 1994). Cystophora torulosa (R. Brown) J. Agardh and C. retroflexa (Labillardière) J. Agardh are widespread in New Zealand and southern Australia. Cystophora platylobium (Mertens) J. Agardh is found from Cook Strait southwards and in southern Australia. Cystophora scalaris $\mathbf{J}$ Agardh is found south of Cook Strait in New Zealand only. Cystophora congesta Womersley \& Nizamuddin was described from Robe, South Australia, in 1964 and has been occasionally reported from New Zealand (Adams 1994, Nelson et al. 1992). Early collections from New Zealand include specimens determined as C. dumosa (Greville) J. Agardh, a name rejected as a nomen confusum by Womersley (1964), under the then current Montreal Code (Lanjouw et al. 1961) Art. 69 (although reported by Womersley as Art. 66). Womersley determined herbarium material used for the original description 
(Sonder 1846) consisted of a mixture of species, and synonymised some of the material with $C$. monilifera. New Zealand specimens might be referable to $C$. congesta (Adams 1994). Cystophora distenta J. Agardh has been reported from the Chatham Islands (Agardh 1870, Lindauer et al. 1961) and other southern New Zealand locations (Nelson et al. 1991, 1992, Adams 1994). A detailed taxonomic history of Cystophora is provided by Womersley $(1964,1987)$.

Lindauer et al. (1961) also report doubtful records of four Australian species (including Cystophora cephalornithos, now Caulocystis) collected from New Zealand. These appear to be many mistakes in identification or incorrect recording of localities on early collections. Difficulties arise in species identification in Cystophora (Adams 1994). Lindauer et al. (1961) suggested two reasons for this: the state of dried herbarium material, which is often poorly preserved and incomplete, and because "within the New Zealand species a degree of hybridization occurs in certain areas where some of the species overlap" (p. 295). Lindauer et al. (1961) only consider $C$. platylobium as distinctive, as other species intergrade. Womersley (1964) also noted that the morphology of some specimens were intermediate between species. Further confusion has arisen from unclear synonymy and inadequate descriptions. Lindauer et al. (1961) describe specimens under the name Cystophora dumosa. Womersley (1964) rejected that name, and created a new species, $C$. congesta, containing many specimens previously assigned to $C$. dumosa. Adams' (1994, p. 141) illustration of $C$. congesta does not resemble Womersley's description, and keys in Lindauer et al. (1961) and Adams (1994) use different characters from Womersley (1964).

Cystophora congesta and $C$. distenta are rarely reported outside of the taxonomic literature. Surveys of the New Zealand coastlines by Morton \& Miller (1968) and Shears \& Babcock (2007) recorded Cystophora platylobium, C. retroflexa, C. scalaris and C. torulosa, but not $C$. congesta or $C$. distenta. A molecular study of the genus (Chapter 4) failed to separate $C$. congesta from $C$. retroflexa and $C$. distenta from C. scalaris. Here I evaluate the evidence for recognising six species of Cystophora in New Zealand, provide additional morphological and molecular data, and formally synonymise the species $C$. congesta and $C$. distenta. 
Table 5.1. Voucher numbers of specimens used in analyses, collection locations, latitude and longitude. A. Cystophora retroflexa and outgroups with haplotypes and GenBank accession numbers of mitochondrial spacer sequences.

\begin{tabular}{|c|c|c|c|c|}
\hline $\begin{array}{l}\text { Herbarium } \\
\text { voucher } \\
\text { number }^{7}\end{array}$ & Species & Location & $\begin{array}{l}\text { Latitude, } \\
\text { Longitude }\end{array}$ & $\begin{array}{l}\text { Haplotype } \\
\text { (see Fig. 1) } \\
\text { and GenBank } \\
\text { Accession } \\
\text { number }\end{array}$ \\
\hline $\begin{array}{l}\text { WELT } \\
\text { A031531 }\end{array}$ & C. retroflexa & Depot Beach NSW & $\begin{array}{l}35^{\circ} 37^{\prime} 37.91^{\prime \prime} \mathrm{S}, \\
150^{\circ} 19^{\prime} 37.27^{\prime \prime} \mathrm{E}\end{array}$ & C (JF309054) \\
\hline $\begin{array}{l}\text { WELT } \\
\text { A030917 }\end{array}$ & C. retroflexa & $\begin{array}{l}\text { Island Bay, } \\
\text { Wellington, NZ }\end{array}$ & $\begin{array}{l}41^{\circ} 20^{\prime} 51.22^{\prime \prime} \mathrm{S}, \\
174^{\circ} 46^{\prime} 9.77^{\prime \prime} \mathrm{E}\end{array}$ & B (JF309069) \\
\hline $\begin{array}{l}\text { WELT } \\
\text { A031510 }\end{array}$ & C. retroflexa & Lonsdale VIC & $\begin{array}{l}38^{\circ} 17^{\prime} 5.30^{\prime \prime} \mathrm{S}, \\
144^{\circ} 36^{\prime} 54.74^{\prime \prime} \mathrm{E}\end{array}$ & B (JF309057) \\
\hline $\begin{array}{l}\text { WELT } \\
\text { A031532 }\end{array}$ & C. retroflexa & $\begin{array}{l}\text { Mimosa Rocks, } \\
\text { Arragunnu NSW }\end{array}$ & $\begin{array}{l}36^{\circ} 35^{\prime} 2.07^{\prime \prime} \mathrm{S}, \\
150^{\circ} 3^{\prime} 15.18^{\prime \prime} \mathrm{E}\end{array}$ & C (JF309056) \\
\hline $\begin{array}{l}\text { WELT } \\
\text { A031533 }\end{array}$ & C. retroflexa & Point Lonsdale VIC & $\begin{array}{l}38^{\circ} 17^{\prime} 20.52^{\prime \prime} \mathrm{S}, \\
144^{\circ} 36^{\prime} 4.42^{\prime \prime} \mathrm{E}\end{array}$ & D (JF309059) \\
\hline $\begin{array}{l}\text { WELT } \\
\text { A031509 }\end{array}$ & C. retroflexa & Port Campbell VIC & $\begin{array}{l}38^{\circ} 37^{\prime} 14.84^{\prime \prime} \mathrm{S}, \\
142^{\circ} 59^{\prime} 32.69^{\prime \prime} \mathrm{E}\end{array}$ & C (JF309060) \\
\hline $\begin{array}{l}\text { WELT } \\
\text { A030926 }\end{array}$ & C. retroflexa & $\begin{array}{l}\text { Princess Bay, } \\
\text { Wellington NZ }\end{array}$ & $\begin{array}{l}41^{\circ} 20^{\prime} 43.05^{\prime \prime} \mathrm{S}, \\
174^{\circ} 47^{\prime} 14.08^{\prime \prime} \mathrm{E}\end{array}$ & B (JF309051) \\
\hline $\begin{array}{l}\text { WELT } \\
\text { A030914 }\end{array}$ & C. retroflexa & $\begin{array}{l}\text { Princess Bay, } \\
\text { Wellington NZ }\end{array}$ & $\begin{array}{l}41^{\circ} 20^{\prime} 43.05^{\prime \prime} \mathrm{S}, \\
174^{\circ} 47^{\prime} 14.08^{\prime \prime} \mathrm{E}\end{array}$ & B (JF309066) \\
\hline $\begin{array}{l}\text { WELT } \\
\text { A030913 }\end{array}$ & C. retroflexa & $\begin{array}{l}\text { Princess Bay, } \\
\text { Wellington NZ }\end{array}$ & $\begin{array}{l}41^{\circ} 20^{\prime} 43.05^{\prime \prime} \mathrm{S}, \\
174^{\circ} 47^{\prime} 14.08^{\prime \prime} \mathrm{E}\end{array}$ & B (JF309067) \\
\hline $\begin{array}{l}\text { WELT } \\
\text { A031511 }\end{array}$ & C. retroflexa & Robe SA & $\begin{array}{l}37^{\circ} 9^{\prime 2} 23.33^{\prime \prime} \mathrm{S}, \\
139^{\circ} 44^{\prime} 56.32^{\prime \prime} \mathrm{E}\end{array}$ & C (JF309061) \\
\hline $\begin{array}{l}\text { WELT } \\
\text { A031508 }\end{array}$ & C. retroflexa & Robe SA & $\begin{array}{l}37^{\circ} 9^{\prime 2} 23.33^{\prime \prime} \mathrm{S}, \\
139^{\circ} 44^{\prime} 56.32^{\prime \prime} \mathrm{E}\end{array}$ & A (JF309062) \\
\hline
\end{tabular}

\footnotetext{
${ }^{7}$ Field numbers are shown. These specimens have been deposited at WELT. Herbarium numbers will be added when the accession process is completed.
} 
Table 5.1 (Continued)

\begin{tabular}{|c|c|c|c|c|}
\hline $\begin{array}{l}\text { Herbarium } \\
\text { voucher } \\
\text { number }\end{array}$ & Species & Location & $\begin{array}{l}\text { Latitude, } \\
\text { Longitude }\end{array}$ & $\begin{array}{l}\text { Haplotype } \\
\text { (see Fig. 1) } \\
\text { and GenBank } \\
\text { Accession } \\
\text { number }\end{array}$ \\
\hline $\begin{array}{l}\text { WELT } \\
\text { A031512 }\end{array}$ & C. retroflexa & Robe SA & $\begin{array}{l}37^{\circ} 9^{\prime 2} 23.33^{\prime \prime} \mathrm{S}, \\
139^{\circ} 44^{\prime} 56.32^{\prime \prime} \mathrm{E}\end{array}$ & C (JF309070) \\
\hline $\begin{array}{l}\text { WELT } \\
\text { A031530 }\end{array}$ & C. retroflexa & Sorrento, VIC & $\begin{array}{l}38^{\circ} 20^{\prime} 5.35^{\prime \prime} \mathrm{S}, \\
144^{\circ} 44^{\prime} 33.96^{\prime \prime} \mathrm{E}\end{array}$ & D (JF309058) \\
\hline $\begin{array}{l}\text { WELT } \\
\text { A030927 }\end{array}$ & C. retroflexa & $\begin{array}{l}\text { The Sirens, } \\
\text { Wellington NZ }\end{array}$ & $\begin{array}{l}41^{\circ} 20^{\prime} 56.91^{\prime \prime} \mathrm{S}, \\
174^{\circ} 45^{\prime} 51.05^{\prime \prime} \mathrm{E}\end{array}$ & B (JF309063) \\
\hline $\begin{array}{l}\text { WELT } \\
\text { A030932 }\end{array}$ & C. retroflexa & $\begin{array}{l}\text { Tokomaru Bay, } \\
\text { Eastland, NZ }\end{array}$ & $\begin{array}{l}38^{\circ} 6^{\prime} 35.83^{\prime \prime} \mathrm{S}, \\
178^{\circ} 21^{\prime} 18.27^{\prime \prime} \mathrm{E}\end{array}$ & D (JF309068) \\
\hline $\begin{array}{l}\text { WELT } \\
\text { A031528 }\end{array}$ & C. subfarcinata & Lonsdale VIC & $\begin{array}{l}38^{\circ} 17^{\prime} 5.30^{\prime \prime} \mathrm{S}, \\
144^{\circ} 36^{\prime} 54.74^{\prime \prime} \mathrm{E}\end{array}$ & F (JF309065) \\
\hline $\begin{array}{l}\text { WELT } \\
\text { A031513 }\end{array}$ & C. subfarcinata & $\begin{array}{l}\text { Observation Head, } \\
\text { Batemans Bay } \\
\text { NSW }\end{array}$ & $\begin{array}{l}35^{\circ} 43^{\prime} 45.50^{\prime \prime} \mathrm{S}, \\
150^{\circ} 12^{\prime} 30.26^{\prime \prime} \mathrm{E}\end{array}$ & E (JF309055) \\
\hline $\begin{array}{l}\text { WELT } \\
\text { A031527 }\end{array}$ & C. subfarcinata & $\begin{array}{l}\text { Squeaky Beach, } \\
\text { Wilsons } \\
\text { Promontory VIC }\end{array}$ & $\begin{array}{l}39^{\circ} 1^{\prime} 45.89^{\prime \prime} \mathrm{S}, \\
146^{\circ} 18^{\prime} 24.24^{\prime \prime} \mathrm{E}\end{array}$ & F (JF309063) \\
\hline $\begin{array}{l}\text { WELT } \\
\text { A031529 }\end{array}$ & C. subfarcinata & Ulladulla, NSW & $\begin{array}{l}35^{\circ} 21^{\prime} 37.65^{\prime \prime} \mathrm{S}, \\
150^{\circ} 29^{\prime} 5.55^{\prime \prime} \mathrm{E}\end{array}$ & E (JF309053) \\
\hline
\end{tabular}


Table 5.1. B. Cystophora scalaris samples with reference numbers to Fig. 5.1.

\begin{tabular}{|c|c|c|c|c|}
\hline $\begin{array}{l}\text { Herbarium } \\
\text { voucher } \\
\text { number }\end{array}$ & Species & Location & $\begin{array}{l}\text { Latitude, } \\
\text { Longitude }\end{array}$ & $\begin{array}{l}\text { Reference } \\
\text { number } \\
\text { (Fig. 5.1) }\end{array}$ \\
\hline $\begin{array}{l}\text { WELT } \\
\text { A030925 }\end{array}$ & C. scalaris & Pukerua Bay NZ & $\begin{array}{l}41^{\circ} 1^{\prime} 28.36^{\prime \prime} \mathrm{S}, \\
174^{\circ} 54^{\prime} 5.54^{\prime \prime} \mathrm{E}\end{array}$ & 1 \\
\hline $\begin{array}{l}\text { WELT } \\
\text { A030921 }\end{array}$ & C. scalaris & $\begin{array}{l}\text { Riversdale, Wairarapa } \\
\text { NZ }\end{array}$ & $\begin{array}{l}41^{\circ} 6^{\prime} 24.49^{\prime \prime} \mathrm{S}, \\
176^{\circ} 4^{\prime} 10.73^{\prime \prime} \mathrm{E}\end{array}$ & 2 \\
\hline $\begin{array}{l}\text { WELT } \\
\text { A031338 }\end{array}$ & C. scalaris & $\begin{array}{l}\text { Evans Bay, Wellington, } \\
\text { NZ }\end{array}$ & $\begin{array}{l}41^{\circ} 18^{\prime} 59.61^{\prime \prime} \mathrm{S}, \\
174^{\circ} 48^{\prime} 23.25^{\prime \prime} \mathrm{E}\end{array}$ & 3 \\
\hline $\begin{array}{l}\text { WELT } \\
\text { A031337 }\end{array}$ & C. scalaris & $\begin{array}{l}\text { Lyall Bay, Wellington, } \\
\text { NZ }\end{array}$ & $\begin{array}{l}41^{\circ} 20^{\prime} 12.67^{\prime \prime} \mathrm{S}, \\
174^{\circ} 47^{\prime} 35.14^{\prime \prime} \mathrm{E}\end{array}$ & 4 \\
\hline $\begin{array}{l}\text { WELT } \\
\text { A030902 }\end{array}$ & C. scalaris & $\begin{array}{l}\text { Moa Point, Wellington, } \\
\text { NZ }\end{array}$ & $\begin{array}{l}41^{\circ} 20^{\prime} 37.68^{\prime \prime} \mathrm{S}, \\
174^{\circ} 48^{\prime} 31.54^{\prime \prime} \mathrm{E}\end{array}$ & 5 \\
\hline $\begin{array}{l}\text { WELT } \\
\text { A030904 }\end{array}$ & C. scalaris & $\begin{array}{l}\text { Moa Point, Wellington, } \\
\text { NZ }\end{array}$ & $\begin{array}{l}41^{\circ} 20^{\prime} 37.68^{\prime \prime} \mathrm{S}, \\
174^{\circ} 48^{\prime} 31.54^{\prime \prime} \mathrm{E}\end{array}$ & 6 \\
\hline $\begin{array}{l}\text { WELT } \\
\text { A030901 }\end{array}$ & C. scalaris & $\begin{array}{l}\text { Tarakena Bay, } \\
\text { Wellington, NZ }\end{array}$ & $\begin{array}{l}41^{\circ} 20^{\prime} 39.95^{\prime \prime} \mathrm{S}, \\
174^{\circ} 49^{\prime} 12.46^{\prime \prime} \mathrm{E}\end{array}$ & 7 \\
\hline $\begin{array}{l}\text { WELT } \\
\text { A030903 }\end{array}$ & C. scalaris & $\begin{array}{l}\text { Princess Bay, } \\
\text { Wellington NZ }\end{array}$ & $\begin{array}{l}41^{\circ} 20^{\prime} 43.05^{\prime \prime} \mathrm{S}, \\
174^{\circ} 47^{\prime} 14.08^{\prime \prime} \mathrm{E}\end{array}$ & 8 \\
\hline $\begin{array}{l}\text { WELT } \\
\text { A031341 }\end{array}$ & C. scalaris & $\begin{array}{l}\text { Te Raekaihau, } \\
\text { Wellington NZ }\end{array}$ & $\begin{array}{l}41^{\circ} 20^{\prime} 50.92^{\prime \prime} \mathrm{S}, \\
174^{\circ} 47^{\prime} 29.01^{\prime \prime} \mathrm{E}\end{array}$ & 9 \\
\hline $\begin{array}{l}\text { WELT } \\
\text { A031344 }\end{array}$ & C. scalaris & $\begin{array}{l}\text { Te Raekaihau, } \\
\text { Wellington NZ }\end{array}$ & $\begin{array}{l}41^{\circ} 20^{\prime} 50.92^{\prime \prime} \mathrm{S}, \\
174^{\circ} 47^{\prime} 29.01^{\prime \prime} \mathrm{E}\end{array}$ & 10 \\
\hline $\begin{array}{l}\text { WELT } \\
\text { A030905 }\end{array}$ & C. scalaris & $\begin{array}{l}\text { Te Raekaihau, } \\
\text { Wellington NZ }\end{array}$ & $\begin{array}{l}41^{\circ} 20^{\prime} 50.92^{\prime \prime} \mathrm{S} \\
174^{\circ} 47^{\prime} 29.01^{\prime \prime} \mathrm{E}\end{array}$ & 11 \\
\hline $\begin{array}{l}\text { WELT } \\
\text { A030923 }\end{array}$ & C. scalaris & $\begin{array}{l}\text { Te Raekaihau, } \\
\text { Wellington NZ }\end{array}$ & $\begin{array}{l}41^{\circ} 20^{\prime} 50.92^{\prime \prime} \mathrm{S}, \\
174^{\circ} 47^{\prime} 29.01^{\prime \prime} \mathrm{E}\end{array}$ & 12 \\
\hline $\begin{array}{l}\text { WELT } \\
\text { A031336 }\end{array}$ & C. scalaris & $\begin{array}{l}\text { Red rocks, Wellington, } \\
\text { NZ }\end{array}$ & $\begin{array}{l}41^{\circ} 20^{\prime} 54.91^{\prime \prime} \mathrm{S}, \\
174^{\circ} 44^{\prime} 30.19^{\prime \prime} \mathrm{E}\end{array}$ & 13 \\
\hline
\end{tabular}


Table 5.1. B. (Continued)

\begin{tabular}{|c|c|c|c|}
\hline $\begin{array}{l}\text { WELT } \\
\text { A031334 }\end{array}$ & C. scalaris & $\begin{array}{l}\text { Red rocks, Wellington, } \\
\text { NZ }\end{array}$ & $\begin{array}{l}41^{\circ} 20^{\prime} 54.91^{\prime \prime} \mathrm{S}, \\
174^{\circ} 44^{\prime} 30.19^{\prime \prime} \mathrm{E}\end{array}$ \\
\hline WELT & C. scalaris & Red rocks, Wellington, & $41^{\circ} 20^{\prime} 54.91^{\prime \prime} \mathrm{S}$ \\
\hline A031335 & & NZ & $174^{\circ} 44^{\prime} 30.19^{\prime \prime} \mathrm{E}$ \\
\hline WELT & C. scalaris & Kaingaroa, Chatham & $43^{\circ} 43^{\prime} 51.20^{\prime \prime} \mathrm{S}$ \\
\hline A031346 & & Islands & $176^{\circ} 16^{\prime} 2.26^{\prime \prime} \mathrm{W}$ \\
\hline WELT & C. scalaris & Point Weeding, & $43^{\circ} 56^{\prime} 32.08^{\prime \prime} \mathrm{S}$ \\
\hline A031345 & & Chatham Islands & $176^{\circ} 34^{\prime} 14.74^{\prime \prime} \mathrm{W}$ \\
\hline WELT & C. scalaris & Point Weeding, & $43^{\circ} 56^{\prime} 32.08^{\prime \prime} \mathrm{S}$ \\
\hline A030909 & & Chatham Islands & $176^{\circ} 34^{\prime} 14.74^{\prime \prime} \mathrm{W}$ \\
\hline WELT & C. scalaris & Point Weeding, & $43^{\circ} 56^{\prime} 32.08^{\prime \prime} \mathrm{S}$ \\
\hline A030908 & & Chatham Islands & $176^{\circ} 34^{\prime} 14.74^{\prime \prime} \mathrm{W}$ \\
\hline WELT & C. scalaris & Point Weeding, & $43^{\circ} 56^{\prime} 32.08^{\prime \prime} \mathrm{S}$ \\
\hline A030910 & & Chatham Islands & $176^{\circ} 34^{\prime} 14.74^{\prime \prime} \mathrm{W}$ \\
\hline WELT & C. scalaris & Waitangi, Chatham & $43^{\circ} 56^{\prime} 41.58^{\prime \prime} \mathrm{S}$ \\
\hline A030911 & & Islands, NZ & $176^{\circ} 33^{\prime} 41.78^{\prime \prime} \mathrm{W}$ \\
\hline WELT & C. scalaris & Ocean Beach, Jackson & $43^{\circ} 57^{\prime} 54.44^{\prime \prime} \mathrm{S}$ \\
\hline A030922 & & Bay NZ & $168^{\circ} 36^{\prime} 21.70^{\prime \prime} \mathrm{E}$ \\
\hline WELT & C. scalaris & Owenga, Chatham & $44^{\circ} 2^{\prime} 0.30^{\prime \prime} \mathrm{S}$ \\
\hline A031343 & & Islands & $176^{\circ} 19^{\prime} 58.80^{\prime \prime} \mathrm{W}$ \\
\hline WELT & C. scalaris & Manukau Reef, & $44^{\circ} 2^{\prime} 4.90^{\prime \prime} \mathrm{S}$ \\
\hline A031340 & & Chatham Islands & $176^{\circ} 19^{\prime} 44.31^{\prime \prime} \mathrm{W}$ \\
\hline WELT & C. scalaris & Mapoutahi, Otago & $45^{\circ} 44^{\prime} 5.57^{\prime \prime} \mathrm{S}$ \\
\hline A030933 & & Peninsula NZ & $170^{\circ} 37^{\prime} 4.53^{\prime \prime} \mathrm{E}$ \\
\hline WELT & C. scalaris & Wellers Rock, Otago & $45^{\circ} 47^{\prime} 51.97^{\prime \prime} \mathrm{S}$ \\
\hline A030906 & & Harbour, NZ & $170^{\circ} 42^{\prime} 53.85^{\prime \prime} \mathrm{E}$ \\
\hline
\end{tabular}




\subsection{Materials and Methods}

Cystophora specimens were collected from around New Zealand, including the Chatham Islands, and from southern Australia and Tasmania (Table 5.1). A priori species assignments were made on the basis of morphological characters from Womersley $(1964,1987)$. Thalli were pressed as herbaria specimens and one or a few ramuli were cleaned of epiphytes and the tissue rapidly dried and stored in silica gel for DNA extraction. In addition, specimens held in WELT were examined (Table 5.1).

Length, width (wider axis of compressed receptacle) and breadth (narrower axis of compressed receptacle) of receptacles of herbaria specimens of $C$. scalaris and C. distenta were measured with digital callipers. Ten randomly selected receptacles were measured from 26 specimens. In three specimens, selected as representing the range of receptacle size, measurements were taken of fresh receptacles. These receptacles were then air dried and remeasured, and a factor estimated by regression to determine a multiplier to convert measurements from herbarium specimens to the equivalent fresh dimensions. ANOVAs, implemented in SPSS16, were used to test for significant differences between mean dimensions. In addition to these specimens, herbaria specimens of all New Zealand species of Cystophora were examined from WELT and my collections and additional measurements were made to determine the range of character dimensions for revised descriptions.

DNA was extracted using a modified CTAB extraction (Zuccarello \& Lokhorst 2005), with the addition of $1 \%$ polyvinylpolypyrrolidone to the extraction buffer. The 23S-tRNA-Lys mitochondrial spacer (Hoarau et al. 2007, Chapter 2) was amplified. Primers and PCR mixes and routines were described in Chapter 2. PCR products were cleaned with ExoSAP-IT (USB, Cleveland, Ohio) enzymes and sequenced commercially (Macrogen Inc., Seoul, Korea). A statistical parsimony network was inferred from mitochondrial spacer sequences from 20 specimens of Cystophora using TCS software (Clement et al. 2000), with linkages made at the $95 \%$ confidence level.

\subsection{Results}

Some specimens were difficult to assign to species using existing keys and morphological characters. Ambiguous specimens were assigned to the more common species. Consequently only seven specimens were assigned to $C$. congesta and four 
specimens to $C$. distenta (Table 5.1). Measurements of receptacles of putative Cystophora scalaris and C. distenta specimens show a wide range of receptacle forms, often with high variation on a single thallus (Fig. 5.1). Specimens from highly exposed locations (e.g., specimens 10-13 in Fig. 5.1) show very reduced receptacle length. Neither length nor width:breadth ratios (a measure of compression of the receptacle) show clusters consistent with separate species (Fig. 5.1).
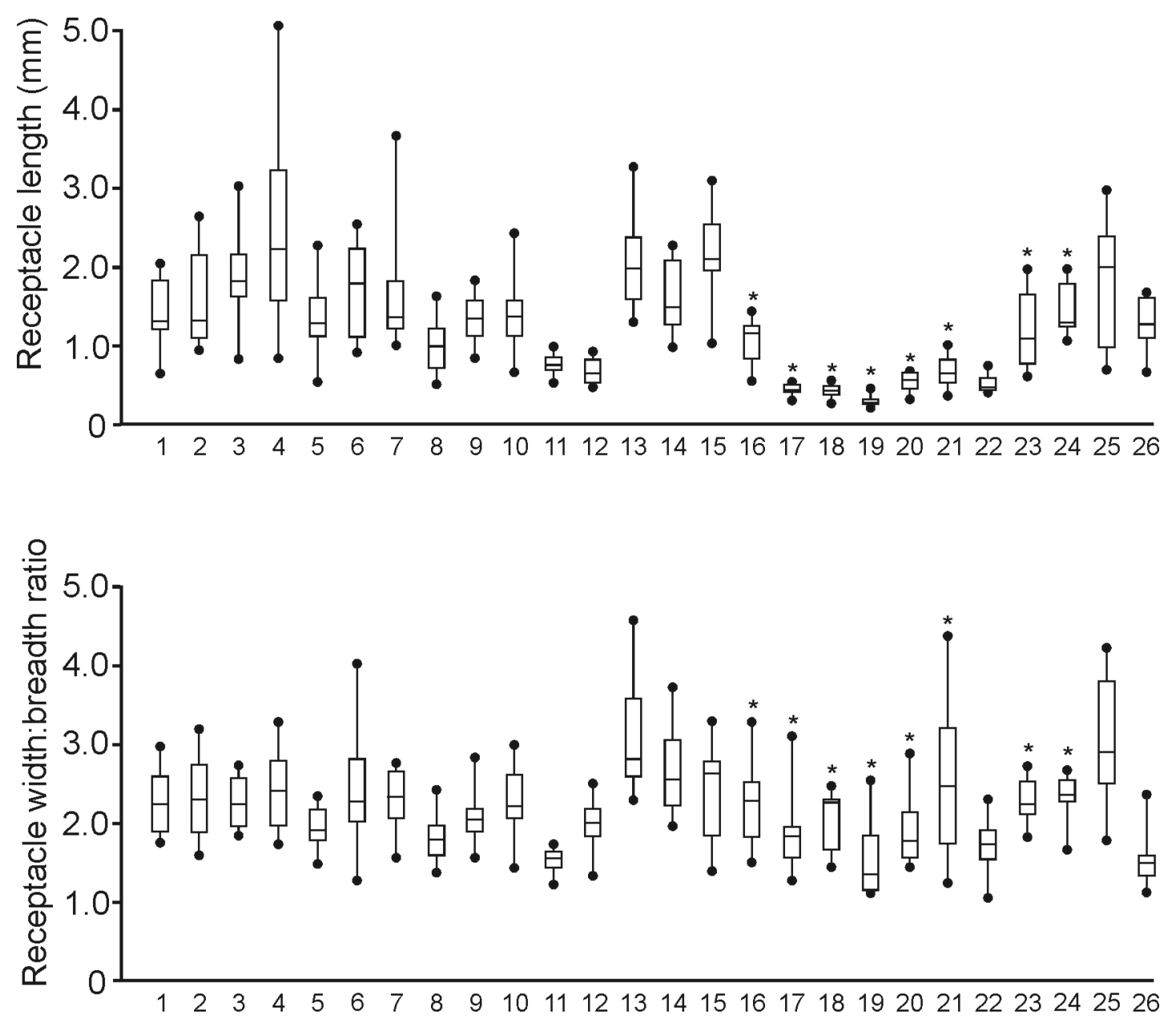

Fig. 5.1. Morphological variation from 26 specimens of Cystophora scalaris. Graphs show maximum, minimum median and $25 \%$ and $75 \%$ quartiles from 26 specimens. Data are arranged from northernmost (1) to southernmost (26) specimens, asterisks indicate specimens from the Chatham Islands. A. Receptacle length. B. Receptacle width: breadth ratios.

ANOVA analysis of log-transformed data showed significant $(\mathrm{P}<0.01)$ differences between means in the data, but post-hoc tests (Tukey's HSD pairwise and 
range tests) showed significant differences only existed between outlier data. For example, mean length of receptacles from specimens 5 and 18 (in Fig. 5.1a) were significantly different from specimens $8-13$, but differences between both groups and intermediate specimens was not significant $(\mathrm{P}>0.05)$. Similarly, specimens with the greatest receptacle width:breadth ratios (specimens 5 and 16 in Fig. 5.1A) showed significant differences from those specimens with the lowest ratios (specimens 12, 23 and 26 in Fig. 5.1B), but none of these specimens showed significant differences from intermediate specimens.

\section{Molecular data}

Four mitochondrial spacer haplotypes were found in C. retroflexa and $C$. congesta (Fig. 5.2, A-D; Appendix 6). Two haplotypes associated with $C$. subfarcinata were included as outgroups (E, F). Four C. retroflexa/C. congesta haplotypes were separated by a single change in each case. Two haplotypes were sampled in specimens of both $C$. congesta and $C$. retroflexa. Only one specimen of $C$. congesta (WELT A031508 from Robe, South Australia) had a unique haplotype (Haplotype A in Fig. 5.2).

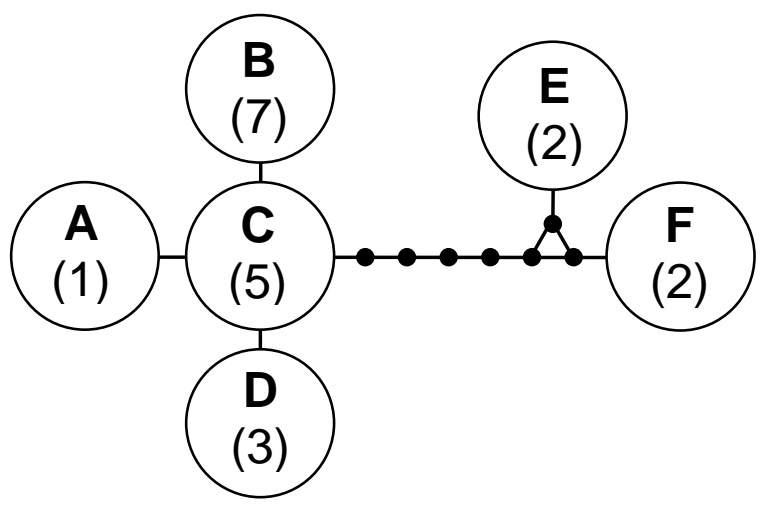

Fig. 5.2. Statistical parsimony network inferred from 20 mitochondrial spacer sequences of Cystophora retroflexa (A-D) and C. subfarcinata (E, F). Estimated at $95 \%$ confidence. Haplotypes A-C include both $C$. retroflexa and $C$. congesta morphotypes. Numbers are sample frequencies. 


\subsection{Discussion}

Two species of Cystophora found in New Zealand do not present any taxonomic problems. Cystophora platylobium is usually found in relatively deep water, and collections are often based on drift specimens. Attached specimens were collected in southern Otago only (at 1-2 metres depth). For this reason, sampling of this species was limited, but available data suggests this species is ecologically, morphologically and genetically (Chapter 4) distinct from other species, and New Zealand specimens are genetically very similar to Australian specimens, with identical cox 1 haplotypes (Chapter 4). Cystophora torulosa is also morphologically and ecologically and genetically distinct from other species (Chapter 4). No difficulty was found in assigning specimens to these species using existing keys and descriptions. These species will not be commented on further.

The remaining New Zealand species of Cystophora present some problems. Specimens of Cystophora congesta can be difficult to separate from $C$. retroflexa, and C. scalaris can be difficult to separate from $C$. distenta. Some confusion also appears to have arisen in distinguishing C. scalaris and C. retroflexa (Lindauer et al. 1961). These problems arise in part from inadequate descriptions and poor character choice in the keys provided in Lindauer et al. (1961) and Adams (1994), which rely on the relative zig-zaggedness of the main axes and laterals for species identification. This is confusing, as from my observations, the degree of zig-zagging in the primary and secondary axes is fairly plastic in several species of Cystophora and is probably related to the growth rate (Klemm \& Hallam 1987). Womersley's (1964) keys separated these species by the arrangement of branching of the ramuli (complanate in C. scalaris and C. distenta, irregularly radial in C. retroflexa and C. congesta) and the size and form of the receptacles, characters which are reliable for separating $C$. retroflexa from $C$. scalaris, but still inadequate for separating both $C$. retroflexa from C. congesta and $C$. scalaris from $C$. distenta. Intermediate forms are common in both pairs of species and I consider the morphological characters used to split species are not discontinuous, but rather lie on a continuum of intra-specific variation. The evidence for maintaining $C$. congesta and $C$. distenta as separate species can be attributed to limited sampling, with specimens examined representing the extremes of a morphological continuum. 
Fig. 5.3. Morphological variation in Cystophora retorta. A. congested form, zig-zag laterals [WELT A031546]; B. distended form, straight laterals [WELT A031547]. Scale bar $=100 \mathrm{~mm}$.

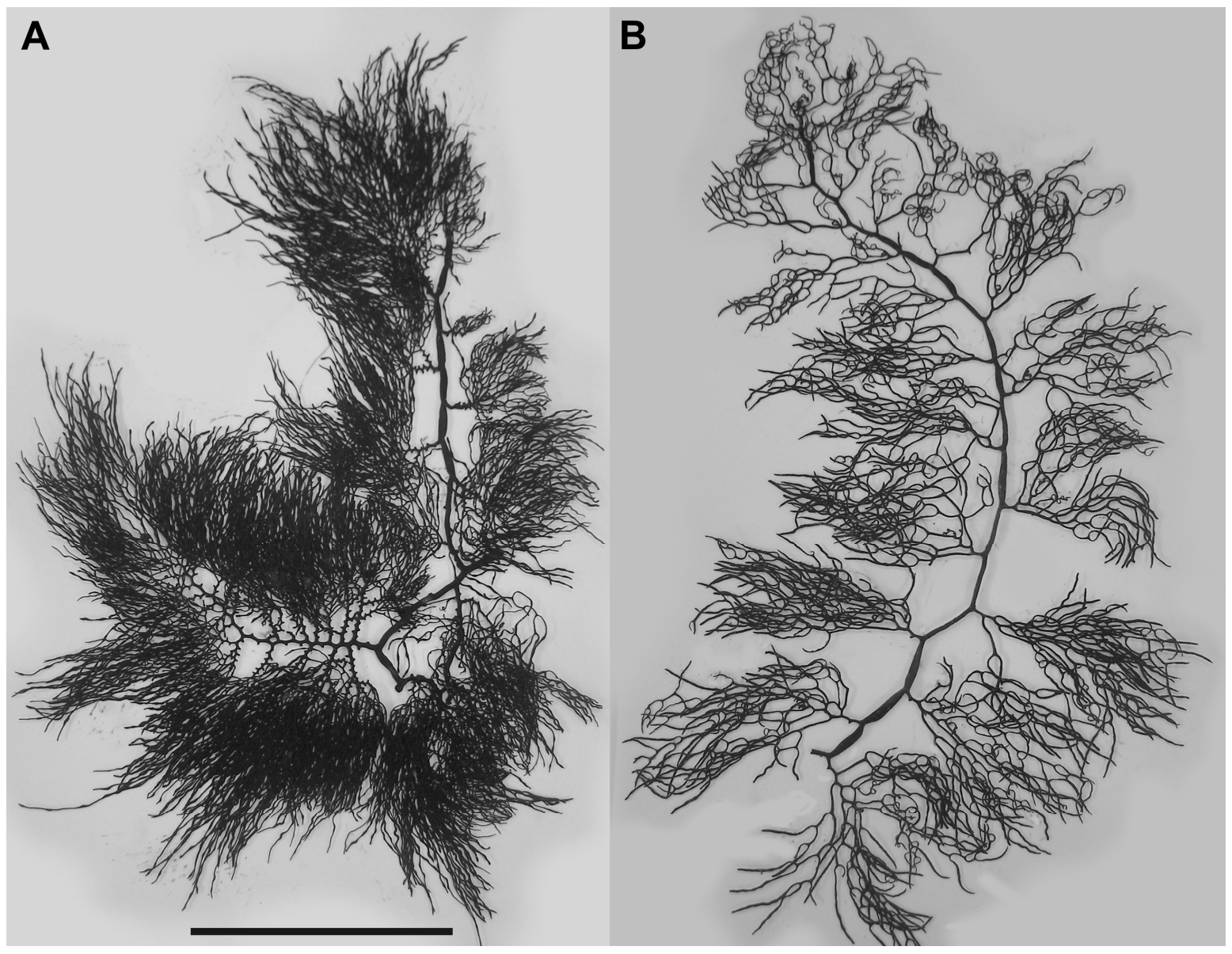




\subsubsection{Cystophora congesta and $C$. retroflexa}

In Chapter 4 I could not separate $C$. retroflexa and $C$. congesta using ITS and cox 1 sequences. The highly variable 23S-tRNA-Lys mitochondrial spacer (Fig. 5.2) also fails to separate these species. Both this study and Chapter 4 include $C$. congesta specimens from the type locality (Robe, South Australia). While sampling in this study is limited, the mitochondrial spacer used here is highly variable in most species of brown algae (Hoarau et al. 2007, Chapter 2), and haplotypes found in all but one specimens assigned to $C$. congesta were also found in typical specimens of $C$. retroflexa. In addition, these species share cox 1 haplotypes and ITS ribotypes (Chapter 4). Together, this is strong evidence against genetic differentiation.

According to Womersley (1964: 87) " $C$. congesta is most closely related to $C$. retroflexa, differing in the much denser laterals and secondary axes, shorter receptacles and thicker, more rigid, primary axis. Occasional intergrades between these species occur." Womersley then separated the species entirely on these vegetative characters, all of which are variable in other species of Cystophora. For example, specimens of $C$. retorta can have a thick primary axis and zig-zag laterals bearing fascicled ramuli and receptacles, and other specimen have a thin primary axis, with straight and sparsely branched laterals (Fig. 5.3). All morphological types share the scattered bisexual conceptacles that distinguish this species from its near relatives (Womersley 1964).

Some specimens could be easily assigned to $C$. retroflexa or $C$. congesta using Womersley's criteria, but many specimens were intermediate and could be assigned to either species (Fig. 5.4). The plasticity of these characters in other species of Cystophora, for example in C. siliquosa and C. subfarcinata (see dimensions in Womersley 1964), the presence of intergrades and the absence of genetic differentiation suggest these characters are inadequate for inferring distinct species.

The weight of the evidence is that $C$. congesta should be regarded as either an ecotype or a developmental form of $C$. retroflexa. I consider $C$. congesta Womersley $\&$ Nizamuddin as synonymous with $C$. retroflexa (Labillardière) J. Agardh, the latter name having priority. 
Fig. 5.4. Morphological variation in Cystophora retroflexa. A. Distended thallus [WELT A031534]. B. Intermediate thallus [WELT A031533]. C. Congested thallus [WELT A031508]. Scale bar $=100 \mathrm{~mm}$.

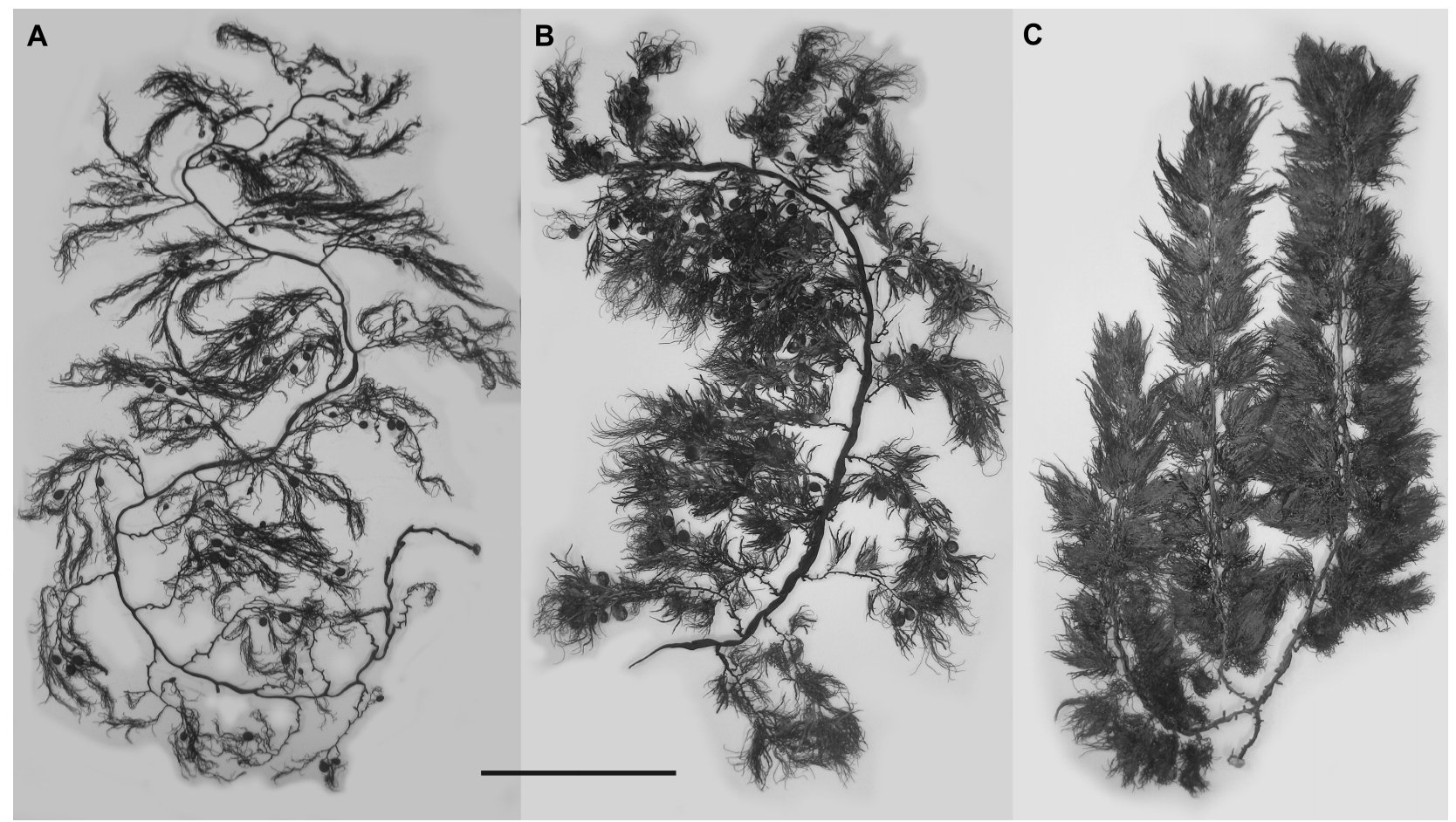


Fig. 5.5. Morphological variation in receptacles of Cystophora scalaris A. WELT A031345A; B. WELT A031345B; C. WELT A030922; D. WELT A031346; E. WELT A031340; F. WELT A031343; G. WELT A031341;

H. Examples of receptacles from a single thallus, WELT A031337). Scale bar $=20 \mathrm{~mm}$.
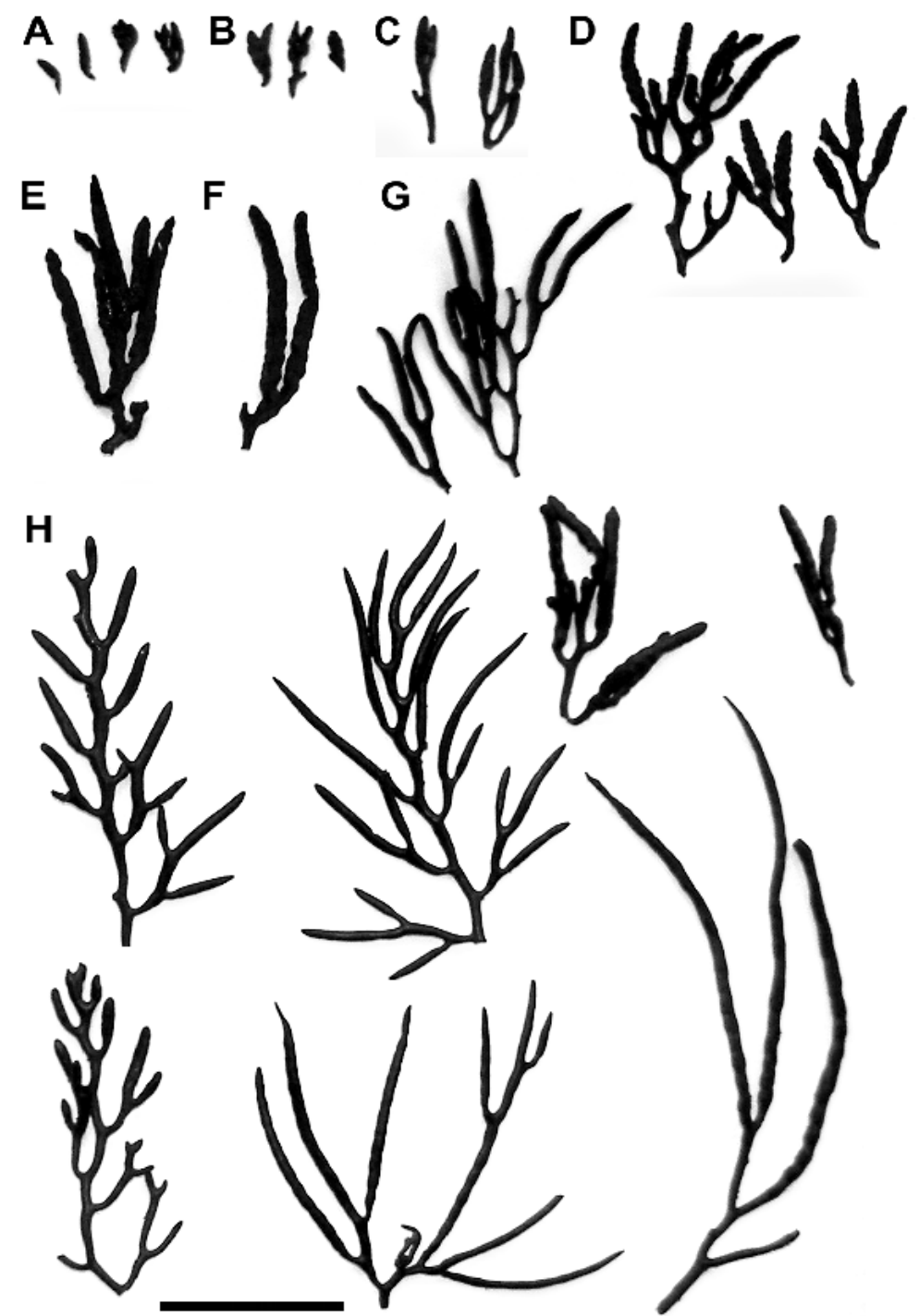


\subsubsection{Amended description}

Cystophora retroflexa (Labillardière) J. Agardh Species Genera et Ordines Algarum

1848: 242. Womersley Aus. J. Bot. 1964: 89, Figs. 31, 32, pl. 10, Fig. 2. Marine Flora of Southern Australia 3 1987: 396, Figs. 132 I, 146B, 149B, C.

Cystophora congesta Womersley \& Nizamuddin ex Womersley Aus. J. Bot. 1964: 86, Fig. 30, pl. 9 Fig. 2. Womersley Marine Flora of Southern Australia 3 1987: 394. Figs. 146A, 149A.

Figs. 4, 5.

Thallus brown, $0.3-1.5(-2) \mathrm{m}$ high, with the primary axes bearing alternate laterals and secondary axes. Holdfast discoid-conical, 3-15 mm diameter, with a short, terete stipe; epilithic. Primary axes compressed, 3-12 mm broad below and 1-4(-5) $\mathrm{mm}$ thick, 2-6(-10) $\mathrm{mm}$ broad above, narrow edged, fairly straight to zig-zag and scalariform, alternately distichously branched from the face of the axes, lower parts often denuded with prominent residues, each branch position giving rise to 1(-3) determinate laterals and 1(-2) indeterminate laterals; lower laterals usually retroflex, often with broad basal wings. Laterals determinate or indeterminate, determinate laterals arising from the edge of an outgrowth of the main axes, 20-100 $\mathrm{mm}$ long, with usually irregular radial, sometimes subtristichous or subdistichous branching, bearing ramuli, sometimes developing into receptacles, lower determinate laterals often with enlarged and flattened ramuli. Indeterminate laterals arising from the centre of outgrowths from the axes, 20-300 mm long, initially terete, becoming flattened, alternately distichously branched, becoming slightly to strongly zig-zag; bearing determinate secondary laterals and/or secondary indeterminate laterals. Ramuli 2040(-50) mm long, 0.4-2(-3) mm broad. Ramuli on lower laterals sometimes enlarged and flattened. Vesicles ovoid, becoming subspherical when old, replacing basal (or lower 2) ramuli of laterals, stalked, mutic, 4-12(-15) mm long and 3-10(-12) mm broad.

Reproduction thalli monecious. Receptacles usually simple, occasionally branched, compressed, margins undulate to torulose when fresh, often strongly torulose when dried, 15-50 (-60) mm long and 1-2 (-4) mm broad, attenuate at apex usually with sterile terminal awn, awn rarely with scattered conceptacles, with 2 rows of conceptacles along the margins; conceptacles bisexual, ostioles along the margin. 
Type locality "Cape van Diemen" (southern Tasmania).

Holotype FI (Herbarium Webbianum).

Distribution Australia: Womersley (1964) reports the species from Bondi (Sydney), NSW. I found specimens from Kiama, NSW southwards. I have not ascertained the western limit of $C$. retroflexa in Australia. Womersley (1987) reports the western limit as "from Cottesloe to Nannarup (Albany), W.A., and from Kangaroo I.". Tasmania, New Zealand, Chatham Is., Auckland Is.

\subsubsection{Cystophora distenta and $C$. scalaris}

J. G. Agardh (1870) described C. scalaris and C. distenta from the Chatham Islands, but regarded them as contracted and distended forms of the same species, stating: "C. scalarem \& C. distentam esse ejusdem specie formas - unam contractam, alteram distentam" (Agardh 1870). ["C. scalaris and C. distenta are forms of the same species - one contracted and the other distended."]. De Toni (1895: 141) also stated that $C$. distenta was "Anne forma laxa C. scalaris J. Ag.?."

Treatment as separate species seems to begin with Laing (1899) who reported both forms as species without comment, and continued to do so in further publications (Laing 1926). Lindauer (1947) followed Laing in listing these as separate species (using the generic name Blossevillea (following Gardner 1913). Lindauer (1947) gave the distribution of $C$. distenta (as Blossevillea distenta) as Chatham Islands and Stewart Island, but noted that in Stewart Island "the habit of the plant is less typical" (p. 560). Lindauer et al. (1961) reported the two entities as separate species, as did Womersley (1964, 1987), Nelson et al. (1991, 1992) and Adams (1994).

Womersley (1964: 91) described C. distenta and C. scalaris as separate species, "differing in the more compressed and much longer receptacles, straighter and less robust axis, and looser branching " [in C. distenta]. This is unhelpful as the dimensions of the axis and looseness of branching are variable in many species of Cystophora (for example, in C. retorta, Fig. 5.3), and receptacle dimensions provided by Womersley (1964) and Lindauer et al. (1961) for these species overlap.

Receptacles are very variable in length in C. scalaris (Figs. 5.1 and 5.5), and from my observations compression appears to be related to the reproductive state of the 
receptacle, rather than any underlying genetic difference. Receptacle dimensions are highly variable, even on a single thallus (Figs. 5.1 and 5.5).

Cystophora distenta was first described from the Chatham Islands by J. Agardh (1870). De Toni listed its distribution as the Chatham Islands and Bluff. Lindauer et al. (1961) extended its distribution to include Stewart Island and Frenchman's Pass (presumably French Pass in the Marlborough Sounds), and also noted that specimens were found in drift at Tauranga. Later specimens were reported from Cape Palliser on the southern North Island (Adams 1994) and Durville Island, on the northern tip of the South Island (Nelson et al.1992). The species appears to be distributed on the mainland south of Cook Strait and on Stewart Island and the Chatham Islands. This distribution is the same as that of $C$. scalaris (Lindauer et al. 1961, Adams 1994).

As I am unable to separate $C$. scalaris and $C$. distenta using morphological or molecular data, I consider Agardh's (1870) assessment to be correct and regard $C$. distenta as a form of $C$. scalaris. The latter name is in more common usage (e.g., Morton \& Miller 1968, Shears \& Babcock 2007).

\subsubsection{Amended species description}

\section{Cystophora scalaris J. Agardh Öfversigt af Kongl. Vetenskaps-Academiens}

Förhandlingar 1870: 442. Womersley Aus. J. Bot. 1964: 82, Figs. 22, 23, pl. 7, fig. 2.

\section{Figs. 5.5, 5.6.}

Thallus brown, (0.1-)0.3-1 m long, with the primary axes bearing alternate, openly to densely branched laterals and secondary axes. Holdfast discoid-conical, 5-20 mm diameter, with a short, terete stipe; epilithic. Primary axes strongly flattened, 3-15 (20) $\mathrm{mm}$ broad and $2-3 \mathrm{~mm}$ thick, strongly zigzag and scalariform to fairly straight, lower parts often denuded with scalariform residues, alternately distichously branched from the face of the axis, with each branch position producing $1(-2)$ indeterminate secondary axes from the centre of the face and/or (0-1) -2 determinate laterals from the edge of the scales, laterals 10-30 (-50) mm apart; secondary and tertiary axes similar, 20-80 cm long, initially terete, becoming flattened, strongly zig-zag and scalariform to fairly straight; lower parts of primary, secondary, and older tertiary axes usually denuded, with very prominent, close-set scalariform residues, and 
markedly broader basal wings on the primary (and often secondary) axis at branch positions. Laterals 20-80 (-100) mm long, complanately branched, often bifurcate at their base, then alternately distichous with ramuli also alternately distichous, with acute to rounded axils; ultimate ramuli terete to compressed, 5-10 (-30) $\mathrm{mm}$ long, 13(-4) mm broad. Ramuli of lower laterals on main axis often enlarged and flattened. Vesicles sparse to numerous, replacing lower 1 to 2 or more ramuli of the lateral of each bifurcation, sub-spherical to slightly ovoid, stalked, mutic, 2-8 (-12) mm diameter.

Reproduction. Thalli monoecious, receptacles developed from ultimate ramuli, simple or occasionally branched, ovoid to compressed in section, 10-50 mm long, (0.5-)1-3 $\mathrm{mm}$ broad and 1-1.5 mm thick, elongate, margins undulate to strongly torulose.

Conceptacles bisexual, ostioles in two rows along the margins of the receptacle, rarely in three rows.

Type locality Chatham Islands.

Lectotype LD (Herbarium Agardh, No. 1113).

Distribution New Zealand, from Wellington southwards; Chatham Islands, Auckland Islands. 


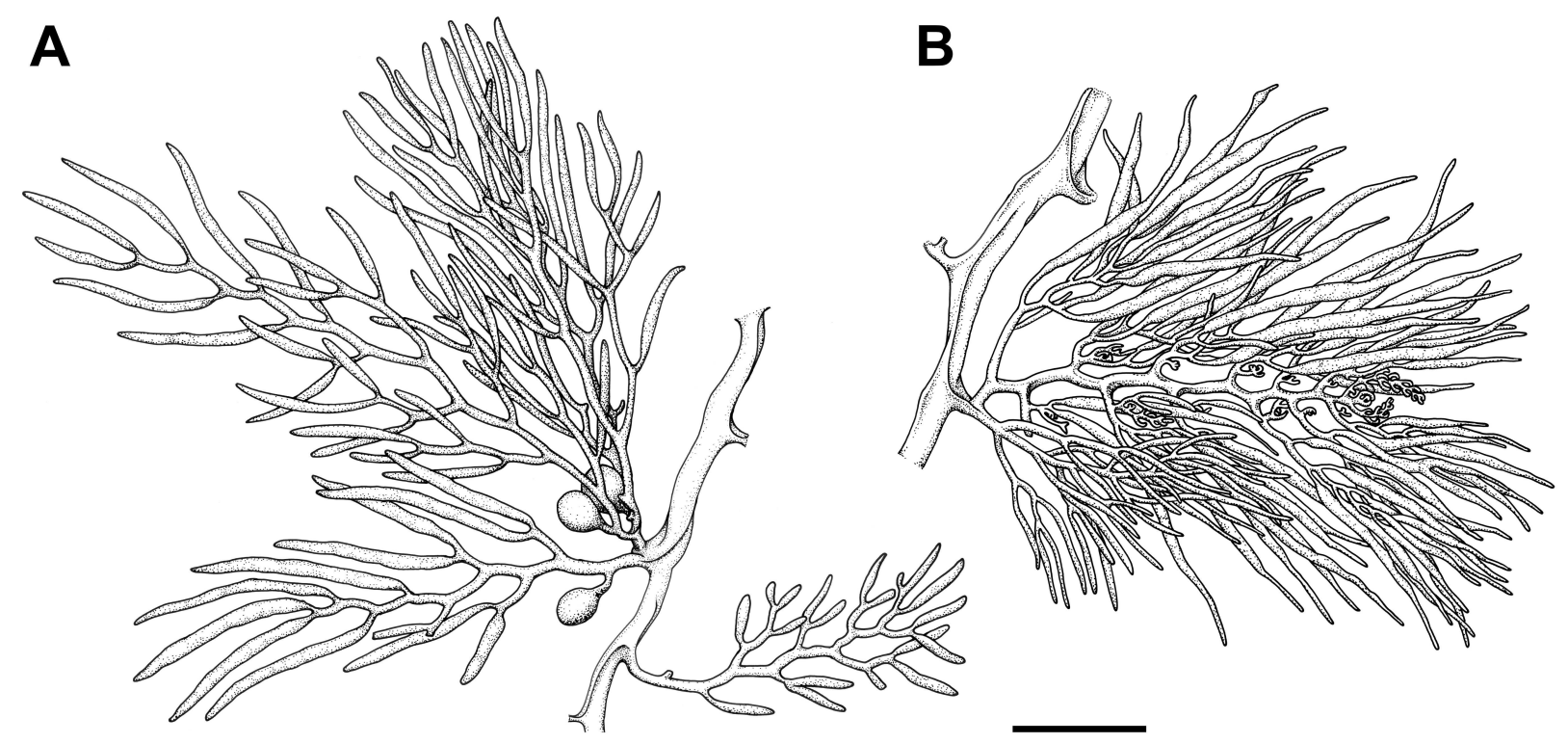

Fig. 5.6. Organisation of ramuli and receptacles in Cystophora. Both specimens show indeterminate (upper) and determinate (lower) laterals. A. Complanate organisation in C. scalaris. B. Radial organisation in $C$. retroflexa. Scale bar $=20 \mathrm{~mm}$.

\subsection{Conclusion}

Four species of Cystophora are present in New Zealand. These can be diagnosed with molecular and morphological characters. These species can be separated by the form and arrangement of receptacles (Table 5.2).

Table 5.2. Key to the New Zealand species of Cystophora

1. Branching from the edge of the main axes, receptacles leaf-like..........platylobium

1. Branching from the face of the axes, receptacles terete or flattened..... 2

2. Receptacles swollen, smooth, terete with rounded apex, densely clustered on laterals; lower intertidal or shallow sub-tidal. C. torulosa

2. Receptacles elongate, slightly to strongly flattened, apex blunt, pointed or with sterile awn, densely to openly clustered on laterals, sub-tidal....................... 3 
3. Receptacles and ramuli arranged radially, usually narrow with long terminal awn

C. retroflexa

3. Receptacles and ramuli distichous, forming complanate lateral branches;

Receptacles slightly to strongly flattened, with blunt to acute tips.

C. scalaris

\subsection{Acknowledgements}

I thank the New Zealand Department of Conservation and Education NZ Study

Abroad Scheme for funding assistance; Wendy Nelson, Tracy Farr, Kate Neill and the

Department of Conservation Chatham Islands staff for assistance with collections and Alan Millar (National Herbarium of New South Wales) and Jenn Dalen (Museum of

New Zealand Te Papa Tongarewa herbarium) for assistance with herbaria access.

\subsection{References}

ADAms, N. M. (1994). Seaweeds of New Zealand: An illustrated guide. Christchurch, New Zealand: Canterbury University Press.

AgArdh, J. G . (1848). Species, Genera et Ordines Algarum. Vol. 1. Lund, Sweden: C. W. K. Gleerup.

AgARDH, J. G. (1870). Om Chatham-öarnes Alger. Öfversigt af Kongl. Vetenskaps-Academiens Förhandlingar, Stockholm, 5, 435-456.

Clement, M., PosAdA, D. \& CRANDAll, K. A. (2000). TCS: a computer program to estimate gene genealogies. Molecular Ecology, 9, 1657-1659.

De Toni, G. B. (1895). Sylloge algarum omnium hucusque cognitarum. Vol. III. Fucoideae. Padua, Italy: Sumptibus auctoris.

GARDNER, N. L. (1913). New Fucaceae. University of California Publications in Botany, 4, 317-374.

Hotrau, G., Coyer, J. A., Veldsink, J. H., Stam, W. T. \& Olsen, J. L. (2007). Glacial refugia and recolonization pathways in the brown seaweed Fucus serratus. Molecular Ecology, 16, 3606-3616.

KLEMM, M. F. \& HALlAM, N. D. (1987). Branching pattern and growth in Cystophora (Fucales, Phaeophyta). Phycologia, 26, 252-261.

LAING, R. M. (1899). Revised List of New Zealand Seaweeds. Transactions and Proceedings of the New Zealand Institute, 32, 57-40, plates V-VIII.

LAING, R. M. (1926). A reference list of New Zealand Marine Algae. Transactions of the New Zealand Institute, 57, 126-185.

Lanjouw, J., BAehni, C., Robyns, W., Ross, R., Rousseau, J., Schopf, J. M., Schulze, G. M., SMith, A. C., VILMORIN, R. DE \& STAFLEU, F. A. (1961). International code of botanical nomenclature, adopted by the ninth International Botanical Congress, Montreal, August 1959. Regnum Vegetabile, 23.

LindAUER, V. W. (1947). An annotated list of the brown seaweeds, Phaeophyceae, of New Zealand. Transactions of the Royal Society of New Zealand, 76, 542-566.

Lindauer, V. W., Chapman, V. J. \& Aiken, M. (1961). The Marine Algae of New Zealand II: Phaeophyceae. Nova Hedwigia, 3, 129-350.

MCDERmotT, C. J. \& Shima, J. S. (2006). Ontogenetic shifts in microhabitat preference of the temperate reef fish Forsterygion lapillum: implications for population limitation. Marine Ecology Progress Series, 320, 259-266. 
Morton J. E. \& Miller M. C. (1968). The New Zealand Sea Shore. London-Auckland: Collins.

Nelson, W. A., Adams, N. M. \& Fox, J. M. (1992). Marine Algae of the Northern South Island. A list of species. National Museum of New Zealand Miscellaneous Series No. 26. 1-79.

Nelson, W. A., AdAms, N. M. \& HAY, C. H. (1991). Marine Algae of the Chatham Islands. National Museum of New Zealand Miscellaneous Series No. 23. 1-58.

SCHIEL, D. R. (1990). Macroalgal assemblages in New Zealand: structure, interactions and demography. Hydrobiologia, 192, 59-76.

SHEARS, N. T. \& BABCOCK, R. C. (2007). Quantitative description of New Zealand's shallow sub-tidal reef communities. (Science for Conservation 280). Wellington, New Zealand: New Zealand Department of Conservation.

SONDER, O. G. (1846). Algae L. Agardh. In: Plantae Preissianae sive enumeratio plantarum quas in Australasia occidentali et meridionali-occidentali annis 1838-1841 collegit Ludovicus Preiss. (Lehmann, C. Eds.), 2, 148-160. Hamburgi [Hamburg]: sumptibus Meissneri.

TAYLOR, R. B. \& COLE, R. G. (1994). Mobile epifauna on subtidal brown seaweeds in northeastern New Zealand. Marine Ecology Progress Series, 115, 271-282.

WOMERSELY, H. B. S. (1964). The morphology and taxonomy of Cystophora and related genera (Phaeophyta). Australian Journal of Botany, 12, 53-110.

Womersley, H. B. S. (1987). The marine benthic flora of southern Australia. Part II. Adelaide, Asutralia: South Australian Government Printing Division.

ZUCCARELlO, G. C. \& LOKHORST, G. M. (2005). Molecular phylogeny of the genus Tribonema (Xanthophyceae) using $r b c \mathrm{~L}$ gene sequence data: monophyly of morphologically simple algal species. Phycologia, 44, 384-392. 


\section{Chapter 6}

Species delimitation in brown algae - insights and applications to New Zealand brown algae. 


\section{1 Abstract}

Species delimitation in brown algae has traditionally proceeded by inferring genetic discontinuities from morphological characters, with additional data from culturing, crossing experiments, and studies of natural hybridisation. The development of molecular methods has provided an additional source of data, but few studies have proceeded to a phylogenetic concept of species. Rather, taxonomists have delimited species using a subjective assessment of available data. I review approaches to species delimitation in brown algae with reference to findings from previous chapters. Recent phylogeographic studies have produced a complex picture of species' history, with extensive changes in distribution, isolation and secondary contact, and a variety of speciation scenarios. I argue that this complexity means no single approach can delimit all species. Rather, an explicitly historical species concept is needed, with the history of species included in species descriptions.

\subsection{Introduction}

THE PREVIOUS CHAPTERS have investigated genetic diversity of Carpophyllum and Cystophora at different scales. Characterising genetic diversity is an essential task for biologists seeking to understand evolution, and different approaches have emerged to deal with the multiple scales of diversity. Phylogeneticists focus on historical relationships between species. Taxonomists use various data to infer discontinuities in genetic variation in order to delimit and describe species. Population geneticists study allele frequencies within and between populations. This thesis began with a detailed mitochondrial DNA phylogeography of $C$. maschalocarpum (Chapter 2), then an investigation into the relationship between two species of Carpophyllum (Chapter 3). I produced a broad phylogeny of Cystophora (Chapter 4), and dealt with the taxonomic separation of two pairs of species (Chapter 5). Here I review this work with reference to approaches to species delimitation in brown algae. 


\subsection{Species delimitation}

Species are basic units of ecological studies and biodiversity assessments, and are a fundamental point of reference for nearly all biological science. Despite this, consistent delimitation of species continues to be problematic and sometimes contentious (Dayrat 2005, Will et al. 2005, De Queiroz 2007). The availability of genetic data and dissatisfaction with traditional methods (Tautz et al. 2003, Godfray et al. 2007) has prompted several attempts at developing objective methods of species delimitation (Sites \& Marshall 2004, Shaffer \& Thomson 2007, Pons et al. 2009, Wiens 2007). These include phylogenetic (tree-based) methods (Brower 1999, Templeton 2001, Wiens \& Penkrot 2002) and population genetic methods, either estimating gene flow (Porter 1990) or genetic distance between populations (Good \& Wake 1992, Highton 1990, 1995). Other approaches include DNA barcoding (Hebert et al. 2003a, Hebert \& Gregory 2005) or deviation from expectations of a coalescence model (Pons et al. 2006).

How to delineate species is the central task of taxonomy. A second task, providing tools (names, descriptions, keys) for accurate species identification, is dependent on accurate species delineation. As the purpose of taxonomy changed from classification - the convenient ordering of life to meet the needs of biologists - to an attempt to explain biological reality, the focus has changed from phenetics to phylogenetics. Most taxonomists now accept a phylogenetic approach (Quicke 1993, Dayrat 2005). This theoretical position has been reinforced by the availability of molecular data that is easily analysed by phylogenetic methods. Taxonomy has become a study of history, specifically, the history of speciation. Reading history directly is difficult for most taxonomists, but is especially difficult for phycologists dealing with brown algae as the fossil record of brown algae is negligible (Silberfield et al. 2010), and well-preserved specimens amenable to ancient DNA work are almost unknown ${ }^{8}$. Therefore the history of speciation in brown algae must be inferred from extant data. Molecular data from brown algae has revealed hybridisation, cryptic speciation, intra-specific variation and incongruities between morphological and molecular data, increasing the complexity of defining species boundaries. An additional problem is applying

\footnotetext{
${ }^{8}$ Dillehay et al. (2008) recovered well preserved 14 000-year-old fragments of seaweed from archaeological sites in South America so the possibility of ancient DNA work exists.
} 
nomenclatural rules, which have a typological basis, to species delineated using molecular methods (Dayrat 2005). In the brown algae, species boundaries have often been described or suggested from molecular data, but authors have refrained from making appropriate nomenclatural changes.

Like other organisms, brown algal species have traditionally been delimited using morphological characters. Cryptic speciation, morphological plasticity, and complex life histories have often confounded morphological prescriptions, which have not always been congruent with other sources of information (e.g., molecular data, culturing, and natural and artificial crossing experiments). In addition, theoretical progress in formulating species concepts and methods of species delimitation has produced a more complex picture of species (Hey 2006, De Queiroz 2007, Mallet 2008). These approaches are discussed below.

\subsection{Morphological approaches}

Morphological approaches have been the mainstay of brown algal taxonomy (e.g., Agardh 1848, De Toni 1895, Setchell \& Gardner 1925, Abbott \& Hollenberg 1976, Fletcher 1987, Womersley 1987), and species delimitation using morphological characters has often been robust, despite rearrangements of higher taxonomic groups. Problems of morphological approaches often invoked (e.g., McDevit \& Saunders 2009) include a limited number of characters, plasticity (Burrows \& Lodge 1951, Mathieson et al. 1981, Henkel et al. 2007, Demes et al. 2009) and convergence (Harvey \& Goff 2006, Jones et al. 2010, Tronholm et al. 2010a). Despite this, morphological characters continue to be given considerable weight, although very recent studies have prioritised molecular data (Macaya \& Zuccarello 2010, Fraser et al. 2010b). Morphological methods are generally descriptive, although numerical taxonomic methods have been used in the brown algae (Russell \& Fletcher 1975, Rice \& Chapman 1985, Pérez-Ruzafa et al. 1993), but have largely been superseded by molecular data, with morphological characters mapped onto trees (e.g., De Clerck et al. 2006, Silberfield et al. 2010). Morphometric methods have also been used (e.g., Widdowson 1971, Rice 1989). Morphometrics are useful when used to determine diagnostic characters in 
conjunction with molecular markers or culturing (Kraan et al. 2001, Roberson \& Coyer 2004, Tronholm et al. 2010a).

In some genera, morphological plasticity has led to a plethora of synonyms and sub-species names. For example, there are 1046 names for species and varieties of Fucus and 869 names for Sargassum in Algaebase (Guiry \& Guiry 2011). In Cystophora, morphological methods have resulted in oversplitting of some species and I have synonymised $C$. scalaris/C. distenta and $C$. retroflexa/congesta. Oversplitting probably results from limited sampling and a typological approach, which fail to capture a continuum of morphological variation. A priori concepts of species might result in conscious or unconscious collection bias for "typical" or "healthy" specimens, reinforcing selective sampling.

\subsection{Culture experiments}

Heteromorphic life histories and environmental plasticity complicates morphological studies. Culture studies can overcome some of these difficulties. Culture experiments have been used to test morphological characters. This is especially informative in species with heteromorphic life histories (e.g., Wynne 1969, Clayton 1976, 1978, Kogame 1996, 1997a, 1997b, Kogame \& Yamagishi 1997) and multiple pathways in morphological development.

\subsection{Crossing experiments and reproductive isolation}

Complete reproductive isolation is often viewed as the ultimate step in speciation and the most fundamental test of species delimitation. Reproductive isolation can be tested directly, at least in species that are amenable to growth in culture, but is often inferred from morphological or phylogenetic data.

The Biological Species Concept (BSC, Mayr 1942, 1996) bases species delimitation on reproductive isolation, although most proponents allow some level of hybridization or gene flow (O’Brien \& Mayr 1991, Coyne \& Orr 2004). The BSC has a compelling logic, but becomes problematic where hybridization is 
widespread $^{9}$, such as in Fucus and Carpophyllum, and can be ahistorical (Velasco 2008). Reproductive isolation is usually inferred, generally from morphological discontinuities, and often with subjective values placed on different characters by taxonomists (Mayr 1996). Reproductive isolation can be tested directly using crossing experiments.

Crossing experiments have been used fairly extensively in a few genera of brown algae, especially Ectocarpus and some Laminariales. Often there has been a reluctance to formally apply results of crossing experiments to name new species or synonymise existing species, even where reproductive compatibility or isolation is clearly shown. For example, Müller (1988) declined to separate Chilean and Mediterranean isolates of Ectocarpus siliculosus, even after crosses showed hybrid sporophytes could not reproduce sexually and therefore could be considered separate species under the Biological Species Concept. In spite of supporting information (differences in development and morphology), Müller declined to separate these species "for practical reasons," apparently because morphological diagnosis would be demanding. Conversely, Lewis et al. (1986) and Lewis \& Neushul (1994) produced viable and fertile sporophytes from crosses of geographically separated Macrocystis specimens, then considered as separate species. However the authors considered that these should be maintained as separate species on the basis of morphological differences. In these cases the morphological species concept appears to have been given priority.

The complexity of crossing data was shown in Alaria (Kraan \& Guiry 1998, 2000, Kraan et al. 2001), where crosses between some isolates of the same morphologically-determined species show limited viability, whereas distinct species can be fully interfertile. This is congruent with molecular data which shows greater genetic variation within $A$. esculenta compared to variation between other recognised Alaria species. Kraan \& Guiry (2000) reject the morphological and biological species concepts for Alaria, and consider only a phylogenetic species concept is appropriate, but refrained from splitting reproductively isolated lineages into species.

\footnotetext{
${ }^{9}$ O'Brien \& Mayr (1991) accept hybridisation between biological species, as long as this does not "disintegrate the genetic integrity of the species". It is not clear what this means for closely related species where gene flow from hybridisation is difficult to distinguish from incomplete lineage sorting.
} 
Druehl et al. (2005) addressed some of the technical difficulties in conducting crossing experiments. Development of sporophytes in negative controls showed several Laminarean species are able to reproduce asexually via parthenogenesis or apogamy. Five species combinations produced putative hybrids in culture, but biparental inheritance of ITS DNA was confirmed in only one combination, raising doubt that progeny are hybrids. Druehl et al. (2005) recommend using molecular data (e.g., Coyer et al. 2002) to test hybrid status of cultured specimens. Parthenogenesis has also been reported in Ectocarpales (Bothwell et al. 2010), Chordariales (Peters 1987) and Fucales (Clayton et al. 1998) and might be common in brown algae. In addition to these problems, crossing experiments are limited to species that are amenable to growth in culture. My attempts to grow Carpophyllum in culture failed, and this difficulty has been reported by other workers (Dromgoole 1973, D. Schiel pers. comm.). This precludes performing artificial crosses, and investigating the fertility of hybrids. Carpophyllum hybrids form receptacles and zygotes, but their subsequent viability is unknown. One approach to these difficulties, and to determine whether potential for interspecific fertility demonstrated in culture is realised in nature, is to study natural hybrids.

\subsection{Hybridisation as natural crossing experiments}

Hybridisation appears to be fairly common in brown algae (Lewis 1996), and hybridisation can be regarded as a natural crossing experiment (Hewitt 1988), with assessments of the fitness and fertility of hybrids pertinent to the understanding of species limits (Arnold \& Hodges 1995, Riesberg 1995).

Several problems arise in determining the prevalence of hybridisation and the importance of hybridisation to species boundaries. First, there are technical issues with identifying hybrids. Morphological intermediacy does not necessarily identify hybrids (Wilson 1992, Riesberg 1995) and Coyer et al. (2006b) showed morphologically similar salt marsh forms of Fucus could be interspecific hybrids or polyploid $F$. vesiculosus. A response to this problem is to identify hybrids by molecular markers, but Lane \& Saunders (2005) showed that the presence of cryptic, epiphytic, gametophyte stages of Laminarialean species on sporophytes of related species could contaminate DNA samples, mimicking the signature of 
hybrids. Wallace et al. (2004) identified Fucus hybrids by microsatellite admixture, but Engel et al. (2005) suggested this inference was confounded by inadequate characterisation of genetic variation in parent populations.

Secondly, hybridisation might be a consequence of taxonomic inflation rather than biologically reality, where progeny of oversplit species are considered hybrids. Macrocystis species were considered to produce hybrids in culture (Lewis et al. 1986, Lewis \& Neushul 1994), but recent studies have synonymised species (Westermeier et al. 2007, Demes et al. 2009) and all forms of Macrocystis are now considered conspecific (Macaya \& Zuccarello 2010).

Lastly, population genetic studies of hybrids are usually limited to one or a few populations (e.g., Wallace et al. 2004, Coyer et al. 2006b, 2006c, 2007). Different population of hybrids with the same parent species might be under different selective regimes and have different evolutionary trajectories (Butlin et al. 2008). Local hybrid zones might not be representative of patterns of hybridisation across species' ranges.

In vitro hybridisation has been widely reported in Laminariales (Liptack \& Druehl 2000, Kraan \& Guiry 2000), but natural hybrids might be rare (Druehl et al. 2005), although an extensive molecular survey of North Pacific Alaria species found evidence for widespread hybridisation (Lane et al. 2007). In this study there was no congruity between cox 1 clusters and morphology and no thresholds in genetic distance between groups. ITS sequences had many polymorphic sites and showed a continuum of variation rather than clustering as species level groups. Lane et al. (2007) suggest extensive hybridisation occurred after secondary contact between previously allopatric species, and ITS data indicates recombination following a breakdown of species barriers.

Extensive hybridisation raises the question of how species are maintained. In Fucus, where hybridisation is best studied (Scott \& Hardy 1994, Coyer et al. 2002, Wallace et al. 2004, Billard et al. 2005, Coyer et al. 2006b, 2006c, Mathieson et al. 2006, Coyer et al. 2007, 2010), selfing acts to restrict introgression in some hermaphrodite species (Engel et al. 2005, Perrin et al. 2007). Selfing is correlated with height in the intertidal, with the inference that species in the upper intertidal have longer periods of emersion, and less time to disperse gametes, and gametes will often be lost from stands, and selfing is advantageous 
under these conditions. Selection against hybrids should reinforce evolution of selfing or of mating barriers.

It is not clear how often species are lost through hybridization. This is unlikely to be obvious in the fossil record, even of species that leave good fossils, such as vertebrates or foraminiferans, as fusion of species may be difficult to distinguish from extinction of one lineage. In a changing environment (climate change, tectonics) a degree of allopatric divergence followed by secondary contact and fusion might be common (Butlin et al. 2008). Major changes in species ranges (Hoarau et al. 2007, Maggs et al. 2008, Fraser et al. 2009b) and demography (Graham et al. 2010) suggest a highly dynamic history of species distributions over the last 20000 years. This in turn suggests a dynamic pattern of allopatry and sympatry (Coyer et al. 2010), where lineages might often diverge for a period, before reticulating following secondary contact.

In Carpophyllum hybridisation appears to be following different patterns in different areas. In Northland there is evidence for hybridisation between $C$. angustifolium and C. maschalocarpum that confounds phylogenetic methods. In the Bay of Plenty C. angustifolium and C. maschalocarpum lineages are distinguishable with nuclear markers, but $C$. maschalocarpum mitochondrial markers appear to have introgressed into populations of $C$. angustifolium. In Carpophyllum, all species are dioecious and sub-tidal. Strong selection might be responsible for the persistence of separate morphological species in areas of sympatry. In particular, C. angustifolium might be adapted for high wave exposure, with a strong terete stipe and a low drag morphology (Hodge 2009). I hypothesise that periodic extreme weather events would remove hybrids and $C$. maschalocarpum from exposed habitats, maintaining species boundaries. Further experimental work to determine the impacts of wave exposure (Thomsen \& Wernberg 2005) on this system would be valuable. Hybrids between $C$. maschalocarpum and C. flexuosum, and between C. maschalocarpum and $C$. plumosum, have been reported (Dromgoole 1973, Lindauer et al. 1961) but seem more localised or morphologically cryptic than the widespread hybridisation found between C. maschalocarpum and C. angustifolium.

In Cystophora most species are hermaphrodite, and hybrids should be rare. Further investigation of the sister species $C$. retorta (hermaphrodite) and $C$. 
siliquosa (dioecious) might show similar patterns of hybridisation and introgression to those found in Fucus. Cystophora subfarcinata and C. retroflexa are morphologically similar, often sympatric and both species are morphologically plastic. This might hide hybridisation between these species and further investigation might also reveal past or current hybridisation. Two specimens resembling $C$. scalaris were found north of the usual range of this species, one from Wilson Bay, Coromandel, the other from Ahuriri Street, Napier. Mitochondrial DNA sequences from these specimens grouped with C. torulosa and $C$. retroflexa (data not shown). Further data might confirm that these are $C$. torulosa $\times$ C. retroflexa hybrids.

Generally, the high frequency of natural hybridisation and absence of reproductive isolation in recognised species suggests reproductive isolation occurs at a late stage of speciation in brown algae, and is often preceded by ecological and morphological differentiation.

\subsection{Molecular data}

Early molecular studies focussed on characterising classes among the heterokontophyta (Bhattacharya et al. 1992, Daugbjerg \& Andersen 1997a, b), or resolving ordinal or familial level phylogenetic relationships within the Phaeophyceae (Tan \& Druehl 1993, 1994, Saunders \& Druehl 1992, 1993, Rousseau et al. 1997, Peters \& Clayton 1998, Siemer et al. 1998, Boo et al. 1999, Rousseau \& de Reviers 1999a, 1999b, Serrão et al. 1999, Kawai \& Sasaki 2000, Rousseau et al. 2000). Intra-familial relationships were investigated in Ectocarpus and Kukuckia (Stache-Crain et al. 1997), and Laminariocolax (Burhardt \& Peters 1998), Pelvetia and Pelvetiopsis (Lee et al. 1998, 1999), and Undaria (Yoon \& Boo 1999). This early work was reviewed by Druehl \& Saunders (1992) and de Reviers \& Rousseau (1999). It resulted in substantial reorganisation of the orders and families within the Phaeophyceae.

Phylogenetic resolution of the brown algal lineage has increased dramatically over the last decade. Taxon representation has increased considerably (Kawai et al. 2001, Rousseau et al. 2001, Draisma et al. 2002, Lee \& Bae 2002, Cho et al. 2006, De Clerck et al. 2006), as have the number of molecular markers used (Kim et al. 2002, 2003, Cho et al. 2004, Lane et al. 2006, 
Phillips et al. 2008, Kogishi et al. 2010). Recent studies have combined markers from nuclear, mitochondrial and chloroplast genomes (Bittner et al. 2008, Fraser et al. 2010b, Tronholm et al. 2010b, Silberfield et al. 2010).

A second focus of molecular studies has been resolving the systematic position of "difficult" or anomalous species, including Notheia anomala (Saunders \& Kraft 1995), Myagropsis myagroides (Horiguchi \& Yoshida 1998), Halosiphon tomentosus (Peters 1998), Laminarionema elsbetiae (Peters \& Burkhardt 1998), Desmarestia chordalis (Peters et al. 2000), Caepidium antarcticum (Peters \& Ramírez 2001), Microzonia velutina (Burrowes et al. 2003), Stschapovia flagellaris (Kawai \& Sasaki 2004), Phaeostrophion irregulare (Kawai et al. 2005), Petrospongium rugosum (Cho \& Boo 2006), Discosporangium mesartrocarpum (Kawai et al. 2007), and Herpodiscus durvillaeae (Heesch et al. 2008).

While not aimed at species differentiation, this phylogenetic work did offer relevant insights. In the Scytosiphonaceae, Kogame et al. (1999) found molecular differentiation was better correlated with the morphology of the sporophyte microthallus than with the morphology of the upright stage, which appears to be more morphologically plastic. Low variation in markers was shown in ITS sequences from Desmarestia (van Oppen et al. 1993), Fucus (Leclerc et al. 1998) and Sargassum (Stiger et al. 2000) and in mitochondrial markers (Coyer et al. 2006a); this suggests these markers are conserved or speciation is recent. The notion that morphological complexity is only associated with the most derived groups of brown algae was finally dispensed with (Rousseau \& de Reviers 1999a, Draisma et al. 2001, Phillips et al. 2008).

Numerous studies have proposed new species supported by phylogenetic data, including Asterocladon lobatum (Müller et al. 1998), Sargassum boreale (Yoshida et al. 2000), Chorda rigida (Kawai et al. 2001), Neoleptonema yongpilii (Lee et al. 2002), Newhousia imbricata (Kraft et al. 2004), Asterocladon interjectum (Uwai et al. 2005), Cladosiphon umezakii (Ajisaka et al. 2007), Aureophycus aleuticus (Kawai et al. 2008), Fucus radicans (Bergström et al. 2005), Dictyota cyanoloma and D. cymatophila (Tronholm et al. 2010a, 2010b), and four Padina species (Ni-Ni-Win et al. 2010). Particularly revealing of the power of molecular techniques is the reinstatement of Ectocarpus crouaniorum, a third European species in this well-studied genus (Peters et al. 2010). In most 
cases, phylogenetic data was used in support of morphological diagnoses, and to place new species in higher taxonomic groups. Recently, Tronholm et al. (2010a) separated the "pseudo-cryptic" Dictyota cymatophila from D. dichotoma, primarily by phylogenetic data. Phenological and morphometric data also separated species, but showed some overlap, and it is unlikely two species would have been diagnosed without phylogenetic data.

In the last decade an increasing number of studies have addressed the phylogeography of single species or closely related species over all or most of their range (Coyer et al. 2003, Cho et al. 2005, Harvey \& Goff 2006, Hoarau et al. 2007, Lane et al. 2007, Fraser et al. 2009a, 2009b, 2009c, Pereyra et al. 2009, Tellier et al. 2009, Uwai et al. 2009, Coyer et al. 2010, Peters et al. 2010, Fraser et al. 2010, Kogishi et al. 2010, Neiva et al. 2010, Olsen et al. 2010, Cheang et al. 2010a, 2010b). These studies have sufficient detail to explore the history of species themselves (rather than a broad history of relationships between species). In many cases (e.g., Tellier et al. 2009, Coyer et al. 2010), multiple lineages have been found within current species, and some authors have proposed splitting species (Fraser et al. 2010b, Martin \& Zuccarello in preparation).

These data should allow species delimitation to proceed from a morphological concept of species to a phylogenetic concept. In general this hasn't happened, as there has been a separation of phylogenetic analyses and taxonomic treatment of species. For example, Stache-Crain et al. (1997), in an early phylogenetic study that included worldwide sampling, found Ectocarpus siliculosus formed several clades which they suggested might have species status, but declined to create new species due to lack of morphological differentiation. Cho et al. (2005) found two species of Colpomenia peregrina, separated by phylogeographic and ecological data, and Cho et al. (2007) found phylogenetic evidence for two species of Scytosiphon lomentaria, but neither study established new species. Only a few authors have explicitly addressed phylogenetic species concepts. Harvey \& Goff (2006) rejected the morphological species concept as misleading in the case of Halidrys and Cystoseira species from the Pacific Coast of North America, showing Pacific species had a common origin, separate from Atlantic members of these genera. Pacific species had independently converged to morphologies similar to Atlantic species. These morphologies were diverse, despite low genetic variation between Pacific species. The authors concluded that 
revision using a phylogenetic species concept was needed. Fraser et al. (2009a) applied a phylogenetic species concept to Durvillaea antarctica and suggested that a morphologically variant form (the 'cape' morphology, where the thallus forms a broad sheet, rather than dividing into thongs) can be separated by morphological and molecular data and should be regarded as a separate species. This highlights the problems with incipient species. The 'cape' form forms a monophyletic group in cox 1 trees, but this renders $D$. antarctica polyphyletic, as the 'thong form' Chilean lineage is sister to the "cape" clade, while the New Zealand and southern ocean lineage is derived (Fraser et al. 2009b). There is no evidence for morphological separation of the Chilean and New Zealand clades, but a pure phylogenetic species concept would support this (Fraser et al. 2010b). Either several lineages must be separated solely on the basis of molecular data or D. antarctica should be regarded as a meta-species (sensu de Queiroz \& Donoghue 1988), encompassing several distinct mitochondrial lineages but without ascribing species status to these lineages. Conversely, D. chathamensis is morphologically distinct from the allopatric $D$. antarctica lineage, but is not differentiated by most markers (only by $r b c$ L, Fraser et al. 2010b). In these examples, the phylogenetic species concept has been invoked to support suggestions for species delimitation, and in support of other data, but no author has split species of brown algae under a purely phylogenetic species concept, although this has been done with green algae (Leliaert et al. 2009) and microalgae (Lilly et al. 2007, Coffroth \& Santos 2005). Instead, phycologists have delimited species by considering the weight of available evidence. Recently, phylogenetic data has been given greater weight, with the synonymisation of some morphologically variable species (Macaya \& Zuccarello 2010).

In part, the reluctance to apply a pure phylogenetic species concept relates to the difficulty in assigning hierarchical levels to phylogenetic lineages and the increasing power of molecular data to diagnose lineage differentiation (Avise \& Wollenberg 2007). Phylogenies are limited in being based on a small sample of genetic information from a small sample of specimens, and generally produce coarse-scale lineages showing simplified relationships between species. Complex histories, with lineages within species lineages, as well as reticulation, raise a major question for taxonomic work: to what degree are speciation processes active within most lineages? At one extreme, lineages might undergo brief periods 
of speciation, separated by long periods of stasis (with cohesive, well differentiated species), at the other extreme, lineages might be continually subdividing, with morphological differentiation, reproductive isolation and other properties exhibiting themselves at different levels throughout a lineages history.

Recent studies in North Atlantic Fucus species demonstrate the difficulty of applying methods of species delimitation that assume simple speciation histories and test properties of species that are confounded by hybridisation and intraspecific morphological variation (Coyer et al. 2006a). Over 125 intraspecific taxa have been described in Fucus (Coyer et al. 2010), based on morphology. Various numbers of species can be recognised, depending on the degree of lineage separation and which property of a species-lineage is tested for (De Queiroz 2007). Phylogenetic approaches using ITS (Serrão et al. 1999) and mitochondrial markers (Coyer et al. 2006a) discerned two major clades, one containing $F$. vesiculosus, $F$. spiralis, $F$. radicans, $F$. ceranoides and $F$. virsoides, but were unable to separate these species. Cluster analyses using microsatellites separated $F$. vesiculosus from $F$. spiralis (Engel et al. 2005) and also separated $F$. ceranoides (Billard et al. 2005). Bergström et al. (2005) delimited a third species Fucus radicans, which is estimated to have diverged from $F$. vesiculosus as little as 400 years ago (Pereyra et al. 2009), driven by adaption to a low salinity habitat (the Baltic Sea), and this delimitation is supported by functional divergence in heat shock response (Lago-Lestón et al. 2010). Billard et al. (2010) then divided F. spiralis into two clusters, spatially segregated into a high shore and low shore varieties. Despite ecological, molecular and morphological differences, they did not interpret these as species, partly because there is less differentiation between the forms than between $F$. spiralis and F. vesiculosus. Most recently, Coyer et al. (2010) found that the southern part of the $F$. spiralis range forms a third cluster. This southern cluster hybridised with $F$. vesiculosus at some point in the past, producing the low shore cluster. Also, while a nuclear marker shows reciprocal monophyly between $F$. ceranoides and $F$. vesiculosus, the entire northern range of $F$. ceranoides is introgressed by mitochondrial DNA from $F$. vesiculosus (Neiva et al. 2010). Coyer et al. (2010) propose a "sliding window" concept of speciation for Fucus, where different species are delineated within a continuum of species separation. 
These studies, and in-depth sampling of other species (Lane et al. 2007, Olsen et al. 2010) show and increasing ability to infer more detailed histories of species, and make the application of an informed historical species concept plausible in brown algae.

\subsection{Species delimitation in Carpophyllum}

Four species are currently recognised in Carpophyllum (Adams 1994, Lindauer et al. 1961), and my molecular data support continued recognition of these species. All species are morphologically and ecologically distinct, but genetic distances between markers are low. C. maschalocarpum and C. angustifolium can be separated by mitochondrial spacer data (Chapter 2) but with some reservations: (1) there is evidence for mitochondrial introgression in some populations (Chapter 3); (2) genetic distances within species are greater than distance between species; and (3) one cluster, associated with specimens from North Cape and Wekarua, is not clearly associated with either species (Chapter 2). Some genetic data was collected on Carpophyllum plumosum and C. flexuosum but was not included in the previous chapters. These data support the continued recognition of these species. For example I found unique ITS2 sequences for $C$. plumosum and $C$. flexuosum (but only one mutational step removed from each other and from $C$. maschalocarpum/C. angustifolium sequences), and mitochondrial spacer sequences that are genetically distant from other species.

The phylogenetic relationship between species is not completely clear. Markers such as ITS and $r b c$ LS spacer show low variation $(r b c$ LS spacer sequences are identical in C. maschalocarpum and C. angustifolium, with three changes separating these from $C$. flexuosum and six changes separating these from C. plumosum). Carpophyllum angustifolium and C. maschalocarpum are sister species according to all markers tested (the above and $r b c \mathrm{~L}, \operatorname{cox} 3, \operatorname{rps} 14-a t p 8$ ), and $C$. plumosum appears to be the earliest branching species. The history of Carpophyllum species is only partly elucidated by these data. Significant changes in the distribution of $C$. maschalocarpum appear to have taken place since the LGM, especially the colonisation of the southern North Island and South Island. The centre of genetic diversity of $C$. angustifolium appears to be Northland, but data are limited, whereas $C$. maschalocarpum is most genetically diverse in the 
Bay of Plenty. Possibly these lineages separated in allopatry during periods of high sea level during the Pliocene (when the northern North Island was separated into islands), and are now hybridising following secondary contact. An alternative explanation is sympatric speciation from a common ancestor driven by strong selective pressure for different habitats, with $C$. angustifolium occupying exposed areas, C. flexuosum sheltered areas and C. maschalocarpum occupying intermediate environments. Further molecular data is needed to complete this picture, especially from C. angustifolium, as is ecophysiological data.

\subsection{Species delimitation in Cystophora}

Cystophora species have been delimited on the basis of morphological data. In New Zealand species I consider that some species have been over-split and I synonymise two pairs of names. I also suspect the Australian species $C$. cuspidata should be synonymised with $C$. subfarcinata, but sampling is inadequate to establish this. I was unable to find C. cymodocea, despite an extensive search of the type locality (Duttons Beach, Portland, Victoria) and suspect this is a distended form of $C$. retroflexa growing epiphytically. In all these cases, oversplitting, or potential oversplitting, appears to have arisen from limited characterisation of the range of morphological expression in species. Further molecular work can address some of these questions, and more work is needed, especially to to clarify species boundaries in Australian species, and to further understand the history of the evolution and dispersal of Cystophora species.

\subsection{Dispersal and history}

Dispersal ability is expected to correlate strongly with gene flow, and be a major factor in algal speciation. Species with limited dispersal potential, with immotile gametes and/or negatively-buoyant thalli, should show limited gene flow between populations, and stronger signatures of genetic structure and founder effects (van den Hoek 1987). Genetic structure is strong in many species of brown algae (Chapter 2, Williams \& DiFiori 1996, Kusmo \& Druehl 2000, Cho et al. 2005, 2007, Hoarau et al. 2007, Fraser et al. 2009b, Cheang et al. 2010), but the relationship between genetic structure and dispersal is complex. Carpophyllum 
maschalocarpum has positively buoyant thalli and is frequently found in drift. Some well separated populations - such as mainland New Zealand and the Chatham Islands, share mitochondrial haplotypes, whereas other relatively close populations are apparently isolated (Chapter 2). In Cystophora torulosa, $C$. platylobium and C. retroflexa, cox 1 haplotypes and ITS ribotypes are shared between New Zealand and Australia, as were haplotypes of a rapidly evolving mitochondrial spacer in $C$. retroflexa, suggesting multiple trans-Tasman dispersal (Chapter 4). In Macrocystis pyrifera-a species that has been shown to remain fertile after extended periods afloat (Macaya et al. 2005, Hernández-Carmona et al. 2006)-Macaya \& Zuccarello (2010) found one cox1 haplotype that is distributed throughout the southern hemisphere, but several other cox 1 haplotypes were sampled in single populations only. Durvillaea is especially interesting, having large buoyant thalli that appear capable of long-distance dispersal through the southern oceans resulting in genetically homogenous populations (Fraser $e t$ al. 2009b), but has limited north-south dispersal resulting in well differentiated lineages in lower latitudes. Also curious is that one lineage of Durvillaea (the “cape form") is found from New Zealand's sub-Antarctic islands and along the eastern coasts of New Zealand's South Island, while other lineages are latitudinally restricted. The cape form has no obvious differences in dispersal potential. These buoyant species contrast with Lessonia variegata and $L$. nigrescens, species with heavy, negatively buoyant thalli, which show strong genetic differentiation between regions of New Zealand (Martin \& Zuccarello in review) and Chile (Tellier et al. 2009), respectively.

These studies suggest brown algae with buoyant thalli have increased potential for long distance transport, but also that this potential is not always realised. Partly this results from geography. Dispersal is rapid along pathways such as the southern ocean west wind drift system (Waters 2008), and perhaps along the East Auckland Current (Chapter 2, although data from other species is needed to confirm this), but might be restricted elsewhere (Fraser et al. 2009b, 2010b, Chapter 2). But biological interactions such as density blocking (suggested by Fraser et al. 2009b, 2010b) might be important. Several areas remain to be addressed. One is the pathways taken by drifting algae. Data from Carpophyllum suggest relatively high gene flow between the Chatham Islands and the North Island. Data from drift devices show current transport between the mainland and 
the Chatham Islands requires 30 to 50 days (Chiswell 2009), but windblown floating material might travel considerably faster, especially during extreme weather events, for example, material from a boat wrecked in Cook Strait has been recorded arriving at the Chatham Islands three weeks later (Young 1929). Direct measurements of seaweed transport rates (Harrold \& Lisina 1989, Hawes 2008) should elucidate drift rates.

Several lines of evidence suggest Cystophora evolved in Australia and species dispersed to New Zealand relatively recently: (1) Species diversity in Cystophora is greatest in southern Australia, and the earliest diverging species $(C$. moniliformis) is endemic to southern Australia; (2) Several species are endemic to Australia, whereas only one species (C. scalaris) is endemic to New Zealand (Womersley 1964); and (3) two mitochondrial spacer haplotypes found in New Zealand specimens are shared with Australian specimens (Chapter 4). Sharing of mitochondrial spacer haplotypes suggests very recent dispersal, given the strong structuring shown in this marker in Carpophyllum. Cystophora is thus part of what Parsons (1985) termed the Australasian element of the New Zealand seaweed flora. All New Zealand species are vesiculate, whereas several Australian species (e.g., C. moniliformis, C. siliquosa, C. xiphocarpa) lack vesicles, or rarely develop vesicles (Womersley 1964). It seems likely that vesicles are associated with long distance dispersal, although several vesiculate Australian species are absent from New Zealand, despite tolerating similar temperature regimes (Adey \& Steneck 2001). Whether successful trans-Tasman dispersal is a matter of chance or if there are other ecophysiological factors involved in dispersal or establishment is not known.

\subsection{Genetic distance - molecular data without history}

Genetic distance is a straightforward method of delineating species that uses phenetic, rather than historical criteria. Various methods of delineating species using genetic distance have been proposed (Sites \& Marshall 2004), usually requiring population level data. These include comparing geographical distance with genetic distance (Good \& Wake 1992), with significant deviations from isolation-by-distance suggesting more than one species. Highton (1989) suggests testing for a significant bimodal distribution of Nei's D parameter for population 
differentiation, with a threshold suggested above which separate peaks represent multiple species. These methods have not been applied to brown algae. Both methods are essentially ahistorical, and might be confounded by strong structuring of populations, for example, the mtDNA spacer dataset for Carpophyllum maschalocarpum shows a bimodal distribution of Nei's D, this is a consequence of demographic expansion of the southern lineage, but there is no supporting evidence that this represents a speciation process. Similarly, the existence of particular dispersal pathways in C. maschalocarpum confounds the assumption of a linear relationship between geographical and genetic distance.

Using genetic distance might overcome the problem created by modern molecular data's power to diagnose extremely fine lineages, which could result in oversplitting of species under the phylogenetic species concept (Avise \& Wollenberg 1997). But, there are problems that genetic distance might not be correlated with reproductive isolation (Ferguson 2002, Gourbière \& Mallet 2009, Presgraves 2010). Speciation times appear very variable. Knowlton et al. (1993) suggested that many marine organisms had developed reproductive barriers since the closing of the Central American isthmus, c. 3 million years ago. Conversely, Fucus radicans might have attained some reproductive isolation in 400 years (Pereyra et al. 2009). In many cases, especially in higher latitudes, substantial demographic and geophysical changes (temperature, sea level changes) have occurred in the last 3 million years (Hewitt 2004, Maggs et al. 2008), creating complex patterns of isolation and contact (Coyer et al. 2010) that confound inferences based on genetic distance.

A recent development in distance methods is the emergence of DNA barcoding. Strictly, barcoding is a method of specimen identification, but the leading proponent of DNA barcoding, Paul Hebert, has described DNA barcoding as a method of species delimitation (Hebert \& Gregory 2005) and assessing the barcoding method requires assessing the ability of mitochondrial data to delimit species.

Molecular tools have long been used for species identification in brown algae. Early studies used allozymes (Benzie et al. 2000, Hull et al. 2001), RAPDs (Ho et al. 1995) or sequence data (Kogame \& Masuda 2001). Molecular identification continues to be a useful tool, especially with cryptic forms (Fox \& 
Swanson 2007), morphologically plastic (Kucera \& Saunders 2008, Endo et al. 2009) or convergent species (Camus et al. 2005, Jones et al. 2010).

DNA barcoding distinguishes species using genetic distance between phenetic clusters inferred from short (c. $600 \mathrm{bp}$ ) mitochondrial DNA sequences. DNA barcoding has a compelling simplicity: a threshold between intraspecific and interspecific genetic variation is defined (usually ten-times, Golding et al. 2009) and specimens exceeding this threshold are considered to be separate species. Species can then be identified by simple sequence comparisons against a universal database.

Barcoding requires that genetic variation in the selected gene region can be adequately characterised. Intraspecific variation requires extensive sampling to understand the genetic structure - and therefore the species history. For example, extensive global sampling of Durvillaea antarctica by Fraser et al. (2010b) showed extensive cox 1 variation that was highly geographically structured, with sufficient lineage delineation to propose a species complex. One cox 1 haplotype was extensively distributed - around most of the southern oceans. In this situation, even widespread sampling, by the standards of barcoding studies, might return a single haplotype, even if samples were drawn from eight different countries. Such a result might suggest identification of $D$. antarctica by cox 1 barcoding was straightforward, but this sampling would not enable accurate identification of further specimens from northern localities.

Similarly in Chapter 2, one mitochondrial spacer haplotype is present over a wide part of the range of Carpophyllum maschalocarpum. This marker that is probably more variable than regions used for barcoding but it illustrates the point. A collection of 10 specimens might detect only a single haplotype. With slightly wider sampling one might get two haplotypes, only two steps removed from each other and conclude that intraspecific variation is low. With more sampling one might find a third haplotype, four steps removed from the others, or even further removed if you sample one of these haplotypes which appear to have entered the C. maschalocarpum mitochondrial genome following introgressive hybridisation with $C$. angustifolium, and assume cryptic speciation was taking place. Accurate characterisation of genetic variation requires sampling from the Bay of Plenty, where most of the variation is found. 
Proponents of barcoding appeal to the speed and low cost of assembling sets of "barcodes" that can then be used as vouchers for subsequent species identification. According to proponents, barcoding will facilitate documenting as many species as possible before they go extinct (Baker et al. 2009), allow fast organisation of molecular data into putative species groups before formal description (Litaker et al. 2007, Borisenko et al. 2009), eliminate the need for the complex taxonomic training that is currently required for species description and identification (Sass et al. 2007), allow identification of incomplete specimens, (Schindel \& Miller 2005), and provide a tool for non-specialists, for example in water quality assessments (Moniz \& Kaczmarska 2009), identifying invasive species (Saunders 2009), correct identification of difficult and cryptic species (Starr et al. 2009), greater discrimination of cryptic species (Sherwood et al. 2008) and standardisation of molecular data (McDevit \& Saunders 2010). The appeal of many of these rationales is low cost, rather than scientific rigour. This might be reasonable in some applications where a number of misidentifications are acceptable, especially where error rates can be estimated and reported, but is of questionable scientific value.

Only a few studies have attempted to validate the use of cox 1 for barcoding brown algae. Lane et al. (2007) attempted a cox 1 barcoding study of Alaria species from the north-east Pacific. Genetic variation was relatively low and there was no clear threshold between inter- and intra-clade variation. In addition, clusters of cox 1 mitotypes were not congruent with a priori morphological species assignments, or with ITS clades. ITS variation was relatively high, and did not resolve species level groups. This result was interpreted as showing widespread introgression following secondary contact by species that evolved in allopatry, with introgression and ITS recombination.

Kucera \& Saunders (2008) used $\operatorname{cox} 1$ to delineate North American samples of Fucus. Mitotypes separated into three clades. Fucus serratus from Canada were well demarcated from other Fucus species but this species is a recent (1887) introduction to North America and this deme would be expected to show low variation. Fucus spiralis and F. vesiculosus were not separated, which is not surprising given the low variation and extensive hybridisation between these species. Fucus distichus and north Pacific specimens identified in the fields as $F$. spiralis were also not separated, but the authors consider $F$. spiralis in this clade 
to result from incorrect morphological assignment of specimens of $F$. distichus that has undergone morphological convergence to an $F$. spiralis form. The authors then made an a posterioi reassignment of these specimens to $F$. distichus, with hybridisation ruled out due to the absence of polymorphic sites in ITS sequences. This was not accompanied by any anatomical evidence, and it seems possible that these are $F$. spiralis with introgressed $F$. distichus mitochondria and ITS which has homogenised to a $F$. distichus-ribotype following an earlier hybridisation event. Widespread mitochondrial introgression has been reported in European $F$. serratus (Coyer et al. 2010) and F. ceranoides (Neiva et al 2010). This study was reported as demonstrating the efficacy of $\operatorname{cox} 1$ barcoding in brown algae, but it is unclear what hypothesis was being tested here, as genetic distance between clusters was low or absent, morphology and molecular delimitation was not congruent, and sampling was limited to North American demes of Fucus species which have their centre of diversity in Europe (Coyer et al. 2003, Hoarau et al. 2007, Coyer et al. 2006a, 2010).

Other studies of brown algae have shown broad variation in cox 1 sequences across orders (McDevit \& Saunders 2009), but did not address species delimitation, which requires inclusion of sister species, and addressed biogeographical structure of populations with extensive sampling (McDevit \& Saunders 2010). In general these studies have shown mean genetic distances between $\operatorname{cox} 1$ sequences of sister species of brown algae are often less than the 10X threshold proposed for barcoding animals. Presumably a high threshold is to compensate for low sampling and distance methods' limitations in capturing evolutionary processes. In Cystophora intraspecific variation was of a similar order to interspecific variation between some sister species. Recognition of these species is supported by morphology and ITS sequences, and further sampling is likely to increase intraspecific variation. An alternative to genetic distances is character based barcoding methods, where a designated number of nucleotide positions or combination of positions is used to characterise species (DeSalle 2006, Rach et al. 2008). This requires extensive sampling to ensure proposed characters are fixed (Wiens \& Servedio 2010).

Cytoplasmic introgression is an obvious problem for mitochondrial sequence based barcoding, and has been found in Fucus (Neiva et al. 2010, Coyer et al. 2010), Alaria (Lane et al. 2007) and Carpophyllum angustifolium (Chapter 
4). Comparison of cytoplasmic markers with single copy nuclear markers (Neiva et al. 2010) should show introgression, but so far these markers have not been widely available for brown algae. Future work should show whether these are unusual cases, or whether cytoplasmic introgression is widespread in the brown algae.

Two developments suggest future barcoding studies will be better integrated with other approaches. One is multi-locus barcoding (Kress et al. 2009) which allows barcoding data to be analysed using phylogenetic methods. Kress et al. (2009) also focussed on a single locality (Barro Colorado Island, Panama), where species diversity is well characterised and sampling intra-species genetic diversity should be relatively straightforward. Other barcoding studies have employed additional markers to overcome uncertainty (Lane et al. 2007, McDevit \& Saunders 2010). A second is development is more widespread sampling, allowing barcoding data to be used for mitochondrial phylogeographic studies (McDevit \& Saunders 2010). These trends might overcome the limitations of low sampling and single markers proposed in the original barcoding concept (Hebert et al. 2003a, 2003b).

\subsection{Model based methods}

Microsatellites analysis has been used to separate closely related brown algal species. Most studies use a Bayesian procedure (STRUCTURE) that simultaneously generates clusters and assigns specimens to clusters based on a model that assumes Hardy-Weinberg equilibrium and linkage equilibrium within populations (Pritchard et al. 2000). This approach has been used to separate species of Fucus (Coyer et al. 2003, Billard et al. 2005, Engel et al. 2005, Tatarenkov et al. 2007) where it has successfully discriminated species where there is low phylogenetic divergence and gene flow between species. This is useful but does not elucidate species histories, as there are difficulties in using microsatellites for phylogenetic inference (Noor et al. 2001, Buschiazzo \& Gemmell 2006).

Knowles \& Carstens (2007) suggested using coalescence to estimate the probabilities of gene trees under a particular history to evaluate the possibility of lineage splitting (i.e. speciation). This models species histories probabilistically 
rather than inferring species history from indications of reciprocal monophyly in sampled genes. A method that combines population biology and phylogenetic approaches was developed by Pons et al. (2006). This method attempts to determine a threshold between inter-species level (phylogenetic) lineage branching and intraspecies (tokogenetic) branching, using a "Generalised Yule Mixed Coalescent model." A maximum likelihood tree is inferred from sequence data, the ages of nodes are estimated, and a lineage-through-time plot constructed. A change in branching rates in this plot should correspond to a change from phylogenetic processes to coalescent processes. This method has not been used in brown algae. Leliaert et al. (2009) applied the method to green algae (Boodlea), but found estimated confidence intervals were very broad, allowing a wide range of species divisions. A preliminary attempt at applying this method to cox 1 data from Cystophora, with changes in branching rates estimated visually from the lineage-through-time plot, was not congruent with expected species boundaries, and different species boundaries were indicated with small changes in parameters.

\subsection{Synthesising species concepts}

Eukaryote algae have not featured greatly in the development of species concepts. Birds seem somewhat overrepresented, probably because of the influence of Ernst Mayr; terrestrial plants usually get a mention (hybridisation), as do prokaryotes (asexuality). None-the-less, debates over species concepts have influenced phycologists and are pertinent to any discussion of species delimitation.

At the end of the 1990s various attempts were made to synthesise species concepts (Avise \& Wollenberg 1997, Mayden 1997, de Queiroz 1998). These attempts were anticipated by Hull (1965) who proposed understanding species as a cluster concept. Avise \& Wollenberg (1997) suggested that there is no difficulty in combining the biological (BSC) and phylogenetic species concepts (PSC), as long as diagnosis of monophyly uses multiple lines of evidence. This "multi-locus PSC" would minimise conflicts between gene trees and species trees, and limit diagnosis of sub-species lineages. Mayden (1997) argues for a hierarchy of species concepts, with the highest order species concept not operable, but based on theory, but supported by various lower order concepts that are, to varying degrees, operable. This allows a unification of species concepts, with the 
relationships between them clearly defined. De Queiroz $(1998,2007)$ suggests separating the definition of species from operational methods used to delimit species, as these are different philosophical concepts, albeit ones that can inform one another. In De Queiroz's scheme (2007), species are metapopulation lineages that acquire different properties (monophyly, reproductive isolation, etc.) at different times during the process of speciation. Species are delimited by testing for these various properties, but not all properties will coincide at one moment in the history of speciation, so no single property is required (or expected) in every species. Successful delimitation of species, therefore, will depend on the property tested and the history of lineage separation.

Piglucci (2003) develops a similar argument to De Queiroz, but one that is not based on history. They argue that the species problem is essentially a philosophical question that needs empirical data to answer it (rather than a scientific question with philosophical aspects). The question can be resolved by viewing species as a cluster concept sensu Wittgenstein, where there are shared properties between all species, none of which are necessary or sufficient alone.

These concepts are compatible with Coyer et al.'s (2010) sliding window concept of species for Fucus. They also suggest a weight of evidence approach to species delimitation, rather than a Popperian hypothesis testing approach. This is similar the actual practice by taxonomists dealing with brown algae. With the availability of various lines of evidence, it is becoming rare for a single property of a species to be privileged above all others. Rather, various properties are considered and weighed before a decision is made.

Uncertainty is likely to remain a problem for species delimitation. Contemporary data will rarely - if ever - support a unique hypothesis about historical events. The complexity of biological processes, the use of proxies (morphology, genetic distance) for speciation, inference from limited data and researchers' biases (splitters and lumpers) suggests species delimitation will remain an exercise in approximation, subject to revision.

I suggest no method is likely to encompass the diversity of evolutionary processes and historical scenarios found in speciation, and conclude that: (1) a weight of evidence approach should be taken in delimiting species, with no single method being privileged (this essentially continues the status quo in brown algal taxonomy) and; (2) different sets of species' properties will be found in different 
species. These properties are best encapsulated by including species' history in species descriptions.

Contingency plays a large role in speciation processes, and the delimitation of species is an exploration of biological history. There are expected to be major differences in the speciation histories of different lineages, for example the fast speciation in Fucus radicans where reinforcement (selection for characters limiting hybridisation) might be expected to play a role, or the slow drift to reproductive isolation in allopatric species. Incorporating species histories into the description of species would overcome the lingering influence of the typological approach, where species are described by a name and morphological diagnosis. Explicitly including history as part of species descriptions would emphasise that recognition that a lineage has species status can reflect different speciation processes.

\subsection{References}

Aвbott, I. A. \& Hollenberg, G. J. (1976). Marine algae of California. Stanford CA: Stanford University Press.

ADAMS, N. M. (1994). Seaweeds of New Zealand: An illustrated guide. Christchurch, New Zealand: Canterbury University Press.

ADEY, W. H. \& STENECK, R. S. (2001). Thermogeography over time creates biogeographic regions: A temperature/space/time-integrated model and an abundance weighted test for benthic marine algae. Journal of Phycology, 37, 677-698.

AgARDH, J. G. (1848). Species genera et ordines algarum, seu descriptiones succinctae specierum, generum et ordinum, quibus algarum regnum constituitur. Volumen Primum. Algas fucoideas complectens. Lundae [Lund], Sweden: C. W. K. Gleerup.

AJISAKA, T., KIM, S. H., UWAI, S. \& KAWAI, H. (2007). Cladosiphon umezakii sp. nov. (Ectocarpales, Phaeophyceae) from Japan. Phycological Research, 55, 193-202.

ARNOLD, M. L. \& HodgeS, S. A. (1995). Are natural hybrids fit or unfit relative to their parents? Trends in Ecology and Evolution, 10, 67-71.

Avise, J. C. \& Wollenberg, K. (1997). Phylogenetics and the origin of species. Proceedings of the National Academy of Sciences of the USA, 94, 7748-7755.

BAKER, A. J., TAVERES, E. S. \& Elbourne, R. F. (2009). Countering criticisms of single mitochondrial DNA gene barcoding in birds. Molecular Ecology Resources, 9, (Suppl. 1) 257268.

BenzIE, J. A. H., BALlMENT, E. \& Edyvane, K. (2000). Allozymes as genetic identification markers of Sargassum spp. (Phaeophyta) from the Great Barrier Reef, Australia. Botanica Marina43, 169-179.

Bergström, L., TAtAREnKov, A., JohAnnesson, K. JÖnsSOn, R. B. \& KAUTSKY, L. (2005). Genetic and morphological identification of Fucus radicans sp. nov. (Fucales, Phaeophyceae) in the brackish Baltic Sea. Journal of Phycology, 41, 1025-1038. 
Bhattacharya, D., Medlin, L., Wainright, P. O., Ariztia, C. B., Stickel, S. K. \& Sogin, M. L. (1992). Algae containing chlorophylls a $+\mathrm{c}$ are paraphyletic: Molecular evolutionary analysis of the chromophyta. Evolution, 46, 1801-1817.

Billard, E., Daguin, C., Pearson, G. Serrão, E., Engel, C. \& Valero, M. (2005). Genetic isolation between three closely related taxa: Fucus vesiculosus, $F$. spiralis and $F$. ceranoides (Phaeophyceae). Journal of Phycology, 41, 900-905.

Billard, E., Serrão, E., Pearson, G. A., Destombe, C. \& VAlero, M. (2010). Fucus vesiculosus and spiralis species complex: a nested model of local adaptation at the shore level. Marine Ecology Progress Series, 405, 163-174.

Billard, E., Serrão, E., Pearson, G. A., Engel, C. R., Destombe, C. \& VAlero, M. (2005). Analysis of sexual phenotyoe and prezygotic fertility in natural populations of $F$, spiralis, $F$. vesiculosus (Fucaceae, Phaeophyta) and their putative hybrids. European Journal of Phycology, 40, 397-407.

Bittner, L., Payri, C. E., CoulouX, A., Cruaud, C., De Reviers, B. \& Rousseau, F. (2008). Molecular phylogeny of the Dictyotales and their position within the Phaeophyceae, based on nuclear, plastid and mitochondrial sequence data. Molecular Phylogenetics and Evolution, 49, 211-226.

Boo, S. M., LeE, W. J, Yoon, H. S., KATO, A. \& KAWAI, H. (1999). Molecular Phylogeny of Laminariales (Phaeophyceae) inferred from small subunit ribosomal DNA sequences. Phycological Research, 47, 109-114.

BorisenKo, A. V., SONES, J. E. \& HEBERT, P. D. N. (2009). The front-end logistics of DNA barcoding: challenges and prospects. Molecular Ecology Resources, 9, (Suppl. 1), 27-34.

Bothwell, J. H., Marie, D., Peters, A. F., Cock, J. M. \& Coelho, S. M. (2010). Role of endoreduplication and apomeiosis during parthenogenetic reproduction in the model brown alga Ectocarpus. New Phytologist, 188, 111-121.

Brower, A. V.Z. (1999). Delimitation of phylogenetic species with DNA methods: A critique of Davis and Nixon's Population Aggregation Analysis. Systematic Biology, 48, 119-213.

BurkhardT, E. \& PETERS, A. F. (1998). Molecular evidence from nrDNA ITS sequences that Laminariocolax (Phaeophyceae, Ectocarpales sensu lato) is a worldwide clade of closely related kelp endophytes. Journal of Phycology, 34, 682-691.

Burrowes, R., Rousseau, F., MüLler, D. G., DE REVIERS, B. (2003). Taxonomic placement of Microzonia (Phaeophyceae) in the Syringodermatales based on the rbcL and 28S nrDNA sequences. Cryptogamie Algologie, 24, 63-73.

Burrows, E.M. \& LodGE, S. (1951). Autecology and the species problem in Fucus. Journal of the Marine Biological Association of the United Kingdom, 30, 161-176.

Buschiazzo, E, \& GEMMELL, N. J. (2006). The rise, fall and renaissance of microsatellites in eukaryotic genomes. BioEssays, 28, 1040-1050.

Butlin, R. K., GALINDO, J. \& GRAHAME, J. W. (2008). Sympatric, parapatric or allopatric: the most important way to classify speciation? Philosophical Transactions of the Royal Society of London B Series, 363, 2997-3007.

Camus, C., Meynard, A. P., Faugeron, S. Kogame, K. \& Correa, J. A. (2005). Differential life history phase expressions in two co-existing species of Scytosiphon (Phaeophyceae) in northen Chile. Journal of Phycology, 41, 931-941.

Cheang, C. C., Chu, K. H. \& Ang, P. O. (2010). Phylogeography of the marine macroalga Sargassum hemiphyllum (Phaeophyceae, Heterokonta) in northwestern Pacific. Molecular Ecology, 19, 2933-2948.

CHISwell, S. M. (2009). Colonisation and connectivity by intertidal limpets among New Zealand, Chatham and Sub-Antarctic Islands. II. Oceanographic connections. Marine Ecology Progress Series, 388, 121-135. 
Cho, G. Y. \& Boo, S. M. (2006). Phylogenetic position of Petrospongium rugosum (Ectocarpales, Phaeophyceae): insights from the protein coding plastid rbcL and psaA gene sequences. Cryptogamie, Algologie, 27, 3-15.

Cho, G. Y., Boo, S. M., Nelson, W. \& ClaYTON, M. N. (2005). Genealogical partitioning and phylogeography of Colpomenia peregrina (Scytosiphonaceae, Phaeophyceae) based on plastid rbcL and nuclear ribosomal DNA internal transcribed spacer sequences. Phycologia, 44, 103111.

Cho, G. A., Kogame, K., KawaI, H. \& Boo, S. M. (2007). Genetic diversity of Scytosiphon lomentaria (Scytosiphonaceae, Phaeophyceae) from the Pacific and Europe based on RuBisCo large subunit and spacer, and ITS nrDNA sequences. Phycologia, 46, 657-665.

ChO, G. A., LeE, S. H. \& Boo, S. M. (2004). A new brown algal order, Ishigeales (Phaeophyceae), established on the basis of plastid protein-coding $r b c \mathrm{~L}, p s a \mathrm{~A}$ and $p s b \mathrm{~A}$ region comparisons. Journal of Phycology, 40, 921-936.

Cho, G. Y., Rousseau, F., Reviers, B. DE \& Boo, S. M. (2006). Phylogenetic relationships within the Fucales (Phaeophyceae) assessed by the photosystem I coding psaA sequences. Phycologia, $45,512-519$.

Clayton, M. N. (1976). The morphology, anatomy and life history of a complanate form of Scytosiphon lomentaria (Scytosiphonales, Phaeophyta) from Southern Australia. Marine Biology, 38, 201-208.

Clayton, M. N. (1978). Morphological variation and life history in cylindrical forms of Scytosiphon lomentaria (Scytosiphonaceae: Phaeophyta) from Southern Australia. Marine Biology, 47, 349-357.

Clayton, M. N., Kevekordes, K., Schoenwaelder, M. E. A., Schmid, C. E. \& Ashburner, C. M. (1998). Parthenogenesis in Hormosira banksii (Phaeophyceae). Botanica Marina, 40, $23-$ 30.

COFFROTH, J. A. \& SANTOS, S. R. (2005). Genetic diversity of symbiotic dinoflagellates in the genus Symbiodinium. Protist, 156, 19-34.

Coyer, J. A., HoArau, G., Costa, J. F., Hogerdjik, B., Billard, E., VAlero, M., ET Al. (2010). Evolution and species diversification within the intertidal brown macroalgae Fucus spiralis/F. vesiculosus species complex in the North Atlantic. Molecular Phylogenetics and Evolution, doi:10.1016/j.ympev.2010.11.015.

Coyer, J. A., HoArau, G., Oudot-Le SecQ, M-P., Stam, W. T. \& Olsen, J. L. (2006a). A mtDNA-based phylogeny of the brown algal genus Fucus (Heterokontophyta; Phaeophyta). Molecular Phylogenetics and Evolution, 39, 209-222.

Coyer, J. A., Hoarau, G., Pearson, G. A., Serrao, E. A., Stam, W. T. \& Olsen, J. L. (2006b). Convergent adaptation to a marginal habitat by homoploid hybrids and polyploid ecads in the seaweed genus Fucus. Biology Letters, 2, 405-408.

Coyer, J. A., Hoarau, G., Skage, M., Stam, W. T. \& Olsen, J. L. (2006c). Origin of Fucus serratus (Heterokontophyta; Fucaceae) populations in Iceland and the Faroes: a microsatellite based assessment. European Journal of Phycology, 41, 235-246.

COYer, J. A., HoARAU, G., STAM, W. T. \& OlSEn, J. L. (2007). Hybridization and introgression in a mixed population of the intertidal seaweeds Fucus evanescens and F. serratus. Journal of Evolutionary Biology, 20, 2322-2333.

Coyer, J. A., Peters, A. F., Hoarau, G., Stam, W. T. \& Olsen, J. L. (2002). Hybridization of the marine seaweeds Fucus serratus and Fucus evanescens (Heterokontophyta: Phaeophyceae) in a 100-year-old zone of secondary contact. Proceedings of the Royal Society of London B Series, $269,1829-1834$.

Coyer, J. A., Peters, A. F., StAM, W. T. \& Olsen, J. L. (2003). Post ice-age recolonization and differentiation of Fucus serratus L. (Phaeophyceae; Fucaceae) populations in Northern Europe. Molecular Ecology, 12, 1817-1829.

COYNE, J. A. \& ORR, H. A. (2004). Speciation. Sunderland, MA: Sinauer Associates. 
DAUGBJERG, N. \& ANDERSEN, R. A. (1997a). Phylogenetic analyses of the $r b c$ L sequences from Haptophytes and Heterokont algae suggest their chloroplasts are unrelated. Molecular Biology and Evolution, 14, 1242-1251.

DAUGBJERG, N. \& ANDERSEN, R. A. (1997b). A molecular phylogeny of the heterokont algae based on analyses of chloroplast encoded $r b c \mathrm{~L}$ sequence data. Journal of Phycology, 33, 10311041.

DAYRAT, B. (2005). Towards integrative taxonomy. Biological Journal of the Linnean Society, 85, $407-415$.

De Clerck, O., Leliaert, F., Verbruggen, H., Lane, C. E., Campos De Paula, J., Payo, D. A. \& CopPEJANS, E. (2006). A revised classification of the Dictyoteae (Dictyotales, Phaeophyceae) based on $r b c \mathrm{~L}$ and $26 \mathrm{~S}$ ribosomal DNA sequence analysis. Journal of Phycology, 42, 12711288.

DE QUEIROZ, K. (1998). The general lineage concept of species, species criteria, and the process of speciation: A conceptual unification and terminological recommendations. In Howard, D. J. \& Berlocher, S. H. (eds.) Endless Forms: Species and Speciation (Chapter 5, pp. 57-75). Oxford, United Kingdom: Oxford University Press.

DE QUEIROZ, K. (2007). Species concepts and species delimitation. Systematic Biology, 56, 879886.

DE QueIroz, K., \& Donoghue, M. J. (1988). Phylogenetic systematics and the species problem. Cladistics, 4, 317-338.

DE REVIERs, B. \& RousseaU, F. (1999). Towards a new classification of the brown algae. Progress in Phycological Research, 13, 107-201.

DE TONI, G. B. (1895). Sylloge algarum omnium hucusque cognitarum. Vol. III. Fucoideae. Padua, Italy: Sumptibus auctoris.

Demes, K. W., Graham, M. H. \& SuskiewiCZ, T. S. (2009). Phenotypic plasticity reconciles incongruous molecular and morphological taxonomies: The giant kelp, Macrocystis (Laminariales, Phaeophyceae), is a monospecific genus. Journal of Phycology, 45, 1266-1269.

DESALLE, R. (2006). Species discovery versus species identification in DNA barcoding efforts: Response to Rubinoff. Conservation Biology, 20, 1545 - 1547.

Dillehay, T. D., Ramírez, C., Pino, M., Collins, M. B., Rossen, J. \& Pino-Navarro, J. D. (2008). Monte Verde: Seaweed, food, medicine, and the peopling of South America. Science, $320,784-786$.

Draisma, S. G. A., Olsen, J. L., Stam, W. T., \& VAn Reine, P. W. F. (2002). Phylogenetic relationships within the Sphacelariales (Phaeophyceae): $r b c \mathrm{~L}, \mathrm{RUBISCO}$ spacer and morphology. European Journal of Phycology, 37, 385-401.

Draisma, S. G. A., VAn Reine, P. W. F., StAM, W. T. \& Olsen, J. L. (2001). A reassessment of phylogenetic relationships within the Phaeophyceae based on Rubisco large subunit and ribosomal DNA sequences. Journal of Phycology, 37, 586-603.

Dromgoole, F. I. (1973). A contribution to the biology of the genus Carpophyllum Grev. Unpublished PhD. Thesis. Auckland, New Zealand: University of Auckland.

DRUEHL, L. D. \& SAUNDERS, G. W. (1992). Molecular explorations in kelp evolution. Progress in Phycological Research, 8, 47-83.

Druehl, L. D., Collins, J. D., LANE, C. E. \& SAunders, G. W. (2005). An evaluation of methods used to assess intergeneric hybridization in kelp using Pacific Laminariales (Phaeophyceae). Journal of Phycology, 41, 250-262.

Endo, H., PARK, E-J., SATO, Y., MizUta, H. \& SAGA, N. (2009). Intraspecific diversity of Undaria pinnatifida (Harvey) Suringar (Laminariales, Phaeophyta) from Japan, China and Korea, based on the cox1 gene and ITS2 sequences. Fisheries Science, 75, 393-400.

ENGEL, C. R., DAGUIN, C. \& SERRÃO, E. (2005). Genetic entities and mating systems in hermaphroditic Fucus spiralis and its close dioecious relative $F$. vesiculosus (Fucaceae, Phaeophyceae). Molecular Ecology, 14, 2033-2046. 
Ferguson, J. W. H. (2002). On the use of genetic divergence for identifying species. Biological Journal of the Linnean Society, 75, 509 - 516.

FLETCHER, R. L. (1987). Seaweeds of the British Isles. Vol. 3. Fucophyceae (Phaeophyceae). London: British Museum (Natural History).

FoX, C. H. \& SWANSON, A. K. (2007). Nested PCR detection of microscopic life-stages of laminarian macroalgae and comparison with adult forms along intertidal height gradients. Marine Ecology Progress Series, 332, 1-10.

FRASER, C. I., HAY, C. H., SPENCER H. G. \& WATERS, J. M. (2009a). Genetic and morphological analyses of the southern Bull Kelp Durvillaea antarctica (Phaeophyceae: Durvilleales) in New Zealand reveals cryptic species. Journal of Phycology, 45, 436-443.

Fraser, C. L., NiKUla, R., SPEnCER, H. G. \& WATERS, J. M. (2009b). Kelp genes reveal effects of subantarctic sea ice during the Last Glacial Maximum. Proceedings of the National Academy of Sciences of the USA, 106, 3249-3253.

FRASER, C. I., SPENCER H. G. \& WATERS, J. M. (2009c). Glacial oceanographic contrasts explain the phylogeography of Australian bull kelp. Molecular Ecology, 18, 2287-2296.

FraSer, C. I, ThIEL, M., SPENCER, H. G. \& WATERS, J. M. (2010a). Contemporary habitat discontinuity and historic glacial ice drive genetic divergence in Chilean kelp. BMC Evolutionary Biology, 19, 203. doi:10.1186/1471-2148-10-203.

Fraser, C. I., Winter, D. J., SPEnCER, H. G. \& WATERS, J. M. (2010b). Multigene phylogeny of the southern bull-kelp genus Durvillaea (Phaeophyceae: Fucales). Molecular Phylogenetics and Evolution, 57, 1301-1311.

Godfray, H. C. J., Clark, B. R., Kitching, I. J., Mayo, S. J. \& Scoble, M. J. (2007). The web and the structure of taxonomy. Systematic Biology, 56, 943-955.

Golding, G. B., Hanner, R. \& Hebert, P. D. N. (2009). Preface. Molecular Ecology Resources, 9, (Suppl. 1) iv-vi.

GOOD, D. A. \& WAKE, D. B. (1992). Geographic variation and speciation in the Torrent Salamanders of the genus Rhyacotriton (Caudata: Rhyacotritonidae) (University of California Publications in Zoology No. 126). California: University of California Press.

GOURBIÈRE, S. \& MALLET, J. (2009). Are species real? The shape of the species boundary with exponential failure, reinforcement and the "missing snowball". Evolution, 64, 1-24.

Graham, M. H., Kinlan, B. P. \& GrosberG, R. K. (2101). Post-glacial redistribution and shifts in productivity of giant kelp forests. Proceedings of the Royal Society of London B Series, 277, 399-406.

GUIRY, M. D. \& GUIRY, G. M. (2011). Algaebase. Retrieved February 1, 2011, from http://www.algaebase.org.

HARROLD, C. \& LISINA, S. (1989). Radio-tracking rafts of giant kelp: local production and regional transport. Journal of Experimental Marine Biology and Ecology, 130, 237-251.

HARVEY, J. B. J. \& GOFF, L. J. (2006). A reassessment of species boundaries in Cystoseira and Halidrys (Phaeophyceae, Fucales) along the North American West Coast. Journal of Phycology, 42, 707-720.

HAWES, N. A. (2008). Nearshore dispersal and reproductive viability of intertidal fucoid algae: How effective is drift in local to regional dispersal? Unpublished masters thesis. Christchurch, New Zealand: University of Canterbury.

HEBERT, P. D. N. \& GREGORY, T. R. (2005). The promise of DNA barcoding for taxonomy. Systematic Biology, 54, 852-859.

Hebert, P. D. N., CYwinsKa, A., BALL, S. L. \& DE WAARD, J. R. (2003a). Biological identifications through DNA barcodes. Proceedings of the Royal Society of London B Series, $270,313-321$. 
HeBert, P. D. N., RATNASINGHAM, S. \& DE WAARD, J. R. (2003b). Barcoding animal life: cytochrome c oxidase subunit 1 divergences among closely related species. Proceedings of the Royal Society of London B Series, 270, (Suppl. 1) S96-S99. doi:10.1098/rsbl.2003.0025.

HeEsch, S., Peters, A. F., Broom, J. E. S. \& Hurd, C. L. (2008). Affiliation of the parasitic brown alga Herpodiscus durvillaeae with the Sphacelariales based on DNA sequence comparisons and morphological observations. European Journal of Phycology, 43, 283-295.

Henkel, S. K., Hofmann, G. E. \& WhitMer, A. C. (2007). Morphological and genetic variation in Egregia menziesii over a latitudinal gradient. Botanica Marina, 50, 159-170.

Hernández-Carmona, G., Hughes, B. \& Graham, M. H. (2006). Reproductive longetivity of drifting kelp Macrocystis pyrifera (Phaeophyceae) in Monterey Bay, USA. Journal of Phycology, 42, 1199-1207.

HEwITT, G. M. (1988). Hybrid zones - natural laboratories for evolutionary studies. Trends in Ecology and Evolution, 3, 158-167.

HEwITT, G. M. (2004). Genetic consequences of climatic oscillations in the Quaternary. Philosophical Proceedings of the Royal Society of London B Series, 359, 183-195.

HEY, J. (2006). On the failure of modern species concepts. Trends in Ecology and Evolution, 21, $447-450$.

Highton, R. (1989). Biochemical evolution in the slimy Salamanders of the Plethodon glutinosus complex in the eastern United States. Part 1. Geographical protein variation. Illinois Biological Monographs, 57, 1-78.

Highton, R. (1990). Taxonomic treatment of genetically differentiated populations. Herpetologica, 46, 114-121.

Highton, R. (1995). Speciation in Eastern North American Salamanders of the Genus Plethodon. Annual Review of Ecology and Systematics, 26, 579-600.

Ho, C. L., PHANG, S. M. \& PANG, T. (1995). Molecular characterisation of Sargassum polycystum and $S$. siliquosum (Phaeophyta) by polymerase chain reaction using random amplified polymorphic DNA (RAPD) primers. Journal of Applied Phycology, 7, 33-41.

HoArau, G., Coyer, J. A., Veldsink, J. H., Stam, W. T. \& Olsen, J. L. (2007). Glacial refugia and recolonization pathways in the brown seaweed Fucus serratus. Molecular Ecology, 16, 3606-3616.

HodGe, F. J. (2009). Hybridisation in the brown algae Carpophyllum: Investigating morphology, distribution and wave exposure. Unpublished masters thesis. Wellington, New Zealand: Victoria University of Wellington.

HORIGUCHI, T. \& YoshIDA, T. (1998). The phylogenetic affinities of Myagropsis myagroides (Fucales, Phaeophyceae) as determined from 18S rDNA sequences. Phycologia, 37, 237-245.

HuLl, D. L. (1965). The effect of essentialism on taxonomy-two thousand years of stasis. The British Journal for the Philosophy of Science, 25, 314-326 (part 1), 16, 1-18 (part II).

Hull, S. L., SCOTT, G. W. \& JohnSON, L.J. (2001). An investigation into the genetic variation in four fucales species using cellulose acetate electrophoresis. Botanica Marina, 44, 119-123.

Jones (Kain), J., Buchanan, J., Boo, S. M. \& LeE, K. M. (2010). Colpomenia bullosa crust masquerading as Ralfsia verrucosa in southeast Australia. Phycologia, 49, 617-627.

Kawai, H., Hanyuda, T., Draisma, S. G. A. \& Müller, D. G. (2007). Molecular phylogeny of Discosporangium mesartrocarpum (Phaeophyceae) with a reinstatement of the order Discosporangiales. Journal of Phycology, 43, 186-194.

KAWAI, H., HANYUdA, T., LindebERG, M. \& LindSTROM, S. C. (2008). Morphology and molecular phylogeny of Aureophycus aleuticus Gen. et Sp. Nov. (Laminariales, Phaeophyceae) from the Aleutian Islands. Journal of Phycology, 44, 1013-1021

KAWAI, H. \& SASAKI, H. (2000). Molecular phylogeny of the brown algal genera Akkesiphycus and Halosiphon (Laminariales), resulting in the circumscription of the new families Akkesiphycaceae and Halosiphonaceae. Phycologia, 39, 416-428. 
KAWAI, H. \& SASAKI, H. (2004). Morphology, life history and molecular phylogeny of Stschapovia flagellaris (Tilopteridales, Phaeophyceae) and the erection of the Stschapoviaceae fam. nov. Journal of Phycology, 40, 1156-1169.

KAWAI, H., SASAKI, H., MAeBA, S., \& HENRY, E. C. (2005). Morphology and molecular phylogengy of Phaeostrophion irregulare (Phaeophyceae) with a proposal for Phaeostrophiaceae fam. nov., and a review of the Ishigeaceae. Phycologia, 44, 169-182.

KAWAI, H., SASAKI, H., MAED, Y. \& ARAI, S. (2001). Morphology, life history, and molecular phylogeny of Chorda rigida sp. nov. (Laminariales, Phaeophyceae) from the Sea of Japan and the genetic diversity of Chorda filum. Journal of Phycology, 37, 130-142.

KIM, S-K \& KAWAI, H. (2002). Taxonomic revision of Chordaria flagelliformis (Chordariales, Phaeophyceae) including novel use of the intragenic spacer region of rDNA for phylogenetic analysis. Phycologia, 41, 328-339.

KIM, S-H., PETERS, A. F. \& KAWAI, H. (2003). Taxonomic revision of Sphaerotrichia divaricata (Ectocarpales, Phaeophyceae), with a reappraisal of $S$. firma from the north-west Pacific. Phycologia, 42, 183-192.

KNOWLES, L. L. \& CARSTENS, B. C. (2007). Delimiting species without monophyletic gene trees. Systematic Biology, 56, 887-895.

Knowlton, N., Weigt, L. A., Solorzano, L. A., Mills, D. E. K. \& Bermingham, E. (1993). Divergence in proteins, mitochondrial DNA, and reproductive compatibility across the Isthmus of Panama. Science, 260, 1629-1632.

KogAME, K. (1996). Morphology and life history of Scytosiphon canaliculatus comb. nov. (Scytosiphonales, Phaeophyceae) from Japan. Phycological Research, 44, 85-94.

Kogame, K. (1997a). Sexual reproduction and life history of Petalonia fascia (Scytosiphonales, Phaeophyceae). Phycologia, 36, 389-394.

Kogame, K. (1997b). Life histories of Colpomenia sinuosa and Hydroclathrus clathratus (Scytosiphonaceae, Phaeophyceae) in culture. Phycological Research, 45, 227-231.

Kogame, K., Horiguchi, T. \& MASUdA, M. (1999). Phylogeny of the order Scytosiphonales (Phaeophyceae) based onDNA sequences of $r b c \mathrm{~L}$, partial $r b c \mathrm{~S}$, and partial LSU nrDNA. Phycologia, 38, 496-502.

Kogishi, K., Kitayama, T., Miller, K. A., Hanyuda, T. \& Kawai, H. (2010). Phylogeography of Cutleria cylindrica (Cutleriales, Phaeophyceae) in northeastern Asia, and the identity of an introduced population in California. Journal of Phycology, 46, 553-558.

Kogame, K. \& MASUdA, M. (2001). Crustose sporophytes of Colpomenia bullosa (Scytosiphonaceae, Phaeophyceae) in nature. Cryptogamie, Algologie, 22, 201-208.

Kogame, K. \& Yamagishi, Y. (1997). The life history and phenology of Colpomenia peregrina (Scytosiphonales, Phaeophyceae) from Japan. Phycologia, 36, 337-344.

KRAAN, S. \& GUIRY, M. D. (1998). Strain selection in the edible brown seaweed Alaria esculenta: Genetic fingerprinting and hybridization studies under laboratory conditions (Marine Resources Series No. 8). Ireland: Marine Institute.

KRAAN, S. \& GUIRY, M. D. (2000). Sexual hybridization experiments and phylogenetic relationships as inferred from Rubisco spacer sequences in the genus Alaria (Phaeophyceae). Journal of Phycology, 36, 190-198.

KraAn, S., RuEness, J., GuIRY, M. D. (2001). Are North Atlantic Alaria esculenta and A. grandifolia (Alariaceae, Phaeophyceae) conspecific? European Journal of Phycology, 36, 3542.

Kraft, G. T., SAunders, G. W., Abbott, I. A. \& Haroun, R. J. (2004). A uniquely calcified brown alga from Hawaii: Newhousia imbricata gen. et sp. nov. (Dictyotales, Phaeophyceae). Journal of Phycology, 40, 383-394.

Kress, W. J., Erickson, D. L., Jones, F. A., Swenson, N. G., Perez, R., SAnJur, O. \& BERMINGHAM, E. (2009). Plant DNA barcodes and a community phylogeny of a tropical forest 
dynamics plot in Panama. Proceedings of the National Academy of Sciences of the U.S.A., doi: 10.1073/pnas.0909820106

KUCERA, H. \& SAUNDERS, G. W. (2008). Assigning morphological variants of Fucus (Fucales, Phaeophyceae) in Canadian waters to recognized species using DNA barcoding. Botany, 86, 1065-1079.

KusUMO, H. T. \& DRUEHL, L. D. (2000). Variablity over space and time in the genetic structure of the winged kelp Alaria marginata. Marine Biology, 136, 397-409.

Lago-Lestón, A, Mota, C., Kautsky, L. \& Pearson, G. A. (2010). Functional divergence in heat shock response following rapid speciation of Fucus spp. in the Baltic Sea. Marine Biology, 157, 683-688.

LANE, C. E., LindSTROM, S. C. \& SAUnders, G. W. (2007). A molecular assessment of northeast Pacific Alaria species (Laminariales, Phaeophyceae) with reference to the utility of DNA barcoding. Molecular Phylogenetics and Evolution, 44, 634-648.

LANE, C. E., MAYes, C. M., Druehl, L. \& SAunders, G. W. (2006). A multi-gene molecular investigation of the kelp (Laminariales, Phaeophyceae) resolves competing phylogenetic hypotheses and supports substantial taxonomic re-organization. Journal of Phycology, 42, 493512.

LANE, C. E. \& SAUNDERS, G. W. (2005). Molecular investigation reveals epi/endophytic extrageneric kelp (Laminariales, Phaeophyceae) gametophytes colonizing Lessoniopsis littoralis thalli. Botanica Marina, 48, 426-436.

LECLERC, M. C., BARRIEL, V., LECOINTRE, G. \& DE REVIERS, B. (1998). Low divergence in rDNA ITS sequences among five species of Fucus serratus (Phaeophyceae) suggests a very recent radiation. Journal of Molecular Evolution, 46, 115-120.

LEE, E. Y., PEDERSEN, P. M., \& LEE, I. K. (2002). Neoleptonema yongpilii E.-Y. Lee \& I.K. Lee, gen. et sp. nov. (Phaeophyceae), based on morphological characters and RuBisCO spacer sequences. European Journal of Phycology, 37, 237-245.

LEE, W. J. \& BAE, K. S. (2002). Phylogenetic relationship among several genera of Dictyotaceae (Dictyotales, Phaeophyceae) based on 18S rRNA and partial rbcL gene sequences. Marine Biology, 140, 1107-1115.

LeE, Y. K., Yoon, H. S., \& Boo, S. M. (1998). Phylogenetic relationships between Pelvetia and Pelvetiopsis (Phaeophyceae) based on small subunit ribosomal DNA sequences. Journal of Plant Biology, 41, 103-109.

LeE, Y. K., Yoon, H. S., Motomura, T., Kim, Y. J. \& Boo, S. M. (1999). Phylogenetic relationships between Pelvetia and Pelvetiopsis (Fucaceae, Phaeophyta) inferred from sequences of the RuBisCo spacer region. European Journal of Phycology, 34, 205-211

LELIAERT, F., Verbruggen, H., WySOR, B. \& DE ClerCK, O. (2009). DNA taxonomy in morphologically plastic taxa: Algorithmic species delimitation in the Boodlea complex (Chlorophyta: Cladophorales). Molecular Phylogenetics and Evolution, 53, 122-133.

LEWIS, R. J. (1996). Hybridization of brown algae: Compatibility and speciation. In Chaudhary, B. R. \& Agrawal, S. B. (Eds.) Cytology, Genetics and Molecular Biology of Algae. (pp. 275-289). Amsterdam: SPB Academic Publishing.

LEWIS, R. J. \& NEUSHUL, M. (1994). Northern and southern hemisphere hybrids of Macrocystis (Phaeophyceae). Journal of Phycology, 30, 346-353.

LEWIS, R. J., Neushul, M. \& HARGER, B. W. W. (1986). Interspecific hybridzation of the species of Macrocystis in California. Aquaculture, 57, 203-210.

LiLly, E. L., HALANYCH, K. M. \& ANDERSON, D. M. (2007). Species boundaries and global biogeography of the Alexandrium tamarense complex (Dinophyceae). Journal of Phycology, $43,1329-1338$.

Lindauer, V. W., Chapman, V. J. \& Aiken, M. (1961). The Marine Algae of New Zealand II: Phaeophyceae. Nova Hedwigia, 3, 129-350. 
LIPTACK, M. K. \& DRUEHL, L. D. (2000). Molecular evidence for an interfamilial laminarialean cross. European Journal of Phycology, 35, 135-142.

LitAker, R. W., ZANDERsea, M. W., Kibler, S. R., Reece, K. S., StoKes, N. A., Lutzoni, F. M., ET AL. (2007). Recognizing dinoflagellate species using ITS rDNA sequences. Journal of Phycology, 43, 344-355.

MACAYA, E. C. \& ZuCCARELlO, G. C. (2010). DNA barcoding and genetic divergence in the giant kelp Macrocystis (Laminariales). Journal of Phycology, 46, 736-742.

Macaya, E., Boltaña, S., Buschmann, A., Hinojosa, I., Macchiavello, J., Valdivia, N., Et $A L$. (2005). Presence of sporophylls in floating kelp rafts of Macrocystis spp. (Phaeophyceae) along the Chilean Pacific Coast. Journal of Phycology, 41, 913-922.

Maggs, C. A., Castilho, R., Foltz, D., Henzler, C., Jolly, M. T., Kelly, J., et al. (2008). Evaluating signatures of glacial refugia for North Atlantic benthic marine taxa. Ecology, 89, (Suppl. 1) S108-S122.

MALLET, J. (2008). Hybridization, ecological races and the nature of species: empirical evidence for the ease of speciation. Philosophical Transactions of the Royal Society of London B Series, 363, 2971-2986.

Mathieson, A. C., Dawes, C. J., Wallace, A. L. \& Klein, A. S. (2006). Distribution, morphology, and genetic affinities of dwarf embedded Fucus populations from the Northwest Atlantic Ocean. Botanica Marina, 49, 283-303.

Mathieson, A. C., Norton, T. A. \& Neushul, M. (1981). The taxonomic implications of genetic and environmentally induced variations in seaweed morphology. The Botanical Review, 47, 313-347.

MAYDEN, R. L. (1997). A hierarchy of species concepts: The denouement in the saga of the species problem. In Claridge, M. F., Dawah, H. A. \& Wilson, M. R. Species: The units of biodiversity. (pp. 381-384). London: Chapman and Hall.

MAYR, E. (1942). Systematics and the origin of species. New York: Columbia University Press.

MAYR, E. (1996). What is a species and what is not? Philosophy of Science, 63, 262-277.

MCDEVIT, D. C \& SAUNDERS, G. W. (2009). On the utility of DNA barcoding for species differentiation among brown macroalgae (Phaeophyceae) including a novel extraction protocol. Phycological Research, 57, 131-141.

MCDEVIT, D. C. \& SAUNDERS, G. W. (2010). A DNA barcode examination of the Laminariaceae (Phaeophyceae) in Canada reveals novel biogeographical and evolutionary insights. Phycologia, 49, 235-248.

MoniZ, B. J. M. \& KACZMARSKA, I. (2009). Barcoding diatoms: Is there a good marker? Molecular Ecology Resources, 9, (Suppl. 1) 65-74.

MüLLER, D. G. (1988). Studies on sexual compatibility between Ectocarpus siliculosus (Phaeophyceae) from Chile and the Mediterranean Sea. Helgolä̈der wissenschaftliche Meeresuntersuchungen, 42, 469-476.

Müller, D. G., PARodi, E. R. \& PeTERS, A. F. (1998). Asterocladon lobatum gen. et sp. nov., a new brown alga with a stellate chloroplast arrangement, and its systematic position judged from nuclear rDNA sequences. Phycologia, 37, 425-432.

Neiva, J., Pearson, G. A., Valero, M. \& Serrao, E. A. (2010). Surfing the wave on a borrowed board: range expansion and spread of introgressed organellar genomes in the seaweed Fucus ceranoides L. Molecular Ecology, 19, 4812-4822.

Ni-Ni-Win, Hanyuda, T., Arai, S., Uchimura, M., Prathep, A., Draisma, S. G. A., Soe-Htun $\&$ KAWAI, H. (2010). Four new species of Padina (Dictyotales, Phaeophyceae) from the western Pacific Ocean, and reinstatement of Padina japonica. Phycologia, 49, 136-153.

NoOR, M. A. F., KlimAn, R. M. \& MACHADO, C. A. (2001). Evolutionary history of microsatellites in the obscure group of Drosophila. Molecular Biology and Evolution, 18, 551-556. 
O'BRIEN, S. J. \& MAYR, E. (1991). Bureaucratic mischief: Recognizing Endangered species and subspecies. Science, 251, 1187-1188.

Olsen, J. L., Zechman, F. W., Hoarau, G., Coyer, J. A., Stam, W. T., Valero, M. \& Aberg, P. (2010). The phylogeographic architecture of the fucoid seaweed Ascophyllum nodosum: an intertidal 'marine tree' and survivor of more than one glacial-interglacial cycle. Journal of Biogeography, 37, 842-856.

PARSONS, M. J. (1985). New Zealand seaweed flora and its relationships. New Zealand Journal of Marine and Freshwater Research, 19, 131-138.

Pereyra, R. T., Bergström, L., KAutsky, L. \& Johannesson, K. (2009). Rapid speciation in a newly opened postglacial marine environment, the Baltic Sea. BMC Evolutionary Biology, 9, 70. doi: $10.1186 / 1471-2148-9-70$

PÉReZ-Ruzafa, I., Gallardo, T. \& GomezCANCiO, R. (1993). Numerical taxonomy of some taxa of the genus Fucus in the Iberian Peninsula. Hydrobiologia, 261, 81-90.

Perrin, C., Daguin, C., Van De Vliet, M., Engel, C. R., Pearson, G. A. \& Serrão, E. A. (2007). Implications of mating system for genetic diversity of sister algal species: Fucus spiralis and Fucus vesiculosus (Heterokontophyta, Phaeophyceae). European Journal of Phycology, 42, 219-230.

Peters, A. F. (1987). Reproduction and sexuality in the Chordariales (Phaeophyceae). A review of culture studies. Progress in Phycological Research, 5, 223-263.

PETERS, A. F. (1998). Ribosomal DNA sequences support taxonomic separation of the two species of Chorda: reinstatement of Halosiphon tomentosus (Lyngbye) Jaasund (Phaeophyceae, Laminariales). European Journal of Phycology, 33, 65-71.

Peters, A. F. \& BurKHARDT, E. (1998). Systematic position of the kelp endophyte Laminarionema elsbetiae (Ectocarpales sensu lato, Phaeophyceae) inferred from nuclear ribosomal DNA sequences. Phycologia, 37, 114-120.

Peters, A. F. \& Clayton, M. N. (1998). Molecular and morphological investigations of three brown algal genera with stellate plastids: Evidence for Scytothamnales ord. nov. (Phaeophyceae). Phycologia, 37, 106-113.

Peters, A. F. \& RAMíREZ, M. E. (2001). Molecular phylogeny of small brown algae, with special reference to the systematic position of Caepidium antarcticum (Adenocystaceae, Ectocarpales). Cryptogamie, Algologie, 22, 187-200.

Peters, A. F., RAMíreZ, M. E. \& RÜLKE, A. (2000). The phylogenetic position of the subantarctic marine macroalga Desmarestia chordalis (Phaeophyceae) inferred from nuclear ribosomal ITS sequences. Polar Biology, 23, 95-99.

Peters, A. F., VAn WiJK, S. J., Cho, G. Y., Scornet, D., HANYUdA, T., KAWAi, H., Et AL. (2010). Reinstatement of Ectocarpus crouaniorum Thuret in Le Jolis as a third common species of Ectocarpus (Ectocarpales, Phaeophyceae) in Western Europe, and its phenology at Roscoff, Brittany. Phycological Research, 58, 157-170.

Phillips, N., Burrowes, R., Rousseau, F., DE Reviers, B. \& SAunders, G. W. (2008). Resolving evolutionary relationships among the brown algae using chloroplast and nuclear genes. Journal of Phycology, 44, 394-405.

PigLuCCI, M. (2003). Species as a family resemblance concept. BioEssays, 25, 596-602

Pons, J., Barraclough, T. G., Gomez-Zurita, J., Cardoso, A., Duran, D. P., Hazell, S., ET AL. (2006). Sequence-based species delimitation for the DNA taxonomy of undescribed insects. Systematic Biology, 55, 595-609.

PORTER, A. H. (1990). Testing nominal species boundaries using gene flow statistics: The taxonomy of two hybridizing Admiral butterflies (Limenitis: Nymphalidae). Systematic Biology, 39, 131-147.

PRESGRAVES, D. C. (2010). The molecular evolutionary basis of species formation. Nature Reviews Genetics, 11, 175-180. 
Pritchard, J. K., Stephens, M. \& Donnelly, P. (2000). Inference of population structure using multilocus genotype data. Genetics, 155, 945-959.

QUICKE, D. L. J. (1993). Principles and techniques of contemporary taxonomy. Glasgow, United Kingdom: Blackie Academic \& Professional.

RACH, J., DeSAlle, R., SARKAR, I. N., Schierwater, B. \& HADRYS, H. (2008). Character-based DNA barcoding allows discrimination of genera, species and populations in Odonata. Philosophical Transactions of the Royal Society of London B Series, 275, 237-247.

RICE, E. L. (1989). A statistical morphological analysis and taxonomic revision of the genus Xiphophora (Fucaceae). Botanical Journal of the Linnean Society, 100, 355-387.

Rice, E. L. \& CHAPMAN, A. R. O (1985). A numerical taxonomic study of Fucus distichus (Phaeophyta). Journal of the Marine Biological Association of the United Kingdom, 65, 433459.

RIESEBERG, L. H. (1995). The role of hybridization in evolution: Old wine in new skins. American Journal of Botany, 82, 955-953.

ROBERSON, L. M. \& COYER, J. A. (2004). Variation in blade morphology of the kelp Eisenia arborea: incipient speciation due to local water motion? Marine Ecology Progress Series, 282, $115-128$.

Rousseau, F. \& DE REVIERS, B. (1999a). Circumscription of the order Ectocarpales (Phaeophyceae): bibliographical synthesis and molecular evidence. Cryptogamie, Algologie, 20, 5-18.

Rousseau, F. \& DE REVIERS, B. (1999b). Phylogenetic relationships within the Fucales (Phaeophyceae) based on combined partial SSU and LSU rDNA sequence data. European Journal of Phycology, 34, 53-64.

Rousseau, F., Burrowes, R., Peters, A. F., Kuhlenkamp, R., \& DE Reviers, B. (2001). A comprehensive phylogeny of the Phaeophyceae based on nrDNA resolves the earliest divergences. Comptes Rendues de la Acadamie des Sciences de Paris - Sciences de la vie, 324, 305-319.

Rousseau, F., De Reviers, B., LeClerc, M-C., Asensi, A. \& Delépine, R. (2000). Adenocystaceae fam. nov. (Phaeophyceae) based on morphological and molecular evidence. European Journal of Phycology, 35, 35-43.

Rousseau, F., LeClerC, M-C. \& ReVIERS, B. DE (1997). Molecular phylogeny of European Fucales (Phaeophyceae) based on large subunit rDNA sequence comparisons. Phycologia, 36, $438-446$.

Russell, G. \& FletChER, R. L. (1975). A numerical taxonomic study of the British Phaeophyta. Journal of the Marine Biological Association of the United Kingdom, 55, 763-783.

Sass, C., Little, D. P., Stevenson, D. W. \& Specht, C. D. (2007). DNA Barcoding in the Cycadales: Testing the potential of proposed barcoding markers for species identification of Cycads. PLoS ONE, 2, e1154. doi:10.1371/journal.pone.0001154.

SAUNDERS, G. W. (2009). Routine DNA barcoding of Canadian Gracilariales (Rhodophyta) reveals the invasive species Gracilaria vermiculophylla in British Columbia. Molecular Ecology Resources, 9, (Suppl. 1) 140-150.

SAUNDERS, G. W. \& DRUEHL, L. D. (1992). Nucleotide sequences of the small sub-unit ribosomal RNA genes from selected Laminariales (Phaeophyta): implications for kelp evolution. Journal of Phycology, 28, 544-549.

SAUNDERS, G. W. \& DRUEHL, L. D. (1993). Revision of the kelp family Alariaceae and the taxonomic affinities of Lessoniopsis Reinke (Laminariales, Phaeophyta). Hydrobiologia, 260/261, 689-697.

SAUNDERS, G. W. \& KRAFT, G. T. (1995). The phylogenetic affinities of Notheia anomala (Fucales, Phaeophyceae) as determined from partial small sub-unit RNA sequences. Phycologia, 34, 383-389. 
SCHINDEL, D. E. \& MiLLER, S. E. (2005). DNA barcoding a useful tool for taxonomists. Nature, $435,17$.

SCOTT, G. W. \& HARDY, F. G. (1994). Observations of the occurrence of hybrids between two sympatric species of fucoid algae. Cryptogamie, Algologie, 15, 297-305.

Serrão, E. A., Alice, L. A. \& Brawley, S. H. (1999). Evolution of the Fucaceae (Phaeophyceae) inferred from nrDNA-ITS. Journal of Phycology, 35, 382-394.

SETChell, W. A. \& GARDNER, N. L. (1925). The marine algae of the Pacific coast of North America, Part III, Melanophyceae. University of California Publications in Botany, 8, 383-898.

Shaffer, H. B. \& Thomson, R. (2007). Delimiting Species in Recent Radiations. Systematic Biology, 56, 896-906.

Sherwood, A. R., Vis, M. L., Entwisle, T. J., NecChi, O. JR. \& Presting, G. G. (2008). Contrasting intra versus interspecies DNA sequence variation for representatives of the Batrachospermales (Rhodophyta): Insights from a DNA barcoding approach. Phycological Research, 56, 269-279.

Siemer, B. L., Stam, W. T., Olsen, J. L., \& Pedersen, P. M. (1998). Phylogenetic relationships of the brown algal orders Ectocarpales, Chordariales, Dictyosiphonales and Tilopteridales (Phaeophyceae) based on Rubisco large subunit and spacer sequences. Journal of Phycology, 34, 1038-1048.

Silberfeld, T., Leigh, J. W., Verbruggen, H., Cruaud, C., De Reviers, B. \& Rousseau, F. (2010). A multi-locus time-calibrated phylogeny of the brown algae (Heterokonta, Ochrophyta, Phaeophyceae): Investigating the evolutionary nature of the "brown algal crown radiation". Molecular Phylogenetics and Evolution, 56, 659-674.

Sites, J. W. JR. \& MARShall, J. C. (2004). Operational criteria for delimiting species. Annual Review of Ecology, Evolution, and Systematics, 35, 199-227.

StAche-Crain, B., Müller, D. G. \& GofF, L. J. (1997). Molecular systematics of Ectocarpus and Kuckuckia (Ectocarpales, Phaeophyceae) inferred from phylogenetic analysis of nuclear and plastid encoded DNA sequences. Journal of Phycology, 33,152-168.

StARr, J. R., NACZI, R. F. C. \& ChOuINARD, B. N. (2009). Plant DNA barcodes and species resolution in sedges (Carex, Cyperaceae). Molecular Ecology Resources, 9, (Suppl. 1) 151-163.

Stiger, V., Horiguchi, T., Yoshida, T., Coleman, A. W. \& Masuda, M. (2000). Phylogenetic relationships of Sargassum (Sargassaceae, Phaeophyceae) with reference to a taxonomic revision of section Phyllocystae based on ITS-2 nrDNA sequences. Phycological Research, 48, 251-260.

TAN, I. H. \& DRUEHL, L. D. (1993). Phylogeny of the Northeast Pacific brown algae (Phaeophycean) orders as inferred from 18S rRNA gene sequences. Hydrobiologia, 260/261 699-704.

TAN, I. H. \& DRUEHL, L. D. (1994). A molecular analysis of Analipus and Ralfsia (Phaeophyceae) suggests the order Ectocarpales is polyphyletic. Journal of Phycology, 30, 721-729.

TATARENKOV, A., JÖNSSON, R. B., KAUTSKY, L. \& JOHANNESSON, K. (2007). Genetic structure in populations of Fucus vesiculosus (Phaeophyceae) over spatial scales from $10 \mathrm{~m}$ to $800 \mathrm{~km}$. Journal of Phycology, 43, 675-685.

Tautz, D., Arctander, P., Minelli, A., Thomas, R. H. \& Vogler, A. P. (2003). A plea for DNA taxonomy. Trends in Ecology and Evolution, 18, 70-74.

Tellier, F., Meynard, A. P., Correa, J. A.Faugeron, S. \& VAlero, M. (2009). Phylogeographic analyses of the 30 degrees S south-east Pacific biogeographic transition zone establish the occurrence of a sharp genetic discontinuity in the kelp Lessonia nigrescens: Vicariance or parapatry? Molecular Phylogenetics and Evolution, 53, 679-693.

TEMPLETON, A. R. (2001). Using phylogeographic analyses of gene trees to test species status and processes. Molecular Ecology, 10, 779-791.

ThOMSEn, M. S. \& WERnBERG, T. (2005). What affects the forces required to break or dislodge macroalgae? European Journal of Phycology, 40, 139-148. 
Tronholm, A., Sanson, M., Afonso-Carillo, J., Verbruggen, H. \& De Clerck, O. (2010a). Niche partioning and the coexistence of two cryptic Dictyota (Dictyotales, Phaeophyceae) species from the Canary Islands. Journal of Phycology, 46, 1075-1087.

Tronholm, A., Steen F., Tyberghein L., Leliaert, F., Verbruggen H., Siguan M. A. R. \& DE ClerCK, O. (2010b). Species delimitation, taxonomy and biogeography of Dictyota in Europe (Dictyotales, Phaeophyceae). Journal of Phycology, 46, 1301-1321.

UwaI, S., Kogame, K., YoshidA, G., KAWAI, H. \& AJISAKA, T. (2009). Geographical genetic structure and phylogeography of the Sargassum horneri/filicinum complex in Japan, based on the mitochondrial cox3 haplotype. Marine Biology, 156, 901-911.

Uwai, S., Nagasato, C., Motomura, T. \& Kogame, K. (2005). Life history and molecular phylogentic relationships of Asterocladon interjectum sp. nov. (Phaeophyceae). European Journal of Phycology, 40, 179-194.

VAN DEN HOEK, C. (1987). The possible significance for long range dispersal for the biogeography of seaweeds. Helgolä̈der wissenschaftliche Meeresuntersuchungen, 41, 261-272.

van Oppen, M. J. H., Olsen, J. L., StAm, W. T., VAn DEN Hoek, C. \& WIENCKE, C. (1993). ArcticAntarctic disjunctions in the benthic seaweeds Acrosiphonia arcta (Chlorophyta) and Desmarestia viridis/willii (Phaeophyta) are of recent origin. Marine Biology, 115, 381-386.

VELASCO, J. D. (2008). Species concepts should not conflict with evolutionary history, but often do. Studies in History and Philosophy of Biological and Biomedical Sciences, 39, 407-414.

Wallace, A. L., Klein, A. S. \& MAthieson, A. C. (2004). Determining the affinities of salt marsh fucoids using microsatellite markers: Evidence of hybridization and introgression between two species of Fucus (Phaeophyta) in a Maine estuary. Journal of Phycology, 40, 1013-1027.

WAters, J. M. (2008). Driven by the West Wind Drift? A synthesis of southern temperate marine biogeography, with new directions for dispersalism. Journal of Biogeography, 35, 417-427.

WestermeIer, R., PATiÑo, D. \& MüLler, D. G. (2007). Sexual compatability and hybrid formation between the giant kelp species Macrocystis pyrifera and $M$. integrifolia (Laminariales, Phaeophyta) in Chile. Journal of Applied Phycology, 19, 215-221.

WidDowson, T. B. (1971). A taxonomic revision of the genus Alaria Greville. Syesis, 4, 11-49.

WIENS, J. J. (2007). Species delimitation: New approaches for discovering diversity. Systematic Biology, 56, 875-878.

WiENS, J. J. \& PENKROT, T. A. (2002). Delimiting species using DNA and morphological variation and discordant species limits in Spiny Lizards (Sceloporus). Sytematic Biology, 51, 69-91.

WIENS, J. J. \& SERVEDIO, M. R. (2000). Species delimitation in systematics: inferring diagnostic differences between species. Proceedings of the Royal Society of London B Series, 267, 631636.

Will, K. W., Mishler, B. D. \& WheELER, Q. D. (2005). The perils of DNA barcoding and the need for integrative taxonomy. Systematic Biology, 54, 844-851.

WILLIAMS, S. L. \& Di FIORI, R. E. (1996). Genetic diversity and structure in Pelvetia fastigiata (Phaeophyta: Fucales): does a small effective neighbourhood size explain fine-scale genetic structure? Marine Biology, 126, 371-382.

WILSON, P. (1992). On inferring hybridisation from morphological intermediacy. Taxon, 41, 1123.

WOMERSELY, H. B. S. (1964). The morphology and taxonomy of Cystophora and related genera (Phaeophyta). Australian Journal of Botany, 12, 53-110.

Womersley, H. B. S. (1987). The marine benthic flora of southern Australia. Part II. Adelaide, Australia: South Australian Government Printing Division.

WynNe, M. J. (1969). Life history and systematic studies of some Pacific North American Phaeophyceae (brown algae). University of California Publications in Botany, 50, 1-88. 
Yoon, H. S. \& Boo, S. M. (1999). Phylogeny of Alariaceae (Phaeophyta) with special reference to Undaria based on sequences of the RuBisCo spacer region. Hydrobiologia, 398-399, 47-55.

YoshidA, T.,, STIGER, V. \& HORIGUCHI, T. (2000). Sargassum boreale sp. nov. (Fucales, Phaeophyceae) from Hokkaido, Japan. Phycological Research, 48, 125-131.

YounG, M. W. (1929). Marine fauna of the Chatham Islands. Transactions and Proceedings of the New Zealand Institute, 60, 136-166. 
Chapter 7

Appendices 


\subsection{Appendix 1. Alignment of mitochondrial spacer sequences from Carpophyllum maschalocarpum. A single specimen is shown for each haplotype/site. Specimen names are truncated as: FieldnumberSitenameHaplotype.}

B5600pap01 GTAAAGTTTTCAGTGGGGGTGAAATTTAATCACTTTGATAGGCGGGGGGTGTAAGAGCTGTGAGGTTTTTAGCTGACC B213Kiri02 GTAAAGTTTTCAGTGGGGGTGAAATTTAATCACTTTGATAGGCGGGGGGTGTAAGAGCTGTGAGGTTTTTAGCTGACC B051Dors03 GTAAAGTTTTCAGTGGGGGTGAAATTTAATCACTTTGATAGGCGGGGGGTGTAAGAGCTGTGAGGTTTTTAGCTGACC A737Kiri04 GTaAaGTTTTCAGTGGGGGTGAAATTTAATCACTTTGATAGGCGGGGGGTGTAAGAGCTGTGAGGTTTTTAGCTGACC A738Kiri05 GTAAAGTTTTCAGTGGGGGTGAAATTTAATCACTTTGATAGGCGGGGGGTGTAAGAGCTGTGAGGTTTTTAGCTGACC B307Whal06 GTAAAGTTTTCAGTGGGGGTGAAATTTAATCACTTTGATAGGCGGGGGGTGTAAGAGCTGTGAGGTTTTTAGCTGACC B256Piha07 GTAAAGTTTTCAGTGGGGGTGAAATTTAATCACTTTGATAGGCGGGGGGTGTAAGAGCTGTGAGGTTTTTAGCTGACC B590Ahur08 GTAAAGTTTTCAGTGGGGGTGAAATTTAATCACTTTGATAGGCGGGGGGTGTAAGAGCTGTGAGGTTTTTAGCTGACC B228Wait09 GTAAAGTTTTCAGTGGGGGTGAAATTTAATCACTTTGATAGGCGGGGGGTGTAAGAGCTGTGAGGTTTTTAGCTGACC B220Wait10 GTAAAGTTTTCAGTGGGGGTGAAATTTAATCACTTTGATAGGCGGGGGGTGTAAGAGCTGTGAGGTTTTTAGCTGACC A679Waik11 GTaAAGTTTTCAGTGGGGGTGAAATTTAATCACTTTGATAGGCGGGGGGTGTAAGAGCTGTGAGGTTTTTAGCTGACC B255Rive12 GTAAAGTTTTCAGTGGGGGTGAAATTTAATCACTTTGATAGGCGGGGGGTGTAAGAGCTGTGAGGTTTTTAGCTGACC A865Leig13 GTAAAGTTTTCAGTGGGGGTGAAATTTAATCACTTTGATAGGCGGGGGGTGTAAGAGCTGTGAGGTTTTTAGCTGACC B392Math14 GTAAAGTTTTCAGTGGGGGTGAAATTTAATCACTTTGATAGGCGGGGGGTGTAAGAGCTGTGAGGTTTTTAGCTGACC A847Mara14 GTAAAGTTTTCAGTGGGGGTGAAATTTAATCACTTTGATAGGCGGGGGGTGTAAGAGCTGTGAGGTTTTTAGCTGACC A809Hybr15 GTAAAGTTTTCAGTGGGGGTGAAATTTAATCACTTTGATAGGCGGGGGGTGTAAGAGCTGTGAGGt TTTTAGCTGACC A808Hybr15 GTAAAGTTTTCAGTGGGGGTGAAATTTAATCACTTTGATAGGCGGGGGGTGTAAGAGCTGTGAGGt TTTTAGCTGACC A835Mara16 GTAAAGTTTTCAGTGGGGGTGAAATTTAATCACTTTGATAGGCGGGGGGTGTAAGAGCTGTGAGGTTTTTAGCTGACC A791Mara17 GTAAAGTTTTCAGTGGGGGTGAAATTTAATCACTTTGATAGGCGGGGGGTGTAAGAGCTGTGAGGTTTTTAGCTGACC A855Mara18 GTAAAGTTTTCAGTGGGGGTGAAATTTAATCACTTTGATAGGCGGGGGGTGTAAGAGCTGTGAGGTTTTTAGCTGACC A795Mara19 GTAAAGTTTTCAGTGGGGGTGAAATTTAATCACTTTGATAGGCGGGGGGTGTAAGAGCTGTGAGGTTTTTAGCTGACC B041Sail20 GTAAAGTTTTCAGTGGGGGTGAAATTTAATCACTTTGATAGGCGGGGGGTGTAAGAGCTGTGAGGTTTTTAGCTGACC A399step21 GTAAAGTTTTCAGTGGGGGTGAAATTTAATCACTTTGATAGGCGGGGGGTGTAAGAGCTGTGAGGTTTTTAGCTGACC A9380tan22 GTaAAGTTTTCAGTGGGGGTGAAATTTAATCACTTTGATAGGCGGGGGGTGTAAGAGCTGTGAGGTTTTTAGCTGACC A799Cang23 GTAAAGTTTTCAGTGGGGGTGAAATTTAATCACTTTGATAGGCGGGGGGTGTAAGAGCTGTGAGGt TTTTAGCTGACC B289Dors24 GTAAAGTTTTCAGTGGGGGTGAAATTTAATCACTTTGATAGGCGGGGGGTGTAAGAGCTGTGAGGTTTTTAGCTGACC B031Sail25 GTAAAGTTTTCAGTGGGGGTGAAATTTAATCACTTTGATAGGCGGGGGGTGTAAGAGCTGTGAGGTTTTTAGCTGACC A9400tan26 GTAAAGTTTTCAGTGGGGGTGAAATTTAATCACTTTGATAGGCGGGGGGTGTAAGAGCTGTGAGGTTTTTAGCTGACC B032Sail27 GTAAAGTTTTCAGTGGGGGTGAAATTTAATCACTTTGATAGGCGGGGGGTGTAAGAGCTGTGAGGTTTTTAGCTGACC B034Sail28 GTAAAGTTTTCAGTGGGGGTGAAATTTAATCACTTTGATAGGCGGGGGGTGTAAGAGCTGTGAGGTTTTTAGCTGACC B033Sail29 GTAAAGTTTTCAGTGGGGGTGAAATTTAATCACTTTGATAGGCGGGGGGTGTAAGAGCTGTGAGGTTTTTAGCTGACC A422NCap30 GTAAAGTTTTCAGTGGGGGTGAAATTTAATCACTTTGATAGGCGGGGGGTGTAAGAGCTGTGAGGTTTTTAGCTGACC A420NCap31 GTAAAGTTTTCAGTGGGGGTGAAATTTAATCACTTTGATAGGCGGGGGGTGTAAGAGCTGTGAGGTTTTTAGCTGACC A421NCap32 GTAAAGTTTTCAGTGGGGGTGAAATTTAATCACTTTGATAGGCGGGGGGTGTAAGAGCTGTGAGGTTTTTAGCTGACC A374 Weka33 GTAAAGTTTTCAGTGGGGGTGAAATTTAATCACTTTGATAGGCGGGGGGTGTAAGAGCTGTGAGGTTTTTAGCTGACC A890Hoop34 GTAAAGTTTTCAGTGGGGGTGAAATTTAATCACTTTGATAGGCGGGGGGTGTAAGAGCTGTGAGGTTTTTAGCTGACC B348Whal35 GTAAAGTTTTCAGTGGGGGTGAAATTTAATCACTTTGATAGGCGGGGGGTGTAAGAGCTGTGAGGTTTTTAGCTGACC A344Cang36 GTAAAGTTTTCAGTGGGGGTGAAATTTAATCCCTTTGATAGGCGGGGGGTGTAAGAGCTGTGAGGTTTTTAGCTGACC B315Whal37 GTAAAGTTTTCAGTGGGGGTGAAATTTAATCACTTTGATAGGCGGGGGGTGTAAGAGCTGTGAGGTTTTTAGCTGACC A834Mara38 GTAAAGTTTTCAGTGGGGGTGAAATTTAATCACTTTGATAGGCGGGGGGTGTAAGAGCTGTGAGGTTTTTAGCTGACC B223Wait39 GTAAAGTTTTCAGTGGGGGTGAAATTTAATCACTTTGATAGGCGGgGGgTGTAAGAGCTGTGAGGTTTTTAGCTGACC B367Ahip40 GTAAAGTTTTCAGTGGGGGTGAAATTTAATCACTTTGATAGGCGGGGGGTGTAAGAGCTGTGAGGTTTTTAGCTGACC A9470tan43 GTAAAGTTTTCAGTGGGGGTGAAATTTAATCACTTTGATAGGCGGGGGGTGTAAGAGCTGTGAGGTTTTTAGCTGACC A555Cang4 4 GTAAAGTTTTCAGTGGGGGTGAAATTTAATCACTTTGATAGGCGGGGGGTGTAAGAGCTGTGAGGTTTTTAGCTGACC A566Fras45 GTAAAGTTTTCAGTGGGGGTGAAATTTAATCACTTTGATAGGCGGGGGGTGTAAGAGCTGTGAGGTTTTTAGCTGACC A932SGhy46 GTAAAGTTTTCAGTGGGGGTGAAATTTAATCACTTTGATAGGCGGGGGGTGTAAGAGCTGTGAGGTTTTTAGCTGACC A353Weka47 GTAAAGTTTTCAGTGGGGGTGAAATTTAATCACTTTGATAGGCGGGGGGTGTAAGAGCTGTGAGGTTTTTAGCTGACC A801Cang 48 GTAAAGTTTTCAGTGGGGGTGAAATTTAATCACTTTGATAGGCGGGGGGTGTAAGAGCTGTGAGGtTTTTAGCTGACC A378Cang49 GTAAAGTTTTCAGTGGGGGTGAAATTTAATCACTTTGATAGGCGGGGGGTGTAAGAGCTGTGAGGTTTTTAGCTGACC A356Weka50 GTAAAGTTTTCAGTGGGGGTGAAATTTAATCACTTTGATAGGCGGGGGGTGTAAGAGCTGTGAGGTTTTTAGCTGACC B499Horo52 GTAAAGTTTTCAGTGGGGGTGAAATTTAATCACTTTGATAGGCGGGGGGTGTAAGAGCTGTGAGGTTTTTAGCTGACC A408Cang53 GTAAAGTTTTCAGTGGGGGTGAAATTTAATCACTTTGATAGGCGGGGGGTGTAAGAGCTGTGAGGTTTTTAGCTGACC B378Math55 GTAAAGTTTTCAGTGGGGGTGAAATTTAATCACTTTGATAGGCGGGGGGTGTAAGAGCTGTGAGGTTTTTAGCTGACC B379Math56 GTAAAGTTTTCAGTGGGGGTGAAATTTAATCACTTTGATAGGCGGGGGGTGTAAGAGCTGTGAGGTTTTTAGCTGACC B394Math57 GTAAAGTTTTCAGTGGGGGTGAAATTTAATCACTTTGATAGGCGGGGGGTGTAAGAGCTGTGAGGTTTTTAGCTGACC B501Make58 GTAAAGTTTTCAGTGGGGGTGAAATTTAATCACTTTGATAGGCGGGGGGTGTAAGAGCTGTGAGGTTTTTAGCTGACC B521Make59 GTAAAGTTTTCAGTGGGGGTGAAATTTAATCACTTTGATAGGCGGGGGGTGTAAGAGCTGTGAGGTTTTTAGCTGACC B507Make60 GTAAAGTTTTCAGTGGGGGTGAAATTTAATCACTTTGATAGGCGGGGGGTGTAAGAGCTGTGAGGTTTTTAGCTGACC B500Horo61 GTAAAGTTTTCAGTGGGGGTGAAATTTAATCACTTTGATAGGCGGGGGGTGTAAGAGCTGTGAGGTTTTTAGCTGACC B487Horo62 GTAAAGTTTTCAGTGGGGGTGAAATTTAATCACTTTGATAGGCGGGGGGTGTAAGAGCTGTGAGGTTTTTAGCTGACC B435Kait63 GTAAAGTTTTCAGTGGGGGTGAAATTTAATCACTTTGATAGGCGGGGGGTGTAAGAGCTGTGAGGTTTTTAGCTGACC B490Horo64 GTAAAGTTTTCAGTGGGGGTGAAATTTAATCACTTTGATAGGCGGGGGGTGTAAGAGCTGTGAGGTTTTTAGCTGACC A901Hoop65 GTAAAGTTTTCAGTGGGGGTGAAATTTAATCACTTTGATAGGCGGGGGGTGTAAGAGCTGTGAGGTTTTTAGCTGACC B377Math66 GTAAAGTTTTCAGTGGGGGTGAAATTTAATCACTTTGATAGGCGGGGGGTGTAAGAGCTGTGAGGTTTTTAGCTGACC A885Hoop67 GTAAAGTTTTCAGTGGGGGTGAAATTTAATCACTTTGATAGGCGGGGGGTGTAAGAGCTGTGAGGTTTTTAGCTGACC B454Kait67 GTAAAGTTTTCAGTGGGGGTGAAATTTAATCACTTTGATAGGCGGGGGGTGTAAGAGCTGTGAGGTTTTTAGCTGACC B525Mati 68 GTAAAGTTTTCAGTGGGGGTGAAATTTAATCACTTTGATAGGCGGGGGGTGTAAGAGCTGTGAGGTTTTTAGCTGACC B5650pap69 GTAAAGTTTTCAGTGGGGGTGAAATTTAATCACTTTGATAGGCGGGGGGTGTAAGAGCTGTGAGGTTTTTAGCTGACC B035Sail70 GTAAAGTTTTCAGTGGGGGTGAAATTTAATCACTTTGATAGGCGGGGGGTGTAAGAGCTGTGAGGTTTTTAGCTGACC A856Mara71 GTAAAGTTTTCAGTGGGGGTGAAATTTAATCACTTTGATAGGCGGGGGGTGTAAGAGCTGTGAGGTTTTTAGCTGACC A766Mara72 GTAAAGTTTTCAGTGGGGGTGAAATCTAATCACTTTGATAGGCGGGGGGTGTAAGAGCTGTGAGGTTTTTAGCTGACC 
Appendix 1. (Continued)

B5600pap01 CGTACTAATCCTAAAAAATGTTGAGGCAAATTACTTTTAAGCTAAACACGCGAAACCGTAGGCTAGAGTGTCCTATGT B213Kiri02 CGTACTAATCCTAAAAAATGTTGAGGCAAATTACTTTTAAGCTAAACACACGAAACCCCAGGCTAGAGTGTCCTATGT B051Dors03 CGTACTAATCCTAAAAAATGTTGAGGCAAATTACTTTTAAGCTAAACACGCGAAACCTTAGGCTAGAGTGTCCTATGT A737Kiri04 CGTACTAATCCTAAAAAATGTTGAGGCAAATTACTTTTAAGCTAAACACGCGAAACCGTGGGCTAGAGTGTCCTATGT A738Kiri05 CGTACTAATCCTAAAAAATGTTGAGGCAAATTACTTTTAAGCTAAACACGCGAAACCGTAGGCTAGATTGTCCTATGT B307Whal06 CGTACTAATCCTAAAAAATGTTGAGGCAAATTACTTTTAAGCTAAACACGCGAAACCGTAGGCTAGGGTGTCCTATGT B256Piha07 CGTACTAATCCTAAAAAATGTTGAGGCAAATTACTTTTAAGCTAAACACGCGAAACCGTAGACTAGAGTGTCCTATGT B590Ahur08 CGTACTAATCCTAAAAAATATTGAGGCAAATTACTTTTAAGCTAAACACGCGAAACCGCAGACTAGAGTGTCCTATGT B228Wait09 CGTACTAATCCTAAAAAATATTGAGGCAAATTACTTTTAAGCTAAACACGCGAAACCGCAGACTAGAGTGTCCTATGT B220Wait10 CGTACTAATCCTAAAAAATATTGAGGCAAATTACTTTTAAGCTAAACACGCGAAACCGCAGACTAGGGTGTCCTATGT A679Waik11 CGTACTAATCCTAAAAAATATTGAGGCAAATTACCTTTAAGCTAAACACGCGAAACCGCAGACTAGGGTGTCCTATGT B255Rive12 CGTACTAATCCTAAAAAATATTGAGGCAAATTACCTTTAAGCTAAACACGCGAAACCGGAGGCTAGAGTGTCCTATGT A865Leig13 CGTACTAATCCTAAAAAATATTGAGGCAAATTACCTTTAAGCTAAACACGCGAAACCGCAGGCTAGAGTGTCCTATGT B392Math14 CGTACTAATCCTAAAAAATATTGAGGCAAATTACCTTTAAGCTAAACACGCGAAACCGCAGGCTCGAGTGTCCTATGT A 847 Mara14 CGTACTAATCCTAAAAAATATTGAGGCAAATTACCTTTAAGCTAAACACGCGAAACCGCAGGCTCGAGTGTCCTATGT A809Hybr15 CGTACTAATCCTAAAAAATATTGAGGCAAATTACCTTTAGGCTAAACACGCGAAACCGCAGGCTCGAGTGTCCTATGT A808Hybr15 CGTACTAATCCTAAAAAATATTGAGGCAAATTACCTTTAGGCTAAACACGCGAAACCGCAGGCTCGAGTGTCCTATGT A835Mara16 CGTACTAATCCTAAAAAATATTGAGGCAAATTACCTTTAAGCTAAACATGCGAAACCGCAGGCTCGAGTGTCCTATGT A791Mara17 CGTACTAATCCTAAAAAATATTGAGGCAAATTATCTTTAAGCTAAACATGCGAAACCGCAGGCTCGAGTGTCCTATGT A855Mara18 CGTACTAATCCTAAGAAATATTGAGGCAAATTACCTTTAAGCTAAACACGCGAAACCGCAGGCTCGAGTGTCCTATGT A795Mara19 CGTACTAATCCTAAAAAATATTGAGGCAAATTACCTTTAAGCTAAACACGCGAAACCGCGGGCTCGAGTGTCCTATGT B041Sail20 CGTACTAATCCTAAAAAATATTGAGGCAAATTGCCTTTAAGCTAAACACGCGAAACCGCGGGCTCGAGTGTCCTATGT A399Step21 CGTACTAATCCTAAAAAATATTGAGGCAAATTATCTTTAAGCTAAACACGCGAAACCGTAGGCTCGAGTGTCCTATGT A9380tan22 CGTACTAATCCTAAAAAATATTGAGGCAAATTATCTTTAAACTAAACACGCGAAACCGTAGGCTCGAGTGTCCTATGT A799Cang23 CGTACTAATCCTAAAAAATATTGAGGCAAATTATTTTTAAGCTAAACACGCGAAACCGTAGGCTCGAGTGTCCTATGT B289Dors24 CGTACTAATCCTAAAAAATATTGAGGCAAATTATATTTAAGCTAAACACGCGAAACCGTAGGCCCGAGTGTCCTATGT B031Sail25 CGTACTAATCCTAAAAAATATTGAGGCAAATTACGCTTAAGCTAAACACGCGAAACCGTAGGCTCGAGTGTCCTATGT A9400tan26 CGTACTAATCCTAAAAAATATTGAGGCAAATAACGTTTAAGCTAAACACGCGAAACCGTAGGCTCGAGTGTCCTATGT B032Sail27 CGTACTAATCCTAAAAAATATTGAGGCAAATCACCTTTAAGCTAAACACGCGAAACCGCAGGCTCGAGTGTCCTATGT B034Sail28 CGTACTAATCCTAAAAAATATTGAGGCAAATCGCCTTTAAGCTAAACACGCGAAACCGCAGGCTCGAGTGTCCTATGT B033Sail29 CGTACTAATCCTAAAAAATATTGAGGCAAATAGTCTTTAAGCTAAACACGCGAAACCGCAGGCTCGAGTGTCCTATGT A422NCap30 CGTACTAATCCTAAAAAATATTGAGTCAAATAACTTTTAAGCTAAACACGCGAAACCGTCGGCCCGGGTGTCCTATGT A420NCap31 CGTACTAATCCTAAAAAATATTGAGTCAAATAACTTTTAAGCTAAACATGCGAAACCGTCGGCCCGGGTGTCCTATGT A421NCap32 CGTACTAATCCTAAAAAATATTGAGTCAAATAAATTTTAAGCTAAACACGCGAAACCGTCGGCCCGGGTGTCCTATGT A374Weka33 CGTACTAATCCTAAAAAATATTGAGTCAAATAACTTTTAGGCTAAACACGCGAAACCGTCGGCCCGGGTGTCCTATGT A890Hoop34 CGTACTAATCCTAAAAAATATTGAGGCAAATTACTTTTAAGCTAAACACGCGAAACCGCCTGACCAGGTGTCCTATGT B348Wha135 CGTACTAATCCTAAAAAATGTTGAGGCAAATTAC-TTTAAGCTAAACACGCGAAACCGTAGGCTAGAGTGTCCTATGT A344Cang36 CGTACTAATCCTAAAAAATGTTGAGGCAAATTACTTTTAAGCTAAACACGCGAAACCGTAGGCTAGAGTGTCCTATGT B315Whal37 CGTACTAATCCTAAAAAATGTTGAGGCAAATTACTTTTAAGCTAAACACGCGAAACCGCAGGCTAGAGTGTCCTATGT A834Mara38 CGTACTAATCCTAAAAAATATTGAGGCAAAGTACCTTTAAGCTAAACACGCGAAACCGCAGGCTCGAGTGTCCTATGT B223Wait39 CGTACTAATCCTAAAAAATATTGAGGCAAATTACCTTTAGGCTAAACACGCGAAACCGTAGGCTAGCGTGTCCTATGT B367Ahip40 CGTACTAATCCTAAAAAATATTGAGGCAAATTATCTTTAAGCTAAACACGCGAAACCGCAGGCTCGAGTGTCCTATGT A9470tan43 CGTACTAATCCTAAAAAATATTGAGGCAAATAGCCTTTAAGCTAAACACGCGAAACCGCAGGCTCGAGTGTCCTATGT A555Cang4 4 CGTACTAATCCTAAAAAATATTGAGGCAAATTACTTTTAAGCTAAACATGCGAAACCGCCCGCACGGGTGTCCTATGT A566Fras 45 CGTACTAATCCTAAAAAATATTGAGGCAAATTACTTTTAAGCTAAACATGCGAAACCGCCCGCACAGGTGTCCTATGT A932SGhy 6 CGTACTAATCCTAAAAAATATTGAGGCAAATTACTTTTAAGCTAAACATGCGAAACCACCTGCACAGGTGTCCTATGT A353Weka47 CGTACTAATCCTAAAAAATATTGAGGCAAATTACTTTTAAGCTAAACATGCGAAACCGCCCACACAGGTGTCCTATGT A801Cang 48 CGTACTAATCCTAAAAAATATTGAGGCAAATCACTTTTAGGCTAAACACGCGAAACCGCCCGCACATGTGTCCTATGT A378Cang 49 CGTACTAATCCTAAAAAATATTGAGGCAAATCGCTTTTAAGCTAAACACGCGAAACCGCCTGCATAGGTGTCCCATGT A356Weka50 CGTACTAATCCTAAAAAATATTGAGGCAAATTACTTTTAAGCTAAACATGCGAAACCGCCTACAAAGGACACCTGTGT B499Horo52 CGTACTAATCCTAAAAAATATTGAGGCAAATTATCTTTAAGCTAAACACGCGAAACCGCAGGCTCGAGTGTCCTATGT A408Cang53 CGTACTAATCCTAAAAAATATTGAGGCAAATCACTTTTAAGCTAAACACGCGAAACCGTACACACAGGGCACCTGTGT B378Math55 CGTACTAATCCTAAAAAATGTTGAGGCAAATTACTTTTAGGCTAAACACGCGAAACCGTGGGCTAGAGTGTCCTATGT B379Math56 CGTACTAATCCTAAAAAATATTGAGGCAAATTACCTTTAAGCTAAACACGCGAAACCGTAGGCTAGAGTGTCCTATGT B394Math57 CGTACTAATCCTAAAAAATATTGAGGCAAATTACCTTTAAGCTAAACAAGCGAAACCGCAGGCTAGAGTGTCCTATGT B501Make58 CGTACTAATCCTAAAAAATATTGAGGCAAATCACCTTTAAGCTAAACACGCGAAACCGTAGGCTCGAGTGTCCTATGT B521Make59 CGTACTAATCCTAAAAAATATTGAGGCAAATCACCTTTAAGCTAAACATGCGAAACCGTAGGCTCGAGTGTCCTATGT B507Make60 CGTACTAATCCTAAAAAATATTGAGGCAAATCACC-TTAAGCTAAACATGCGAAACCGTAGGCTCGAGTGTCCTATGT B500Horo61 CGTACTAATCCTAAAAAATATTGAGGCAAATTACGCTTAAGCTAAACACGCGAAACCGTAGGCTCGGGTGTCCTATGT B487Horo62 CGTACTAATCCTAAAAAATATTGAGGCAAATTACGCTTAAGCTAAACACGCGAAACCGTGGGCTCGGGTGTCCTATGT B435Kait63 CGTACTAATCCTAAAAAATATTGAGGCAAATTATCTTTAAGCTAAACACGCGAAACCGTACGCTCGAGTGTCCTATGT B490Horo64 CGTACTAATCCTAAAAAATATTGAGGCAACTTATCTTTAAGCTAAACACGCGAAACCGTAGGCTCGAGTGTCCTATGT A901Hoop65 CGTACTAATCCTAAAAAATATTGAGGCAAATTACTTTTAAGCTAAACACGCGAAACCACCTGACCAGGTGTCCTATGT B377Math66 CGTACTAATCCTAAAAAATATTGAGGCAAATTACTTTTAGGCTAAACACGCGAAACCGCCTGACCAGGTGTCCTATGT A885Hoop 67 CGTACTAATCCTAAAAAATATTGAGGCAAATTACTTTTAAGCTAAACACGCGAAACCGCCTGACCAGGTGTCCTATGT B454Kait 67 CGTACTAATCCTAAAAAATATTGAGGCAAATTACTTTTAAGCTAAACACGCGAAACCGCCTGACCAGGTGTCCTATGT B525Mati 68 CGTACTAATCCTAAAAAATATTGAGGCAAATTATCTTTAAGCTAAACACGCGAAACCGTAGGCTCGAGTGTCCTATGT B5650pap69 CGTACTAATCCTAAAAAATATTGAGGCAAATTACCTTTAAGCTAAGCACGCGAAACCGCAGGCTCGAGTGTCCTATGT B035Sail70 CGTACTAATCCTAAAAAATATTGAGGCAAATCGCCTTTAAGCTAAACACGCGAAACCGCGGGCTCGAGTGTCCTATGT A856Mara71 CGTACTAATCCTAAAAAATATTGAGGCAAATTACCTTTAAGATAAACACGCGAAACCGCAGGCTCGAGTGTCCTATGT A766Mara72 CGTACTAATCCTAAAAAATATTGAGGCAAATTACCTTTAAGCTAAACATGCGAAACCGCAGGCTCGAGTGTCCTATGT 
Appendix 1. (Continued)

B5600pap01 GCCTCTATTTAAATTTTTAATCAAAGTAAAGTTATGTCCGTATTTTTTTTTTTTGAACGTAGTTTACC B213Kiri02 GCCTCTATTTAAATTTTTAATCAAAGTAAAGTTATGTCCGTATTTTTTTTTTTTGAACGTAGTTTACC B051Dors03 GCCTCTATTTAAATTTTTAATCAAAGTAAAGTTATGTCCGTATTTTTTTTTTTTGAACGTAGTTTaCC A737Kiri04 GCCTCTATTTAAATTTTTAATCAAAGTAAAGTTATGTCCGTATTTTTTTTTTTTGAACGTAGTTTACC A738Kiri05 GCCTCTATTTAAATTTTTAATCAAAGTAAAGTTATGTCCGTATTTTTTTTTTTTGAACGTAGTTTACC B307Whal06 GCCTCTATTTAAATTTTTAATCAAAGTAAAGTTATGTCCGTATTTTTTTTTTTTGAACGTAGTTTACC B256Piha07 GCCTCTATTTAAATTTTTAATCAAAGTAAAGTTATGTCCGTATTTTTTTTTTTTGAACGTAGTTTACC B590Ahur08 GCCTCTATTTAAATTTTTAATCAAAGTAAAGTTATGTCCGTATTTTTTTTTTTTGAACGTAGTTTACC B228Wait09 GCTTCTATTTAAATTTTTAATCAAAGTAAAGTTATGTCCGTATTTTTTTTTTTTGAACGTAGTTTaCC B220Wait10 GCTTCTATTTAAATTTTTAATCAAAGTAAAGTTATGTCCGTATTTTTTTTTTTTGAACGTAGTTTACC A679Waik11 GCCTCTATTTAAATTTTTAATCAAAGTAAAGTTATGTCCGTATTTTTTTTTTTTGAACGTAGTTTaCC B255Rive12 GCCTCTATTTAAATTTTTAATCAAAGTAAAGTTATGTCCGTATTTTTTTTTTTTGAACGTAGTTTACC A865Leig13 GCCTCTATTTAAATTTTTAATCAAAGTAAAGTTATGTCCGTATTTTTTTTTTTTGAACGTAGTTTACC B392Math14 GCCTCTATTTAAATTTTTAATCAAAGTAAAGTTATGTCCGTATTTTTTTTTTTTGAACGTAGTTTACC A847Mara14 GCCTCTATTTAAATTTTTAATCAAAGTAAAGTTATGTCCGTATTTTTTTTTTTTGAACGTAGTTTACC A809Hybr15 GCCTCTATTTAAATTTTTAATCAAAGTAAAGTTATGTCCGTATTTTTTTTTTTTGAACGTAGTTTACC A808Hybr15 GCCTCTATTTAAATTTTTAATCAAAGTAAAGTTATGTCCGTATTTTTTTTTTTTGAACGTAGTTTACC A835Mara16 GCCTCTATTTAAATTTTTAATCAAAGTAAAGTTATGTCCGTATTTTTTTTTTTTGAACGTAGTTTACC A791Mara17 GCCTCTATTTAAATTTTTAATCAAAGTAAAGTTATGTCCGTATTTTTTTTTTTTGAACGTAGTTTACC A855Mara18 GCCTCTATTTAAATTTTTAATCAAAGTAAAGTTATGTCCGTATTTTTTTTTTTTGAACGTAGTTTACC A795Mara19 GCCTCTATTTAAATTTTTAATCAAAGTAAAGTTATGTCCGTATTTTTTTTTTTTGAACGTAGTTTACC B041Sail20 GCCTCTATTTAAATTTTTAATCAAAGTAAAGTTATGTCCGTATTTTTTTTTTTTGAACGTAGTTTACC A399Step21 GCCTCTATTTAAATTTTTAATCAAAGTGAAGTTATGTCCGTATTTTTTTTTTTTGAACGTAGTTTACC A9380tan22 GCCTCTATTTAAATTTTTAATCAAAGTGAAGTTATGTCCGTATTTTTTTTTTTTGAACGTAGTTTACC A799Cang23 GCCTCTATTTAAATTTTTAATCAAAGTGAAGTTATGTCCGTATTTTTTTTTTTTGAACGTAGTTTACC B289Dors24 GCCTCTATTTAAATTTTTAATCAAAGTGAAGTTATGTCCGTATTTTTTTTTTTTGAACGTAGTTTACC B031Sail25 GCCTCTATTTAAATTTTTAATCAAAGTAAAGTTATGTCCGTATTTTTTTTTTTTGAACGTAGTTTACC A9400tan26 GCCTCTATTTAAATTTTTAATCAAAGTAAAGTTATGTCCGTATTTTTTTTTTTTGAACGTAGTTTACC B032Sail27 GCCTCTATTTAAATTTTTAATCAAAGTAAAGTTATGTCCGTATTTTTTTTTTTTGAACGTAGTTTACC B034Sail28 GCCTCTATTTAAATTTTTAATCAAAGTAAAGTTATGTCCGTATTTTTTTTTTTTGAACGTAGTTTACC B033Sail29 GCCTCTATTTAAATTTTTAATCAAAGTAAAGTTATGTCCGTATTTTTTTTTTTTGAACGTAGTTTACC A422NCap30 GCCTCTATTTAAATTTTTAATCAAAGTAAAGTTATGTCCGTATTTTTTTTTTTTGAACGTAGTTTACC A420NCap31 GCCTCTATTTAAATTTTTAATCAAAGTAAAGTTATGTCCGTATTTTTTTTTTTTGAACGTAGTTTACC A421NCap32 GCCTCTATTTAAATTTTTAATCAAAGTAAAGTTATGTCCGTATTTTTTTTTTTTGAACGTAGTTTaCC A374Weka33 GCCTCTATTTAAATTTTTAATCAAAGTAAAGTTATGTCCGTATTTTTTTTTTTTGAACGTAGTTTACC A890Hoop34 GGCTTTATTTAAATTTTTAATCAAAGTAAAGTTATGTCCGTATTTTTTTTTTTTGAACGtAgTTTaCC B348Whal35 GCCTCTATTTAAATTTTTAATCAAAGTAAAGTTATGTCCGTATTTTTTTTTTTTGAACGTAGTTTaCC A344Cang36 GCCTCTATTTAAATTTTTAATCAAAGTAAAGTTATGTCCGTATTTTTTTTTTTTGAACGTAGTTTACC B315Whal37 GCCTCTATTTAAATTTTTAATCAAAGTAAAGTTATGTCCGTATTTTTTTTTTTTGAACGTAGTTTaCC A834Mara38 GCCTCTATTTAAATTTTTAATCAAAGTAAAGTTATGTCCGTATTTTTTTTTTTTGAACGTAGTTTACC B223Wait39 GCCTCTaTTTAAATTTTTAATCAAAGTGAAGTTATGTCCGTATTTTTTTTTTTTGAACGTAGTTTACC B367Ahip40 GCCTCTATTTAAATTTTTAATCAAAGTGAAGTTATGTCCGTATTTTTTTTTTTTGAACGTAGTTTACC A9470tan43 GCCTCTATTTAAATTTTTAATCAAAGTAAAGTTATGTCCGTATTTTTTTTTTTTGAACGTAGTTTACC A555Cang 44 GGCTCTATTTAAATTTTTAATCAAAGTAAAGTTATGTCCGTATTTTTTTTTTTTGAACGTAGTTTACC A566Fras45 GGCTCTATTTAAATTTTTAATCAAAGTAAAGTTATGTCCGTATTTTTTTTTTTTGAACGTAGTTTACC A932SGhy46 GGCTCTATTTAAATTTTTAATCAAAGTAAAGTTATGTCCGTATTTTTTTTTTTTGAACGTAGTTTaCC A353Weka47 GGCTCTATTTAAATTTTTAATCAAAGTAAAGTTATGTCCGTATTTTTTTTTTTTGAATGTAGTTTACC A801Cang 48 AGCTCTATTTAAATTTTTAATCAAATTAAAGTTATGTCCGTATTTTTTTTTTTTGAACGTAGTTTACC A378Cang 49 GGCTCTATTTAAATTTTTAATCAAAGTAAAGTTATGTCCGTATTTTTTTTTTTTGAACGTAGTTTACC A356Weka50 GGCTCTATTTAAATTTTTAATCAAAGTAAAGTTATGTCCGTATTTTTTTTTTTTGAATGTAGTTTACC B499Horo52 GCCTCTATTTAAATTTTTAATCAAAGTGAAGTTATGTCCGTATTTTTTTTTTTTGAACGTAgTTTACC A408Cang53 GGCTCTATTTAAATTTTTAATCAAAGTAAAGTTATGTCCGTATTTTTTTTTTTTGAACGTAGTTTACC B378Math55 GCCTCTATTTAAATTTTTAATCAAAGTAAAGTTATGTCCGTATTTTTTTTTTTTGAACGTAgTTTACC B379Math56 GCCTCTATTTAAATTTTTAATCAAAGTAAAGTTATGTCCGTATTTTTTTTTTTTGAACGTAgTTTACC B394Math57 GCCTCTATTTAAATTTTTAATCAAAGTAAAGTTATGTCCGTATTTTTTTTTTTTGAACGTAGTTTACC B501Make58 GCCTCTATTTAAATTTTTAATCAAAGTAAAGTTATGTCCGTATTTTTTTTTTTTGAACGTAgTTTACC B521Make59 GCCTCTATTTAAATTTTTAATCAAAGTAAAGTTATGTCCGTATTTTTTTTTTTTGAACGTAgTTTACC B507Make60 GCCTCTATTTAAATTTTTAATCAAAGTAAAGTTATGTCCGTATTTTTTTTTTTTGAACGTAgTTTACC B500Horo61 GCCTCTATTTAAATTTTTAATCAAAGTAAAGTTATGTCCGTATTTTTTTTTTTTGAACGTAGTTTACC B487Horo62 GCCTCTATTTAAATTTTTAATCAAAGTAAAGTTATGTCCGTATTTTTTTTTTTTGAACGTAgTTTACC B435Kait63 GCCTCTATTTAAATTTTTAATCAAAGTGAAGTTATGTCCGTATTTTTTTTTTTTGAACGTAgTTTACC B490Horo64 GCCTCTATTTAAATTTTTAATCAAAGTGAAGTTATGTCCGTATTTTTTTTTTTTGAACGTAgTTTACC A901Hoop65 GGCTTTATTTAAATTTTTAATCAAAGTAAAGTTATGTCCGTATTTTTTTTTTTTGAACGTAgTTTACC B377Math66 GGCTTTATTTAAATTTTTAATCAAAGTAAAGTTATGTCCGTATTTTTTTTTTTTGAACGTAgTTTACC A885Hoop67 GGCTTTATTTAAATTTTTAATCAAAGTAAAGTTATGTCCGTATTTTTTTTTTTTGAACATAGTTTACC B454Kait67 GGCTTTATTTAAATTTTTAATCAAAGTAAAGTTATGTCCGTATTTTTTTTTTTTGAACATAgTTTACC B525Mati68 GCCTCTATTTAAATTTTTAATCAAAGTGAAGTTATGTCCGTATTTTTTTTTTTTGAACGTATTTTACC B5650pap69 GCCTCTATTTAAATTTTTAATCAAAGTAAAGTTATGTCCGTATTTTTTTTTTTTGAACGTAGTTTACC B035Sail70 GCCTCTATTTAAATTTTTAATCAAAGTAAAGTTATGTCCGTATTTTTTTTTTTTGAACGTAGTTTACC A856Mara71 GCCTCTATTTAAATTTTTAATCAAAGTAAAGTTATGTCCGTATTTTTTTTTTTTGAACGTAGTTTACC A766Mara72 GCCTCTATTTAAATTTTTAATCAAAGTAAAGTTATGTCCGTATTTTTTTTTTTTGAACGTAGTTTACC 
7.2 Appendix 2. Alignment of ITS2 sequences from Carpophyllum. Specimen names are truncated as: FieldNumberSpecies [Cangu=C. angustifolium; $\mathrm{Cmasc}=C$. maschalocarpum; Chybr= Carpophyllum hybrid].

A799Cangu ATCATCGAAACTTCGAACGCATCTTGCGCTCCCGGGATATGCCTGGGAGCATGCTTGTCGGGGAGGAGGAGGCGAAAA A801Cangu ATCATCGAAACTTCGAACGCATCTTGCGCTCCCGGGATATGCCTGGGAGCATGCTTGTCGGGGAGGAGGAGGCGAAAA A805Cangu ATCATCGAAACTTCGAACGCATCTTGCGCTCCCGGGATATGCCTGGGAGCATGCTTGTCGGGGAGGAGGAGGCGAAAA A829Cangu ATCATCGAAACTTCGAACGCATCTTGCGCTCCCGGGATATGCCTGGGAGCATGCTTGTCGGGGAGGAGGAGGCGAAAA A845Cangu ATCATCGAAACTTCGAACGCATCTTGCGCTCCCGGGATATGCCTGGGAGCATGCTTGTCGGGGAGGAGGAGGCGAAAA A833Cangu ATCATCGAAACTTCGAACGCATCTTGCGCTCCCGGGATATGCCTGGGAGCATGCTTGTCGGGGAGGAGGAGGCGAAAA A809Chybr ATCATCGAAACTTCGAACGCATCTTGCGCTCCCGGGATATGCCTGGGAGCATGCTTGTCGGGGAGGAGGAGGCGAAAA A758Chybr ATCATCGAAACTTCGAACGCATCTTGCGCTCCCGGGATATGCCTGGGAGCATGCTTGTCGGGGAGGAGGAGGCGAAAA A917Chybr ATCATCGAAACTTCGAACGCATCTTGCGCTCCCGGGATATGCCTGGGAGCATGCTTGTCGGGGAGGAGGAGGCGAAAA A924Chybr ATCATCGAAACTTCGAACGCATCTTGCGCTCCCGGGATATGCCTGGGAGCATGCTTGTCGGGGAGGAGGAGGCGAAAA A922Chybr ATCATCGAAACTTCGAACGCATCTTGCGCTCCCGGGATATGCCTGGGAGCATGCTTGTCGGGGAGGAGGAGGCGAAAA A916Chybr ATCATCGAAACTTCGAACGCATCTTGCGCTCCCGGGATATGCCTGGGAGCATGCTTGTCGGGGAGGAGGAGGCGAAAA A895Chybr ATCATCGAAACTTCGAACGCATCTTGCGCTCCCGGGATATGCCTGGGAGCATGCTTGTCGGGGAGGAGGAGGCGAAAA A909Chybr ATCATCGAAACTTCGAACGCATCTTGCGCTCCCGGGATATGCCTGGGAGCATGCTTGTCGGGGAGGAGGAGGCGAAAA A908Chybr ATCATCGAAACTTCGAACGCATCTTGCGCTCCCGGGATATGCCTGGGAGCATGCTTGTCGGGGAGGAGGAGGCGAAAA A796Cmasc ATCATCGAAACTTCGAACGCATCTTGCGCTCCCGGGATATGCCTGGGAGCATGCTTGTCGGGGAGGAGGAGGCGAAAA A836Cmasc ATCATCGAAACTTCGAACGCATCTTGCGCTCCCGGGATATGCCTGGGAGCATGCTTGTCGGGGAGGAGGAGGCGAAAA A766Cmasc ATCATCGAAACTTCGAACGCATCTTGCGCTCCCGGGATATGCCTGGGAGCATGCTTGTCGGGGAGGAGGAGGCGAAAA A855 Cmasc ATCATCGAAACTTCGAACGCATCTTGCGCTCCCGGGATATGCCTGGGAGCATGCTTGTCGGGGAGGAGGAGGCGAAAA A792Cmasc ATCATCGAAACTTCGAACGCATCTTGCGCTCCCGGGATATGCCTGGGAGCATGCTTGTCGGGGAGGAGGAGGCGAAAA A853Cmasc ATCATCGAAACTTCGAACGCATCTTGCGCTCCCGGGATATGCCTGGGAGCATGCTTGTCGGGGAGGAGGAGGCGAAAA A 725 Cmasc ATCATCGAAACTTCGAACGCATCTTGCGCTCCCGGGATATGCCTGGGAGCATGCTTGTCGGGGAGGAGGAGGCGAAAA A728Cmasc ATCATCGAAACTTCGAACGCATCTTGCGCTCCCGGGATATGCCTGGGAGCATGCTTGTCGGGGAGGAGGAGGCGAAAA A716Cangu ATCATCGAAACTTCGAACGCATCTTGCGCTCCCGGGATATGCCTGGGAGCATGCTTGTCGGGGAGGAGGAGGCGAAAA A713 Cmasc ATCATCGAAACTTCGAACGCATCTTGCGCTCCCGGGATATGCCTGGGAGCATGCTTGTCGGGGAGGAGGAGGCGAAAA A730 Cmasc ATCATCGAAACTTCGAACGCATCTTGCGCTCCCGGGATATGCCTGGGAGCATGCTTGTCGGGGAGGAGGAGGCGAAAA A399 Cmasc ATCATCGAAACTTCGAACGCATCTTGCGCTCCCGGGATATGCCTGGGAGCATGCTTGTCGGGGAGGAGGAGGCGAAAA A345Cangu ATCATCGAAACTTCGAACGCATCTTGCGCTCCCGGGATATGCCTGGGAGCATGCTTGTCGGGGAGGAGGAGGCGAAAA A398Cangu ATCATCGAAACTTCGAACGCATCTTGCGCTCCCGGGATATGCCTGGGAGCATGCTTGTCGGGGAGGAGGAGGCGAAAA A408Cangu ATCATCGAAACTTCGAACGCATCTTGCGCTCCCGGGATATGCCTGGGAGCATGCTTGTCGGGGAGGAGGAGGCGAAAA A659Cangu ATCATCGAAACTTCGAACGCATCTTGCGCTCCCGGGATATGCCTGGGAGCATGCTTGTCGGGGAGGAGGAGGCGAAAA A555Cangu ATCATCGAAACTTCGAACGCATCTTGCGCTCCCGGGATATGCCTGGGAGCATGCTTGTCGGGGAGGAGGAGGCGAAAA A378Cangu ATCATCGAAACTTCGAACGCATCTTGCGCTCCCGGGATATGCCTGGGAGCATGCTTGTCGGGGAGGAGGAGGCGAAAA A379Cangu ATCATCGAAACTTCGAACGCATCTTGCGCTCCCGGGATATGCCTGGGAGCATGCTTGTCGGGGAGGAGGAGGCGAAAA A350Cangu ATCATCGAAACTTCGAACGCATCTTGCGCTCCCGGGATATGCCTGGGAGCATGCTTGTCGGGGAGGAGGAGGCGAAAA A106Cmasc ATCATCGAAACTTCGAACGCATCTTGCGCTCCCGGGATATGCCTGGGAGCATGCTTGTCGGGGAGGAGGAGGCGAAAA A597Cmasc ATCATCGAAACTTCGAACGCATCTTGCGCTCCCGGGATATGCCTGGGAGCATGCTTGTCGGGGAGGAGGAGGCGAAAA A509Cmasc ATCATCGAAACTTCGAACGCATCTTGCGCTCCCGGGATATGCCTGGGAGCATGCTTGTCGGGGAGGAGGAGGCGAAAA A598Cmasc ATCATCGAAACTTCGAACGCATCTTGCGCTCCCGGGATATGCCTGGGAGCATGCTTGTCGGGGAGGAGGAGGCGAAAA A2 43Cmasc ATCATCGAAACTTCGAACGCATCTTGCGCTCCCGGGATATGCCTGGGAGCATGCTTGTCGGGGAGGAGGAGGCGAAAA A2 $40 \mathrm{Cmasc}$ ATCATCGAAACTTCGAACGCATCTTGCGCTCCCGGGATATGCCTGGGAGCATGCTTGTCGGGGAGGAGGAGGCGAAAA A342Cmasc ATCATCGAAACTTCGAACGCATCTTGCGCTCCCGGGATATGCCTGGGAGCATGCTTGTCGGGGAGGAGGAGGCGAAAA A569 Cmasc ATCATCGAAACTTCGAACGCATCTTGCGCTCCCGGGATATGCCTGGGAGCATGCTTGTCGGGGAGGAGGAGGCGAAAA A220 Cmasc ATCATCGAAACTTCGAACGCATCTTGCGCTCCCGGGATATGCCTGGGAGCATGCTTGTCGGGGAGGAGGAGGCGAAAA A111 Cmasc ATCATCGAAACTTCGAACGCATCTTGCGCTCCCGGGATATGCCTGGGAGCATGCTTGTCGGGGAGGAGGAGGCGAAAA A $404 \mathrm{Cmasc}$ ATCATCGAAACTTCGAACGCATCTTGCGCTCCCGGGATATGCCTGGGAGCATGCTTGTCGGGGAGGAGGAGGCGAAAA A418Cmasc ATCATCGAAACTTCGAACGCATCTTGCGCTCCCGGGATATGCCTGGGAGCATGCTTGTCGGGGAGGAGGAGGCGAAAA A389 cmasc ATCATCGAAACTTCGAACGCATCTTGCGCTCCCGGGATATGCCTGGGAGCATGCTTGTCGGGGAGGAGGAGGCGAAAA A353Cmasc ATCATCGAAACTTCGAACGCATCTTGCGCTCCCGGGATATGCCTGGGAGCATGCTTGTCGGGGAGGAGGAGGCGAAAA A575Cmasc ATCATCGAAACTTCGAACGCATCTTGCGCTCCCGGGATATGCCTGGGAGCATGCTTGTCGGGGAGGAGGAGGCGAAAA

A799Cangu ATCGCCCACAGCTTCGGGTTCGATCTCGATCTCGAGGCGGTGGAGCGGACTCTGAGTGTTCCGGGGGGCAGTGGTGCC A801Cangu ATCGCCCACAGCTTCGGGTTCGATCTCGATCTCGAGGCGGTGGAGCGGACTCTGAGTGTTCCGGGGGGCAGTGGTGCC A805Cangu ATCGCCCACAGCTTCGGGTTCGATCTCGATCTCGAGGCGGTGGAGCGGACTCTGAGTGTTCCGGGGGGCAGTGGTGCC A829Cangu ATCGCCCACAGCTTCGGGTTCGATCTCGATCTCGAGGCGGTGGAGCGGACTCTGAGTGTTCCGGGGGGCAGTGGTGCC A845Cangu ATCGCCCACAGCTTCGGGTTCGATCTCGATCTCGAGGCGGTGGAGCGGACTCTGAGTGTTCCGGGGGGCAGTGGTGCC A833Cangu ATCGCCCACAGCTTCGGGTTCGATCTCGATCTCGAGGCGGTGGAGCGGACTCTGAGTGTTCCGGGGGGCAGTGGTGCC A809Chybr ATCGCCCACAGCTTCGGGTTCGATCTCGATCTCGAGGCGGTGGAGCGGACTCTGAGTGTTCCGGGGGGCAGTGGTGCG A758Chybr ATCGCCCACAGCTTCGGGTTCGATCTCGATCTCGAGGCGGTGGAGCGGACTCTGAGTGTTCCGGGGGGCAGTGGTGCG A 917 Chybr ATCGCCCACAGCTTCGGGTTCGATCTCGATCTCGAGGCGGTGGAGCGGACTCTGAGTGTTCCGGGGGGCAGTGGTGCG A924Chybr ATCGCCCACAGCTTCGGGTTCGATCTCGATCTCGAGGCGGTGGAGCGGACTCTGAGTGTTCCGGGGGGCAGTGGTGCG A922Chybr ATCGCCCACAGCTTCGGGTTCGATCTCGATCTCGAGGCGGTGGAGCGGACTCTGAGTGTTCCGGGGGGCAGTGGTGCG A916Chybr ATCGCCCACAGCTTCGGGTTCGATCTCGATCTCGAGGCGGTGGAGCGGACTCTGAGTGTTCCGGGGGGCAGTGGtGCG A895Chybr ATCGCCCACAGCTTCGGGTTCGATCTCGATCTCGAGGCGGTGGAGCGGACTCTGAGTGTTCCGGGGGGCAGTGGTGCG A909Chybr ATCGCCCACAGCTTCGGGTTCGATCTCGATCTCGAGGCGGTGGAGCGGACTCTGAGTGTTCCGGGGGGCAGTGGTGCG A908Chybr ATCGCCCACAGCTTCGGGTTCGATCTCGATCTCGAGGCGGTGGAGCGGACTCTGAGTGTTCCGGGGGGCAGTGGTGCG A 796 Cmasc ATCGCCCACAGCTTCGGGTTCGATCTCGATCTCGAGGCGGTGGAGCGGACTCTGAGTGTTCCGGGGGGCAGTGGTGCG A836Cmasc ATCGCCCACAGCTTCGGGTTCGATCTCGATCTCGAGGCGGTGGAGCGGACTCTGAGTGTTCCGGGGGGCAGTGGTGCG A766 Cmasc ATCGCCCACAGCTTCGGGTTCGATCTCGATCTCGAGGCGGTGGAGCGGACTCTGAGTGTTCCGGGGGGCAGTGGTGCG A855Cmasc ATCGCCCACAGCTTCGGGTTCGATCTCGATCTCGAGGCGGTGGAGCGGACTCTGAGTGTTCCGGGGGGCAGTGGTGCG A792Cmasc ATCGCCCACAGCTTCGGGTTCGATCTCGATCTCGAGGCGGTGGAGCGGACTCTGAGTGTTCCGGGGGGCAGTGGTGCG A853Cmasc ATCGCCCACAGCTTCGGGTTCGATCTCGATCTCGAGGCGGTGGAGCGGACTCTGAGTGTTCCGGGGGGCAGTGGTGCG 
Appendix 2. (Continued)

A725Cmasc ATCGCCCACAGCTTCGGGTTCGATCTCGATCTCGAGGCGGTGGAGCGGACTCTGAGTGTTCCGGGGGGCAGTGGTGCG A728Cmasc ATCGCCCACAGCTTCGGGTTCGATCTCGATCTCGAGGCGGTGGAGCGGACTCTGAGTGTTCCGGGGGGCAGTGGTGCG A716Cangu ATCGCCCACAGCTTCGGGTTCGATCTCGATCTCGAGGCGGTGGAGCGGACTCTGAGTGTTCCGGGGGGCAGTGGTGCG A713CmasC ATCGCCCACAGCTTCGGGTTCGATCTCGATCTCGAGGCGGTGGAGCGGACTCTGAGTGTTCCGGGGGGCAGTGGTGCC A730Cmasc ATCGCCCACAGCTTCGGGTTCGATCTCGATCTCGAGGCGGTGGAGCGGACTCTGAGTGTTCCGGGGGGCAGTGGTGCG A399Cmasc ATCGCCCACAGCTTCGGGTTCGATCTCGATCTCGAGGCGGTGGAGCGGACTCTGAGTGTTCCGGGGGGCAGTGGTGCG A345Cangu ATCGCCCACAGCTTCGGGTTCGATCTCGATCTCGAGGCGGTGGAGCGGACTCTGAGTGTTCCGGGGGGCAGTGGTGCG A398Cangu ATCGCCCACAGCTTCGGGTTCGATCTCGATCTCGAGGCGGTGGAGCGGACTCTGAGTGTTCCGGGGGGCAGTGGTGCC A408Cangu ATCGCCCACAGCTTCGGGTTCGATCTCGATCTCGAGGCGGTGGAGCGGACTCTGAGTGTTCCGGGGGGCAGTGGTGCC A659Cangu ATCGCCCACAGCTTCGGGTTCGATCTCGATCTCGAGGCGGTGGAGCGGACTCTGAGTGTTCCGGGGGGCAGTGGTGCC A555Cangu ATCGCCCACAGCTTCGGGTTCGATCTCGATCTCGAGGCGGTGGAGCGGACTCTGAGTGTTCCGGGGGGCAGTGGTGCC A378Cangu ATCGCCCACAGCTTCGGGTTCGATCTCGATCTCGAGGCGGTGGAGCGGACTCTGAGTGTTCCGGGGGGCAGTGGTGCC A379Cangu ATCGCCCACAGCTTCGGGTTCGATCTCGATCTCGAGGCGGTGGAGCGGACTCTGAGTGTTCCGGGGGGCAGTGGTGCC A350Cangu ATCGCCCACAGCTTCGGGTTCGATCTCGATCTCGAGGCGGTGGAGCGGACTCTGAGTGTTCCGGGGGGCAGTGGTGCC A106Cmasc ATCGCCCACAGCTTCGGGTTCGATCTCGATCTCGAGGCGGTGGAGCGGACTCTGAGTGTTCCGGGGGGCAGTGGTGCG A597Cmasc ATCGCCCACAGCTTCGGGTTCGATCTCGATCTCGAGGCGGTGGAGCGGACTCTGAGTGTTCCGGGGGGCAGTGGTGCG A509 Cmasc ATCGCCCACAGCTTCGGGTTCGATCTCGATCTCGAGGCGGTGGAGCGGACTCTGAGTGTTCCGGGGGGCAGTGGTGCG A598Cmasc ATCGCCCACAGCTTCGGGTTCGATCTCGATCTCGAGGCGGTGGAGCGGACTCTGAGTGTTCCGGGGGGCAGTGGTGCG A2 43Cmasc ATCGCCCACAGCTTCGGGTTCGATCTCGATCTCGAGGCGGTGGAGCGGACTCTGAGTGTTCCGGGGGGCAGTGGTGCG A240Cmasc ATCGCCCACAGCTTCGGGTTCGATCTCGATCTCGAGGCGGTGGAGCGGACTCTGAGTGTTCCGGGGGGCAGTGGTGCG A342Cmasc ATCGCCCACAGCTTCGGGTTCGATCTCGATCTCGAGGCGGTGGAGCGGACTCTGAGTGTTCCGGGGGGCAGTGGTGCG A569 Cmasc ATCGCCCACAGCTTCGGGTTCGATCTCGATCTCGAGGCGGTGGAGCGGACTCTGAGTGTTCCGGGGGGCAGTGGTGCG A220Cmasc ATCGCCCACAGCTTCGGGTTCGATCTCGATCTCGAGGCGGTGGAGCGGACTCTGAGTGTTCCGGGGGGCAGTGGTGCG A111Cmasc ATCGCCCACAGCTTCGGGTTCGATCTCGATCTCGAGGCGGTGGAGCGGACTCTGAGTGTTCCGGGGGGCAGTGGTGCG A404Cmasc ATCGCCCACAGCTTCGGGTTCGATCTCGATCTCGAGGCGGTGGAGCGGACTCTGAGTGTTCCGGGGGGCAGTGGCGCG A418Cmasc ATCGCCCACAGCTTCGGGTTCGATCTCGATCTCGAGGCGGTGGAGCGGACTCTGAGTGTTCCGGGGGGCAGTGGYGCG A389Cmasc ATCGCCCACAGCTTCGGGTTCGATCTCGATCTCGAGGCGGTGGAGCGGACTCTGAGTGTTCCGGGGGGCAGTGGTGCG A353Cmasc ATCGCCCACAGCTTCGGGTTCGATCTCGATCTCGAGGCGGTGGAGCGGACTCTGAGTGTTCCGGGGGGCAGTGGTGCG A575Cmasc ATCGCCCACAGCTTCGGGTTCGATCTCGATCTCGAGGCGGTGGAGCGGACTCTGAGTGTTCCGGGGGGCAGTGGTGCC

A799Cangu GTGTGTATTTTCACGTACATACTGCCAGCTCGTCCCCTGAGTTCACCGAAGCCTAGAGAG-GAAACCGACCGTCCGGG A801Cangu GTGTGTATTTTCACGTACATACTGCCAGCTCGTCCCCTGAGTTCACCGAAGCCTAGAGAG-GAAACCGACCGTCCGGG A805Cangu GTGTGTATTTTCACGTACATACTGCCAGCTCGTCCCCTGAGTTCACCGAAGCCTAGAGAG-GAAACCGACCGTCCGGG A829Cangu GTGTGTATTTTCACGTACATACTGCCAGCTCGTCCCCTGAGTTCACCGAAGCCTAGAGAG-GAAACCGACCGTCCGGG A845Cangu GTGTGTATTTTCACGTACATACTGCCAGCTCGTCCCCTGAGTTCACCGAAGCCTAGAGAG-GAAACCGACCGTCCGGG A833Cangu GTGTGTATTTTCACGTACATACTGCCAGCTCGTCCCCTGAGTTCACCGAAGCCTAGAGAG-GAAACCGACCGTCCGGG A809Chybr GTGTGTATTTTCACGTACATACTGCCAGCTCGTCCCCTGAGTTCACCGAAGCCTAGAGAGAGAAACCGACCGTCCGGG A758Chybr GTGTGTATTTTCACGTACATACTGCCAGCTCGTCCCCTGAGTTCACCGAAGCCTAGAGAGAGAAACCGACCGTCCGGG A917Chybr GTGTGTATTTTCACGTACATGCTGCCAGCTCGTCCCCTGAGTTCACCGAAGCCTAGAGAG--AAACCGACCGTCCGGG A924Chybr GTGTGTATTTTCACGTACATGCTGCCAGCTCGTCCCCTGAGTTCACCGAAGCCTAGAGAG--AAACCGACCGTCCGGG A922Chybr GTGTGTATTTTCACGTACATGCTGCCAGCTCGTCCCCTGAGTTCACCGAAGCCTAGAGAG--AAACCGACCGTCCGGG A916Chybr GTGTGTATTTTCACGTACATGCTGCCAGCTCGTCCCCTGAGTTCACCGAAGCCTAGAGAG--AAACCGACCGTCCGGG A895Chybr GTGTGTATTTTCACGTACATGCTGCCAGCTCGTCCCCTGAGTTCACCGAAGCCTAGAGAG--AAACCGACCGTCCGGG A909Chybr GTGTGTATTTTCACGTACATGCTGCCAGCTCGTCCCCTGAGTTCACCGAAGCCTAGAGAG--AAACCGACCGTCCGGG A908Chybr GTGTGTATTTTCACGTACATACTGCCAGCTCGTCCCCTGAGTTCACCGAAGCCTAGAGAGAGAAACCGACCGTCCGGG A796Cmasc GTGTGTATTTTCACGTACATACTGCCAGCTCGTCCCCTGAGTTCACCGAAGCCTAGAGAGAGAAACCGACCGTCCGGG A836Cmasc GTGTGTaTTTTCACGTACATACTGCCAGCTCGTCCCCTGAGTTCACCGAAGCCTAGAGAGAGAAACCGACCGTCCGGG A766Cmasc GTGTGTATTTTCACGTACATACTGCCAGCTCGTCCCCTGAGTTCACCGAAGCCTAGAGAGAGAAACCGACCGTCCGGG A855Cmasc GTGTGTATTTTCACGTACATACTGCCAGCTCGTCCCCTGAGTTCACCGAAGCCTAGAGAGAGAAACCGACCGTCCGGG A792Cmasc GTGTGTATTTTCACGTACATACTGCCAGCTCGTCCCCTGAGTTCACCGAAGCCTAGAGAGAGAAACCGACCGTCCGGG A853Cmasc GTGTGTATTTTCACGTACATACTGCCAGCTCGTCCCCTGAGTTCACCGAAGCCTAGAGAGAGAAACCGACCGTCCGGG A725Cmasc GTGTGTATTTTCACGTACATACTGCCAGCTCGTCCCCTGAGTTCACCGAAGCCTAGAGAGAGAAACCGACCGTCCGGG A728Cmasc GTGTGTAYTTTCACGTACATACTGCCAGCTCGTCCCCTGAGTTCACCGAAGCCTAGAGAGAGAAACCGACCGTCCGGG A716Cangu GTGTGTATTTTCACGTACATGCTGCCAGCTCGTCCCCTGAGTTCACCGAAGCCTAGAGAG--AAACCGACCGTCCGGG A713Cmasc GTGTGTATTTTCACGTACATACTGCCAGCTCGTCCCCTGAGTTCACCGAAGCCTAGAGAG-GAAACCGACCGTCCGGG A730Cmasc GTGTGTACTTTCACGTACATACTGCCAGCTCGTCCCCTGAGTTCACCGAAGCCTAGAGAGAGAAACCGACCGTCCGGG A399Cmasc GTGTGTATTTTCACGTACATACTGCCAGCTCGTCCCCTGAGTTCACCGAAGCCTAGAGAGAGAAACCGACCGTCCGGG A345Cangu GTGTGTATTTTCACGTACATGCTGCCAGCTCGTCCCCTGAGTTCACCGAAGCCTAGAGAG--AAACCGACCGTCCGGG A398Cangu GTGTGTATTTTCACGTACATACTGCCAGCTCGTCCCCTGAGTTCACCGAAGCCTAGAGAG-GAAACCGACCGTCCGGG A408Cangu GTGTGTATTTTCACGTACATACTGCCAGCTCGTCCCCTGAGTTCACCGAAGCCTAGAGAG-GAAACCGACCGTCCGGG A659Cangu GTGTGTATTTTCACGTACATACTGCCAGCTCGTCCCCTGAGTTCACCGAAGCCTAGAGAG-GAAACCGACCGTCCGGG A555Cangu GTGTGTATTTTCACGTACATACTGCCAGCTCGTCCCCTGAGTTCACCGAAGCCTAGAGAG-GAAACCGACCGTCCGGG A378Cangu GTGTGTATTTTCACGTACATACTGCCAGCTCGTCCCCTGAGTTCACCGAAGCCTAGAGAG-GAAACCGACCGTCCGGG A379Cangu GTGTGTATTTTCACGTACATACTGCCAGCTCGTCCCCTGAGTTCACCGAAGCCTAGAGAG-GAAACCGACCGTCCGGG A350Cangu GTGTGTATTTTCACGTACATACTGCCAGCTCGTCCCCTGAGTTCACCGAAGCCTAGAGAG-GAAACCGACCGTCCGGG A106Cmasc GTGTGTATTTTCACGTACATACTGCCAGCTCGTCCCCTGAGTTCACCGAAGCCTAGAGAGAGAAACCGACCGTCCGGG A597Cmasc GTGTGTATTTTCACGTACATACTGCCAGCTCGTCCCCTGAGTTCACCGAAGCCTAGAGAGAGAAACCGACCGTCCGGG A509Cmasc GTGTGTATTTTCACGTACATACTGCCAGCTCGTCCCCTGAGTTCACCGAAGCCTAGAGAGAGAAACCGACCGTCCGGG A598Cmasc GTGTGTATTTTCACGTACATACTGCCAGCTCGTCCCCTGAGTTCACCGAAGCCTAGAGAGAGAAACCGACCGTCCGGG A2 43 Cmasc GTGTGTATTTTCACGTACATACTGCCAGCTCGTCCCCTGAGTTCACCGAAGCCTAGAGAGAGAAACCGACCGTCCGGG A240Cmasc GTGTGTATTTTCACGTACATACTGCCAGCTCGTCCCCTGAGTTCACCGAAGCCTAGAGAGAGAAACCGACCGTCCGGG A342Cmasc GTGTGTATTTTCACGTACATACTGCCAGCTCGTCCCCTGAGTTCACCGAAGCCTAGAGAGAGAAACCGACCGTCCGGG A569Cmasc GTGTGTATTTTCACGTACATACTGCCAGCTCGTCCCCTGAGTTCACCGAAGCCTAGAGAGAGAAACCGACCGTCCGGG A220Cmasc GTGTGTATTTTCACGTACATACTGCCAGCTCGTCCCCTGAGTTCACCGAAGCCTAGAGAGAGAAACCGACCGTCCGGG A111Cmasc GTGTGTATTTTCACGTACATACTGCCAGCTCGTCCCCTGAGTTCACCGAAGCCTAGAGAGAGAAACCGACCGTCCGGG A404Cmasc GTGTGTATTTTCACGTACATACTGCCAGCTCGTCCCCTGAGTTCACCGAAGCCTAGAGAG--AAACCGACCGTCCGGG 
Appendix 2. (Continued)

A418Cmasc GTGTGTATTTTCACGTACATACTGCCAGCTCGTCCCCTGAGTTCACCGAAGCCTAGAGAG--AAACCGACCGTCCGGG A389 Cmasc GTGTGTATTTTCACGTACATGCTGCCAGCTCGTCCCCTGAGTTCACCGAAGCCTAGAGAG--AAACCGACCGTCCGGG A353Cmasc GTGTGTATTTTCACGTACATGCTGCCAGCTCGTCCCCTGAGTTCACCGAAGCCTAGAGAG--AAACCGACCGTCCGGG A575Cmasc GTGTGTATTTTCACGTACATACTGCCAGCTCGTCCCCTGAGTTCACCGAAGCCTAGAGAG-GAAACCGACCGTCCGGG

A799Cangu CATTTATTCTCTTTGCGGCGCTTAAGGCAGGTTCACTTTGCGTCCTCCAGAAGATCCGTTGTTGACGGCGCCCCCTTT A801Cangu CATTTATTCTCTTTGCGGCGCTTAAGGCAGGTTCACTTTGCGTCCTCCAGAAGATCCGTTGTTGACGGCGCCCCCTTT A805Cangu CATTTATTCTCTTTGCGGCGCTTAAGGCAGGTTCACTTTGCGTCCTCCAGAAGATCCGTTGTTGACGGCGCCCCCTTT A829Cangu CATTTATTCTCTTTGCGGCGCTTAAGGCAGGTTCACTTTGCGTCCTCCAGAAGATCCGTTGTTGACGGCGCCCCCTTT A845Cangu CATTTATTCTCTTTGCGGCGCTTAAGGCAGGTTCACTTTGCGTCCTCCAGAAGATCCGTTGTTGACGGCGCCCCCTTT A833Cangu CATTTATTCTCTTTGCGGCGCTTAAGGCAGGTTCACTTTGCGTCCTCCAGAAGATCCGTTGTTGACGGCGCCCCCTTT A809Chybr CATTTATTCTCTTTGCGGCGCTTAAGGCAGGTTCACTTTGCGTCCTCCAGAAGATCCGTTGTTGACGGCGCCCCCTTT A758Chybr CATTTATTCTCTTTGCGGCGCTTAAGGCAGGTTCACTTTGCGTCCTCCAGAAGATCCGTTGTTGACGGCGCCCCCTTT A917Chybr CATTTATTCTCTTTGCGGCGCTTAAGGCAGGTTCACTTTGCGTCCTCCAGAAGATCCGTTGTTGACGGCGCCCCCTTT A924Chybr CATTTATTCTCTTTGCGGCGCTTAAGGCAGGTTCACTTTGCGTCCTCCAGAAGATCCGTTGTTGACGGCGCCCCCTTT A922Chybr CATTTATTCTCTTTGCGGCGCTTAAGGCAGGTTCACTTTGCGTCCTCCAGAAGATCCGTTGTTGACGGCGCCCCCTTT A916Chybr CATTTATTCTCTTTGCGGCGCTTAAGGCAGGTTCACTTTGCGTCCTCCAGAAGATCCGTTGTTGACGGCGCCCCCTTT A895Chybr CATTTATTCTCTTTGCGGCGCTTAAGGCAGGTTCACTTTGCGTCCTCCAGAAGATCCGTTGTTGACGGCGCCCCCTTT A909Chybr CATTTATTCTCTTTGCGGCGCTTAAGGCAGGTTCACTTTGCGTCCTCCAGAAGATCCGTTGTTGACGGCGCCCCCTTT A908Chybr CATTTATTCTCTTTGCGGCGCTTAAGGCAGGTTCACTTTGCGTCCTCCAGAAGATCCGTTGTTGACGGCGCCCCCTTT A796Cmasc CATTTATTCTCTTTGCGGCGCTTAAGGCAGGTTCACTTTGCGTCCTCCAGAAGATCCGTTGTTGACGGCGCCCCCTTT A836Cmasc CATTTATTCTCTTTGCGGCGCTTAAGGCAGGTTCACTTTGCGTCCTCCAGAAGATCCGTTGTTGACGGCGCCCCCTTT A766Cmasc CATTTATTCTCTTTGCGGCGCTTAAGGCAGGTTCACTTTGCGTCCTCCAGAAGATCCGTTGTTGACGGCGCCCCCTTT A855Cmasc CATTTATTCTCTTTGCGGCGCTTAAGGCAGGTTCACTTTGCGTCCTCCAGAAGATCCGTTGTTGACGGCGCCCCCTTT A792 Cmasc CATTTATTCTCTTTGCGGCGCTTAAGGCAGGTTCACTTTGCGTCCTCCAGAAGATCCGTTGTTGACGGCGCCCCCTTT A853Cmasc CATTTATTCTCTTTGCGGCGCTTAAGGCAGGTTCACTTTGCGTCCTCCAGAAGATCCGTTGTTGACGGCGCCCCCTTT A725Cmasc CATTTATTCTCTTTGCGGCGCTTAAGGCAGGTTCACTTTGCGTCCTCCAGAAGATCCGTTGTTGACGGCGCCCCCTTT A728Cmasc CATTTATTCTCTTTGCGGCGCTTAAGGCAGGTTCACTTTGCGTCCTCCAGAAGATCCGTTGTTGACGGCGCCCCCTTT A716Cangu CATTTATTCTCTTTGCGGCGCTTAAGGCAGGTTCACTTTGCGTCCTCCAGAAGATCCGTTGTTGACGGCGCCCCCTTT A713Cmasc CATTTATTCTCTTTGCGGCGCTTAAGGCAGGTTCACTTTGCGTCCTCCAGAAGATCCGTTGTTGACGGCGCCCCCTTT A730 Cmasc CATTTATTCTCTTTGCGGCGCTTAAGGCAGGTTCACTTTGCGTCCTCCAGAAGATCCGTTGTTGACGGCGCCCCCTTT A399Cmasc CATTTATTCTCTTTGCGGCGCTTAAGGCAGGTTCACTTTGCGTCCTCCAGAAGATCCGTTGTTGACGGCGCCCCCTTT A345Cangu CATTTATTCTCTTTGCGGCGCTTAAGGCAGGTTCACTTTGCGTCCTCCAGAAGATCCGTTGTTGACGGCGCCCCCTTT A398Cangu CATTTATTCTCTTTGCGGCGCTTAAGGCAGGTTCACTTTGCGTCCTCCAGAAGATCCGTTGTTGACGGCGCCCCCTTT A408Cangu CATTTATTCTCTTTGCGGCGCTTAAGGCAGGTTCACTTTGCGTCCTCCAGAAGATCCGTTGTTGACGGCGCCCCCTTT A659Cangu CATTTATTCTCTTTGCGGCGCTTAAGGCAGGTTCACTTTGCGTCCTCCAGAAGATCCGTTGTTGACGGCGCCCCCTTT A555Cangu CATTTATTCTCTTTGCGGCGCTTAAGGCAGGTTCACTTTGCGTCCTCCAGAAGATCCGTTGTTGACGGCGCCCCCTTT A378Cangu CATTTATTCTCTTTGCGGCGCTTAAGGCAGGTTCACTTTGCGTCCTCCAGAAGATCCGTTGTTGACGGCGCCCCCTTT A379Cangu CATTTATTCTCTTTGCGGCGCTTAAGGCAGGTTCACTTTGCGTCCTCCAGAAGATCCGTTGTTGACGGCGCCCCCTTT A350Cangu CATTTATTCTCTTTGCGGCGCTTAAGGCAGGTTCACTTTGCGTCCTCCAGAAGATCCGTTGTTGACGGCGCCCCCTTT A106Cmasc CATTTATTCTCTTTGCGGCGCTTAAGGCAGGTTCACTTTGCGTCCTCCAGAAGATCCGTTGTTGACGGCGCCCCCTTT A597Cmasc CATTTATTCTCTTTGCGGCGCTTAAGGCAGGTTCACTTTGCGTCCTCCAGAAGATCCGTTGTTGACGGCGCCCCCTTT A509Cmasc CATTTATTCTCTTTGCGGCGCTTAAGGCAGGTTCACTTTGCGTCCTCCAGAAGATCCGTTGTTGACGGCGCCCCCTTT A598Cmasc CATTTATTCTCTTTGCGGCGCTTAAGGCAGGTTCACTTTGCGTCCTCCAGAAGATCCGTTGTTGACGGCGCCCCCTTT A243Cmasc CATTTATTCTCTTTGCGGCGCTTAAGGCAGGTTCACTTTGCGTCCTCCAGAAGATCCGTTGTTGACGGCGCCCCCTTT A2 40 Cmasc CATTTATTCTCTTTGCGGCGCTTAAGGCAGGTTCACTTTGCGTCCTCCAGAAGATCCGTTGTTGACGGCGCCCCCTTT A342Cmasc CATTTATTCTCTTTGCGGCGCTTAAGGCAGGTTCACTTTGCGTCCTCCAGAAGATCCGTTGTTGACGGCGCCCCCTTT A569Cmasc CATTTATTCTCTTTGCGGCGCTTAAGGCAGGTTCACTTTGCGTCCTCCAGAAGATCCGTTGTTGACGGCGCCCCCTTT A220Cmasc CATTTATTCTCTTTGCGGCGCTTAAGGCAGGTTCACTTTGCGTCCTCCAGAAGATCCGTTGTTGACGGCGCCCCCTTT A111Cmasc CATTTATTCTCTTTGCGGCGCTTAAGGCAGGTTCACTTTGCGTCCTCCAGAAGATCCGTTGTTGACGGCGCCCCCTTT A 404 Cmasc CATTTATTCTCTTTGCGGCGCTTAAGGCAGGTTCACTTTGCGTCCTCCAGAAGATCCGTTGTTGACGGCGCCCCCTTT A 418Cmasc CATTTATTCTCTTTGCGGCGCTTAAGGCAGGTTCACTTTGCGTCCTCCAGAAGATCCGTTGTTGACGGCGCCCCCTTT A389Cmasc CATTTATTCTCTTTGCGGCGCTTAAGGCAGGTTCACTTTGCGTCCTCCAGAAGATCCGTTGTTGACGGCGCCCCCTTT A353Cmasc CATTTATTCTCTTTGCGGCGCTTAAGGCAGGTTCACTTTGCGTCCTCCAGAAGATCCGTTGTTGACGGCGCCCCCTTT A575Cmasc CATTTATTCTCTTTGCGGCGCTTAAGGCAGGTTCACTTTGCGTCCTCCAGAAGATCCGTTGTTGACGGCGCCCCCTTT

A799Cangu CGTGGGGCGGGGACACGACGGGTTGCTGGGGATGAGCGCGGGTGGCCTTGCTGCGTCGCGCCGGAGGCCAGTGGACGG A801Cangu CGTGGGGCGGGGACACGACGGGTTGCTGGGGATGAGCGCGGGTGGCCTTGCTGCGTCGCGCCGGAGGCCAGTGGACGG A805Cangu CGTGGGGCGGGGACACGACGGGTTGCTGGGGATGAGCGCGGGTGGCCTTGCTGCGTCGCGCCGGAGGCCAGTGGACGG A829Cangu CGTGGGGCGGGGACACGACGGGTTGCTGGGGATGAGCGCGGGTGGCCTTGCTGCGTCGCGCCGGAGGCCAGTGGACGG A845Cangu CGTGGGGCGGGGACACGACGGGTTGCTGGGGATGAGCGCGGGTGGCCTTGCTGCGTCGCGCCGGAGGCCAGTGGACGG A833Cangu CGTGGGGCGGGGACACGACGGGTTGCTGGGGATGAGCGCGGGTGGCCTTGCTGCGTCGCGCCGGAGGCCAGTGGACGG A809Chybr CGTGGGGCGGGGACACGACGGGTTGCTGGGGATGAGCGCGGGTGGCCTTGCTGCGTCGCGCTGGAGGCCCGTGGACGG A758Chybr CGTGGGGCGGGGACACGACGGGTTGCTGGGGATGAGCGCGGGTGGCCTTGCTGCGTCGCGCTGGAGGCCCGTGGACGG A917 Chybr CGTGGGGCGGGGACACGACGGGTTGCTGGGGATGAGCGCGGGTGGCCTTGCTGCGTCGCGCTGGAGGCCCGTGGACGG A924 Chybr CGTGGGGCGGGGACACGACGGGTTGCTGGGGATGAGCGCGGGTGGCCTTGCTGCGTCGCGCTGGAGGCCCGTGGACGG A922Chybr CGTGGGGCGGGGACACGACGGGTTGCTGGGGATGAGCGCGGGTGGCCTTGCTGCGTCGCGCTGGAGGCCCGTGGACGG A916 Chybr CGTGGGGCGGGGACACGACGGGTTGCTGGGGATGAGCGCGGGTGGCCTTGCTGCGTCGCGCTGGAGGCCCGTGGACGG A895Chybr CGTGGGGCGGGGACACGACGGGTTGCTGGGGATGAGCGCGGGTGGCCTTGCTGCGTCGCGCTGGAGGCCCGTGGACGG A909Chybr CGTGGGGCGGGGACACGACGGGTTGCTGGGGATGAGCGCGGGTGGCCTTGCTGCGTCGCGCTGGAGGCCCGTGGACGG A908Chybr CGTGGGGCGGGGACACGACGGGTTGCTGGGGATGAGCGCGGGTGGCCTTGCTGCGTCGCGCTGGAGGCCCGTGGACGG A796Cmasc CGTGGGGCGGGGACACGACGGGTTGCTGGGGATGAGCGCGGGTGGCCTTGCTGCGTCGCGCTGGAGGCCCGTGGACGG A836Cmasc CGTGGGGCGGGGACACGACGGGTTGCTGGGGATGAGCGCGGGTGGCCTTGCTGCGTCGCGCTGGAGGCCCGTGGACGG A 766 Cmasc CGTGGGGCGGGGACACGACGGGTTGCTGGGGATGAGCGCGGGTGGCCTTGCTGCGTCGCGCTGGAGGCCCGTGGACGG A 855 Cmasc CGTGGGGCGGGGACACGACGGGTTGCTGGGGATGAGCGCGGGTGGCCTTGCTGCGTCGCGCTGGAGGCCCGTGGACGG A792 Cmasc CGTGGGGCGGGGACACGACGGGTTGCTGGGGATGAGCGCGGGTGGCCTTGCTGCGTCGCGCTGGAGGCCCGTGGACGG 
Appendix 2. (Continued)

A853Cmasc CGTGGGGCGGGGACACGACGGGTTGCTGGGGATGAGCGCGGGTGGCCTTGCTGCGTCGCGCTGGAGGCCCGTGGACGG A 725 Cmasc CGTGGGGCGGGGACACGACGGGTTGCTGGGGATGAGCGCGGGTGGCCTTGCTGCGTCGCGCTGGAGGCCCGTGGACGG A728Cmasc CGTGGGGCGGGGACACGACGGGTTGCTGGGGATGAGCGCGGGTGGCCTTGCTGCGTCGCGCTGGAGGCCCGTGGACGG A716Cangu CGTGGGGCGGGGACACGACGGGTTGCTGGGGATGAGCGCGGGTGGCCTTGCTGCGTCGCGCCGGAGGCCCGTGGACGG A713Cmasc CGTGGGGCGGGGACACGACGGGTTGCTGGGGATGAGCGCGGGTGGCCTTGCTGCGTCGCGCCGGAGGCCAGTGGACGG A730 Cmasc CGTGGGGCGGGGACACGACGGGTTGCTGGGGATGAGCGCGGGTGGCCTTGCTGCGTCGCGCTGGAGGCCCGTGGACGG A399 Cmasc CGTGGGGCGGGGACACGACGGGTTGCTGGGGATGAGCGCGGGTGGCCTTGCTGCGTCGCGCTGGAGGCCCGTGGACGG A345Cangu CGTGGGGCGGGGACACGACGGGTTGCTGGGGATGAGCGCGGGTGGCCTTGCTGCGTCGCGCCGGAGGCCCGTGGACGG A398Cangu CGTGGGGCGGGGACACGACGGGTTGCTGGGGATGAGCGCGGGTGGCCTTGCTGCGTCGCGCCGGAGGCCAGTGGACGG A 408Cangu CGTGGGGCGGGGACACGACGGGTTGCTGGGGATGAGCGCGGGTGGCCTTGCTGCGTCGCGCCGGAGGCCAGTGGACGG A659 Cangu CGTGGGGCGGGGACACGACGGGTTGCTGGGGATGAGCGCGGGTGGCCTTGCTGCGTCGCGCCGGAGGCCAGTGGACGG A555Cangu CGTGGGGCGGGGACACGACGGGTTGCTGGGGATGAGCGCGGGTGGCCTTGCTGCGTCGCGCCGGAGGCCAGTGGACGG A378Cangu CGTGGGGCGGGGACACGACGGGTTGCTGGGGATGAGCGCGGGTGGCCTTGCTGCGTCGCGCCGGAGGCCAGTGGACGG A379 Cangu CGTGGGGCGGGGACACGACGGGTTGCTGGGGATGAGCGCGGGTGGCCTTGCTGCGTCGCGCCGGAGGCCAGTGGACGG A350Cangu CGTGGGGCGGGGACACGACGGGTTGCTGGGGATGAGCGCGGGTGGCCTTGCTGCGTCGCGCTGGAGGCCCGTGGACGG A106Cmasc CGTGGGGCGGGGACACGACGGGTTGCTGGGGATGAGCGCGGGTGGCCTTGCTGCGTCGCGCTGGAGGCCCGTGGACGG A597Cmasc CGTGGGGCGGGGACACGACGGGTTGCTGGGGATGAGCGCGGGTGGCCTTGCTGCGTCGCGCTGGAGGCCCGTGGACGG A509 Cmasc CGTGGGGCGGGGACACGACGGGTTGCTGGGGATGAGCGCGGGTGGCCTTGCTGCGTCGCGCTGGAGGCCCGTGGACGG A598Cmasc CGTGGGGCGGGGACACGACGGGTTGCTGGGGATGAGCGCGGGTGGCCTTGCTGCGTCGCGCTGGAGGCCCGTGGACGG A243Cmasc CGTGGGGCGGGGACACGACGGGTTGCTGGGGATGAGCGCGGGTGGCCTTGCTGCGTCGCGCTGGAGGCCCGTGGACGG A240 Cmasc CGTGGGGCGGGGACACGACGGGTTGCTGGGGATGAGCGCGGGTGGCCTTGCTGCGTCGCGCTGGAGGCCCGTGGACGG A342Cmasc CGTGGGGCGGGGACACGACGGGTTGCTGGGGATGAGCGCGGGTGGCCTTGCTGCGTCGCGCTGGAGGCCCGTGGACGG A569 Cmasc CGTGGGGCGGGGACACGACGGGTTGCTGGGGATGAGCGCGGGTGGCCTTGCTGCGTCGCGCTGGAGGCCCGTGGACGG A220 Cmasc CGTGGGGCGGGGACACGACGGGTTGCTGGGGATGAGCGCGGGTGGCCTTGCTGCGTCGCGCTGGAGGCCCGTGGACGG A111 Cmasc CGTGGGGCGGGGACACGACGGGTTGCTGGGGATGAGCGCGGGTGGCCTTGCTGCGTCGCGCTGGAGGCCCGTGGACGG A 404 Cmasc CGTGGGGCGGGGACACGACGGGTTGCTGGGGATGAGCGCGGGTGGCCTTGCTGCGTCGCGCTGGAGGCCCGTGGACGG A418Cmasc CGTGGGGCGGGGACACGACGGGTTGCTGGGGATGAGCGCGGGTGGCCTTGCTGCGTCGCGCTGGAGGCCCGTGGACGG A389 Cmasc CGTGGGGCGGGGACACGACGGGTTGCTGGGGATGAGCGCGGGTGGCCTTGCTGCGTCGCGCTGGAGGCCCGTGGACGG A353Cmasc CGTGGGGCGGGGACACGACGGGTTGCTGGGGATGAGCGCGGGTGGCCTTGCTGCGTCGCGCTGGAGGCCCGTGGACGG A575Cmasc CGTGGGGCGGGGACACGACGGGTTGCTGGGGATGAGCGCGGGTGGCCTTGCTGCGTCGCGCYGGAGGCCCGTGGACGG

A799Cangu TGGGCAGTCTCGAGAATACCGGAGAGAGACCGGTGATAATGACGATGCCATACCCCCGAT A801Cangu TGGGCAGTCTCGAGAATACCGGAGAGAGACCGGTGATAATGACGATGCCATACCCCCGAT A805Cangu TGGGCAGTCTCGAGAATACCGGAGAGAGACCGGTGATAATGACGATGCCATACCCCCGAT A829Cangu TGGGCAGTCTCGAGAATACCGGAGAGAGACCGGTGATAATGACGATGCCATACCCCCGAT A845Cangu TGGGCAGTCTCGAGAATACCGGAGAGAGACCGGTGATAATGACGATGCCATACCCCCGAT A833Cangu TGGGCAGTCTCGAGAATACCGGAGAGAGACCGGTGATAATGACGATGCCATACCCCCGAT A809Chybr TGGGCAGTCTCGAGAATACCGGAGAGAGACCGGTGATAATGACGATGCCATACCCCCGAT A758Chybr TGGGCAGTCTCGAGAATACCGGAGAGAGACCGGTGATAATGACGATGCCATACCCCCGAT A917Chybr TGGGCAGTCTCGAGAATACCGGAGAGAGACCGGTGATAATGACGATGCCATACCCCCGAT A 924 Chybr TGGGCAGTCTCGAGAATACCGGAGAGAGACCGGTGATAATGACGATGCCATACCCCCGAT A922Chybr TGGGCAGTCTCGAGAATACCGGAGAGAGACCGGTGATAATGACGATGCCATACCCCCGAT A916Chybr TGGGCAGTCTCGAGAATACCGGAGAGAGACCGGTGATAATGACGATGCCATACCCCCGAT A895Chybr TGGGCAGTCTCGAGAATACCGGAGAGAGACCGGTGATAATGACGATGCCATACCCCCGAT A909Chybr TGGGCAGTCTCGAGAATACCGGAGAGAGACCGGTGATAATGACGATGCCATACCCCCGAT A908Chybr TGGGCAGTCTCGAGAATACCGGAGAGAGACCGGTGATAATGACGATGCCATACCCCCGAT A796Cmasc TGGGCAGTCTCGAGAATACCGGAGAGAGACCGGTGATAATGACGATGCCATACCCCCGAT A836Cmasc TGGGCAGTCTCGAGAATACCGGAGAGAGACCGGTGATAATGACGATGCCATACCCCCGAT A766Cmasc TGGGCAGTCTCGAGAATACCGGAGAGAGACCGGTGATAATGACGATGCCATACCCCCGAT A855Cmasc TGGGCAGTCTCGAGAATACCGGAGAGAGACCGGTGATAATGACGATGCCATACCCCCGAT A792Cmasc TGGGCAGTCTCGAGAATACCGGAGAGAGACCGGTGATAATGACGATGCCATACCCCCGAT A853Cmasc TGGGCAGTCTCGAGAATACCGGAGAGAGACCGGTGATAATGACGATGCCATACCCCCGAT A725Cmasc TGGGCAGTCTCGAGAATACCGGAGAGAGACCGGTGATAATGACGATGCCATACCCCCGAT A728Cmasc TGGGCAGTCTCGAGAATACCGGAGAGAGACCGGTGATAATGACGATGCCATACCCCCGAT A716Cangu TGGGCAGTCTCGAGAATACCGGAGAGAGACCGGTGATAATGACGATGCCATACCCCCGAT A713Cmasc TGGGCAGTCTCGAGAATACCGGAGAGAGACCGGTGATAATGACGATGCCATACCCCCGAT A730 Cmasc TGGGCAGTCTCGAGAATACCGGAGAGAGACCGGTGATAATGACGATGCCATACCCCCGAT A399 Cmasc TGGGCAGTCTCGAGAATACCGGAGAGAGACCGGTGATAATGACGATGCCATACCCCCGAT A345Cangu TGGGCAGTCTCGAGAATACCGGAGAGAGACCGGTGATAATGACGATGCCATACCCCCGAT A398Cangu TGGGCAGTCTCGAGAATACCGGAGAGAGACCGGTGATAATGACGATGCCATACCCCCGAT A408Cangu TGGGCAGTCTCGAGAATACCGGAGAGAGACCGGTGATAATGACGATGCCATACCCCCGAT A659Cangu TGGGCAGTCTCGAGAATACCGGAGAGAGACCGGTGATAATGACGATGCCATACCCCCGAT A555Cangu TGGGCAGTCTCGAGAATACCGGAGAGAGACCGGTGATAATGACGATGCCATACCCCCGAT A378Cangu TGGGCAGTCTCGAGAATACCGGAGAGAGACCGGTGATAATGACGATGCCATACCCCCGAT A379Cangu TGGGCAGTCTCGAGAATACCGGAGAGAGACCGGTGATAATGACGATGCCATACCCCCGAT A350Cangu TGGGCAGTCTCGAGAATACCGGAGAGAGACCGGTGATAATGACGATGCCATACCCCCGAT A106Cmasc TGGGCAGTCTCGAGAATACCGGAGAGAGACCGGTGATAATGACGATGCCATACCCCCGAT A597Cmasc TGGGCAGTCTCGAGAATACCGGAGAGAGACCGGTGATAATGACGATGCCATACCCCCGAT A509 Cmasc TGGGCAGTCTCGAGAATACCGGAGAGAGACCGGTGATAATGACGATGCCATACCCCCGAT A598Cmasc TGGGCAGTCTCGAGAATACCGGAGAGAGACCGGTGATAATGACGATGCCATACCCCCGAT A243Cmasc TGGGCAGTCTCGAGAATACCGGAGAGAGACCGGTGATAATGACGATGCCATACCCCCGAT A2 40 Cmasc TGGGCAGTCTCGAGAATACCGGAGAGAGACCGGTGATAATGACGATGCCATACCCCCGAT A 342 Cmasc TGGGCAGTCTCGAGAATACCGGAGAGAGACCGGTGATAATGACGATGCCATACCCCCGAT A569 Cmasc TGGGCAGTCTCGAGAATACCGGAGAGAGACCGGTGATAATGACGATGCCATACCCCCGAT A220 Cmasc TGGGCAGTCTCGAGAATACCGGAGAGAGACCGGTGATAATGACGATGCCATACCCCCGAT A111Cmasc TGGGCAGTCTCGAGAATACCGGAGAGAGACCGGTGATAATGACGATGCCATACCCCCGAT 
Appendix 2. (Continued)

A404Cmasc TGGGCAGTCTCGAGAATACCGGAGAGAGACCGGTGATAATGACGATGCCATACCCCCGAT A418Cmasc TGGGCAGTCTCGAGAATACCGGAGAGAGACCGGTGATAATGACGATGCCATACCCCCGAT A389 Cmasc TGGGCAGTCTCGAGAATACCGGAGAGAGACCGGTGATAATGACGATGCCATACCCCCGAT A353Cmasc TGGGCAGTCTCGAGAATACCGGAGAGAGACCGGTGATAATGACGATGCCATACCCCCGAT A575Cmasc TGGGCAGTCTCGAGAATACCGGAGAGAGACCGGTGATAATGACGATGCCATACCCCCGAT 


\subsection{Appendix 3. Alignment of cloned ITS2 sequences from Carpophyllum. Each alignment shows 8-12 sequences recovered from cloned DNA from one specimen.}

\subsubsection{Sequences from A347, Waterfall Reef, Leigh.}

A347_30 ATCATCGAAACTTCGAACGCATCTTGCGCTCCCGGGATATGCCTGGGAGCATGCTTGTCGGGGAGGAGGAGGCGAAAAAT A347 3C ATCATCGAAACTTCGAACGCATCTTGCGCTCCCGGGATATGCCTGGGAGCATGCTTGTCGGGGAGGAGGAGGCGAAAAAT A347_3D ATCATCGAAACTTCGAACGCATCTTGCGCTCCCGGGATATGCCTGGGAGCATGCTTGTCGGGGAGGAGGAGGCGAAAAAT A347_3G ATCATCGAAACTTCGAACGCATCTTGCGCTCCCGGGATATGCCTGGGAGCATGCTTGTCGGGGAGGAGGAGGCGAAAAAT A347_3H ATCATCGAAACTTCGAACGCATCTTGCGCTCCCGGGATATGCCTGGGAGCATGCTTGTCGGGGAGGAGGAGGCGAAAAAT A347_3P ATCATCGAAACTTCGAACGCATCTTGCGCTCCCGGGATATGCCTGGGAGCATGCTTGTCGGGGAGGAGGAGGCGAAAAAT A347 3K ATCATCGAAACTTCGAACGCATCTTGCGCTCCCGGGATATGCCTGGGAGCATGCTTGTCGGGGAGGAGGAGGCGAAAAAT A347_3L ATCATCGAAACTTCGAACGCATCTTGCGCTCCCGGGATATGCCTGGGAGCATGCTTGTCGGGGAGGAGGAGGCGAAAAAT A347_3a ATCATCGAAACTTCGAACGCATCTTGCGCTCCCGGGATATGCCTGGGAGCATGCTTGTCGGGGAGGAGGAGGCGAAAAAT A347_3I ATCATCGAAACTTCGAACGCATCTTGCGCTCCCGGGATATGCCTGGGAGCATGCTTGTCGGGGAGGAGGAGGCGAAAAAT

A347_30 CGCCCACAGCTTCGGGTTCGATCTCGATCTCGAGGCGGTGGAGCGGACTCTGAGTGTTCCGGGGGGCAGTGGTGCCGTGT A347_3C CGCCCACAGCTTCGGGTTCGATCTCGATCTCGAGGCGGTGGAGCGGACTCTGAGTGTTCCGGGGGGCAGTGGTGCGGTGT A347_3D CGCCCACAGCTTCGGGTTCGATCTCGATCTCGAGGCGGTGGAGCGGACTCTGAGTGTTCCGGGGGGCAGTGGTGCCGTGT A347_3G CGCCCACAGCTTCGGGTTCGATCTCGATCTCGAGGCGGTGGAGCGGACTCTGAGTGTTCCGGGGGGCAGTGGTGCCGTGT A347_3H CGCCCACAGCTTCGGGTTCGATCTCGATCTCGAGGCGGTGGAGCGGACTCTGAGTGTTCCGGGGGGCAGTGGTGCCGTGT A347_3P CGCCCACAGCTTCGGGTTCGATCTCGATCTCGAGGCGGTGGAGCGGACTCTGAGTGTTCCGGGGGGCAGTGGTGCGGTGT A347_3K CGCCCACAGCTTCGGGTTCGATCTCGATCTCGAGGCGGTGGAGCGGACTCTGAGTGTTCCGGGGGGCAGTGGTGCGGTGT A347_3L CGCCCACAGCTTCGGGTTCGATCTCGATCCCGAGGCGGTGGAGCGGACTCTGAGTGTTCCGGGGGGCAGTGGTGCGGTGT A347_3a CGCCCACAGCTTCGGGTTCGATCTCGATCTCGAGGCGGTGGAGCGGACTCTGAGTGTTCCGGGGGGCAGTGGTGCGGTGT A347_3I CGCCCACAGCTTCGGGTTCGATCTCGATCTCGAGGCGGTGGAGCGGACTCTGAGTGTTCCGGGGGGCGGTGGTGCCGTGT

A34730 GTATTTTCACGTACATACTGCCAGCTCGTCCCCTGAGTTCACCGAAGCCTAGAGAGGAAACCGACCGTCCGGGCATTTAT A347_3C GTATTTTCACGTACATACTGCCAGCTCGTCCCCTGAGTTCACCGAAGCCTAGAGAGGAAACCGACCGTCCGGGCATTTAT A347_3D GTATTTTCACGTACATACTGCCAGCTCGTCCCCTGAGTTCACCGAAGCCTAGAGAGGAAACCGACCGTCCGGGCATTTAT A347_3G GTATTTTCACGTACATACTGCCAGCTCGTCCCCTGAGTTCACCGAAGCCTAGAGAGGAAACCGACCGTCCGGGCATTTAT A347_3H GTATTTTCACGTACATACTGCCAGCTCGTCCCCTGAGTTCACCGAAGCCTAGAGAGGAAACCGACCGTCCGGGCATTTAT A347_3P GTATTTTCACGTACATACTGCCAGCTCGTCCCCTGAGTTCACCGAAGCCTAGAGAG-AAACCGACCGTCCGGGCATTTAT A347_3K GTATTTTCACGTACATACTGCCAGCTCGTCCCCTGAGTTCACCGAAGCCTAGAGAG-AAACCGACCGTCCGGGCATTTAT A347_3L GTATTTTCACGTACATACTGCCAGCTCGTCCCCTGAGTTCACCGAAGCCTAGAGAG-AAACCGACCGTCCGGGCATTTAT A347_3a GTACTTTCACGTACATACCGCCAGCTCGTCCCCTGAGTTCACCGAAGCCTAGAGAG-AAACCGACCGTCCGGGCATTTAT A347_3I GTATTTTCACGTACATACTGCCAGCTCGTCCCCTGAGTTCACCGAAGCCTAGAGAGGAAACCGACCGTCCGGGCATTTAT

A347_30 TCTCT?TGCGGCGCTTAAGGCAGGTTCACTTTGCGTCCTCCAGAAGATCCGTTGTTGACGGCGCCCCCTTTCGTGGGGCG A347_3C TCTCTTTGCGGCGCTTAAGGCAGGTTCACTTTGCGTCCTCCAGAAGATCCGTTGTTGACGGCGCCCCCTTTCGTGGGGCG A347_3D TCTCTTTGCGGCGCTTAAGGCAGGTTCACTTTGCGTCCTCCAGAAGATCCGTTGTTGACGGCGCCCCCTTTCGTGGGGCG A347_3G TCTCTTTGCGGCGCTTAAGGCAGGTTCACTTTGCGTCCTCCAGAAGATCCGTTGTTGACGGCGCCCCCTTTCGTGGGGCG A347_3H TCTCTTTGCGGCGCTTAAGGCAGGTTCACTTTGCGTCCTCCAGAAGATCCGTTGTTGACGGCGCCCCCTTTCGTGGGGCG A347 3P TCTCTTTGCGGCGCTTAAGGCAGGTTCACTTTGCGTCCTCCAGAAGATCCGTTGTTGACGGCGCCCCCTTTCGTGGGGCG A347_3K TCTCTTTGCGGCGCTTAAGGCAGGTTCACTTTGCGTCCTCCAGAAGATCCGTTGTTGACGGCGCCCCCTTTCGTGGGGCG A347_3L TCTCTTTGCGGCGCTTAAGGCAGGTTCACTTTGCGTCCTCCAGAAGATCCGTTGTTGACGGCGCCCCCTTTCGTGGGGCG A347_3a TCTCTTTGCGGCGCTTAAAGCAGGTTCACTTTGCGTCCTCCAGAAGATCCGTTGTTGACGGCGCCCCCTTTCGTGGGGCG A347_3I TCTCTTTGCGGCGCTTAAGGCAGGTTCACTTTGCGTCCTCCAGAAGATCCGTTGTTGACGGCGCTCCCTTTCGTGGGGCG

A347_30 GGGACACGACGGGTTGCTGGGGATGAGCGCGGGTGGCCTTGCTGCGTCGCGCTGGAGGCCCGTGGACGGTGGGCAGTCTC A347_3C GGGACACGACGGGTTGCTGGGGATGAGCGCGGGTGGCCTTGCTGCGTCGCGCTGGAGGCCCGTGGACGGTGGGCAGTCTC A347_3D GGGACACGACGGGTTGCTGGGGATGAGCGCGGGTGGCCTTGCTGCGTCGCGCTGGAGGCCCGTGGACGGTGGGCAGTCTC A347_3G GGGACACGACGGGTTGCTGGGGATGAGCGCGGGTGGCCTTGCTGCGTCGCGCTGGAGGCCCGTGGACGGTGGGCAGTCTC A347_3H GGGACACGACGGGTTGCTGGGGATGAGCGCGGGTGGCCTTGCTGCGTCGCGCTGGAGGCCCGTGGACGGTGGGCAGTCTC A347_3P GGGACACGGCGGGTTGCTGGGGATGAGCGCGGGTGGCCTTGCTGCGTCGCGCTGGAGGCCCGTGGGCGGTGGGCAGTCTC A347_3K GGGACACGACGGGTTGCCGGGGATGAGCGCGGGTGGCCTTGCTGCGTCGCGCTGGAGGCCCGTGGACGGTGGGCAGTCTC A347_3L GGGACACGACGGGTTGCTGGGGATGAGCGCGGGTGGCCTTGCTGCGTCGCGCTGGAGGCCCGTGGACGGTGGGCAGTCTC A347_3a GGGACACGACAGGTTGCTGGGGATGAGCGCGGGTGGCCTTGCTGCGTCGCGCTGGAGGCCCGTGGACGGTGGGCAGTCTC A347_3I GGGACACGACGGGTTGCTGGGGATGAGCGCGGGTGGCCTTGCTGCGTCGCGCTGGAGGCCCGTGGACGGTGGGCAGTCTC

A347_30 GAGAATACCGGAGAGAGACCGGTGATAATGACGATGCCATACCCCCGAT A347_3C GAGAATACCGGAGAGAGACCGGTGATAATGACGATGCCATACCCCCGAT A347_3D GAGAATACCGGAGAGAGACCGGTGATAATGACGATGCCATACCCCCGAT A347_3G GAGAATACCGGAGAGAGACCGGTGATAATGACGATGCCATACCCCCGAT A347_3H GAGAATACCGGAGAGAGACCGGTGATAATGACGATGCCATACCCCCGAT A347_3P GAGAATACCGGAGAGAGACCGGTGATAATGACGATGCCATACCCCCGAT A347_3K GAGAATACCGGAGAGAGACCGGTGATAATGACGATGCCATACCCCCGAT A347_3L GAGAATACCGGAGAGAGACCGGTGATAATGACGATGCCATACCCCCGAT A347_3a GAGAATACCGGAGGGAGACCGGTGATAATGACGATGCCATACCCCCGAT A347_3I GAGAATACCGGAGAGAGACCGGTGATAACGACGATGCCATACCCCCGAT

\subsubsection{Sequences from A810, Maraehako Bay}

A810 4R ATCATCGAAACTTCGAACGCATCTTGCGCTCCCGGGATATGCCTGGGAGCATGCTTGTCGGGGAGGAGGAGGCGAAAA A810_40 ATCATCGAAACTTCGAACGCATCTTGCGCTCCCGGGATATGCCTGGGAGCATGCTTGTCGGGGAGGAGGAGGCGAAAA A810_4K ATCATCGAAACTTCGAACGCATCTTGCGCTCCCGGGATATGCCTGGGAGCATGCTTGTCGGGGAGGAGGAGGCGAAAA A810_4G ATCATCGAAACTTCGAACGCATCTTGCGCTCCCGGGATATGCCTGGGAGCATGCTTGTCGGGGAGGAGGAGGCGAAAA 
Appendix 3. (Continued)

A810_4H ATCATCGAAACTTCGAACGCATCTTGCGCTCCCGGGATATGCCTGGGAGCATGCTTGTCGGGGAAGAGGAGGCGAAAA A810_4A ATCATCGAAACTTCGAACGCATCTTGCGCTCCCGGGATATGCCTGGGAGCATGCTTGTCGGGGAGGAGGAGGCGAAAA A810_4M ATCATCGAAACTTCGAACGCATCTTGCGCTCCCGGGATATGCCTGGGAGCATGCTTGTCGGGGAGGAGGAGGCGAAAA A810_4B ATCATCGAAACTTCGAACGCATCTTGCGCTCCCGGGATATGCCTGGGAGCATGCTTGTCGGGGAGGAGGAGGCGAAAA A810_4J ATCATCGAAACTTCGAACGCATCTTGCGCTCCCGGGATATGCCTGGGAGCATGCTTGTCGGGGAGGAGGAGGCGAAAA A810_4T ATCATCGAAACTTCGAACGCATCTTGCGCTCCCGGGATATGCCTGGGAGCATGCTTGTCGGGGAGGAGGAGGCGAAAA A810 4D ATCATCGAAACTTCGAACGCATCTTGCGCTCCCGGGATATGCCTGGGAGCATGCTTGTCGGGGAGGAGGAGGCGAAAA A810_4N ATCATCGAAACTTCGAACGCATCTTGCGCTCCCGGGATATGCCTGGGAGCATGCTTGTCGGGGAGGAGGAGGCGAAAA

A810 4R ATCGCCCACAGCTTCGGGTTCGATCTCGATCTCGAGGCGGTGGAGCGGACTCTGAGTGTTCCGGGGGGCAGTGGTGCC A810_40 ATCGCCCACAGCTTCGGGTTCGATCTCGATCTCGAGGCGGTGGAGCGGACTCTGAGTGTTCCGGGGGGCAGTGGTGCC A810_4K ATCGCCCACAGCTTCGGGTTCGATCTCGATCTCGAGGCGGTGGAGCGGACTCTGAGTGTTCCGGGGGGCAGTGGTGCC A810_4G ATCGCCCACAGCTTCGGGTTCGATCTCGATCTCGAGGCGGTGGAGCGGACTCTGAGTGTTCCGGGGGGCAGTGGTGCC A810_4H ATCGCCCACAGCTTCGGGTTCGATCTCGATCTCGAGGCGGTGGAGCGGACTCTGAGTGTTCCGGGGGGCAGTGGTGCC A810 4A ATCGCCCACAGCTTCGGGTTCGATCTCGATCTCGAGGCGGTGGAGCGGACTCTGAGTGTTCCGGGGGGCAGTGGTGCC A810_4M ATCGCCCACAGCTTCGGGTTCGATCTCGATTTCGAGGCGGTGGAGCGGACTCTGAGTGTTCCGGGGGGCAGTGGTGCC A810_4B ATCGCCCACAGCTTCGGGTTCGATCTCGATTTCGAGGCGGTGGAGCGGACTCTGAGTGTTCCGGGGGGCAGTGGTGCC A810 4J ATCGCCCACAGCTTCGGGTTCGATCTCGATCTCGAGGCGGTGGAGCGGACTCTGAGTGTTCCGGGGGGCAGTGGTGCG A810_4T ATCGCCCACAGCTTCGGGTTCGATCTCGATCTCGAGGCGGTGGAGCGGACTCTGAGTGTTCCGGGGGGCAGTGGTGCG A810_4D ATCGCCCACAGCTTCGGGTTCGATCTCGATCTCGAGGCGGTGGAGCGGACTCTGAGTGTTCCGGGGGGCAGTGGTGCG A810_4N ATCGCCCACAGCTTCGGGTTCGATCTCGATCTCGAGGCGGTGGAGCGGACTCTGAGTGTTCCGGGGGGCAGTGGTGCG

A810 4R GTGTGTATTTTCACGTACATACTGCCAGCTCGTCCCCTGAGTTCACCGAAGCCTAGAGAG-GAAACCGACCGTCCGGG A810_40 GTGTGTATTTTCACGTACATACTGCCAGCTCGTCCCCTGAGTTCACCGAAGCCTAGAGAG-GAAACCGACCGTCCGGG A810_4K GTGTGTATTTTCACGTACATACTGCCAGCTCGTCCCCTGAGTTCACCGAAGCCTAGAGAG-GAAACCGACCGTCCGGG A810 4G GTGTGTATTTTCACGTACATACTGCCAGCTCGTCCCCTGAGTTCACCGAAGCCTAGAGAG-GAAACCGACCGTCTGGG A810_4H GTGTGTATTTTCACGTACATACTGCCAGCTCGTCCCCTGAGTTCACCGAAGCCTAGAGAG-GAAACCGACCGTCCGGG A810_4A GTGTGTATTTTCACGTACATACTGCCAGCTCGTCCCCTGAGTTCACCGAAGCCTAGAGAGAGAAACCGACCGTCCGGG A810_4M GTGTGTATTTTCACGTACATACTGCCAGCTCGTCCCCTGAGTTCACCGAAGCCTAGAGAGAGAAACCGACCGTCCGGG A810_4B GTGTGTATTTTCACGTACATACTGCCAGCTCGTCCCCTGAGTTCACCGAAGCCTAGAGAGAGAAACCGACCGTCCGGG A810 4 J GTGTGTATTTTCACGTACATACTGCCAGCTCGTCCCCTGAGTTCACCGAAGCCTAGAGAGAGAAACCGACCGTCCGGG A810_4T GTGTGTATTTTCACGTACATACTGCCAGCTCGTCCCCTGAGTTCACCGAAGCCTAGAGAGAGAAACCGACCGTCCGGG A810_4D GCGTGTATTTTCACGTACATACTGCCAGCTCGTCCCCTGAGTTCACCGAAGCCTAGAGAGAGAAACCGACCGTCCGGG A810_4N GCGTGTATTTTCACGTACATACTGCCAGCTCGTCCCCTGAGTTCACCGAAGCCTAGAGAGAGAAACCGACCGTCCGGG

A810_4R CATTTATTCTCTTTGCGGCGCTTAAGGCAGGTTCACTTTGCGTCCTCCAGAAGATCCGTTGTTGACGGCGCCCCCTTT A810_40 CATTTATTCTCTTTGCGGCGCTTAAGGCAGGTTCACTTTGCGTCCTCCAGAAGATCCGTTGTTGACGGCGCCCCCTTT A810_4K CATTTATTCTCTTTGCGGCGCTTAAGGCAGGTTCACTTTGCGTCCTCCAGAAGATCCGTTGTTGACGGCGCCCCCTTT A810 4G CATTTATTCTCTTTGCGGCGCTTAAGGCAGGTTCACTTTGCGTCCTCCAGAAGATCCGTTGTTGACGGCGCCCCCTTT A810_4H CATTTATTCTCTTTGCGGCGCTTAAGGCAGGTTCACTTTGCGTCCTCCAGAAGATCCGTTGTTGACGGCGCCCCCTTT A810_4A CATTTATTCTCTTTGCGGCGCTTAAGGCAGGTTCACTTTGCGTCCTCCAGAAGATCCGTTGTTGACGGCGCCCCCTTT A810_4M CATTTATTCTCTTTGCGGCGCTTAAGGCAGGTTCACTTTGCGTCCTCCAGAAGATCCGTTGTTGACGGCGCCCCCTTT A810_4B CATTTATTCTCTTTGCGGCGCTTAAGGCAGGTTCACTTTGCGTCCTCCAGAAGATCCGTTGTTGACGGCGCCCCCTTT A810_4J CATTTATTCTCTTTGCGGCGCTTAAGGCAGGTTCACTTTGCGTCCTCCAGAAGATCCGTTGTTGACGGCGCCCCCTTT A810_4T CATTTATTCTCTTTGCGGCGCTTAAGGCAGGTTCACTTTGCGTCCTCCAGAAGATCCGTTGTTGACGGCGCCCCCTTT A810_4D CATTTATTCTCTTTGCGGCGCTTAAGGCAGGTTCACTTTGCGTCCTCCAGAAGATCCGTTGTTGACGGCGCCCCCTTT A810_4N CATTTATTCTCTTTGCGGCGCTTAAGGCAGGTTCACTTTGCGTCCTCCAGAAGATCCGTTGTTGACGGCGCCCCCTTT

A810_4R CGTGGGGCGGGGACACGACGGGTTGCTGGGGATGAGCGCGGGTGGCCTTGCTGCGTCGCGCCGGAGGCCAGTGGACGG A810_40 CGTGGGGCGGGGACACGACGGGTTGCTGGGGATGAGCGCGGGTGGCCTTGCTGCGTCGCGCCGGAGGCCAGTGGACGG A810_4K CGTGGGGCGGGGACACGACGGGTCGCTGGGGATGAGCGCGGGTGGCCTTGCTGCGTCGCGCCGGAGGCCAGTGGACGG A810 4G CGTGGGGCGGGGACACGACGGGTTGCTGGGGATGAGCGCGGGTGGCCTTGCTGCGTCGCGCCGGAGGCCAGTGGACGG A810_4 H CGTGGGGCGGGGACACGACGGGTTGCTGGGGATGAGCGCGGGTGGCCTTGCTGCGTCGCGCCGGAGGCCAGTGGACGG A810_4A CGTGGGGCGGGGACACGACGGGTTGCTGGGGATGAGCGCGGGTGGCCTTGCTGCGTCGCGCTGGAGGCCCGTGGACGG A810 4M CGTGGGGCGGGGACACGACGGGTTGCTGGGGATGAGCGCGGGTGGCCTTGCTGCGTCGCGCCGGAGGCCAGTGGACGG A810_4B CGTGGGGCGGGGACACGACGGGTTGCTGGGGATGAGCGCGGGTGGCCTTGCTGCGTCGCGCCGGAGGCCAGTGGACGG A810_4J CGTGGGGCGGGGACACGACGGGTTGCTGGGGATGAGCGCGGGTGGCCTTGCTGCGTCGCGCTGGAGGCCCGTGGACGG A810_4T CGTGGGGCGGGGACACGACGGGTTGCTGGGGATGAGCGCGGGTGGCCTTGCTGCGTCGCGCCGGAGGCCAGTGGACGG A810_4D CGTGGGGCGGGGACACGACGGGTTGCTGGGGATGAGCGCGGGTGGCCTTGCTGCGTCGCGCTGGAGGCCCGTGGACGG A810_4N CGTGGGGCGGGGACACGACGGGTTGCTGGGGATGAGCGCGGGTGGCCTTGCTGCGTCGCGCTGGAGGCCCGTGGACGG

A810_4R TGGGCAGTCTCGAGAATACCGGAGAGGGACCGGTGATAATGACGATGCCATACCCCCGAT A810_40 TGGGCAGTCTCGAGAATACCGGAGAGAGACCGGTGATAATGACGATGCCATACCCCCGAT A810_4K TGGGCAGTCTCGAGAATACCGGAGAGAGACCGGTGATAATGACGATGCCATACCCCCGAT A810_4G TGGGCAGTCTCGAGAATACCGGAGAGAGACCGGTGATAATGACGATGCCATACCCCCGAT A810 4H TGGGCAGTCTCGAGAATACCGGAGAGAGACCGGTGATAATGACGATGCCATACCCCCGAT A810_4A TGGGCAGTCTCGAGAATACCGGAGAGAGACCGGTGATAATGACGATGCCATACCCCCGAT A810 4M TGGGCAGTCTCGAGAATACCGGAGAGAGACCGGTGATAATGACGATGCCATACCCCCGAT A810_4B TGGGCAGTCTCGAGAATACCGGAGAGAGACCGGTGATAATGACGATGCCATACCCCCGAT A810_4J TGGGCAGTCTCGAGAATACCGGAGAGAGACCGGTGATAATGACGATGCCATACCCCCGAT A810_4T TGGGCAGTCTCGAGAATACCGGAGAGAGACCGGTGATAATGACGATGCCATACCCCCGAT A810_4D TGGGCAGTCTCGAGAATACCGGAGAGAGACCGGTGATAATGACGATGCCATACCCCCGAT A810_4N TGGGCAGTCTCGAGAATACCGGAGAGAGACCGGTGATAATGACGATGCCATACCCCCGAT 


\subsubsection{Sequences from A980, Otanga}

A980 7G ATCATCGAAACTTCGAACGCATCTTGCGCTCCCGGGATATGCCTGGGAGCATGCTTGTCGGGGAGGAGGAGGCGAAAA A980_7B ATCATCGAAACTTCGAACGCATCTTGCGCTCCCGGGATATGCCTGGGAGCATGCTTGTCGGGGAGGAGGAGGCGAAAA A980_7A ATCATCGAAACTTCGAACGCATCTTGCGCTCCCGGGATATGCCTGGGAGCATGCTTGTCGGGGAGGAGGAGGCGAAAA A980_7C ATCATCGAAACTTCGAACGCATCTTGCGCTCCCGGGATATGCCTGGGAGCATGCTTGTCGGGGAGGAGGAGGCGAAAA A980_7D ATCATCGAAACTTCGAACGCATCTTGCGCTCCCGGGATATGCCTGGGAGCATGCTTGTCGGGGAGGAGGAGGCGAAAA A980_7E ATCATCGAAACTTCGAACGCATCTTGCGCTCCCGGGATATGCCTGGGAGCATGCTTGTCGGGGAGGAGGAGGCGAAAA A980_7G ATCATCGAAACTTCGAACGCATCTTGCGCTCCCGGGATATGCCTGGGAGCATGCTTGTCGGGGAGGAGGAGGCGAAAA A980_7H ATCATCGAAACTTCGAACGCATCTTGCGCTCCCGGGATATGCCTGGGAGCATGCTTGTCGGGGAGGAGGAGGCGAAAA A980 7 I ATCATCGAAACTTCGAACGCATCTTGCGCTCCCGGGATATGCCTGGGAGCATGCTTGTCGGGGAGGAGGAGGCGAAAA A980_7K ATCATCGAAACTTCGAACGCATCTTGCGCTCCCGGGATATGCCTGGGAGCATGCTTGTCGGGGAGGAGGAGGCGAAAA A980_7L ATCATCGAAACTTCGAACGCATCTTGCGCTCCCGGGATATGCCTGGGAGCATGCTTGTCGGGGAGGAGGAGGCGAAAA

A980_7G ATCGCCCACAGCTTCGGGTTCGATCTCGATCTCGAAGCGGTGGAGCGGACTCTGAGTGTTCCGGGGGGCAGTGGTGCG A980 7B ATCGCCCACAGCTTCGGGTTCGATCTCGATCTCGAGGCGGTGGAGCGGACTCTGAGTGTTCCGGGGGGCAGTGGTGCG A980_7A ATCGCCCACAGCTTCGGGTTCGATCTCGATCTCGAGGCGGTGGAGCGGACTCTGAGTGTTCCGGGGGGCAGTGGTGCC A980_7C ATCGCCCACAGCTTCGGGTTCGATCTCGATCTCGAGGCGGTGGAGCGGACTCTGAGTGTTCCGGGGGGCAGTGGTGCC A980 7D ATCGCCCACAGCTTCGGGTTCGATCTCGATCTCGAGGCGGTGGAGCGGACTCTGAGTGTTCCGGGGGGCAGTGGTGCC A980_7E ATCGCCCACAGCTTCGGGTTCGATCTCGATCTCGAGGCGGTGGAGCGGACTCTGAGTGTTCCGGGGGGCAGTGGTGCC A980_7G ATCGCCCACAGCTTCGGGTTCGATCTCGATCTCGAGGCGGTGGAGCGGACTCTGAGTGTTCCGGGGGGCAGTGGTGCC A980_7H ATCGCCCACAGCTTCGGGTTCGATCTCGATCTCGAGGCGGTGGAGCGGACTCTGAGTGTTCCGGGGGGCAGTGGTGCC A980_7I ATCGCCCACAGCTTCGGGTTCGATCTCGATCTCGAGGCGGTGGAGCGGACTCTGAGTGTTCCGGGGGGCAGTGGTGCC A980 7K ATCGCCCACAGCTTCGGGTTCGATCTCGATCTCGAGGCGGTGGAGCGGACTCTGAGTGTTCCGGGGGGCAGTGGTGCC A980_7L ATCGCCCACAGCTTCGGGTTCGATCTCGATCTCGAGGCGGTGGAGCGGACTCTGAGTGTTCCGGGGGGCAGTGGTGCC

A980 7G GTGTGTATTTTCACGTACATACTGCCAGCTCGTCCCCTGAGTTCACCGAAGCCTAGAGAGAGAAACCGACCGTCCGGG A980_7B GTGTGTATTTTCACGTACATACTGCCAGCTCGTCCCCTGAGTTCACCGAAGCCTAGAGAGAGAAACCGACCGTCCGGG A980_7A GTGTGTATTTTCACGTACATACTGCCAGCTCGTCCCCTGAGTTCACCGAAGCCTAGAGAG-GAAACCGACCGTCCGGG A980_7C GTGTGTATTTTCACGTACATACTGCCAGCTCGTCCCCTGAGTTCACCGAAGCCTAGAGAG-GAAACCGACCGTCCGGG A980_7D GTGTGTATTTTCACGTACATACTGCCAGCTCGTCCCCTGAGTTCACCGAAGCCTAGAGAG-GAAACCGACCGTCCGGG A980 7E GTGTGTATTTTCACGTACATACTGCCAGCTCGTCCCCTGAGTTCACCGAAGCCTAGAGAG-GAAACCGACCGTCCGGG A980_7G GTGTGTATTTTCACGTACATACTGCCAGCTCGTCCCCTGAGTTCACCGAAGCCTAGAGAG-GAAACCGACCGTCCGGG A980_7H GTGTGTATTTTCACGTACATACTGCCAGCTCGTCCCCTGAGTTCACCGAAGCCTAGAGAG-GAAACCGACCGTCCGGG A980_7I GTGTGTATTTTCACGTACATACTGCCAGCTCGTCCCCTGAGTTCACCGAAGCCTAGGGAG-GAAACCGACCGTCCGGG A980_7K GTGTGTATTTTCACGTACATACTGCCAGCTCGTCCCCTGAGTTCACCGAAGCCTAGAGAG-GAAACCGACCGTCCGGG A980_7L GTGTGTATTTTCACGTACATACTGCCAGCTCGTCCCCTGAGTTCACCGAAGCCTAGAGAG-GAAACCGACCGTCCGGG

A980_7G CATTTATTCTCTTTGCGGCGCTTAAGGCAGGTTCACTTTGCGTCCTCCAGAAGATCCGTTGTTGACGGCGCCCCCTTT A980_7B CATTTATTCTCTTTGCGGCGCTTAAGGCAGGTTCACTTTGCGTCCTCCAGAAGATCCGTTGTTGACGGCGCCCCCTTT A980_7A CATTTATTCTCTTTGCGGCGCTTAAGGCAGGTTCACTTTGCGTCCTCCAGAAGATCCGTTGTTGACGGCGCCCCCTTT A980_7C CATTTATTCTCTTTGCGGCGCTTAAGGCAGGTTCACTTTGCGTCCTCCAGAAGATCCGTTGTTGACGGCGCCCCCTTT A980_7D CATTTATTCTCTTTGCGGCGCTTAAGGCAGGTTCACTTTGCGTCCTCCAGAAGATCCGTTGTTGACGGCGCCCCCTTT A980_7E CATTTATTCTCTTTGCGGCGCTTAAGGCAGGTTCACTTTGCGTCCTCCAGAAGATCCGTTGTTGACGGCGCCCCCTTT A980_7G CATTTATTCTCTTTGCGGCGCTTAAGGCAGGTTCACTTTGCGTCCTCCAGAAGATCCGTTGTTGACGGCGCCCCCTTT A980_7H CATTTATTCTCTTTGCGGCGCTTAAGGCAGGTTCACTTTGCGTCCTCCAGAAGATCCGTTGTTGACGGCGCCCCCTTT A980_7I CATTTATTCTCTTTGCGGCGCTTAAGGCAGGTTCACTTTGCGTCCTCCAGAAGATCCGTTGTTGACGGCGCCCCCTTT A980_7K CATTTATTCTCTTTGCGGCGCTTAAGGCAGGTTCACTTTGCGTCCTCCAGAAGATCCGTTGTTGACGGCGCCCCCTTT A980_7L CATTTATTCTCTTTGCGGCGCTTAAGGCAGGTTCACTTTGCGTCCTCCAGAAGATCCGTTGTTGACGGCGCCCCCTTT

A980_7G CGTGGGGCGGGGACACGACGGGTTGCTGGGGATGAGCGCGGGTGGCCTTGCTGCGTCGCGCTGGAGGCCCGTGGACGG A980_7B CGTGGGGCGGGGACACGACGGGTTGCTGGGGATGAGCGCGGGTGGCCTTGCTGCGTCGCGCTGGAGGCCCGTGGACGG A980_7A CGTGGGGCGGGGACACGACGGGTTGCTGGGGATGAGCGCGGGTGGCCTTGCTGCGTCGCGCCGGAGGCCAGTGGACGG A980_7C CGTGGGGCGGGGACACGACGGGTTGCTGGGGATGAGCGCGGGTGGCCTTGCTGCGTCGCGCCGGAGGCCAGTGGACGG A980_7D CGTGGGGCGGGGACACGGCGGGTTGCTGGGGATGAGCGCGGGTGGCCTTGCTGCGTCGCGCCGGAGGCCAGTGGACGG A 980 7F CGTGGGGCGGGGACACGACGGGTTGCTGGGGATGAGCGCGGGTGGCCTTGCTGCGTCGCGCCGGAGGCCAGTGGACGG A980_7G CGTGGGGCGGGGACACGACGGGTTGCTGGGGATGAGCGCGGGTGGCCTTGCTGCGTCGCGCCGGAGGCCAGTGGACGG A980_7H CGTGGGGCGGGGACACGACGGGTTGCTGGGGTTGAGCGCGGGTGGCCTTGCTGCGTCGCGCCGGAGGCCAGTGGACGG A980_7I CGTGGGGCGGGGACACGACGGGTTGCTGGGGATGAGCGCGGGTGGCCTTGCTGCGTCGCGCCGGAGGCCAGTGGACGG A980_7K CGTGGGGCGGGGACACGACGGGTTGCTGGGGATGAGCGCGGGTGGCCTTGCTGCGTCGCGCCGGAGGCCAGTGGACGG A980_7L CGTGGGGCGGGGACACGACGGGTTGCTGGGGATGAGCGCGGGTGGCCTTGCTGCGTCGCGCCGGAGGCCAGTGGACGG

A980_7G TGGGCAGTCTCGAGAATACCGGAGAGAGACCGGTGATAATGACGATGCCATACCCCCGAT A980 7B TGGGCAGTCTCGAGAATACCGGAGAGAGACCGGTGATAATGACGATGCCATACCCCCGAT A980_7A TGGGCAGTCTCGAGAATACCGGAGAGAGACCGGTGATAATGACGATGCCATACCCCCGAT A980_7C TGGGCAGTCTCGAGAATACCGGAGAGAGACCGGTGATAATGACGATGCCATACCCCCGAT A980_7D TGGGCAGTCTCGAGAATACCGGAGAGAGACCGGTGATAATGACGATGCCATACCCCCGAT A980_7E TGGGCAGTCTCGAGAATACCGGAGAGAGACCGGTGATAATGACGATGCCATACCCCCGAT A980_7G TGGGCAGTCTCGAGAATACCGGAGAGAGACCGGTGATAATGACGATGCCATACCCCCGAT A980_7H TGGGCAGTCTCGAGAATACCGGAGAGAGACCGGTGATAATGACGATGCCATACCCCCGAT A980_7I TGGGCAGTCTCGAGAATACCGGAGAGAGACCGGTGATAATGACGATGCCATACCCCCGAT A980_7K TGGGCAGTCTCGAGAATACCGGAGAGAGACCGGTGATAATGACGATGCCATACCCCCGAT A980_7L TGGGCAGTCTCGAGAATACCGGAGAGAGACCGGTGATAATGACGATGCCATACCCCCGAT 


\subsubsection{Sequences from A868, Waterfall Reef, Leigh}

A 868_5N ATCATCGAAACTTCGAACGCATCTTGCGCTCCCGGGATATGCCTGGGAGCATGCTTGTCGGGGAGGAGGAGGCGAAAA A868_5R ATCATCGAAACTTCGAACGCATCTTGCGCTCCCGGGATATGCCTGGGAGCATGCTTGTCGGGGAGGAGGAGGCGAAAA A868_5G ATCATCGAAACTTCGAACGCATCTTGCGCTCCCGGGATATGCCTGGGAGCATGCTTGTCGGGGAGGAGGAGGCGAAAA A868_5L ATCATCGAAACTTCGAACGCATCTTGCGCTCCCGGGATATGCCTGGGAGCATGCTTGTCGGGGAGGAGGAGGCGAAAA A868_5B ATCATCGAAACTTCGAACGCATCTTGCGCTCCCGGGATATGCCTGGGAGCATGCTTGTCGGGGAGGAGGAGGCGAAAA A868 5D ATCATCGAAACTTCGAACGCATCTTGCGCTCCCGGGATATGCCTGGGAGCATGCTTGTCGGGGAGGAGGAGGCGAAAA A868_5H ATCATCGAAACTTCGAACGCATCTTGCGCTCCCGGGATATGCCTGGGAGCATGCTTGTCGGGGAGGAGGAGGCGAAAA A868_5K ATCATCGAAACTTCGAACGCATCTTGCGCTCCCGGGATATGCCTGGGAGCATGCTTGTCGGGGAGGAGGAGGCGAAAA

A868_5N ATCGCCCACAGCTTCGGGTTCGATCTCGATCTCGAGGCGGTGGAGCGGACTCTGAGTGTTCCGGGGGGCAGTGGTGCG A868_5R ATCGCCCACAGCTTCGGGTTCGATCTCGATCTCGAGGCGGTGGAGCGGACTCTGAGTGTTCCGGGGGGCAGTGGTGCG A868_5G ATCGCCCACAGCTTCGGGTTCGATCTCGATCTCGAGGCGGTGGAGCGGACTCTGAGTGTTCCGGGAGGCAGTGGTGCG A868_5L ATCGCCCACAGCTTCGGGTTCGATCTCGATCTCGAGGCGGTGGAGCGGACTCTGAGTGTTCCGGGGGGCAGTGGTGCG A868 5B ATCGCCCACAGCTTCGGGTTCGATCTCGATCTCGAGGCGGTGGAGCGGACTCTGAGTGTTCCGGGGGGCAGTGGTGCG A868_5D ATCGCCCACAGCTTCGGGTTCGATCTCGATCTCGAGGCGGTGGAGCGGACTCTGAGTGTTCCGGGGGGCAGTGGTGGG A868_5H ATCGCCCACAGCTTCGGGTTCGATCTCGATCTCGAGGCGGTGGAGCGGACTCTGAGTGTTCCGGGGGGCAGTGGTGGG A868_5K ATCGCCCACAGCTTCGGGTTCGATCTCGATCTCGAGGCGGTGGAGCGGACTCTGAGTGTTCCGGGGGGCAGTGGTGGG

A868_5N GTGTGTATTTTCACGTACATACTGCCAGCTCGTCCCCTGAGTTCACCGAAGCCTAGAGAGAGAAACCGACCGTCCGGG A868_5R GTGTGTATTTTCACGTACATACTGCCAGCTCGTCCCCTGAGTTCACCGAAGCCTAGAGAGAGAAACCGACCGTCCGGG A868_5G GTGTGTATTTTCACGTACATACTGCCAGCTCGTCCCCTGAGTTCACCGAAGCCTAGAGAGAGAAACCGACCGTCCGGG A868 5L GTGTGTATTTTCACGTACATACTGCCAGCTCGTCCCCTGAGTTCACCGAAGCCTAGAGAGAGAAACCGACCGTCCGGG A868_5B GTGTGTATTTTCACGTACATGCTGCCAGCTCGTCCCCTGAGTTCACCGAAGCCTAGAGAG--AAACCGACCGTCCGGG A868_5D GTGTGTATTTTCACGTACATGCTGCCAGCTCGTCCCCTGAGTTCACCGAAGCCTAGAGAG--AAACCGACCGTCCGGG A868 5H GTGTGTATTTTCACGTACATGCTGCCAGCTCGTCCCCTGAGTTCACCGAAGCCTAGAGAG--AAACCGACCGTCCGGG A868_5K GTGTGTATTTTCACGTACATGCTGCCAGCTCGTCCCCTGAGTTCACCGAAGCCTAGAGAG--AAACCGACCGTCCGGG

A868_5N CATTTATTCTCTTTGCGGCGCTTAAGGCAGGTTCACTTTGCGTCCTCCAGAAGATCCGTTGTTGACGGCGCCCCCTTT A868_5R CATTTATTCTCTTTGCGGCGCTTAAGGCAGGTTCACTTTGCGTCCTCCAGAAGATCCGTTGTTGACGGCGCCCCCTTT A868 5G CATTTATTCTCTTTGCGGCGCTTAAGGCAGGTTCACTTTGCGTCCTCCAGAAGATCCGTTGTTGACGGCGCCCCCTTT A868_5L CATTTATTCTCTTTGCGGCGCTTAAGGCAGGTTCACTTTGCGTCCTCCAGAAGATCCGTTGTTGACGGCGCCCCCTTT A868_5B CATTTATTCTCTTTGCGGCGCTTAAGGCAGGTTCACTTTGCGTCCTCCAGAAGATCCGTTGTTGACGGCGCCCCCTTT A868 5D CATTTATTCTCTTTGCGGCGCTTAAGGCAGGTTCACTTTGCGTCCTCCAGAAGATCCGTTGTTGACGGCGCCCCCTTT A868_5H CATTTATTCTCTTTGCGGCGCTTAAGGCAGGTTCACTTTGCGTCCTCCAGAAGATCCGTTGTTGACGGCGCCCCCTTT A868_5K CATTTATTCTCTTTGCGGCGCTTAAGGCAGGTTCACTTTGCGTCCTCCAGAAGATCCGTTGTTGACGGCGCCCCCTTT

A868_5N CGTGGGGCGGGGACACGACGGGTTGCTGGGGATGAGCGCGGGTGGCCTTGCTGCGTCGCGCTGGAGGCCCGTGGACGG A868 5R CGTGGGGCGGGGACACGACGGGTTGCTGGGGATGAGCGCGGGTGGCCTTGCTGCGTCGCGCTGGAGGCCCGTGGACGG A868_5G CGTGGGGCGGGGACACGACGGGTTGCTGGGGATGAGCGCGGGTGGCCTTGCTGCGTCGCGCTGGAGGCCCGTGGACGG A868_5L CGTGGGGCGGGGACACGACGGGTTGCTGGGGATGAGCGCGGGTGGCCTTGCTGCGTCGCGCTGGAGGCCCGTGGACGG A868 5B CGTGGGGCGGGGACACGACGGGTTGCTGGGGATGAGCGCGGGTGGCCTTGCTGCGTCGCGCTGGAGGCCCGTGGACGG A868_5D CGTGGGGCGGGGACACGACGGGTTGCTGGGGATGAGCGCGGGTGGCCTTGCTGCGTCGCGCCGGAGGCCCGTGGACGG A868_5H CGTGGGGCGGGGACACGACGGGTTGCTGGGGATGAGCGCGGGTGGCCTTGCTGCGTCGCGCCGGAGGCCCGTGGACGG A868_5K CGTGGGGCGGGGACACGACGGGTTGCTGGGGATGAGCGCGGGTGGCCTTGCTGCGTCGCGCCGGAGGCCCGTGGACGG

A868 5N TGGGCAGTCTCGAGAATACCGGAGAGAGACCGGTGATAATGACGATGCCATACCCCCGAT A868_5R TGGGCAGTCTCGAGAATACCGGAGAGAGACCGGTGATAATGACGATGCCATACCCCCGAT A868_5G TGGGCAGTCTCGAGAATACCGGAGAGAGACCGGTGATAATGACGATGCCATACCCCCGAT A868_5L TGGGCAGTCTCGAGAATACCGGAGAGAGACCGGTGATAATGACGATGCCATACCCCCGAT A868_5B TGGGCAGTCTCGAGAATACCGGAGAGAGACCGGTGATAATGACGATGCCATACCCCCGAT A868_5D TGGGCAGTCTCGAGAATACCGGAGAGAGACCGGTGATAATGACGATGCCATACCCCCGAT A868_5H TGGGCAGTCTCGAGAATACCGGAGAGAGACCGGTGATAATGACGATGCCATACCCCCGAT A868_5K TGGGCAGTCTCGAGAATACCGGAGAGAGACCGGTGATAATGACGATGCCATACCCCCGAT 


\subsection{Appendix 4. Alignment of cox1 sequences from Cystophora. Specimen names are truncated to FieldnumberSpecies.}

B601Ccephalorni B327Cconfluens B162Cconfluens B174Lquercifoli B318Cmonilifera B092Cmonilifera B095Cmonilifera B102Cmonilifera B120Cmonilifera B093Cmoniliform B163Cmoniliform B094Csubfarcina B100Csubfarcina B101Cretroflexa B099Cretroflexa B123Cretroflexa B124Cretroflexa B166Csubfarcina B108Cretorta B617Cretroflexa B430Cretroflexa A615Cretroflexa B137Cretorta B169Cretroflexa B425Cretroflexa B426Cretroflexa B335Ccongesta B436Cretroflexa A154Cscalaris A080Cretroflexa B602Cretroflexa A085Cretroflexa B556Cretroflexa A196Cretroflexa B412Csubfarcina B121Cretroflexa B109Cretorta B170Cretorta B415Csiliquosa B111Cpolycystid B112Cpolycystid B148Cpolycystid B171Cpolycystid A168Cplatylobiu B140Cplatylobiu B104Cplatylobiu B116Ccongesta B115Ccongesta B152Ccongesta B455Ccongesta B129Cretorta B131Cretorta B161Csubfarcina B626Cretroflexa B146Csubfarcina B146Csubfarcina B128Csubfarcina B127Csubfarcina B159Cretroflexa B134Csubfarcina B168Csubfarcina B136Csubfarcina B626Cretroflexa B153Csubfarcina B110Csubfarcina B417Cretroflexa B624Csubfarcina B428Ctorulosa B103Ctorulosa B165Ctorulosa B125Ctorulosa B147Ctorulosa B179Ctorulosa
GGTGTCTTGGGTACAGCTATGTCTGTTCTTATCAGGTTGCAGCTTGGTAGCCCaGGAAATATGTTTTTAGGTGGCAAT GGTGTCTTGGGTACAGCTATGTCTGTTCTTATCAGGTTGCAGCTTGGTAGCCCAGGAAATATGTTTTTAGGTGGCAAT GGTGTTTTAGGTACAATGATGTCTGTTATTATTAGGTTGCAGCTTGCTAGTCCTGGCAATATGTTTTTGGGTGGCAAT GGTGTTTTAGGTACAATGATGTCTGTTATTATTAGGTTGCAGCTTGCTAGTCCTGGCAATATGTTTTTGGGTGGCAAT GGTGTTTTGGGTACAGTAATGTCTGTTCTTATTAGGTTACAGCTTGCAAGCCCGGGTAATATGTTTTTGGGAGGCAAT GGTATTTTGGGTACAGCAATGTCTGTTCTTATTAGGTTGCAGCTTGCAAGCCCCGGCAATATGTTTTTGAGTGGCAAT GGTATTTTGGGTACAGCAATGTCTGTTCTTATTAGGTTGCAGCTTGCAAGCCCCGGCAATATGTTTTTGAGTGGCAAT GGTATTTTGGGTACAGCAATGTCTGTTCTTATTAGGTTGCAGCTTGCAAGCCCCGGCAATATGTTTTTGAGTGGCAAT GGTATTTTGGGTACAGCAATGTCTGTTCTTATTAGGTTGCAGCTTGCAAGCCCCGGCAATATGTTTTTGAGTGGCAAT GGTATTTTGGGTACAGCAATGTCTGTTCTTATTAGGTTGCAGCTTGCAAGCCCCGGCAATATGTTTTTGAGTGGCAAT GGTATTTTGGGCACAGCAATGTCTGTTCTTATTAGGTTACAGCTCGCAAGTCCCGGCAATATGTTTTTGGGGGGCAAT GGTATTTTGGGCACAGCAATGTCTGTTCTTATCAGGTTACAGCTCGCAAGTCCCGGCAATATGTTTTTGGGGGGCAAT GGTATTTTGGGTACAGCAATGTCTGTTCTTATTAGGTTGCAGCTTGCAAGCCCCGGCAATATGTTTTTGAGTGGCAAT GGTATTTTGGGTACAGCAATGTCTGTTCTTATTAGGTTGCAGCTTGCAAGCCCCGGCAATATGTTTTTGAGTGGCAAT GGTATTTTGGGTACAGCAATGTCTGTTCTTATTAGGTTGCAGCTTGCAAGCCCCGGCAATATGTTTTTGAGCGGCAAT GGTATTTTGGGTACAGCAATGTCTGTTCTTATTAGGTTGCAGCTTGCAAGCCCCGGCAATATGTTTTTGAGCGGCAAT GGTATTTTGGGTACAGCAATGTCTGTTCTTATTAGGTTGCAGCTTGCAAGCCCCGGCAATATGTTTTTGAGCGGCAAT GGTATTTTGGGTACAGCAATGTCTGTTCTTATTAGGTTGCAGCTTGCAAGCCCCGGCAATATGTTTTTGAGCGGCAAT GGTATTTTGGGTACAGCAATGTCTGTTCTTATTAGGTTGCAGCTTGCAAGCCCCGGCAATATGTTTTTGAGTGGCAAT GGTATTTTGGGTACAGCAATGTCTGTTCTTATTAGGTTGCAGCTTGCAAGCCCCGGCAATATGTTTTTGGGTGGCAAT GGTATTTTGGGTACAGCAATGTCTGTTCTTATTAGGTTGCAGCTTGCAAGCCCCGGCAATATGTTTTTGAGCGGCAAT GGTATTTTGGGTACAGCAATGTCTGTTCTTATTAGGTTGCAGCTTGCAAGCCCCGGCAATATGTTTTTGAGCGGCAAT GGTATTTTGGGTACAGCAATGTCTGTTCTTATTAGGTTGCAGCTTGCAAGCCCCGGCAATATGTTTTTGAGCGGCAAT GGTATTTTGGGTACAGCAATGTCTGTTCTTATTAGGTTGCAGCTTGCAAGCCCCGGCAATATGTTTTTGGGTGGCAAT GGTATTTTGGGTACAGCAATGTCTGTTCTTATTAGGTTGCAGCTTGCAAGCCCCGGCAATATGTTTTTGAGCGGCAAT GGTATTTTGGGTACAGCAATGTCTGTTCTTATTAGGTTGCAGCTTGCAAGCCCCGGCAATATGTTTTTGAGCGGCAAT GGTATTTTGGGTACAGCAATGTCTGTTCTTATTAGGTTGCAGCTTGCAAGCCCCGGCAATATGTTTTTGAGCGGCAAT GGTATTTTGGGTACAGCAATGTCTGTTCTTATTAGGTTGCAGCTTGCAAGCCCCGGCAATATGTTTTTGAGCGGCAAT GGTATTTTGGGTACAGCAATGTCTGTTCTTATTAGGTTGCAGCTTGCAAGCCCCGGCAATATGTTTTTGAGCGGCAAT GGTATTTTGGGTACAGCAATGTCTGTTCTTATTAGGTTGCAGCTTGCAAGCCCCGGCAATATGTTTTTGAGTGGCAAT GGTAtTTTGGGTACAGCAATGTCTGTTCTTATTAGGTTGCAGCTTGCAAGCCCCGGCAATATGTTTTTGAGCGGCAAT GGTATTTTGGGTACAGCAATGTCTGTTCTTATTAGGTTGCAGCTTGCAAGCCCCGGCAATATGTTTTTGAGCGGCAAT GGTATTTTGGGTACAGCAATGTCTGTTCTTATTAGGTTGCAGCTTGCAAGCCCCGGCAATATGTTTTTGAGCGGCAAT GGTATTTTGGGTACAGCAATGTCTGTTCTTATTAGGTTGCAGCTTGCAAGCCCCGGCAATATGTTTTTGAGCGGCAAT GGTATTTTGGGTACAGCAATGTCTGTTCTTATTAGGTTGCAGCTTGCAAGCCCCGGCAATATGTTTTTGAGCGGCAAT GGTATTTTGGGTACAGCAATGTCTGTTCTTATTAGGTTGCAGCTTGCAAGCCCCGGCAATATGTTTTTGAGTGGCAAT GGTATTTTGGGTACAGCAATGTCTGTTCTTATTAGGTTGCAGCTTGCAAGCCCCGGCAATATGTTTTTGAGCGGCAAT GGTATTTTGGGTACAGCAATGTCTGTTCTTATTAGGTTGCAGCTTGCAAGCCCCGGCAATATGTTTTTGGGTGGCAAT GGTATTTTGGGTACAGCAATGTCTGTTATTATTAGGTTGCAGCTTGCAAGCCCCGGCAATATGTTTTTGGGTGGCAAT GGTATTTTGGGTACAGCAATGTCTGTTCTTATTAGGTTGCAGCTTGCAAGCCCCGGCAATATGTTTTTGGGTGGCAAT GGTATTTTGGGTACAGCAATGTCTGTTCTTATTAGATTGCAGCTTGCAAGCCCTGGCAATATGTTTTTGAGTGGCAAT GGTATTTTGGGTACAGCAATGTCTGTTCTTATTAGATTGCAGCTTGCAAGCCCTGGCAATATGTTTTTGAGTGGCAAT GGTATTTTGGGTACAGCAATGTCTGTTCTTATTAGATTGCAGCTTGCAAGCCCTGGCAATATGTTTTTGAGTGGCAAT GGTATTTTGGGTACAGCAATGTCTGTTCTTATTAGATTGCAGCTTGCAAGCCCTGGCAATATGTTTTTGAGTGGCAAT GGTATTTTGGGTACAGCAATGTCTGTTCTTATTAGGTTGCAGCTTGCAAGCCCCGGCAATATGTTTTTGGGTGGCAAT GGTATTTTGGGTACAGCAATGTCTGTTCTTATTAGGTTGCAGCTTGCAAGCCCCGGCAATATGTTTTTGGGTGGCAAT GGTATTTTGGGTACAGCAATGTCTGTTCTTATTAGGTTGCAGCTTGCAAGCCCCGGCAATATGTTTTTGGGTGGCAAT GGTATTTTGGGTACAGCAATGTCTGTTCTTATTAGGTTGCAGCTTGCAAGCCCCGGCAATATGTTTTTGAGCGGCAAT GGTATTTTGGGTACAGCAATGTCTGTTCTTATTAGGTTGCAGCTTGCAAGCCCCGGCAATATGTTTTTGAGCGGCAAT GGTATTTTGGGTACAGCAATGTCTGTTCTTATTAGGTTGCAGCTTGCAAGCCCCGGCAATATGTTTTTGAGCGGCAAT GGTATTTTGGGTACAGCAATGTCTGTTCTTATTAGGTTGCAGCTTGCAAGCCCCGGCAATATGTTTTTGAGCGGCAAT GGTATTTTGGGTACAGCAATGTCTGTTCTTATTAGGTTGCAGCTTGCAAGCCCCGGCAATATGTTTTTGGGTGGCAAT GGTATTTTGGGTACAGCAATGTCTGTTCTTATTAGGTTGCAGCTTGCAAGCCCCGGCAATATGTTTTTGGGTGGCAAT GGTATTTTGGGTACAGCAATGTCTGTTCTTATTAGGTTGCAGCTTGCAAGCCCCGGCAATATGTTTTTGAGTGGCAAT GGTATTTTGGGTACAGCAATGTCTGTTCTTATTAGGTTGCAGCTTGCAAGCCCCGGCAATATGTTTTTGAGTGGCAAT GGTATTTTGGGTACAGCAATGTCTGTTCTTATTAGGTTGCAGCTTGCAAGCCCCGGCAATATGTTTTTGAGTGGCAAT GGTATTTTGGGTACAGCAATGTCTGTTCTTATTAGGTTGCAGCTTGCAAGCCCCGGCAATATGTTTTTGAGTGGCAAT GGTATTTTGGGTACAGCAATGTCTGTTCTTATTAGGTTGCAGCTTGCAAGCCCCGGCAATATGTTTTTGAGTGGCAAT GGTATTTTGGGTACAGCAATGTCTGTTCTTATTAGGTTGCAGCTTGCAAGCCCCGGCAATATGTTTTTGAGTGGTAAT GGTATTTTGGGTACAGCAATGTCTGTTCTTATTAGGTTGCAGCTTGCAAGCCCCGGCAATATGTTTTTGAGCGGCAAT ggTaTTTTGGGTACAGCAATGTCTGTTCTTATTAGGTTGCAGCTTGCAAGCCCCGGCAATATGTTTTTGAGTGGCAAT GGTATTTTGGGTACAGCAATGTCTGTTCTTATTAGGTTGCAGCTTGCAAGCCCCGGCAATATGTTTTTGAGTGGCAAT GGTATTTTGGGTACAGCAATGTCTGTTCTTATTAGGTTGCAGCTTGCAAGCCCCGGCAATATGTTTTTGAGTGGCAAT GGTATTTTGGGTACAGCAATGTCTGTTCTTATTAGGTTGCAGCTTGCAAGCCCCGGCAATATGTTTTTGAGCGGCAAT GGTATTTTGGGTACAGCAATGTCTGTTCTTATTAGGTTGCAGCTTGCAAGCCCCGGCAATATGTTTTTGAGTGGCAAT GGTATTTTGGGTACAGCAATGTCTGTTCTTATTAGGTTGCAGCTTGCAAGCCCCAGCAATATGTTTTTGAGTGGCAAT GGTATTTTGGGTACAGCAATGTCTGTTCTTATTAGGTTGCAGCTTGCAAGCCCCGGCAATATGTTTTTGAGCGGCAAT GGTATTTTGGGTACAGCAATGTCTGTTCTTATTAGGTTGCAGCTTGCAAGCCCCGGCAATATGTTTTTGAGTGGCAAT GGTATTTTGGGTACAGCAATGTCTGTTCTTATTAGGTTGCAGCTTGCAAGCCCCGGCAATATGTTTTTGAGTGGTAAT GGTATTTTGGGTACAGCAATGTCTGTTCTTATTAGGTTGCAGCTTGCAAGCCCCGGCAATATGTTTTTGAGTGGTAAT GGTATTTTGGGTACAGCAATGTCTGTTCTTATTAGGTTGCAGCTTGCAAGCCCCGGCAATATGTTTTTGAGTGGTAAT GGTATTTTGGGTACAGCAATGTCTGTTCTTATTAGGTTGCAGCTTGCAAGCCCCGGCAATATGTTTTTGAGTGGCAAT GGTATTTTGGGTACAGCAATGTCTGTTCTTATTAGGTTGCAGCTTGCAAGCCCCGGCAATATGTTTTTGAGTGGTAAT GGTATTTTGGGTACAGCAATGTCTGTTCTTATTAGGTTGCAGCTTGCAAGCCCCGGCAATATGTTTTTGAGTGGTAAT 
Appendix 4. (Continued)

A271Ctorulosa B175Ctorulosa A093Ctorulosa B320Ctorulosa A198Ctorulosa B316Ctorulosa B167Ctorulosa B145Ccongesta B149Ccongesta B416Ccongesta B176Cscalaris B178Cscalaris A318Cscalaris A469Cscalaris B330Cscalaris B333Cscalaris B334Cscalaris B336Cscalaris B337Cscalaris B338Cscalaris B611Cscalaris B612Cscalaris B608Cscalaris B607Cscalaris B606Cscalaris B177Cscalaris B605Cscalaris B332Cscalaris A099Cscalaris A614Cscalaris A596Cscalaris A292Cscalaris B351CspWilson B319Csiliquosa B130Csiliquosa B143Csiliquosa B118Csiliquosa B325Cretorta B324Cretorta

GGTATTTTGGGTACAGCAATGTCTGTTCTTATTAGGTTGCAGCTTGCAAGCCCCGGCAATATGTTTTTGAGTGGTAAT GGTATTTTGGGTACAGCAATGTCTGTTCTTATTAGGTTGCAGCTTGCAAGCCCCGGCAATATGTTTTTGAGTGGTAAT GGTATTTTGGGTACAGCAATGTCTGTTCTTATTAGGTTGCAGCTTGCAAGCCCCGGCAATATGTTTTTGAGTGGTAAT GGTATTTTGGGTACAGCAATGTCTGTTCTTATTAGGTTGCAGCTTGCAAGCCCCGGCAATATGTTTTTGAGTGGTAAT GGTATTTTGGGTACAGCAATGTCTGTTCTTATTAGGTTGCAGCTTGCAAGCCCCGGCAATATGTTTTTGAGTGGTAAT GGTATTTTGGGTACAGCAATGTCTGTTCTTATTAGGTTGCAGCTTGCAAGCCCCGGCAATATGTTTTTGAGTGGTAAT GGTATTTTGGGTACAGCAATGTCTGTTCTTATTAGGTTGCAGCTTGCAAGCCCCGGCAATATGTTTTTGAGTGGTAAT GGTATTTTGGGTACAGCAATGTCTGTTCTTATTAGGTTGCAGCTTGCAAGCCCCGGCAATATGTTTTTGAGCGGCAAT GGTATTTTGGGTACAGCAATGTCTGTTCTTATTAGGTTGCAGCTTGCAAGCCCCGGCAATATGTTTTTGAGCGGCAAT GGTATTTTGGGTACAGCAATGTCTGTTCTTATTAGGTTGCAGCTTGCAAGCCCCGGCAATATGTTTTTGAGTGGCAAT GGTATTTTGGGTACAGCAATGTCTGTTCTTATTAGGTTGCAGCTTGCAAGCCCCGGCAATATGTTTTTGAGTGGCAAT GGTATTTTGGGTACAGCAATGTCTGTTCTTATTAGGTTGCAGCTTGCAAGCCCCGGCAATATGTTTTTGAGTGGCAAT GGTATTTTGGGTACAGCAATGTCTGTTCTTATTAGGTTGCAGCTTGCAAGCCCCGGCAATATGTTTTTGAGTGGCAAT GGTATTTTGGGTACAGCAATGTCTGTTCTTATTAGGTTGCAGCTTGCAAGCCCCGGCAATATGTTTTTGAGTGGCAAT GGTATTTTGGGTACAGCAATGTCTGTTCTTATTAGGTTGCAGCTTGCAAGCCCCGGCAATATGTTTTTGAGCGGCAAT GGTATTTTGGGTACAGCAATGTCTGTTCTTATTAGGTTGCAGCTTGCAAGCCCCGGCAATATGTTTTTGAGTGGCAAT GGTATTTTGGGTACAGCAATGTCTGTTCTTATTAGGTTGCAGCTTGCAAGCCCCGGCAATATGTTTTTGAGTGGCAAT GGTATTTTGGGTACAGCAATGTCTGTTCTTATTAGGTTGCAGCTTGCAAGCCCCGGCAATATGTTTTTGAGTGGCAAT GGTATTTTGGGTACAGCAATGTCTGTTCTTATTAGGTTGCAGCTTGCAAGCCCCGGCAATATGTTTTTGAGTGGCAAT GGTATTTTGGGTACAGCAATGTCTGTTCTTATTAGGTTGCAGCTTGCAAGCCCCGGCAATATGTTTTTGAGTGGCAAT GGTATTTTGGGTACAGCAATGTCTGTTCTTATTAGGTTGCAGCTTGCAAGCCCCGGCAATATGTTTTTGAGTGGCAAT GGTATTTTGGGTACAGCAATGTCTGTTCTTATTAGGTTGCAGCTTGCAAGCCCCGGCAATATGTTTTTGAGTGGCAAT GGTATTTTGGGTACAGCAATGTCTGTTCTTATTAGGTTGCAGCTTGCAAGCCCCGGCAATATGTTTTTGAGTGGCAAT GGTATTTTGGGTACAGCAATGTCTGTTCTTATTAGGTTGCAGCTTGCAAGCCCCGGCAATATGTTTTTGAGTGGCAAT GGTATTTTGGGTACAGCAATGTCTGTTCTTATTAGGTTGCAGCTTGCAAGCCCCGGCAATATGTTTTTGAGTGGCAAT GGTATTTTGGGTACAGCAATGTCTGTTCTTATTAGGTTGCAGCTTGCAAGCCCCGGCAATATGTTTTTGAGTGGCAAT GGTATTTTGGGTACAGCAATGTCTGTTCTTATTAGGTTGCAGCTTGCAAGCCCCGGCAATATGTTTTTGAGTGGCAAT GGTATTTTGGGTACAGCAATGTCTGTTCTTATTAGGTTGCAGCTTGCAAGCCCCGGCAATATGTTTTTGAGTGGCAAT GGTATTTTGGGTACAGCAATGTCTGTTCTTATTAGGTTGCAGCTTGCAAGCCCCGGCAATATGTTTTTGAGTGGCAAT GGTATTTTGGGTACAGCAATGTCTGTTCTTATTAGGTTGCAGCTTGCAAGCCCCGGCAATATGTTTTTGAGTGGCAAT GGTATTTTGGGTACAGCAATGTCTGTTCTTATTAGGTTGCAGCTTGCAAGCCCCGGCAATATGTTTTTGAGTGGCAAT GGTATTTTGGGTACAGCAATGTCTGTTCTTATTAGGTTGCAGCTTGCAAGCCCCGGCAATATGTTTTTGAGTGGCAAT gGTATTTTGGGTACAGCAATGTCTGTTCTTATTAGGTTGCAGCTTGCAAGCCCCGGCAATATGTTTTTGAGTGGTAAT GGTATTTTGGGTACAGCAATGTCTGTTCTTATTAGGTTGCAGCTTGCAAGCCCCGGCAATATGTTTTTGGGTGGCAAT GGTATTTTGGGTACAGCAATGTCTGTTCTTATTAGGTTGCAGCTTGCAAGCCCCGGCAATATGTTTTTGGGTGGCAAT GGTATTTTGGGTACAGCAATGTCTGTTCTTATTAGGTTGCAGCTTGCAAGCCCCGGCAATATGTTTTTGGGTGGCAAT GGTATTTTGGGTACAGCAATGTCTGTTCTTATTAGGTTGCAGCTTGCAAGCCCCGGCAATATGTTTTTGGGTGGCAAT GGTATTTTGGGTACAGCAATGTCTGTTCTTATTAGGTTGCAGCTTGCAAGCCCCGGCAATATGTTTTTGGGTGGCAAT GGTATTTTGGGTACAGCAATGTCTGTTCTTATTAGGTTGCAGCTTGCAAGCCCCGGCAATATGTTTTTGGGTGGCAAT

B601Ccephalorni TATCAGTTGTATAATGTTATTGTAACAGCTCATGCTTTTTTGATGATTTTCTTTATGGTTATGCCTGTTCTGATTGGT Bo91Ccephalorni TATCAGTTGTATAATGTTATTGTAACAGCTCATGCTTTTTTGATGATTTTCTTTATGGTTATGCCTGTTCTGATTGGT B327Carpoconflu TACCAGTTGTATAATGTTATTGTAACGGCTCACGCTTTTTTGATGATTTTTTTTATGGTGATGCCTGTCCTTATTGGC B162Carpoconflu TACCAGTTGTATAATGTTATTGTAACGGCTCACGCTTTTTTGATGATTTTTTTTATGGTCATGCCTGTCCTTATTGGC B174Lquercifoli TACCAGTTGTATAATGTTATTGTAACGGCTCACGCCTTTTTGATGATTTTTTTTATGGTTATGCCTGTCCTTATTGGC B318Cmonilifera TACCAGTTGTATAATGTTATCGTAACGGCTCATGCTTTTTTGATGATTTTCTTTATGGTTATGCCTGTGCTTATCGGC B092Cmonilifera TACCAGTTGTATAATGTTATCGTAACGGCTCATGCTTTTTTGATGATTTTCTTTATGGTTATGCCTGTGCTTATCGGC B095Cmonilifera TACCAGTTGTATAATGTTATCGTAACGGCTCATGCTTTTTTGATGATTTTCTTTATGGTTATGCCTGTGCTTATCGGC B102Cmonilifera TACCAGTTGTATAATGTTATCGTAACGGCTCATGCTTTTTTGATGATTTTCTTTATGGTTATGCCTGTGCTTATCGGC B120Cmonilifera TACCAGTTGTATAATGTTATCGTAACGGCTCATGCTTTTTTGATGATTTTCTTTATGGTTATGCCTGTGCTTATCGGC B093Cmoniliform TATCAGTTGTATAATGTCATTGTAACGGCTCACGCTTTTTTGATGATTTTCTTTATGGTTATGCCTGTCCTTATTGGC B163Cmoniliform TATCAGTTGTATAATGTCATTGTAACGGCTCACGCTTTTTTGATGATTTTCTTTATGGTTATGCCTGTCCTTATTGGC B094Csubfarcina TACCAGTTGTATAATGTTATTGTAACGGCTCATGCTTTTTTGATGATTTTCTTTATGGTTATGCCTGTGCTTATCGGC B100Csubfarcina TACCAGTTGTATAATGTTATTGTAACGGCTCATGCTTTTTTGATGATTTTCTTTATGGTTATGCCTGTGCTTATCGGC B101Cretroflexa TACCAGTTGTATAATGTTATTGTAACGGCTCATGCTTTTTGATGATTTTCTTTATGGTTATGCCTGTGCTTATCGGC B099Cretroflexa TACCAGTTGTATAATGTTATTGTAACGGCTCATGCTTTTTTGATGATTTTCTTTATGGTTATGCCTGTGCTTATCGGC B123Cretroflexa TACCAGTTGTATAATGTTATTGTAACGGCTCATGCTTTTTTGATGATTTTCTTTATGGTTATGCCTGTGCTTATCGGC B124Cretroflexa TACCAGTTGTATAATGTTATTGTAACGGCTCATGCTTTTTTGATGATTTTCTTTATGGTTATGCCTGTGCTTATCGGC B166Csubfarcina TACCAGTTGTATAATGTTATTGTAACGGCTCATGCTTTTTTGATGATTTTCTTTATGGTTATGCCTGTGCTTATCGGC B108Cretorta TATCAGTTGTATAATGTTATTGTAACGGCTCACGCTTTTTTGATGATTTTCTTTATGGTTATGCCTGTGCTTATCGGC B617Cretroflexa TACCAGTTGTATAATGTTATTGTAACGGCTCATGCTTTTTTGATGATTTTCTTTATGGTTATGCCTGTGCTTATCGGC B430Cretroflexa TACCAGTTGTATAATGTTATTGTAACGGCTCATGCTTTTTTGATGATTTTCTTTATGGTTATGCCTGTGCTTATCGGC A615Cretroflexa TACCAGTTGTATAATGTTATTGTAACGGCTCATGCTTTTTTGATGATTTTCTTTATGGTTATGCCTGTGCTTATCGGC B137Cretorta B169Cretroflexa B425Cretroflexa B426Cretroflexa B335Ccongesta B436Cretroflexa A154Cscalaris A080Cretroflexa B602Cretroflexa A085Cretroflexa B556Cretroflexa A196Cretroflexa B412Csubfarcina TATCAGTTGTATAATGTTATTGTAACGGCTCACGCTTTTTTGATGATTTTCTTTATGGTTATGCCTGTGCTTATCGGC TACCAGTTGTATAATGTTATTGTAACGGCTCATGCTTTTTTGATGATTTTCTTTATGGTTATGCCTGTGCTTATCGGC TACCAGTTGTATAATGTTATTGTAACGGCTCATGCTTTTTTGATGATTTTCTTTATGGTTATGCCTGTGCTTATCGGC TACCAGTTGTATAATGTTATTGTAACGGCTCATGCTTTTTTGATGATTTTCTTTATGGTTATGCCTGTGCTTATCGGC TACCAGTTGTATAATGTTATTGTAACGGCTCATGCTTTTTTGATGATTTTCTTTATGGTTATGCCTGTGCTTATCGGC TACCAGTTGTATAATGTTATTGTAACGGCTCATGCTTTTTTGATGATTTTCTTTATGGTTATGCCTGTGCTTATCGGC TACCAGTTGTATAATGTTATTGTAACGGCTCATGCTTTTTTGATGATTTTCTTTATGGTTATGCCTGTGCTTATCGGC TACCAGTTGTATAATGTTATTGTAACGGCTCATGCTTTTTTGATGATTTTCTTTATGGTTATGCCTGTGCTTATCGGC TACCAGTTGTATAATGTTATTGTAACGGCTCATGCTTTTTTGATGATTTTCTTTATGGTTATGCCTGTGCTTATCGGC TACCAGTTGTATAATGTTATTGTAACGGCTCATGCTTTTTTGATGATTTTCTTTATGGTTATGCCTGTGCTTATCGGC TACCAGTTGTATAATGTTATTGTAACGGCTCATGCTTTTTTGATGATTTTCTTTATGGTTATGCCTGTGCTTATCGGC TACCAGTTGTATAATGTTATTGTAACGGCTCATGCTTTTTTGATGATTTTCTTTATGGTTATGCCTGTGCTTATCGGC TACCAGTTGTATAATGTTATTGTAACGGCTCATGCTTTTTTGATGATTTTCTTTATGGTTATGCCTGTGCTTATCGGC 
Appendix 4. (Continued)

B121CretroflexTACCAGTTGTATAATGTTATTGTAACGGCTCATGCTTTTTTGATGATTTTCTTTATGGTTATGCCTGTGCTTATCGGC B109Cretorta TATCAGTTGTATAATGTTATTGTAACGGCTCACGCTTTTTTGATGATTTTCTTTATGGTTATGCCTGTGCTTATCGGC B170Cretorta TATCAGTTGTATAATGTTATTGTAACGGCTCACGCTTTTTTGATGATTTTCTTTATGGTTATGCCTGTGCTTATCGGC B415Cretorta TACCAGTTGTATAATGTCATTGTAACGGCTCACGCTTTTTTGATGATTTTCTTTATGGTTATGCCTGTGCTTATCGGC B111Cpolycyst TACCAGTTATATAATGTTATTGTAACGGCTCATGCTTTTTTGATGATTTTCTTTATGGTTATGCCTGTGCTTATCGGC B112Cpolycyst TACCAGTTATATAATGTTATTGTAACGGCTCATGCTTTTTTGATGATTTTCTTTATGGTTATGCCTGTGCTTATCGGC B148Cpolycyst TACCAGTTATATAATGTTATTGTAACGGCTCATGCTTTTTTGATGATTTTCTTTATGGTTATGCCTGTGCTTATCGGC B171Cpolycyst TACCAGTTATATAATGTTATTGTAACGGCTCATGCTTTTTTGATGATTTTCTTTATGGTTATGCCTGTGCTTATCGGC A168Cplatylob TACCAGTTGTATAATGTTATTGTAACGGCTCATGCTTTTTTGATGATTTTCTTTATGGTTATGCCTGTGCTTATCGGC B140Cplatylob TACCAGTTGTATAATGTTATTGTAACGGCTCATGCTTTTTTGATGATTTTCTTTATGGTTATGCCTGTGCTTATCGGC B104Cplatylob TACCAGTTGTATAATGTTATTGTAACGGCTCATGCTTTTTTGATGATTTTCTTTATGGTTATGCCTGTGCTTATCGGC B116CCongesta TACCAGTTGTATAATGTTATTGTAACGGCTCATGCTTTTTTGATGATTTTCTTTATGGTTATGCCTGTGCTTATCGGC B115Ccongesta TACCAGTTGTATAATGTTATTGTAACGGCTCATGCTTTTTTGATGATTTTCTTTATGGTTATGCCTGTGCTTATCGGC B152Ccongesta TACCAGTTGTATAATGTTATTGTAACGGCTCATGCTTTTTTGATGATTTTCTTTATGGTTATGCCTGTGCTTATCGGC B455Ccongesta TACCAGTTGTATAATGTTATTGTAACGGCTCATGCTTTTTTGATGATTTTCTTTATGGTTATGCCTGTGCTTATCGGC B129Cretorta TATCAGTTGTATAATGTTATTGTAACGGCTCACGCTTTTTTGATGATTTTCTTTATGGTTATGCCTGTGCTTATCGGC B131Cretorta TATCAGTTGTATAATGTTATTGTAACGGCTCACGCTTTTTTGATGATTTTCTTTATGGTTATGCCTGTGCTTATCGGC B161Ccuspidat TACCAGTTGTATAATGTTATTGTAACGGCTCATGCTTTTTTGATGATTTTCTTTATGGTTATGCCTGTGCTTATCGGC B628Ccuspidat TACCAGTTGTATAATGTTATTGTAACGGCTCATGCTTTTTTGATGATTTTCTTTATGGTTATGCCTGTGCTTATCGGC B146Ccuspidat TACCAGTTGTATAATGTTATTGTAACGGCTCATGCTTTTTTGATGATTTTCTTTATGGTTATGCCTGTGCTTATCGGC B627Ccuspidat TACCAGTTGTATAATGTTATTGTAACGGCTCATGCTTTTTTGATGATTTTCTTTATGGTTATGCCTGTGCTTATCGGC B128CsubfarcC TACCAGTTGTATAATGTTATTGTAACGGCTCATGCTTTTTTGATGATTTTCTTTATGGTTATGCCTGTGCTTATCGGC B127CsubfarcC TACCAGTTGTATAATGTTATTGTAACGGCTCATGCTTTTTTGATGATTTTCTTTATGGTTATGCCTGTGCTTATCGGC B159Csubfarci TACCAGTTGTATAATGTTATTGTAACGGCTCATGCTTTTTTGATGATTTTCTTTATGGTTATGCCTGTGCTTATCGGC B134Csubfarci TACCAGTTGTATAATGTTATTGTAACGGCTCATGCTTTTTTGATGATTTTCTTTATGGTTATGCCTGTGCTTATCGGC B168Csubfarci TACCAGTTGTATAATGTTATTGTAACGGCTCATGCTTTTTTGATGATTTTCTTTATGGTTATGCCTGTGCTTATCGGC B136Csubfarci TACCAGTTGTATAATGTTATTGTAACGGCTCATGCTTTTTTGATGATTTTCTTTATGGTTATGCCTGTGCTTATCGGC B626Csubfarci TACCAGTTGTATAATGTTATTGTAACGGCTCATGCTTTTTTGATGATTTTCTTTATGGTTATGCCTGTGCTTATCGGC B153Csubfarci TACCAGTTGTATAATGTTATTGTAACGGCTCATGCTTTTTTGATGATTTTCTTTATGGTTATGCCTGTGCTTATCGGC B110Csubfarci TACCAGTTGTATAATGTTATTGTAACGGCTCATGCTTTTTTGATGATTTTCTTTATGGTTATGCCTGTGCTTATCGGC B417Csubfarci TACCAGTTGTATAATGTTATTGTAACGGCTCATGCTTTTTTGATGATTTTCTTTATGGTTATGCCTGTGCTTATCGGC B624Csubfarci TACCAGTTGTATAATGTTATTGTAACGGCTCATGCTTTTTTGATGATTTTCTTTATGGTTATGCCTGTGCTTATCGGC B428Ctorulosa TACCAGTTGTATAATGTTATTGTAACGGCTCATGCTTTTTTGATGATTTTCTTTATGGTTATGCCTGTGCTTATCGGC B103Ctorulosa TACCAGTTGTATAATGTTATTGTAACGGCTCATGCTTTTTTGATGATTTTCTTTATGGTTATGCCTGTGCTTATCGGC B165Ctorulosa TACCAGTTGTATAATGTTATTGTAACGGCTCATGCTTTTTTGATGATTTTCTTTATGGTTATGCCTGTGCTTATCGGC B125Ctorulosa TACCAGTTGTATAATGTTATTGTAACGGCTCATGCTTTTTTGATGATTTTCTTTATGGTTATGCCTGTGCTTATCGGC B147Ctorulosa TACCAGTTGTATAATGTTATTGTAACGGCTCATGCTTTTTTGATGATTTTCTTTATGGTTATGCCTGTGCTTATCGGC B179Ctorulosa TACCAGTTGTATAATGTTATTGTAACGGCTCATGCTTTTTTGATGATTTTCTTTATGGTTATGCCTGTGCTTATCGGC A271Ctorulosa TACCAGTTGTATAATGTTATTGTAACGGCTCATGCTTTTTTGATGATTTTCTTTATGGTTATGCCTGTGCTTATCGGC B175Ctorulosa TACCAGTTGTATAATGTTATTGTAACGGCTCATGCTTTTTTGATGATTTTCTTTATGGTTATGCCTGTGCTTATCGGC A093Ctorulosa TACCAGTTGTATAATGTTATTGTAACGGCTCATGCTTTTTTGATGATTTTCTTTATGGTTATGCCTGTGCTTATCGGC B320Ctorulosa TACCAGTTGTATAATGTTATTGTAACGGCTCATGCTTTTTTGATGATTTTCTTTATGGTTATGCCTGTGCTTATCGGC A198Ctorulosa TACCAGTTGTATAATGTTATTGTAACGGCTCATGCTTTTTTGATGATTTTCTTTATGGTTATGCCTGTGCTTATCGGC B316Ctorulosa TACCAGTTGTATAATGTTATTGTAACGGCTCATGCTTTTTTGATGATTTTCTTTATGGTTATGCCTGTGCTTATCGGC B167Ctorulosa TACCAGTTGTATAATGTTATTGTAACGGCTCATGCTTTTTTGATGATTTTCTTTATGGTTATGCCTGTGCTTATCGGC B145Ccongesta TACCAGTTGTATAATGTTATTGTAACGGCTCATGCTTTTTTGATGATTTTCTTTATGGTTATGCCTGTGCTTATCGGC B149Ccongesta TACCAGTTGTATAATGTTATTGTAACGGCTCATGCTTTTTTGATGATTTTCTTTATGGTTATGCCTGTGCTTATCGGC B416Ccongesta TACCAGTTGTATAATGTTATTGTAACGGCTCATGCTTTTTTGATGATTTTCTTTATGGTTATGCCTGTGCTTATCGGC B176Cscalaris TACCAGTTGTATAATGTTATTGTAACGGCTCATGCTTTTTTGATGATTTTCTTTATGGTTATGCCTGTGCTTATCGGC B178Cscalaris TACCAGTTGTATAATGTTATTGTAACGGCTCATGCTTTTTTGATGATTTTCTTTATGGTTATGCCTGTGCTTATCGGC A318Cscalaris TACCAGTTGTATAATGTTATTGTAACGGCTCATGCTTTTTTGATGATTTTCTTTATGGTTATGCCTGTGCTTATCGGC A469Cscalaris TACCAGTTGTATAATGTTATTGTAACGGCTCATGCTTTTTTGATGATTTTCTTTATGGTTATGCCTGTGCTTATCGGC B330Cscalaris TACCAGTTGTATAATGTTATTGTAACGGCTCATGCTTTTTTGATGATTTTCTTTATGGTTATGCCTGTGCTTATCGGC B333Cscalaris TACCAGTTGTATAATGTTATTGTAACGGCTCATGCTTTTTTGATGATTTTCTTTATGGTTATGCCTGTGCTTATCGGC B334Cscalaris TACCAGTTGTATAATGTTATTGTAACGGCTCATGCTTTTTTGATGATTTTCTTTATGGTTATGCCTGTGCTTATCGGC B336Cscalaris TACCAGTTGTATAATGTTATTGTAACGGCTCATGCTTTTTTGATGATTTTCTTTATGGTTATGCCTGTGCTTATCGGC B337Cscalaris TACCAGTTGTATAATGTTATTGTAACGGCTCATGCTTTTTTGATGATTTTCTTTATGGTTATGCCTGTGCTTATCGGC B338Cscalaris TACCAGTTGTATAATGTTATTGTAACGGCTCATGCTTTTTTGATGATTTTCTTTATGGTTATGCCTGTGCTTATCGGC B611Cscalaris TACCAGTTGTATAATGTTATTGTAACGGCTCATGCTTTTTTGATGATTTTCTTTATGGTTATGCCTGTGCTTATCGGC B612Cscalaris TACCAGTTGTATAATGTTATTGTAACGGCTCATGCTTTTTTGATGATTTTCTTTATGGTTATGCCTGTGCTTATCGGC B608Cscalaris TACCAGTTGTATAATGTTATTGTAACGGCTCATGCTTTTTTGATGATTTTCTTTATGGTTATGCCTGTGCTTATCGGC B607Cscalaris TACCAGTTGTATAATGTTATTGTAACGGCTCATGCTTTTTTGATGATTTTCTTTATGGTTATGCCTGTGCTTATCGGC B606Cscalaris TACCAGTTGTATAATGTTATTGTAACGGCTCATGCTTTTTTGATGATTTTCTTTATGGTTATGCCTGTGCTTATCGGC B177Cscalaris TACCAGTTGTATAATGTTATTGTAACGGCTCATGCTTTTTTGATGATTTTCTTTATGGTTATGCCTGTGCTTATCGGC B605Cscalaris TACCAGTTGTATAATGTTATTGTAACGGCTCATGCTTTTTTGATGATTTTCTTTATGGTTATGCCTGTGCTTATCGGC B332Cscalaris TACCAGTTGTATAATGTTATTGTAACGGCTCATGCTTTTTTGATGATTTTCTTTATGGTTATGCCTGTGCTTATCGGC A099Cscalaris TACCAGTTGTATAATGTTATTGTAACGGCTCATGCTTTTTTGATGATTTTCTTTATGGTTATGCCTGTGCTTATCGGC A614Cscalaris TACCAGTTGTATAATGTTATTGTAACGGCTCATGCTTTTTTGATGATTTTCTTTATGGTTATGCCTGTGCTTATCGGC A596Cscalaris TACCAGTTGTATAATGTTATTGTAACGGCTCATGCTTTTTTGATGATTTTCTTTATGGTTATGCCTGTGCTTATCGGC A292CspManuka TACCAGTTGTATAATGTTATTGTAACGGCTCATGCTTTTTTGATGATTTTCTTTATGGTTATGCCTGTGCTTATCGGC B351CspWilson TACCAGTTGTATAATGTTATTGTAACGGCTCATGCTTTTTTGATGATTTTCTTTATGGTTATGCCTGTGCTTATCGGC B319Csiliquos TACCAGTTGTATAATGTCATTGTAACGGCTCACGCTTTTTTGATGATTTTCTTTATGGTTATGCCTGTGCTTATCGGC B130Csiliquos TACCAGTTGTATAATGTCATTGTAACGGCTCACGCTTTTTTGATGATTTTCTTTATGGTTATGCCTGTGCTTATCGGC B143Csiliquos TACCAGTTGTATAATGTCATTGTAACGGCTCACGCTTTTTTGATGATTTTCTTTATGGTTATGCCTGTGCTTATCGGC B118Csiliquos TACCAGTTGTATAATGTCATTGTAACGGCTCACGCTTTTTTGATGATTTTCTTTATGGTTATGCCTGTGCTTATCGGC B325Cretorta TATCAGTTGTATAATGTTATTGTAACGGCTCACGCTTTTTTGATGATTTTCTTTATGGTTATGCCTGTGCTTATCGGC 
Appendix 4. (Continued)

B324Cretorta TATCAgTTGTATAATGTTATTGTAACGGCTCACGCTTTTTTGATGATTTTCTTTATGGTTATGCCTGTGCTTATCGGC

B601Ccephalorni GGTTTCGGTAATTGGTTTGTTCCTTTAATGATAGGCGCTCCGGATATGGCGTTTCCCCGTATGAACAATATAAGTTTT Bo91Ccephalorni GGTTTCGGTAATTGGTTTGTTCCTTTAATGATAGGCGCTCCGGATATGGCGTTTCCCCGTATGAACAATATAAGTTTT B327Carpoconflu GGATTTGGTAATTGGTTTGTTCCTTTAATGATAGGTGCTCCCGATATGGCGTTTCCTCGTATGAATAATATTAGTTTT B162Carpoconflu GGATTTGGTAATTGGTTTGTTCCTTTAATGATAGGTGCTCCCGATATGGCGTTTCCTCGTATGAATAATATTAGTTTT B174Lquercifoli GGGTTTGGTAATTGGTTTGTTCCTTTAATGATAGGTGCTCCAGATATGGCGTTTCCGCGTATGAACAACATAAGTTTT B318Cmonilifera GGATTTGGTAATTGGTTTGTTCCTTTAATGATAGGTGCTCCAGATATGGCGTTTCCTCGCATGAATAATATAAGTTTT B092Cmonilifera GGATTTGGTAATTGGTTTGTTCCTTTAATGATAGGTGCTCCAGATATGGCGTTTCCTCGCATGAATAATATAAGTTTT B095Cmonilifera GGATTTGGTAATTGGTTTGTTCCTTTAATGATAGGTGCTCCAGATATGGCGTTTCCTCGCATGAATAATATAAGTTTT B102Cmonilifera GGATTTGGTAATTGGTTTGTTCCTTTAATGATAGGTGCTCCAGATATGGCGTTTCCTCGCATGAATAATATAAGTTTT B120Cmonilifera GGATTTGGTAATTGGTTTGTTCCTTTAATGATAGGTGCTCCAGATATGGCGTTTCCTCGCATGAATAATATAAGTTTT B093Cmoniliform GGGTTTGGTAATTGGTTTGTTCCTTTAATGATAGGTGCTCCGGATATGGCGTTTCCTCGCATGAATAATATAAGTTTT B163Cmoniliform GGGTTTGGTAATTGGTTTGTTCCTTTAATGATAGGTGCTCCGGATATGGCGTTTCCTCGCATGAATAATATAAGTTTT B094Csubfarcina GGATTTGGTAATTGGTTTGTTCCTTTAATGATAGGTGCTCCAGATATGGCGTTTCCTCGCATGAATAATATAAGTTTT B100Csubfarcina GGATTTGGTAATTGGTTTGTTCCTTTAATGATAGGTGCTCCAGATATGGCGTTTCCtCGCAtGAATAAtAtAAGTTTT B101Cretroflexa GGATTTGGTAATTGGTTTGTTCCTTTAATGATAGGTGCTCCAGATATGGCGTTTCCTCGCATGAATAATATAAGTTTT B099Cretroflexa GGATTTGGTAATTGGTTTGTTCCTTTAATGATAGGTGCTCCAGATATGGCGTTTCCTCGCATGAATAATATAAGTTTT B123Cretroflexa GGATTTGGTAATTGGTTTGTTCCTTTAATGATAGGTGCTCCAGATATGGCGTTTCCTCGCATGAATAATATAAGTTTT B124Cretroflexa GGATTTGGTAATTGGTTTGTTCCTTTAATGATAGGTGCTCCAGATATGGCGTTTCCTCGCATGAATAATATAAGTTTT B108Cretorta B617Cretroflexa B430Cretroflexa A615Cretroflexa B137Cretorta B169Cretroflexa B425Cretroflexa B426Cretroflexa B335Ccongesta B436Cretroflexa A154Cscalaris A080Cretroflexa B602Cretroflexa A085Cretroflexa B556Cretroflexa A196Cretroflexa B412Csubfarcina B121Cretroflexa B109Cretorta B170Cretorta B415Csiliquosa B111Cpolycystid B112Cpolycystid B148Cpolycystid B171Cpolycystid A168Cplatylobiu B140Cplatylobiu B104Cplatylobiu B116Ccongesta B115Ccongesta B152Ccongesta B455Ccongesta B129Cretorta B131Cretorta B161Csubfarcina B626Cretroflexa B146Csubfarcina B146Csubfarcina B128Csubfarcina B127Csubfarccus B159Cretroflexa B134Csubfarcina B168Csubfarcina B136Csubfarcina B626Cretroflexa B153Csubfarcina B110Csubfarcina B417Cretroflexa B624Csubfarcina B428Ctorulosa B103Ctorulosa B165Ctorulosa B125Ctorulosa B147Ctorulosa B179ctorulosa GGATTTGGTAATTGGTTTGTTCCTTTAATGATAGGTGCTCCAGATATGGCGTTTCCTCGCATGAATAATATAAGTTTT GGATTTGGTAATTGGTTTGTTCCTTTAATGATAGGTGCTCCAGATATGGCGTTTCCTCGCATGAATAATATAAGTTTT GGATTTGGTAATTGGTTTGTTCCTTTAATGATAGGTGCTCCAGATATGGCGTTTCCTCGCATGAATAATATAAGTTTT GGATTTGGTAATTGGTTTGTTCCTTTAATGATAGGTGCTCCAGATATGGCGTTTCCTCGCATGAATAATATAAGTTTT GGATTTGGTAATTGGTTTGTTCCTTTAATGATAGGTGCTCCAGATATGGCGTTTCCTCGCATGAATAATATAAGTTTT GGATTTGGTAATTGGTTTGTTCCTTTAATGATAGGTGCTCCAGATATGGCGTTTCCTCGCATGAATAATATAAGTTTT GGATTTGGTAATTGGTTTGTTCCTTTAATGATAGGTGCTCCAGATATGGCGTTTCCTCGCATGAATAATATAAGTTTT GGATTTGGTAATTGGTTTGTTCCTTTAATGATAGGTGCTCCAGATATGGCGTTTCCTCGCATGAATAATATAAGTTTT GGATTTGGTAATTGGTTTGTTCCTTTAATGATAGGTGCTCCAGATATGGCGTTTCCTCGCATGAATAATATAAGTTTT GGATTTGGTAATTGGTTTGTTCCTTTAATGATAGGTGCTCCAGATATGGCGTTTCCTCGCATGAATAATATAAGTTTT GGATTTGGTAATTGGTTTGTTCCTTTAATGATAGGTGCTCCAGATATGGCATTTCCTCGCATGAATAATATAAGTTTT GGATTTGGTAATTGGTTTGTTCCTTTAATGATAGGTGCTCCAGATATGGCGTTTCCTCGCATGAATAATATAAGTTTT GGATTTGGTAATTGGTTTGTTCCTTTAATGATAGGTGCTCCAGATATGGCGTTTCCTCGCATGAATAATATAAGTTTT GGATTTGGTAATTGGTTTGTTCCTTTAATGATAGGTGCTCCAGATATGGCGTTTCCTCGCATGAATAATATAAGTTTT GGATTTGGTAATTGGTTTGTTCCTTTAATGATAGGTGCTCCAGATATGGCGTTTCCTCGCATGAATAATATAAGTTTT GGATTTGGTAATTGGTTTGTTCCTTTAATGATAGGTGCTCCAGATATGGCGTTTCCTCGCATGAATAATATAAGTTTT GGATTTGGTAATTGGTTTGTTCCTTTAATGATAGGTGCTCCAGATATGGCGTTTCCTCGCATGAATAATATAAGTTTT GGATTTGGTAATTGGTTTGTTCCTTTAATGATAGGTGCTCCAGATATGGCGTTTCCTCGCATGAATAATATAAGTTTT GGATTTGGTAATTGGTTTGTTCCTTTAATGATAGGTGCTCCAGATATGGCGTTTCCTCGCATGAATAATATAAGTTTT GGATTTGGTAATTGGTTTGTTCCTTTAATGATAGGTGCTCCAGATATGGCGTTTCCTCGCATGAATAATATAAGTTTT GGATTTGGTAATTGGTTTGTTCCTTTAATGATAGGTGCTCCAGATATGGCGTTTCCTCGCATGAATAATATAAGTTTT GGATTTGGTAATTGGTTTGTTCCTTTAATGATAGGTGCTCCGGATATGGCGTTTCCTCGCATGAATAATATAAGTTTT GGATTTGGTAATTGGTTTGTTCCTTTAATGATAGGTGCTCCGGATATGGCGTTTCCTCGCATGAATAATATAAGTTTT GGATTTGGTAATTGGTTTGTTCCTTTAATGATAGGTGCTCCGGATATGGCGTTTCCTCGCATGAATAATATAAGTTTT GGATTTGGTAATTGGTTTGTTCCTTTAATGATAGGTGCTCCGGATATGGCGTTTCCTCGCATGAATAATATAAGTTTT GGATTTGGTAATTGGTTTGTTCCTTTAATGATAGGTGCTCCAGATATGGCGTTTCCTCGGATGAATAATATAAGTTTT GGATTTGGTAATTGGTTTGTTCCTTTAATGATAGGTGCTCCAGATATGGCGTTTCCTCGGATGAATAATATAAGTTTT GGATTTGGTAATTGGTTTGTTCCTTTAATGATAGGTGCTCCAGATATGGCGTTTCCTCGGATGAATAATATAAGTTTT GGATTTGGTAATTGGTTTGTTCCTTTAATGATAGGTGCTCCAGATATGGCGTTTCCTCGCATGAATAATATAAGTTTT GGATTTGGTAATTGGTTTGTTCCTTTAATGATAGGTGCTCCAGATATGGCATTTCCTCGCATGAATAATATAAGTTTT GGATTTGGTAATTGGTTTGTTCCTTTAATGATAGGTGCTCCAGATATGGCATTTCCTCGCATGAATAATATAAGTTTT GGATTTGGTAATTGGTTTGTTCCTTTAATGATAGGTGCTCCAGATATGGCGTTTCCTCGCATGAATAATATAAGTTTT GGATTTGGTAATTGGTTTGTTCCTTTAATGATAGGTGCTCCAGATATGGCGTTTCCTCGCATGAATAATATAAGTTTT GGATTTGGTAATTGGTTTGTTCCTTTAATGATAGGTGCTCCAGATATGGCGTTTCCTCGCATGAATAATATAAGTTTT GGATTTGGTAATTGGTTTGTTCCTTTAATGATAGGTGCTCCAGATATGGCGTTTCCTCGCATGAATAATATAAGTTTT GGATTTGGTAATTGGTTTGTTCCTTTAATGATAGGTGCTCCAGATATGGCGTTTCCTCGCATGAATAATATAAGTTTT GGATTTGGTAATTGGTTTGTTCCTTTAATGATAGGTGCTCCAGATATGGCGTTTCCTCGCATGAATAATATAAGTTTT GGATTTGGTAATTGGTTTGTTCCTTTAATGATAGGTGCTCCAGATATGGCGTTTCCTCGCATGAATAATATAAGTTTT GGATTTGGTAATTGGTTTGTTCCTTTAATGATAGGTGCTCCAGATATGGCGTTTCCTCGCATGAATAATATAAGTTTT GGATTTGGTAATTGGTTTGTTCCTTTAATGATAGGTGCTCCGGATATGGCGTTTCCTCGCATGAATAATATAAGTTTT GGATTTGGTAATTGGTTTGTTCCTTTAATGATAGGTGCTCCAGATATGGCATTTCCTCGCATGAATAATATAAGTTTT GGATTTGGTAATTGGTTTGTTCCTTTAATGATAGGTGCTCCAGATATGGCGTTTCCTCGCATGAATAATATAAGTTTT GGATTTGGTAATTGGTTTGTTCCTTTAATGATAGGTGCTCCAGATATGGCGTTTCCTCGCATGAATAATATAAGTTTT GGATTTGGTAATTGGTTTGTTCCTTTAATGATAGGTGCTCCAGATATGGCGTTTCCTCGCATGAATAATATAAGTTTT GGATTTGGTAATTGGTTTGTTCCTTTAATGATAGGTGCTCCAGATATGGCATTTCCTCGCATGAATAATATAAGTTTT GGATTTGGTAATTGGTTTGTTCCTTTAATGATAGGTGCTCCAGATATGGCGTTTCCTCGCATGAATAATATAAGTTTT GGATTTGGTAATTGGTTTGTTCCTTTAATGATAGGTGCTCCAGATATGGCGTTTCCTCGCATGAATAATATAAGTTTT GGATTTGGTAATTGGTTTGTTCCTTTAATGATAGGTGCTCCAGATATGGCGTTTCCTCGCATGAATAATATAAGTTTT GGATTTGGTAATTGGTTTGTTCCTTTAATGATAGGTGCTCCAGATATGGCGTTTCCTCGCATGAATAATATAAGTTTT GGATTTGGTAATTGGTTTGTTCCTTTAATGATAGGTGCTCCGGATATGGCGTTTCCTCGCATGAATAATATAAGTTTT GGATTTGGTAATTGGTTTGTTCCTTTAATGATAGGTGCTCCGGATATGGCGTTTCCTCGCATGAATAATATAAGTTTT GGATTTGGTAATTGGTTTGTTCCTTTAATGATAGGTGCTCCGGATATGGCGTTTCCTCGCATGAATAATATAAGTTTT GGATTTGGTAATTGGTTTGTTCCTTTAATGATAGGTGCTCCAGATATGGCGTTTCCTCGCATGAATAATATAAGTTTT GGATTTGGTAATTGGTTTGTTCCTTTAATGATAGGTGCTCCGGATATGGCGTTTCCTCGCATGAATAATATAAGTTTT GGATTTGGTAATTGGTTTGTTCCTTTAATGATAGGTGCTCCGGATATGGCGTTTCCTCGCATGAATAATATAAGTTTT 
Appendix 4. (Continued)

A271Ctorulosa B175Ctorulosa A093Ctorulosa B320Ctorulosa A198Ctorulosa B316Ctorulosa B167Ctorulosa B145Ccongesta B149Ccongesta B416Ccongesta B176Cscalaris B178Cscalaris A318Cscalaris A469Cscalaris B330Cscalaris B333Cscalaris B334Cscalaris B336Cscalaris B337Cscalaris B338Cscalaris B611Cscalaris B612Cscalaris B608Cscalaris B607Cscalaris B606Cscalaris B177Cscalaris B605Cscalaris B332Cscalaris A099Cscalaris A614Cscalaris A596Cscalaris A292Cscalaris B351CspWilson B319Csiliquosa B130Csiliquosa B143Csiliquosa B118Csiliquosa B325Cretorta B324Cretorta
GGATTTGGTAATTGGTTTGTTCCTTTAATGATAGGTGCTCCGGATATGGCGTTTCCTCGCATGAATAATATAAGTTTT GGATTTGGTAATTGGTTTGTTCCTTTAATGATAGGTGCTCCGGATATGGCGTTTCCTCGCATGAATAATATAAGTTTT GGATTTGGTAATTGGTTTGTTCCTTTAATGATAGGTGCTCCGGATATGGCGTTTCCTCGCATGAATAATATAAGTTTT GGATTTGGTAATTGGTTTGTTCCTTTAATGATAGGTGCTCCGGATATGGCGTTTCCTCGCATGAATAATATAAGTTTT GGATTTGGTAATTGGTTTGTTCCTTTAATGATAGGTGCTCCGGATATGGCGTTTCCTCGCATGAATAATATAAGTTTT GGATTTGGTAATTGGTTTGTTCCTTTAATGATAGGTGCTCCGGATATGGCGTTTCCTCGCATGAATAATATAAGTTTT GGATTTGGTAATTGGTTTGTTCCTTTAATGATAGGTGCTCCGGATATGGCGTTTCCTCGCATGAATAATATAAGTTTT GGATTTGGTAATTGGTTTGTTCCTTTAATGATAGGTGCTCCAGATATGGCGTTTCCTCGCATGAATAATATAAGTTTT GGATTTGGTAATTGGTTTGTTCCTTTAATGATAGGTGCTCCAGATATGGCGTTTCCTCGCATGAATAATATAAGTTTT GGATTTGGTAATTGGTTTGTTCCTTTAATGATAGGTGCTCCAGATATGGCGTTTCCTCGCATGAATAATATAAGTTTT GGATTTGGTAATTGGTTTGTTCCTTTAATGATAGGTGCTCCAGATATGGCATTTCCTCGCATGAATAATATAAGTTTT GGATTTGGTAATTGGTTTGTTCCTTTAATGATAGGTGCTCCAGATATGGCATTTCCTCGCATGAATAATATAAGTTTT GGATTTGGTAATTGGTTTGTTCCTTTAATGATAGGTGCTCCAGATATGGCATTTCCTCGCATGAATAATATAAGTTTT GGATTTGGTAATTGGTTTGTTCCTTTAATGATAGGTGCTCCAGATATGGCATTTCCTCGCATGAATAATATAAGTTTT GGATTTGGTAATTGGTTTGTTCCTTTAATGATAGGTGCTCCAGATATGGCGTTTCCTCGCATGAATAATATAAGTTTT GGATTTGGTAATTGGTTTGTTCCTTTAATGATAGGTGCTCCAGATATGGCATTTCCTCGCATGAATAATATAAGTTTT GGATTTGGTAATTGGTTTGTTCCTTTAATGATAGGTGCTCCAGATATGGCATTTCCTCGCATGAATAATATAAGTTTT GGATTTGGTAATTGGTTTGTTCCTTTAATGATAGGTGCTCCAGATATGGCATTTCCTCGCATGAATAATATAAGTTTT GGATTTGGTAATTGGTTTGTTCCTTTAATGATAGGTGCTCCAGATATGGCATTTCCTCGCATGAATAATATAAGTTTT GGATTTGGTAATTGGTTTGTTCCTTTAATGATAGGTGCTCCAGATATGGCATTTCCTCGCATGAATAATATAAGTTTT GGATTTGGTAATTGGTTTGTTCCTTTAATGATAGGTGCTCCAGATATGGCATTTCCTCGCATGAATAATATAAGTTTT GGATTTGGTAATTGGTTTGTTCCTTTAATGATAGGTGCTCCAGATATGGCATTTCCTCGCATGAATAATATAAGTTTT GGATTTGGTAATTGGTTTGTTCCTTTAATGATAGGTGCTCCAGATATGGCATTTCCTCGCATGAATAATATAAGTTTT GGATTTGGTAATTGGTTTGTTCCTTTAATGATAGGTGCTCCAGATATGGCATTTCCTCGCATGAATAATATAAGTTTT GGATTTGGTAATTGGTTTGTTCCTTTAATGATAGGTGCTCCAGATATGGCATTTCCTCGCATGAATAATATAAGTTTT GGATTTGGTAATTGGTTTGTTCCTTTAATGATAGGTGCTCCAGATATGGCATTTCCTCGCATGAATAATATAAGTTTT GGATTTGGTAATTGGTTTGTTCCTTTAATGATAGGTGCTCCAGATATGGCATTTCCTCGCATGAATAATATAAGTTTT GGATTTGGTAATTGGTTTGTTCCTTTAATGATAGGTGCTCCAGATATGGCATTTCCTCGCATGAATAATATAAGTTTT GGATTTGGTAATTGGTTTGTTCCTTTAATGATAGGTGCTCCAGATATGGCATTTCCTCGCATGAATAATATAAGTTTT GGATTTGGTAATTGGTTTGTTCCTTTAATGATAGGTGCTCCAGATATGGCATTTCCTCGCATGAATAATATAAGTTTT GGATTTGGTAATTGGTTTGTTCCTTTAATGATAGGTGCTCCAGATATGGCATTTCCTCGCATGAATAATATAAGTTTT GGATTTGGTAATTGGTTTGTTCCTTTAATGATAGGTGCTCCAGATATGGCATTTCCTCGCATGAATAATATAAGTTTT GGATTTGGTAATTGGTTTGTTCCTTTAATGATAGGTGCTCCGGATATGGCGTTTCCTCGCATGAATAATATAAGTTTT GGATTTGGTAATTGGTTTGTTCCTTTAATGATAGGTGCTCCAGATATGGCGTTTCCTCGCATGAATAATATAAGTTTT GGATTTGGTAATTGGTTTGTTCCTTTAATGATAGGTGCTCCAGATATGGCGTTTCCTCGCATGAATAATATAAGTTTT GGATTTGGTAATTGGTTTGTTCCTTTAATGATAGGTGCTCCAGATATGGCGTTTCCTCGCATGAATAATATAAGTTTT GGATTTGGTAATTGGTTTGTTCCTTTAATGATAGGTGCTCCAGATATGGCGTTTCCTCGCATGAATAATATAAGTTTT GGATTTGGTAATTGGTTTGTTCCTTTAATGATAGGTGCTCCAGATATGGCGTTTCCTCGCATGAATAATATAAGTTTT GGATTTGGTAATTGGTTTGTTCCTTTAATGATAGGTGCTCCAGATATGGCGTTTCCTCGCATGAATAATATAAGTTTT

B601Ccephalorn TGGCTATTACCACCGTCTTTACTACTTCTTTTAGCCTCCTCATTAGTTGAATCCGGGGCTGGTACTGGTTGGACTGTT B091Ccephalorn TGGCTATTACCACCGTCTTTACTACTTCTTTTAGCCTCCTCATTAGTTGAATCCGGGGCTGGTACTGGTTGGACTGTT B327Carpoconfl TGGTTATTGCCGCCGTCCCTAATACTTCTTTTAGCTTCTTCATTGGTTGAAGCGGGTGCTGGTACTGGTTGGACTGTT B162Carpoconfl TGGTTATTGCCGCCGTCCCTTATACTTCTTTTAGCTTCTTCATTGGTTGAAGCGGGTGCTGGTACTGGTTGGACTGTT B174Lquercifol TGGCTGTTACCGCCATCCTTAATACTTCTTTTAGCGTCTTCATTAGTGGAAGCCGGGGCAGGTACGGGTTGGACTGTT B318Cmonilifer TGGCTGTTACCTCCCTCTTTAATACTTCTTTTAGCGTCCTCATTGGTAGAAGCTGGGGCAGGTACCGGTTGGACTGTT B092Cmonilifer TGGCTGTTACCTCCCTCTTTAATACTTCTTTTAGCGTCCTCATTGGTAGAAGCTGGGGCAGGTACCGGTTGGACTGTT B095Cmonilifer TGGCTGTTACCTCCCTCTTTAATACTTCTTTTAGCGTCCTCATTGGTAGAAGCTGGGGCAGGTACCGGTTGGACTGTT B102Cmonilifer TGGCTGTTACCTCCCTCTTTAATACTTCTTTTAGCGTCCTCATTGGTAGAAGCTGGGGCAGGTACCGGTTGGACTGTT B120 Cmonilifer TGGCTGTTACCTCCCTCTTTAATACTTCTTTTAGCGTCCTCATTGGTAGAAGCTGGGGCAGGTACCGGTTGGACTGTT B093Cmonilifor TGGCTATTGCCACCGTCTTTAATACTACTTTTGTCGTCTTCATTAGTGGAAGCCGGGGCGGGTACTGGTTGGACCGTT B163Cmonilifor TGGCTATTGCCACCGTCTTTAATACTACTTTTGTCGTCTTCATTAGTGGAAGCCGGGGCGGGTACTGGTTGGACCGTT B094Cretroflex TGGCTGTTACCTCCCTCTTTAATACTTCTTTTAGCGTCCTCATTAGTAGAAGCTGGGGCAGGTACCGGTTGGACTGTT B100Cretroflex TGGCTGTTACCTCCCTCTTTAATACTTCTTTTAGCGTCCTCATTAGTAGAAGCTGGGGCAGGTACCGGTTGGACTGTT B101Cretroflex TGGCTGTTACCTCCCTCTTTAATACTTCTTTTAGCGTCCTCATTAGTAGAAGCCGGGGCAGGTACCGGTTGGACTGTT B099Cretroflex TGGCTGTTACCTCCCTCTTTAATACTTCTTTTAGCGTCCTCATTAGTAGAAGCCGGGGCAGGTACCGGTTGGACTGTT B123Cretroflex TGGCTGTTACCTCCCTCTTTAATACTTCTTTTAGCGTCCTCATTAGTAGAAGCCGGGGCAGGTACCGGTTGGACTGTT B124Cretroflex TGGCTGTTACCTCCCTCTTTAATACTTCTTTTAGCGTCCTCATTAGTAGAAGCCGGGGCAGGTACCGGTTGGACTGTT B166Cretroflex TGGCTGTTACCTCCCTCTTTAATACTTCTTTTAGCGTCCTCATTAGTAGAAGCTGGGGCAGGTACCGGTTGGACTGTT B108Cretroflex TGGCTGTTACCTCCATCTTTAATACTTCTTTTAGCCTCTTCATTAGTAGAAGCCGGGGCAGGTACTGGTTGGACTGTT B617Cretroflex TGGCTGTTACCTCCCTCTTTAATACTTCTTTTAGCGTCCTCATTAGTAGAAGCCGGGGCAGGTACCGGTTGGACTGTT B430Cretroflex TGGCTGTTACCTCCCTCTTTAATACTTCTTTTAGCGTCCTCATTAGTAGAAGCCGGGGCAGGTACCGGTTGGACTGTT A615Cretroflex TGGCTGTTACCTCCCTCTTTAATACTTCTTTTAGCGTCCTCATTAGTAGAAGCCGGGGCAGGTACCGGTTGGACTGTT B137Cretroflex TGGCTGTTACCTCCATCTTTAATACTTCTTTTAGCCTCTTCATTAGTAGAAGCCGGGGCAGGTACTGGTTGGACTGTT B169Cretroflex TGGCTGTTACCTCCCTCTTTAATACTTCTTTTAGCGTCCTCATTAGTAGAAGCCGGGGCAGGTACCGGTTGGACTGTT B425CretroflexaTGGCTGTTACCTCCCTCTTTAATACTTCTTTTAGCGTCCTCATTAGTAGAAGCCGGGGCAGGTACCGGTTGGACTGTT B426Cretroflex TGGCTGTTACCTCCCTCTTTAATACTTCTTTTAGCGTCCTCATTAGTAGAAGCCGGGGCAGGTACCGGTTGGACTGTT B335Cretroflex TGGCTGTTACCTCCCTCTTTAATACTTCTTTTAGCGTCCTCATTAGTAGAAGCCGGGGCAGGTACCGGTTGGACTGTT B436Cretroflex TGGCTGTTACCTCCCTCTTTAATACTTCTTTTAGCGTCCTCATTAGTAGAAGCCGGGGCAGGTACCGGTTGGACTGTT A154Cretroflex TGGCTGTTACCCCCCTCTTTAATACTTCTTTTAGCGTCCTCATTAGTTGAAGCCGGGGCAGGTACCGGTTGGACTGTT A080Cretroflex TGGCTGTTACCTCCCTCTTTAATACTTCTTTTAGCGTCCTCATTAGTAGAAGCCGGGGCAGGTACCGGTTGGACTGTT B602Cretroflex TGGCTGTTACCTCCCTCTTTAATACTTCTTTTAGCGTCCTCATTAGTAGAAGCCGGGGCAGGTACCGGTTGGACTGTT A085Cretroflex TGGCTGTTACCTCCCTCTTTAATACTTCTTTTAGCGTCCTCATTAGTAGAAGCCGGGGCAGGTACCGGTTGGACTGTT B556Cretroflex TGGCTGTTACCTCCCTCTTTAATACTTCTTTTAGCGTCCTCATTAGTAGAAGCCGGGGCAGGTACCGGTTGGACTGTT A196Cretroflex TGGCTGTTACCTCCCTCTTTAATACTTCTTTTAGCGTCCTCATTAGTAGAAGCCGGGGCAGGTACCGGTTGGACTGTT B412Cretroflex TGGCTGTTACCTCCCTCTTTAATACTTCTTTTAGCGTCCTCATTAGTAGAAGCTGGGGCAGGTACCGGTTGGACTGTT 
Appendix 4. (Continued)

B121CretroflexaTGGCTGTTACCTCCCTCTTTAATACTTCTTTTAGCGTCCTCATTAGTAGAAGCCGGGGCAGGTACCGGTTGGACTGTT B109Cretorta TGGCTGTTACCTCCATCTTTAATACTTCTTTTAGCCTCTTCATTAGTAGAAGCCGGGGCAGGTACTGGTTGGACTGTT B170Cretorta TGGCTGTTACCTCCATCTTTAATACTTCTTTTAGCCTCTTCATTAGTAGAAGCCGGGGCAGGTACTGGTTGGACTGTT B415Csiliquosa TGGCTGTTACCTCCGTCTTTAATACTTCTTTTAGCCTCTTCATTAGTAGAAGCCGGGGCGGGTACTGGTTGGACTGTT B111Cpolycysti TGGCTTTTACCTCCCTCTTTAATACTTCTTTTAGCGTCCTCATTAGTAGAAGCTGGGGCAGGTACCGGTTGGACTGTT B112Cpolycysti TGGCTTTTACCTCCCTCTTTAATACTTCTTTTAGCGTCCTCATTAGTAGAAGCTGGGGCAGGTACCGGTTGGACTGTT B148Cpolycysti TGGCTTTTACCTCCCTCTTTAATACTTCTTTTAGCGTCCTCATTAGTAGAAGCTGGGGCAGGTACCGGTTGGACTGTT B171Cpolycysti TGGCTTTTACCTCCCTCTTTAATACTTCTTTTAGCGTCCTCATTAGTAGAAGCTGGGGCAGGTACCGGTTGGACTGTT A168Cplatylobi TGGCTGTTACCTCCGTCTTTAATACTTCTTTTAGCCTCTTCATTAGTAGAAGCTGGGGCAGGTACTGGTTGGACTGTT B140Cplatylobi TGGCTGTTACCTCCGTCTTTAATACTTCTTTTAGCCTCTTCATTAGTAGAAGCTGGGGCAGGTACTGGTTGGACTGTT B104Cplatylobi TGGCTGTTACCTCCGTCTTTAATACTTCTTTTAGCCTCTTCATTAGTAGAAGCTGGGGCAGGTACTGGTTGGACTGTT B116Ccongesta TGGCTGTTACCTCCCTCTTTAATACTTCTTTTAGCGTCCTCATTAGTAGAAGCCGGGGCAGGTACCGGTTGGACTGTI B115Ccongesta TGGCTGTTACCTCCCTCTTTAATACTTCTTTTAGCGTCCTCATTAGTAGAAGCCGGGGCAGGTACCGGTTGGACTGTT B152Ccongesta TGGCTGTTACCTCCCTCTTTAATACTTCTTTTAGCGTCCTCATTAGTAGAAGCCGGGGCAGGTACCGGTTGGACTGTT B455Ccongesta TGGCTGTTACCTCCCTCTTTAATACTTCTTTTAGCGTCCTCATTAGTAGAAGCCGGGGCAGGTACCGGTTGGACTGTT B129Cretorta TGGCTGTTACCTCCATCTTTAATACTTCTTTTAGCCTCTTCATTAGTAGAAGCCGGGGCAGGTACTGGTTGGACTGTT B131Cretorta TGGCTGTTACCTCCATCTTTAATACTTCTTTTAGCCTCTTCATTAGTAGAAGCCGGGGCAGGTACTGGTTGGACTGTT B161CsubfarcinaTGGCTGTTACCTCCCTCTTTAATACTTCTTTTAGCGTCCTCATTAGTAGAAGCTGGGGCAGGTACCGGTTGGACTGTT B626CretroflexaTGGCTGTTACCTCCCTCTTTAATACTTCTTTTAGCGTCCTCATTAGTAGAAGCTGGGGCAGGTACCGGTTGGACTGTT B146CsubfarcinaTGGCTGTTACCTCCCTCTTTAATACTTCTTTTAGCGTCCTCATTAGTAGAAGCTGGGGCAGGTACCGGTTGGACTGTT B146CsubfarcinaTGGCTGTTACCTCCCTCTTTAATACTTCTTTTAGCGTCCTCATTAGTAGAAGCTGGGGCAGGTACCGGTTGGACTGTT B128CsubfarcinaTGGCTGTTACCTCCCTCTTTAATACTTCTTTTAGCGTCCTCATTAGTAGAAGCTGGGGCAGGTACCGGTTGGACTGTT B127CsubfarcinaTGGCTGTTACCCCCCTCTTTAATACTTCTTTTAGCGTCCTCATTAGTAGAAGCTGGGGCAGGTACCGGTTGGACTGTT B159Csubfarcin TGGCTGTTACCTCCCTCTTTAATACTTCTTTTAGCGTCCTCATTAGTAGAAGCCGGGGCAGGTACCGGTTGGACTGTT B134Csubfarcin TGGCTGTTACCTCCCTCTTTAATACTTCTTTTAGCGTCCTCATTAGTAGAAGCTGGGGCAGGTACCGGTTGGACTGTT B168Csubfarcin TGGCTGTTACCTCCCTCTTTAATACTTCTTTTAGCGTCCTCATTAGTAGAAGCTGGGGCAGGTACCGGTTGGACTGTT B136Csubfarcin TGGCTGTTACCTCCCTCTTTAATACTTCTTTTAGCGTCCTCATTAGTAGAAGCTGGGGCAGGTACCGGTTGGACTGTT B626Csubfarcin TGGCTGTTACCTCCCTCTTTAATACTTCTTTTAGCGTCCTCATTAGTAGAAGCCGGGGCAGGTACCGGTTGGACTGTT B153Csubfarcin TGGCTGTTACCTCCCTCTTTAATACTTCTTTTAGCGTCCTCATTAGTAGAAGCTGGGGCAGGTACCGGTTGGACTGTT B110Csubfarcin TGGCTGTTACCTCCCTCTTTAATACTTCTTTTAGCGTCCTCATTAGTAGAAGCTGGGGCAGGTACCGGTTGGACTGTT B417Csubfarcin TGGCTGTTACCTCCCTCTTTAATACTTCTTTTAGCGTCCTCATTAGTAGAAGCCGGGGCAGGTACCGGTTGGACTGTT B624Csubfarcin TGGCTGTTACCTCCCTCTTTAATACTTCTTTTAGCGTCCTCATTAGTAGAAGCTGGGGCAGGTACCGGTTGGACTGTT B428Ctorulosa TGGCTGTTACCCCCCTCTTTAATACTTCTTTTAGCGTCCTCATTAGTAGAAGCTGGGGCAGGTACCGGTTGGACTGTT B103Ctorulosa TGGCTGTTACCCCCCTCTTTAATACTTCTTTTAGCGTCCTCATTAGTAGAAGCTGGGGCAGGTACCGGTTGGACTGTT B165Ctorulosa TGGCTGTTACCCCCCTCTTTAATACTTCTTTTAGCGTCCTCATTAGTAGAAGCTGGGGCAGGTACCGGTTGGACTGTT B125Ctorulosa TGGCTGTTACCTCCCTCTTTAATACTTCTTTTAGCGTCCTCATTAGTAGAAGCTGGGGCAGGTACCGGTTGGACTGTT B147Ctorulosa TGGCTGTTACCCCCCTCTTTAATACTTCTTTTAGCGTCCTCATTAGTAGAAGCTGGGGCAGGTACCGGTTGGACTGTT B179Ctorulosa TGGCTGTTACCCCCCTCTTTAATACTTCTTTTAGCGTCCTCATTAGTAGAAGCTGGGGCAGGTACCGGTTGGACTGTT A271Ctorulosa TGGCTGTTACCCCCCTCTTTAATACTTCTTTTAGCGTCCTCATTAGTAGAAGCTGGGGCAGGTACCGGTTGGACTGTT B175Ctorulosa TGGCTGTTACCCCCCTCTTTAATACTTCTTTTAGCGTCCTCATTAGTAGAAGCTGGGGCAGGTACCGGTTGGACTGTT A093Ctorulosa TGGCTGTTACCCCCCTCTTTAATACTTCTTTTAGCGTCCTCATTAGTAGAAGCTGGGGCAGGTACCGGTTGGACTGTT B320Ctorulosa TGGCTGTTACCCCCCTCTTTAATACTTCTTTTAGCGTCCTCATTAGTAGAAGCTGGGGCAGGTACCGGTTGGACTGTT A198Ctorulosa TGGCTGTTACCCCCCTCTTTAATACTTCTTTTAGCGTCCTCATTAGTAGAAGCTGGGGCAGGTACCGGTTGGACTGTT B316Ctorulosa TGGCTGTTACCCCCCTCTTTAATACTTCTTTTAGCCTCCTCATTAGTAGAAGCTGGGGCAGGTACCGGTTGGACTGTT B167Ctorulosa TGGCTGTTACCCCCCTCTTTAATACTTCTTTTAGCGTCCTCATTAGTAGAAGCTGGGGCAGGTACCGGTTGGACTGTT B145Ccongesta TGGCTGTTACCTCCCTCTTTAATACTTCTTTTAGCGTCCTCATTAGTAGAAGCCGGGGCAGGTACCGGTTGGACTGTT B149Ccongesta TGGCTGTTACCTCCCTCTTTAATACTTCTTTTAGCGTCCTCATTAGTAGAAGCCGGGGCAGGTACCGGTTGGACTGTT B416Ccongesta TGGCTGTTACCTCCCTCTTTAATACTTCTTTTAGCGTCCTCATTAGTAGAAGCTGGGGCAGGTACCGGTTGGACTGTT B176Cscalaris B178Cscalaris A318Cscalaris A469Cscalaris B330Cscalaris B333Cscalaris B334Cscalaris B336Cscalaris B337Cscalaris B338Cscalaris B611Cscalaris B612Cscalaris B608Cscalaris B607Cscalaris B606Cscalaris B177Cscalaris B605Cscalaris B332Cscalaris A099Cscalaris A614Cscalaris A596Cscalaris A292Cscalaris B351CspWilson B319Csiliquosa B130Csiliquosa B143Csiliquosa B118Csiliquosa B325Cretorta TGGCTGTTACCCCCCTCTTTAATACTTCTTTTAGCGTCCTCATTAGTAGAAGCCGGGGCAGGTACCGGTTGGACTGTT TGGCTGTTACCCCCCTCTTTAATACTTCTTTTAGCGTCCTCATTAGTAGAAGCCGGGGCAGGTACCGGTTGGACTGTT TGGCTGTTACCCCCCTCTTTAATACTTCTTTTAGCGTCCTCATTAGTAGAAGCCGGGGCAGGTACCGGTTGGACTGTT TGGCTGTTACCCCCCTCTTTAATACTTCTTTTAGCGTCCTCATTAGTAGAAGCCGGGGCAGGTACCGGTTGGACTGTT TGGCTGTTACCTCCCTCTTTAATACTTCTTTTAGCGTCCTCATTAGTAGAAGCCGGGGCAGGTACCGGTTGGACTGTT TGGCTGTTACCCCCCTCTTTAATACTTCTTTTAGCGTCCTCATTAGTTGAAGCCGGGGCAGGTACCGGTTGGACTGTT TGGCTGTTACCCCCCTCTTTAATACTTCTTTTAGCGTCCTCATTAGTTGAAGCCGGGGCAGGTACCGGTTGGACTGTT TGGCTGTTACCCCCCTCTTTAATACTTCTTTTAGCGTCCTCATTAGTAGAAGCCGGGGCAGGTACCGGTTGGACTGTT TGGCTGTTACCCCCCTCTTTAATACTTCTTTTAGCGTCCTCATTAGTAGAAGCCGGGGCAGGTACCGGTTGGACTGTT TGGCTGTTACCCCCCTCTTTAATACTTCTTTTAGCGTCCTCATTAGTAGAAGCCGGGGCAGGTACCGGTTGGACTGTT TGGCTGTTACCCCCCTCTTTAATACTTCTTTTAGCGTCCTCATTAGTAGAAGCCGGGGCAGGTACCGGTTGGACTGTT TGGCTGTTACCCCCCTCTTTAATACTTCTTTTAGCGTCCTCATTAGTTGAAGCCGGGGCAGGTACCGGTTGGACTGTT TGGCTGTTACCCCCCTCTTTAATACTTCTTTTAGCGTCCTCATTAGTAGAAGCCGGGGCAGGTACCGGTTGGACTGTT TGGCTGTTACCCCCCTCTTTAATACTTCTTTTAGCGTCCTCATTAGTAGAAGCCGGGGCAGGTACCGGTTGGACTGTT TGGCTGTTACCCCCCTCTTTAATACTTCTTTTAGCGTCCTCATTAGTAGAAGCCGGGGCAGGTACCGGTTGGACTGTT TGGCTGTTACCCCCCTCTTTAATACTTCTTTTAGCGTCCTCATTAGTAGAAGCCGGGGCAGGTACCGGTTGGACTGTT TGGCTGTTACCCCCCTCTTTAATACTTCTTTTAGCGTCCTCATTAGTAGAAGCCGGGGCAGGTACCGGTTGGACTGTT TGGCTGTTACCCCCCTCTTTAATACTTCTTTTAGCGTCCTCATTAGTTGAAGCCGGGGCAGGTACCGGTTGGACTGTT TGGCTGTTACCCCCCTCTTTAATACTTCTTTTAGCGTCCTCATTAGTTGAAGCCGGGGCAGGTACCGGTTGGACTGTT TGGCTGTTACCCCCCTCTTTAATACTTCTTTTAGCGTCCTCATTAGTTGAAGCCGGGGCAGGTACCGGTTGGACTGTT TGGCTGTTACCCCCCTCTTTAATACTTCTTTTAGCGTCCTCATTAGTTGAAGCCGGGGCAGGTACCGGTTGGACTGTT TGGCTGTTACCCCCCTCTTTAATACTTCTTTTAGCGTCCTCATTAGTAGAAGCCGGGGCAGGTACCGGTTGGACTGTT TGGCTGTTACCCCCCTCTTTAATACTTCTTTTAGCGTCCTCATTAGTAGAAGCTGGGGCAGGTACCGGTTGGACTGTT TGGCTGTTACCTCCGTCTTTAATACTTCTTTTAGCCTCTTCATTAGTAGAAGCCGGGGCGGGTACTGGTTGGACTGTT TGGCTGTTACCTCCGTCTTTAATACTTCTTTTAGCCTCTTCATTAGTAGAAGCCGGGGCGGGTACTGGTTGGACTGTT TGGCTGTTACCTCCGTCTTTAATACTTCTTTTAGCCTCTTCATTAGTAGAAGCCGGGGCGGGTACTGGTTGGACTGTT TGGCTGTTACCTCCGTCTTTAATACTTCTTTTAGCCTCTTCATTAGTAGAAGCCGGGGCGGGTACTGGTTGGACTGTT TGGCTGTTACCTCCATCTTTAATACTTCTTTTAGCCTCTTCATTAGTAGAAGCGGGGGCAGGTACTGGTTGGACTGTT 
Appendix 4. (Continued)

B324 Cretorta TGgCTGTTACCTCCATCTTTAATACTTCTTTTAGCCTCTTCATTAGTAGAAGCGGGGGCAGGTACTGGTTGGACTGTT

B601Ccephalorni TACCCCCCCTTAAGTGGTATTCAAGCACACTCGGGACCATCGGTTGATTTAGCTATTTTTAGCCTCCATTTATCGGGT B091Ccephalorni TACCCCCCCTTAAGTGGTATTCAAGCACACTCGGGACCATCGGTTGATTTAGCTATTTTTAGCCTCCATTTATCGGGT B327Carpoconflu TACCCGCCGTTAaGTGGTATCCAAGCACACTCGGGTCCTTCTGTCGATTTAGCTATTTTTAGTCTTCATTTATCAGGT B162Carpoconflu TACCCGCCGTTAAGTGGTATCCAAGCACACTCGGGTCCTTCTGTCGATTTAGCTATTTTTAGTCTTCATTTATCAGGT B174Lquercifoli TACCCTCCTCTAAGTGGTATTCAAGCACATTCGGGACCATCGGTCGATTTAGCTATTTTTAGTCTTCACTTATCTGGT B318Cmonilifera TATCCTCCCTTAAGCGGTATTCAAGCCCATTCAGGTCCATCGGTTGATTTAGCTATTTTTAGTCTTCATTTATCTGGT B092Cmonilifera TATCCTCCCTTAAGCGGTATTCAAGCCCATTCAGGTCCATCGGTTGATTTAGCTATTTTTAGTCTTCATTTATCTGGT B095Cmonilifera TATCCTCCCTTAAGCGGTATTCAAGCCCATTCAGGTCCATCGGTTGATTTAGCTATTTTTAGTCTTCATTTATCTGGT B102Cmonilifera TATCCTCCCTTAAGCGGTATTCAAGCCCATTCAGGTCCATCGGTTGATTTAGCTATTTTTAGTCTTCATTTATCTGGT B120Cmonilifera TATCCTCCCTTAAGCGGTATTCAAGCCCATTCAGGTCCATCGGTTGATTTAGCTATTTTTAGTCTTCATTTATCTGGT B093Cmoniliform TACCCCCCTTTAAGCGGTATTCAAGCCCATTCGGGACCATCGGTCGATTTAGCTATCTTTAGTCTTCATTTATCTGGT B163Cmoniliform TACCCCCCTTTAaGCGGTATTCAAGCCCATTCAGGACCATCGGTCGATTTAGCTATCTTTAGTCTTCATTTATCTGGT B094Csubfarcina TATCCTCCCTTAAGTGGTATTCAAGCCCATTCAGGGCCGTCGGTTGATTTAGCTATTTTTAGTCTTCATTTATCTGGT B100Csubfarcina TATCCTCCCTTAAGTGGTATTCAAGCCCATTCAGGGCCGTCGGTTGATTTAGCTATTTTTAGTCTTCATTTATCTGGT B101Cretroflexa TATCCTCCCTTAAGTGGTATTCAAGCCCATTCAGGGCCGTCGGTCGATTTAGCTATTTTTAGTCTTCATTTATCTGGT B099Cretroflexa TATCCTCCCTTAAGTGGTATTCAAGCCCATTCAGGGCCGTCGGTCGATTTAGCTATTTTTAGTCTTCATTTATCTGGT B123Cretroflexa TATCCTCCCTTAAGTGGTATTCAAGCCCATTCAGGGCCGTCGGTTGATTTAGCTATTTTTAGTCTTCATTTATCTGGT B124Cretroflexa TATCCTCCCTTAAGTGGTATTCAAGCCCATTCAGGGCCGTCGGTTGATTTAGCTATTTTTAGTCTTCATTTATCTGGT B166Csubfarcina TATCCCCCCTTAAGTGGTATTCAAGCCCATTCAGGGCCGTCGGTTGATTTAGCTATTTTTAGTCTTCATTTATCTGGT B108Cretorta B617Cretroflexa B430Cretroflexa A615Cretroflexa B137Cretorta TATCCTCCCTTAAGTGGTATTCAAGCCCATTCGGGACCATCGGTTGATTTAGCTATTTTTAGTCTTCATTTATCTGGT TATCCTCCCTTAaGTGGTATTCAAGCCCATTCAGGGCCGTCGGTCGATTTAGCTATTTTTAGTCTTCATTTATCTGGT TATCCTCCCTTAAGTGGTATTCAAGCCCATTCAGGGCCGTCGGTTGATTTAGCTATTTTTAGTCTTCATTTATCTGGT TATCCTCCCTTAAGTGGTATTCAAGCCCATTCAGGGCCGTCGGTCGATTTAGCTATTTTTAGTCTTCATTTATCTGGT TATCCTCCCTTAAGTGGTATTCAAGCCCATTCGGGACCATCGGTTGATTTAGCTATTTTTAGTCTTCATTTATCTGGT B169Cretroflexa TATCCTCCCTTAAGTGGTATTCAAGCCCATTCAGGGCCGTCGGTTGATTTAGCTATTTTTAGTCTTCATTTATCTGGT B425Cretroflexa TATCCTCCCTTAAGTGGTATTCAAGCCCATTCAGGGCCGTCGGTCGATTTAGCTATTTTTAGTCTTCATTTATCTGGT B426Cretroflexa TATCCTCCCTTAAGTGGTATTCAAGCCCATTCAGGGCCGTCGGTCGATTTAGCTATTTTTAGTCTTCATTTATCTGGT B335Ccongesta TATCCTCCCTTAAGTGGTATTCAAGCCCATTCAGGGCCGTCGGTCGATTTAGCTATTTTTAGTCTTCATTTATCTGGT B436Cretroflexa TATCCTCCCTTAaGTGGTATTCAAGCCCATTCAGGGCCGTCGGTCGATTTAGCTATTTTTAGTCTTCATTTATCTGGT A154Cscalaris TATCCTCCCTTAAGTAGTATTCAAGCCCATTCAGGGCCATCGGTTGATTTAGCTATTTTTAGTCTTCATTTATCTGGT A080Cretroflexa TATCCTCCCTTAAGTGGTATTCAAGCCCATTCAGGGCCGTCGGTCGATTTAGCTATTTTTAGTCTTCATTTATCTGGT B602Cretroflexa TATCCTCCCTTAaGTGGTATTCAAGCCCATTCAGGGCCGTCGGTTGATTTAGCTATTTTTAGTCTTCATTTATCTGGT A085Cretroflexa TATCCTCCCTTAAGTGGTATTCAAGCCCATTCAGGGCCGTCGGTCGATTTAGCTATTTTTAGTCTTCATTTATCTGGT B556Cretroflexa TATCCTCCCTTAaGTGGTATTCAAGCCCATTCAGGGCCGTCGGTTGATTTAGCTATTTTTAGTCTTCATTTATCTGGT A196Cretroflexa TATCCTCCCTTAaGTGGTATTCAAGCCCATTCAGGGCCGTCGGTCGATTTAGCTATTTTTAGTCTTCATTTATCTGGT B412Csubfarcina TATCCTCCCTTAAGTGGTATTCAAGCCCATTCAGGGCCGTCGGTTGATTTAGCTATTTTTAGTCTTCATTTATCTGGT B121Cretroflexa TATCCTCCCTTAAGTGGTATTCAAGCCCATTCAGGGCCGTCGGTTGATTTAGCTATTTTTAGTCTTCATTTATCTGGT B109Cretorta B170 Cretorta B415Csiliquosa B111Cpolycystid TATCCTCCCTTAAGTGGAATTCAAGCCCATTCAGGGCCATCGGTTGATTTAGCTATTTTTAGTCTTCATTTATCTGGT B112Cpolycystid TATCCTCCCTTAAgTGGAATTCAAGCCCATTCAGGGCCATCGGTTGATTTAGCTATTTTTAGTCTTCATTTATCTGGT B148Cpolycystid TATCCTCCCTTAAGTGGAATTCAAGCCCATTCAGGGCCATCGGTTGATTTAGCTATTTTTAGTCTTCATTTATCTGGT B171Cpolycystid TATCCTCCCTTAAGTGGAATTCAAGCCCATTCAGGGCCATCGGTTGATTTAGCTATTTTTAGTCTTCATTTATCTGGT A168Cplatylobiu TATCCTCCCTTAAGTGGTATTCAAGCCCATTCGGGACCATCGGTTGATTTAGCTATTTTTAGTCTTCATTTATCTGGT B140Cplatylobiu TATCCTCCCTTAAGTGGTATTCAAGCCCATTCGGGACCATCGGTTGATTTAGCTATTTTTAGTCTTCATTTATCTGGT B104Cplatylobiu TATCCTCCCTTAAGTGGTATTCAAGCCCATTCGGGACCATCGGTTGATTTAGCTATTTTTAGTCTTCATTTATCTGGT B116Ccongesta TATCCTCCCTTAAGTGGTATTCAAGCCCATTCAGGGCCGTCGGTCGATTTAGCTATTTTTAGTCTTCATTTATCTGGT B115Ccongesta TATCCTCCCTTAAGTGGTATTCAAGCCCATTCAGGGCCGTCGGTCGATTTAGCTATTTTTAGTCTTCATTTATCTGGT B152Ccongesta B455Ccongesta B129Cretorta B131Cretorta TATCCTCCCTTAAGTGGTATTCAAGCCCATTCAGGGCCGTCGGTCGATTTAGCTATTTTTAGTCTTCATTTATCTGGT TATCCTCCCTTAAGTGGTATTCAAGCCCATTCAGGGCCGTCGGTTGATTTAGCTATTTTTAGTCTTCATTTATCTGGT TATCCTCCCTTAAGTGGTATTCAAGCCCATTCGGGACCATCGGTTGATTTAGCTATTTTTAGTCTTCATTTATCTGGT TATCCTCCCTTAAGTGGTATTCAAGCCCATTCGGGACCATCGGTTGATTTAGCTATTTTTAGTCTTCATTTATCTGGT B161Csubfarcina TATCCTCCCTTAAGTGGTATTCAAGCCCATTCAGGGCCGTCGGTTGATTTAGCTATTTTTAGTCTTCATTTATCTGGT B626Cretroflexa TATCCTCCCTTAaGTGGTATTCAAGCCCATTCAGGGCCGTCGGTTGATTTAGCTATTTTTAGTCTTCATTTATCTGGT B146Csubfarcina TATCCTCCCTTAaGTGGTATTCAAGCCCATTCAGGGCCGTCGGTTGATTTAGCTATTTTTAGTCTTCATTTATCTGGT B146Csubfarcina TATCCTCCCTTAaGTGGTATTCAAGCCCATTCAGGGCCGTCGGTTGATTTAGCTATTTTTAGTCTTCATTTATCTGGT B128Csubfarccus TATCCTCCCTTAAGTGGTATTCAAGCCCATTCAGGGCCGTCGGTTGATTTAGCTATTTTTAGTCTTCATTTATCTGGT B127Csubfarccus TATCCTCCCTTAAGTGGTATTCAAGCCCATTCAGGGCCATCGGTTGATTTAGCTATTTTTAGTCTTCATTTATCCGGT B159Cretroflexa TATCCTCCCTTAAGTGGTATTCAAGCCCATTCAGGGCCGTCGGTCGATTTAGCTATTTTTAGTCTTCATTTATCTGGT B134Csubfarcina TATCCTCCCTTAAGTGGTATTCAAGCCCATTCAGGGCCGTCGGTTGATTTAGCTATTTTTAGTCTTCATTTATCTGGT B168Csubfarcina TATCCTCCCTTAAGTGGTATTCAAGCCCATTCAGGGCCGTCGGTTGATTTAGCTATTTTTAGTCTTCATTTATCTGGT B136Csubfarcina TATCCTCCCTTAAGTGGTATTCAAGCCCATTCAGGGCCGTCGGTTGATTTAGCTATTTTTAGTCTTCATTTATCTGGT B626Cretroflexa TATCCTCCCTTAaGTGGTATTCAAGCCCATTCAGGGCCGTCGGTCGATTTAGCTATTTTTAGTCTTCATTTATCTGGT B153Csubfarcina TATCCTCCCTTAAGTGGTATTCAAGCCCATTCAGGGCCGTCGGTTGATTTAGCTATTTTTAGTCTTCATTTATCTGGT B110Csubfarcina TATCCTCCCTTAaGTGGTATTCAAGCCCATTCAGGGCCGTCGGTTGATTTAGCTATTTTTAGTCTTCATTTATCTGGT B417Cretroflexa TATCCTCCCTTAaGTGGTATTCAAGCCCATTCAGGGCCGTCGGTTGATTTAGCTATTTTTAGTCTTCATTTATCTGGT B624Csubfarcina TATCCTCCCTTAAGTGGTATTCAAGCCCATTCAGGGCCGTCGGTTGATTTAGCTATTTTTAGTCTTCATTTATCTGGT B428Ctorulosa TATCCTCCCTTAAGTGGTATTCAAGCCCATTCAGGGCCATCGGTTGATTTAGCTATTTTTAGTCTTCATTTATCCGGT B103Ctorulosa TATCCTCCCTTAAGTGGTATTCAAGCCCATTCAGGGCCATCGGTTGATTTAGCTATTTTTAGTCTTCATTTATCCGGT B165Ctorulosa B125Ctorulosa B147Ctorulosa B179ctorulosa (1) TATCCTCCCTTAAGTGGTATTCAAGCCCATTCAGGGCCGTCGGTTGATTTAGCTATTTTTAGTCTTCATTTATCTGGT TATCCTCCCTTAAGTGGTATTCAAGCCCATTCAGGGCCATCGGTTGATTTAGCTATTTTTAGTCTTCATTTATCCGGT TATCCTCCCTTAAGTGGTATTCAAGCCCATTCAGGGCCATCGGTTGATTTAGCTATTTTTAGTCTTCATTTATCCGGT 
Appendix 4. (Continued)

A271Ctorulosa B175Ctorulosa A093Ctorulosa B320Ctorulosa A198Ctorulosa B316Ctorulosa B167Ctorulosa B145Ccongesta B149Ccongesta B416Ccongesta B176Cscalaris B178Cscalaris A318Cscalaris A469Cscalaris B330Cscalaris B333Cscalaris B334Cscalaris B336Cscalaris B337Cscalaris B338Cscalaris B611Cscalaris B612Cscalaris B608Cscalaris B607Cscalaris B606Cscalaris B177Cscalaris B605Cscalaris B332Cscalaris A099Cscalaris A614Cscalaris A596Cscalaris A292Cscalaris B351CspWilson B319Csiliquos B130Csiliquosa B143Csiliquosa B118Csiliquosa B325Cretorta B324Cretorta

TATCCTCCCTTAAGTGGTATTCAAGCCCATTCAGGGCCATCGGTTGATTTAGCTATTTTTAGTCTTCATTTATCCGGT TATCCTCCCTTAAGTGGTATTCAAGCCCATTCAGGGCCATCGGTTGATTTAGCTATTTTTAGTCTTCATTTATCCGGT TATCCTCCCTTAAGTGGTATTCAAGCCCATTCAGGGCCATCGGTTGATTTAGCTATTTTTAGTCTTCATTTATCCGGT TATCCTCCCTTAAGTGGTATTCAAGCCCATTCAGGGCCATCGGTTGATTTAGCTATTTTTAGTCTTCATTTATCCGGT TATCCTCCCTTAaGTGGTATTCAAGCCCATTCAGGGCCATCGGTTGATTTAGCTATTTTTAGTCTTCATTTATCCGGT TATCCTCCCTTAaGTGGTATTCAAGCCCATTCAGGGCCATCGGTTGATTTAGCTATTTTTAGTCTTCATTTATCCGGT TATCCTCCCTTAaGTGGTATTCAAGCCCATTCAGGGCCATCGGTTGATTTAGCTATTTTTAGTCTTCATTTATCCGGT TATCCTCCCTTAaGTGGTATTCAAGCCCATTCAGGGCCGTCGGTTGATTTAGCTATTTTTAGTCTTCATTTATCTGGT TATCCTCCCTTAaGTGGTATTCAAGCCCATTCAGGGCCGTCGGTTGATTTAGCTATTTTTAGTCTTCATTTATCTGGT TATCCTCCCTTAAGTGGTATTCAAGCCCATTCAGGGCCGTCGGTTGATTTAGCTATTTTTAGTCTTCATTTATCTGGT TATCCTCCCTTAAGTAGTATTCAAGCCCATTCAGGGCCATCGGTTGATTTAGCTATTTTTAGTCTTCATTTATCTGGT TATCCTCCCTTAAGTAGTATTCAAGCCCATTCAGGGCCATCGGTTGATTTAGCTATTTTTAGTCTTCATTTATCTGGT TATCCTCCCTTAAGTAGTATTCAAGCCCATTCAGGGCCATCGGTTGATTTAGCTATTTTTAGTCTTCATTTATCTGGT TATCCTCCCTTAAGTAGTATTCAAGCCCATTCAGGGCCATCGGTTGATTTAGCTATTTTTAGTCTTCATTTATCTGGT TATCCTCCCTTAAGTGGTATTCAAGCCCATTCAGGGCCGTCGGTCGATTTAGCTATTTTTAGTCTTCATTTATCTGGT TATCCTCCCTTAAGTAGTATTCAAGCCCATTCAGGGCCATCGGTTGATTTAGCTATTTTTAGTCTTCATTTATCTGGT TATCCTCCCTTAAGTAGTATTCAAGCCCATTCAGGGCCATCGGTTGATTTAGCTATTTTTAGTCTTCATTTATCTGGT TATCCTCCCTTAAGTAGTATTCAAGCCCATTCAGGGCCATCGGTTGATTTAGCTATTTTTAGTCTTCATTTATCTGGT TATCCTCCCTTAAGTAGTATTCAAGCCCATTCAGGGCCATCGGTTGATTTAGCTATTTTTAGTCTTCATTTATCTGGT TATCCTCCCTTAAGTAGTATTCAAGCCCATTCAGGGCCATCGGTTGATTTAGCTATTTTTAGTCTTCATTTATCTGGT TATCCTCCCTTAaGTAGTATTCAAGCCCATTCAGGGCCATCGGTTGATTTAGCTATTTTTAGTCTTCATTTATCTGGT TATCCTCCCTTAaGTAGTATTCAAGCCCATTCAGGGCCATCGGTTGATTTAGCTATTTTTAGTCTTCATTTATCTGGT TATCCTCCCTTAaGTAGTATTCAAGCCCATTCAGGGCCATCGGTTGATTTAGCTATTTTTAGTCTTCATTTATCTGGT TATCCTCCCTTAaGTAGTATTCAAGCCCATTCAGGGCCATCGGTTGATTTAGCTATTTTTAGTCTTCATTTATCTGGT TATCCTCCCTTAaGTAGTATTCAAGCCCATTCAGGGCCATCGGTTGATTTAGCTATTTTTAGTCTTCATTTATCTGGT TATCCTCCCTTAAGTAGTATTCAAGCCCATTCAGGGCCATCGGTTGATTTAGCTATTTTTAGTCTTCATTTATCTGGT TATCCTCCCTTAaGTAGTATTCAAGCCCATTCAGGGCCATCGGTTGATTTAGCTATTTTTAGTCTTCATTTATCTGGT TATCCTCCCTTAaGTAGTATTCAAGCCCATTCAGGGCCATCGGTTGATTTAGCTATTTTTAGTCTTCATTTATCTGGT TATCCTCCCTTAAGTAGTATTCAAGCCCATTCAGGGCCATCGGTTGATTTAGCTATTTTTAGTCTTCATTTATCTGGT TATCCTCCCTTAaGTAGTATTCAAGCCCATTCAGGGCCATCGGTTGATTTAGCTATTTTTAGTCTTCATTTATCTGGT TATCCTCCCTTAaGTAGTATTCAAGCCCATTCAGGGCCATCGGTTGATTTAGCTATTTTTAGTCTTCATTTATCTGGT TATCCTCCCTTAAGTAGTATTCAAGCCCATTCAGGGCCATCGGTTGATTTAGCTATTTTTAGTCTTCATTTATCTGGT TATCCTCCCTTAaGTGGTATTCAAGCCCATTCAGGGCCATCGGTTGATTTAGCTATTTTTAGTCTTCATTTATCCGGT TATCCTCCCTTAaGTGGTATTCAAGCCCATTCGGGACCATCGGTTGATTTAGCTATTTTTAGTCTTCATTTATCTGGT TATCCTCCCTTAAGTGGTATTCAAGCCCATTCGGGACCATCGGTTGATTTAGCTATTTTTAGTCTTCATTTATCTGGT TATCCTCCCCTAAGTGGTATTCAAGCCCATTCGGGACCATCGGTTGATTTAGCTATTTTTAGTCTTCATTTATCTGGT TATCCTCCCTTAaGTGGTATTCAAGCCCATTCGGGACCATCGGTTGATTTAGCTATTTTTAGTCTTCATTTATCTGGT TATCCTCCCTTAaGTGGTATTCAAGCCCATTCGGGACCATCGGTTGATTTAGCTATTTTTAGTCTTCATTTATCTGGT TATCCTCCCTTAAGTGGTATTCAAGCCCATTCGGGACCATCGGTTGATTTAGCTATTTTTAGTCTTCATTTATCTGGT

B601Ccephalorni GCTGCTTCTATTTTAGGTGCCATTAATTTTATTACAACTATTTTTAACATGCGTGCTCCTGGAATGAGCATGCATCGT Bo91Ccephalorni GCTGCTTCTATTTTAGGTGCCATTAATTTTATTACAACTATTTTTAACATGCGTGCTCCTGGAATGAGCATGCATCGT B327Carpoconflu GCAGCCTCTATTTTAGGTGCCATTAATTTTATTACAACCATTTTTAACATGCGTGCTCCTGGTATGAGCATGCACCGT B162Carpoconflu GCAGCCTCTATTTTAGGTGCCATTAATTTTATTACAACCATTTTTAACATGCGTGCTCCTGGTATGAGCATGCACCGT B174Lquercifoli GCGGCTTCTATTTTAGGTGCTATTAATTTCATAACGACTATTTTTAACATGCGTGCCCCGGGTATGAGCATGCACCGC B318Cmonilifera GCAGCTTCTATTTTAGGTGCTATTAATTTCATAACAACTATTTTTAACATGCGTGCCCCAGGTATGAGCATGCACCGT B092Cmonilifera GCAGCTTCTATTTTAGGTGCTATTAATTTCATAACAACTATTTTTAACATGCGTGCCCCAGGTATGAGCATGCACCGT B095Cmonilifera GCAGCTTCTATTTTAGGTGCTATTAATTTCATAACAACTATTTTTAACATGCGTGCCCCAGGTATGAGCATGCACCGT B102Cmonilifera GCAGCTTCTATTTTAGGTGCTATTAATTTCATAACAACTATTTTTAACATGCGTGCCCCAGGTATGAGCATGCACCGT B120Cmonilifera GCAGCTTCTATTTTAGGTGCTATTAATTTCATAACAACTATTTTTAACATGCGTGCCCCAGGTATGAGCATGCACCGT B093Cmoniliform GCAGCTTCTATTTTAGGTGCTATTAATTTCATAACAACTATTTTTAACATGCGTGCCCCCGGTATGAGCATGCATCGC B163Cmoniliform GCAGCTTCTATTTTAGGTGCTATTAATTTCATAACAACTATTTTTAACATGCGTGCCCCCGGTATGAGCATGCATCGC B094Csubfarcina GCAGCTTCTATTTTAGGCGCTATTAATTTCATAACAACTATTTTTAACATGCGTGCCCCAGGTATGAGCATGCACCGT B100Csubfarcina GCAGCTTCTATTTTAGGCGCTATTAATTTCATAACAACTATTTTTAACATGCGTGCCCCAGGTATGAGCATGCACCGT B101Cretroflexa GCAGCTTCTATTTAGGCGCTATTAATTTCATAACAACTATTTTAACATGCGTGCCCCAGGTATGAGCATGCACCGI B099Cretroflexa GCAGCTTCTATTTTAGGCGCTATTAATTTCATAACAACTATTTTTAACATGCGTGCCCCAGGTATGAGCATGCACCGT B123Cretroflexa GCAGCTTCTATTTTAGGCGCTATTAATTTCATAACAACTATTTTTAACATGCGTGCCCCAGGTATGAGCATGCACCGT B124Cretroflexa GCAGCTTCTATTTTAGGCGCTATTAATTTCATAACAACTATTTTTAACATGCGTGCCCCAGGTATGAGCATGCACCGT B166Csubfarcina GCAGCTTCTATTTTAGGCGCTATTAATTTCATAACAACTATTTTTAACATGCGTGCCCCAGGTATGAGCATGCACCGT B108Cretorta GCAGCTTCTATTTTAGGCGCTATTAATTTCATAACAACTATTTTTAACATGCGTGCCCCAGGTATGAGTATGCACCGT B617Cretroflexa GCAGCTTCTATTTTAGGCGCTATTAATTTCATAACAACTATTTTTAACATGCGTGCCCCAGGTATGAGCATGCACCGT B430Cretroflexa GCAGCTTCTATTTTAGGCGCTATTAATTTCATAACAACTATTTTTAACATGCGTGCCCCAGGTATGAGCATGCACCGT A615Cretroflexa GCAGCTTCTATTTTAGGCGCTATTAATTTCATAACAACTATTTTTAACATGCGTGCCCCAGGTATGAGCATGCACCGT B137Cretorta B169cretroflexa B425Cretroflexa B426Cretroflexa B335Ccongesta B436Cretroflexa A154Cscalaris A080Cretroflexa B602Cretroflexa A085Cretroflexa B556Cretroflexa A196Cretroflexa B412Csubfarcina GCAGCTTCTATTTTAGGCGCTATTAATTTCATAACAACTATTTTTAACATGCGTGCCCCAGGTATGAGTATGCACCGT GCAGCTTCTATTTTAGGCGCTATTAATTTCATAACAACTATTTTTAACATGCGTGCCCCAGGTATGAGCATGCACCGT GCAGCTTCTATTTTAGGCGCTATTAATTTCATAACAACTATTTTTAACATGCGTGCCCCAGGTATGAGCATGCACCGT GCAGCTTCTATTTTAGGCGCTATTAATTTCATAACAACTATTTTTAACATGCGTGCCCCAGGTATGAGCATGCACCGT GCAGCTTCTATTTTAGGCGCTATTAATTTCATAACAACTATTTTTAACATGCGTGCCCCAGGTATGAGCATGCACCGT GCAGCTTCTATTTTAGGCGCTATTAATTTCATAACAACTATTTTTAACATGCGTGCCCCAGGTATGAGCATGCACCGT GCAGCTTCTATTTTAGGCGCTATTAATTTCATAACAACTATTTTTAACATGCGTGCCCCAGGTATGAGCATGCACCGT GCAGCTTCTATTTTAGGCGCTATTAATTTCATAACAACTATTTTTAACATGCGTGCCCCAGGTATGAGCATGCACCGT GCAGCTTCTATTTTAGGCGCTATTAATTTCATAACAACTATTTTTAACATGCGTGCCCCAGGTATGAGCATGCACCGT GCAGCTTCTATTTTAGGCGCTATTAATTTCATAACAACTATTTTTAACATGCGTGCCCCAGGTATGAGCATGCACCGT GCAGCTTCTATTTTAGGCGCTATTAATTTCATAACAACTATTTTTAACATGCGTGCCCCAGGTATGAGCATGCACCGT GCAGCTTCTATTTTAGGCGCTATTAATTTCATAACAACTATTTTTAACATGCGTGCCCCAGGTATGAGCATGCACCGT GCAGCTTCTATTTTAGGCGCTATTAATTTCATAACAACTATTTTTAACATGCGTGCCCCAGGTATGAGCATGCACCGT 
Appendix 4. (Continued)

B121Cretroflexa B109Cretorta B170Cretorta B415Csiliquosa B111Cpolycystid B112Cpolycystid B148Cpolycystid B171Cpolycystid A168Cplatylobiu B140Cplatylobiu B104Cplatylobiu B116Ccongesta B115Ccongesta B152Ccongesta B455Ccongesta B129Cretorta B131Cretorta B161Csubfarcina B626Cretroflexa B146Csubfarcina B146Csubfarcina B128Csubfarccus B127Csubfarccup B159Cretroflexa B134Csubfarcina B168Csubfarcina B136Csubfarcina B626Cretroflexa B153Csubfarcina B110Csubfarcina B417Cretroflexa B624Csubfarcina B428Ctorulosa B103Ctorulosa B165Ctorulosa B125Ctorulosa B147Ctorulosa B179Ctorulosa A271Ctorulosa B175Ctorulosa A093Ctorulosa B320Ctorulosa A198Ctorulosa B316Ctorulosa B167Ctorulosa B145Ccongesta B149Ccongesta B416Ccongesta B176Cscalaris B178Cscalaris A318Cscalaris A469Cscalaris B330Cscalaris B333Cscalaris B334Cscalaris B336Cscalaris B337Cscalaris B338Cscalaris B611Cscalaris B612Cscalaris B608Cscalaris B607Cscalaris B606Cscalaris B177Cscalaris B605Cscalaris B332Cscalaris A099Cscalaris A614Cscalaris A596Cscalaris A292Cscalaris B351CspWilson B319Csiliquosa B130Csiliquosa B143Csiliquosa B118Csiliquosa B325Cretorta
GCAGCTTCTATTTTAGGCGCTATTAATTTCATAACAACTATTTTTAACATGCGTGCCCCAGGTATGAGCATGCACCGT GCAGCTTCTATTTTAGGCGCTATTAATTTCATAACAACTATTTTTAACATGCGTGCCCCAGGTATGAGTATGCACCGT GCAGCTTCTATTTTAGGCGCTATTAATTTCATAACAACTATTTTTAACATGCGTGCCCCGGGTATGAGTATGCACCGT GCAGCTTCTATTTTAGGTGCCATTAATTTCATAACAACTATTTTTAACATGCGTGCCCCAGGTATGAGCATGCACCGT GCAGCCTCTATTTTAGGCGCTATTAATTTCATAACAACTATTTTTAACATGCGTGCCCCAGGTATGAGCATGCACCGT GCAGCCTCTATTTTAGGCGCTATTAATTTCATAACAACTATTTTTAACATGCGTGCCCCAGGTATGAGCATGCACCGT GCAGCCTCTATTTTAGGCGCTATTAATTTCATAACAACTATTTTTAACATGCGTGCCCCAGGTATGAGCATGCACCGT GCAGCCTCTATTTTAGGCGCTATTAATTTCATAACAACTATTTTTAACATGCGTGCCCCAGGTATGAGCATGCACCGT GCAGCTTCTATTTTAGGCGCTATTAATTTCATAACAACTATTTTTAACATGCGTGCCCCAGGTATGAGCATGCACCGT GCAGCTTCTATTTTAGGCGCTATTAATTTCATAACAACTATTTTTAACATGCGTGCCCCAGGTATGAGCATGCACCGT GCAGCTTCTATTTTAGGCGCTATTAATTTCATAACAACTATTTTTAACATGCGTGCCCCAGGTATGAGCATGCACCGT GCAGCTTCTATTTTAGGCGCTATTAATTTCATAACAACTATTTTTAACATGCGTGCCCCAGGTATGAGCATGCACCGT GCAGCTTCTATTTTAGGCGCTATTAATTTCATAACAACTATTTTTAACATGCGTGCCCCAGGTATGAGCATGCACCGT GCAGCTTCTATTTTAGGCGCTATTAATTTCATAACAACTATTTTTAACATGCGTGCCCCAGGTATGAGCATGCACCGT GCAGCTTCTATTTTAGGCGCTATTAATTTCATAACAACTATTTTTAACATGCGTGCCCCAGGTATGAGCATGCACCGT GCAGCTTCTATTTTAGGCGCTATTAATTTCATAACAACTATTTTTAACATGCGTGCCCCAGGTATGAGTATGCACCGT GCAGCTTCTATTTTAGGCGCTATTAATTTCATAACAACTATTTTTAACATGCGTGCCCCAGGTATGAGTATGCACCGT GCAGCTTCTATTTTAGGCGCTATTAATTTCATAACAACTATTTTTAACATGCGTGCCCCAGGTATGAGCATGCACCGT GCAGCTTCTATTTTAGGCGCTATTAATTTCATAACAACTATTTTTAACATGCGTGCCCCAGGTATGAGCATGCACCGT GCAGCTTCTATTTTAGGCGCTATTAATTTCATAACAACTATTTTTAACATGCGTGCCCCAGGTATGAGCATGCACCGT GCAGCTTCTATTTTAGGCGCTATTAATTTCATAACAACTATTTTTAACATGCGTGCCCCAGGTATGAGCATGCACCGT GCAGCTTCTATTTTAGGCGCTATTAATTTCATAACAACTATTTTTAACATGCGTGCCCCAGGTATGAGCATGCACCGT GCAGCTTCTATTTTAGGCGCTATTAATTTCATAACAACTATTTTTAACATGCGTGCCCCAGGTATGAGCATGCACCGT GCAGCTTCTATTTTAGGCGCTATTAATTTCATAACAACTATTTTTAACATGCGTGCCCCAGGTATGAGCATGCACCGT GCAGCTTCTATTTTAGGCGCTATTAATTTCATAACAACTATTTTTAACATGCGTGCCCCAGGTATGAGCATGCACCGT GCAGCTTCTATTTTAGGCGCTATTAATTTCATAACAACTATTTTTAACATGCGTGCCCCAGGTATGAGCATGCACCGT GCAGCTTCTATTTTAGGCGCTATTAATTTCATAACAACTATTTTTAACATGCGTGCCCCAGGTATGAGCATGCACCGT GCAGCTTCTATTTTAGGCGCTATTAATTTCATAACAACTATTTTTAACATGCGTGCCCCAGGTATGAGCATGCACCGT GCAGCTTCTATTTTAGGCGCTATTAATTTCATAACAACTATTTTTAACATGCGTGCCCCAGGTATGAGCATGCACCGT GCAGCTTCTATTTTAGGCGCTATTAATTTCATAACAACTATTTTTAACATGCGTGCCCCAGGTATGAGCATGCACCGT GCAGCTTCTATTTTAGGCGCTATTAATTTCATAACAACTATTTTTAACATGCGTGCCCCAGGTATGAGCATGCACCGT GCAGCTTCTATTTTAGGCGCTATTAATTTCATAACAACTATTTTTAACATGCGTGCCCCAGGTATGAGCATGCACCGT GCAGCTTCTATTTTAGGCGCTATTAATTTCATAACAACTATTTTTAACATGCGTGCCCCAGGTATGAGCATGCACCGT GCAGCTTCTATTTTAGGCGCTATTAATTTCATAACAACTATTTTTAACATGCGTGCCCCAGGTATGAGCATGCACCGT GCAGCTTCTATTTTAGGCGCTATTAATTTCATAACAACTATTTTTAACATGCGTGCCCCAGGTATGAGCATGCACCGT GCAGCTTCTATTTTAGGCGCTATTAATTTCATAACAACTATTTTTAACATGCGTGCCCCAGGTATGAGCATGCACCGT GCAGCTTCTATTTTAGGCGCTATTAATTTCATAACAACTATTTTTAACATGCGTGCCCCAGGTATGAGCATGCACCGT GCAGCTTCTATTTTAGGCGCTATTAATTTCATAACAACTATTTTTAACATGCGTGCCCCAGGTATGAGCATGCACCGT GCAGCTTCTATTTTAGGCGCTATTAATTTCATAACAACTATTTTTAACATGCGTGCCCCAGGTATGAGCATGCACCGT GCAGCTTCTATTTTAGGCGCTATTAATTTCATAACAACTATTTTTAACATGCGTGCCCCAGGTATGAGCATGCACCGT GCAGCTTCTATTTTAGGCGCTATTAATTTCATAACAACTATTTTTAACATGCGTGCCCCAGGTATGAGCATGCACCGT GCAGCTTCTATTTTAGGCGCTATTAATTTCATAACAACTATTTTTAACATGCGTGCCCCAGGTATGAGCATGCACCGT GCAGCTTCTATTTTAGGCGCTATTAATTTCATAACAACTATTTTTAACATGCGTGCCCCAGGTATGAGCATGCACCGT GCAGCTTCTATTTTAGGCGCTATTAATTTCATAACAACTATTTTTAACATGCGTGCCCCAGGTATGAGCATGCACCGT GCAGCTTCTATTTTAGGCGCTATTAATTTCATAACAACTATTTTTAACATGCGTGCCCCAGGTATGAGCATGCACCGT GCAGCTTCTATTTTAGGCGCTATTAATTTCATAACAACTATTTTTAACATGCGTGCCCCAGGTATGAGCATGCACCGT GCAGCTTCTATTTTAGGCGCTATTAATTTCATAACAACTATTTTTAACATGCGTGCCCCAGGTATGAGCATGCACCGT GCAGCTTCTATTTTAGGCGCTATTAATTTCATAACAACTATTTTTAACATGCGTGCCCCAGGTATGAGCATGCACCGT GCAGCTTCTATTTTAGGCGCTATTAATTTCATAACAACTATTTTTAACATGCGTGCCCCAGGTATGAGCATGCACCGT GCAGCTTCTATTTTAGGCGCTATTAATTTCATAACAACTATTTTTAACATGCGTGCCCCAGGTATGAGCATGCACCGT GCAGCTTCTATTTTAGGCGCTATTAATTTCATAACAACTATTTTTAACATGCGTGCCCCAGGTATGAGCATGCACCGT GCAGCTTCTATTTTAGGCGCTATTAATTTCATAACAACTATTTTTAACATGCGTGCCCCAGGTATGAGCATGCACCGT GCAGCTTCTATTTTAGGCGCTATTAATTTCATAACAACTATTTTTAACATGCGTGCCCCAGGTATGAGCATGCACCGT GCAGCTTCTATTTTAGGCGCTATTAATTTCATAACAACTATTTTTAACATGCGTGCCCCAGGTATGAGCATGCACCGT GCAGCTTCTATTTTAGGCGCTATTAATTTCATAACAACTATTTTTAACATGCGTGCCCCAGGTATGAGCATGCACCGT GCAGCTTCTATTTTAGGCGCTATTAATTTCATAACAACTATTTTTAACATGCGTGCCCCAGGTATGAGCATGCACCGT GCAGCTTCTATTTTAGGCGCTATTAATTTCATAACAACTATTTTTAACATGCGTGCCCCAGGTATGAGCATGCACCGT GCAGCTTCTATTTTAGGCGCTATTAATTTCATAACAACTATTTTTAACATGCGTGCCCCAGGTATGAGCATGCACCGT GCAGCTTCTATTTTAGGCGCTATTAATTTCATAACAACTATTTTTAACATGCGTGCCCCAGGTATGAGCATGCACCGT GCAGCTTCTATTTTAGGCGCTATTAATTTCATAACAACTATTTTTAACATGCGTGCCCCAGGTATGAGCATGCACCGT GCAGCTTCTATTTTAGGCGCTATTAATTTCATAACAACTATTTTTAACATGCGTGCCCCAGGTATGAGCATGCACCGT GCAGCTTCTATTTTAGGCGCTATTAATTTCATAACAACTATTTTTAACATGCGTGCCCCAGGTATGAGCATGCACCGT GCAGCTTCTATTTTAGGCGCTATTAATTTCATAACAACTATTTTTAACATGCGTGCCCCAGGTATGAGCATGCACCGT GCAGCTTCTATTTTAGGCGCTATTAATTTCATAACAACTATTTTTAACATGCGTGCCCCAGGTATGAGCATGCACCGT GCAGCTTCTATTTTAGGCGCTATTAATTTCATAACAACTATTTTTAACATGCGTGCCCCAGGTATGAGCATGCACCGT GCAGCTTCTATTTTAGGCGCTATTAATTTCATAACAACTATTTTTAACATGCGTGCCCCAGGTATGAGCATGCACCGT GCAGCTTCTATTTTAGGCGCTATTAATTTCATAACAACTATTTTTAACATGCGTGCCCCAGGTATGAGCATGCACCGT GCAGCTTCTATTTTAGGCGCTATTAATTTCATAACAACTATTTTTAACATGCGTGCCCCAGGTATGAGCATGCACCGT GCAGCTTCTATTTTAGGCGCTATTAATTTCATAACAACTATTTTTAACATGCGTGCCCCAGGTATGAGCATGCACCGT GCAGCTTCTATTTTAGGCGCTATTAATTTCATAACAACTATTTTTAACATGCGTGCCCCAGGTATGAGCATGCACCGT GCAGCTTCTATTTTAGGCGCTATTAATTTCATAACAACTATTTTTAACATGCGTGCCCCAGGTATGAGCATGCACCGT GCAGCTTCTATTTTAGGTGCCATTAATTTCATAACAACTATTTTTAACATGCGTGCCCCAGGTATGAGCATGCACCGT GCAGCTTCTATTTTAGGTGCCATTAATTTCATAACAACTATTTTTAACATGCGTGCCCCAGGTATGAGCATGCACCGT GCAGCTTCTATTTTAGGTGCCATTAATTTCATAACAACTATTTTTAACATGCGTGCCCCAGGTATGAGCATGCACCGT GCAGCTTCTATTTTAGGTGCCATTAATTTCATAACAACTATTTTTAACATGCGTGCCCCAGGTATGAGCATGCACCGT GCAGCTTCTATTTTAGGCGCTATTAATTTCATAACAACTATTTTTAACATGCGTGCCCCAGGTATGAGCATGCACCGT 
Appendix 4. (Continued)

B324Cretorta

B601Ccephalorni B091Ccephalorni B327Carpoconflu B162Carpoconflu B174 Lquercifoli B318Cmonilifera B092Cmonilifera B095Cmonilifera B102Cmonilifera B120Cmonilifera B093Cmoniliform B163Cmoniliform B094Csubfarcina B100Csubfarcina B101Cretroflexa B099Cretroflexa B123Cretroflexa B124Cretroflexa B166Csubfarcina B108Cretorta B617Cretroflexa B430Cretroflexa A615Cretroflexa B137Cretorta B169Cretroflexa B425Cretroflexa B426Cretroflexa B335Ccongesta B436Cretroflexa A154Cscalaris A080Cretroflexa B602Cretroflexa A085Cretroflexa B556Cretroflexa A196Cretroflexa B412Csubfarcina B121Cretroflexa B109Cretorta B170Cretorta B415Csiliquosa B111Cpolycystid B112Cpolycystid B148Cpolycystid B171Cpolycystid A168Cplatylobiu B140Cplatylobiu B104Cplatylobiu B116Ccongesta B115Ccongesta B152Ccongesta B455Ccongesta B129Cretorta B131Cretorta B161Csubfarcina B626Cretroflexa B146Csubfarcina B146Csubfarcina B128Csubfarccus B127Csubfarccus B159Cretroflexa B134Csubfarcina B168Csubfarcina B136Csubfarcina B626Cretroflexa B153Csubfarcina B110Csubfarcina B417Cretroflexa B624Csubfarcina B428Ctorulosa B103Ctorulosa B165Ctorulosa B125Ctorulosa B147Ctorulosa B179Ctorulosa

TTACCCTTATTCGTTTGGTCTGTATTAATAACAGCATTTTTACTTTTATTGTCGCTTCCTGTTTTAGCTGGAGGTATT TTACCCTTATTCGTTTGGTCTGTATTAATAACAGCATTTTTACTTTTATTGTCGCTTCCTGTTTTAGCTGGAGGTATT TTACCTCTTTTTGTATGGTCTGTATTAATAACGGCATTTTTACTTTTGCTGTCTCTTCCTGTTTTAGCCGGTGGCATT TAACTCTTTTTGTATGGTCTGTATTAATAACGGCATTTTTACTTTTGCTGTCTCTTCCTGTTTTAGCCGGTGGCATT TTACCGCTATTTGTATGGTCTGTACTGATAACAGCATTTTTACTTTTGCTATCTCTTCCTGTTTTAGCAGGGGGTATT TACCCCTATTTGTATGGTCTGTACTAATAACAGCATTTTTACTTTTGCTGTCTCTTCCTGTTTTAGCTGGAGGTATT TTACCCCTATTTGTATGGTCTGTACTAATAACAGCATTTTTACTTTTGCTGTCTCTTCCTGTTTTAGCTGGAGGTATT TTACCCCTATTTGTATGGTCTGTACTAATAACAGCATTTTTACTTTTGCTGTCTCTTCCTGTTTTAGCTGGAGGTATT TTACCCCTATTTGTATGGTCTGTACTAATAACAGCATTTTTACTTTTGCTGTCTCTTCCTGTTTTAGCTGGAGGTATT TTACCCCTATTTGTATGGTCTGTACTAATAACAGCATTTTTACTTTTGCTGTCTCTTCCTGTTTTAGCTGGAGGTATT TTGCCTCTATTTGTATGGTCTGTGCTAATAACAGCATTTTTACTTCTACTTTCTCTTCCTGTTTTAGCCGGGGGTATT TTGCCTCTATTTGTATGGTCTGTGCTAATAACAGCATTTTTACTTCTACTTTCTCTTCCTGTTTTAGCCGGGGGTATT TTACCTCTATTTGTATGGTCTGTACTAATAACAGCATTTTTACTTTTGCTGTCTCTTCCTGTTTTAGCTGGGGGTATT TTACCTCTATTTGTATGGTCTGTACTAATAACAGCATTTTTACTTTTGCTGTCTCTTCCTGTTTTAGCTGGGGGTATT TTACCTCTATTTGTATGGTCTGTACTAATAACAGCATTTTTACTTTTGCTGTCTCTTCCTGTTTTAGCTGGAGGTATT TTACCTCTATTTGTATGGTCTGTACTAATAACAGCATTTTTACTTTTGCTGTCTCTTCCTGTTTTAGCTGGAGGTATT TTACCTCTATTTGTATGGTCTGTACTAATAACAGCATTTTTACTTTTGCTGTCTCTTCCTGTTTTAGCGGGAGGTATT TTACCTCTATTTGTATGGTCTGTACTAATAACAGCATTTTTACTTTTGCTGTCTCTTCCTGTTTTAGCGGGAGGTATT TTACCTCTATTTGTATGGTCTGTACTAATAACAGCATTTTTACTTTTGCTGTCTCTTCCTGTTTTAGCTGGGGGTATT TTACCTCTATTTGTATGGTCTGTGCTAATAACAGCATTTTTACTTTTACTGTCTCTTCCTGTTTTAGCTGGAGGTATT TTACCTCTATTTGTATGGTCTGTACTAATAACAGCATTTTTACTTTTGCTGTCTCTTCCTGTTTTAGCTGGAGGTATT TTACCTCTATTTGTATGGTCTGTACTAATAACAGCATTTTTACTTTTGCTGTCTCTTCCTGTTTTAGCGGGAGGTATT TTACCTCTATTTGTATGGTCTGTACTAATAACAGCATTTTTACTTTTGCTGTCTCTTCCTGTTTTAGCTGGAGGTATT TTACCTCTATTTGTATGGTCTGTGCTAATAACAGCATTTTTACTTTTACTGTCTCTTCCTGTTTTAGCTGGAGGTATT TTACCTCTATTTGTATGGTCTGTACTAATAACAGCATTTTTACTTTTGCTGTCTCTTCCTGTTTTAGCGGGAGGTATT TTACCTCTATTTGTATGGTCTGTACTAATAACAGCATTTTTACTTTTGCTGTCTCTTCCTGTTTTAGCTGGAGGTATT TTACCTCTATTTGTATGGTCTGTACTAATAACAGCATTTTTACTTTTGCTGTCTCTTCCTGTTTTAGCTGGAGGTATT TTACCTCTATTTGTATGGTCTGTACTAATAACAGCATTTTTACTTTTGCTGTCTCTTCCTGTTTTAGCTGGAGGTATT TTACCTCTATTTGTATGGTCTGTACTAATAACAGCATTTTTACTTTTGCTGTCTCTTCCTGTTTTAGCTGGAGGTATT TTACCTCTATTTGTATGGTCTGTACTAATAACAGCATTTTTACTTCTACTGTCTCTTCCTGTTTTAGCTGGAGGTATT TTACCTCTATTTGTATGGTCTGTACTAATAACAGCATTTTTACTTTTGCTGTCTCTTCCTGTTTTAGCTGGAGGTATT TTACCTCTATTTGTATGGTCTGTACTAATAACAGCATTTTTACTTTTGCTGTCTCTTCCTGTTTTAGCGGGAGGTATT TTACCTCTATTTGTATGGTCTGTACTAATAACAGCATTTTTACTTTTGCTGTCTCTTCCTGTTTTAGCTGGAGGTATT TTACCTCTATTTGTATGGTCTGTACTAATAACAGCATTTTTACTTTTGCTGTCTCTTCCTGTTTTAGCGGGAGGTATT TTACCTCTATTTGTATGGTCTGTACTAATAACAGCATTTTTACTTTTGCTGTCTCTTCCTGTTTTAGCTGGAGGTATT TTACCTCTATTTGTATGGTCTGTACTAATAACAGCATTTTTACTTTTGCTGTCTCTTCCTGTTTTAGCTGGGGGTATT TTACCTCTATTTGTATGGTCTGTACTAATAACAGCATTTTTACTTTTGCTGTCTCTTCCTGTTTTAGCGGGAGGTATT TTACCTCTATTTGTATGGTCTGTGCTAATAACAGCATTTTTACTTTTACTGTCTCTTCCTGTTTTAGCTGGAGGTATT TTACCTCTATTTGTATGGTCTGTGCTAATAACAGCATTTTTACTTTTACTGTCTCTTCCTGTTTTAGCTGGAGGTATT TTACCTCTATTTGTATGGTCTGTGCTAATAACAGCATTTTTACTTTTACTGTCTCTTCCTGTTTTAGCTGGAGGTATT TTACCTCTATTTGTATGGTCTGTGCTAATAACAGCATTTTTACTTTTGCTGTCTCTTCCTGTTTTAGCTGGAGGTATT TTACCTCTATTTGTATGGTCTGTGCTAATAACAGCATTTTTACTTTTGCTGTCTCTTCCTGTTTTAGCTGGAGGTATT TTACCTCTATTTGTATGGTCTGTGCTAATAACAGCATTTTTACTTTTGCTGTCTCTTCCTGTTTTAGCTGGAGGTATT TTACCTCTATTTGTATGGTCTGTGCTAATAACAGCATTTTTACTTTTGCTGTCTCTTCCTGTTTTAGCTGGAGGTATT TTACCTCTATTTGTATGGTCTGTGCTAATAACAGCATTTTTACTTTTACTTTCTCTTCCTGTTTTAGCTGGAGGTATT TTACCTCTATTTGTATGGTCTGTGCTAATAACAGCATTTTTACTTTTACTTTCTCTTCCTGTTTTAGCTGGAGGTATT TTACCTCTATTTGTATGGTCTGTGCTAATAACAGCATTTTTACTTTTACTTTCTCTTCCTGTTTTAGCTGGAGGTATT TTACCTCTATTTGTATGGTCTGTACTAATAACAGCATTTTTACTTTTGCTGTCTCTTCCTGTTTTAGCTGGAGGTATT TTACCTCTATTTGTATGGTCTGTACTAATAACAGCATTTTTACTTTTGCTGTCTCTTCCTGTTTTAGCTGGAGGTATT TTACCTCTATTTGTATGGTCTGTACTAATAACAGCATTTTTACTTTTGCTGTCTCTTCCTGTTTTAGCTGGAGGTATT TTACCTCTATTTGTATGGTCTGTACTAATAACAGCATTTTTACTTTTGCTGTCTCTTCCTGTTTTAGCTGGAGGTATT TTACCTCTATTTGTATGGTCTGTGCTAATAACAGCATTTTTACTTTTACTGTCTCTTCCTGTTTTAGCTGGAGGTATT TTACCTCTATTTGTATGGTCTGTGCTAATAACAGCATTTTTACTTTTACTGTCTCTTCCTGTTTTAGCTGGAGGTATT TTACCTCTATTTGTATGGTCTGTACTAATAACAGCATTTTTACTTTTGCTGTCTCTTCCTGTTTTAGCTGGGGGTATT TTACCTCTATTTGTATGGTCTGTACTAATAACAGCATTTTTACTTTTGCTGTCTCTTCCTGTTTTAGCTGGGGGTATT TTACCTCTATTTGTATGGTCTGTACTAATAACAGCATTTTTACTTTTGCTGTCTCTTCCTGTTTTAGCTGGGGGTATT TTACCTCTATTTGTATGGTCTGTACTAATAACAGCATTTTTACTTTTGCTGTCTCTTCCTGTTTTAGCTGGGGGTATT TTACCTCTATTTGTATGGTCTGTACTAATAACAGCATTTTTACTTTTGCTGTCTCTTCCTGTTTTAGCTGGGGGTATT TTACCTCTATTTGTATGGTCTGTACTAATAACAGCATTTTTACTTTTATTGTCTCTTCCTGTTTTAGCTGGAGGTATT TTACCTCTATTTGTATGGTCTGTACTAATAACAGCATTTTTACTTTTGCTGTCTCTTCCTGTTTTAGCTGGAGGTATT TTACCTCTATTTGTATGGTCTGTACTAATAACAGCATTTTTACTTTTGCTGTCTCTTCCTGTTTTAGCTGGGGGTATT TTACCTCTATTTGTATGGTCTGTACTAATAACAGCATTTTTACTTTTGCTGTCTCTTCCTGTTTTAGCTGGGGGTATT TTACCTCTATTTGTATGGTCTGTACTAATAACAGCATTTTTACTTTTGCTGTCTCTTCCTGTTTTAGCTGGGGGTATT TTACCTCTATTTGTATGGTCTGTACTAATAACAGCATTTTTACTTTTGCTGTCTCTTCCTGTTTTAGCTGGAGGTATT TTACCTCTATTTGTATGGTCTGTACTAATAACAGCATTTTTACTTTTGCTGTCTCTTCCTGTTTTAGCTGGGGGTATT TTACCTCTATTTGTATGGTCTGTACTAATAACAGCATTTTTACTTTTGCTGTCTCTTCCTGTTTTAGCTGGGGGTATT TTACCTCTATTTGTATGGTCTGTACTAATAACAGCATTTTTACTTTTGCTGTCTCTTCCTGTTTTAGCGGGAGGTATT TTACCTCTATTTGTATGGTCTGTACTAATAACAGCATTTTTACTTTTGCTGTCTCTTCCTGTTTTAGCTGGGGGTATT TTACCTCTATTTGTATGGTCTGTACTAATAACAGCATTTTTACTTTTATTGTCTCTTCCTGTTTTAGCTGGAGGTATT TTACCTCTATTTGTATGGTCTGTACTAATAACAGCATTTTTACTTTTATTGTCTCTTCCTGTTTTAGCTGGAGGTATT TTACCTCTATTTGTATGGTCTGTACTAATAACAGCATTTTTACTTTTATTGTCTCTTCCTGTTTTAGCTGGAGGTATT TTACCTCTATTTGTATGGTCTGTACTAATAACAGCATTTTTACTTTTGCTGTCTCTTCCTGTTTTAGCTGGGGGTATT TTACCTCTATTTGTATGGTCTGTACTAATAACAGCATTTTTACTTTTATTGTCTCTTCCTGTTTTAGCTGGAGGTATT TTACCTCTATTTGTATGGTCTGTACTAATAACAGCATTTTTACTTTTATTGTCTCTTCCTGTTTTAGCTGGAGGTATT 
Appendix 4. (Continued)

A271Ctorulosa TTACCTCTATTTGTATGGTCTGTACTAATAACAGCATTTTTACTTTTATTGTCTCTTCCTGTTTTAGCTGGAGGTATT B175Ctorulosa TTACCTCTATTTGTATGGTCTGTACTAATAACAGCATTTTTACTTTTATTGTCTCTTCCTGTTTTAGCTGGAGGTATT A093Ctorulosa TTACCTCTATTTGTATGGTCTGTACTAATAACAGCATTTTTACTTTTATTGTCTCTTCCTGTTTTAGCTGGAGGTATT B320Ctorulosa TTACCTCTATTTGTATGGTCTGTACTAATAACAGCATTTTTACTTTTATTGTCTCTTCCTGTTTTAGCTGGAGGTATT A198Ctorulosa TTACCTCTATTTGTATGGTCTGTACTAATAACAGCATTTTTACTTTTATTGTCTCTTCCTGTTTTAGCTGGAGGTATT B316Ctorulosa TTACCTCTATTTGTATGGTCTGTACTAATAACAGCATTTTTACTTTTATTGTCTCTTCCTGTTTTAGCTGGAGGTATT B167Ctorulosa TTACCTCTATTTGTATGGTCTGTACTAATAACAGCATTTTTACTTTTATTGTCTCTTCCTGTTTTAGCTGGAGGTATT B145Ccongesta TTACCTCTATTTGTATGGTCTGTACTAATAACAGCATTTTTACTTTTGCTGTCTCTTCCTGTTTTAGCTGGAGGTATT B149Ccongesta TTACCTCTATTTGTATGGTCTGTACTAATAACAGCATTTTTACTTTTGCTGTCTCTTCCTGTTTTAGCTGGAGGTATT B416Ccongesta TTACCTCTATTTGTATGGTCTGTACTAATAACAGCATTTTTACTTTTGCTGTCTCTTCCTGTTTTAGCTGGGGGTATT B176Cscalaris TTACCTCTATTTGTATGGTCTGTACTAATAACAGCATTTTTACTTCTACTGTCTCTTCCTGTTTTAGCTGGAGGTATT B178Cscalaris TTACCTCTATTTGTATGGTCTGTACTAATAACAGCATTTTTACTTCTACTGTCTCTTCCTGTTTTAGCTGGAGGTATT A318Cscalaris TTACCTCTATTTGTATGGTCTGTACTAATAACAGCATTTTTACTTCTACTGTCTCTTCCTGTTTTAGCTGGAGGTATT A469Cscalaris TTACCTCTATTTGTATGGTCTGTACTAATAACAGCATTTTTACTTCTACTGTCTCTTCCTGTTTTAGCTGGAGGTATT B330 Cscalaris TTACCTCTATTTGTATGGTCTGTACTAATAACAGCATTTTTACTTTTGCTGTCTCTTCCTGTTTTAGCTGGAGGTATT B333Cscalaris TTACCTCTATTTGTATGGTCTGTACTAATAACAGCATTTTTACTTCTACTGTCTCTTCCTGTTTTAGCTGGAGGTATT B334Cscalaris TTACCTCTATTTGTATGGTCTGTACTAATAACAGCATTTTTACTTCTACTGTCTCTTCCTGTTTTAGCTGGAGGTATT B336Cscalaris TTACCTCTATTTGTATGGTCTGTACTAATAACAGCATTTTTACTTCTACTGTCTCTTCCTGTTTTAGCTGGAGGTATT B337Cscalaris TTACCTCTATTTGTATGGTCTGTACTAATAACAGCATTTTTACTTCTACTGTCTCTTCCTGTTTTAGCTGGAGGTATT B338Cscalaris TTACCTCTATTTGTATGGTCTGTACTAATAACAGCATTTTTACTTCTACTGTCTCTTCCTGTTTTAGCTGGAGGTATT B611Cscalaris TTACCTCTATTTGTATGGTCTGTACTAATAACAGCATTTTTACTTCTACTGTCTCTTCCTGTTTTAGCTGGAGGTATT B612Cscalaris TTACCTCTATTTGTATGGTCTGTACTAATAACAGCATTTTTACTTCTACTGTCTCTTCCTGTTTTAGCTGGAGGTATT B608Cscalaris TTACCTCTATTTGTATGGTCTGTACTAATAACAGCATTTTTACTTCTACTGTCTCTTCCTGTTTTAGCTGGAGGTATT B607Cscalaris TTACCTCTATTTGTATGGTCTGTACTAATAACAGCATTTTTACTTCTACTGTCTCTTCCTGTTTTAGCTGGAGGTATT B606Cscalaris TTACCTCTATTTGTATGGTCTGTACTAATAACAGCATTTTTACTTCTACTGTCTCTTCCTGTTTTAGCTGGAGGTATT B177Cscalaris TTACCTCTATTTGTATGGTCTGTACTAATAACAGCATTTTTACTTCTACTGTCTCTTCCTGTTTTAGCTGGAGGTATT B605Cscalaris TTACCTCTATTTGTATGGTCTGTACTAATAACAGCATTTTTACTTCTACTGTCTCTTCCTGTTTTAGCTGGAGGTATT B332Cscalaris TTACCTCTATTTGTATGGTCTGTACTAATAACAGCATTTTTACTTCTACTGTCTCTTCCTGTTTTAGCTGGAGGTATT A099Cscalaris TTACCTCTATTTGTATGGTCTGTACTAATAACAGCATTTTTACTTCTACTGTCTCTTCCTGTTTTAGCTGGAGGTATT A614Cscalaris TTACCTCTATTTGTATGGTCTGTACTAATAACAGCATTTTTACTTCTACTGTCTCTTCCTGTTTTAGCTGGAGGTATT A596Cscalaris TTACCTCTATTTGTATGGTCTGTACTAATAACAGCATTTTTACTTCTACTGTCTCTTCCTGTTTTAGCTGGAGGTATT A292CspManuka TTACCTCTATTTGTATGGTCTGTACTAATAACAGCATTTTTACTTCTACTGTCTCTTCCTGTTTTAGCTGGAGGTATT B351CspWilson TTACCTCTATTTGTATGGTCTGTACTAATAACAGCATTTTTACTTTTATTGTCTCTTCCTGTTTTAGCTGGAGGTATT B319Csiliquos TTACCTCTATTTGTATGGTCTGTGCTAATAACAGCATTTTTACTTTTACTGTCTCTTCCTGTTTTAGCTGGAGGTATT B130Csiliquos TTACCTCTATTTGTATGGTCTGTGCTAATAACAGCATTTTTACTTTTACTGTCTCTTCCTGTTTTAGCTGGAGGTATT B143Csiliquos TTACCTCTATTTGTATGGTCTGTGCTAATAACAGCATTTTTACTTTTACTGTCTCTTCCTGTTTTAGCTGGAGGTATT B118Csiliquos TTACCTCTATTTGTATGGTCTGTGCTAATAACAGCATTTTTACTTTTACTGTCTCTTCCTGTTTTAGCTGGAGGTATT B325Cretorta TTACCTCTATTTGTATGGTCTGTGCTAATAACAGCATTTTTACTTTTACTGTCTCTTCCTGTTTTAGCTGGAGGTATT B324Cretorta TTACCTCTATTTGTATGGTCTGTGCTAATAACAGCATTTTTACTTTTACTGTCTCTTCCTGTTTTAGCTGGAGGTATT

B601Ccephalornithos ACTATGCTTTTAACAGATCGTAATTTTAACACAACGTTTTTTGATCCAGCGGGTGGTGGTGATCCT Bo91Ccephalornithos ACTATGCTTTTAACAGATCGTAATTTTAACACAACGTTTTTTGATCCAGCGGGTGGTGGTGATCCT B327Carpoconfluens ACGATGCTTTTGACAGACCGTAATTTTAATACAACATTTTTTGATCCAGCGGGTGGTGGTGACCCT B162Carpoconfluens ACGATGCTTTTGACAGACCGTAATTTTAATACAACATTTTTTGATCCAGCGGGTGGTGGTGATCCT B174Lquercifolium ACCATGCTTTTAACAGATCGTAATTTTAATACCACATTTTTTGATCCGGCTGGTGGTGGtGATCCT B318Cmonilifera B092Cmonilifera B095Cmonilifera B102Cmonilifera B120Cmonilifera B093Cmoniliformis B163Cmoniliformis B094Csubfarcina B100Csubfarcina B101Cretroflexa B099Cretroflexa B123Cretroflexa B124Cretroflexa B166Csubfarcina B108Cretorta B617Cretroflexa B430Cretroflexa A615Cretroflexa B137Cretorta B169Cretroflexa B425Cretroflexa B426Cretroflexa B335Ccongesta B436Cretroflexa A154Cscalaris A080Cretroflexa B602Cretroflexa A085Cretroflexa B556Cretroflexa A196Cretroflexa B412Csubfarcina ACCATGCTTTTAACGGATCGTAATTTTAATACAACGTTTTTTGATCCAGCCGGTGGTGGTGATCCT ACCATGCTTTTAACGGATCGTAATTTTAATACAACGTTTTTTGATCCAGCCGGTGGTGGTGATCCT ACCATGCTTTTAACGGATCGTAATTTTAATACAACGTTTTTTGATCCAGCCGGTGGTGGTGATCCT ACCATGCTTTTAACGGATCGTAATTTTAATACAACGTTTTTTGATCCAGCCGGTGGTGGTGATCCT ACCATGCTTTTAACGGATCGTAATTTTAATACAACGTTTTTTGATCCAGCCGGTGGTGGTGATCCT ACCATGCTTTTAACGGATCGTAATTTTAATACAACATTTTTTGATCCAGCTGGTGGTGGTGACCCT ACCATGCTTTTAACGGATCGTAATTTTAATACAACATTTTTTGATCCAGCTGGTGGTGGTGACCCT ACCATGCTTTTAACGGATCGTAATTTTAATACAACGTTTTTTGATCCAGCCGGTGGTGGTGATCCT ACCATGCTTTTAACGGATCGTAATTTTAATACAACGTTTTTTGATCCAGCCGGTGGTGGTGATCCT ACCATGCTTTTAACGGATCGTAATTTTAATACAACGTTTTTTGATCCAGCCGGTGGTGGTGATCCT ACCATGCTTTTAACGGATCGTAATTTTAATACAACGTTTTTTGATCCAGCCGGTGGTGGTGATCCT ACCATGCTTTTAACGGATCGTAATTTTAATACAACGTTTTTTGATCCAGCCGGTGGTGGTGATCCT ACCATGCTTTTAACGGATCGTAATTTTAATACAACGTTTTTTGATCCAGCCGGTGGTGGTGATCCT ACCATGCTTTTAACGGATCGTAATTTTAATACAACGTTTTTTGATCCAGCCGGTGGTGGTGATCCT ACCATGCTTTTAACAGATCGTAATTTTAATACAACGTTTTTTGATCCAGCTGGTGGTGGTGATCCT ACCATGCTTTTAACGGATCGTAATTTTAATACAACGTTTTTTGATCCAGCCGGTGGTGGTGATCCT ACCATGCTTTTAACGGATCGTAATTTTAATACAACGTTTTTTGATCCAGCCGGTGGTGGTGATCCT ACCATGCTTTTAACGGATCGTAATTTTAATACAACGTTTTTTGATCCAGCCGGTGGTGGTGATCCT ACCATGCTTTTAACAGATCGTAATTTTAATACAACGTTTTTTGATCCAGCTGGTGGTGGTGATCCT ACCATGCTTTTAACGGATCGTAATTTTAATACAACGTTTTTTGATCCAGCCGGTGGTGGTGATCCT ACCATGCTTTTAACGGATCGTAATTTTAATACAACGTTTTTTGATCCAGCCGGTGGTGGTGATCCT ACCATGCTTTTAACGGATCGTAATTTTAATACAACGTTTTTTGATCCAGCCGGTGGTGGTGATCCT ACCATGCTTTTAACGGATCGTAATTTTAATACAACGTTTTTTGATCCAGCCGGTGGTGGTGATCCT ACCATGCTTTTAACGGATCGTAATTTTAATACAACGTTTTTTGATCCAGCCGGTGGTGGTGATCCT ACCATGCTTTTAACGGATCGTAATTTTAATACAACGTTTTTTGATCCAGCTGGTGGTGGTGATCCT ACCATGCTTTTAACGGATCGTAATTTTAATACAACGTTTTTTGATCCAGCCGGTGGTGGTGATCCT ACCATGCTTTTAACGGATCGTAATTTTAATACAACGTTTTTTGATCCAGCCGGTGGTGGTGATCCT ACCATGCTTTTAACGGATCGTAATTTTAATACAACGTTTTTTGATCCAGCCGGTGGTGGTGATCCT ACCATGCTTTTAACGGATCGTAATTTTAATACAACGTTTTTTGATCCAGCCGGTGGTGGTGATCCT ACCATGCTTTTAACGGATCGTAATTTTAATACAACGTTTTTTGATCCAGCCGGTGGTGGTGATCCT ACCATGCTTTTAACGGATCGTAATTTTAATACAACGTTTTTTGATCCAGCCGGTGGTGGTGATCCT 
Appendix 4. (Continued)

B121Cretroflexa B109Cretorta B170Cretorta B415Csiliquosa B111Cpolycystidea B112Cpolycystidea B148Cpolycystidea B171Cpolycystidea A168Cplatylobium B140Cplatylobium B104Cplatylobium B116Ccongesta B115Ccongesta B152Ccongesta B455Ccongesta B129Cretorta B131Cretorta B161Csubfarcina B626Cretroflexa B146Csubfarcina B146Csubfarcina B128Csubfarccusp B127Csubfarccusp B159Cretroflexata B134Csubfarcinata B168Csubfarcinata B136Csubfarcinata B626Cretroflexata B153Csubfarcinata B110Csubfarcinata B417Cretroflexata B624Csubfarcinata B428Ctorulosa B103Ctorulosa B165Ctorulosa B125Ctorulosa B147Ctorulosa B179Ctorulosa A271Ctorulosa B175Ctorulosa A093Ctorulosa B320Ctorulosa A198Ctorulosa B316Ctorulosa B167Ctorulosa B145Ccongesta B149Ccongesta B416Ccongesta B176Cscalaris B178Cscalaris A318Cscalaris A469Cscalaris B330Cscalaris B333Cscalaris B334Cscalaris B336Cscalaris B337Cscalaris B338Cscalaris B611Cscalaris B612Cscalaris B608Cscalaris B607Cscalaris B606Cscalaris B177Cscalaris B605Cscalaris B332Cscalaris A099Cscalaris A614Cscalaris A596Cscalaris A292Cscalaris B351CspWilson B319Csiliquosa B130Csiliquosa B143Csiliquosa B118Csiliquosa B325Cretorta B324Cretorta
ACCATGCTTTTAACGGATCGTAATTTTAATACAACGTTTTTTGATCCAGCCGGTGGTGGTGATCCT ACCATGCTTTTAACAGATCGTAATTTTAATACAACGTTTTTTGATCCAGCTGGTGGTGGTGATCCT ACCATGCTTTTAACAGATCGTAATTTTAATACAACGTTTTTTGATCCAGCTGGTGGTGGTGATCCT ACCATGCTTTTAACAGATCGTAATTTTAATACAACGTTTTTTGATCCAGCTGGTGGTGGTGATCCT ACCATGCTTTTAACGGATCGTAATTTTAATACAACGTTTTTTGATCCAGCCGGTGGTGGTGATCCT ACCATGCTTTTAACGGATCGTAATTTTAATACAACGTTTTTTGATCCAGCCGGTGGTGGTGATCCT ACCATGCTTTTAACGGATCGTAATTTTAATACAACGTTTTTTGATCCAGCCGGTGGTGGTGATCCT ACCATGCTTTTAACGGATCGTAATTTTAATACAACGTTTTTTGATCCAGCCGGTGGTGGTGATCCT ACCATGCTTTTAACAGATCGTAATTTTAATACAACGTTTTTTGATCCAGCTGGTGGTGGTGATCCT ACCATGCTTTTAACAGATCGTAATTTTAATACAACGTTTTTTGATCCAGCTGGTGGTGGTGATCCT ACCATGCTTTTAACAGATCGTAATTTTAATACAACGTTTTTTGATCCAGCTGGTGGTGGTGATCCT ACCATGCTTTTAACGGATCGTAATTTTAATACAACGTTTTTTGATCCAGCCGGGGGTGGTGATCCT ACCATGCTTTTAACGGATCGTAATTTTAATACAACGTTTTTTGATCCAGCCGGTGGTGGTGATCCT ACCATGCTTTTAACGGATCGTAATTTTAATACAACGTTTTTTGATCCAGCCGGTGGTGGTGATCCT ACCATGCTTTTAACGGATCGTAATTTTAATACAACGTTTTTTGATCCAGCCGGTGGTGGTGATCCT ACCATGCTTTTAACAGATCGTAATTTTAATACAACGTTTTTTGATCCAGCTGGTGGTGGTGATCCT ACCATGCTTTTAACAGATCGTAATTTTAATACAACGTTTTTTGATCCAGCTGGTGGTGGTGATCCT ACCATGCTTTTAACGGATCGTAATTTTAATACAACGTTTTTTGATCCAGCCGGTGGTGGTGATCCT ACCATGCTTTTAACGGATCGTAATTTTAATACAACGTTTTTTGATCCAGCCGGTGGTGGTGATCCT ACCATGCTTTTAACGGATCGTAATTTTAATACAACGTTTTTTGATCCAGCCGGTGGTGGTGATCCT ACCATGCTTTTAACGGATCGTAATTTTAATACAACGTTTTTTGATCCAGCCGGTGGTGGTGATCCT ACCATGCTTTTAACGGATCGTAATTTTAATACAACGTTTTTTGATCCAGCCGGTGGTGGtGATCCT ACCATGCTTTTAACGGATCGTAATTTTAATACAACGTTTTTTGATCCAGCTGGTGGTGGTGATCCT ACCATGCTTTTAACGGATCGTAATTTTAATACAACGTTTTTTGATCCAGCCGGTGGTGGTGATCCT ACCATGCTTTTAACGGATCGTAATTTTAATACAACGTTTTTTGATCCAGCCGGTGGTGGTGATCCT ACCATGCTTTTAACGGATCGTAATTTTAATACAACGTTTTTTGATCCAGCCGGTGGTGGTGATCCT ACCATGCTTTTAACGGATCGTAATTTTAATACAACGTTTTTTGATCCAGCCGGTGGTGGTGATCCT ACCATGCTTTTAACGGATCGTAATTTTAATACAACGTTTTTTGATCCAGCCGGTGGTGGTGATCCT ACCATGCTTTTAACGGATCGTAATTTTAATACAACGTTTTTTGATCCAGCCGGTGGTGGTGATCCT ACCATGCTTTTAACGGATCGTAATTTTAATACAACGTTTTTTGATCCAGCCGGTGGTGGTGATCCT ACCATGCTTTTAACGGATCGTAATTTTAATACAACGTTTTTTGATCCAGCCGGTGGTGGTGATCCT ACCATGCTTTTAACGGATCGTAATTTTAATACAACGTTTTTTGATCCAGCCGGTGGTGGTGATCCT ACCATGCTTTTAACGGATCGTAATTTTAATACAACGTTTTTTGATCCAGCTGGTGGTGGTGATCCT ACCATGCTTTTAACGGATCGTAATTTTAATACAACGTTTTTTGATCCAGCTGGTGGTGGTGATCCT ACCATGCTTTTAACGGATCGTAATTTTAATACAACGTTTTTTGATCCAGCTGGTGGTGGTGATCCT ACCATGCTTTTAACGGATCGTAATTTTAATACAACGTTTTTTGATCCAGCCGGTGGTGGTGATCCT ACCATGCTTTTAACGGATCGTAATTTTAATACAACGTTTTTTGATCCAGCTGGTGGTGGTGATCCT ACCATGCTTTTAACGGATCGTAATTTTAATACAACGTTTTTTGATCCAGCTGGTGGTGGTGATCCT ACCATGCTTTTAACGGATCGTAATTTTAATACAACGTTTTTTGATCCAGCTGGTGGTGGTGATCCT ACCATGCTTTTAACGGATCGTAATTTTAATACAACGTTTTTTGATCCAGCTGGTGGTGGTGATCCT ACCATGCTTTTAACGGATCGTAATTTTAATACAACGTTTTTTGATCCAGCTGGTGGTGGTGATCCT ACCATGCTTTTAACGGATCGTAATTTTAATACAACGTTTTTTGATCCAGCTGGTGGTGGTGATCCT ACCATGCTTTTAACGGATCGTAATTTTAATACAACGTTTTTTGATCCAGCTGGTGGTGGTGATCCT ACCATGCTTTTAACGGATCGTAATTTTAATACAACGTTTTTTGATCCAGCTGGTGGTGGTGATCCT ACCATGCTTTTAACGGATCGTAATTTTAATACAACGTTTTTTGATCCAGCTGGTGGTGGTGATCCT ACCATGCTTTTAACGGATCGTAATTTTAATACAACGTTTTTTGATCCAGCCGGTGGTGGTGATCCT ACCATGCTTTTAACGGATCGTAATTTTAATACAACGTTTTTTGATCCAGCCGGTGGTGGTGATCCT ACCATGCTTTTAACGGATCGTAATTTTAATACAACGTTTTTTGATCCAGCCGGTGGTGGTGATCCT ACCATGCTTTTAACGGATCGTAATTTTAATACAACGTTTTTTGATCCAGCTGGTGGTGGTGATCCT ACCATGCTTTTAACGGATCGTAATTTTAATACAACGTTTTTTGATCCAGCTGGTGGTGGTGATCCT ACCATGCTTTTAACGGATCGTAATTTTAATACAACGTTTTTTGATCCAGCTGGTGGTGGTGATCCT ACCATGCTTTTAACGGATCGTAATTTTAATACAACGTTTTTTGATCCAGCTGGTGGTGGTGATCCT ACCATGCTTTTAACGGATCGTAATTTTAATACAACGTTTTTTGATCCAGCCGGTGGTGGTGATCCT ACCATGCTTTTAACGGATCGTAATTTTAATACAACGTTTTTTGATCCAGCTGGTGGTGGTGATCCT ACCATGCTTTTAACGGATCGTAATTTTAATACAACGTTTTTTGATCCAGCTGGTGGTGGTGATCCT ACCATGCTTTTAACGGATCGTAATTTTAATACAACGTTTTTTGATCCAGCTGGTGGTGGTGATCCT ACCATGCTTTTAACGGATCGTAATTTTAATACAACGTTTTTTGATCCAGCTGGTGGTGGTGATCCT ACCATGCTTTTAACGGATCGTAATTTTAATACAACGTTTTTTGATCCAGCTGGTGGTGGTGATCCT ACCATGCTTTTAACGGATCGTAATTTTAATACAACGTTTTTTGATCCAGCTGGTGGTGGTGATCCT ACCATGCTTTTAACGGATCGTAATTTTAATACAACGTTTTTTGATCCAGCTGGTGGTGGTGATCCT ACCATGCTTTTAACGGATCGTAATTTTAATACAACGTTTTTTGATCCAGCTGGTGGTGGTGATCCT ACCATGCTTTTAACGGATCGTAATTTTAATACAACGTTTTTTGATCCAGCTGGTGGTGGTGATCCT ACCATGCTTTTAACGGATCGTAATTTTAATACAACGTTTTTTGATCCAGCTGGTGGTGGTGATCCT ACCATGCTTTTAACGGATCGTAATTTTAATACAACGTTTTTTGATCCAGCTGGTGGTGGTGATCCT ACCATGCTTTTAACGGATCGTAATTTTAATACAACGTTTTTTGATCCAGCTGGTGGTGGTGATCCT ACCATGCTTTTAACGGATCGTAATTTTAATACAACGTTTTTTGATCCAGCTGGTGGTGGTGATCCT ACCATGCTTTTAACGGATCGTAATTTTAATACAACGTTTTTTGATCCAGCTGGTGGTGGTGATCCT ACCATGCTTTTAACGGATCGTAATTTTAATACAACGTTTTTTGATCCAGCTGGTGGTGGTGATCCT ACCATGCTTTTAACGGATCGTAATTTTAATACAACGTTTTTTGATCCAGCTGGTGGTGGTGATCCT ACCATGCTTTTAACGGATCGTAATTTTAATACAACGTTTTTTGATCCAGCTGGTGGTGGTGATCCT ACCATGCTTTTAACGGATCGTAATTTTAATACAACGTTTTTTGATCCAGCTGGTGGTGGTGATCCT ACCATGCTTTTAACAGATCGTAATTTTAATACAACGTTTTTTGATCCAGCTGGTGGTGGTGATCCT ACCATGCTTTTAACAGATCGTAATTTTAATACAACGTTTTTTGATCCAGCTGGTGGTGGTGATCCT ACCATGCTTTTAACAGATCGTAATTTTAATACAACGTTTTTTGATCCAGCTGGTGGTGGTGATCCT ACCATGCTTTTAACAGATCGTAATTTTAATACAACGTTTTTTGATCCAGCTGGTGGTGGTGATCCT ACCATGCTTTTAACAGATCGTAATTTTAATACAACGTTTTTTGATCCAGCTGGTGGTGGTGATCCT ACCATGCTTTTAACAGATCGTAATTTTAATACAACGTTTTTTGATCCAGCTGGTGGTGGTGATCCT 


\subsection{Appendix 5. Alignment of ITS sequences from Cystophora. Specimen names are truncated to FieldnumberSpecies.}

B174Lquercifoli ACCCACTCACCCGTCGGGGACGAGCGAGCGAGCGAGCGAG----------------------------------TC B090Cmoniliform ACCCCCTCACCCGTCGGGGATGAGCAAGCGAGCGAGCGAGCGAGCGAGTGAGCGAGCGA---------ACGAGCCACC B114Cexpansa B109Cretorta B131Cretorta ACCCACTCACCCGTCGGGGACGAGCGAGCGAGCGAGCGAGCGA--------------------ATGGACCATC

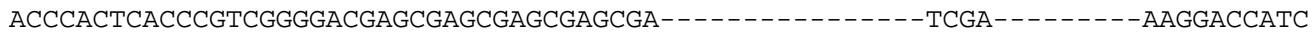

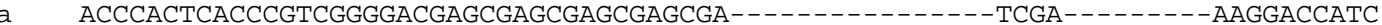
B415Cretroflexa ACCCACTCACCCGTCGGGGACGAGCGAGCGAGCGAGCGAGCGA-------------TCGA---------AAGGACCATC B118Csiliquosa ACCCACTCACCCGTCGGGGACGAGCGAGCGAGCGAGCGAGCGA------------TCGA---------AAGGACCATC B143Csiliquosa ACCCACTCACCCGTCGGGGACGAGCGAGCGAGCGAGCGAGCGA------------TCGA---------AAGGACCATC B100Csubfarcina ACCCACTCACCCGTCGGGGACGAGCGAGCGA---------------------- TCGA---------AAGGAC----

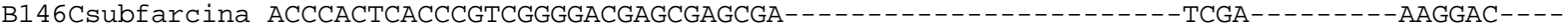
B153Csubfarcina ACCCACTCACCCGTCGGGGACGAGCGAGCGA------------------------TCGA---------AAGGAC---B110Csubfarcina ACCCACTCACCCGTCGGGGACGAGCGAGCGA----------------------TCGA--------AAGGAC---B127Csubfarcina ACCCACTCACCCGTCGGGGACGAGCGAGCGA-------------------------TCGA---------AAGGACCATC B168Csubfarcina ACCCACTCACCCGTCGGGGACGAGCGAGCGA-----------------------TCGA---------AAGGAC---B136Csubfarcina ACCCACTCACCCGTCGGGGACGAGCGAGCGA-------------------------TCGA---------AAGGAC---B161Cretroflexa ACCCACTCACCCGTCGGGGACGAGCGAGCGA---------------------1TCGA--------AAGGAC---B103Ctorulosa ACCCACTCACCCGTCGGGGACGAGCGAGCGA----------------------TCGA--------AAGGACCATC

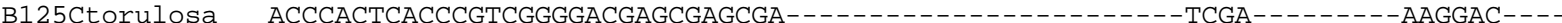
B179Ctorulosa ACCCACTCACCCGTCGGGGACGAGCGAGCGA-----------------------TCGA---------AAGGACCATC B165Ctorulosa ACCCACTCACCCGTCGGGGACGAGCGAGCGA---------------------TCGA--------AAGGACCATC B171Cpolycystid ACCCACTCACCCGTCGGGGACGAGCGAGCGAGCGAGCGA----------------TCGA---------AAGGACCATC B112Cpolycystid ACCCACTCACCCGTCGGGGACGAGCGAGCGAGCGAGCGA----------------TCGA---------AAGGACCACC

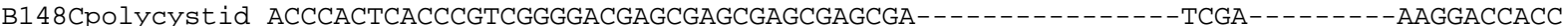
B111Cpolycystid ACCCACTCACCCGTCGGGGACGAGCGAGCGAGCGAGCGA----------------TCGA---------AAGGACCATC B102Cmonilifera ACCCACTCACCCGTCGGGGACGAGCGAGCGAGCGAGCGAGCGA-----------TCGA--------AAGGACCATC B119Cmonilifera ACCCACTCACCCGTCGGGGACGAGCGAGCGAGCGAGCGA----------------TCGA---------AAGGACCATC B318Cmonilifera ACCCACTCACCCGTCGGGGACGAGCGAGCGAGCGAGCGA-----------------TCGA---------AAGGACCATC B095CMONILIFERA ACCCACTCACCCGTCGGGGACGAGCGAGCGAGCGAGCGA----------------TCGA---------TAGGACCATC B092Cmonilifera B159Csubfarcina A154Cscalaris A292Cscalaris A469Cscalaris B178Cscalaris B321Csp B336Cdistenta B337Cdistenta B336Cscalaris B104Cplatylobiu A168Cplatylobiu B149Cycongesta B152Ccongesta B101Cretroflexa A080Cretroflexa A196Cretroflexa A085Cretroflexa B335Ccongesta B166Csubfarcina B116Ccongesta B115Ccongesta B121Cretroflexa ACCCACTCACCCGTCGGGGACGAGCGAGCGAGCGA--

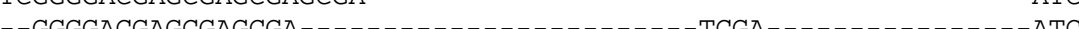

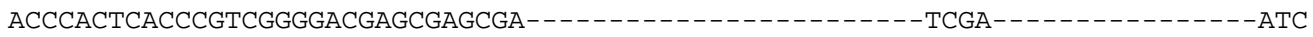

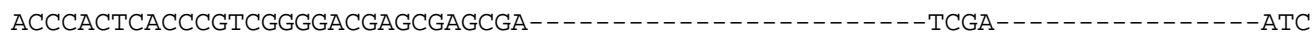

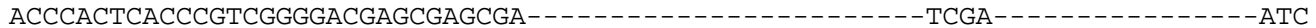

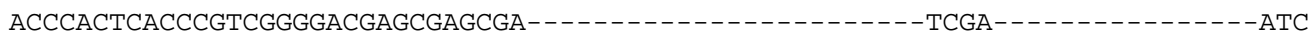
ACCCACTCACCCGTCGGGGACGAGCGAGCGA-----

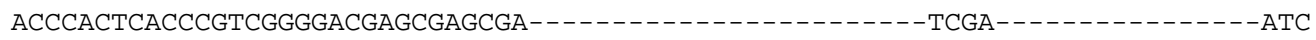
ACCCACTCACCCGTCGGGGACGAGCGAGCGA----ACCCACTCACCCGTCGGGGACGAGCGAGCGAGCGAGCGAGCGAGCTAACTAACTATCGATAGAAAGGAAAGGACCATC ACCCACTCACCCGTCGGGGACGAGCGAGCGAGCGAGCGAGCGAGCTAACTAACTATCGATAGAAAGGAAAGGACCATC

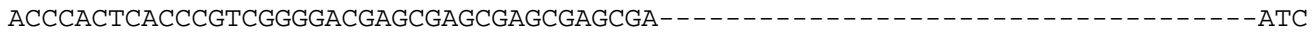

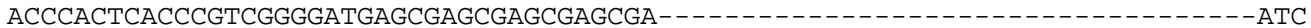

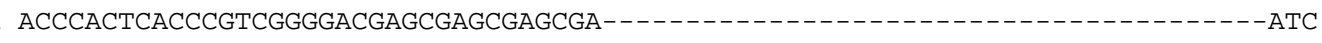

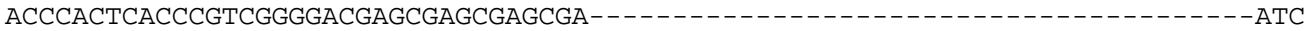

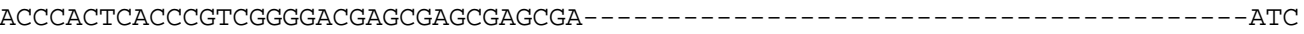

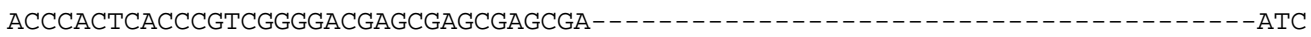

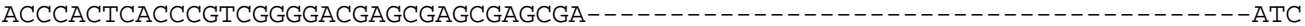

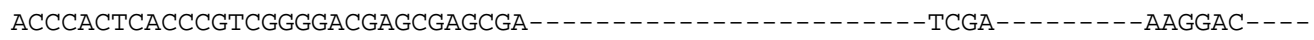
ACCCACTCACCCGTCGGGGACGAGCGAGCGAGCGA----

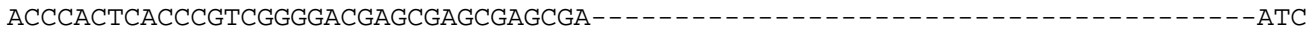

B174Lquercifoli ACGC---------_CCGCCCGCCCG---------------------TACCCGGGTGCGATGAACGAG---AAGCGGGGGG B090Cmoniliform ACGCTCCGCTCGCCCGGCCGCCCGCCCGCCCGCCCGCCCGTTCGTTCCCGGGTGCGATGAACGAGG---AGCGGGGGG

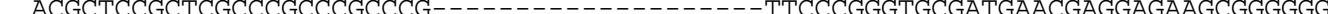
B109Cretorta B131Cretorta AGGCTCCGCTCGCCCGCCCGCCCG-------------------TTCCCGGGTGCGATGAACGAGGAGAAGCGGGGGG AGGCTCCGCTCGCCCGCCCGCCCG-----------------TTCCCGGGTGCGATGAACGAGGAGAAGCGGGGGG B415Cretroflexa AGGCTCCGCTCGCCCGCCCGCCCG--------------------TTCCCGGGTGCGATGAACGAGGAGAAGCGGGGGG B118Csiliquosa AGGCTCCGCTCGCCCGCCCGCCCG------------------TTCCCGGGTGCGATGAACGAGGAGAAGCGGGGGG B143Csiliquosa AGGCTCCGCTCGCCCGCCCGCCCG--------------------TTCCCGGGTGCGATGAACGAGGAGAAGCGGGGGG

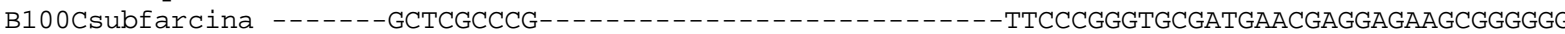
B146Csubfarcina ------GCTCGCCCG-----------------------TTCCCGGGTGCGATGAACGAGGAGAAGCGGGGGG

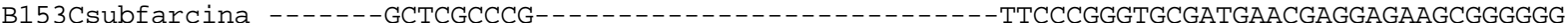

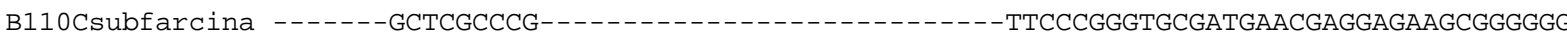
B127Csubfarcina ACGCTCCGCTCGCCCGCCCGCCCG-----------------TTCCCGGGTGCGATGAACGAGGAGAAGCGGGGGG

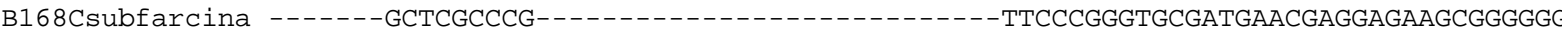
B136Csubfarcina -------GCTCGCCCG------------------------TTCCCGGGTGCGATGAACGAGGAGAAGCGGGGGG

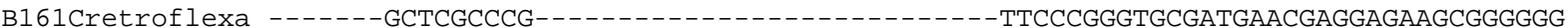
B103Ctorulosa B125Ctorulosa B179Ctorulosa B165Ctorulosa

ACGCTCCGCTCGCCCGCCCGCCCG-$------G C T C G C C C G--------$ ACGCTCCGCTCGCCCGCCCGCCCG---------------TTCCCGGGTGCGATGAACGAGGAGAAGCGGGGGG B171Cpolycystid ACGCTCCGCTCGCCCG--_-_-_-_-_-_-_-_-_-_-_--TTCCCGGGTGCGATGAACGAGGAGAAGCGGGGGG B112Cpolycystid ACGCTCCGCTCGCCCG---------------------TTCCCGGGTGCGATGAACGAGGAGAAGCGGGGGG 
Appendix 5. (Continued)

B148Cpolycystid ACGCTCCGCTCGCCCG---------------------------TTCCCGGGTGCGATGAACGAGGAGAAGCGGGGGG B111Cpolycystid ACGCTCCGCTCGCCCG-------------------------TTCCCGGGTGCGATGAACGAGGAGAAGCGGGGGG B102Cmonilifera ACGCTCCGCTCGCCCG------------------------TTCCCGGGTGCGATGAACGAGGAGAAGCGGGGGG

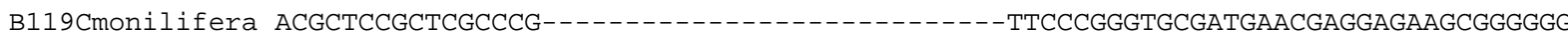
B318Cmonilifera ACGCTCCGCTCGCCCG------------------------- TTCCCGGGTGCGATGAACGAGGAGAAGCGGGGGG B095CMONILIFERA ACGCTCCGTTCGCTCG-------------------------TTCGC--

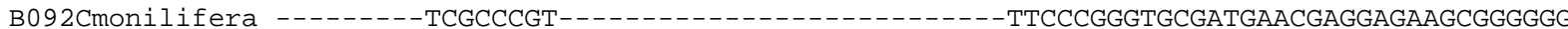

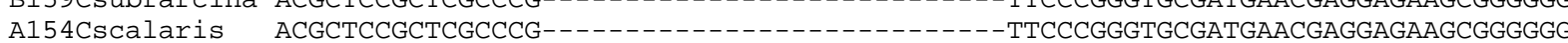

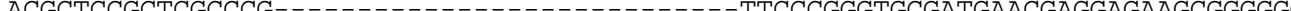
A469Cscalaris ACGCTCCGCTCGCCCG-------------------------TTCCCGGGTGCGATGAACGAGGAGAAGCGGGGGG

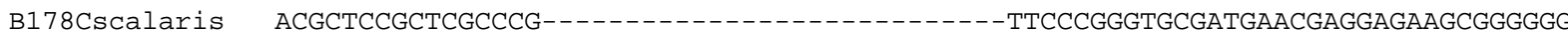
B321Csp B336Cdistenta B337Cdistenta B336Cscalaris ACGCTCCGCTCGCCCGTTCCCGGGTGCGATGAACGAGGAGAAGCGGGGGG ACGCTCCGCTCGCCCG------------------------TTCCCGGGTGCGATGAACGAGGAGAAGCGGGGGG

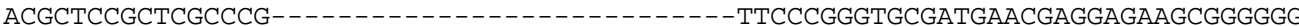
ACGCTCCGCTCGCCCG-------------------------1TCCCGGGTGCGATGAACGAGGAGAAGCGGGGGG B104Cplatylobiu ACGCTCCGCTCGCCCGCCCG----------------------TTCCCGGGTGCGATGAACGAGGAGAAGCGGGGGG A168Cplatylobiu ACGCTCCGCTCGCCCGCCCG---------------------TTCCCGGGTGCGATGAACGAGGAGAAGCGGGGGG B149Cycongesta ACGCTCCGCTCGCCCG------------------------GTTCCCGGGTGCGATGAACGAGGAGAAGCGGGGGG

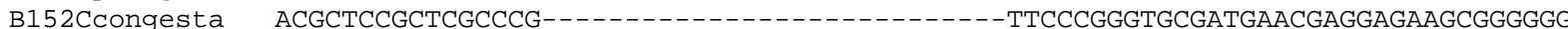

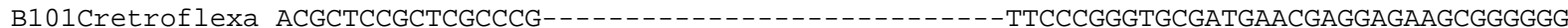
A080Cretroflexa ACGCTCCGCTCGCCCG------------------------TTCCCGGGTGCGATGAACGAGGAGAAGCGGGGGG

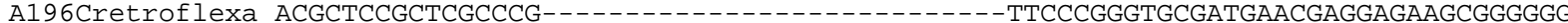

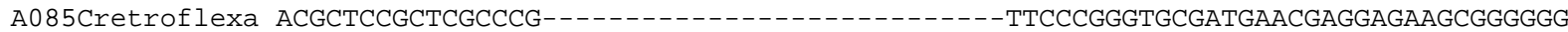
B335Ccongesta B166Csubfarcina B116Ccongesta B115Ccongesta B121Cretroflexa ACGCTCCGCTCGCCCG TTCCCGGTGCGATGAACGAGGAGAAGCGGGGGG (1) ACGCTCCGCTCGCCCG-------------------------TTCCCGGGTGCGATGAACGAGGAGAAGCGGGGGG ACGCTCCGCTCGCCCG-------------------------TTCCCGGGTGCGATGAACGAGGAGAAGCGGGGGG

B174lquercifoli ACGGAGCTGACG-GCTTCGTCCGCTCGTGAAAGGACCCCCTCCCTTCGGTGTGGCAGACTTGGGTGCTGCCGCGGTAC B090Cmoniliform AGGAAGCTTTCTTGCTCCGTCCGCTCGTGAAAGGACCCCCTCCCTTCAGTGTGGCAGACTTGGGTGCTGCCGCGGTAC B114Cexpansa ACGGAGCTTTCTTGCTTCGTCCGCTCGTGGAAGGACCCCCTCCCTTCAGTGTGGGAGGCTTGGGTGCTGCCGCGGTAC B109Cretc B131Cretorta B415Cretroflexa B118Csiliquosa B143Csiliquosa B100Csubfarcina B146Csubfarcina B153Csubfarcina B110Csubfarcina B127Csubfarcina B168Csubfarcina B136Csubfarcina B161Cretroflexa B103Ctorulosa B125Ctorulosa B179Ctorulosa B165Ctorulosa B171Cpolycystid B112Cpolycystid B148Cpolycystid B111Cpolycystid B102Cmonilifera B119Cmonilifera B318Cmonilifera B0 95CMONILIFERA B092Cmonilifera B159Csubfarcina A154Cscalaris A292Cscalaris A469Cscalaris B178Cscalaris B321 Csp B336Cdistenta B337Cdistenta B336Cscalaris B104Cplatylobiu A168Cplatylobiu B149Cycongesta B152Ccongesta B101Cretroflexa A080Cretroflexa A196Cretroflexa A085Cretroflexa GCGGAGCTATCTTGCTTCGTCCACTCGTGAAAGGACCCCCTCCCTTCAGTGTGGCAGGCTTGGGTGCTGCCGCGGTAC GCGGAGCTATCTTGCTTCGTCCACTCGTGAAAGGACCCCCTCCCTTCAGTGTGGCAGGCTTGGGTGCTGCCGCGGTAC GCGGAGCTATCTTGCTTCGTCCTCTCGTGAAAGGACCCCCTCCCTTCAGTGTGGCAGGCTTGGGTGCTGCCGCGGTAC GCGGAGCTATCTTGCTTCGTCCTCTCGTGAAAGGACCCCCTCCCTTCAGTGTGGCAGGCTTGGGTGCTGCCGCGGTAC GCGGAGCTATCTTGCTTCGTCCTCTCGTGAAAGGACCCCCTCCCTTCAGTGTGGCAGGCTTGGGTGCTGCCGCGGTAC GCGGAGCTATCTTGCTTCGTCCGCTCGTGAAAGGACCCCTTCCCTTCAGTGTGGCAGGCTTGGGTGCTGCCGCGGTAC GCGGAGCTATCTTGCTTCGTCCGCTCGTGAAAGGACCCCTTCCCTTCAGTGTGGCAGGCTTGGGTGCTGCCGCGGTAC GCGGAGCTATCTTGCTTCGTCCGCTCGTGAAAGGACCCCTTCCCTTCAGTGTGGCAGGCTTGGGTGCTGCCGCGGTAC GCGGAGCTATCTTGCTTCGTCCGCTCGTGAAAGGACCCCTTCCCTTCAGTGTGGCAGGCTTGGGTGCTGCCGCGGTAC GCGGAGCTATCTTGCTTCGTCCGCTCGTGAAAGGACCCCCTCCCTTCAGTGTGGCAGGCTTGGGTGCTGCCGCGGTAC GCGGAGCTATCTTGCTTCGTCCGCTCGTGAAAGGACCCCTTCCCTTCAGTGTGGCAGGCTTGGGTGCTGCCGCGGTAC GCGGAGCTATCTTGCTTCGTCCGCTCGTGAAAGGACCCCTTCCCTTCAGTGTGGCAGGCTTGGGTGCTGCCGCGGTAC GCGGAGCTATCTTGCTTCGTCCGCTCGTGAAAGGACCCCTTCCCTTCAGTGTGGCAGGCTTGGGTGCTGCCGCGGTAC GCGGAGCTATCTTGCTTCGTCCGCTCGTGAAAGGACCCCCTCCCTTCAGTGTGGCAGGCTTGGGTGCTGCCGCGGTAC GCGGAGCTATCTTGCTTCGTCCGCTCGTGAAAGGACCCCTTCCCTTCAGTGTGGCAGGCTTGGGTGCTGCCGCGGTAC GCGGAGCTATCTTGCTTCGTCCGCTCGTGAAAGGACCCCCTCCCTTCAGTGTGGCAGGCTTGGGTGCTGCCGCGGTAC GCGGAGCTATCTTGCTTCGTCCGCTCGTGAAAGGACCCCCTCCCTTCAGTGTGGCAGGCTTGGGTGCTGCCGCGGTAC GCGGAGCTATCTTGCTTCGTCCGCTCGTGAAAGGACCCCCTCCCTTCAGTGTGGCAGGCTTGGGTGCTGCCGCGGTAC GCGGAGCTATCTTGCTTCGTCCGCTCGTGAAAGGACCCCCTCCCTTCAGTGTGGCAGGCTTGGGTGCTGCCGCGGTAC GCGGAGCTATCTTGCTTCGTCCGCTCGTGAAAGGACCCCCTCCCTTCAGTGTGGCAGGCTTGGGTGCTGCCGCGGTAC GCGGAGCTATCTTGCTTCGTCCGCTCGTGAAAGGACCCCCTCCCTTCAGTGTGGCAGGCTTGGGTGCTGCCGCGGTAC GCGGAGCAATCTTGCTTCGTCCGCTCGTGAAAGGACCCCCTCCCTTCAGTGTGGCAGGCTTGGGTGCTGCCGCGGTAC GCGGAGCAATCTTGCTTCGTCCGCTCGTGAAAGGACCCCCTCCCTTCAGTGTGGCAGGCTTGGGTGCTGCCGCGGTAC GCGGAGCAATCTTGCTTCGTCCGCTCGTGAAAGGACCCCCTCCCTTCAGTGTGGCAGGCTTGGGTGCTGCCGCGGTAC GCGGAGCAATCTTGCTTCGTCCGCTCGTGAAAGGACCCCCTCCCTTCAGTGTGGCAGGCTTGGGTGCTGCCGCGGTAC GCGGAGCTATCTTGCTTCGTCCGCTCGTGAAAGGACCCCCTCCCTTCAGTGTGGCAGGCTTGGGTGCTGCCGCGGTAC GCGGAGCTATCTTGCTTCGTCCGCTCGTGAAAGGACCCCCTCCCTTCAGTGTGGCAGGCTTGGGTGCTGCCGCGGTAC GCGGAGCTATCTTGCTTCGTCCGCTCGTGAAAGGACCCCCTCCCTTCAGTGTGGCAGGCTTGGGTGCTGCCGCGGTAC GCGGAGCTATCTTGCTTCGTCCGCTCGTGAAAGGACCCCCTCCCTTCAGTGTGGCAGGCTTGGGTGCTGCCGCGGTAC GCGGAGCTATCTTGCTTCGTCCGCTCGTGAAAGGACCCCCTCCCTTCAGTGTGGCAGGCTTGGGTGCTGCCGCGGTAC GCGGAGCTATCTTGCTTCGTCCGCTCGTGAAAGGACCCCCTCCCTTCAGTGTGGCAGGCTTGGGTGCTGCCGCGGTAC GCGGAGCTATCTTGCTTCGTCCGCTCGTGAAAGGACCCCCTCCCTTCAGTGTGGCAGGCTTGGGTGCTGCCGCGGTAC GCGGAGCTATCTTGCTTCGTCCGCTCGTGAAAGGACCCCCTCCCTTCAGTGTGGCAGGCTTGGGTGCTGCCGCGGTAC GCGGAGCTATCTTGCTTCGTCCGCTCGTGAAAGGACCCCCTCCCTTCAGTGTGGCAGGCTTGGGTGCTGCCGCGGTAC GCGGAGCTATCTTGCTTCGTCCGCTCGTGAAAGGACCCCCTCCCTTCAGTGTGGCAGGCTTGGGTGCTGCCGCGGTAC GCGGAGCTATCTTGCTTCGTCCGCTCGTGAAAGGACCCCCTCCCTTCAGTGTGGCAGGCTTGGGTGCTGCCGCGGTAC GCGGAGCTATCTTGCTTCGTCCGCTCGTGAAAGGACCCCCTCCCTTCAGTGTGGCAGGCTTGGGTGCTGCCGCGGTAC GCGGAGCTATCTTGCTTCGTCCGCTCGTGAAAGGACCCCCTCCCTTCAGTGTGGMAGGCTTGGGTGCTGCCGCGGTAC GCGGAGCTATCTTGCTTCGTCCGCTCGTGAAAGGACCCCCTCCCTTCAGTGTGGCAGGCTTGGGTGCTGCCGCGGTAC GCGGAGCTATCTTGCTTCGTCCGCTCGTGAAAGGACCCCCTCCCTTCAGTGTGGCAGGCTTGGGTGCTGCCGCGGTAC GCGGAGCTATCTTGCTTCGTCCGCTCGTGAAAGGACCCCCTCCCTTCAGTGTGGCAGGCTTGGGTGCTGCCGCGGTAC GCGGAGCTATCTTGCTTCGTCCGCTCGTGAAAGGACCCCCTCCCTTCAGTGTGGCAGGCTTGGGTGCTGCCGCGGTAC 
Appendix 5. (Continued)

B335Ccongesta B166Csubfarcina B116Ccongesta B115Ccongesta B121Cretroflexa
GCGGAGCTATCTTGCTTCGTCCGCTCGTGAAAGGACCCCCTCCCTTCAGTGTGGCAGGCTTGGGTGCTGCCGCGGTAC GCGGAGCTATCTTGCTTCGTCCGCTCGTGAAAGGACCCCTTCCCTTCAGTGTGGCAGGCTTGGGTGCTGCCGCGGTAC GCGGAGCTATCTTGCTTCGTCCGCTCGTGAAAGGACCCCCTCCCTTCAGTGTGGCAGGCTTGGGTGCTGCCGCGGTAC GCGGAGCTATCTTGCTTCGTCCGCTCGTGAAAGGACCCCCTCCCTTCAGTGTGGCAGGCTTGGGTGCTGCCGCGGTAC GCGGAGCTATCTTGCTTCGTCCGCTCGTGAAAGGACCCCCTCCCTTCAGTGTGGCAGGCTTGGGTGCTGCCGCGGTAC
B174Lquercifoli B090Cmoniliform B114 Cexpansa B109Cretorta B131Cretorta B415Cretroflexa B118Csiliquosa B143Csiliquosa B100Csubfarcina B146Csubfarcina B153Csubfarcina B110Csubfarcina B127Csubfarcina B168Csubfarcina B136Csubfarcina B161Cretroflexa B103Ctorulosa B125Ctorulosa B179Ctorulosa B165Ctorulosa B171Cpolycystid B112Cpolycystid B148Cpolycystid B111Cpolycystid B102Cmonilifera B119Cmonilifera B318Cmonilifera B095CMONILIFERA B092Cmonilifera B159Csubfarcina A154Cscalaris A292Cscalaris A469Cscalaris B178Cscalaris B321Csp B336Cdistenta B337Cdistenta B336Cscalaris B104Cplatylobiu A168Cplatylobiu B14 9Cycongesta B152Ccongesta B101Cretroflexa A080Cretroflexa A196Cretroflexa A085Cretroflexa B335Ccongesta B166Csubfarcina B116Ccongesta B115Ccongesta B121Cretroflexa

B174Lquercifoli B090Cmoniliform B114 Cexpansa B109Cretorta B131Cretorta B415Cretroflexa B118Csiliquosa B143Csiliquosa B100Csubfarcina B146Csubfarcina B153Csubfarcina B110Csubfarcina B127Csubfarcina B168Csubfarcina B136Csubfarcina B161Cretroflexa B103Ctorulosa B125Ctorulosa
TGGAGTGGGGAGGCTCGGGAGCGCCCGCAACCC-TCTCCGAGTGGGGCCGCCTTGTCGGGGCGGGGAGGGCCCGAGGT TGGAGTGGGGAGGCTCGGGAGCGCCCGCAACCCCTCTCCGAGTGGGGCCGCCTTGGCGTGGCGGAGAGGGCTCGAGGT TGGACGGGGGAGGCTCGGGAGCGCCCGCAACCCCTCTCCGAGTGGGGCCGCCTTGGCGGGGCGGAgAGGGCCCGAGGT TGGACGGGGGAGGCTCGGGAGCGCCCACAACCCCTCTCCGAGTGGGGCCGCCTTGGCGGGGCGGAGAGGGCCCGAGGT TGGACGGGGGAGGCTCGGGAGCGCCCACAACCCCTCTCCGAGTGGGGCCGCCTTGGCGGGGCGGAGAGGGCCCGAGGT TGGGCGGGGGAGGCTCGGGAGCGCCCACAACCCCTCTCCGAGTGGGGCCGCCTTGGCGGGGCGGAGAGGGCCCGAGGT TGGACGGGGGAGGCTCGGGAGCGCCCACAACCCCTCTCCGAGTGGGGCCGCCTTGGCGGGGCGGAGAGGGCCCGAGGT TGGACGGGGGAGGCTCGGGAGCGCCCACAACCCCTCTCCGAGTGGGGCCGCCTTGGCGGGGCGGAGAGGGCCCGAGGT TGGACGGGGGCGGCTCGGGAGCGCCCGCAACCCCTCTCCGAGTGGGGCCGCCTTGGCGGGGCGGAGAGGGCCCGAGGT TGGACGGGGGCGGCTCGGGAGCGCCCGCAACCCCTCTCCGAGTGGGGCCGCCTTGGCGGGGCGGAGAGGGCCCGAGGT TGGACGGGGGCGGCTCGGGAGCGCCCGCAACCCCTCTCCGAGTGGGGCCGCCTTGGCGGGGCGGAGAGGGCCCGAGGT TGGACGGGGGCGGCTCGGGAGCGCCCGCAACCCCTCTCCGAGTGGGGCCGCCTTGGCGGGGCGGAGAGGGCCCGAGGT TGGACGGGGGCGGCTCGGGAGCGCCCGCAACCCCTCTCCGAGTGGGGCCGCCTTGGCGGGGCGGAGAGGGCCCGAGGT TGGACGGGGGCGGCTCGGGAGCGCCCGCAACCCCTCTCCGAGTGGGGCCGCCTTGGCGGGGCGGAGAGGGCCCGAGGT TGGACGGGGGCGGCTCGGGAGCGCCCGCAACCCCTCTCCGAGTGGGGCCGCCTTGGCGGGGCGGAGAGGGCCCGAGGT TGGACGGGGGCGGCTCGGGAGCGCCCGCAACCCCTCTCCGAGTGGGGCCGCCTTGGCGGGGCGGAGAGGGCCCGAGGT TGGACGGGGGCGGCTCGGGAGCGCCCGCAACCCCTCTCCGAGTGGGGCCGCCTTGGCGGGGCGGAGAGGGCCCGAGGT TGGACGGGGGCGGCTCGGGAGCGCCCGCAACCCCTCTCCGAGTGGGGCCGCCTTGGCGGGGCGGAGAGGGCCCGAGGT TGGACGGGGGCGGCTCGGGAGCGCCCGCAACCCCTCTCCGAGTGGGGCCGCCTTGGCGGGGCGGAGAGGGCCCGAGGT TGGACGGGGGCGGCTCGGGAGCGCCCGCAACCCCTCTCCGAGTGGGGCCGCCTTGGCGGGGCGGAGAGGGCCCGAGGT TGGACGGGGGCGGCTCGGGAGCGCCCGCAACCCCTCTCCGAGTGGGGCCGCCTTGGCGGGGCGGAGAGGGCCCGAGGT TGGACGGGGGCGGCTCGGGAGCGCCCGCAACCCCTCTCCGAGTGGGGCCGCCTTGGCGGGGCGGAGAGGGCCCGAGGT TGGACGGGGGCGGCTCGGGAGCGCCCGCAACCCCTCTCCGAGTGGGGCCGCCTTGGCGGGGCGGAGAGGGCCCGAGGT TGGACGGGGGCGGCTCGGGAGCGCCCGCAACCCCTCTCCGAGTGGGGCCGCCTTGGCGGGGCGGAGAGGGCCCGAGGT TGGACGGGGGCGGCTCGGGAGCGCCCGCAACCCCTCTCCGAGTGGGGCCGCCTTGGCGGGGCGGAGAGGGCCCGAGGT TGGACGGGGGCGGCTCGGGAGCGCCCGCAACCCCTCTCCGAGTGGGGCCGCCTTGGCGGGGCGGAGAGGGCCCGAGGT TGGACGGGGGCGGCTCGGGAGCGCCCGCAACCCCTCTCCGAGTGGGGCCGCCTTGGCGGGGCGGAGAGGGCCCGAGGT (1) TGGACGGGGGCGGCTCGGGAGCGCCCGC-ACCCCTCTCCGAGTGGGGCCGCCTTGGCGGGGCGGAGAGGGCCCGAGGT TGGACGGGGGCGGCTCGGGAGCGCCCGCAACCCCTCTCCGAGTGGGGCCGCCTTGGCGGGGCGGAGAGGGCCCGAGGT TGGACGGGGGCGGCTCGGGAGCGCCCGCAACCCCTCTCCGAGTGGGGCCGCCTTGGCGGGGCGGAGAGGGCCCGAGGT TGGACGGGGGCGGCTCGGGAGCGCCCGCAACCCCTCTCCGAGTGGGGCCGCCTTGGCGGGGCGGAGAGGGCCCGAGGT TGGACGGGGGCGGCTCGGGAGCGCCCGCAACCCCTCTCCGAGTGGGGCCGCCTTGGCGGGGCGGAGAGGGCCCGAGGT TGGACGGGGGCGGCTCGGGAGCGCCCGCAACCCCTCTCCGAGTGGGGCCGCCTTGGCGGGGCGGAGAGGGCCCGAGGT TGGACGGGGGCGGCTCGGGAGCGCCCGCAACCCCTCTCCGAGTGGGGCCGCCTTGGCGGGGCGGAGAGGGCCCGAGGT TGGACGGGGGCGGCTCGGGAGCGCCCGCAACCCCTCTCCGAGTGGGGCCGCCTTGGCGGGGCGGAGAGGGCCCGAGGT TGGACGGGGGCGGCTCGGGAGCGCCCGCAACCCCTCTCCGAGTGGGGCCGCCTTGGCGGGGCGGAGAGGGCCCGAGGT TGGACGGGGGCGGCTCGGGAGCGCCCGCAACCCCTCTCCGAGTGGGGCCGCCTTGGCGGGGCGGAGAGGGCCCGAGGT TGGACGGGGGCGGCTCGGGAGCGCCCACAACCCCTCTCCGAGTGGGGCCGCCTTGGCGGGGCGGAGAGGGCCCGAGGT TGGACGGGGGCGGCTCGGGAGCGCCCACAACCCCTCTCCGAGTGGGGCCGCCTTGGCGGGGCGGAGAGGGCCCGAGGT TGGACGGGGGCGGCTCGGGAGCGCCCGCAACCCCTCTCCGAGTGGGGCCGCCTTGGCGGGGCGGAGAGGGCCCGAGGT TGGACGGGGGCGGCTCGGGAGCGCCCGCAACCCCTCTCCGAGTGGGGCCGCCTTGGCGGGGCGGAGAGGGCCCGAGGT TGGACGGGGGCGGCTCGGGAGCGCCCGCAACCCCTCTCCGAGTGGGGCCGCCTTGGCGGGGCGGAGAGGGCCCGAGGT TGGACGGGGGCGGCTCGGGAGCGCCCGCAACCCCTCTCCGAGTGGGGCCGCCTTGGCGGGGCGGAGAGGGCCCGAGGT TGGACGGGGGCGGCTCGGGAGCGCCCGCAACCCCTCTCCGAGTGGGGCCGCCTTGGCGGGGCGGAGAGGGCCCGAGGT TGGACGGGGGCGGCTCGGGAGCGCCCGCAACCCCTCTCCGAGTGGGGCCGCCTTGGCGGGGCGGAGAGGGCCCGAGGT TGGACGGGGGCGGCTCGGGAGCGCCCGCAACCCCTCTCCGAGTGGGGCCGCCTTGGCGGGGCGGAGAGGGCCCGAGGT TGGACGGGGGCGGCTCGGGAGCGCCCGCAACCCCTCTCCGAGTGGGGCCGCCTTGGCGGGGCGGAGAGGGCCCGAGGT TGGACGGGGGCGGCTCGGGAGCGCCCGCAACCCCTCTCCGAGTGGGGCCGCCTTGGCGGGGCGGAGAGGGCCCGAGGT TGGACGGGGGCGGCTCGGGAGCGCCCGCAACCCCTCTCCGAGTGGGGCCGCCTTGGCGGGGCGGAGAGGGCCCGAGGT TGGACGGGGGCGGCTCGGGAGCGCCCGCAACCCCTCTCCGAGTGGGGCCGCCTTGGCGGGGCGGAGAGGGCCCGAGGT

--CGCTGCATCG--CACAATGCGCT-GCACTCCTCGCGAAGATCCCAGTGGCTCGGTCGG-

--CACTGC---------ACGCGGT-GCACTCCTCGCGAAGATCCCAGTGGCTCCGTCGGTCGATCGGTCGGTCGGTC --CACTGCATCGCGCACGACGCGGtGGCACTCCT? ?CGAAGATCTCAGTGGCTCGGTCGG----TCGGTCGGTCGGTC --CACTGCATCGCGCACGACGCGGT-GCACTCCTCGCGAAGATCCCAGTGGCTCGGTCGA---------------

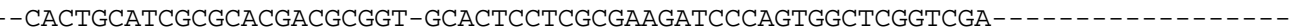
--CACTGCATCGCGCACGACGCGGT-GCACTCCTCGCGAAGATCCCAGTGGCTCGGTCGA------------------CACTGCATCGCGCACGACGCGGT-GCACTCCTCGCGAAGATCCCAGTGGCTCGGTCGA-----------------

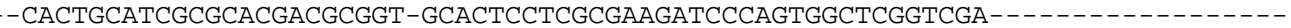
CTCACTGCATCGCGCACGACGCGGT-GCACTCCTCGCGAAGATCCCAGTGGCTCGGTCGG----------------CTCACTGCATCGCGCACGACGCGGT-GCACTCCTCGCGAAGATCCCAGTGGCTCGGTCGG---------------CTCACTGCATCGCGCACGACGCGGT-GCACTCCTCGCGAAGATCCCAGTGGCTCGGTCGG----------------CTCACTGCATCGCGCACGACGCGGT-GCACTCCTCGCGAAGATCCCAGTGGCTCGGTCGG------------------CACTGCATCGCGCACGACGCGGT-GCACTCCTCGCGAAGATCCCAGTGGCTCGGTCGG---------------CTCACTGCATCGCGCACGACGCGGT-GCACTCCTCGCGAAGATCCCAGTGGCTCGGTCGG---------------CTCACTGCATCGCGCACGACGCGGT-GCACTCCTCGCGAAGATCCCAGTGGCTCGGTCGG----------------CTCACTGCATCGCGCACGACGCGGT-GCACTCCTCGCGAAGATCCCAGTGGCTCGGTCGG-----------------CACTGCATCGCGCACGACGCGGT-GCACTCCTCGCGAAGATCCCAGTGGCTCGGTCGG-----------------

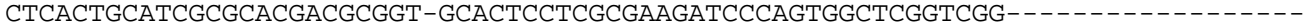


Appendix 5. (Continued)

B179Ctorulosa B165Ctorulosa B171Cpolycystid B112Cpolycystid B148Cpolycystid B111Cpolycystid B102Cmonilifera B119Cmonilifera B318Cmonilifera B0 95CMONILIFERA B092Cmonilifera B159Csubfarcina A154Cscalaris A292Cscalaris A469Cscalaris B178Cscalaris B321 Csp B336Cdistenta B337Cdistenta B336Cscalaris B104Cplatylobiu A168Cplatylobiu B149Cycongesta B152Ccongesta B101Cretroflexa A080Cretroflexa A196Cretroflexa A085Cretroflexa B335Ccongesta B166Csubfarcina B116Ccongesta B115Ccongesta B121Cretroflexa

B174Lquercifoli B090Cmoniliform B114 Cexpansa B109Cretorta B131Cretorta B415Cretroflexa B118Csiliquosa B143Csiliquosa B100Csubfarcina B146Csubfarcina B153Csubfarcina B110Csubfarcina B127Csubfarcina B168Csubfarcina B136Csubfarcina B161Cretroflexa B103Ctorulosa B125Ctorulosa B179Ctorulosa B165Ctorulosa B171Cpolycystid B112Cpolycystid B148Cpolycystid B111Cpolycystid B102Cmonilifera B119Cmonilifera B318Cmonilifera B0 95CMONILIFERA B092Cmonilifera B159Csubfarcina A154Cscalaris A292Cscalaris A469Cscalaris B178Cscalaris B321Csp B336Cdistenta B337Cdistenta B336Cscalaris B104Cplatylobiu A168Cplatylobiu B149Cycongesta B152Ccongesta
--CACTGCATCGCGCACGACGCGGT-GCACTCCTCGCGAAGATCCCAGTGGCTCGGTCGG----------------CC --CACTGCATCGCGCACGACGCGGT-GCACTCCTCGCGAAGA TCCCAGTGGCTCGGTCGG----------------CACTGCATCGCGCACGACGCGGT-GCACTCCTCGCGAAGATCCCAGTGGCTCGGTCGG----------------CACTGCATCGCGCACGACGCGGT-GCACTCCTCGCGAAGATCCCAGTGGCTCGGTCGG-----------------CACTGCATCGCGCACGACGCGGT-GCACTCCTCGCGAAGATCCCAGTGGCTCGGTCGG-----------------CACTGCATCGCGCACGACGCGGT-GCACTCCTCGCGAAGATCCCAGTGGCTCGGTCGG-------------------CACTGCATCGCGCACGACGCGGT-GCACTCCTCGCGAAGA TCCCAGTGGCTCGGTCGG------------CCGGCC --CACTGCATCGCGCACGACGCGGT-GCACTCCTCGCGAAGATCCCAGTGGCTCGGTCGG---------------CC --CACTGCATCGCGCACGACGCGGT-GCACTCCTCGCGAAGATCCCAGTGGCTCGGTCGG---------------CC -CACTGCATCGCGCACGACGCGGT-GCACTCCTCGCGAAGATCCCAGTGGCTCGGTCGG-----------CCGGCC --CACTGCATCGCGCACGACGCGGT-GCACTCCTCGCGAAGATCCCAGTGGCTCGGTCGG------------CCGGCC --CACTGCATCGCGCACGACGCGGT-GCACTCCTCGCGAAGATCCCAGTGGCTCGGTCGG----------------

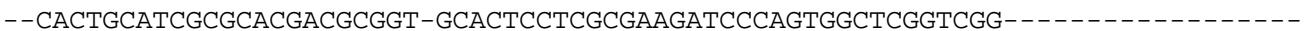
--CACTGCATCGCGCACGACGCGGT-GCACTCCTCGCGAAGATCCCAGTGGCTCGGTCGG---------------

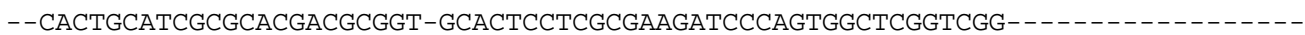
--CACTGCATCGCGCACGACGCGGT-GCACTCCTCGCGAAGATCCCAGTGGCTCGGTCGG------------------CACTGCATCGCGCACGACGCGGT-GCACTCCTCGCGAAGATCCCAGTGGCTCGGTCGG------------------CACTGCATCGCGCACGACGCGGT-GCACTCCTCGCGAAGATCCCAGTGGCTCGGTCGG---CACTGCATCGCGCACGACGCGGT-GCACTCCTCGCGAAGATCCCAGTGGCTCGGTCGG-----------------

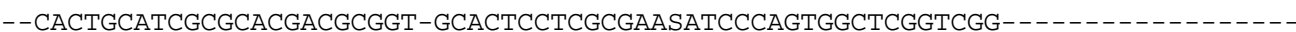

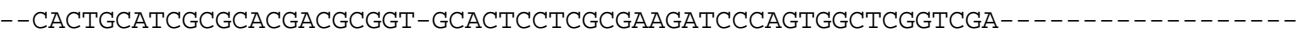
--CACTGCATCGCGCACGACGCGGT-GCACTCCTCGCGAAGATCCCAGTGGCTCGGTCGA----------------

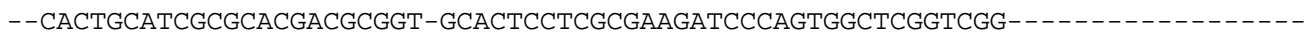
--CACTGCATCGCGCACGACGCGGT-GCACTCCTCGCGAAGATCCCAGTGGCTCGGTCGG----------------CACTGCATCGCGCACGACGCGGT-GCACTCCTCGCGAAGATCCCAGTGGCTCGGTCGG-----------------

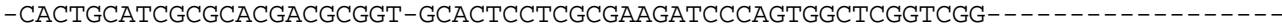
-CACTGCATCGCGCACGACGCGGT-GCACTCCTCGCGAAGATCCCAGTGGCTCGGTCGG------------------CACTGCATCGCGCACGACGCGGT-GCACTCCTCGCGAAGATCCCAGTGGCTCGGTCGG----------------CACTGCATCGCGCACGACGCGGT-GCACTCCTCGCGAAGATCCCAGTGGCTCGGTCGGCTCACTGCATCGCGCACGACGCGGT-GCACTCCTCGCGAAGATCCCAGTGGCTCGGTCGG----------------

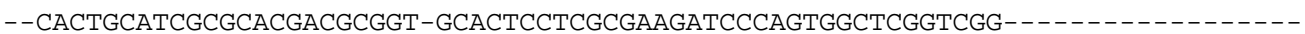
--CACTGCATCGCGCACGACGCGGT-GCACTCCTCGCGAAGATCCCAGTGGCTCGGTCGG-----------------

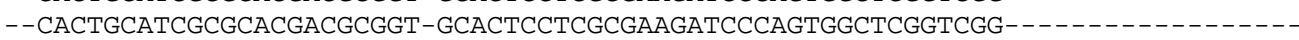

--CCGGTCGGTCGGCCTGGAGCCAGGTTGTCCTCTTCCTCCCGCACCATCGTTATCTTTTGTTGCTTGCCGCCGC--GGTCGGTCGGTCGGTCTGGAGCCACAGTGTCCTCTTTCCCTTGCAACACCATTACTTTTCGTTGCCTGCCGCCGCCTT GGTCGGTCGGTCGGCCTGGAGCCGAAGTGTCCTCTTCCCCTTGCAACATTATTACTTTTCGTTGCATGCCGCCGC----TCGGTCGGTCGGCCTGGAGCCGGAGTGTCCTCTTCCCCTTGCAACATCATTA-TTTTCGTTGCCTGCCGCCGC----TCGGTCGGTCGGCCTGGAGCCGGAGTGTCCTCTTCCCCTTGCAACATCATTA-TTTTCGTTGCCTGCCGCCGC----TCGGTCGGTCGGCCTGGAGCCGGAGTGTCCTCTTCCCCTTGCAACATCATTA-TTTTCGTTGCCTGCCGCCGC----TCGGTCGGTCGGCCTGGAGCCGGAGTGTCCTCTTCCCCTTGCAACATCATTA-TTTTCGTTGCCTGCCGCCGC----TCGGTCGGTCGGCCTGGAGCCGGAGTGTCCTCTTCCCCTTGCAACATCATTA-TTTTCGTTGCCTGCCGCCGC----CCGGTCGGTCGGCCTGGAGCCGGAGTGTCCTCTTCCCCTCGCAACATCATTACTTTTCGTTGCCTGCCGCCGC---CCGGTCGGTCGGCCTGGAGCCGGAGTGTCCTCTTCCCCTCGCAACATCATTACTTTTCGTTGCCTGCCGCCGC---CCGGTCGGTCGGCCTGGAGCCGGAGTGTCCTCTTCCCCTCGCAACATCATTACTTTTCGTTGCCTGCCGCCGC---_CCGGTCGGTCGGCCTGGAGCCGGAGTGTCCTCTTCCCCTCGCAACATCATTACTTTTCGTTGCCTGCCGCCGC---CCGGTCGGTCGGCCTGGAGCCGGAGTGTCCTCTTCCCCTCGCAACATCATTACTTTTCGTTGCCTGCCGCCGC---CCGGTCGGTCGGCCTGGAGCCGGAGTGTCCTCTTCCCCTCGCAACATCATTACTTTTCGTTGCCTGCCGCCGC----CCGGTCGGTCGGCCTGGAGCCGGAGTGTCCTCTTCCCCTCGCAACATCATTACTTTTCGTTGCCTGCCGCCGC----CCGGTCGGTCGGCCTGGAGCCGGAGTGTCCTCTTCCCCTCGCAACATCATTACTTTTCGTTGCCTGCCGCCGC----CCGGTCGGTCGGCCTGGAGCCGGAGTGTCCTCTTCCCCTCGCAACATCATTACTTTTCGTTGCCTGCCGCCGC----CCGGTCGGTCGGCCTGGAGCCGGAGTGTCCTCTTCCCCTCGCAACATCATTACTTTTCGTTGCCTGCCGCCGC--GGTCGGTCGGTCGGCCTGGAGCCGGAGTGTCCTCTTCCCCTCGCAACATCATTACTTTTCGTTGCCTGCCGCCGC----CCGGTCGGTCGGCCTGGAGCCGGAGTGTCCTCTTCCCCTCGCAACATCATTACTTTTCGTTGCCTGCCGCCGC----CCGGTCGGTCGGCCTGGAGCCGGAGTGTCCTCTTCCCCTCGCAACATCATTACTTTTCGTTGCCTGCCGCCGC----CCGGTCGGTCGGCCTGGAGCCGGAGTGTCCTCTTCCCCTCGCAACATCATTACTTTTCGTTGCCTGCCGCCGC----CCGGTCGGTCGGCCTGGAGCCGGAGTGTCCTCTTCCCCTCGCAACATCATTACTTTTCGTTGCCTGCCGCCGC---CCGGTCGGTCGGCCTGGAGCCGGAGTGTCCTCTTCCCCTCGCAACATCATTACTTTTCGTTGCCTGCCGCCGC--GGTCGGTCGGTCGGCCTGGAGCCGGAGTGTCCTCTTCCCCTCGCAACATCATTACTTTTCGTTGCCTGCCGCCGC--GGTCGGTCGGTCGGCCTGGAGCCGGAGTGTCCTCTTCCCCTCGCAACATCATTACTTTTCGTTGCCTGCCGCCGC--GGTCGGTCGGTCGGCCTGGAGCCGGAGTGTCCTCTTCCCCTCGCAACATCATTACTTTTCGTTGCCTGCCGCCGC--GGTCGGTCGGTCGGCCTGGAGCCGGAGTGTCCTCTTCCCCTCGCAACATCATTACTTTTCGTTGCCTGCCGCCGC--GGTCGGTCGGTCGGCCTGGAGCCGGAGTGTCCTCTTCCCCTCGCAACATCATTACTTTTCGTTGCCTGCCGCCGC----CCGGTCGGTCGGCCTGGAGCCGGAGTGTCCTCTTCCCCTCGCAACATCATTACTTTTCGTTGCCTGCCGCCGC----CCGGTCGGTCGGCCTCGAGCTGGAGTGTCCTCTTCCCCTCGCAACATTATTACTTTTCGTTGCCTGCCGCCGC----CCGGTCGGTCGGCCTCGAGCTGGAGTGTCCTCTTCCCCTCGCAACATTATTACTTTTCGTTGCCTGCCGCCGC----CCGGTCGGTCGGCCTCGAGCTGGAGTGTCCTCTTCCCCTCGCAACATTATTACTTTTCGTTGCCTGCCGCCGC----CCGGTCGGTCGGCCTCGAGCTGGAGTGTCCTCTTCCCCTCGCAACATTATTACTTTTCGTTGCCTGCCGCCGC----CCGGTCGGTCGGCCTCGAGCTGGAGTGTCCTCTTCCCCTCGCAACATTATTACTTTTCGTTGCCTGCCGCCGC----CCGGTCGGTCGGCCTCGAGCTGGAGTGTCCTCTTCCCCTCGCAACATTATTACTTTTCGTTGCCTGCCGCCGC----CCGGTCGGTCGGCCTCGAGCTGGAGTGTCCTCTTCCCCTCGCAACATTATTACTTTTCGTTGCCTGCCGCCGC----CCGGTCGGTCGGCCTCGAGCTGGAGTGTCCTCTTCCCCTCGCAACATTATTACTTTTCGTTGCCTGCCGCCGC----TCGGTCGGTCGGCCTGCAGCCGGAGTGTCCTCTTCCCCTTGCAACATGATTA-TTTTCGTTGCCTGCCGCCGC----TCGGTCGGTCGGCCTGCAGCCGGAGTGTCCTCTTCCCCTTGCAACATGATTA-TTTTCGTTGCCTGCCGCCGC----CCGGTCGGTCGGCCTGGAGCCGGAGTGTCCTCTTCCCCTCGCAACATCATTACTTTTCGTTGCCTGCCGCCGC----CCGGTCGGTCGGCCTGGAGCCGGAGTGTCCTCTTCCCCTCGCAACATCATTACTTTTCGTTGCCTGCCGCCGC--- 
Appendix 5. (Continued)

B101Cretroflexa --CCGGTCGGTCGGCCTGGAGCCGGAGTGTCCTCTTCCCCTCGCAACATCATTACTTTTCGTTGCCTGCCGCCGC--A080Cretroflexa --CCGGTCGGTCGGCCTGGAGCCGGAGTGTCCTCTTCCCCTCGCAACATCATTACTTTTCGTTGCCTGCCGCCGC--A196Cretroflexa --CCGGTCGGTCGGCCTGGAGCCGGAGTGTCCTCTTCCCCTCGCAACATCATTACTTTTCGTTGCCTGCCGCCGC--A085Cretroflexa --CCGGTCGGTCGGCCTGGAGCCGGAGTGTCCTCTTCCCCTCGCAACATCATTACTTTTCGTTGCCTGCCGCCGC--B335Ccongesta --CCGGTCGGTCGGCCTGGAGCCGGAGTGTCCTCTTCCCCTCGCAACATCATTACTTTTCGTTGCCTGCCGCCGC--B166Csubfarcina --CCGGTCGGTCGGCCTGGAGCCGGAGTGTCCTCTTCCCCTCGCAACATCATTACTTTTCGTTGCCTGCCGCCGC---B116Ccongesta --CCGGTCGGTCGGCCTGGAGCCGGAGTGTCCTCTTCCCCTCGCAACATCATTACTTTTCGTTGCCTGCCGCCGC--B115Ccongesta --CCGGTCGGTCGGCCTGGAGCCGGAGTGTCCTCTTCCCCTCGCAACATCATTACTTTTCGTTGCCTGCCGCCGC--B121Cretroflexa --CCGGTCGGTCGGCCTGGAGCCGGAGTGTCCTCTTCCCCTCGCAACATCATTACTTTTCGTTGCCTGCCGCCGC---

B174Lquercifoli GCCGTCGTCCCG-AAAAGGTGATGGTGGCGGTCGCGAGCAGTGGCAGC---GATT----GTTGCGGGAGGGAGAGCGA B090Cmoniliform GCCATCGTCCCC-AAAAGATGATGGTGGTGGTCGTGA----_----------TTGGCTGTTGTGGGAGGGAGAGTGA B114Cexpansa B109Cretorta B131Cretorta B415Cretroflexa B118Csiliquosa B143Csiliquosa B100Csubfarcina B146Csubfarcina GCCATCATCCCCCAAAAGGTGATGGTGGCGGTCGCGAGTGATGGAGA------TTAGCTGTTGTGGGAGGGAGAGGGA GCCATCGTCCCC-AAAATATGATGGTGGCGGTCGCGAGTGATGGAGA------TTAGCTGTTGTGGGAGGGAGAGTGA GCCATCGTCCCC-AAAATATGATGGTGGCGGTCGCGAGTGATGGAGA------TTAGCTGTTGTGGGAGGGAGAGTGA GCCATCGTCCCC-AAAATATGATGGTGGCGGTCGCGAGTGATGGAGA------TTAGCTGTTGTGGGAGGGAGAGTGA GCCATCGTCCCC-AAAATATGATGGTGGCGGTCGCGAGTGATGGAGA------TTAGCTGTTGTGGGAGGGAGAGTGA GCCATCGTCCCC-AAAATATGATGGTGGCGGTCGCGAGTGATGGAGA------TTAGCTGTTGTGGGAGGGAGAGTGA GCCATCG------------ATGGTGTCGGTCGCGAGTGATGGAGA---TTATTAGCTGTTGTGGGAGGGAGAGTGA GCCATCG--------------ATGGTGTCGGTCGCGAGTGATGGAGA---TTATTAGCTGTTGTGGGAGGGAGAGTGA B153Csubfarcina GCCATCG--------------ATGGTGTCGGTCGCGAGTGATGGAGA---TTATTAGCTGTTGTGGGAGGGAGAGTGA B110Csubfarcina GCCATCG--------------ATGGTGTCGGTCGCGAGTGATGGAGA---TTATTAGCTGTTGTGGGAGGGAGAGTGA B127Csubfarcina GCCATCG--------------ATGGTGTCGGTCGCGAGTGATGGAGA---TTATTAGCTGTTGTGGGAGGGAGAGTGA B168Csubfarcina GCCATCG--------------ATGGTGTCGGTCGCGAGTGATGGAGA---TTATTAGCTGTTGTGGGAGGGAGAGTGA B136Csubfarcina GCCATCG-------------ATGGTGTCGGTCGCGAGTGATGGAGA---TTATTAGCTGTTGTGGGAGGGAGAGTGA B161Cretroflexa GCCATCG--B103Ctorulosa B125Ctorulosa B179Ctorulosa B165Ctorulosa GCCATCG--------------ATGGTGTCGGTCGCGAGTGATGGAGA---TTATTAGCTGTTGTGGGAGGGAGAGTGA GCCATCG-------------ATGGTGTCGGTCGCGAGTGATGGAGA---TTATTAGCTGTTGTGGGAGGGAGAGTGA GCCATCG--------------ATGGTGTCGGTCGCGAGTGATGGAGA---TTATTAGCTGTTGTGGGAGGGAGAGTGA GCCATCG-------------ATGGTGTCGGTCGCGAGTGATGGAGA---TTATTAGCTGTTGTGGGAGGGAGAGTGA B171Cpolycystid GCCATCGCCCCC-AAAATATGATGGTGGCGGTCGCGAGTGATGGAGA---TTATTAGCTGTTGTGGGAGGGAGAGTGA B112Cpolycystid GCCATCGCCCCC-AAAATATGATGGTGGCGGTCGCGAGTGATGGAGA---TTATTAGCTGTTGTGGGAGGGAGAGTGA B148Cpolycystid GCCATCGCCCCC-AAAATATGATGGTGGCGGTCGCGAGTGATGGAGA---TTATTAGCTGTTGTGGGAGGGAGAGTGA B111Cpolycystid GCCATCGCCCCC-AAAATATGATGGTGGCGGTCGCGAGTGATGGAGA---TTATTAGCTGTTGTGGGAGGGAGAGTGA B102Cmonilifera GCCATCGCCCCC-AAAATATGATGGTGGCGGTCGCGAGCGATGGAGA---TTATTAGCTGTTGTGGGAGGGAGAGTGA B119Cmonilifera GCCATCGCCCCC-AAAATATGATGGTGGCGGTCGCGAGCGATGGAGA---TTATTAGCTGTTGTGGGAGGGAGAGTGA B318Cmonilifera GCCATCGCCCCC-AAAATATGATGGTGGCGGTCGCGAGCGATGGAGA---TTATTAGCTGTTGTGGGAGGGAGAGTGA B095CMONILIFERA GCCATCGCCCCC-AAAATATGATGGTGGCGGTCGCGAGCGATGGAGA---TTATTAGCTGTTGTGGGAGGGAGAGTGA B092Cmonilifera GCCATCGCCCCC-AAAATATGATGGTGGCGGTCGCGAGCGATGGAGA---TTATTAGCTGTTGTGGGAGGGAGAGTGA B159Csubfarcina GCCATCG--------------ATGGTGTCGGTCGCGAGTGATGGAGACTATTATTAGCTGTTGTGGGAGGGAGAGTGA A154Cscalaris GCCATCG-------------ATGGTGTCGGTCGCGAGTGATGGAGA---TTATTAGCTGTTGTGGGAGGGAGAGTGA A292Cscalaris GCCATCG--_-_-_--_----ATGGTGTCGGTCGCGAGTGATGGAGA---TTATTAGCTGTTGTGGGAGGGAGAGTGA A469Cscalaris GCCATCG--------------ATGGTGTCGGTCGCGAGTGATGGAGA---TTATTAGCTGTTGTGGGAGGGAGAGTGA B178Cscalaris GCCATCG----_--_-----ATGGTGTCGGTCGCGAGTGATGGAGA---TTATTAGCTGTTGTGGGAGGGAGAGTGA B321 csp B336Cdistenta B337Cdistenta B336Cscalaris B104Cplatylobiu A168Cplatylobiu B149Cycongesta B152Ccongesta B101Cretroflexa A080Cretroflexa A196Cretroflexa A085Cretroflexa B335Ccongesta B166Csubfarcina B116Ccongesta B115Ccongesta B121Cretroflexa GCCATCG------------ATGGTGTCGGTCGCGAGTGATGGAGA---TTATTAGCTGTTGTGGGAGGGAGAGTGA GCCATCG-------------ATGGTGTCGGTCGCGAGTGATGGAGA---TTATTAGCTGTTGTGGGAGGGAGAGTGA GCCATCG-------_-----ATGGTGTCGGTCGCGAGTGATGGAGA---TTATTAGCTGTTGTGGGAGGGAGAGTGA GCCATCG-------------ATGGTGTCGGTCGCGAGTGATGGAGA---TTATTAGCTGTTGTGGGAGGGAGAGTGA ACCATCGTCCCC-GAAATATGACGGTGGCGGTCGCGAGTGGTGGAGA------TTAGCTGTTGCGGGAGGGAGAGTGA ACCATCGTCCCC-AAAATATGACGGTGGCGGTCGCGAGTGGTGGAGA------TTAGCTGTTGCGGGAGGGAGAGTGA GCCATCG-------------ATGGTGTCGGTCGCGAGTGATGGAGACTATTATTAGCTGTTGTGGGAGGGAGAGTGA GCCATCG-------------ATGGTGTCGGTCGCGAGTGATGGAGACTATTATTAGCTGTTGTGGGAGGGAGAGTGA GCCATCG-------------ATGGTGTCGGTCGCGAGTGATGGAGACTATTATTAGCTGTTGTGGGAGGGAGAGTGA GCCATCG-------------ATGGTGTCGGTCGCGAGTGATGGAGACTATTATTAGCTGTTGTGGGAGGGAGAGTGA GCCATCG---_---_-----ATGGTGTCGGTCGCGAGTGATGGAGACTATTATTAGCTGTTGTGGGAGGGAGAGTGA GCCATCG-------------_ATGGTGTCGGTCGCGAGTGATGGAGACTATTATTAGCTGTTGTGGGAGGGAGAGTGA GCCATCG----_--_-_--_ATGGTGTCGGTCGCGAGTGATGGAGACTATTATTAGCTGTTGTGGGAGGGAGAGTGA GCCATCG-----_-----_ATGGTGTCGGTCGCGAGTGATGGAGA---TTATTAGCTGTTGTGGGAGGGAGAGTGA GCCATCG-------------_ATGGTGTCGGTCGCGAGTGATGGAGACTATTATTAGCTGTTGTGGGAGGGAGAGTGA GCCATCG--------------ATGGTGTCGGTCGCGAGTGATGGAGACTATTATTAGCTGTTGTGGGAGGGAGAGTGA GCCATCG--------------ATGGTGTCGGTCGCGAGTGATGGAGACTATTATTAGCTGTTGTGGGAGGGAGAGTGA

B174Lquercifoli ATTCGAATGAATGGGCAAGTAACACGTCGCGGAGGT--CACGGCGTGGGGCCGGGCGCGGTCGGATC-CATTA----B090Cmoniliform ATTAGAATGAATGGGCAAGTAGCACGTCGTGGAGAT--CAGGGCGTGGGGCCGGGCGCGATCGGATC---------B114Cexpansa B109Cretorta GTTAGAATGAATGGGCAAGTAGCACGTCGTGGAGGT--CATGGCGTGGGGTCGGGCGCGATCG--------------ATTAGAATGAATGGGCAAGTAGCTCGTCGCGGAGGT--CATGGCGTGGGGTCGGGCGCGATCGGATC-TACT-----B131Cretorta ATTAGAATGAATGGGCAAGTAGCTCGTCGCGGAGGT--CATGGCGTGGGGTCGGGCGCGATCGGATC-TACT------B415Cretroflexa ATTAGAATGAATGGGCAAGTAGCTCGTCGCGGAGGT--CATGGCGTGGGGTCGGGCGCGATCGGATC-TACT-----B118Csiliquosa ATTAGAATGAATGGGCAAGTAGCTCGTCGCGGAGGT--CATGGCGTGGGGTCGGGCGCGATCGGATC-TACT-----B143Csiliquosa ATTAGAATGAATGGGCAAGTAGCTCGTCGCGGAGGT--CATGGCGTGGGGTCGGGCGCGATCGGATC-TACT-----B100Csubfarcina ATTAGAATGAATGGGCAAGTAGCTCGTCGCGGAGGTGTCATGGCGTGGGGTCGGTCGCGATCGGATC-TACT-----B146Csubfarcina ATTAGAATGAATGGGCAAGTAGCTCGTCGCGGAGGTGTCATGGCGTGGGGTCGGTCGCGATCGGATC-TACT------B153Csubfarcina ATTAGAATGAATGGGCAAGTAGCTCGTCGCGGAGGTGTCATGGCGTGGGGTCGGTCGCGATCGGATC-TACT-----B110Csubfarcina ATTAGAATGAATGGGCAAGTAGCTCGTCGCGGAGGTGTCATGGCGTGGGGTCGGTCGCGATCGGATC-TACT-----B127Csubfarcina ATTAGAATGAATGGGCAAGTAGCTCGTCGCGGAGGT--CATGGCGTGGGGTCGGTCGCGATCGGATC-TACT-----B168Csubfarcina ATTAGAATGAATGGGCAAGTAGCTCGTCGCGGAGGTGTCATGGCGTGGGGTCGGTCGCGATCGGATC-TACT------ 
Appendix 5. (Continued)

B136Csubfarcina ATTAGAATGAATGGGCAAGTAGCTCGTCGCGGAGGTGTCATGGCGTGGGGTCGGTCGCGATCGGATC-TACT-----B161Cretroflexa ATTAGAATGAATGGGCAAGTAGCTCGTCGCGGAGGTGTCATGGCGTGGGGTCGGTCGCGATCGGATC-TACT-----B103Ctorulosa ATTAGAATGAATGGGCAAGTAGCTCGTCGCGGAGGT--CATGGCGTGGGGTCGGTCGCGATCGGATC-TACT-----B125Ctorulosa ATTAGAATGAATGGGCAAGTAGCTCGTCGCGGAGGTGTCATGGCGTGGGGTCGGTCGCGATCGGATC-TACT-----B179Ctorulosa ATTAGAATGAATGGGCAAGTAGCTCGTCGCGGAGGT--CATGGCGTGGGGTCGGTCGCGACCGGATC-TACT-----B165Ctorulosa ATTAGAATGAATGGGCAAGTAGCTCGTCGCGGAGGT--CATGGCGTGGGGTCGGTCGCGATCGGATC-TACT-----B171Cpolycystid ATTAGAATGAATGGGCAAGTAGCTCGTCGCGGAGGT--CATGGCGTGGGGTCGGGCGCGATCGGATCCTACG-----B112Cpolycystid ATTAGAATGAATGGGCAAGTAGCTCGTCGCGGAGGT--CATGGCGTGGGGTCGGGCGCGATCGGATCCTACG-----B148Cpolycystid ATTAGAATGAATGGGCAAGTAGCTCGTCGCGGAGGT--CATGGCGTGGGGTCGGGCGCGATCGGATCCTACG-----B111Cpolycystid ATTAGAATGAATGGGCAAGTAGCTCGTCGCGGAGGT--CATGGCGTGGGGTCGGGCGCGATCGGATCCTACG-----B102Cmonilifera ATTAGAATGAATGGGCAAGTAGCTCGTCGCGGAGGT--CATGGCGTGGGGTCGGGCGCGATCGGATC-TACT-----B119Cmonilifera ATTAGAATGAATGGGCAAGTAGCTCGTCGCGGAGGT--CATGGCGTGGGGTCGGGCGCGATCGGATC-TACT-----B318Cmonilifera ATTAGAATGAATGGGCAAGTAGCTCGTCGCGGAGGT--CATGGCGTGGGGTCGGGCGCGATCGGATC-TACT-----B095CMONILIFERA ATTAGAATGAATGGGCAAGTAGCTCGTCGCGGAGGT--CATGGCGTGGGGTCGGGCGCGATCGGATC-TACT-----B092Cmonilifera ATTAGAATGAATGGGCAAGTAGCTCGTCGCGGAGGT--CATGGCGTGGGGTCGGGCGCGATCGGATC-TACT-----B159Csubfarcina ATTAGAATGAATGGGCAAGTAGCTCGTCGCGGAGGT--CATGGCGTGGGGTCGGTCGCGATCGGATC-TACT-----A154Cscalaris ATTAGAATGAATGGGCAAGTAGCTCGTCGCGGAGGTGTCATGGCGTGGGGTCGGGCGCGATCGGATC-TACTACTGTT A292Cscalaris ATTAGAATGAATGGGCAAGTAGCTCGTCGCGGAGGTGTCATGGCGTGGGGTCGGGCGCGATCGGATC-TACTACTGTT A469Cscalaris ATTAGAATGAATGGGCAAGTAGCTCGTCGCGGAGGTGTCATGGCGTGGGGTCGGGCGCGATCGGATC-TACTACTGTT B178Cscalaris ATTAGAATGAATGGGCAAGTAGCTCGTCGCGGAGGTGTCATGGCGTGGGGTCGGGCGCGATCGGATC-TACTACTGTT B321Csp B336Cdistenta B337Cdistenta B336Cscalaris B104Cplatylobiu A168Cplatylobiu B149Cycongesta B152Ccongesta B101Cretroflexa A080Cretroflexa ATTAGAATGAATGGGCAAGTAGCTCGTCGCGGAGGT--CATGGCGTGGGGTCGGTCGCGATCGGATC-TACT-----A196Cretroflexa ATTAGAATGAATGGGCAAGTAGCTCGTCGCGGAGGT--CATGGCGTGGGGTCGGTCGCGATCGGATC-TACT-----A085Cretroflexa ATTAGAATGAATGGGCAAGTAGCTCGTCGCGGAGGT--CATGGCGTGGGGTCGGTCGCGATCGGATC-TACT-----B335Ccongesta ATTAGAATGAATGGGCAAGTAGCTCGTCGCGGAGGT--CATGGCGTGGGGTCGGTCGCGATCGGATC-TACT-----B166Csubfarcina ATTAGAATGAATGGGCAAGTAGCTCGTCGCGGAGGTGTCATGGCGTGGGGTCGGTCGCGATCGGATC-TACT-----B116Ccongesta ATTAGAATGAATGGGCAAGTAGCTCGTCGCGGAGGT--CATGGCGTGGGGTCGGTCGCGATCGGATC-TACT-----B115Ccongesta ATTAGAATGAATGGGCAAGTAGCTCGTCGCGGAGGT--CATGGCGTGGGGTCGGTCGCGATCGGATC-TACT-----B121Cretroflexa ATTAGAATGAATGGGCAAGTAGCTCGTCGCGGAGGT--CATGGCGTGGGGTCGGTCGCGATCGGATC-TACT------

B174Lquercifoli B090Cmoniliform B114 Cexpansa B109Cretorta B131Cretorta B415Cretroflexa B118Csiliquosa B143Csiliquosa B100Csubfarcina B146Csubfarcina B153Csubfarcina B110Csubfarcina B127Csubfarcina B168Csubfarcina B136Csubfarcina B161Cretroflexa B103Ctorulosa B125Ctorulosa B179Ctorulosa B165Ctorulosa B171Cpolycystid B112Cpolycystid B148Cpolycystid B111Cpolycystid B102Cmonilifera B119Cmonilifera B318Cmonilifera B0 95CMONILIFERA B092Cmonilifera B159Csubfarcina A154Cscalaris A292Cscalaris A469Cscalaris B178Cscalaris B321Csp B336Cdistenta B337Cdistenta B336Cscalaris

--TGTGTCCGGTCGTGTGCGGCCTCAGTCGACCTTCTTGGCGGCGGCT---TGCTGGCGCGGTGGT---CGG--------GTGTCTGGTCGTGGGCGGCCTCAGTCGACCTTGGCGGCGGCGGTT---CGCTGGCGCGGTGGTGGGCGGTGCCGG ----TGTCTGGTCGTGGGCGGCCYCAGTCGACCTTCGCGGCGGCG------CGCTGGCGCGGTGGTGGGCGGGGCGAG GTTGTGTCTGGTCGTGGGCGGCCTTCGTCGACCTTCGCGGCGGCGGCG---CGCTGGCGCGTTGGTGGGTGGGGCGAG GTTGTGTCTGGTCGTGGGCGGCCTTCGTCGACCTTCGCGGCGGCGGCG---CGCTGGCGCGTTGGTGGGTGGGGCGAG GTTGTGTCTGGTCGTGGGCGGCCTTCGTCGACCTTCGCGGCGGCGGCG---CGCTGGCGCGTTGGTGGGTGGGGCGAG GTTGTGTCTGGTCGTGGGCGGCCTTCGTCGACCTTCGCGGCGGCGGCG---CGCTGGCGCGTTGGTGGGTGGGGCGAG GTTGTGTCTGGTCGTGGGCGGCCTTCGTCGACCTTCGCGGCGGCGGCG---CGCTGGCGCGTTGGTGGGTGGGGCGAG GT--------GTCGTGGGCGGCCTCAGTCGTTCTTCGCGGCGGCGGCGGCGCGCTGGCGCGTTGGTGGGTGGGTTCAG GT--------GTCGTGGGCGGCCTCAGTCGTTCTTCGCGGCGGCGGCGGCGCGCTGGCGCGTTGGTGGGTGGGGCGAG GT--------GTCGTGGGCGGCCTCAGTCGTTCTTCGCGGCGGCGGCGGCGCGCTGGCGCGTTGGTGGGTGGGGCGAG GT--------GTCGTGGGCGGCCTCAGTCGTTCTTCGCGGCGGCGGCGGCGCGCTGGCGCGTTGGTGGGTGGGGCGAG GTTGTGTCTGGTCGTGGGCGGCCTCAGTCGTTCTTCGCGGCGGCGGCGGCGCGCTGGCGCGTTGGTGGGTGGGGCGAG GT-------GTCGTGGGCGGCCTCAGTCGTTCTTCGCGGCGGCGGCGGCGCGCTGGCGCGTTGGTGGGTGGGGCGAG GT--------GTCGTGGGCGGCCTCAGTCGTTCTTCGCGGCGGCGGCGGCGCGCTGGCGCGTTGGTGGGTGGGGCGAG GT--------GTCGTGGGCGGCCTCAGTCGTTCTTCGCGGCGGCGGCGGCGCGCTGGCGCGTTGGTGGGTGGGGCGAG GTTGTGTCTGGTCGTGGGCGGCCTCAGTCGTTCTTCGCGGCGGCGGCGGCGCGCTGGCGCGTTGGTGGGTGGGGCGAG GT--------GTCGTGGGCGGCCTCAGTCGTTCTTCGCGGCGGCGGCGGCGCGCTGGCGCGTTGGTGGGTGGGGCGAG GTTGTGTCTGGTCGTGGGCGGCCTCAGTCGTTCTTCGCGGCGGCGGCGGCGCGCTGGCGCGTTGGTGGGTGGGGCGAG GTTGTGTCTGGTCGTGGGCGGCCTCAGTCGTTCTTCGCGGCGGCGGCGGCGCGCTGGCGCGTTGGTGGGTGGGGCGAG GTTGTGTCTGGTCGTCGGCGGCCTCAGTCGGCCTTCGCGGCGGCGGCGGCGCGCTGGCGCGTTGGTGGGTGGGGCGAG GTTGTGTCTGGTCGTCGGCGGCCTCAGTCGGCCTTCGCGGCGGCGGCGGCGCGCTGGCGCGTTGGTGGGTGGGGCGAG GTTGTGTCTGGTCGTCGGCGGCCTCAGTCGGCCTTCGCGGCGGCGGCGGCGCGCTGGCGCGTTGGTGGGTGGGGCGAG GTTGTGTCTGGTCGTCGGCGGCCTCAGTCGGCCTTCGCGGCGGCGGCGGCGCGCTGGCGCGTTGGTGGGTGGGGCGAG GTTGTGTCTGGTCGTGGGCGGCCTCAGTCGACCTTCGCGGCGGCGGCGGCGCGCTGGCGCGTTGGTGGGTGGGGCGAG GTTGTGTCTGGTCGTGGGCGGCCTCAGTCGACCTTCGCGGCGGCGGCGGCGCGCTGGCGCGTTGGTGGGTGGGGCGAG GTTGTGTCTGGTCGTGGGCGGCCTCAGTCGACCTTCGCGGCGGCGGCGGCGCGCTGGCGCGTTGGTGGGTGGGGCGAG GTTGTGTCTGGTCGTGGGCGGCCTCAGTCGACCTTCGCGGCGGCGGCGGCGCGCTGGCGCGTTGGTGGGTGGGGCGAG GTTGTGTCTGGTCGTGGGCGGCCTCAGTCGACCTTCGCGGCGGCGGCGGCGCGCTGGCGCGTTGGTGGGTGGGGCGAG GTTGTGTCTGGTCGTGGGCGGCCTCAGTCGTTCTTCGCGGCGGCGGCGGCGCGCTGGCGCGTTGGTGGGTGGGGCGAG GTTGTGTCTGGTCGTGGGCGGCCTCAGTCGGCCTTCGCGGCGGCGGCGGCGCGCTGGCGCGTTGGTGGGTGGGGCGAG GTTGTGTCTGGTCGTGGGCGGCCTCAGTCGGCCTTCGCGGCGGCGGCGGCGCGCTGGCGCGTTGGTGGGTGGGGCGAG GTTGTGTCTGGTCGTGGGCGGCCTCAGTCGGCCTTCGCGGCGGCGGCGGCGCGCTGGCGCGTTGGTGGGTGGGGCGAG GTTGTGTCTGGTCGTGGGCGGCCTCAGTCGGCCTTCGCGGCGGCGGCGGCGCGYTGGCGCGTTGGTGGGTGGGGCGAG GTTGTGTCTGGTCGTGGGCGGCCTCAGTCGGCCTTCGCGGCGGCGGCGGCGCGCTGGCGCGTTGGTGGGTGGGGCGAG GTTGTGTCTGGTCGTGGGCGGCCTCAGTCGGCCTTCGCGGCGGCGGCGGCGCGCTGGCGCGTTGGTGGGTGGGGCGAG GTTGTGTCTGGTCGTGGGCGGCCTCAGTCGGCCTTCGCGGCGGCGGCGGCGCGCTGGCGCGTTGGTGGGTGGGGCGAG GTTGTGTCTGGTCGTGGGCGGCCTCAGTCGGCCTTCGCGGCGGCGGCGGCGCGCTGGCGCGTTGGTGGGTGGGGCGAG 
Appendix 5. (Continued)

B104Cplatylobim ------TCTGGTCGTGGGCGGCCTTCGTCGACCTTCGCGGCGGCGGCG---CGCTGGCGCGTTGGTGGGTGGGGCGAG A168Cplatylobiu ------TCTGGTCGTGGGCGGCCTTCGTCGACCTTCGCGGCGGCGGCG---CGCTGGCGCGTTGGTGGGTGGGGCGAG B149Cycongesta GTTGTGTCTGGTCGTGGGCGGCCTCAGTCGTTCTTCGCGGCGGCGGCGGCGCGCTGGCGCGTTGGTGGGTGGGGCGAG B152Ccongesta GTTGTGTCTGGTCGTGGGCGGCCTCAGTCGTTCTTCGCGGCGGCGGCGGCGCGCTGGCGCGTTGGTGGGTGGGGCGAG B101Cretroflexa GTTGTGTCTGGTCGTGGGCGGCCTCAGTCGTTCTTCGCGGCGGCGGCGGCGCGCTGGCGCGTTGGTGGGTGGGGCGAG A080Cretroflexa GTTGTGTCTGGTCGTGGGCGGCCTCAGTCGTTCTTCGCGGCGGCGGCGGCGCGCTGGCGCGTTGGTGGGTGGGGCGAG A196Cretroflexa GTTGTGTCTGGTCGTGGGCGGCCTCAGTCGTTCTTCGCGGCGGCGGCGGCGCGCTGGCGCGTTGGTGGGTGGGGCGAG A085Cretroflexa GTTGTGTCTGGTCGTGGGCGGCCTCAGTCGTTCTTCGCGGCGGCGGCGGCGCGCTGGCGCGTTGGTGGGTGGGGCGAG B335Ccongesta B166Csubfarcina B116Ccongesta B115Ccongesta B121Cretroflexa GT GTTGTGTCTGGTCGTGGGCGGCCTCAGTCGTTCTTCGCGGCGGCGGCGGCGCGCTGGCGCGTTGGTGGGTGGGGCGAG GTTGTGTCTGGTCGTGGGCGGCCTCAGTCGTTCTTCGCGGCGGCGGCGGCGCGCTGGCGCGTTGGTGGGTGGGGCGAG GTTGTGTCTGGTCGTGGGCGGCCTCAGTCGTTCTTCGCGGCGGCGGCGGCGCGCTGGCGCGTTGGTGGGTGGGGCGAG

B174Lquercifoli B090Cmoniliform B114Cexpansa B109Cretorta B131Cretorta B415Cretroflexa B118Csiliquosa B143Csiliquosa B100Csubfarcina B146Csubfarcina B153Csubfarcina B110Csubfarcina B127Csubfarcina B168Csubfarcina B136Csubfarcina B161Cretroflexa B103Ctorulosa B125Ctorulosa B179Ctorulosa B165Ctorulosa B171Cpolycystid B112Cpolycystid B148Cpolycystid B111Cpolycystid B102Cmonilifera B119Cmonilifera B318Cmonilifera B095CMONILIFERA B092Cmonilifera B159Csubfarcina A154Cscalaris A292Cscalaris A469Cscalaris B178Cscalaris B321Csp

B336Cdistenta B337Cdistenta B336Cscalaris B104Cplatylobiu A168Cplatylobiu B149Cycongesta B152Ccongesta B101Cretroflexa A080Cretroflexa A196Cretroflexa A085Cretroflexa B335Ccongesta B166Csubfarcina B116Ccongesta B115Ccongesta

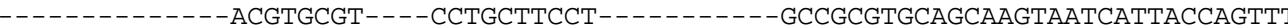
GTACGCGTGTAGGCACGTGCGC----CCAACTTCCTCC----CCACCGCCGCGTGCAGGGAGCAAATATTAGCAGTTT GTACGCGCGTACGTACGTACGTGCTCCCAACTCCCTCC----TTCCCATCGCGTGCAGCGAGCAAATATTACCAGTGT GTAGGCGTGTACGTACGTGCGC----CCAACTCCCTCC----TTTCCATCGCGTGCAGCGGGCRAAAATTACCAGTTT GTAGGCGTGTACGTACGTGCGC----CCAACTCCCTCC----TTTCCATCGCGTGCAGCGGGCAAAAATTACCAGTTT GTAGGCGTGTACGTACGTGCGC----CCAACTCCCTCC----TTTCCATCGCGTGCAGCGAGCAAAAATTACCAGTTT GTAGGCGTGTACGTACGTGCGC----CCAACTCCCTCC----TTTCCATCGCGTGCAGCGAGCAAAAATTACCAGTTT GTAGGCGTGTACGTACGTGCGC-----CCAACTCCCTCC----TTTCCATCGCGTGCAGCGAGCAAAAATTACCAGTTT GTAGGCGTGTACGTACGTGCGC----CCAACTCCCTCCTTC-TTTCCATCGCGTGCAGCGAGCAAAAATTACCAGTTT GTAGGCGTGTACGTACGTGCGC----CCAACTCCCTCCTTC-TTTCCATCGCGTGCAGCGAGCAAAAATTACCAGTTT GTAGGCGTGTACGTACGTGCGC----CCAACTCCCTCCTTC-TTTCCATCGCGTGCAGCGAGCAAAAATTACCAGTTT GTAGGCGTGTACGTACGTGCGC----CCAACTCCCTCCTTC-TTTCCATCGCGTGCAGCGAGCAAAAATTACCAGTTT GTAGGCGTGTACGTACGTGCGC----CCAACTCCCTCCTTC-TTTCCATCGCGTGCAGCGAGCAAAAATTACCAGTTT GTAGGCGTGTACGTACGTGCGC----CCAACTCCCTCCTTC-TTTCCATCGCGTGCAGCGAGCAAAAATTACCAGTTT GTAGGCGTGTACGTACGTGCGC----CCAACTCCCTCCTTC-TTACCATCGCGTGCAGCGAGCAAAAATTACCAGTTT GTAGGCGTGTACGTACGTGCGC----CCAACTCCCTCCTTC-TTTCCATCGCGTGCAGCGAGCAAAAATTACCAGTTT GTAGGCGTGTACGTACGTGCGC----CCAACTCCCTCCTTC-TTTCCATCGCGTGCAGCGAGCAAAAATTACCAGTTT GTAGGCGTGTACGTACGTGCGC----CCAACTCCCTCCTTC-TTTCCATCGCGTGCAGCGAGCAAAAATTACCAGTTT GTAGGCGTGTACGTACGTGCGC----CCAACTCCCTCCTTC-TTTCCATCGCGTGCAGCGAGCAAAAATTACCAGTTT GTAGGCGTGTACGTACGTGCGC----CCAACTCCCTCCTTC-TTTCCATCGCGTGCAGCGAGCAAAAATTACCAGTTT GTAGGCGTGTACGTACGTGCGC----CCAACTCCCTCC----TTTCCATCGCGTGCAGCGAGCAAAAATTACCAGTTT GTAGGCGTGTACGTACGTGCGC----CCAACTCCCTCC----TTTCCATCGCGTGCAGCGAGCAAAAATTACCAGTTT GTAGGCGTGTACGTACGTGCGC----CCAACTCCCTCC----TTTCCATCGCGTGCAGCGAGCAAAAATTACCAGTTT GTAGGCGTGTACGTACGTGCGC----CCAACTCCCTCC----TTTCCATCGCGTGCAGCGAGCAAAAATTACCAGTTT GTAGGCGTGTACGTACGTGCGC----CCAACTCCCTCC----TTTCCATCGCGTGCAGCGAGCAAAAATTACCAGTTT GTAGGCGTGTACGTACGTGCGC----CCAACTCCCTCC----TTTCCATCGCGTGCAGCGAGCAAAAATTACCAGTTT GTAGGCGTGTACGTACGTGCGC----CCAACTCCCTCC----TTTCCATCGCGTGCAGCGAGCAAAAATTACCAGTTT GTAGGCGTGTACGTACGTGCGC----CCAACTCCCTCC----TTTCCATCGCGTGCAGCGAGCAAAAATTACCAGTTT GTAGGCGTGTACGTACGTGCGC----CCAACTCCCTCC----TTTCCATCGCGTGCAGCGAGCAAAAATTACCAGTTT GTAGGCGTGTACGTACGTGCGC----CCAACTCCCTCCTTC-TTTCCATCGCGTGCAGCGAGCAAATATTACCAGTTT GTAGGCGTGTACGTACGTGCGCGCGCCCAACTAACTCCCTCCTTTCCATCGCGTGCAGCGAGCAAAAATTACCAGTTT GTAGGCGTGTACGTACGTGCGCGCGCCCAACTAACTCCCTCCTTTCCATCGCGTGCAGCGAGCAAAAATTACCAGTTT GTAGGCGTGTACGTACGTGCGCGCGCCCAACTAACTCCCTCCTTTCCATCGCGTGCAGCGAGCAAAAATTACCAGTTT GTAGGCGTGTACGTACGTGCGCGCGCCCAACTAACTCCCTCCTTTCCATCGCGTGCAGCGAGCAAAAATTACCAGTTT GTAGGCGTGTACGTACGTGCGCGCGCCCAACTAACTCCCTCCTTTCCATCGCGTGCAGCGAGCAAAAATTACCAGTTT GTAGGCGTGTACGTACGTGCGCGCGCCCAACTAACTCCCTCCTTTCCATCGCGTGCAGCGAGCAAAAATTACCAGTTT GTAGGCGTGTACGTACGTGCGCGCGCCCAACTAACTCCCTCCTTTCCATCGCGTGCAGCGAGCAAAAATTACCAGTTT GTAGGCGTGTACGTACGTGCGCGCGCCCAACTAACTCCCTCCTTTCCATCGCGTGCAGCGAGCAAAAATTACCAGTTT GTAGGCCTGTACGTACGTGCGC----CCAACTCCCTCC----TCTCCATCGCGTGCAGCGAGCAAAAATTACCAGTTT GTAGGCCTGTACGTACGTGCGC----CCAACTCCCTCC----TCTCCATCGCGTGCAGCGAGCAAAAATTACCAGTTT GTAGGCGTGTACGTACGTGCGC----CCAACTCCCTCCTTC-TTTCCATCGCGTGCAGCGAGCAAATATTACCAGTTT GTAGGCGTGTACGTACGTGCGC----CCAACTCCCTCCTTC-TTTCCATCGCGTGCAGCGAGCAAATATTACCAGTTT GTAGGCGTGTACGTACGTGCGC----CCAACTCCCTCCTTC-TTTCCATCGCGTGCAGCGAGCAAATATTACCAGTTT GTAGGCGTGTACGTACGTGCGC----CCAACTCCCTCCTTC-TTTCCATCGCGTGCAGCGAGCAAATATTACCAGTTT GTAGGCGTGTACGTACGTGCGC----CCAACTCCCTCCTTC-TTTCCATCGCGTGCAGCGAGCAAATATTACCAGTTT GTAGGCGTGTACGTACGTGCGC----CCAACTCCCTCCTTC-TTTCCATCGCGTGCAGCGAGCAAATATTACCAGTTT GTAGGCGTGTACGTACGTGCGC----CCAACTCCCTCCTTC-TTTCCATCGCGTGCAGCGAGCAAATATTACCAGTTT GTAGGCGTGTACGTACGTGCGC----CCAACTCCCTCCTTC-TTTCCATCGCGTGCAGCGAGCAAAAATTACCAGTTT GTAGGCGTGTACGTACGTGCGC----CCAACTCCCTCCTTC-TTTCCATCGCGTGCAGCGAGCAAATATTACCAGTTT GTAGGCGTGTACGTACGTGCGC----CCAACTCCCTCCTTC-TTTCCATCGCGTGCAGCGAGCAAATATTACCAGTTT B121Cretroflexa GTAGGCGTGTACGTACGTGCGC----CCAACTCCCTCCTTC-TTTCCATCGCGTGCAGCGAGCAAATATTACCAGTTT

B174 Lquercifoli ----CTCTGATCTGACGCGAGGGAGGGGGCGTGGCTGCCCGACGCGGTGGCTGCAGCCCCC-TCC---CGGA----GC B090Cmoniliform GTTTCTCTGAACTGACCCGAGGGAGGGA-_-_-_-_--_-_--_-GGGGGCTACAGGCCCC-TCCCCCCGGA----TC B114Cexpansa B109Cretorta B131Cretorta TTTTCTCTGAACTGTCCCGAGGGA--_-_-_-_-_-_--_--_--GGGGGCTAC-GGCCCCCTCCTCCCGGA----_GC TTTTCTCTGGACTGACCCGAGGGA----------------CGGGGGCTAC-GGCCCC-CCCTCCCGGA----GC TTTTCTCTGGACTGACCCGAGGGA---_-_---_---_---_---CGGGGGCTAC-GGCCCC-CCCTCCCGGA----GC B415Cretroflexa TTTTCTCTGGACTGACCCGAGGGA--------------------GGGGGCTAC-GGCCCC-CCCTCCCGGA----GC B118Csiliquosa TTTTCTCTGGACTGACCCGAGGGA---------------------GGGGGCTAC-GGCCCC-CCCTCCCGGA----GC

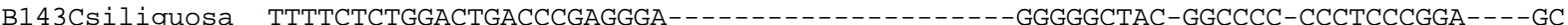
B100Csubfarcina TTTTCTCTGGACTGACCCGAAGGA------------------GGGGGCTACAGGCCCC----TCCCGGAGCGGTC B146Csubfarcina TTTTCTCTGGACTGACCCGAAGGA-------------------GGGGGCTACAGGCCCC----TCCCGGAGCGGTC 
Appendix 5. (Continued)

B153Csubfarcina TTTTCTCTGGACTGACCCGAAGGA---------------------GGGGGCTACAGGCCCC----TCCCGGAGCGGTC B110Csubfarcina TTTTCTCTGGACTGACCCGAAGGA--------------------GGGGGCTACAGGCCCC----TCCCGGAGCGGTC B127Csubfarcina TTTTCTCTGGACTGACCCGAAGGA-------------------GGGGGCTACAGGCCCC----TCCCGGAGCGGTC B168Csubfarcina TTTTCTCTGGACTGACCCGAAGGA---------------------GGGGGCTACAGGCCCC----TCCCGGAGCGGTC B136Csubfarcina TTTTCTCTGGACTGACCCGAAGGA-------------------GGGGGCTACAGGCCCC----TCCCGGAGCGGTC B161Cretroflexa TTTTCTCTGGACTGACCCGAAGGA---------------------GGGGGCTACAGGCCCC----TCCCGGAGCGGTC B103Ctorulosa TTTTCTCTGGACTGACCCGAAGGA-------------------GGGGGCTACAGGCCCC----TCCCGGAGCGGTC B125Ctorulosa TTTTCTCTGGACTGACCCGAAGGA--------------------GGGGGCTACAGGCCCC----TCCCGGAGCGGTC B179Ctorulosa TTTTCTCTGGACTGACCCGAAGGA--------------------GGGGGCTACAGGCCCC----TCCCGGAGCGGTC B165Ctorulosa TTTTCTCTGGACTGACCCGAAGGA-------------------GGGGGCTACAGGCCCC----TCCCGGAGCGGTC B171Cpolycystid TTTTCTCTGGACTGACCCGAGGGA---------------------GGGGGCTGCAGGCCCC----TCCCGGA----GC B112Cpolycystid TTTTCTCTGGACTGACCCGAGGGA--------------------GGGGGCTGCAGGCCCC----TCCCGGA----GC B148Cpolycystid TTTTCTCTGGACTGACCCGAGGGA--------------------GGGGGCTGCAGGCCCC----TCCCGGA----GC B111Cpolycystid TTTTCTCTGGACTGACCCGAGGGA--------------------GGGGGCTGCAGGCCCC----TCCCGGA----GC

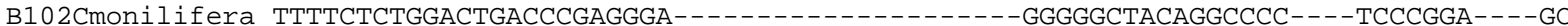
B119Cmonilifera TTTTCTCTGGACTGACCCGAGGGA---------------------GGGGGCTACAGGCCCC----TCCCGGA----GC B318Cmonilifera TTTTCTCTGGACTGACCCGAGGGA--------------------GGGGGCTACAGGCCCC----TCCCGGA----GC B095CMONILIFERA TTTTCTCTGGACTGACCCGAGGGA-------------------GGGGGCTACAGGCCCC----TCCCGGA----GC B092Cmonilifera TTTTCTCTGGACTGACCCGAGGGA--------------------GGGGGCTACAGGCCCC----TCCCGGA----GC B159Csubfarcina TTTTCTCTGGACTGACCCGAAGGA--------------------GGGGGCTACAGGCCCC----TCCCGGAGCGGTC A154Cscalaris TTTTCTCTGGACTGACCCGAGGGA-------------------GGGGGCTACAGGCCCC----TCCCGGA----GC A292Cscalaris TTTTCTCTGGACTGACCCGAGGGA---------------------GGGGGCTACAGGCCCC----TCCCGGA----GC

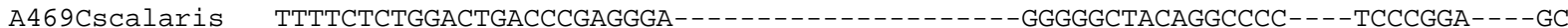
B178Cscalaris TTTTCTCTGGACTGACCCGAGGGA--------------------GGGGGCTACAGGCCCC----TCCCGGA----GC B321Csp B336Cdistenta B337Cdistenta B336Cscalaris B104Cplatylobiu A168Cplatylobiu B149Cycongesta B152Ccongesta B101Cretroflexa A080Cretroflexa A196Cretroflexa A085Cretroflexa B335Ccongesta B166Csubfarcina B116Ccongesta B115Ccongesta B121Cretroflexa TTTTCTCTGGACTGACCCGAGGGATTTTCTCTGGRCTGACCCGAGGGA-------TTTTCTCTGGACTGACCCGAGGGA--------------------GGGGGCTACAGGCCCC----TCCCGGA----GC TTTTCTCTGGACTGACCCGAGGGA--------------------GGGGGCTACAGGCCCC----TCCCGGA----GC TTTTCTCCGGACTGCCCCGAGGGA--------------------CGGGGCTACAGGCCCC---CTCCCGGA----GC TTTTCTCCGGACTGCCCCGAGGGA--------------------CGGGGCTACAGGCCCC---CTCCCGGA----GC TTTTCTCTGGACTGACCCGAAGGA--------------------GGGGGCTACAGGCCCC----TCCCGGAGCGGTC TTTTCTCTGGACTGACCCGAAGGA---------------------GGGGGCTACAGGCCCC----TCCCGGAGCGGTC TTTTCTCTGGACTGACCCGAAGGA--------------------GGGGGCTACAGGCCCC----TCCCGGAGCGGTC

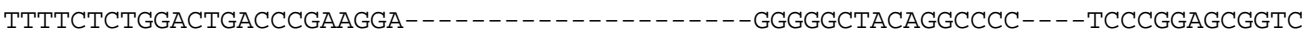
TTTTCTCTGGACTGACCCGAAGGA--------------------GGGGGCTACAGGCCCC----TCCCGGAGCGGTC TTTTCTCTGGACTGACCCGAAGGA--------------------GGGGGCTACAGGCCCC----TCCCGGAGCGGTC TTTTCTCTGGACTGACCCGAAGGA---------------------GGGGGCTACAGGCCCC----TCCCGGAGCGGTC TTTTCTCTGGACTGACCCGAAGGA--------------------GGGGGCTACAGGCCCC----TCCCGGAGCGGTC TTTTCTCTGGACTGACCCGAAGGA-------------------GGGGGCTACAGGCCCC----TCCCGGAGCGGTC TTTTCTCTGGACTGACCCGAAGGA--------------------GGGGGCTACAGGCCCC----TCCCGGAGCGGTC

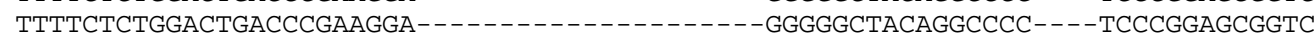

B174Lquercifoli GGTCCAATCTATAATTAGCGTAAAACTTTCAGCGACGGATGTCTTGGCTCCCACAACGATGAAGAACGCAGCGAAATG B090Cmoniliform GGTCCAATCTTTAATTAGCGTAAAACTTTCAGCGACGGATGTCTTGGCTCCCACAACGATGAAGAACGCAGCGAAATG B114Cexpansa B109Cretorta B131Cretort B415Cretroflexa B118Csiliquosa B143Csiliquosa B100Csubfarcina B146Csubfarcina B153Csubfarcina B110Csubfarcina B127Csubfarcina B168Csubfarcina B136Csubfarcina B161Cretroflexa B103Ctorulosa B125Ctorulosa B179ctorulosa B165Ctorulosa GGTCCAATCTCTAATTAGCGTAAAACTTTCAGCGACGGATGTCTTGGCTCCCACAACGATGAAGAACGCAGCGAAATG GGTCCAATCTCTAATTAGCGTAAAACTTTCAGCGACGGATGTCTTGGCTCCCACAACGATGAAGAACGCAGCGAAATG GGTCCAATCTCTAATTAGCGTAAAACTTTCAGCGACGGATGTCTTGGCTCCCACAACGATGAAGAACGCAGCGAAATG GGTCCAATCTCTAATTAGCGTAAAACTTTCAGCGACGGATGTCTTGGCTCCCACAACGATGAAGAACGCAGCGAAATG GGTCCAATCTCTAATTAGCGTAAAACTTTCAGCGACGGATGTCTTGGCTCCCACAACGATGAAGAACGCAGCGAAATG GGTCCAATCTCTAATTAGCGTAAAACTTTCAGCGACGGATGTCTTGGCTCCCACAACGATGAAGAACGCAGCGAAATG GGTCCAATCTCTAATTAGCGTAAAACTTTCAGCGACGGATGTCTTGGCTCCCACAACGATGAAGAACGCAGCGAAATG GGTCCAATCTCTAATTAGCGTAAAACTTTCAGCGACGGATGTCTTGGCTCCCACAACGATGAAGAACGCAGCGAAATG GGTCCAATCTCTAATTAGCGTAAAACTTTCAGCGACGGATGTCTTGGCTCCCACAACGATGAAGAACGCAGCGAAATG GGTCCAATCTCTAATTAGCGTAAAACTTTCAGCGACGGATGTCTTGGCTCCCACAACGATGAAGAACGCAGCGAAATG GGTCCAATCTCTAATTAGCGTAAAACTTTCAGCGACGGATGTCTTGGCTCCCACAACGATGAAGAACGCAGCGAAATG GGTCCAATCTCTAATTAGCGTAAAACTTTCAGCGACGGATGTCTTGGCTCCCACAACGATGAAGAACGCAGCGAAATG GGTCCAATCTCTAATTAGCGTAAAACTTTCAGCGACGGATGTCTTGGCTCCCACAACGATGAAGAACGCAGCGAAATG GGTCCAATCTCTAATTAGCGTAAAACTTTCAGCGACGGATGTCTTGGCTCCCACAACGATGAAGAACGCAGCGAAATG GGTCCAATCTCTAATTAGCGTAAAACTTTCAGCGACGGATGTCTTGGCTCCCACAACGATGAAGAACGCAGCGAAATG GGTCCAATCTCTAATTAGCGTAAAACTTTCAGCGACGGATGTCTTGGCTCCCACAACGATGAAGAACGCAGCGAAATG GGTCCAATCTCTAATTAGCGTAAAACTTTCAGCGACGGATGTCTTGGCTCCCACAACGATGAAGAACGCAGCGAAATG GGTCCAATCTCTAATTAGCGTAAAACTTTCAGCGACGGATGTCTTGGCTCCCACAACGATGAAGAACGCAGCGAAATG B171Cpolycystid GGTCCAATCTCTAATTAGCGTAAAACTTTCAGCGACGGATGTCTTGGCTCCCACAACGATGAAGAACGCAGCGAAATG B112Cpolycystid GGTCCAATCTCTAATTAGCGTAAAACTTTCAGCGACGGATGTCTTGGCTCCCACAACGATGAAGAACGCAGCGAAATG B148Cpolycystid GGTCCAATCTCTAATTAGCGTAAAACTTTCAGCGACGGATGTCTTGGCTCCCACAACGATGAAGAACGCAGCGAAATG B111Cpolycystid GGTCCAATCTCTAATTAGCGTAAAACTTTCAGCGACGGATGTCTTGGCTCCCACAACGATGAAGAACGCAGCGAAATG B102Cmonilifera GGTCCAATCTCTAATTAGCGTAAAACTTTCAGCGACGGATGTCTTGGCTCCCACAACGATGAAGAACGCAGCGAAATG B119Cmonilifera GGTCCAATCTCTAATTAGCGTAAAACTTTCAGCGACGGATGTCTTGGCTCCCACAACGATGAAGAACGCAGCGAAATG B318Cmonilifera GGTCCAATCTCTAATTAGCGTAAAACTTTCAGCGACGGATGTCTTGGCTCCCACAACGATGAAGAACGCAGCGAAATG B095CMONILIFERA GGTCCAATCTCTAATTAGCGTAAAACTTTCAGCGACGGATGTCTTGGCTCCCACAACGATGAAGAACGCAGCGAAATG B159Csubfarcina GGTCCAATCTCTAATTAGCGTAAAACTTTCAGCGACGGATGTCTTGGCTCCCACAACGATGAAGAACGCAGCGAAATG A154Cscalaris A292Cscalaris A469Cscalaris B178Cscalaris GGTCCAATCTCTAATTAGCGTAAAACTTTCAGCGACGGATGTCTTGGCTCCCACAACGATGAAGAACGCAGCGAAATG GGTCCAATCTCTAATTAGCGTAAAACTTTCAGCGACGGATGTCTTGGCTCCCACAACGATGAAGAACGCAGCGAAATG GGTCCAATCTCTAATTAGCGTAAAACTTTCAGCGACGGATGTCTTGGCTCCCACAACGATGAAGAACGCAGCGAAATG GGTCCAATCTCTAATTAGCGTAAAACTTTCAGCGACGGATGTCTTGGCTCCCACAACGATGAAGAACGCAGCGAAATG 
Appendix 5. (Continued)

B321Csp B336Cdistenta B337Cdistenta B336Cscalaris B104Cplatylobiu A168Cplatylobiu B149Cycongesta B152Ccongesta B101Cretroflexa A080Cretroflexa A196Cretroflexa A085Cretroflexa B335Ccongesta B166Csubfarcina B116Ccongesta B115Ccongesta B121Cretroflexa

B174Lquercifoli B090Cmoniliform B114 Cexpansa B109Cretorta B131Cretorta B415Cretroflexa B118Csiliquosa B143Csiliquosa B100Csubfarcina B146Csubfarcina B153Csubfarcina B110Csubfarcina B127Csubfarcina B168Csubfarcina B136Csubfarcina B161Cretroflexa B103Ctorulosa B125Ctorulosa B179ctorulosa B165Ctorulosa B171Cpolycystid B112Cpolycystid B148Cpolycystid B111Cpolycystid B102Cmonilifera B119Cmonilifera B318Cmonilifera B0 95CMONILIFERA B092Cmonilifera B159Csubfarcina A154Cscalaris A292Cscalaris A469Cscalaris B178Cscalaris B321Csp B336Cdistenta B337Cdistenta B336Cscalaris B104Cplatylobiu A168Cplatylobiu B149Cycongesta B152Ccongesta

B101Cretroflexa A080Cretroflexa A196Cretroflexa A085Cretroflexa B335Ccongesta B166Csubfarcina B116Ccongesta B115Ccongesta B121Cretroflexa

GGTCCAATCTCTAATTAGCGTAAAACTTTCAGCGACGGATGTCTTGGCTCCCACAACGATGAAGAACGCAGCGAAATG GGTCCAATCTCTAATTAGCGTAAAACTTTCAGCGACGGATGTCTTGGCTCCCACAACGATGAAGAACGCAGCGAAATG GGTCCAATCTCTAATTAGCGTAAAACTTTCAGCGACGGATGTCTTGGCTCCCACAACGATGAAGAACGCAGCGAAATG GGTCCAATCTCTAATTAGCGTAAAACTTTCAGCGACGGATGTCTTGGCTCCCACAACGATGAAGAACGCAGCGAAATG GGTCCAATCTCTAATTAGCGTAAAACTTTCAGCGACGGATGTCTTGGCTCCCACAACGATGAAGAACGCAGCGAAATG GGTCCAATCTCTAATTAGCGTAAAACTTTCAGCGACGGATGTCTTGGCTCCCACAACGATGAAGAACGCAGCGAAATG GGTCCAATCTCTAATTAGCGTAAAACTTTCAGCGACGGATGTCTTGGCTCCCACAACGATGAAGAACGCAGCGAAATG GGTCCAATCTCTAATTAGCGTAAAACTTTCAGCGACGGATGTCTTGGCTCCCACAACGATGAAGAACGCAGCGAAATG GGTCCAATCTCTAATTAGCGTAAAACTTTCAGCGACGGATGTCTTGGCTCCCACAACGATGAAGAACGCAGCGAAATG GGTCCAATCTCTAATTAGCGTAAAACTTTCAGCGACGGATGTCTTGGCTCCCACAACGATGAAGAACGCAGCGAAATG GGTCCAATCTCTAATTAGCGTAAAACTTTCAGCGACGGATGTCTTGGCTCCCACAACGATGAAGAACGCAGCGAAATG GGTCCAATCTCTAATTAGCGTAAAACTTTCAGCGACGGATGTCTTGGCTCCYACAACGATGAAGAACGCAGCGAAATG GGTCCAATCTCTAATTAGCGTAAAACTTTCAGCGACGGATGTCTTGGCTCCCACAACGATGAAGAACGCAGCGAAATG GGTCCAATCTCTAATTAGCGTAAAACTTTCAGCGACGGATGTCTTGGCTCCCACAACGATGAAGAACGCAGCGAAATG GGTCCAATCTCTAATTAGCGTAAAACTTTCAGCGACGGATGTCTTGGCTCCCACAACGATGAAGAACGCAGCGAAATG GGTCCAATCTCTAATTAGCGTAAAACTTTCAGCGACGGATGTCTTGGCTCCCACAACGATGAAGAACGCAGCGAAATG GGTCCAATCTCTAATTAGCGTAAAACTTTCAGCGACGGATGTCTTGGCTCCCACAACGATGAAGAACGCAGCGAAATG

CGATACGTCTTGCGACTTGCAGAATCCCGTGAATCATCGAAACTTTGAACGCACCTTGCGCTCCCGGGATATGCCTGG CGATACGTCTTGCGACTTGCAGAATCCCGTGAATCATCGAAACTTTGAACGCACCTTGCGCTCCCGGGATATGCCTGG CGATACGTCtTGCGACTTGCAGAATCCCGTGAATCATCGAAACTTTGAACGCACCTTGCGCTCCCGGGATATGCCTGG CGATACGTCTTGCGACTTGCAGAATCCCGTGAATCATCGAAACTTTGAACGCACCTTGCGCTCCCGGGATATGCCTGG CGATACGTCTTGCGACTTGCAGAATCCCGTGAATCATCGAAACTTTGAACGCACCTTGCGCTCCCGGGATATGCCTGG CGATACGTCTTGCGACTTGCAGAATCCCGTGAATCATCGAAACTTTGAACGCACCTTGCGCTCCCGGGATATGCCTGG CGATACGTCTTGCGACTTGCAGAATCCCGTGAATCATCGAAACTTTGAACGCACCTTGCGCTCCCGGGATATGCCTGG CGATACGTCTTGCGACTTGCAGAATCCCGTGAATCATCGAAACTTTGAACGCACCTTGCGCTCCCGGGATATGCCTGG CGATACGTCTTGCGACTTGCAGAATCCCGTGAATCATCGAAACTTTGAACGCACCTTGCGCTCCCGGGATATGCCTGG CGATACGTCTTGCGACTTGCAGAATCCCGTGAATCATCGAAACTTTGAACGCACCTTGCGCTCCCGGGATATGCCTGG CGATACGTCTTGCGACTTGCAGAATCCCGTGAATCATCGAAACTTTGAACGCACCTTGCGCTCCCGGGATATGCCTGG CGATACGTCTTGCGACTTGCAGAATCCCGTGAATCATCGAAACTTTGAACGCACCTTGCGCTCCCGGGATATGCCTGG CGATACGTCTTGCGACTTGCAGAATCCCGTGAATCATCGAAACTTTGAACGCACCTTGCGCTCCCGGGATATGCCTGG CGATACGTCTTGCGACTTGCAGAATCCCGTGAATCATCGAAACTTTGAACGCACCTTGCGCTCCCGGGATATGCCTGG CGATACGTCtTGCGACTTGCAGAATCCCGTGAATCATCGAAACTTTGAACGCACCTTGCGCTCCCGGGATATGCCTGG CGATACGTCTTGCGACTTGCAGAATCCCGTGAATCATCGAAACTTTGAACGCACCTTGCGCTCCCGGGATATGCCTGG CGATACGTCTTGCGACTTGCAGAATCCCGTGAATCATCGAAACTTTGAACGCACCTTGCGCTCCCGGGATATGCCTGG CGATACGTCTTGCGACTTGCAGAATCCCGTGAATCATCGAAACTTTGAACGCACCTTGCGCTCCCGGGATATGCCTGG CGATACGTCTTGCGACTTGCAGAATCCCGTGAATCATCGAAACTTTGAACGCACCTTGCGCTCCCGGGATATGCCTGG CGATACGTCTTGCGACTTGCAGAATCCCGTGAATCATCGAAACTTTGAACGCACCTTGCGCTCCCGGGATATGCCTGG CGATACGTCTTGCGACTTGCAGAATCCCGTGAATCATCGAAACTTTGAACGCACCTTGCGCTCCCGGGATATGCCTGG CGATACGTCTTGCGACTTGCAGAATCCCGTGAATCATCGAAACTTTGAACGCACCTTGCGCTCCCGGGATATGCCTGG CGATACGTCTTGCGACTTGCAGAATCCCGTGAATCATCGAAACTTTGAACGCACCTTGCGCTCCCGGGATATGCCTGG CGATACGTCTTGCGACTTGCAGAATCCCGTGAATCATCGAAACTTTGAACGCACCTTGCGCTCCCGGGATATGCCTGG CGATACGTCTTGCGACTTGCAGAATCCCGTGAATCATCGAAACTTTGAACGCACCTTGCGCTCCCGGGATATGCCTGG CGATACGTCTTGCGACTTGCAGAATCCCGTGAATCATCGAAACTTTGAACGCACCTTGCGCTCCCGGGATATGCCTGG CGATACGTCTTGCGACTTGCAGA-TCCCGTGAATCATCGAAACTTTGAACGCACCTTGCGCTCCCGGGATATGCCTGG CGATACGTCTTGCGACTTGCAGAATCCCGTGAATCATCGAAACTTTGAACGCACCTTGCGCTCCCGGGATATGCCTGG CGATACGTCTt GCGACTTGCAGAATCCCGTGAATCATCGAAACTTTGAACGCACCTTGCGCTCCCGGGATATGCCTGG CGATACgTCTTGCGACTTGCAGAATCCCGTGAATCATCGAAACTTTGAACGCACCTTGCGCTCCCGGGATATGCCTGG CGATACGTCTTGCGACTTGCAGAATCCCGTGAATCATCGAAACTTTGAACGCACCTTGCGCTCCCGGGATATGCCTGG CGATACGTCTTGCGACTTGCAGAATCCCGTGAATCATCGAAACTTTGAACGCACCTTGCGCTCCCGGGATATGCCTGG CGATACGTCTTGCGACTTGCAGAATCCCGTGAATCATCGAAACTTTGAACGCACCTTGCGCTCCCGGGATATGCCTGG CGATACGTCTTGCGACTTGCAGAATCCCGTGAATCATCGAAACTTTGAACGCACCTTGCGCTCCCGGGATATGCCTGG CGATACGTCTTGCGACTTGCAGAATCCCGTGAATCATCGAAACTTTGAACGCACCTTGCGCTCCCGGGATATGCCTGG CGATACGTCTTGCGACTTGCAGAATCCCGTGAATCATCGAAACTTTGAACGCACCTTGCGCTCCCGGGATATGCCTGG CGATACSTCTTGCGACTTGCAGAATCCCGTGAATCATCGAAACTTTGAACGCACCTTGCGCTCCCGGGATATGCCTGG CGATACGTCTTGCGACTTGCAGAATCCCGTGAATCATCGAAACTTTGAACGCACCTTGCGCTCCCGGGATATGCCTGG CGATACGTCTTGCGACTTGCAGAATCCCGTGAATCATCGAAACTTTGAACGCACCTTGCGCTCCCGGGATATGCCTGG CGATACGTCTTGCGACTTGCAGAATCCCGTGAATCATCGAAACTTTGAACGCACCTTGCGCTCCCGGGATATGCCTGG CGATACGTCTTGCGACTTGCAGAATCCCGTGAATCATCGAAACTTTGAACGCACCTTGCGCTCCCGGGATATGCCTGG CGATACGTCTTGCGACTTGCAGAATCCCGTGAATCATCGAAACTTTGAACGCACCTTGCGCTCCCGGGATATGCCTGG CGATACGTCTTGCGACTTGCAGAATCCCGTGAATCATCGAAACTTTGAACGCACCTTGCGCTCCCGGGATATGCCTGG CGATACGTCTTGCGACTTGCAGAATCCCGTGAATCATCGAAACTTTGAACGCACCTTGCGCTCCCGGGATATGCCTGG CGATACGTCTTGCGACTTGCAGAATCCCGTGAATCATCGAAACTTTGAACGCACCTTGCGCTCCCGGGATATGCCTGG CGATACGTCTTGCGACTTGCAGAATCCCGTGAATCATCGAAACTTTGAACGCACCTTGCGCTCCCGGGATATGCCTGG CGATACGTCTTGCGACTTGCAGAATCCCGTGAATCATCGAAACTTTGAACGCACCTTGCGCTCCCGGGATATGCCTGG CGATACGTCTTGCGACTTGCAGAATCCCGTGAATCATCGAAACTTTGAACGCACCTTGCGCTCCCGGGATATGCCTGG CGATACGTCTTGCGACTTGCAGAATCCCGTGAATCATCGAAACTTTGAACGCACCTTGCGCTCCCGGGATATGCCTGG CGATACGTCTTGCGACTTGCAGAATCCCGTGAATCATCGAAACTTTGAACGCACCTTGCGCTCCCGGGATATGCCTGG CGATACGTCTTGCGACTTGCAGAATCCCGTGAATCATCGAAACTTTGAACGCACCTTGCGCTCCCGGGATATGCCTGG

B174Lquercifoli GAGCATGCTTGTCGGGGAGGAGGAGGCGAAAAATCGCCCACCGCTTTGGAGT------------------CCCTCCG B090 Cmoniliform GAGCATGCTTGTCGGGGAGGAGGAGGCGAAAAATCGCCCACCGCTTCGGAA-------------------CCCTCCG B114 Cexpansa GAGCATGCTTGTCGGGGAGGAGGAGGCGAAAAATCGCCCACGGCCTTGGAGGGAGTTAATAAT-------CCCCTCCG B109Cretorta GAGCATGCTTGTCGGGGAGGAGGAGGCGAAAAATCGCCCACGGCCTTGGAGTGGGTTAATAAAAT-----CCCCTCCG B131Cretorta GAGCATGCTTGTCGGGGAGGAGGAGGCGAAAAATCGCCCACGGCCTTGGAGTGGGTTAATAAAAT-----CCCCTCCG B415Cretroflexa GAGCATGCTTGTCGGGGAGGAGGAGGCGAAAAATCGCCCACGGCCTTGGAGTGGGTTAATAAAAT-----CCCCTCCG 
Appendix 5. (Continued)

B118Csiliquosa B143Csiliquosa B100Csubfarcina B146Csubfarcina B153Csubfarcina B110Csubfarcina B127Csubfarcina B168Csubfarcina B136Csubfarcina B161Cretroflexa B103Ctorulosa B125Ctorulosa B179Ctorulosa B165Ctorulosa B171Cpolycystid B112Cpolycystid B148Cpolycystid B111Cpolycystid B102Cmonilifera B119Cmonilifera B318Cmonilifera B095CMONILIFERA B092Cmonilifera B159Csubfarcina A154Cscalaris A292Cscalaris A469Cscalaris B178Cscalaris B321 Csp B336Cdistenta B337Cdistenta B336Cscalaris B104Cplatylobi A168Cplatylobiu B149Cycongesta B152Ccongesta B101Cretroflexa A080Cretroflexa A196Cretroflexa A085Cretroflexa B335Ccongesta B166Csubfarcina B116Ccongesta B115Ccongesta B121Cretroflexa
GAGCATGCTTGTCGGGGAGGAGGAGGCGAAAAATCGCCCACGGCCTTGGAGTGGGTTAATAAAAT-----CCCCTCCG GAGCATGCTTGTCGGGGAGGAGGAGGCGAAAAATCGCCCACGGCCTTGGAGTGGGTTAATAAAAT-----CCCCTCCG GAGCATGCTTGTCGGGGAGGAGGAGGCGAAAAATCGCCCACGGTCTTGGAGTGAGTTAATAATAT--TATCCCCTCCG GAGCATGCTTGTCGGGGAGGAGGAGGCGAAAAATCGCCCACGGTCTTGGAGTGAGTTAATAATAT--TATCCCCTCCG GAGCATGCTTGTCGGGGAGGAGGAGGCGAAAAATCGCCCACGGTCTTGGAGTGAGTTAATAATAT--TATCCCCTCCG GAGCATGCTTGTCGGGGAGGAGGAGGCGAAAAATCGCCCACGGTCTTGGAGTGAGTTAATAATAT--TATCCCCTCCG GAGCATGCTTGTCGGGGAGGAGGAGGCGAAAAATCGCCCACGGTCTTGGAGTGAGTTAATAATAT--TATCCCCTCCG GAGCATGCTTGTCGGGGAGGAGGAGGCGAAAAATCGCCCACGGTCTTGGAGTGAGTTAATAATAT--TATCCCCTCCG GAGCATGCTTGTCGGGGAGGAGGAGGCGAAAAATCGCCCACGGTCTTGGAGTGAGTTAATAATAT--TATCCCCTCCG GAGCATGCTTGTCGGGGAGGAGGAGGCGAAAAATCGCCCACGGTCTTGGAGTGAGTTAATAATAT--TATCCCCTCCG GAGCATGCTTGTCGGGGAGGAGGAGGCGAAAAATCGCCCACGGTCTTGGAGTGAGTTAATAATAT--TATCCCCTCCG GAGCATGCTTGTCGGGGAGGAGGAGGCGAAAAATCGCCCACGGTCTTGGAGTGAGTTAATAATAT--TATCCCCTCCG GAGCATGCTTGTCGGGGAGGAGGAGGCGAAAAATCGCCCACGGTCTTGGAGTGAGTTAATAATAT--TATCCCCTCCG GAGCATGCTTGTCGGGGAGGAGGAGGCGAAAAATCGCCCACGGTCTTGGAGTGAGTTAATAATAT--TATCCCCTCCG GAGCATGCTTGTCGGGGAGGAGGAGGCGAAAAATCGCCCACGGTCTTGGAGTGAGTTAATAATAT--TATCCCCTCCG GAGCATGCTTGTCGGGGAGGAGGAGGCGAAAAATCGCCCACGGTCTTGGAGTGAGTTAATAATAT--TATCCCCTCCG GAGCATGCTTGTCGGGGAGGAGGAGGCGAAAAATCGCCCACGGTCTTGGAGTGAGTTAATAATAT--TATCCCCTCCG GAGCATGCTTGTCGGGGAGGAGGAGGCGAAAAATCGCCCACGGTCTTGGAGTGAGTTAATAATAT--TATCCCCTCCG GAGCATGCTTGTCGGGGAGGAGGAGGCGAAAAATCGCCCACGGTCTTGGAGTGAGTTAATAATAT--TATCCCCTCCG GAGCATGCTTGTCGGGGAGGAGGAGGCGAAAAATCGCCCACGGTCTTGGAGTGAGTTAATAATAT--TATCCCCTCCG GAGCATGCTTGTCGGGGAGGAGGAGGCGAAAAATCGCCCACGGTCTTGGAGTGAGTTAATAATAT--TATCCCCTCCG GAGCATGCTTGTCGGGGAGGAGGAGGCGAAAAATCGCCCACGGTCTTGGAGTGAGTTAATAATAT--TATCCCCTCCG GAGCATGCTTGTCGGGGAGGAGGAGGCGAAAAATCGCCCACGGTCTTGGAGTGAGTTAATAATAT--TATCCCCTCCG GAGCATGCTTGTCGGGGAGGAGGAGGCGAAAAATCGCCCACGGTCTTGGAGTGAGTTAATAATAT--TATCCCCTCCG GAGCATGCTTGTCGGGGAGGAGGAGGCGAAAAATCGCCCACGGTCTTGGAGTGAGTTAATAATATATTATCCCCTCCG GAGCATGCTTGTCGGGGAGGAGGAGGCGAAAAATCGCCCACGGTCTTGGAGTGAGTTAATAATATATTATCCCCTCCG GAGCATGCTTGTCGGGGAGGAGGAGGCGAAAAATCGCCCACGGTCTTGGAGTGAGTTAATAATATATTATCCCCTCCG GAGCATGCTTGTCGGGGAGGAGGAGGCGAAAAATCGCCCACGGTCTTGGAGTGAGTTAATAATATATTATCCCCTCCG GAGCATGCTTGTCGGGGAGGAGGAGGCGAAAAATCGCCCACGGTCTTGGAGTGAGTTAATAATATATTATCCCCTCCG GAGCATGCTTGTCGGGGAGGAGGAGGCGAAAAATCGCCCACGGTCTTGGAGTGAGTTAATAATATATTATCCCCTCCG GAGCATGCTTGTCGGGGAGGAGGAGGCGAAAAATCGCCCACGGTCTTGGAGTGAGTTAATAATATATTATCCCCTCCG GAGCATGCTTGTCGGGGAGGAGGAGGCGAAAAATCGCCCACGGTCTTGGAGTGAGTTAATAATATATTATCCCCTCCG GAGCATGCTTGTCGGGGAGGAGGAGGCGAAAAATCGCCCACGGCCTTGGAGTGGGTTA-TAATA-A-TATCCCCTCCG GAGCATGCTTGTCGGGGAGGAGGAGGCGAAAAATCGCCCACGGCCTTGGAGTGGGTTA-TAATA-A-TATCCCCTCCG GAGCATGCTTGTCGGGGAGGAGGAGGCGAAAAATCGCCCACGGTCTTGGAGTGAGTTAATAATAT--TATCCCCTCCG GAGCATGCTTGTCGGGGAGGAGGAGGCGAAAAATCGCCCACGGTCTTGGAGTGAGTTAATAATAT--TATCCCCTCCG GAGCATGCTTGTCGGGGAGGAGGAGGCGAAAAATCGCCCACGGTCTTGGAGTGAGTTAATAATAT--TATCCCCTCCG GAGCATGCTTGTCGGGGAGGAGGAGGCGAAAAATCGCCCACGGTCTTGGAGTGAGTTAATAATAT--TATCCCCTCCG GAGCATGCTTGTCGGGGAGGAGGAGGCGAAAAATCGCCCACGGTCTTGGAGTGAGTTAATAATAT--TATCCCCTCCG GAGCATGCTTGTCGGGGAGGAGGAGGCGAAAAATCGCCCACGGTCTTGGAGTGAGTTAATAATAT--TATCCCCTCCG GAGCATGCTTGTCGGGGAGGAGGAGGCGAAAAATCGCCCACGGTCTTGGAGTGAGTTAATAATAT--TATCCCCTCCG GAGCATGCTTGTCGGGGAGGAGGAGGCGAAAAATCGCCCACGGTCTTGGAGTGAGTTAATAATAT--TATCCCCTCCG GAGCATGCTTGTCGGGGAGGAGGAGGCGAAAAATCGCCCACGGTCTTGGAGTGAGTTAATAATAT--TATCCCCTCCG GAGCATGCTTGTCGGGGAGGAGGAGGCGAAAAATCGCCCACGGTCTTGGAGTGAGTTAATAATAT--TATCCCCTCCG GAGCATGCTTGTCGGGGAGGAGGAGGCGAAAAATCGCCCACGGTCTTGGAGTGGGTTAATAATAT--TATCCCCTCCG

B174Lquercifoli AGGCGGTGGCGCGGACTCTGCGTGTTCCGGGGGACGA--------CGGAAGTACGTCGT----CCCCCGAGCTCACCC B090Cmoniliform AGGCGGTGGCGCGGACTCTGCGTGTTCCGGGGGACGA--------CGAGAGTACGTCGT----ACCCTGAGTTCACCC B114 Cexpansa AGGCGGTGGCGCGGACTCTGCGTGTTCCGGGGGACGAGACGACGACGAGAGTACGTCGTCGTTCCCCTGAGTTCACCC B109Cretorta AGGCGGTGGCGCGGACTCTGCGTGTCCCGGGGGACGAGACGACGACGAAAGTACGTCGT---TCCCCTGAGTTCACCC B131Cretorta AGGCGGTGGCGCGGACTCTGCGTGTCCCGGGGGACGAGACGACGACGAAAGTACGTCGT---TCCCCTGAGTTCACCC B415Cretroflexa AGGCGGTGGCGCGGACTCTGCGTGTCCCGGGGGACGAGACGACGACGAAAGTACGTCGT---TCCCCTGAGTTCACCC B118Csiliquosa AGGCGGTGGCGCGGACTCTGCGTGTCCCGGGGGACGAGACGACGACGAAAGTACGTCGT---TCCCCTGAGTTCACCC B143Csiliquosa AGGCGGTGGCGCGGACTCTGCGTGTCCCGGGGGACGAGACGACGACGAAAGTACGTCGT---TCCCCTGAGTTCACCC B100Csubfarcina AGGCGGTGGCGCGGACTCTGCGTGTCCCGGGGGACGAGACGACGACGAAAGTACGTCGT---TCCCCTGAGTTCACCC B146Csubfarcina AGGCGGTGGCGCGGACTCTGCGTGTCCCGGGGGACGAGACGACGACGAAAGTACGTCGT---TCCCCTGAGTTCACCC B153Csubfarcina AGGCGGTGGCGCGGACTCTGCGTGTCCCGGGGGACGAGACGACGACGAAAGTACGTCGT---TCCCCTGAGTTCACCC B110Csubfarcina AGGCGGTGGCGCGGACTCTGCGTGTCCCGGGGGACGAGACGACGACGAAAGTACGTCGT---TCCCCTGAGTTCACCC B127Csubfarcina AGGCGGTGGCGCGGACTCTGCGTGTCCCGGGGGACGAGACGACGACGAAAGTACGTCGT---TCCCCTGAGTTCACCC B168Csubfarcina AGGCGGTGGCGCGGACTCTGCGTGTCCCGGGGGACGAGACGACGACGAAAGTACGTCGT---TCCCCTGAGTTCACCC B136Csubfarcina AGGCGGTGGCGCGGACTCTGCGTGTCCCGGGGGACGAGACGACGACGAAAGTACGTCGT---TCCCCTGAGTTCACCC B161Cretroflexa AGGCGGTGGCGCGGACTCTGCGTGTCCCGGGGGACGAGACGACGACGAAAGTACGTCGT---TCCCCTGAGTTCACCC B103Ctorulosa AGGCGGTGGCGCGGACTCTGCGTGTCCCGGGGGACGAGACGACGACGAAAGTACGTCGT---TCCCCTGAGTTCACCC B125Ctorulosa AGGCGGTGGCGCGGACTCTGCGTGTCCCGGGGGACGAGACGACGACGAAAGTACGTCGT---TCCCCTGAGTTCACCC B179Ctorulosa AGGCGGTGGCGCGGACTCTGCGTGTCCCGGGGGACGAGACGACGACGAAAGTACGTCGT---TCCCCTGAGTTCACCC B165Ctorulosa AGGCGGTGGCGCGGACTCTGCGTGTCCCGGGGGACGAGACGACGACGAAAGTACGTCGT---TCCCCTGAGTTCACCC B171Cpolycystid AGGCGGTGGCGCGGACTCTGCGTGTTCCGGGGGACGAGACGGCGACGAAAGTACGTCGT---TCCCCTGAGTTCACCC B112Cpolycystid AGGCGGTGGCGCGGACTCTGCGTGTTCCGGGGGACGAGACGGCGACGAAAGTACGTCGT---TCCCCTGAGTTCACCC B148Cpolycystid AGGCGGTGGCGCGGACTCTGCGTGTTCCGGGGGACGAGACGGCGACGAAAGTACGTCGT---TCCCCTGAGTTCACCC B111Cpolycystid AGGCGGTGGCGCGGACTCTGCGTGTTCCGGGGGACGAGACGGCGACGAAAGTACGTCGT---TCCCCTGAGTTCACCC B102Cmonilifera AGGCGGTGGCGCGGACTCTGCGTGTCCCGGGGGACGAGACGACGACGAAAGTACGTCGT---TCCCCTGAGTTCACCC B119Cmonilifera AGGCGGTGGCGCGGACTCTGCGTGTCCCGGGGGACGAGACGACGACGAAAGTACGTCGT---TCCCCTGAGTTCACCC B318Cmonilifera AGGCGGTGGCGCGGACTCTGCGTGTCCCGGGGGACGAGACGACGACGAAAGTACGTCGT---TCCCCTGAGTTCACCC B095CMONILIFERA AGGCGGTGGCGCGGACTCTGCGTGTCCCGGGGGACGAGACGACGACGAAAGTACGTCGT---TCCCCTGAGTTCACCC B092Cmonilifera AGGCGGTGGCGCGGACTCTGCGTGTCCCGGGGGACGAGACGACGACGAAAGTACGTCGT---TCCCCTGAGTTCACCC B159Csubfarcina AGGCGGTGGCGCGGACTCTGCGTGTTCCGGGGGACGAGACGACGACGAAAGTACGTCGT---TCCCCTGAGTTCACCC 
Appendix 5. (Continued)

A154Cscalaris A292Cscalaris A469Cscalaris B178Cscalaris B321Csp B336Cdistenta B337Cdistenta B336Cscalaris B104Cplatylobiu A168Cplatylobiu B149Cycongesta B152Ccongesta B101Cretroflexa A080Cretroflexa A196Cretroflexa A085Cretroflexa B335Ccongesta B166Csubfarcina B116Ccongesta B115Ccongesta B121Cretroflexa

AGGCGGTGGCGCGGACTCTGCGTGTTCCGGGGGACGAGACGACGACGAAAGTTCGTCGT---TCCCCTGAGTTCACCC AGGCGGTGGCGCGGACTCTGCGTGTTCCGGGGGACGAGACGACGACGAAAGTTCGTCGT---TCCCCTGAGTTCACCC AGGCGGTGGCGCGGACTCTGCGTGTTCCGGGGGACGAGACGACGACGAAAGTTCGTCGT---TCCCCTGAGTTCACCC AGGCGGTGGCGCGGACTCTGCGTGTTCCGGGGGACGAGACGACGACGAAAGTTCGTCGT---TCCCCTGAGTTCACCC AGGCGGTGGCGCGGACTCTGCGTGTTCCGGGGGACGAGACGACGACGAAAGTTCGTCGT---TCCCCTGAGTTCACCC AGGCGGTGGCGCGGACTCTGCGTGTTCCGGGGGACGAGACGACGACGAAAGTTCGTCGT---TCCCCTGAGTTCACCC AGGCGGTGGCGCGGACTCTGCGTGTTCCGGGGGACGAGACGACGACGAAAGTTCGTCGT---TCCCCTGAGTTCACCC AGGCGGTGGCGCGGACTCTGCGTGTTCCGGGGGACGAGACGACGACGAAAGTTCGTCGT---TCCCCTGAGTTCACCC AGGCGGTGGCGCGGACTCTGCGTGTCCCGGGGGACGA-----------GTACGTCGT---TCCCCTGAGTTCACCC

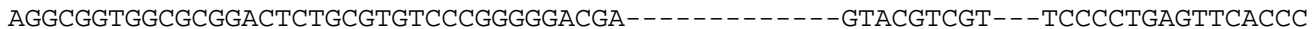
AGGCGGTGGCGCGGACTCTGCGTGTTCCGGGGGACGAGACGACGACGAAAGTACGTCGT---TCCCCTGAGTTCACCC AGGCGGTGGCGCGGACTCTGCGTGTTCCGGGGGACGAGACGACGACGAAAGTACGTCGT---TCCCCTGAGTTCACCC AGGCGGTGGCGCGGACTCTGCGTGTTCCGGGGGACGAGACGACGACGAAAGTACGTCGT---TCCCCTGAGTTCACCC AGGCGGTGGCGCGGACTCTGCGTGTTCCGGGGGACGAGACGACGACGAAAGTACGTCGT---TCCCCTGAGTTCACCC AGGCGGTGGCGCGGACTCTGCGTGTTCCGGGGGACGAGACGACGACGAAAGTACGTCGT---TCCCCTGAGTTCACCC AGGCGGTGGCGCGGACTCTGCGTGTTCCGGGGGACGAGACGACGACGAAAGTACGTCGT---TCCCCTGAGTTCACCC AGGCGGTGGCGCGGACTCTGCGTGTTCCGGGGGACGAGACGACGACGAAAGTACGTCGT---TCCCCTGAGTTCACCC AGGCGGTGGCGCGGACTCTGCGTGTCCCGGGGGACGAGACGACGACGAAAGTACGTCGT---TCCCCTGAGTTCACCC AGGCGGTGGCGCGGACTCTGCGTGTTCCGGGGGACGAGACGACGACGAAAGTACGTCGT---TCCCCTGAGTTCACCC AGGCGGTGGCGCGGACTCTGCGTGTTCCGGGGGACGAGACGACGACGAAAGTACGTCGT---TCCCCTGAGTTCACCC AGGCGGTGGCGCGGACTCTGCGTGTTCCGGGGGACGAGACGACGACGAAAGTACGTCGT---TCCCCTGAGTTCACCC

B174 Lquercifoli AAGGCTGGAGGGCAACCGACCGGCCGGCCA----CGAGTTGCGGCG---CCGGAGGCGTTCGCTTCAAGGCCCCCCCC B090Cmoniliform AAGGCTGGAGGGCAACCGACCGGCCGGCCGGCCACGAGTTGCGGCG---CTGGAGGCGTTCACTTCGA--TGCCCTCC B114 Cexpansa AAGGCTGGAGGGCAACCGACCGACCGGCCGACCACGAGTCG-----------AGGCGTTCGCTTCTAA-CGCCCTTC B109Cretorta AAGGCTGGAGGGCAACCGACCGGCCGGCCA----CGAGTTGCGGCG---CCGGAGGCGTTCGCTTCAA--CGCCCTTC B131Cretorta AAGGCTGGAGGGCAACCGACCGGCCGGCCA----CGAGTTGCGGCG---CCGGAGGCGTTCGCTTCAA--CGCCCTTC B415Cretroflexa AAGGCTGGAGGGCAACCGACCGGCCGGCCA----CGAGTTGCGGCGGCGCCGGAGGCGTTCGCTTCAA--CGCCCTTC B118Csiliquosa AAGGCTGGAGGGCAACCGACCGGCCGGCCA----CGAGTTGCGGCGGCGCCGGAGGCGTTCGCTTCAA--CGCCCTTC B143Csiliquosa AAGGCTGGAGGGCAACCGACCGGCCGGCCA----CGAGTTGCGGCGGCGCCGGAGGCGTTCGCTTCAA--CGCCCTTC B100Csubfarcina AAGGCTGGAGGGCAACCGACCGGCCGGCCA----CGAGTTGCGGCG---CCGGAGGCGTTCGCTTCAA--CGCCCTTC B146Csubfarcina AAGGCTGGAGGGCAACCGACCGGCCGGCCA----CGAGTTGCGGCG---CCGGAGGCGTTCGCTTCAA--CGCCCTTC B153Csubfarcina AAGGCTGGAGGGCAACCGACCGGCCGGCCA----CGAGTTGCGGCG---CCGGAGGCGTTCGCTTCAA--CGCCCTTC B110Csubfarcina AAGGCTGGAGGGCAACCGACCGGCCGGCCA----CGAGTTGCGGCG---CCGGAGGCGTTCGCTTCAA--CGCCCTTC B127Csubfarcina AAGGCTGGAGAGCAACCGACCGGCCGGCCA----CGAGTTGCGGCG---CCGGAGGCGTTCGCTTCAA--CGCCCTTC B168Csubfarcina AAGGCTGGAGGGCAACCGACCGGCCGGCCA----CGAGTTGCGGCG---CCGGAGGCGTTCGCTTCAA--CGCCCTTC B136Csubfarcina AAGGCTGGAGGGCAACCGACCGGCCGGCCA----CGAGTTGCGGCG---CCGGAGGCGTTCGCTTCAA--CGCCCTTC B161Cretroflexa AAGGCTGGAGGGCAACCGACCGGCCGGCCA----CGAGTTGCGGCG---CCGGAGGCGTTCGCTTCAA--CGCCCTTC B103Ctorulosa AAGGCTGGAGAGCAACCGACCGGCCGGCCA----CGAGTTGCGGCG---CCGGAGGCGTTCGCTTCAA--CGCCCTTC B125Ctorulosa AAGGCTGGAGGGCAACCGACCGGCCGGCCA----CGAGTTGCGGCG---CCGGAGGCGTTCGCTTCAA--CGCCCTTC B179Ctorulosa AAGGCTGGAGAGCAACCGACCGGCCGGCCA----CGAGTTGCGGCG---CCGGAGGCGTTCGCTTCAA--CGCCCTTC B165Ctorulosa AAGGCTGGAGAGCAACCGACCGGCCGGCCA----CGAGTTGCGGCG---CCGGAGGCGTTCGCTTCAA--CGCCCTTC B171Cpolycystid AAGGCTGGAGGGCAACCGACCGGCCGGCCT----CGAGTTGCGGCG---CCGGAGGCGTTCGCTTCAA--CGCCCTTC B112Cpolycystid AAGGCTGGAGGGCAACCGACCGGCCGGCCT----CGAGTTGCGGCG---CCGGAGGCGTTCGCTTCAA--CGCCCTTC B148Cpolycystid AAGGCTGGAGGGCAACCGACCGGCCGGCCT----CGAGTTGCGGCG---CCGGAGGCGTTCGCTTCAA--CGCCCTTC B111Cpolycystid AAGGCTGGAGGGCAACCGACCGGCCGGCCT----CGAGTTGCGGCG---CCGGAGGCGTTCGCTTCAA--CGCCCTTC B102Cmonilifera AAGGTTGGAGGGCAACCGACCGGCCGGCCG----CGAGTTGCGGCG---CCGGAGGCGTTCGCTTCAA--CGCCCTTC B119Cmonilifera AAGGTTGGAGGGCAACCGACCGGCCGGCCG----CGAGTTGCGGCG---CCGGAGGCGTTCGCTTCAA--CGCCCTTC B318Cmonilifera AAGGTTGGAGGGCAACCGACCGGCCGGCCG----CGAGTTGCGGCG---CCGGAGGCGTTCGCTTCAA--CGCCCTTC B095CMONILIFERA AAGGTTGGAGGGCAACCGACCGGCCGGCCG----CGAGTTGCGGCG---CCGGAGGCGTTCGCTTCAA--CGCCCTTC B092Cmonilifera AAGGTTGGAGGGCAACCGACCGGCCGGCCG----CGAGTTGCGGCG---CCGGAGGCGTTCGCTTCAA--CGCCCTTC B159Csubfarcina AAGGCTGGAGGGCAACCGACCGGCCGGCCG----CGAGTTGCGGCG---CCAGAGGCGTTCGCTTCAA--CGCCCTTC A154Cscalaris AAGGCTGGAGGGCAACCGACCGGCCGGCCG----CGAGTTGCGGCG---CCAGAGGCGTTCGCTTCAA--CGCCCTTC A292Cscalaris AAGGCTGGAGGGCAACCGACCGGCCGGCCG----CGAGTTGCGGCG---CCAGAGGCGTTCGCTTCAA--CGCCCTTC A469Cscalaris AAGGCTGGAGGGCAACCGACCGGCCGGCCG----CGAGTTGCGGCG---CCAGAGGCGTTCGCTTCAA--CGCCCTTC B178Cscalaris AAGGCTGGAGGGCAACCGACCGGCCGGCCG----CGAGTTGCGGCG---CCAGAGGCGTTCGCTTCAA--CGCCCTTC B321Csp B336Cdistenta B337Cdistenta B336Cscalaris B104Cplatylobiu A168Cplatylobiu B149Cycongesta B152Ccongesta AAGGCTGGAGGGCAACCGACCGGCCGGCCG----CGAGTTGCGGCG---CCAGAGGCGTTCGCTTCAA--CGCCCTTC AAGGCTGGAGGGCAACCGACCGGCCGGCCG----CGAGTTGCGGCG---CCAGAGGCGTTCGCTTCAA--CGCCCTTC AAGGCTGGAGGGCAACCGACCGGCCGGCCG----CGAGTTGCGGCG---CCAGAGGCGTTCGCTTCAA--CGCCCTTC AAGGCTGGAGGGCAACCGACCGGCCGGCCG----CGAGTTGCGGCG---CCAGAGGCGTTCGCTTCAA--CGCCCTTC AAGGCTGGAGGGCAACCGACCGGCCGGCCA----CGAGTTGCGGCG---CCTTAGGCGTTCGCTTCAA--CGCCCTTC AAGGCTGGAGGGCAACCGACCGGCCGGCCA----CGAGTTGCGGCG---CCTTAGGCGTTCGCTTCAA--CGCCCTTC AAGGCTGGAGGGCAACCGACCGGCCGGCCG----CGAGTTGCGGCG---CCAGAGGCGTTCGCTTCAA--CGCCCTTC AAGGCTGGAGGGCAACCGACCGGCCGGCCG----CGAGTTGCGGCG---CCAGAGGCGTTCGCTTCAA--CGCCCTTC B101Cretroflexa AAGGCTGGAGGGCAACCGACCGGCCGGCCG----CGAGTTGCGGCG---CCAGAGGCGTTCGCTTCAA--CGCCCTTC A080Cretroflexa AAGGCTGGAGGGCAACCGACCGGCCGGCCG----CGAGTTGCGGCG---CCAGAGGCGTTCGCTTCAA--CGCCCTTC A196Cretroflexa AAGGCTGGAGGGCAACCGACCGGCCGGCCG----CGAGTTGCGGCG---CCAGAGGCGTTCGCTTCAA--CGCCCTTC A085Cretroflexa AAGGCTGGAGGGCAACCGACCGGCCGGCCG----CGAGTTGCGGCG---CCAGAGGCGTTCGCTTCAA--CGCCCTTC B335Ccongesta AAGGCTGGAGGGCAACCGACCGGCCGGCCG----CGAGTTGCGGCG---CCAGAGGCGTTCGCTTCAA--CGCCCTTC B166Csubfarcina AAGGCTGGAGGGCAACCGACCGGCCGGCCA----CGAGTTGCGGCG---CCGGAGGCGTTCGCTTCAA--CGCCCTTC B116Ccongesta AAGGCTGGAGGGCAACCGACCGGCCGGCCG----CGAGTTGCGGCG---CCAGAGGCGTTCGCTTCAA--CGCCCTTC B115Ccongesta AAGGCTGGAGGGCAACCGACCGGCCGGCCG----CGAGTTGCGGCG---CCAGAGGCGTTCGCTTCAA--CGCCCTTC B121Cretroflexa AAGGCTGGAGGGCAACCGACCGGCCGGCCG----CGAGTTGCGGCG---CCAGAGGCGTTCGCTTCAA--CGCCCTTC

B174Lquercifoli GGACGAGCCGTTGTTGACGGCGCCCCCTTCGCGGGGCGGGGACACGACGGGTCGCTCGGGGTG-GA-GCTTGGACGAG B090Cmoniliform GGACGAGCCGTTGTTGACGGCGCCCCCTTCGCGGGGCGGGGACACGACGGGTCGCTCGGGGTGA---GCTTGGACGAG 
Appendix 5. (Continued)

B114Cexpansa B109Cretorta B131Cretorta B415Cretroflexa B118Csiliquosa B143Csiliquosa B100Csubfarcina B146Csubfarcina B153Csubfarcina B110Csubfarcina B127Csubfarcina B168Csubfarcina B136Csubfarcina B161Cretroflexa B103Ctorulosa B125Ctorulosa B179Ctorulosa B165Ctorulosa B171Cpolycystid B112Cpolycystid B148Cpolycystid B111Cpolycystid B102Cmonilifera B119Cmonilifera B318Cmonilifera B0 95CMONILIFERA B092Cmonilifera B159Csubfarcina A154Cscalaris A292Cscalaris A469Cscalaris B178Cscalaris B321 Csp B336Cdistenta B337Cdistenta B336Cscalaris B104Cplatylobiu A168Cplatylobiu B149Cycongesta B152Ccongesta B101Cretroflexa A080Cretroflexa A196Cretroflexa A085Cretroflexa B335Ccongesta B166Csubfarcina B116Ccongesta B115Ccongesta B121Cretroflexa

B174Lquercifoli B090Cmoniliform B114 Cexpansa B109Cretorta B131Cretorta B415Cretroflexa B118Csiliquosa B143Csiliquosa B100Csubfarcina B146Csubfarcina B153Csubfarcina B110Csubfarcina B127Csubfarcina B168Csubfarcina B136Csubfarcina B161Cretroflexa B103Ctorulosa B125Ctorulosa B179Ctorulosa B165Ctorulosa B171Cpolycystid B112Cpolycystid B148Cpolycystid B111Cpolycystid B102Cmonilifera B119Cmonilifera
GGACGAGCCGTTGTTGACGGCGCCCCCTTCGCGGGGCGGGGACACGACGGGTCGCTCGGGGTGGGAAGCTTAGAC--GGACGAGCTGTTGTTGACGGCGCCCCCTTCGCGGGGCGGGGACACGACGGGTCGCTCGGGGTGAG----------GGACGAGCTGTTGTTGACGGCGCCCCCTTCGCGGGGCGGGGACACGACGGGTCGCTCGGGGTGAG-----------GGACGAGCTGTTGTTGACGGCGCCCCCTTCGCGGGGCGGGGACACGACGGGTCGCTCGGGGTGAG-----------GGACGAGCTGTTGTTGACGGCGCCCCCTTCGCGGGGCGGGGACACGACGGGTCGCTCGGGGTGAG----------GGACGAGCTGTTGTTGACGGCGCCCCCTTCGCGGGGCGGGGACACGACGGGTCGCTCGGGGTGAG------------GGACGAGCTGTTGTTGACGGCGCCCCCTTCGCGGGGCGGGGACACGACGGGTCGCTCGGGGTGAT----------GGACGAGCTGTTGTTGACGGCGCCCCCTTCGCGGGGCGGGGACACGACGGGTCGCTCGGGGTGAT----------GGACGAGCTGTTGTTGACGGCGCCCCCTTCGCGGGGCGGGGACACGACGGGTCGCTCGGGGTGAT-----------

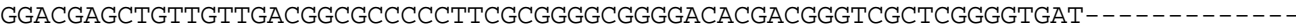
GGACGAGCTGTTGTTGACGGCGCCCCCTTCGCGGGGCGGGGACACGACGGGTCGCTCGGGGTGAT-----------GGACGAGCTGTTGTTGACGGCGCCCCCTTCGCGGGGCGGGGACACGACGGGTCGCTCGGGGTGAT-----------GGACGAGCTGTTGTTGACGGCGCCCCCTTCGCGGGGCGGGGACACGACGGGTCGCTCGGGGTGAT-- - - - - - GGACGAGCTGTTGTTGACGGCGCCCCCTTCGCGGGGCGGGGACACGACGGGTCGCTCGGGGTGAT----------GGACGAGCTGTTGTTGACGGCGCCCCCTTCGCGGGGCGGGGACACGACGGGTCGCTCGGGGTGAT----------GGACGAGCTGTTGTTGACGGCGCCCCCTTCGCGGGGCGGGGACACGACGGGTCGCTCGGGGTGAT-----------GGACGAGCTGTTGTTGACGGCGCCCCCTTCGCGGGGCGGGGACACGACGGGTCGCTCGGGGTGAT-----------GGACGAGCTGTTGTTGACGGCGCCCCCTTCGCGGGGCGGGGACACGACGGGTCGCTCGGGGTGAT----------GGACGAGCTGTTGTTGACGGCGCCCCCTTCGCGGGGCGGGGACACGACGGGTCGCTCGGGGTGAT------------GGACGAGCTGTTGTTGACGGCGCCCCCTTCGCGGGGCGGGGACACGACGGGTCGCTCGGGGTGAT-----------GGACGAGCTGTTGTTGACGGCGCCCCCTTCGCGGGGCGGGGACACGACGGGTCGCTCGGGGTGAT---------GGACGAGCTGTTGTTGACGGCGCCCCCTTCGCGGGGCGGGGACACGACGGGTCGCTCGGGGTGAT-----------GGACGAGCTGTTGTTGACGGCGCCCCCTTCGCGGGGCGGGGACACGACGGGTCGCTCGGGGTGAT-----------GGACGAGCTGTTGTTGACGGCGCCCCCTTCGCGGGGCGGGGACACGACGGGTCGCTCGGGGTGAT-----------GGACGAGCTGTTGTTGACGGCGCCCCCTTCGCGGGGCGGGGACACGACGGGTCGCTCGGGGTGAT----------GGACGAGCTGTTGTTGACGGCGCCCCCTTCGCGGGGCGGGGACACGACGGGTCGCTCGGGGTGAT----------GGACGAGCTGTTGTTGACGGCGCCCCCTTCGCGGGGCGGGGACACGACGGGTCGCTCGGGGTGAT-----------GGACGAGCTGTTGTTGACGGCGCCCCCTTCGCGGGGCGGGGACACGACGGGTCGCTCGGGGTGAT------------

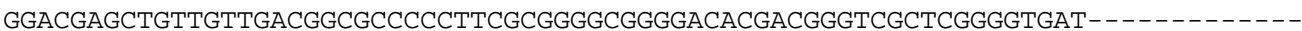
GGACGAGCTGTTGTTGACGGCGCCCCCTTCGCGGGGCGGGGACACGACGGGTCGCTCGGGGTGAT-----------

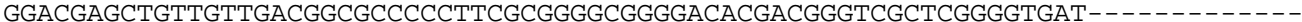
GGACGAGCTGTTGTTGACGGCGCCCCCTTCGCGGGGCGGGGACACGACGGGTCGCTCGGGGTGAT-----------GGACGAGCTGTTGTTGACGGCGCCCCCTTCGCGGGGCGGGGACACGACGGGTCGCTCGGGGTGAT-_-_-.--_-_GGACGAGCTGTTGTTGACGGCGCCCCCTTCGCGGGGCGGGGACACGACGGGTCGCTCGGGGTGAT-----------GGACGAGCTGTTGTTGACGGCGCCCCCTTCGCGGGGCGGGGACACGACGGGTCGCTCGGGGTGAT-----------GGACGAGCTGTTGTTGACGGCGCCCCCTTCGCGGGGCGGGGACACGACGGGTCGCTCGGGGTGAT-----------GGACGAGCTGTTGTTGACGGCGCCCCCTTCGCGGGGCGGGGACACGACGGGTCGCTCGGGGTGAG----------GGACGAGCTGTTGTTGACGGCGCCCCCTTCGCGGGGCGGGGACACGACGGGTCGCTCGGGGTGAG----------GGACGAGCTGTTGTTGACGGCGCCCCCTTCGCGGGGCGGGGACACGACGGGTCGCTCGGGGTGAT----------GGACGAGCTGTTGTTGACGGCGCCCCCTTCGCGGGGCGGGGACACGACGGGTCGCTCGGGGTGAT-----------GGACGAGCTGTTGTTGACGGCGCCCCCTTCGCGGGGCGGGGACACGACGGGTCGCTCGGGGTGAT----------GGACGAGCTGTTGTTGACGGCGCCCCCTTCGCGGGGCGGGGACACGACGGGTCGCTCGGGGTGAT-----------GGACGAGCTGTTGTTGACGGCGCCCCCTTCGCGGGGCGGGGACACGACGGGTCGCTCGGGGTGAT-----------GGACGAGCTGTTGTTGACGGCGCCCCCTTCGCGGGGCGGGGACACGACGGGTCGCTCGGGGTGAT----------GGACGAGCTGTTGTTGACGGCGCCCCCTTCGCGGGGCGGGGACACGACGGGTCGCTCGGGGTGAT----------GGACGAGCTGTTGTTGACGGCGCCCCCTTCGCGGGGCGGGGACACGACGGGTCGCTCGGGGTGAT----------GGACGAGCTGTTGTTGACGGCGCCCCCTTCGCGGGGCGGGGACACGACGGGTCGCTCGGGGTGAT-----------GGACGAGCTGTTGTTGACGGCGCCCCCTTCGCGGGGCGGGGACACGACGGGTCGCTCGGGGTGAT-----------GGACGAGCTGTTGTTGACGGCGCCCCCTTCGCGGGGCGGGGACACGACGGGTCGCTCGGGGTGAT-----------_

GACAGCGTCGCTCGATCGCTC---------------GAGGGCCGGAAGGGAGGTAGGCTCGTGA----CGAC-GA-GACAGCGTCGCTCGATCGCTCGATCGCTCGATCGCTCGAGGGCCGGAAGGGAGGTAGGCTCGTG-----CGACT-------------------------------------GAGG-CCGGAAGGGAGGTAGGCTCGTGA----GGACTG---

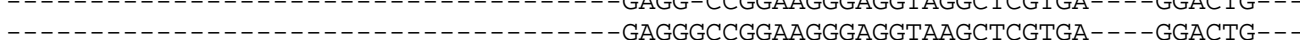
----------------------------------GAGGGCCGGAAGGGAGGTAAGCTCGTGA----GGACTG--GAGGGCCGGAAGGGAGGTAAGCTCGTGA----GGACTG--GAGGGCCGGAAGGGAGGTAAGCTCGTGA----GGACTG--GAGGGCCGGAAGGGAGGTAAGCTCGTGA----GGACTG--GAGGGCCGGAAGGGAGGTAGGCTCGTGA----GGACTGACT GAGGGCCGGAAGGGAGGTAGGCTCGTGA----GGACTGACT GAGGGCCGGAAGGGAGGTAGGCTCGTGA----GGACTGACT GAGGGCCGGAAGGGAGGTAGGCTCGTGA----GGACTGACT GAGGGCCGGAAGGGAGGTAGGCTCGTGA----GGACTGACT -GAGGGCCGGAAGGGAGGTAGGCTCGTGA----GGACTGACT GAGGGCCGGAAGGGAGGTAGGCTCGTGA----GGACTGACT GAGGGCCGGAAGGGAGGTAGGCTCGTGA----GGACTGACT -GAGGGCCGGAAGGGAGGTAGGCTCGTGA----GGACTGACT GAGGGCCGGAAGGGAGGTAGGCTCGTGA----GGACTGACT -GAGGGCCGGAAGGGAGGTAGGCTCGTGA----GGACTGACT GAGGGCCGGAAGGGAGGTAGGCTCGTGA----GGACTGACT -GAGGGCCGGAAGGGAGGTAGGCTCGTGA----GGACTGA-GAGGGCCGGAAGGGAGGTAGGCTCGTGA----GGACTGA-GAGGGCCGGAAGGGAGGTAGGCTCGTGA----GGACTGA-GAGGGCCGGAAGGGAGGTAGGCTCGTGA----GGACTGA-GAGGGCCGGAAGGGAGGTAGGCTCGTGA----GGACTGA-GAGGGCCGGAAGGGAGGTAGGCTCGTGA----GGACTGA-- 
Appendix 5. (Continued)

B318Cmonilifera B095CMONILIFERA B159Csubfarcina A154Cscalaris A292Cscalaris A469Cscalaris B178Cscalaris B321 Csp B336Cdistenta B337Cdistenta B336Cscalaris B104Cplatylobiu A168Cplatylobiu B149Cycongesta B152Ccongesta B101Cretroflexa A080Cretroflexa A196Cretroflexa A085Cretroflexa B335Ccongesta B166Csubfarcina B116Ccongesta B115Ccongesta B121Cretroflexa B092Cmonilifera

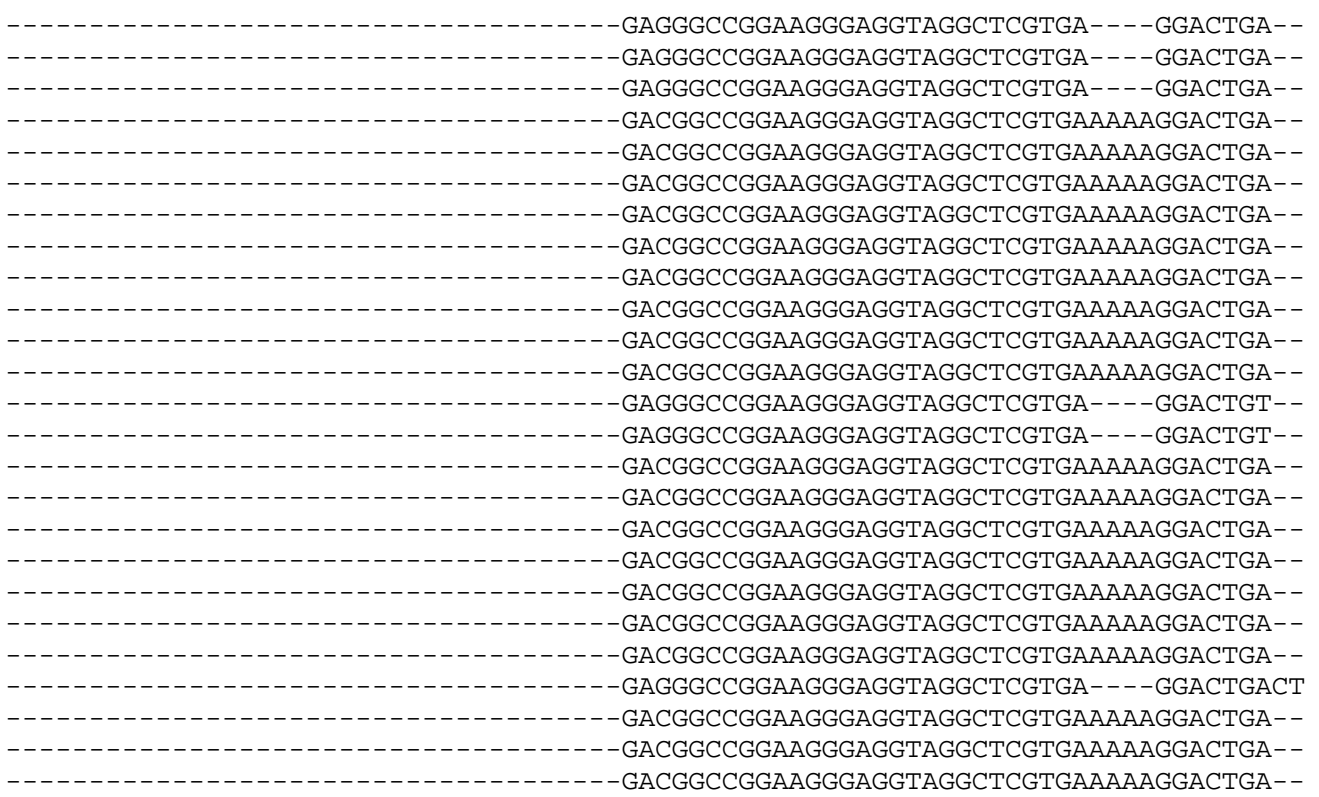

B174Lquercifolia B090Cmoniliformis B114 Cexpansa B109Cretorta B131Cretorta B415Cretroflexa B118Csiliquosa B143Csiliquosa B100Csubfarcina B146Csubfarcina B153Csubfarcina B110Csubfarcinata B127Csubfarcinata B168Csubfarcinata B136Csubfarcinata B161Cretroflexa B103Ctorulosa B125Ctorulosa B179Ctorulosa B165Ctorulosa B171Cpolycystidea B112Cpolycystidid B148Cpolycystidea B111Cpolycystidea B102Cmonilifera B119Cmonilifera B318Cmonilifera B095CMONI LIFERA B092Cmonilifera B159Csubfarcinata A154Cscalaris A292Cscalaris A469Cscalaris B178Cscalaris B336Cdistenta B337Cdistenta B336Cscalaris B104Cplatylobium A168Cplatylobium B149Cycongesta B152Ccongesta B101Cretroflexa A080Cretroflexa A196Cretroflexa A085Cretroflexa B335Ccongesta B166Csubfarcina B116Ccongesta B115Ccongesta B121Cretroflexa
-CTT------------GAACGTA-----------AAACAACG-ACGACGACGCCATACCCCCGAT ---TCTT-T--------------AAGAAAGGAACG-ACG-ACGACGACGCCATACCCCCGAT -AG-AACGAACGAACGAACGACGACGCCATACCCCCGAT -

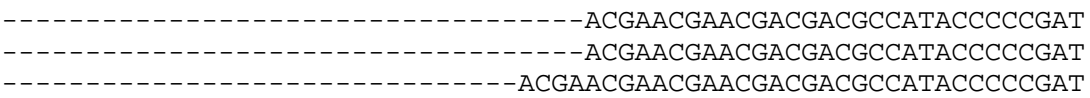
-----------------------------ACGAACGAACGAACGACGACGCCATACCCCCGAT ACTTCTT--------------------------AACGAACGACGACGCCATACCCCCGAT АСТTCTT---------------------------AACGAACGACGACGCCATACCCCCGAT ACTTCTT-----------------------------AACGAACGACGACGCCATACCCCCGAT АСТTCTT----------------------------AACGAACGACGACGCCATACCCCCGAT

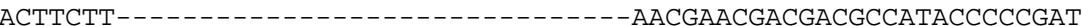
АСTTCTT-----------------------------AACGAACGACGACGCCATACCCCCGAT АСТTCTT---------------------------AACGAACGACGACGCCATACCCCCGAT АСTTCTT---------------------------AACGAACGACGACGCCATACCCCCGAT АСТTCTT---------------------------AACGAACGACGACGCCATACCCCCGAT

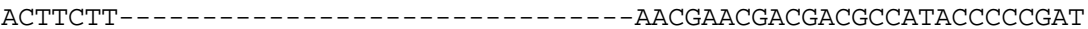

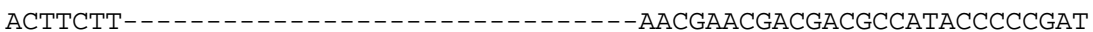
АСTTCTT-----------------------------AACGAACGACGACGCCATACCCCCGAT

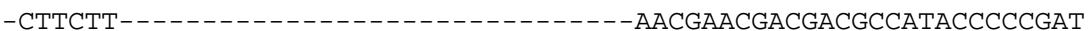
-CTTCTT------------------------------AACGAACGACGACGCCATACCCCCGAT -CTTCTT--------------------------AACGAACGACGACGCCATACCCCCGAT -CTTCTT---------------n---n---n--AACGAACGACGACGCCATACCCCCGAT - CTTCTT----------------------------AACGAACGACGACGCCATACCCCCGAT -CTTCTT--------------------------AACGAACGACGACGCCATACCCCCGAT - CTTCTT----------------------------AACGAACGACGACGCCATACCCCCGAT - CTTCTT----------------------------AACGAACGACGACGCCATACCCCCGAT

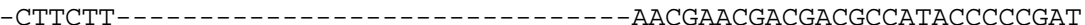
-CTTCTTCTTCTTAAGGAAGGAAGGGA----------AACGAACAACGACGCCATACCCCCGAT -CTTCTTCTTCTTAAGGAAGGA-GGGA-------AACGAACG-ACGACGACGCCATACCCCCGAT -СTTCTTCTTCTTAAGGAAGGA-GGGA------AACGAACG-ACGACGACGCCATACCCCCGAT -CTTCTTCTTCTTAAGGAAGGA-GGGA-------AACGAACG-ACGACGACGCCATACCCCCGAT -СTTCTTCTTCTTAAGGAAGGA-GGGA-------AACGAACG-ACGACGACGCCATACCCCCGAT -СTTCTTCTTCTTAAGGAAGGA-GGGA-------AACGAACG-ACGACGACGCCATACCCCCGAT -CTTCTTCTTCTTAAGGAAGGA-GGGA-------AACGAACG-ACGACGACGCCATACCCCCGAT -СTTCTTCTTCTTAAGGAAGGA-GGGA------AACGAACG-ACGACGACGCCATACCCCCGAT -CTTCT-CTTCGT--CGGTCGAA-CGA----GCGAACGAACGAACGACGACGCCATACCCCCGAT -CTTCT-CTTCGT--CGAACGAA-CGAACGAACGAACGAACGAACGACGACGCCATACCCCCGAT -CTTCTTCTTCTTAAGGAAGGAAGGGA----------AACGAACAACGACGCCATACCCCCGAT -CTTCTTCTTCTTAAGGAAGGAAGGGA----------AACGAACAACGACGCCATACCCCCGAT -CTTCTTCTTCTTAAGGAAGGAAGGGA----------AACGAACAACGACGCCATACCCCCGAT -CTTCTTCTTCTTAAGGAAGGAAGGGA----------AACGAACAACGACGCCATACCCCCGAT -CTTCTTCTTCTTAAGGAAGGAAGGGA----------AACGAACAACGACGCCATACCCCCGAT -CTTCTTCTTCTTAAGGAAGGAAGGGA----------AACGAACAACGACGCCATACCCCCGAT -CTTCTTCTTCTTAAGGAAGGAAGGGA----------AACGAACAACGACGCCATACCCCCGAT

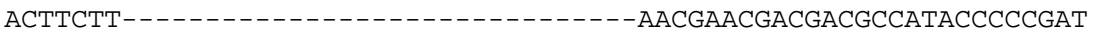
-CTTCTTCTTCTTAAGGAAGGAAGGGA----------AACGAACAACGACGCCATACCCCCGAT -CTTCTTCTTCTTAAGGAAGGAAGGGA----------AACGAACAACGACGCCATACCCCCGAT -CTTCTTCTTCTTAAGGAAGGAAGGGA----------AACGAACAACGACGCCATACCCCCGAT 


\subsection{Appendix 6. Alignment of mitochondrial spacer sequences from Cystophora retroflexa and related species.}

A085Cretroflexa CATCGAGAAAAGATAATTGGCCGTTAGGCAAGAAACTCACCTCAAGTAAAGTTTTCAATAGGGGTGAAATATAATCAC B094Csubfarcina CATCGAGAAAAGATAATTGGCCGTTAGGCAAGAAACTCACCTCAAGTAAAGTTTTCAATAGGGGTGAAATATAATCAC B099Cretroflexa CATCGAGAAAAGATAATTGGCCGTTAGGCAAGAAACTCACCTCAAGTAAAGTTTTCAATAGGGGTGAAATATAATCAC B100Csubfarcina CATCGAGAAAAGATAATTGGCCGTTAGGCAAGAAACTCACCTCAAGTAAAGTTTTCAATAGGGGTGAAATATAATCAC B101Cretroflexa CATCGAGAAAAGATAATTGGCCGTTAGGCAAGAAACTCACCTCAAGTAAAGTTTTCAATAGGGGTGAAATATAATCAC B116Ccongesta CATCGAGAAAAGATAATTGGCCGTTAGGCAAGAAACTCACCTCAAGTAAAGTTTTCAATAGGGGTGAAATATAATCAC B121Cretroflexa CATCGAGAAAAGATAATTGGCCGTTAGGCAAGAAACTCACCTCAAGTAAAGTTTTCAATAGGGGTGAAATATAATCAC B124Cretroflexa CATCGAGAAAAGATAATTGGCCGTTAGGCAAGAAACTCACCTCAAGTAAAGTTTTCAATAGGGGTGAAATATAATCAC B145Ccongesta B149Ccongesta B152Ccongesta B166Cretroflexa B169Csubfarcina B335Cretroflexa B412Csubfarcina B416Csubfarcina B425Cretroflexa B426Cretroflexa B430Cretroflexa B436Cretroflexa B455Ccongesta CATCGAGAAAAGATAATTGGCCGTTAGGCAAGAAACTCACCTCAAGTAAAGTTTTCAATAGGGGTGAAATATAATCAC CATCGAGAAAAGATAATTGGCCGTTAGGCAAGAAACTCACCTCAAGTAAAGTTTTCAATAGGGGTGAAATATAATCAC CATCGAGAAAAGATAATTGGCCGTTAGGCAAGAAACTCACCTCAAGTAAAGTTTTCAATAGGGGTGAAATATAATCAC CATCGAGAAAAGATAATTGGCCGTTAGGCAAGAAACTCACCTCAAGTAAAGTTTTCAATAGGGGTGAAATATAATCAC CATCGAGAAAAGATAATTGGCCGTTAGGCAAGAAACTCACCTCAAGTAAAGTTTTCAATAGGGGTGAAATATAATCAC CATCGAGAAAAGATAATTGGCCGTTAGGCAAGAAACTCACCTCAAGTAAAGTTTTCAATAGGGGTGAAATATAATCAC CATCGAGAAAAGATAATTGGCCGTTAGGCAAGAAACTCACCTCAAGTAAAGTTTTCAATAGGGGTGAAATATAATCAC CATCGAGAAAAGATAATTGGCCGTTAGGCAAGAAACTCACCTCAAGTAAAGTTTTCAATAGGGGTGAAATATAATCAC CATCGAGAAAAGATAATTGGCCGTTAGGCAAGAAACTCACCTCAAGTAAAGTTTTCAATAGGGGTGAAATATAATCAC CATCGAGAAAAGATAATTGGCCGTTAGGCAAGAAACTCACCTCAAGTAAAGTTTTCAATAGGGGTGAAATATAATCAC CATCGAGAAAAGATAATTGGCCGTTAGGCAAGAAACTCACCTCAAGTAAAGTTTTCAATAGGGGTGAAATATAATCAC CATCGAGAAAAGATAATTGGCCGTTAGGCAAGAAACTCACCTCAAGTAAAGTTTTCAATAGGGGTGAAATATAATCAC CATCGAGAAAAGATAATTGGCCGTTAGGCAAGAAACTCACCTCAAGTAAAGTTTTCAATAGGGGTGAAATATAATCAC

A085Cretroflexa TTTGATAGGCGGGGTGTGTAAGAGCTGCAAAGTTTTAAGCTGACCCGTACTAATCCTAAATGGTATTTGTGTTGGGTC B094Csubfarcina TTTGATAGGCGGGATGTGTAAGAGCTGCAAAGTTTTAAGCTGACCCGTACTAATCCTAAATGGTATTTGTGTTGGGTC B099Cretroflexa TTTGATAGGCGGGGTGTGTAAGAGCTGCAAAGTTTTAAGCTGACCCGTACTAATCCTAAATGGTATTTGTGTTGGGTC B100Csubfarcina TTTGATAGGCGGGATGTGTAAGAGCTGCAAAGTTTTAAGCTGACCCGTACTAATCCTAAATGGTATTTGTGTTGGGTC B101Cretroflexa TTTGATAGGCGGGGTGTGTAAGAGCTGCAAAGTTTTAAGCTGACCCGTACTAATCCTAAATGGTATTTGTGTTGGGTC B116Ccongesta B121Cretroflexa B124Cretroflexa B145Ccongesta B149Ccongesta B152Ccongesta B166Cretroflexa B169Csubfarcina B335Cretroflexa B412Csubfarcina B416Csubfarcina B425Cretroflexa B426Cretroflexa B430Cretroflexa B436Cretroflexa B455Ccongesta TTTGATAGGCGGGGTGTGTAAGAGCTGCAAAGTTTTAAGCTGACCCGTACTAATCCTAAATGGTATTTGTGTTGGGTC TTTGATAGGCGGGGTGTGTAAGAGCTGCAAAGTTTTAAGCTGACCCGTACTAATCCTAAATGGTATTTGTGTTGGGTC TTTGATAGGCGGGGTGTGTAAGAGCTGCAAAGTTTTAAGCTGACCCGTACTAATCCTAAATGGTATTTGTGTTGGGTC TTTGATAGGCGGGGTGTGTAAGAGCTGCAAAGTTTTAAGCTGACCCGTACTAATCCTAAATGGTATTTGTGTTGGGTC TTTGATAGGCGGGGTGTGTAAGAGCTGCAAAGTTTTAAGCTGACCCGTACTAATCCTAAATGGTATTTGTGTTGGGTC TTTGATAGGCGGGGTGTGTAAGAGCTGCAAAGTTTTAAGCTGACCCGTACTAATCCTAAATGGTATTTGTGTTGGGTC TTTGATAGGCGGGGTGTGTAAGAGCTGCAAAGTTTTAAGCTGACCCGTACTAATCCTAAATGGTATTTGTGTTGGGTC TTTGATAGGCGGGATGTGTAAGAGCTGCAAAGTTTTAAGCTGACCCGTACTAATCCTAAATGGTATTTGTGTTGGGTC TTTGATAGGCGGGGTGTGTAAGAGCTGCAAAGTTTTAAGCTGACCCGTACTAATCCTAAATGGTATTTGTGTTGGGTC TTTGATAGGCGGGATGTGTAAGAGCTGCAAAGTTTTAAGCTGACCCGTACTAATCCTAAATGGTATTTGTGTTGGGTC TTTGATAGGCGGGATGTGTAAGAGCTGCAAAGTTTTAAGCTGACCCGTACTAATCCTAAATGGTATTTGTGTTGGGTC TTTGATAGGCGGGGTGTGTAAGAGCTGCAAAGTTTTAAGCTGACCCGTACTAATCCTAAATGGTATTTGTGTTGGGTC TTTGATAGGCGGGGTGTGTAAGAGCTGCAAAGTTTTAAGCTGACCCGTACTAATCCTAAATGGTATTTGTGTTGGGTC TTTGATAGGCGGGGTGTGTAAGAGCTGCAAAGTTTTAAGCTGACCCGTACTAATCCTAAATGGTATTTGTGTTGGGTC TTTGATAGGCGGGGTGTGTAAGAGCTGCAAAGTTTTAAGCTGACCCGTACTAATCCTAAATGGTATTTGTGTTGGGTC TTTGATAGGCGGGGTGTGTAAGAGCTGCAAAGTTTTAAGCTGACCCGTACTAATCCTAAATGGTATTTGTGTTGGGTC

A085Cretroflexa TGCGCCGGATAGACACGTAGAATCGCCGAATACCTTGTAGATATTTTAGGTAATGGTTATTTATGTCCGTATTTTTTT B094Csubfarcina TGCACCGAATAGACACGTAGAATCGCCGGATGCATTGTAGATATTTTAGGTAATGGTTATTTATGTCCGTATTTTTTT B099Cretroflexa TGCGCCGGATAGACACGTAGAATCGCCGAATACCTTGTAGATATTTTAGGTAATGGTTATTTATGTCCGTATTTTTTT B100Csubfarcina TGCACCGAATAGACACGTAGAATCGCCGGATGCATTGTAGATATTTTAGGTAATGGTTATTTATGTCCGTATTTTTTT B101Cretroflexa TGCGCCGGATAGACACGTAGAATCGCCGAATACCTTGTAGATATTTTAGGTAATGGTTATTTATGTCCGTATTTTTTT B116Ccongesta TGCGCCGGATAGACACGTAGAATCGCCGAATACCTTGTAGATATTTTAGGTAATGGTTATTTATGTCCGTATTTTTTT B121Cretroflexa TGTGCCGGATAGACACGTAGAATCGCCGAATACCTTGTAGATATTTTAGGTAATGGTTATTTATGTCCGTATTTTTTT B124Cretroflexa TGTGCCGGATAGACACGTAGAATCGCCGAATACCTTGTAGATATTTTAGGTAATGGTTATTTATGTCCGTATTTTTTT B145Ccongesta TGCGCCGGATAGACACGTAGAATCGCCGAATACCTTGTAGATATTTTAGGTAATGGTTATTTATGTCCGTATTTTTTT B149Ccongesta TGCGCCGGATAGACACGTAGAATCGCCGAATACCTTGTAGATATTTTAGGTAATGGTTATTTATGTCCGTATTTTTTT B152Ccongesta TGCGTCGGATAGACACGTAGAATCGCCGAATACCTTGTAGATATTTTAGGTAATGGTTATTTATGTCCGTATTTTTTT B166Cretroflexa TGTGCCGGATAGACACGTAGAATCGCCGAATACCTTGTAGATATTTTAGGTAATGGTTATTTATGTCCGTATTTTTTT B169Csubfarcina TGCACCGAATAGACACGTAGAATCGCCGGATGCATTGTAGATATTTTAGGTAATGGTTATTTATGTCCGTATTTTTTT B335retroflexa TGCGCCGGATAGACACGTAGAATCGCCGAATACCTTGTAGATATTTTAGGTAATGGTTATTTATGTCCGTATTTTTTT B412Csubfarcina TGCGCCGAATAGACACGTAGAATCGCCGGATGAGTTGTAGATATTTTAGGTAATGGTTATTTATGTCCGTATTTTTTT B416Csubfarcina TGCGCCGAATAGACACGTAGAATCGCCGGATGAGTTGTAGATATTTTAGGTAATGGTTATTTATGTCCGTATTTTTTT B425Cretroflexa TGCGCCGGATAGACACGTAGAATCGCCGAATACCTTGTAGATATTTTAGGTAATGGTTATTTATGTCCGTATTTTTTT B426Cretroflexa TGCGCCGGATAGACACGTAGAATCGCCGAATACCTTGTAGATATTTTAGGTAATGGTTATTTATGTCCGTATTTTTTT B430Cretroflexa TGTGCCGGATAGACACGTAGAATCGCCGAATACCTTGTAGATATTTTAGGTAATGGTTATTTATGTCCGTATTTTTTT B436Cretroflexa TGCGCCGGATAGACACGTAGAATCGCCGAATACCTTGTAGATATTTTAGGTAATGGTTATTTATGTCCGTATTTTTTT B455Ccongesta TGCGCCGGATAGACACGTAGAATCGCCGAATACCTTGTAGATATTTTAGGTAATGGTTATTTATGTCCGTATTTTTTT

A085Cretroflexa TTTGTGAAAGTAGTTTACCTACAGTATAAGAGAAATTGTTTTCACAAGAAGTTAAG B094Csubfarcina TTTGTGAAAGTGGTTTACCTACAGTATAAGAGAAATTTTTTCACAAAAAGTTAAG B099Cretroflexa TTTGTGAAAGTAGTTTACCTACAGTATAAGAGAAATTGTTTTCACAAAAAGTTAAG B100Csubfarcina TTTGTGAAAGTGGTTTACCTACAGTATAAGAGAAATTGTTTTCACAAAAAGTTAAG B101Cretroflexa TTTGTGAAAGTAGTTTACCTACAGTATAAGAGAAATTGTTTTCACAAAAAGTTAAG B116Ccongesta TTTGTGAAAGTAGTTTACCTACAGTATAAGAGAAATTGTTTCACAAGAAGTTAAG B121Cretroflexa TTTGTGAAAGTAGTTTACCTACAGTATAAGAGAAATTGTTTTCACAAAAAGTTAAG B124Cretroflexa TTTGTGAAAGTAGTTTACCTACAGTATAAGAGAAATTGTTTTCACAAAAAGTTAAG 
Appendix 6. (Continued)

B145Ccongesta TTtgTGAAAgtAgtTTACCTACAgtATAAGAGAAATTGTTTCACAAAAAgTTAAG B149Ccongesta TTTGTGAAAGTAGTTTACCTACAGTATAAGAGAAATTGTTTTCACAAAAAGTTAAG B152Ccongesta TTTGTGAAAGTAGTTTACCTACAGTATAAGAGAAATTGTTTTCACAAAAAGTTAAG B166Cretroflexa TTTGTGAAAGTAGTTTACCTACAGTATAAGAGAAATTGTTTTCACAAAAAGTTAAG B169Csubfarcina TTTGTGAAAGTGGTTTACCTACAGTATAAGAGAAATTGTTTTCACAAAAAGTTAAG B335cretroflexa TTTGTGAAAGTAGTTTACCTACAGTATAAGAGAAATTGTTTTCACAAGAAGTTAAG B412Csubfarcina TTTGTGAAAGTGGTTTACCTACAGTATAAGAGAAATTGTTTTCACAAAAAGTTAAG B416Csubfarcina TTTGTGAAAGTGGTTTACCTACAGTATAAGAGAAATTGTTTTCACAAAAAGTTAAG B425Cretroflexa TTTGTGAAAGTAGTTTACCTACAGTATAAGAGAAATTGTTTTCACAAGAAGTTAAG B426Cretroflexa TTTGTGAAAGTAGTTTACCTACAGTATAAGAGAAATTGTTTTCACAAGAAGTTAAG B430Cretroflexa TTTGTGAAAGTAGTTTACCTACAGTATAAGAGAAATTGTTTTCACAAAAAGTTAAG B436Cretroflexa TTTGTGAAAGTAGTTTACCTACAGTATAAGAGAAATTGTTTTCACAAGAAGTTAAG B455Ccongesta TTTGTGAAAgTAGTTTACCTACAgTATAAGAGAAATTGTTTTCACAAAAAGTTAAG 
7.7 Appendix 7. Additional work.

During the period of work on this thesis I have also contributed to the following published papers:

ZucCarello, G. C., Buchanan, J. \& West, J. A. (2006). Increased sampling for inferring phylogeographic patterns in Bostrychia radicans/B. moritziana (Rhodomeleaceae, Rhodophyta) in the eastern USA. Journal of Phycology, 42, 1349-1352.

Hodge, F., Buchanan, J. \& ZucCARello, G. C. (2010). Hybridisation between the endemic brown algae Carpophyllum maschalocarpum and Carpophyllum angustifolium (Fucales): Genetic and morphological evidence. Phycological Research, 58, 239-247.

Jones (Kain), J., Buchanan, J., BoO, S. M. \& LeE, K. M. (2010). Colpomenia bullosa crust masquerading as Ralfsia verrucosa in southeast Australia. Phycologia, 49, 617-627.

Zuccarello, G. C., Buchanan, J., West, J. A. \& Pedroche, F. F. (2011). Genetic diversity of the mangrove associated alga Bostrychia moritziana (Ceramiales, Rhodophyta) from southern Central America. Phycological Research. doi: 10.1111/j.1440-1835.2010.00605.x 


\subsection{Appendix 8}

\section{Phylogeography of Carpophyllum maschalocarpum}

\section{Joe Buchanan \& G. C. Zuccarello}

School of Biological Sciences, Victoria University of Wellington

A highly variable 225 bp mitochondrial spacer region from 651 samples of the endemic fucoid alga Carpophyllum maschalocarpum was analysed by SSCP or sequencing. We identified 52 haplotypes, and found a further 15 haplotypes in the sister species Carpophyllum angustifolium and in hybrids between these species (Fig. 1).

1. Forty-one C. maschalocarpum haplotypes were restricted to a single population. Most other haplotypes were restricted to regions.

2. Haplotypic diversity was low in southern populations.

3. High diversity in three far north populations arises from hybridisation with C. angustifolium.

4. Connectivity was strong between East Coast and Northland populations and between the mainland and the Chatham Islands. 5. High diversity was also found in the Chatham Islands.

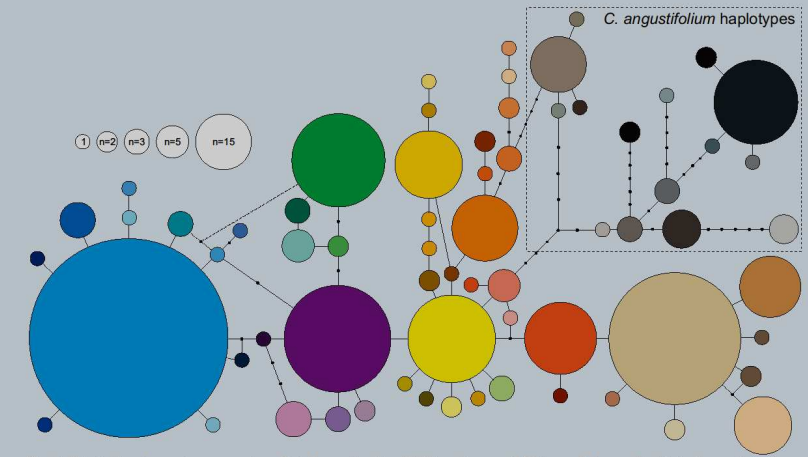

1. Population differentiation and dispersal limitation Population differentiation between populations with shared haplotypes was moderate to strong at distances over 50 kilometres (see Table 1 below), especially where there are habitat discontinuities. Despite large numbers of C. maschalocarpum thalli observed in drift (Kingsford
1992 ), gene flow is low. At several sites, all or most haplotypes sampled were restricted to that population.

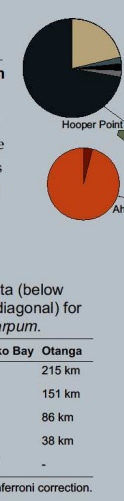

Table 1. Pairwise $\Phi$ st estimates from mtDNA spacer data (below diagonal) and minimum round coast distances (above diagoon
Bay of Plenty populations of Carpophyllum maschalocarpum.

\begin{tabular}{|c|c|c|c|c|c|}
\hline & Sailors Grave & Maketu & Opape & Maraehako Bay & Otanga \\
\hline Sailors Grave & & $103 \mathrm{~km}$ & $179 \mathrm{~km}$ & $190 \mathrm{~km}$ & $215 \mathrm{~km}$ \\
\hline Maketu & $0.54931^{*}$ & - & $87 \mathrm{~km}$ & $117 \mathrm{~km}$ & $151 \mathrm{~km}$ \\
\hline Opape & $0.46280 \%$ & $0.84906^{*}$ & - & $48 \mathrm{~km}$ & $86 \mathrm{~km}$ \\
\hline Maraehako Bay & $0.42232^{*}$ & $0.68024^{*}$ & N.S. & - & $38 \mathrm{~km}$ \\
\hline Otanga & $0.12573^{*}$ & $0.26357^{*}$ & $0.1134^{*}$ & $0.1254^{* *^{*}}$ & - \\
\hline
\end{tabular}

\section{Low southern diversity}

Haplotypic diversity was low in southern populations, and a single haplotype was sampled in the South Island. The southern limit of $C$. maschalocarpum is correlated with the $15^{\circ} \mathrm{C}$ sea surface temperature isotherm for the warmest month (Fig. 3 below). Northward movement of this isotherm during the Last Glacial Maximum (LGM) would have restricted C. maschalocarpum populations to the northern half of the North Island. Stepping stone recolonisation of southern New Zealand following the LGM would reduce genetic diversity through repeated founder effects.

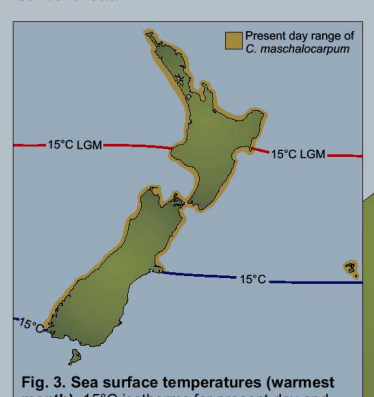

Fig. 3. Sea surface tomp month). $15^{\circ} \mathrm{C}$ isotherms for present day and
estimate for LGM (Barrows \& Juggins 2005).

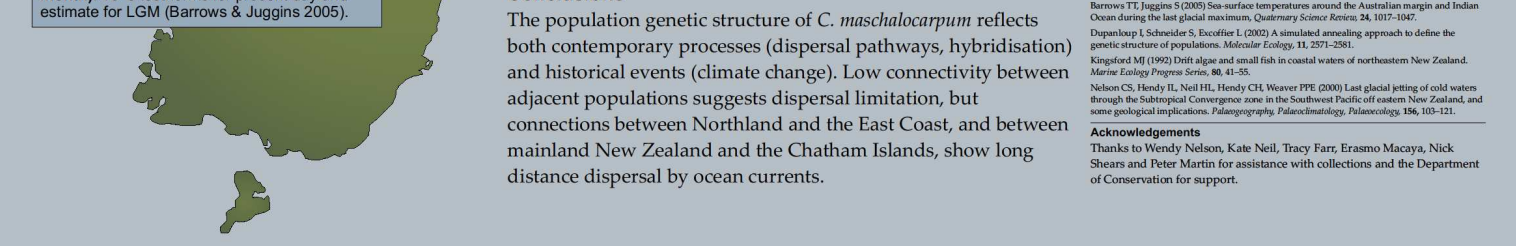

Fig 1. Statistical parsimony network inferred using TCS software $(95 \%$ confidence limits). Ar
is proportional to number of haplotypes sampled. Small black circles represent missing haplotypes.

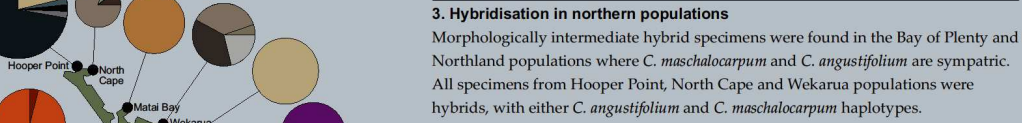

Northland populations where C. maschalocarpum and C. angustifolium are sympatric. hybrids, with either C. angustifolium and C. maschalocarpum haplotypes.
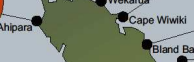

4. Northland and the East Coast connectivity n Northland (Cape Wiwiki and the Poor Knights) and the East Coast (Horoera and Kaiti Beach), but was absent from interjacent sites. The East Cape Current is a potential dispersal pathway connecting these populations. This current does not extend into the Bay of Plenty and the Hauraki Gulf. SAMOVA analysis (Dupanloup et al. 2002) grouped these populations together despite their spatial separation (Fig. 4 below).

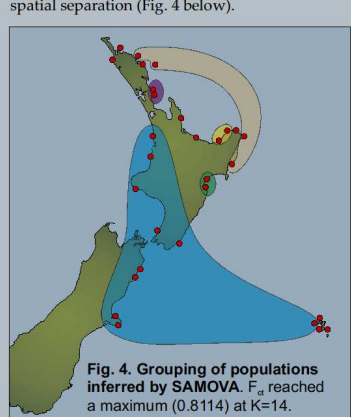

\section{Fig 2. Distribution of mtDNA} maximum (0.8114) at $K=14$. 
7.9 Appendix 9

Phycological Research

Phycological Research 2010; 58: 239-247

\section{Hybridization between the endemic brown algae Carpophyllum maschalocarpum and Carpophyllum angustifolium (Fucales): Genetic and morphological evidence}

Fiona J. Hodge, Joseph Buchanan and Giuseppe C. Zuccarello*

School of Biological Sciences, Victoria University of Wellington, Wellington 6140, New Zealand

\section{SUMMARY}

Hybridization is an important evolutionary process, which can have significant effects on biodiversity. While hybridization is well known in plants, less is known about the prevalence of hybridization in other kingdoms. Hybridization in the field has been confirmed in brown algae in a few cases, mainly in the northern hemisphere genus Fucus. Putative hybrids have been found in the New Zealand endemic species Carpophyllum angustifolium and Carpophyllum maschalocarpum. We used nuclear-encoded molecular data (ITS2) and morphometrics to confirm hybridization between $C$. angustifolium and C. maschalocarpum. Putative hybrid thalli were collected that had heterozygous ITS2, each copy corresponding to one of the parental species from that population. Morphological analysis also showed that the three classes (two parental species and hybrids) were easily distinguishable in these populations. It was found that the hybrids had an intermediate morphology to the parent species. Some individuals with $C$. angustifolium morphology had hybrid ITS2 ribotypes suggestive of backcrossing between the hybrids and $C$. angustifolium. Our data reveal another case of hybridization within the Fucales and suggests that further research on how these species remain separate is needed.

Key words: Carpophyllum angustifolium, Carpophyllum maschalocarpum, Fucales, hybrids, hybridization, ITS2, New Zealand, morphometrics, Phaeophyceae.

\section{INTRODUCTION}

Hybridization is an important evolutionary process that brings together diverged genetic lineages, through the crossing of two genetically distinct species. Hybridization challenges our species definitions and provides insight into speciation processes (Seehausen 2004). Often it also produces unique hybrid morphologies. Hybrids are generally expected to have intermediate morphologies reflecting their mixed genotypes, but may also have morphologies similar to, novel from, or more extreme than the parental species (Coyer et al. 2002a; Seehausen 2004; Lihova et al. 2007). Identification of hybrids based on morphology alone can be difficult due to the large degree of intra-specific variation and phenotypic plasticity present in many taxa (Rieseberg \& Ellstrand 1993; Scott \& Hardy 1994). Furthermore, morphological intermediacy does not always indicate hybrids and may reflect patterns of plasticity or environmental variation (Mathieson et al. 1981).

Introgression, the backcrossing of hybrids with parental species, can result in a continuum of morphologies between the parental species (Albert et al. 1997). Introgression is of great evolutionary significance as it can result in the transfer of adaptations between species (Seehausen 2004). Other potential outcomes of introgression include the strengthening of reproductive barriers and further divergence of the parental species, or the development of new hybrid lineages (Grant et al. 2004; Seehausen 2004).

The Phaeophyceae, brown algae, are morphologically diverse. Individuals range from microscopic filaments to the more familiar large conspicuous fleshy seaweeds (Graham \& Wilcox 2000). Even within species there is great morphological variation (Mathieson et al. 1981). Despite this variability putative hybrids, especially in the morphologically complex Fucales, have been observed in wild populations since the 1850s (references within Thuret 1854; Mathieson et al. 1981).

New Zealand has a distinct brown algal flora with high levels of endemism (Nelson 1994). The dominance of Fucalean algae in the shallow subtidal is considered one of the more unusual aspects of the flora (Schiel 1990). Fucalean algae in the Northern Hemisphere dominate the intertidal, and consequently have

*To whom correspondence should be addressed.

Email: joe.zuccarello@vuw.ac.nz

Communicating editor: C. Katsaros.

Received 17 December 2009; accepted 26 March 2010.

doi: 10.1111/j.1440-1835.2010.00583.x 
been relatively well studied (Chapman 1995). The vast majority of research into hybridization in Phaeophyceae is on the Northern Hemisphere fucalean genus Fucus (Mathieson et al. 1981; Chapman 1995; Wallace et al. 2004; Engel et al. 2005; Perrin et al. 2005; Billard et al. 2005b; Coyer et al. 2006b). Research into hybridization has revealed hybrids with intermediate morphologies, and in some cases evidence of introgression has been reported (Coyer et al. 2002a; Wallace et al. 2004; Billard et al. 2005b; Mathieson et al. 2006). Little work has been done on hybridization in Fucales outside of Fucus, despite the well documented abundance, diversity and ecological importance of this order in the Southern Hemisphere (Clayton 1984).

In north-eastern New Zealand two species of Fucales (Sargassaceae) form dominant stands in the high subtidal: Carpophyllum maschalocarpum (Turner) Greville and Carpophyllum angustifolium J. Agardh (Dromgoole 1973; Schiel 1988; Schiel 1990). Based on intermediate morphotypes it has been hypothesized that hybridization is occurring between the two species (Dromgoole 1973).

The internal-transcribed-spacer (ITS) is part of the nuclear ribosomal cistron, and is an often used sequence in plant evolutionary studies (Feliner \& Rossello 2007). ITS is multi-copy, and homogenization of the multiple ITS sequences can occur (Álvarez \& Wendel 2003). Coyer et al. (2002b) showed that artificially produced $F_{1}$ hybrids of two Fucus species with distinct ITS ribotypes were all heterozygous in ITS. Introgressed and $F_{2}$ individuals will not necessarily have heterozygous ITS ribotypes (Álvarez \& Wendel 2003). Combining ITS and morphometric data can allow nonsubjective identification of hybrid and parental individuals, and help determine the presence of introgression and $F_{2}$ hybrids within a population.

The present study using combined ITS2 identification and morphometric analysis confirmed hybridization between the non-Fucus fucalean algae, $C$. angustifolium and C. maschalocarpum. The expansion of the study of hybridization from the one northern hemisphere model, to a related but endemic Fucalean alga, will provide additional understanding of the importance of hybridization in this class.

\section{MATERIALS AND METHODS}

\section{Sampling}

Samples were collected from two sites on the East Cape of the North Island of New Zealand, where putative $C$. angustifolium $\times C$. maschalocarpum hybrids were known to occur (Fig. 1). The two sites are both within the greater Whanarua Bay, which faces north-west and contains a number of smaller sandy bays separated by large rocky islands. The first site is located at the

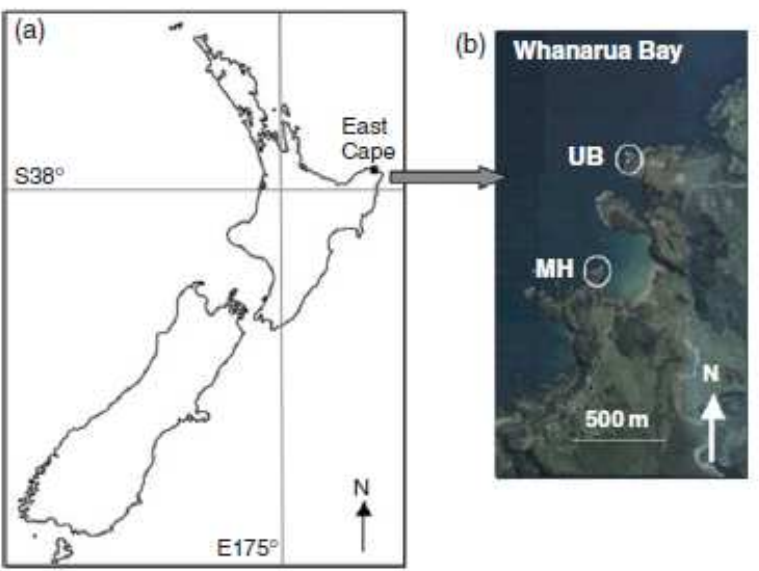

Fig. 1. The location of sampling (a) on the East Cape of the North Island of New Zealand, and (b) the two sites in the greater Whanarua Bay: Maraehako Bay (MH) and Uncles Bay (UB) (Googie Earth 5.0).

south-eastern end of Maraehako Bay (S37 $40.4^{\prime}$ $\left.E 177^{\circ} 47.8^{\prime}\right)$. The second site was located at Uncles Bay $\left(\mathrm{S} 37^{\circ} 40.0^{\prime} \mathrm{E} 177^{\circ} 48.0^{\prime}\right)$, which is the adjacent bay to the north-east. The two sites are approximately $500 \mathrm{~m}$ apart, and are separated by Motu Kaimeanui Island and two deep inlets. Sampling was conducted during the 2007-2008 summer.

Transect lines were laid along rock walls in the high subtidal, and quadrat locations were selected randomly from the top $0.5 \mathrm{~m}$ of Carpophyllum depth distribution. Quadrats were rejected if the rock face was not vertical, less than three individuals were present, or if the quadrat was less than $0.5 \mathrm{~m}$ from a previously sampled quadrat. All Carpophyllum individuals with holdfasts inside the $20 \mathrm{~cm}$ by $20 \mathrm{~cm}$ quadrats were collected. Sixty-nine quadrats were sampled in the two sites, with $280 \mathrm{C}$. angustifolium, 152 C. maschalocarpum and 32 hybrid adults collected in total (see Fig. 2 for typical morphologies). Only a subset that was characterized molecular was used in this study $(n=80)$. Collected material was frozen at $-20^{\circ} \mathrm{C}$ within a week of collection, and thawed in seawater prior to morphometric analysis.

Representative herbarium specimens of $C$. angustifolium, C. maschalocarpum and (putative) hybrids collected in East Cape during this study have been deposited in the Museum of New Zealand - Te Papa Tongarewa herbarium under the WELT numbers A029625-29, A029635-38 and A029630-34, respectively.

\section{Morphometrics}

Adults longer than $20 \mathrm{~cm}$ were morphologically identified, cleared of epiphytes, and measured. Only those individuals with complete haptera were used in mor- 
Hybrids in Carpophyllum

Fig. 2. Typical morphology of (a) Carpophyllum maschalocarpum, (b) putative Carpophyllum angustifolium $\times$ C. maschalocarpum hybrids, and (c) $C$. angustifolium. All at the same scale, scale bar in (a) shows $50 \mathrm{~mm}$.
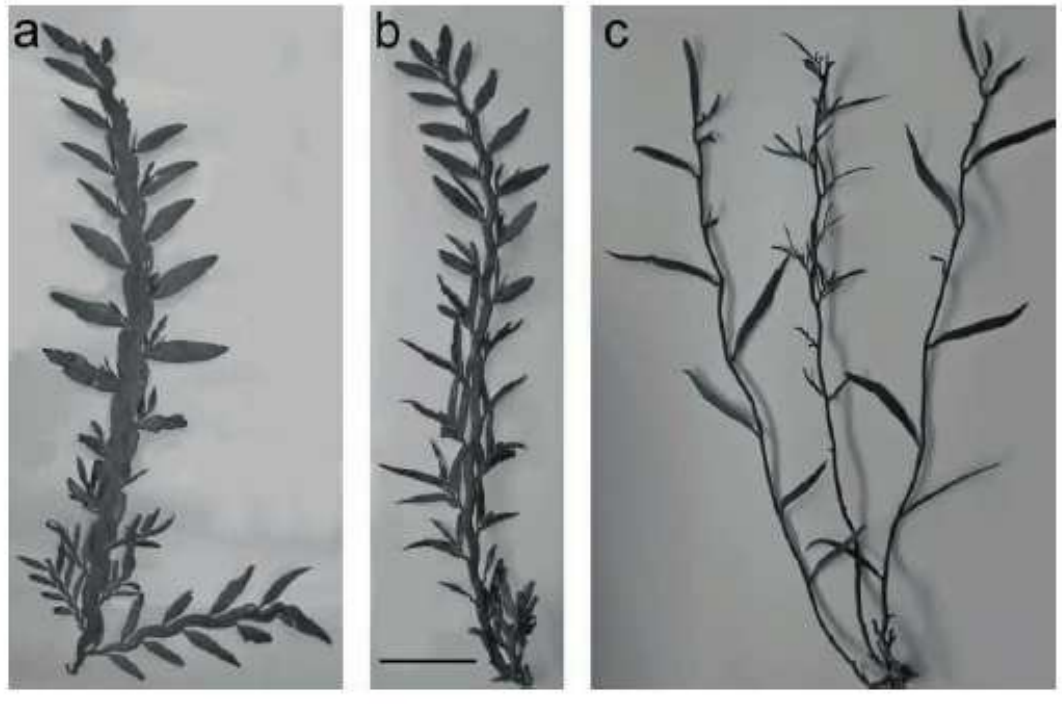

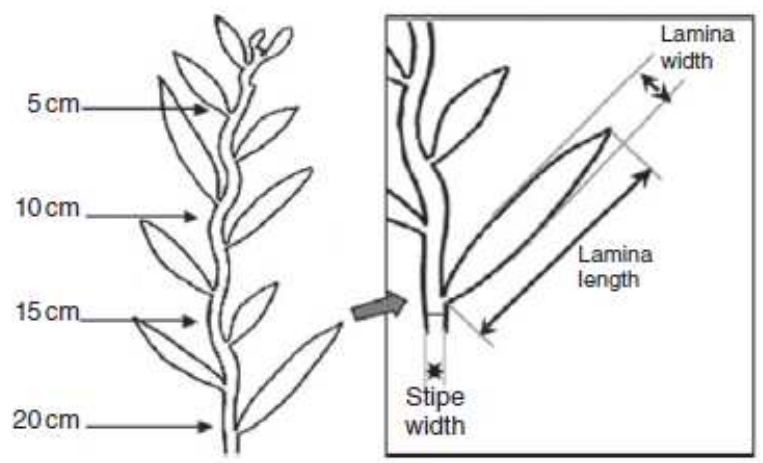

Fig. 3. The location of the measurements taken from each individual are shown with arrows on a stylized axis. Stipe width, lamina length and width are illustrated at $20 \mathrm{~cm}$ from the apex.

phometrics so as to avoid pseudo-replication (i.e. the doubling up of measurements from the same individual). Individuals were measured using digital callipers and a meter rule. A small section of lamina was removed from each individual after processing and placed into a labeled tube with silica gel for genetic analysis. The total length of the individual, presence of vesicles longer than $8 \mathrm{~mm}$, and the presence of secondary branches longer than $20 \mathrm{~cm}$ were also recorded.

The morphometric characteristics selected for measurement were stipe width and thickness; and lamina length, width and thickness (Fig. 3). The present study focused on the stipe and lamina characteristics of the primary axis (defined as the dominant axis, which arises directly from the holdfast). The stipe and lamina measurements were taken from approximately $5,10,15$, and $20 \mathrm{~cm}$ from the tip of the axis. Lamina length was measured from the edge of the stipe where the lamina forms to its tip. Lamina and stipe width were measured at the widest point, perpendicular to an imagined midline. Stipe and lamina thickness was measured at the thickest point. In some places herbivory had altered the morphology of the stipe and lamina; these could be detected by sudden and distinct changes in lamina or stipe outline. Measurements of stipe and lamina that were affected by herbivory were excluded, and if possible replaced by measurements from the nearest intact equivalent within $3 \mathrm{~cm}$.

Digital images for the C. angustifolium (\#2572, Botanical Museum Lund) and C. maschalocarpum (\#000562635, The Natural History Museum, London Department of Botany) type specimens were obtained and measurements of lamina length, lamina width and stipe width were taken where possible.

\section{Genetic analysis}

Validity of the morphological identification for the hybrids and parental species were checked by genetically identifying 80 individuals. Individuals with unusual morphological characteristics were also checked genetically.

DNA was extracted from approximately $3 \mathrm{mg}$ of dry tissue using a cetyltrimethylammonium bromide (CTAB) extraction protocol (Zuccarello \& Lokhorst 2005). The ITS2 was amplified using a PTC-100 (Programmable Thermal Controller, MJ Research Inc. Waltham, MA, USA) polymerase chain reaction (PCR) machine, and the primers KG4 (CTTTTCCTCCGCT TAGTTATATG) and KP5 (ACAACGATGAAGAACGCAG) (Lane et al. 2006). The PCR conditions were an initial $94^{\circ} \mathrm{C}$ for $4 \mathrm{~min}$, followed by five cycles of $1 \mathrm{~min}$ at $94^{\circ} \mathrm{C}, 1 \mathrm{~min} 59^{\circ} \mathrm{C}, 1 \mathrm{~min} 72^{\circ} \mathrm{C}$ with the annealing temperature decreased by $1^{\circ} \mathrm{C}$ each cycle. Then 30 
cycles of $45 \mathrm{~s} 94^{\circ} \mathrm{C}, 45 \mathrm{~s} 53^{\circ} \mathrm{C}, 45 \mathrm{~s} 72^{\circ} \mathrm{C}$, followed by $10 \mathrm{~min}$ at $72^{\circ} \mathrm{C}$. Sequencing was done commercially (Macrogen Inc., Seoul, Korea). The chromatograms were visually examined and individuals identified as either a parental species or a heterozygous hybrid (where double peaks were present).

\section{Cloning}

One specimen from Maraehako Bay that was found to be heterozygotic for ITS2 in direct sequencing was selected for cloning to determine whether both parental ribotypes could be obtained. The complete ITS1-5.8SITS 2 cistron was amplified using KP1 and KG4 primers (Lane et al. 2006). PCR product was cloned using the pGEM-T Easy vector kit (Promega Corporation, Madison, WI, USA) following the manufacturer's protocols. Transformed colonies were sub-cultured and plasmid preparations carried out by alkali lysis (Sambrook et al. 1989). Inserts were sequenced commercially using pUC M13 forward and reverse primers.

\section{Morphometric data analysis}

The morphometric data contained a large number of missing values. Scatterplots showed no difference between the character traits measurements at 5, 10, 15 and $20 \mathrm{~cm}$ from the apex, so the measurements from each individual were averaged. There were some missing data for lamina characteristics after this averaging, as many lamina were excluded from measurement due to herbivory damage. The missing values were not randomly distributed, and $C$. maschalocarpum averages were based on fewer data points than the others due to greater levels of herbivory and exposure damage. Randomly removing data points to an equivalent level in $C$. angustifolium and hybrid data made little or no change to overall group averages $(0.002 \%$ to $0.03 \%$ change). This suggests no bias in accuracy due to variation in the number of data points averaged between the species.

Cluster analysis finds natural groupings or clusters within the data (Fielding 2007). These were conducted with genetically confirmed data and type specimens using the software NTSYSpc version 2.11 software (Rohlf 2000). The unweighted pair-groups method average (UPGMA) clustering method was used; this is a common and accepted method (Fielding 2007) for this type of data.

Boxplots were used to identify morphological traits that showed difference. These characters were incorporated into a distance matrix using Gower's Index in Le Progiciel R 4.0 software (Casgrain \& Legendre 1999). This index was used as it can cope with missing values (Montanari \& Mignani 1994; Podani 1999). It has also been used in other studies of macroalgae morphology (Fowler-Walker et al. 2006). Cophenetic values were calculated to test how well the cluster tree represents the data (Rohlf \& Sokal 1981; Rohlf 2000).

ANova was used to compare the morphological groups found in the cluster analysis. Non-normal data were log transformed prior to analysis with ANOVA. Log transformed data that still did not meet ANova assumptions was analyzed using the non-parametric Kruskal-Wallis test. $\chi^{2}$ tests were used to test for associations between wave exposure zones and the presence of vesicles and branches. Significance was determined at the 0.05 probability level.

\section{RESULTS}

\section{ITS2 sequences and morphological identification}

Only two ITS2 ribotypes were found, corresponding to the two morphologically identified parent species. The ribotypes differed by three different point mutations and one base pair indel (GenBank Numbers GU992939-GU992940). The point mutations appeared as double peaks in chromatograms from heterozygous individuals, and the indel appeared as a change from predominantly single peaks to all superimposed double peaks. This change occurred at the same base position in both forward and reverse sequences. All samples indentified a priori as hybrids had heterozygotic sequences (i.e. sequences of both $C$. maschalocarpum and $C$. angustifolium).

Twelve ITS2 sequences were obtained from cloned DNA from the heterozygotic specimen. Multiple copies of the two ribotypes were found, corresponding to those expected from direct sequencing. Some sequences showed single base changes (autoapomorphies) that were not previously detected by direct sequencing and were only present in a single clone from each specimen. We attribute these to copy errors during PCR with Taq polymerase.

Morphological identifications matched with genetic sequences in $93.8 \%$ of the individuals $(n=80)$. All C. maschalocarpum $(n=25)$ and hybrid $(n=27)$ morphological assignments were congruent with ITS2 sequences. $82.1 \%$ of the samples $(n=28)$ morphologically identified as $C$. angustifolium had matching $C$. angustifolium ITS2 sequences. The remaining $17.9 \%$ were five individuals with hybrid sequences; these will be described from here on as 'putative backcrosses'.

\section{Cluster analysis}

Stipe width, lamina length and lamina width were used in the cluster analyses. The cluster analysis tree of the genetically identified individuals $(n=80)$ and the type specimens is shown (Fig. 4). This had a cophenetic correlation of 0.84 , indicating a 'good fit' (Rohlf 2000). 


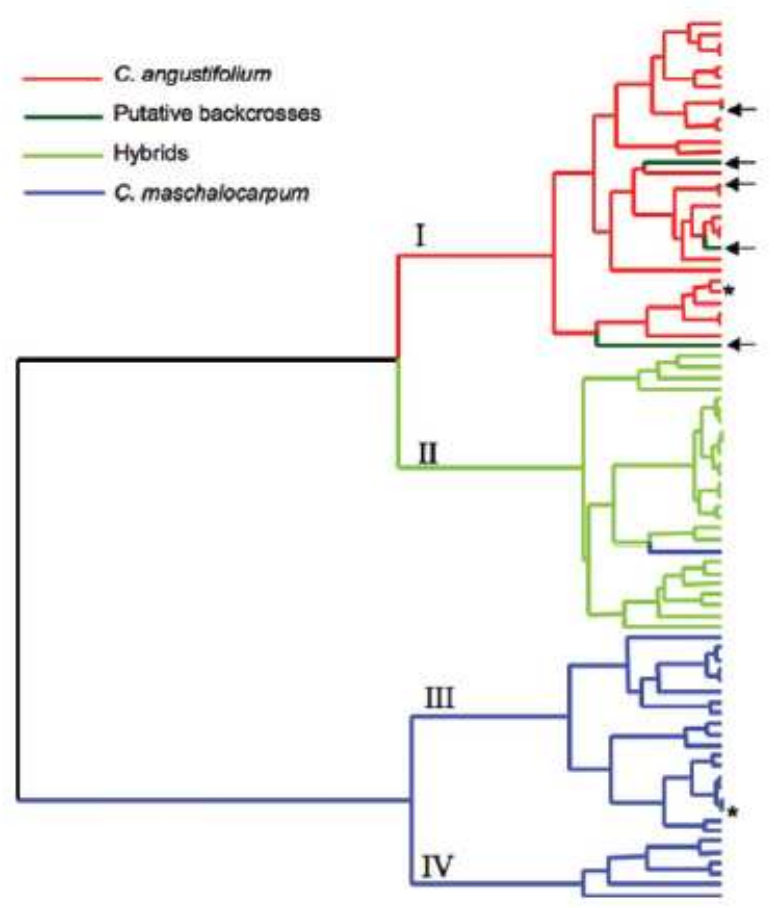

Fig. 4. Cluster analysis showing the morphology of a random sub-sample of genetically identified individuals, and the type specimens for the parental species (shown by asterisks). Individuals cluster into four morphological groups as labeled I to IV. Colors represent the identity of the individuals (see legend). Putative backcrosses are those morphologically identified as Carpophyllum angustifolium but with hybrid ITS2 sequences, as shown with arrows. The coenphetic value of this tree is $r=0.84486$.

A cluster analysis of all individuals collected showed the groupings as seen for the genetically identified samples (Hodge 2009)

Genetically identified individuals clustered into four main morphological groups. Group I contained all of the genetically confirmed $C$. angustifolium $(n=23)$, two hybrids, and the putative backcrosses $(n=5)$. Group II included all of the other hybrids $(n=25)$, and one individual identified as $C$. maschalocarpum. Closer examination of this $C$. maschalocarpum individual reveals it was only just long enough to be considered 'adult' ( $>20 \mathrm{~cm}$ long) and therefore included in this study. Groups III and IV were composed of $C$. maschalocarpum only (III, $n=19$; IV, $n=6$ ). Hereafter Group I will be referred to as $C$. angustifolium, Group II as the hybrids, Groups III and IV combined as C. maschalocarpum. A major subdivision between the morphology of $C$. angustifolium and hybrid individuals, and the $C$. maschalocarpum individuals, was revealed in the cluster analysis. The hybrid cluster had a higher similarity coefficient with the $C$. angustifolium cluster (0.75) than with the $C$. maschalocarpum clusters (0.49).

C구이 2010 Japanese Society of Phycology
A cluster analysis of all individuals collected, i.e. including specimens only morphologically identified, had a cophenetic correlation of greater than 0.90 , indicating the cluster tree is a 'very good fit' of the data (Rohlf 2000). This cluster analysis showed the same group structure and membership of genetically identified individuals as the cluster tree of only genetically identified individuals (Hodge 2009). Consequently morphological comparisons were done between groups using data from both morphologically and genetically identified individuals.

\section{Comparing morphologies}

Comparisons of the morphologies of the $C$. angustifolium group (I), the hybrid group (II) and the pooled $C$. maschalocarpum groups (III and IV) found a range of differences between them (Table 1). Log stipe width $(P<0.001)$, lamina length $(P<0.001)$, and lamina width $(P<0.001)$ were different between the three groups (all pairwise Tukey Tests were $P<0.05$ ) (Fig. 5). The pooled $C$. maschalocarpum group had a wider stipe, and a shorter and wider lamina than the $C$. angustifolium group. The hybrid group exhibited traits intermediate to the parents for each of these traits. There was no overlap in log stipe width for the three groups (Fig. 5a).

Stipe thickness was also different between the three groups $(P<0.001)$ with median stipe thickness being thickest for the $C$. angustifolium group (I), and thinnest for the hybrid group (II). Lamina thickness was also found to be non-uniform $(P<0.01)$. The $C$. angustifolium group (I) had significantly thicker lamina than the hybrids (II), and the pooled C. maschalocarpum group (III and IV) (Tukey tests: $P<0.05$ ). The lamina thickness of the hybrid group (II) and the pooled $C$. maschalocarpum group (III and IV) were not significantly different (Tukey test: $P=0.952$ ).

There were significant differences in total length, stipe width, stipe thickness, presence of vesicles between the two groups (III and IV) of $C$. maschalocarpum (Table 2). Group IV was generally longer in total length, had a wider and thicker stipe, and had a greater proportion of individuals with vesicles present than Group III. There were also non-significant trends $(0.05<P<0.10)$ of Group IV having wider and thicker lamina, and more frequently having secondary branches. There was no difference between the lamina length of the two groups. There was no difference in the distributions between the two $C$. maschalocarpum groups between sites $\left(X_{2}=3.146\right.$, d.f. $=1, n=146$, $P=0.076$ ) or exposure zones.

\section{DISCUSSION}

Our molecular data confirms that Carpophyllum angustifolium and C. maschalocarpum hybridize in popula- 
Table 1. Relative morphological differences between the three groups (tested with ANovA and Kruskal-Wallis tests)

\begin{tabular}{|c|c|c|c|c|}
\hline Character trait & Group I & Group II & Group III and IV & Statistics \\
\hline Stipe width & Narrow & Intermediate & Wide & $F=4843.291$, d.f. $=2, n=463, P<0.001$ \\
\hline Lamina length & Long & Intermediate & Short & $F=43.275$, d.f. $=2, n=240, P<0.001$ \\
\hline Lamina width & Narrow & Intermediate & Wide & $F=247.230$, d.f. $=2, n=240, P<0.001$ \\
\hline Stipe thickness & Thick & Thin & Intermediate & $\chi^{2}=23.134$, d.f. $=2, n=463, P<0.001$ \\
\hline Lamina thickness & Thick & Thin & Thin & $F=21.22$, d.f. $=2, n=240, P<0.001$ \\
\hline
\end{tabular}

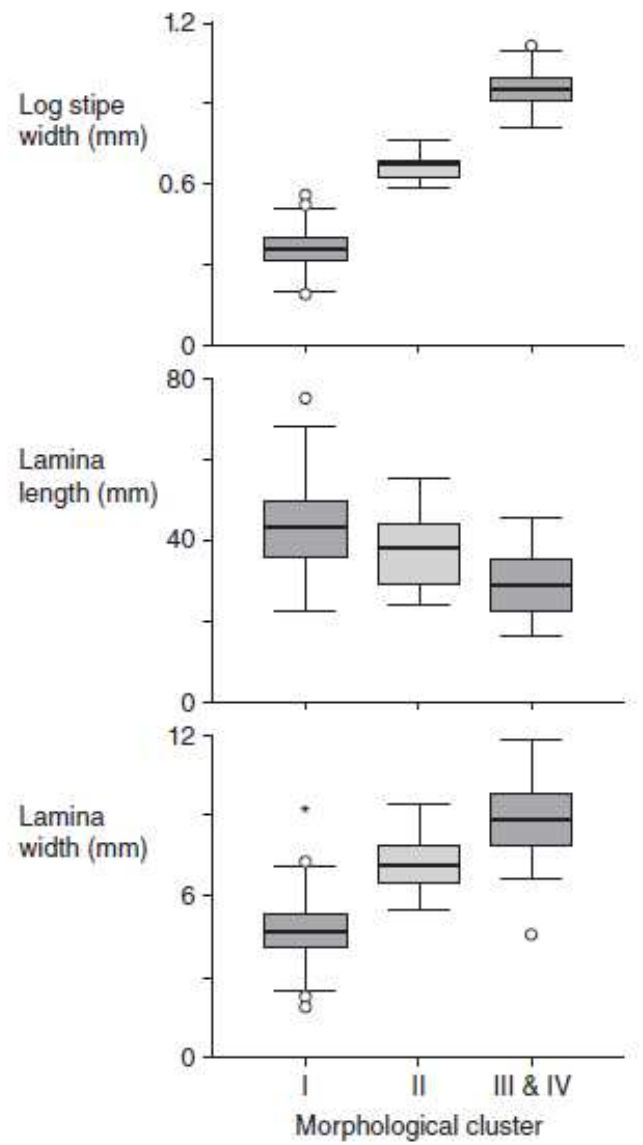

Fig. 5. The three groups had significantly different (a) log stipe widths, (b) lamina lengths and (c) lamina widths. The boxplots show the spread of data (line in box $=$ mean, box $=75 \%$ of values measured, lines $=95 \%$ of values) with outliers marked by circles and extreme outliers marked with asterisks.

tions from East Cape. Carpophyllum angustifolium, C. maschalocarpum and their hybrids have distinct and distinguishable morphologies. Identifiable hybrid and parental morphotypes have been found within many Fucus hybrid species complexes; however, morphologically ambiguous individuals are often present (Scott \& Hardy 1994; Coyer et al. 2002a; Kucera \& Saunders 2008). No other detailed morphometric analysis of randomly sampled and molecularly identified individu- als has been done in a Fucalean hybrid system. Subsequently the range and degree of overlap of parental and hybrid morphologies are unknown in other Fucalean hybrid systems.

Stipe width alone can distinguish between $C$. angustifolium, C. maschalocarpum and their hybrids, and provides a useful taxonomic character for field identification. Stipe width meets three requirements described for a useful macroalgal taxonomic character in macro-algae; it is constant, easy to observe and non-destructive (Mathieson et al. 1981). Stipe width of the parent species and hybrids was easy to measure and rarely affected by herbivory or exposure damage (pers. obs.). An investigation into the spatial variability of $F$. spiralis and $F$. vesiculosus (Coleman \& Muhlin 2008) found stipe width is also a valuable character for identification of Fucus species.

Carpophyllum angustifolium $\times$ C. maschalocarpum hybrids generally had an intermediate morphology to the parent species. Hybrids had intermediate stipe width, lamina length, lamina width and vesicle presence. However, the thickness of hybrid lamina was novel, being thinner than both parents. Furthermore the proportion of hybrid individuals with secondary branching was indistinguishable from $C$. maschalocarpum. Intermediate hybrid morphologies are usually found in hybrid systems although not necessarily in all cases (Rieseberg \& Ellstrand 1993; Seehausen 2004; Coyer et al. 2006b). Intermediate morphology is used to identify putative hybrid individuals for further investigation in Fucus (Scott \& Hardy 1994; Coyer et al. 2002a). Despite this there are examples of morphological traits in hybrids being aligned to one of the parental species. For example, hybridization between the dioecious Fucus vesiculosus and the hermaphroditic Fucus spiralis results in hybrids with parental sexual phenotypes rather than intermediate sexual allocation (Billard et al. $2005 b)$. In salt marsh habitats $F$. vesiculosus $\times F$. spiralis hybrids are morphologically indistinguishable from polyploid $F$. vesiculosus individuals (Coyer et al. 2006b).

The presence of hybrid genotypes with $C$. angustifolium morphotypes suggests introgression might be occurring. Hybrid ITS genotypes with parental morphology were also found in the $F$. vesiculosus $\times F$. spiralis species complex, and were also cautiously interpreted 
Hybrids in Carpophyllum

Table 2. Relative morphological differences between the Carpophyllum maschalocarpum clusters III and IV

\begin{tabular}{lllll}
\hline Significance & Morphological trait & Group III & Group IV & Statistics \\
\hline Statistically significant at & Total length & Shorter & Longer & $F=6.803, d . f=1, n=146, P=0.010$ \\
$5 \%$ level & Stipe width & Narrower & Wider & $F=250.906, d . f .=1, n=146, P<0.001$ \\
& Stipe thickness & Thinner & Thicker & $F=14.188, d . f=1, n=146, P<0.001$ \\
& Proportion with vesicles & Low & High & $\chi^{2}=11.026, d . f=1, n=146, P=0.001$ \\
Trends in the data (significant & Lamina width & Narrower & Wider & $F=2.885, d . f .=1, n=49, P=0.096$ \\
at the $10 \%$ level) & Lamina thickness & Thinner & Thicker & $F=3.837, d . f .=1, n=49, P=0.056$ \\
& Proportion with secondary & Low & High & $\chi^{2}=3.161, d . f .=1, n=146, P=0.075$ \\
Not significant and no trends. & Lamina length & Same & Same & $F=1.517, d . f .=1, n=49, P=0.224$ \\
\hline
\end{tabular}

as indicating introgression (Kucera \& Saunders 2008). Introgression is an important evolutionary process that has the potential to integrate genetic material from one species into another (Coyer et al. 2007). Introgression has been identified in Fucus hybrid complexes, and is considered a significant factor in the evolution of Fucus lineages (Wallace etal. 2004; Coyer et al. 2006a, 2007). Further investigation with nuclear markers lacking the unusual properties of ITS (Álvarez \& Wendel 2003) are needed to confirm introgression and the degree of introgression.

Fucus species seem to have maintained their genetic integrity despite extensive hybridization. For example, hybrids made up $13 \%$ of Fucus serratus and Fucus evanescens in one population; however, nuclear DNA introgression was only $1.5 \%$ in the two species, and both species maintain different distributions and morphologies (Coyer et al. 2002a, 2007). Coyer et al. (2006a) suggested different parental mating systems might act as a barrier to extensive introgression, and protect the parental species integrity. Hybridization in Fucus appears to occur between dioecious (having separate male and female individuals) and hermaphroditic species (e.g. Wallace et al. 2004; Billard et al. 2005a; Mathieson et al. 2006; Coyer et al. 2007). All members of the genus Carpophyllum are dioecious (Lindauer et al. 1961). Extensive introgression, and the loss of parental species genetic integrity, could be more likely in Carpophyllum hybrid systems if Coyer et al. (2006a) hypothesis is correct.

The absence of individuals with $C$. maschalocarpum morphology and hybrid genotypes suggests introgression may be asymmetrical, with backcrossing only between hybrids and $C$. angustifolium. Asymmetries in angiosperm reproduction are thought to be common in a broad range of taxa (Tiffin et al. 2000). Asymmetrical hybridization and introgression has been found in Fucus spp. (Coyer et al. 2002a, 2007). Determining the symmetry of introgression is important for predicting its implications on parental species integrity (Coyer et al. 2007).

The morphometric analysis distinguished variation within C. maschalocarpum, which could be related to demography. The differences between the two $C$. maschalocarpum clusters (i.e. total length, stipe width, stipe thickness, vesicles) were characteristics thought to be associated with maturity (Dromgoole 1965). Carpophyllum maschalocarpum has pulsed peak recruitment, and has been shown to recruit in cohorts after bare rock is opened up by disturbance (Schiel 1980, 1988).

This work on Carpophyllum combining morphometric data with ITS2 identification found generally distinct and distinguishable parental and hybrid morphologies. Further investigation needs to be done using microsatellites and maternally inherited DNA in conjunction with morphology to confirm and determine the extent and symmetry of introgression, and identify backcrosses, $F_{2}$ and later hybrids.

\section{ACKNOWLEDGMENTS}

We thank Carlos Lehnebach for statistical help, and Tracey Taylor, Jen Van der Veur, and Aaron Packard for field assistance.

\section{REFERENCES}

Albert, M. E., Dantonio, C. M. and Schierenbeck, K. A. 1997. Hybridization and introgression in Carpobrotus spp. (Aizoaceae) in California.1. Morphological evidence. Am. J. Bot. 84: 896-904.

Álvarez, I. and Wendel, J. F. 2003. Ribosomal ITS sequences and plant phylogenetic inference. Mol. Phylogenet. Evol. 29: 417-34.

Billard, E., Daguin, C., Pearson, G., Serrăo, E., Engel, C. and Valero, M. 2005a. Genetic isolation between three closely related taxa: Fucus vesiculosus, F. spiralis, and F. ceranoides (Phaophyceae). J. Phycol. 41: 900-5.

Billard, E., Serrāo, E. A., Pearson, G. A., Engel, C. R., Destombe, C. and Valero, M. 2005b. Analysis of sexual phenotype and prezygotic fertility in natural populations of Fucus spiralis, F. vesiculosus (Fucaceae, Phaeophyceae) and their putative hybrids. Eur. J. Phycol. 40: 397-407.

Casgrain, P. and Legendre, P. 1999. The R Package. version 4.0. 
Chapman, A. R. O. 1995. Functional ecology of fucoid algae -23 years of progress. Phycologia 34: 1-32.

Clayton, M. N. 1984. Evolution of the Phaeophyta with particular reference to the Fucales. In Round, F. E. and Chapman, D. J. (Eds) Progress in Phycological Research, Vol. 3. Biopress Ltd, Bristol, pp. 11-46.

Coleman, M. A. and Muhlin, J. F. 2008. Patterns of spatial variability in the morphology of sympatric fucoids. Northeast Nat. 15: 111-22.

Coyer, J. A., Peters, A. F., Hoarau, G., Stam, W. T. and Olsen, J. L. 2002a. Hybridization of the marine seaweeds, Fucus serratus and Fucus evanescens (Heterokontophyta: Phaeophyceae) in a 100-year-old zone of secondary contact. Proc. R. Soc. Biol. Sci. Ser. B 269: 1829-34.

Coyer, J. A., Peters, A. F., Hoarau, G., Stam, W. T. and Olsen, J. L. 2002b. Inheritance patterns of ITS1, chloroplasts and mitochondria in artificial hybrids of the seaweeds Fucus serratus and $F$. evanescens (Phaeophyceae). Eur. J. Phycol. 37: 173-8.

Coyer, J. A., Hoarau, G., Oudot-Le Secq, M.-P., Stam, W. T. and Olsen, J. L. 2006a. A mtDNA-based phylogeny of the brown algal genus Fucus (Heterokontophyta; Phaeophyta). Mol. Phylogenet. Evol. 39: 209-22.

Coyer, J. A., Hoarau, G., Pearson, G. A., Serrão, E. A., Stam, W. T. and Olsen, J. L. 2006b. Convergent adaptation to a marginal habitat by homoploid hybrids and polyploid ecads in the seaweed genus Fucus. Biol. Lett. 2: 405-8.

Coyer, J. A., Hoarau, G., Stam, W. T. and Olsen, J. L. 2007. Hybridization and introgression in a mixed population of the intertidal seaweeds Fucus evanescens and F. serratus. J. Evol. Biol. 20: 2322-33.

Dromgoole, F. I. 1965. Contribution to the ecology of Carpophyllum maschalocarpum (Turn.) Grev. MSc thesis, University of Auckland.

Dromgoole, F. I. 1973. A contribution to the biology of the genus Carpophyllum Grev. PhD thesis, University of Auckland.

Engel, C. R., Daguin, C. and Serrão, E. 2005. Genetic entities and mating systems in hermaphroditic Fucus spiralis and its close dioecious relative $F$. vesiculosus (Fucaceae, Phaeophyceae). Mol. Ecol. 14: 2033-46.

Feliner, G. N. and Rossello, J. A. 2007. Better the devil you know? Guidelines for insightful utilization of nrDNA ITS in species-level evolutionary studies in plants. Mol. Phylogenet. Evol. 44: 911-9.

Fielding, A. H. 2007. Cluster and Classification Techniques for the Biosciences. Cambridge University Press, Cambridge.

Fowler-Walker, M. J., Wernberg, T. and Connell, S. D. 2006. Differences in kelp morphology between wave sheltered and exposed localities: morphologically plastic or fixed traits? Mar Biol. 148: 755-67.

Graham, L. E. and Wilcox, L. W. 2000. Algae. Prentice Hall, Upper Saddle River, NJ.

Grant, P. R., Grant, B. R., Markert, J. A., Keller, L. F. and Petren, K. 2004. Convergent evolution of Darwin's finches caused by introgressive hybridization and selection. Evolution 58: 1588-99.

Hodge, F. J. 2009. Hybridisation in the brown alga Carpophyllum: investigating morphology, distribution and wave exposure. MSc thesis, Victoria University of Wellington.

Kucera, H. and Saunders, G. W. 2008. Assigning morphological variants of Fucus (Fucales, Phaeophyceae) in Canadian waters to recognized species using DNA barcoding. Botany 86: 1065-79.

Lane, C. E., Mayes, C., Druehl, L. D. and Saunders, G. W. 2006. A multi-gene molecular investigation of the kelp (Laminariales, Phaeophyceae) supports substantial taxonomic re-organization. J. Phycol. 42: 493-512.

Lihova, J., Kucera, J., Perny, M. and Marhold, K. 2007. Hybridization between two polyploid Cardamine (Brassicaceae) species in north-western Spain: Discordance between morphological and genetic variation patterns. Ann. Botany. 99: 1083-96.

Lindauer, V. W., Chapman, V. J. and Aiken, M. 1961. The marine algae of New Zealand: Phaeophyceae. Nova Hedwigia 3: 129-350.

Mathieson, A. C., Norton, T. A. and Neushul, M. 1981. The taxonomic implications of genetic and environmentally induced variations in seaweed morphology. Bot. Rev. 47: 313-47.

Mathieson, A. C., Dawes, C. J., Wallace, A. L. and Klein, A. S. 2006. Distribution, morphology, and genetic affinities of dwarf embedded Fucus populations from the Northwest Atlantic Ocean. Bot. Mar. 49: 283-303.

Montanari, A. and Mignani, S. 1994. Notes on the bias of dissimilarity indices: the case of archaeological classification. Questiio 18: 39-49.

Nelson, W. A. 1994. Distribution of macroalgae in New Zealand - an archipelago in space and time. Bot. Mar. 37: 221-33.

Perrin, C., De Vliet, M. V., Daguin, C., Engel, C., Pearson, G. A. and Serrão, E. A. 2005. Population genetic structure of dioecious versus hermaphrodite Fucus species, hybridisation along sympatric and allopatric zones. Phycologia 44: 78-9.

Podani, J. 1999. Extending Gower's general coefficient of similarity to ordinal characters. Taxon 48: 331-40.

Rieseberg, L. H. and Ellstrand, N. C. 1993. What can molecular and morphological markers tell us about plant hybridization? Crit. Rev. Plant Sci. 12: 213-41.

Rohlf, F. J. 2000. NTSYS-pc: Numerical Taxonomy and Multivariate Analysis System. Version 2.11. Exeter Software, New York.

Rohlf, F. J. and Sokal, R. R. 1981. Comparing numerical taxonomic studies. Syst. Zool. 30: 459-90.

Sambrook, J., Fritsch, E. F. and Maniatis, T. 1989. Molecular Cloning. A Laboratory Manual, 2nd edn. Cold Springs Harbor Laboratory, Cold Springs Harbor, NY.

Schiel, D. R. 1980. A demographic and experimental evaluation of plant and herbivore interactions in subtidal algal stands. PhD thesis, University of Auckland. 
Schiel, D. R. 1988. Algal interactions on shallow subtidal reefs in northern New Zealand - a review. N. Z. J. Mar Freshwat. Res. 22: 481-9.

Schiel, D. R. 1990. Macroalgal assemblages in New Zealand - structure, interactions and demography. Hydrobiologia 192: 59-76.

Scott, G. W. and Hardy, F. G. 1994. Observations of the occurrence of hybrids between two sympatric species of Fucoid algae. Cryptogam. Algol. 15: 297-305.

Seehausen, 0. 2004. Hybridization and adaptive radiation. Trends Ecol. Evol. 19: 198-207.

Thuret, G. 1854. Recherches sur la fecondation des Fucacees. Ann. Sci. Nat. Bot. 4: 197-214.
Tiffin, P., Olsen, M. S. and Moyle, L. C. 2000. Asymmetrical crossing barriers in angiosperms. Proc. R. Soc. Biol. Sci. Ser. B 268: 861-7.

Wallace, A. L., Klein, A. S. and Mathieson, A. C. 2004. Determining the affinities of salt marsh fucoids using microsatellite markers: Evidence of hybridization and introgression between two species of Fucus (Phaeophyta) in a Maine estuary. J. Phycol. 40: 1013-27.

Zuccarello, G. C. and Lokhorst, G. M. 2005. Molecular phylogeny of the genus Tribonema (Xanthophyceae) using rbcL gene sequence data: monophyly of morphologically simple algal species. Phycologia 44: 384-92. 